

\section{AFEHAN JWHAD}

A Quarterly Publication of The Cultural Council of . Afghanistan Resistance

\section{MANAGING EDITOR\&}

Sabahuddin Kushkaki

January-March, 1988

\section{SUBSCRIPTION}

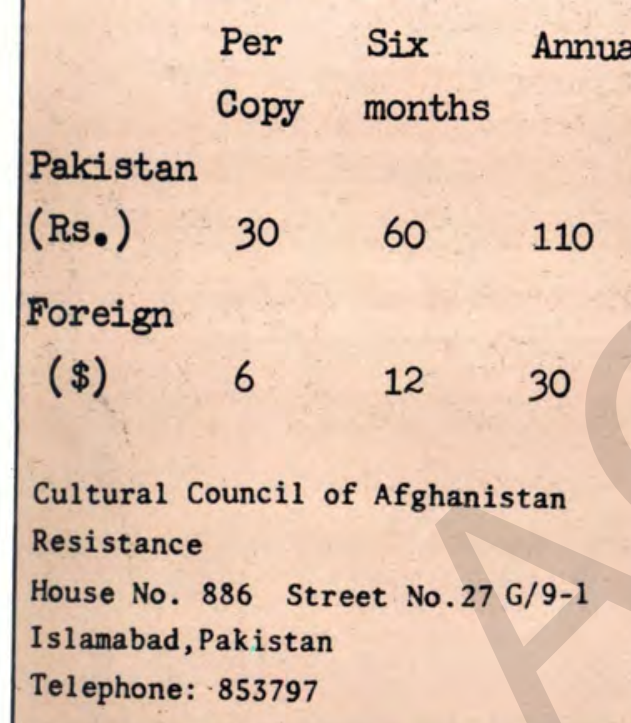

\section{CONTENTS}

EDITORIAL, POLITICAL ANALYSIS, MI LITARY REPORT,

MAJOR DOCUMENTS:

1. IUAM statement on the mujaheddin interim government,(2) Biographies of the President and Vice-President of the Interim government, (3) IUAM statement on the political solution of the Afghanistan problem, (4) IUAM communique on the occassion of the anniversary of the military invasion of Afghanistan, (5) Join statement by Afghan-Pakistan religious scholars on the occasion of the anniversery of military invasion of Afghanistan, (6) Text of report by international jurists on human rights situation in Afghanistan (7) Biographies, views and writings of IUAM leaders (Part I), (8) Charters of IUAM member parties (Part-I).

AFGHANISTAN IN INTERNATIONAL FORUMS:

1. Paris International Conference

2. Summary of speeches by 13 UN delegates on Afghanistan (Part II).

CATALOGUE OF MUJAHEDDIN PRESS

DIGEST OF MUJAHEDDIN PRESS

(JANUARY-MARCH 1988)

BOOKS BY THE MUJAHEDDIN, FOR THE

\section{MUJAHEDDIN}

CHRONOLOGY OF AFGHAN EVENTS

(JANUARY - MARCH, 1988) 


\section{Vol.1, No.3}

\section{Editorial}

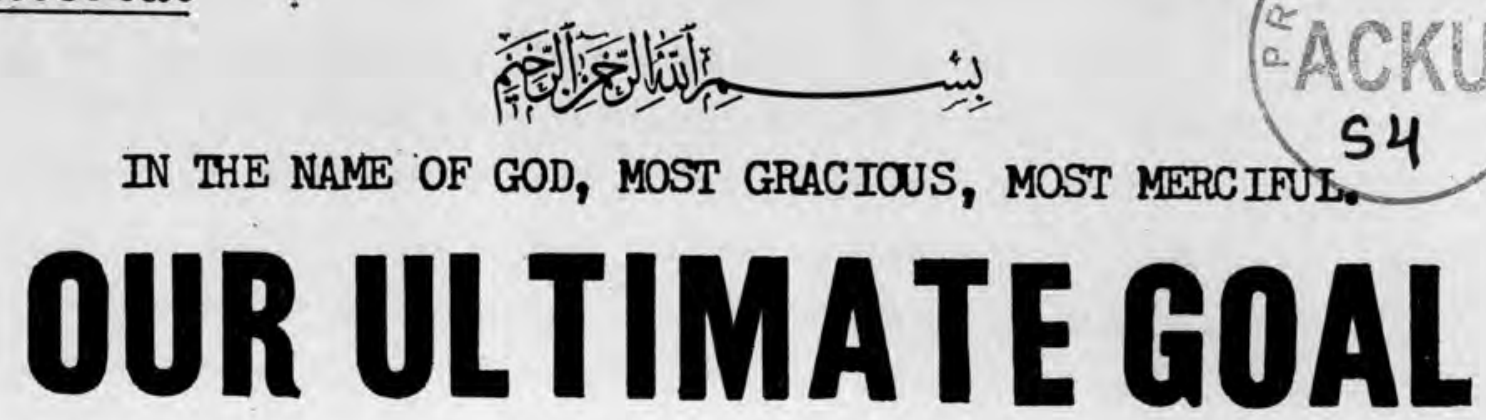

If the Geneva accords on Afghanistan are signed as they have been prepared so far - - and with most probabilities they would be signed - - it would mean that, from then on, the Afghans have to carry on jehad on their own until they achieve the ultimate objective of establishing a government of their own choice in Kabul proclaiming the word of God.

When we say the Afghans have to carry forward the rest of the fighting alone, we do not want to create the impression that up to now others had been fighting along our side.But,according to the provisions of Geneva agreement, any kind of foreign "interference" in Afghanistan - - which according to the terms of accord, include providing to the resistance military assistance by foreign powers or sources or allowing the mujaheddin to use others' territories for training purposes, etc. - - will be banned. Furthermore, the huge international pressure which existed up to now demanding a withdrawal of the foreign troops from Afghanistan will no longer be strong. The world, mostly vold of the kind of feeling which drives a committed Muslim to sacrifice himself for the cause of Allah, will not care much whether an atheist government remains in power in Kabul or a Muslim regime replaces it and; as a matter of fact, some quarters or countries will be happy not to see the triumph of an Islamic state in this part of the world.

True, there will be still some sympathy and support in the outside world for the Afghan cause because we will be fighting against a Soviet puppet government which,ifconsolidated its position in Afghanistan, will become a springboard for furthering Soviet and world communism causes.

The Pakistanis, undoubtedly have to give up to the Geneva accords very reluctantly. If a statesman like General Ziaul Haq, had to act at his own he would surely vehemently oppose the signing of the Geneva accords with the 
PDPA regime. But by, not signing, Pakistan, too, will be left alone and it is upto our Pakistani brethren to really weigh the repercussions of a puppet atheist regime at their door step despite waning international support.

Let us not lose sight of realities: whatever interpretation Kremlin or its apologists might offer, the fact is that the Soviet super power failed to defeat the Afghan resistance and had to greatly suffer in men and material. Not only it failed to defeat us but the communist war machine was no longer able to defend its action in Afghanistan in the eyes of the people of the Soviet Union or the world at large. History will record us as a people who valorously fought and, in fact, forced that most cruel super power on earth to retreat.

Despite the many unforturate divisions in the leadership ranks of our jehad throughout these years, it has been a fact that all of us have remained unanimous in our action, to drive the Soviet invading forces out of our country. The non-communist world was with us. This all substituted, indeed, a great force and pressure - - a plus - - for our cause.

Now, too, it is gratifying to notice that all of us are unanimous in saying that we are not going to have any kind of partnership with communist puppets in the govermment after Soviets withdraw from Afghanistan. We are all unanimous in saying, through peaceful means or otherwise, the PDPA regime must be toppled.

Efforts by Pakistan to bring about a change in the government - - even a coalition government with the communist (which is, of course, not acceptable to the Afghans) - - before the signing of the Geneva accords or before the Soviet troops departure have so far failed. In other words, we Afghans have realized that primarily the staunch Afghan resistance and then international tactics and pressure have succeeded to bring about a Soviet troops withdrawal from Afghanistan but not, yet, the kind of conditions for which we Afghans had began our jehad. Our jehad was to eliminate an atheist regime functioning under Soviet behest and, while we were doing so, the Soviets invaded Afghanis$\tan$ to sustain that regime. Now the Soviets are very much likely to withdraw their troops but, as far as possible, they are going to defend the regime they have set in Kabul. The Russian withdrawal from Afghanistan is going to be partial. The very government which has been in power in Kabul is a part of occupation forces and then a withdrawal of mere Soviet troops from Afghanis- 
tan would mean that all the other things they have done in the way of trampling and abrogating the rights and privileges of a free and independent state- e.g. many treaties and agreements signed with the puppet regime at the Soviet behest - - are going to remain intact.

At any rate, the Afghan resolve is to see the PDPA regime dismantled by peaceful means or otherwise. As it seems peaceful means will not achieve the Afghan demand, we have to continue our jehad until the banner of Islam is hoisted in Kabul. We have fought this war to earn the pleasure of Allah and we will further fight, with His help, to achieve our final goal.

The Afghans, at their entirety, are also on record that they are not going to be bound to the provisions of the Geneva accords. That accord has been negotiated between parties not directly involved in the Afghan issue. It was a sheer submission to a super power hegemony that the Kabul regime - a part and parcel of Soviet occupation forces - - became a party to the talks. We Afghans have said we have nothing to do with these Geneva talks, which, furthermore, is conducted under the madiation of a UN official mistrusted by the Afghans as he has been tacitly favoring communist position and interests. The Afghans in no way are going to observe any so-called ceasefire so long as the Kabul PDPA regime is in power. They will continue their jehad.

This is the kind of scenario that we Afghans are going to offer to the world, whether they like it or not.

The Afghan mujaheddin have already announced the outlines of an interim government which they expect to replace the puppet Kabul regime. In it, seven portfolios have been reserved to those Muslims who have been living inside Afghanistan. Who these people are going to be, may be open to several specplations, but it is quite obvious that this has been the maximum compromise the mujaheddin leadership was able to make in the formation of an interim govermment within the limits of Islamic laws and jurisprudence. One should not expect us to include in the mujaheddin proposed government the communist die hards, the ones who have been symbols of treason and destruction, who, on the basis of the record of such coalition governments in other parts of the world, will serve only to create discord and confusion, and whose security and safety will be under constant threat by those who want to revenge. No one should expect the torch bearers of Islam to act against a basic principle of their religion by accepting at the very start a govern- 
ment formed by them to join hand with those who in today's legal terms are committed to the overthrow of a state through violence and subversion.

The government announced by the mujaheddin is to remain in power only until a new government takes over. The most crucial part of the mujaheddin scenario in their bid to assume power will be that their leadership and all field commanders remain cohesive like a cemented structure, to use a Quranic allegory.

The Russian scenario may be to capitalize on mujaheddin divisions and assist the Kabul regime in all other forms other than the stationing of its troops (and this makes a redicule of the non-interference clause in the Geneva accord). But the majority of military analysts are of the opinion that, deprived of direct and active support of Soviet army and power, the Kabul regime will still wither away both from within and without in a short period of time. But Moscow, which, under present circumstances is intent to preserve its puppet PDPA regime, is banking primarily on possible mujaheddin divisions to buy time for the survival of this regime.

If the Afghan mujaheddin leadership failed to understand and resist this Kremlin plot, indeed the nation - - way Almighty God, - - will never forgive them. Already it has been a result of their bickerings and rivalries that the war has been prolonged to such an extent that more than a million of our people had to be annihilated and our country turned into a wasteland. For, with their cohesiveness and unity, under the Quranic motto "be not divided amongst yourself", the enemy might have kneed down years ago.

The mujaheddin strategy should be simple, forward looking and should prevail itself: We are in no way going to be bound by the provisions of the Geneva accords for we are not a party to it ;... if the PDPA government in Kabul is not dissolved peacefully, we will continue to dismantle it otherwise; $\ldots$ the kind of interim government proposed by the IUAM is the best option the mujaheddin can offer within the limits of Islamic mandate; ... this government must move inside Afghanistan and mobilize all the mujaheddin battle machinery under its own command to bring about the dismantling of the PDPA regime; . . we are not an arrogant nation but we are a proud and yet humble people because we obey Almighty God and we shall continue to fight until achieve our ultimate objective with the help of God, in unity and decisiveness. 


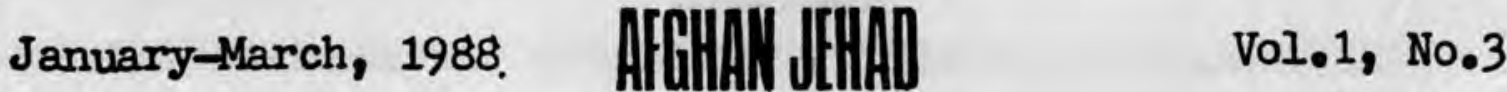

\section{Political Dimensions}

\section{After the Geneva Accord:}

\section{PDPA Regime Must Go}

AFGHAN CONSENSUS:

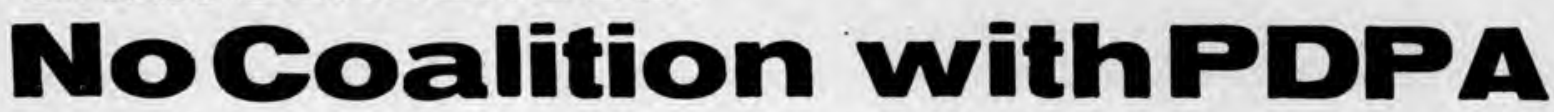

\section{Accords:}

\section{Betrayal of AfghanCause}

While, on the one hand, the three months pest, were witness to the most dramatic events in relations to the Afghanistan issue, ori the other hand, by the time The Afghan Jehad was going to the press, nothing had happened to really show that the Russians were sincere in seeking a just and equitable peace in Afghanistan. The Geneva talks on Afghanistan, which began March 2, remained deadlocked on two issues, which, somehow, said to be not of direct issues in the main provisions of Geneva Accords on Afghanistan: The first point was a Pakistani insistence that, either before the signing of an agreement or before the deadline for the start of Russian troops withdrawal from Afghanistan, an interim government must be formed. The Pakistanis argued that in the Geneva accords it has been insisted that conditions should be made fit for a safe and honorable return of millions of Afghan refugees. With the govermment of the PDPA, part of the occupation forces and against which the Afghans had originally rebelled still in power, the refugee will not go home

The second point was an American insistence that Washington will refuse to guarantee the Afghan accords if it had to stop military aid to the mujaheddin, while the Russians continue to send military assistance to the Kabul regime. Under the Geneva accords on Afghanistan the two super powers are to act as guarantors of a peace plan in Afghanistan. The Russian argued that the Kabul regime is the legal government of Afghanistan and it should not be treated at par with the mujaheddin, which to Moscow are "rebels".

With emerging difficulties, as these, it has became known to the Afghans that the whole socalled proximity talks, conducted in their absence, have been lopsided to please a super power or they are actually tantamount to a super power collusion or, at most, it is to accomodate the positions of the sides directly involved in the talks. In a pamphlet, written by a "Dr. Afghan" (psuedo name) on the contents of the draft of Geneva accords, not yet made public(the writer says, on the basis of his contacts with UN officials, he was able to obtain a copy of these accords) it has been stated that both the UN Secretary General and his special envoy on Afghanistan have acted beyond their mandates expressed in the UN Charter and in the resolutions adopted by the world body on Afghanistan. The writer says "the agreement between Pakistan and the Kabul regime, as a (mere) bilateral document, are meant to solve their present and future difficulties. It is based on the concept of providing security for Pakistan and for the continuation of the rule of present Soviet client communist regime in Kabul. The agreement recognizes the Kabul government as a lawful govermment which has the right to sovereignty and represent the people and is entitled to respect. 
"In the agreement attempts have been made to secure this position for the Kabul regime by eliminating (the realities) of the jehad and calls for the return of refugees under the PDPA rule. In the eyes of the agreement, the resistance of the Afghan people against the Russian invasion and their migration to neighbouring countries is a crime worthy of condemnation and punishment. And the agreement promises graciousness on the part of Kabul regime by saying that, after their return, the refugees will be granted amnesty and they will be parcioned (Section B, Instrument III)。

"Section A of instrument III of the agreement says the returnees, at present, will have the right to freely travel inside Afghanistan. According to the agreement, the returnees will have the right to work but it should be in civilian fields. They have no right to take jobs in security, policy making or other important positions. The returnees will be recognized in Afghanistan as a working class deprived of any (real) power. They will be able to enjoy from the gains brought about a result of reforms launched by the communist regime since April, 1978 (Section C Instrument III).

"The agreement also extends the right to Afghan refugees to express view on measures adopted for their return and obviously they would not be asked whether they like the Kabul government or not, or whether the reasons which forced them to leave the country have been eliminated. However, they might be asked (according to the last Section of Instrument III) to say through what routes they would like to return home - - Torkham or Chaman - - and what facilities they would like to have for being transported - - doneky or truck or they want to go on foot.

"According to Instrument IV of the agreement, all provisions of the solution of the Afghanistan problem will begin to be implemented simultaneously. The same day Soviet forces begin to withdraw from Afghanistan, refugees from Pakistan and Iran, too, will start their returr. to Afghanistan. All the refugees will be repartriated by the Soviet client communist regime in the presence of Russian soldiers. When the last refugee is repatriated, in accordance with the wishes of the Kabul regime, the last Russian soldier will be withdrawn from Afghanistan. In other words; the agreement implies, when the Russians are completely convinced of the total elimination of the resistance, when foreign assistance is completely halted to the resistance forces .... and when the Kabul government is completely in control of events, only then will be Russians troops withdrawn from Afghanistan..."

We quoted in length from this assessment of the Geneva accords in order to explain the Afghan fears which were confirmed by being officially known that, as part of the agreement, the present Kabul regime, opposition to which forms the genesis of the Afghan resistance, is to remain intact. It also became known that the agreement is advocating a double standard role by cutting aid to the resistance while it assumes that the Russian are to be allowed to continue military aid to its client government.

The Afghans, at their part, have said from the very beginning that they would have nothing to do with the Geneva accords as they have demanded talks between the real parties to the conflict, the Afghan mujaheddin and the Russians.

It was 8 February when Soviet leader Mikhail Gorbochev, in a nationwide statement announced that the Soviet Union was prepared to begin withdrawing its troops from Afghanistan on May 15 this year if the Geneva talks on Afghanistan result in a settlement two months before that time. 
The western world, and everybody else, were caught in surprise. The Russians had finally realized that they were unable to win the Afghan war. The decision was apparently made because after a one grueling year of campaign, conducted inside Afghanistan and throughout the world, the Soviets were not able either to defeat the Afghan resistance or convince the international community that the Kabul puppet regime or Moscow were on the right tract by adopting what they themselves called a conciliatory policy in Afghanistan. The Russian frustration culminated when the United Nations voted with a record number for the withdrawal of foreign troops fron Afghanistan and the mujaheddin assumed an offensive position in the war inside Afghanistan.

Western view is that Gorbochev has been against Soviet military involvement in Afghanistan from the very beginning. He was consolidating his position both in the party and the army on the issue and only now he has been able to announce that the Soviet troops will be definitely withdrawn from Afghanistan. Western circles say, regardless of an agreement at Geneva on the Afghanistan issue, the Soviets are intent to pull-out their troops from Afghanistan, although they are not sure that, with the lack of actual agreement signed on a pull-out time-table, when the Russians will actually begin their withdrawal which they have said will be completed in nine months.

These are all Western scenarios. The Afghans - - and indeed perhaps the Russians themselves - have a different one. The Afghans are of the opinion that the Russian are playing a trick or there might be an East-West conspiracy or deal to accomodate US-USSR positions in Asia and Latin American countries. The Afghans argue unless the Soviet installed government in Kabul is dismantalled, the Soviet Union will continue to do whatever it had intended to accomplish in Afghanistan. The PDPA is a puppet regime and will consider its survival possible only under Soviet protection. With this, and also on the basis of its ideological commitments, it will still remain a puppet and not only do what it intended to do inside the country but will become a soviet spring board in the region.

Those who say a US-USSR conspiracy is hatching over Afghanistan argue that in Washington, there has been a group of influential experts who maintain that, if the Russians take off hands from interferring in the Latin American countries and leave those areas to be part of American sphere of influence, let us leave Afghanistan to be a Russian sphere of influence. They say, as far as the Western security and balance of powers in this part of the world is concerned, the West should be satisfied with a Russian troops withdrawal from Afghanistan.

But the traditional supporters of the Afghan mujaheddin in Washington, mainly in the US Congress, were said to be furious with this reportedly American stand and, at the eleventh hour, they stopped the Reagan Administration from concluding the deal in the guise of the socalled Geneva accords. The belated American insistence that there should be a symmetrical cut-off of assistance to both the mujaheddin and the Kabul regime is said to be initiated at the behest of the American Congress trying to prove, among other things, that the Americans are not going to sell-out the Afghan freedom fighters.

So much for the Soviet postures and the Western response. As far as the Afghans are concern, the entire public opinion has been vehemently urging the resistance to come up with a viable plan to counter the so-called Soviet "peace" offensives. A resignation by Prof. Sebghatullah Mojaddedi leader of one of the seven resistance groups in the alliance early in March was in no 
way in the mood of things as far as the Afghans were concerned. Maybe Prof. Mojaddedi was, indeed, frustrated with the failure of the IUAM leaders to adopt appropriate measures with full speed. However, Prof。 Mojaddedi had to withdraw his resignation in the face of wide range public opposition to his move.

A few days later, the President of the Islamic Unity of the Afghanistan Mujaheddin (IUAM) also announced his resignation from his post.Officially saying that he has resigned on health reasons, Mawlawi Mohammad Younus Khales was said to be opposed to an inststence on the part of some other IUAM leaders, and, reportedly, the government of Pakistan to send a mujaheddin delegation to Geneva.

However the new President of the IUAM Gulbuddin Hekmatyar, too, was in no way ready to sent an IUAM delegation to Geneva.Sending an Afghan delegation to the parleys would have meant a mujaheddin consensus with the talks, while it has been known for many years that the Afghans were not obliged to abide by the provisions of the accords. In an interview with the official newspaper of his party, Gulbuddin Hekmatyar, had said as early as January that the mujaheddin had never agreed with the Geneva talks, because they had not been made a party to the dispute; Najib, leader of the Kabul regime, who is no more than a soldier in the service of Russians, is participating in these talks as representative of the Afghan nation; the Russians are jnvolved in the talks directly and indirectly and every phase of the talk begins when Cordovez visits Moscow for seeking Kremlin's approval (for details see The Afghan Jehad, The Mujaheddin Press, The Shahadat 28 January, 1988).

Although they should have done it months ago, the mujaheddin leaders in Peshawar last February came out with a plan of their own about an interim government for Afghanistan. The government is expected to take over at the wake of Soviet troops withdrawal from Afghanistan headed by the deputy leader of the Ittehad-e-Islami Engineer Ahmad Shah. With Jabha-e-Nejat's Secretary General Zabiullah Mojaddidi is its second man. The IUAM government is comprised of 28 members 14 of whom are from the mujaheddin, 7 from Afghan refugees living outside Afghanistan and the remaining 7 from Muslims inside the country. Each party leader is to introduce four members to this mujaheddin government.

All the mujaheddin leadership - - and indeed the whole non-cómumist Afghan specturm - - have been unanimous in their flat refusal of joining any kind of coalition with the communists.

Members of the mujaheddin government had not been announced but it is expected to be comprised of techrical minded personalities who will deal with specific question such as overseeing the Russian troop withdrawal from Afghanistan, repatriation of the refugees, maintaining law and order in the country during the Russian army withdrawal, and paving the way for elections for an Islamic government.

As to where the mujaheddin will establish the headquarters of their government, there have been many different comments by the Afghan leaders. Leader of the Hezb-e-Islami Hekmatyar had said (before his term as the IUAM President), that, if Pakistan signed the Geneva accords, he will shift his activities out of Pakistan. Khales, during his Presidency, said the resistance will move to the tribal areas. However, after the announcement of the plan for an interim government, the general consensus has been that the government should be established Inolde Afghanistan and latest news indicated that the jehad leaders have been working on selecting a venue for the government 
inside the country.

Both Kabul and Moscow, as expected, rejected the mujaheddin government. The communist position is that any government in Afghanistan ought to function under the PDPA, a stand completely opposed by the mujaheddin and refugees. They would have nothing to do with a Kabul government as long as it is staffed with atheist no matter in what cloak they may appear.

The Zahir Shah issue, which at one time, despite vehement opposition by the hard line core of the mujaheddin and, indeed, a significant number of intellectuals, had become in vogue at an international levels, seemed to have become a dead one. There were two rallys in his support, one in Baluchistan and the other in the NWFP, but there were many to oppose and condern him. The final blow came when the Indian Minister of State for External Affairs had a meeting with the former King Zahir in Italy. That was enough to alarm many who had from the very beginning condemned the "Indian treachery" vis-a-vis the Afghan issue.

Hectic activities, underway by the Kabul regime to show that it is in normal charge of the affairs by announcing a plan for holding election for a national assembly, etc, did not seem to impress many quarters. A regime which has been set and have been working at the behest of Soviet occupation forces and with more than $80 \%$ of the country not under its control was in no way in a position to earn the support of the Afghans.

All in all, it seemed once the hurdle over the symmetrical cut-off of aid to the Afghans mujaheddin and the Kabul regime was over, Pakistan will not insist on the formation of an acceptable interim government in Kabul and will sign the Geneva accords. Pakistan is said to remain satisfied with a promise, supported by Moscow, that Cordovez (in his private capacity) will continue to work for the establishment of an interim government after the Geneva accord is signed.

But the Afghans will not accept the accord and are expected to find a military solution to the rest of the scenario - - the toppling of the PDPA regime.If they remain united and intact, they will be able to overthrow the regime easily. But the Russians are said to be already working hard to create divisions in mujaheddin ranks. This, according to Soviet scheme, will buy time for its puppet regime in Kabul. Indeed for the mujaheddin it is going to be a great period of test whether being aware of these plans remain united.

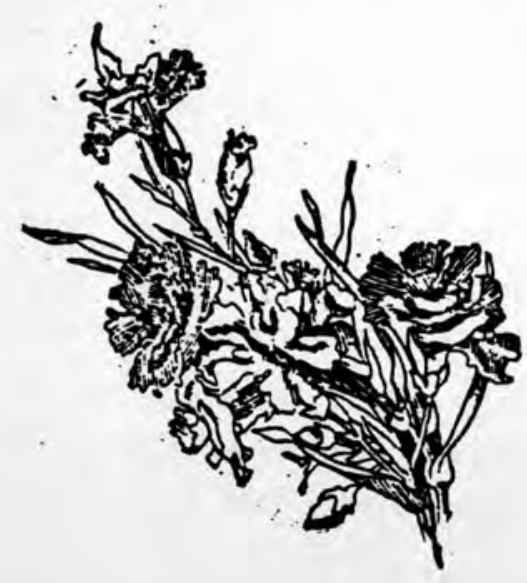




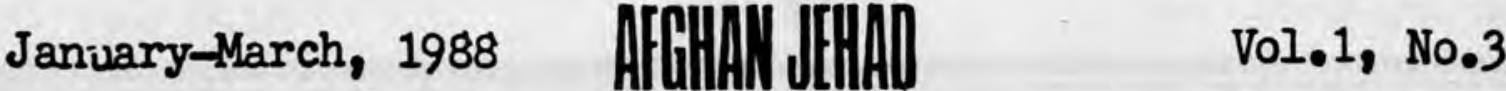

\section{Military Dimensions}

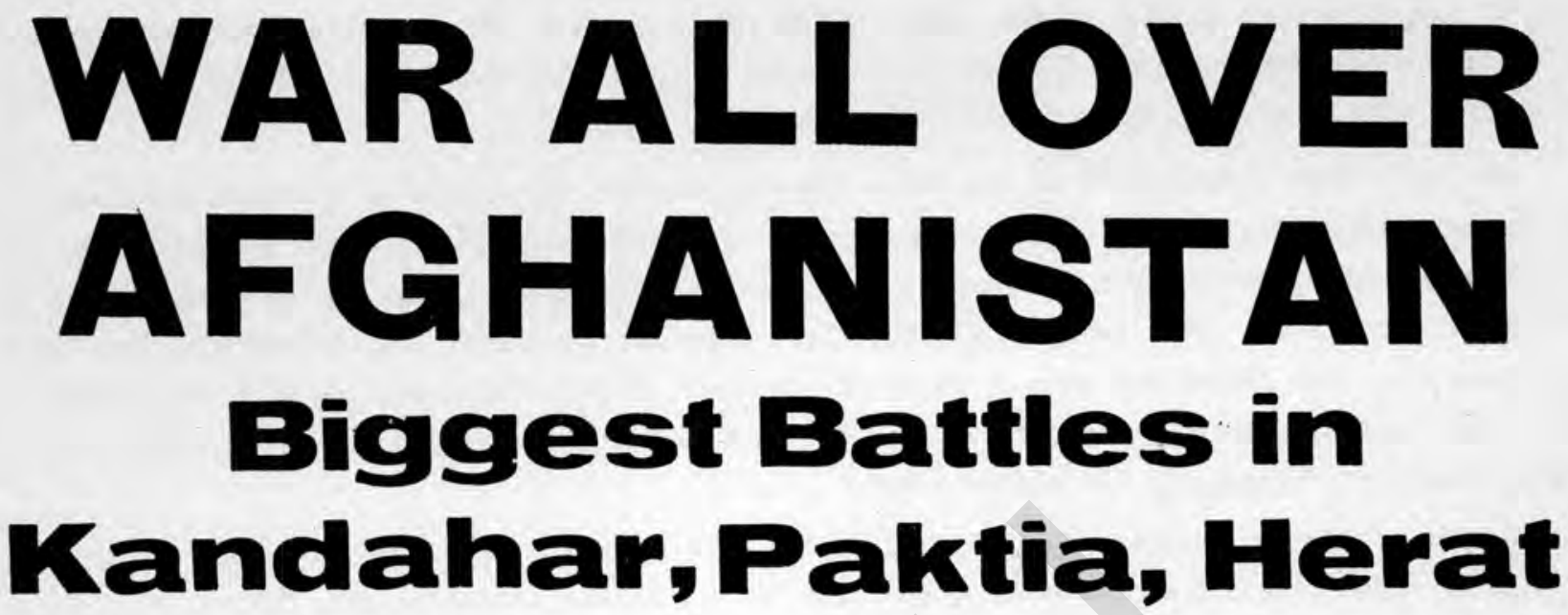

While the Kabuil regime and the Russians launohed a huge publicity campaign in the political field under the so oelled NRP and a Soviet tooops pulliout ploy, they continued the war in almost all the provinces of Afghanistan. However Soviet and Kabul regtme troops had to adopt defensive positions in most. of the areas.

Fighting continued during the last three months in:

* KaBUL: Macroriair, Kabul Airport, Shakardara, Khairkhana, Deh Sabz, Soviet Embassy, Pul-eCharkhi Jail, Darul Aman, Hawz-e-Wazir,Mahipar Electric Power House, Sayyed Noor Mohammad Shah Meena, Gogamanda, Shapoli Baba, Benihessar, Dasht, Paai Munar, Sarobi, Gahi, Tangi, Tangi Abrishomin, Pul-e-Surkh, Bagh-e-Daoud, Paghman, Kargha, Kabul city.

* PAKTIA : Zadran, Khost, Jaji Maidan, Pak, Gardez, Sayyed Karam, Mangal, Jaji Aryub, Ahmadkhel, Tsamkani, Trizai, Toro Obo, Gorbaz and Matakhan,

* KANDAHAR: Mahallajat, Panjwaee, Kandahar city, Spinboldak, Karezak, Darra-e-Soof, Gondigan base, Mir Bazar, Kandahar jail, Deh Khawaja, Yakh Karez, Taimurian, Rambasi, Palendi, Zala Khan, Nakhooni, Qala Fatehullah, Khanjgak, Chehl Zeena, Arghandab, Pashmol, Spin Ziarat, Qalacha, Kandahar division, Gulran, Ali Zai, "Company", Maiwand, Daman.

* HEIMAND: Lashkargah, Gerishk, Nawa sub division, Sarban Qala, Mosa Qala, Karez base, Qala -e Shadian, Nawzad, Zamindawar, Kajaki, Sangin, Shorki,

* HERAT: Herat City, Islam Qala, Ganda, Shindand, Qala Khawaja, Karrukh, Kalabacha, Ahmadabad, Kushk, Saboor, Rozang, Hajiabad, Doab, Darb-e-Iraq, Ghorian, Dadshan, Shahbolak, Adraskan, Mahalla-e-Babaji, Siaushan, Sar-e-pul, Sang-e-Surakh, Rubat, and Pusht-e-Koh,

* NANGAPHAR: Jalalabad, Semarkhail, Jalalabad airport, Khogiani, Mamakhel, Enzarian, Hesarak, Tawdacheena, Spinghar, Mazeena, Roadat, Bam Ragha, Mohmandarra, Surkhroad, Ghanjkhel, Chauni Kahi, Taro, Garo, Haska Meena, Basol, Spina Borka, Shinwar, Pasholi, Acheen, Kamadaka, Torkham, Girdi Ghaws, and Daka.

* KUNAR: Chegha Sarai, Assadabad, Asmar, Pashad, Afhandbagh, Darrasin, Nauabad, Nari and Barikote, 
* GHAZNI: Ghazni city, Karabagh, Mogor, Kalalgo, Balahissar and Alamkhel,

* FARYAB : Maimana city, Taimurak, Qala-e-Khawaja Atta Khan, Pashtun Kot, Murghab, Almar, Qala-eKarez, Khishtkhoon, Iaghman, Shirin Taghab, Dawlatabad, Stana Baba, and Andkhoy.

* FaraH: Balablok, Jawain, Delaram, Parozha, Gulistan and Fararoad,

* BAGHLAN : Baghlan city, Pul-e-Khumri, Tapa-e-Haji Malang, Surkh Kotal, Chashma-e-Sher, Dahana-e Ghori, Khanjan and Chehl Dukhtaran.

* ZABUL: Janda, Meezan district, and Dalki.

* NTMROZ: Khashroad, Rubat, Razarij, and Charburjak,

* BALKH : Sardarak, Markaz, Chamtal, Aqcha, Charbolak, Sang Charak, and Gortipa,

* PARWAN : Charikar, Bagram, Panjehir, Anaba, Guldara, Najrab, Salang, Ghorband, and Gulbahar

* BADGHIS: Murghab, Ghormach, Chakchal, Qala-e-Nau, Kharistan, Kandran, Moqor, Rubat, Gulchin.

* URUZGan: Dehroad.

* GHOR Cheghcheran.

* IAGHMan: Karghai, Surkhakan, Spina Tana, and hilly areas of Nooristan.

* PAKTEKa: Urgun, Khairkot and Wazakhwa.

* BAMIAN: The Airport

* BaMIAN : Bamian airport.

* LOGAR: Kulangar, Sheikh Omarwali, Charkh, Mohammad Agha, and Abchakan,

* WARDAK MAIDAN: Darra Noor, Chak, Tangi Sisi, and Kabul-Kandahar highway.

* TAKHAR: Chaab, Daghak Taluqan, and Shiber Siah.

* BADAKHSHAN: Faizabad and Darwaz.

* KUNDUZ: Char Darra, Kunduz, Qarya-e-Buta Kashan, Imam Saheb and Arji sub division.

* Jauzjan: Karkin

* KAPESA: Pahlwan Koh and Sayyad.

The following is the highlights of the battles fought during this period between the communists and the mujaheddin.

\section{Paktla}

1. As the Khost government cantonment had remained under a mujaheddin siege for a long time, Kabul-Russian forces launch an operation to break through the siege. They resorted to intensive aerial and ground operations on resistance centers and rural areas of Zadran from Satto Kando. The mujaheddin, who expected such operations, offered stiff resistance. Mujaheddin leaders visited the area to witch the mujaheddin activities. The mujaheddin at the same time were busy fighting the enemy on various other Paktia fronts in Zadran and Jaji Maidan and Bak to reduce pressure on mujaheddin positions in Zadran. After one month, Soviet-Kabul troops broke the economic siege around the Khost cantonment and succeeded carrying in foodstuff to the town. However Soviet-Kabul troops could not stay for a longer period and they had to return 10 January to Kabul and Gardez. The mujaheddin once again occupied their trenches and the Khost cantonment 
was again sieged and by the end of March, mujaheddin attacks were continuing on the Khost Cantonment, Jaji Maidan and Bak.

Mujaheddin losses in these battles:

153 martyred and 80 injured (estimates), large quantities of mujaheddin arms were destroyed as a result of constant bombings. Soviet-Kabul losses (estimates):

818 killed, 2,100 injured, 10 aircraft shot down, 130 pieces of arms seized, 18 tanks, 9 transport vehicles, three wireless sets, and a heavy gun destroyed, 9 tanks and four water supply tankeirs capture, 1, 160 soldiers tincluding four pillots and three Russians joined the mujaheddin.

The mujaheddin killed three trained Soviet dogs and Afs. 80 million were also gutted ds á result of the artillery shelling on the Khost bank. General Imamuddin who was said to have killed President Mohammad Daoud, on the day of April 27 coup, 1978, was also killed in the Khost battles,

\section{Kabul}

2. The Deh Sabz mujaheddin attacked 31 December the 15 armored forces destroying 19 transport vehicles, and killed 29 troops. On the same day the mujaheddin attacked the Khairkhana ThermoElectric Center destroying five tanks and killing 12 persons.

* The mujaheddin carried out operations 22 December and 12 January on the Naghlu 100 garrisson and power station, causing heavy losses to Soviet-Kabul troops, damaging a Naghlu power transformer, destroying a tank and killing or capturing a number of guards.

* The Shakardara mujaheddin attacked 28-29 December Soviet-Kabul troops on Guldara road killing 26 troops and injuring 40 others: A tank and three trucks were destroyed. In the battle, a mujahed was martyred and three others injured.

* The mujaheddin attacked 23 December a Soviet-Kabul military convoy in Hawz-e-Wazir, Shapli Baba, Gogamanda, and Mahipar destroying five tanks and three trucks and damaging three turbines of Mahipar power station.

* The mujaheddin attacked 27 December a center of the Soviet troops in Darul Aman killing 11 Russian troops, destroying two tanks and three trucks and damaging the building of that. center.

* The mujaheddin also cạrried out activities in Binihessar and many other places.

* The mujaheddin killed 5 January a Russian soldier in Darul Aman and captured his arms. On the other hand, 18 bomb explosions took place late February in Kabul. One of the explosions was in the Soviet Embassy in Kabul. Rocket attacks were also launched on the Embassy causing losses.

* The mujaheddin carried out operations on the airport and the Pul-e-Charkhi jail as a result of which five aircraft were destroyed at the airport and 200 prisoners were released from the prison.

* The mujaheddin attacked 14 February a security post in Shakardara killing three Soviet troops and causing damages. They also hit 21 February a jet aircraft in Shakardara which crashed near Bagram. In the combat, one mujahed was martyred and three others injured.

Soviet-Kabul casualties: 40 injured, 41 tanks and transport vehicles destroyed, 7 aircraft shot down and 200 prisoners were released from the Pul-e-Charkhi jail. 


\section{Herat}

3. The mujaheddin attacked 11 centers of the Soviet-Kabul troops late December destroying 10 tanks and capturing 100 pieces of arms. To reduce intensive attacks by Soviet-Kabul troops on Khost and Zadran, the Herat mujaheddin carried out 15 December extensive operations on enemy position in south and western sectors and also lauched offensive in Fnjeel, Guzarah, Karukh, Ghorian, Zindajan, Shindand, Pashtun Zarghun and Herat city. In Herat city the targets included the 4th district of the Party, Karez Sufi, Olang, Sang-e-Safaid, Herat hotel anci other important districts. The mujaheddin affensives continued until late December in which 87 troops were killed, three aircraft shot down, four tanks and three vehicles destroyed and a huge 3 quantity of arms were captured by the mujaheddin. Three mujaheddin were martyred and eight others injured. Similarly in a mujaheddin attack on a convoy, six militiamen were killed and seven trucks destroyed and Afs. 21 million were seized by the mujaheddin.

* The mujaheddin attacked a squad of troops, who intended to search the houses, killing four of them and capturing four others.

* The inujaheddin attacked 27 . December the centers of the Soviet-Kabul troops in Herat city. In retaliation Soviet-Kabul troops attacked 28 December the mujaheddin positions to break through the siege as a result of which many villagers were killed or injured. Ten Communists were killed when their vehicle hit a mine. The Shindand mujaheddin shot down 27 December a helicopter and a jet aircraft. All those on board were killed.

* The Herat mujaheddin attacked 27 December the Ghaizan Hotel, KHAD office, Herat division 4-armored forces and the Dalkhchak base. Thirty Russians were killed in Ghaizan post, eight tanks were destroyed while five tanks were destroyed in other operations. Similarly, 45 persons were killed, 32 injured and six persons with their arms were captured by the mujaheddin.

* Extensive fighting between the mujaheddin and Soviet-Kabul troops took place 23,28, 30 and 31 December in Mir Daoud, Anjirak, and Galabacha, in which 16 troops were killed, 10 tanks, a vehicle and a depot were destroyed. The mujaheddin captured 50 pieces of arms and an officer, Ghulam Mahbub, with seven troops with their arms joined the mujaheddin. In the operation 35 mujaheddin and the civilians were martyred.

* In mujaheddin attacks 30 December - 1 January, in Karak and Islam Qala, 14 communists were killed and 10 kilashinkovs and a truck load of foodstuff was also captured by the mujaheddin. The mujaheddin also attacked 7 January a Soviet-Kabul center near the Soviet border.The operation lasted for 10 days during which the mujaheddin captured 10 posts.

* In their operation 12 - 21 January in the outskirts of Sabur and Rozanak, Kohsan sub division, the mujaheddin captured a truck and killed eight persons. Fifteen Soviet-Kabul troops were also killed and two mujaheddin martyred.

* In an attack on a Soviet-Kabul convoy, in Islam Qala, the mujaheddin destroyed a tank and two trucks killing four troops and capturing a machine gun.

* The mujaheddin attacked 20,23 and 30 January Russian bases in Darwaza-e-Iraq and Ghorian subdivision killing 41 troops and six officers and injuring three others, capturing seven pieces of arms and damaging a tank. One mujahed was martyred and another injured in the operation. 
* The mujaheddin launched operations 12-14 February on the Herat fourth security belt from Dasha to Babaji district liberating 9 villages. They captured foor tanks and two trucks. The mujaheddin captured 30 pieces of arms, killed nine militiamen and captured six others. Six mujaheddin were injured in the operations.

* As a result of mujaheddin activities 8 February on two posts in Ghorian sub-division an officer and eight troops were captured, three persons were killed and 26 items.of arms fell to the mujaheddin. Two mujaheddin were injured.

* In the mujaheddin activities on Herat city and Islam Qala, 31 persons were killed, 100 injured and 15 persons captured. The mujaheddin killed six persons and destroyed two tanks in Siaoshan area. They attacked during February various localities in Herat destroying four tanks and killing 18 persons.

* In these battles as a whole, 41 mujaheddin were martyred and 17 injured. Three hundred twenty three troops and officers of the Kabul regime and 30 Soviet troops were killed, 135 were injured and 35 others were captured. The mujaheddin also captured a truck, and Afs. 21 million. Forty eight tanks of the Soviet-Kabul troops and 1.5 vehicles were destroyed and two planes shot down.

\section{Kandahar}

Kandahar has been an arena of fierce and continuous combats and battles were fought 26,27 , 30, 31 December, $1,3,4,5,9,10,11,14,15,17,18,21,24,25,28,29,30$ January, 1,3,9,15,16,17 and 19 February and 2 March in different, parts of the province.

* As a result of heavy shelling 26 December on Kandahar garrison 17 Soviet-Kabul troops were killed, eight infured and two ammunition depots destroyed.

In a mujaheddin attack on the city and Mard Qala 13 troops were killed and 18 others injured. The mujaheddin captured six rifles. Two mujaheddin were martyred and three injured.

* The mujaheddin freed 9 January 35 mujaheddin who were arrested recently by Soviet-Kabul troops in Mahallajat.

* The mujaheddin attacked 26 December the office of KHAD in Kandahar city killing six KHAD activists, injuring three others and capturing six kilashinkovs. Six communists were killed and four injured as a result of mujaheddin operation in Charsoo, while on the same day 80 civilians were martyred in a bombardment by the Soviet aircraft in areas surrounding Kandahar city.

* In continued mujaheddin attacks 30-31 December and 1-2 January on Soviet bases in Mahallajat, Darra-e-Soof, Gondigan, Baba Ghazi and Karezak, 20 Russians and six Kabul troops were killed and four others injured and two tanks and arms depot destroyed.

* Soviet troops, who had retreated 30 December from Mahallajat as a result of mujaheddin resistance, once again returned 1 January to Mahallajat and attacked 4 January mujaheddin positions. The enemy was assisted by 18 aircraft in Mir Bazar and Darra-e-Soof. Although Soviet-Kabul troops sustained heavy losses they were able to sieged the Mahallajat. In the battle 25 Soviet-Kabul transport vehicles were destroyed and 600 troops killed. Yet the Soviet-Kabul troops sieged 1,500 mujaheddin and closed all routes on them. But the Arghandab and Panjwaee mujaheddin intensified their attacks on the Soviet-Kabul troops to reduce pressure on the besieged mujaheddin. The muja- 
heddin launched $14-15$ and 18 January extensive attacks on the offices of Soviet-Kabul troops and . the trenches of the "Jauzjani" militia in Deh Khawaja, Darra-e-Soof, Wazir base, Deh Mardan, Taimurian, Rambasi, Palandi, Zillakhana, Nakhooni, Qala Fatehullah; and Khanjak killing 48 SovietKabul troops, injuring 59 others, and destroying two tanks and two jeeps. Three mujaheddin were injured and six civilians martyred. Meanwhile the mujaheddin succeeded in lifting the siege of Yakh Karez, Mahallajat, and were able to enter the Kandahar city.

* As a result of mujaheddin heavy shelling on a Soviet military base, 43 Soviet troops were killed and 10 trucks destroyed.

* In the mujaheddin attack 24 January, on Mir Baz post, 9 troops were killed and 12 persons captured while one mujahed was martyred and another injured.

* In a mujaheddin attack 28 and 29 January on posts of Haji Baqi, Qalacha, Bazar Shekarpur and Mahallajat, 11 militiamen were killed, a number of others injured and two mujaheddin were martyred and 9 others injured. Seven buildozers were destroyed as a result of explosion of mine planted by the mujaheddin. .

* While fierce battle continued in Mahallajat, Kandahar, the Kabul Defense Minister with 230 troops arrived 27 January in Kandahar to launch a counter offensive. However after loosing six officers, the rest of the troops fled and only 15 were reported to have survived.

* In the mujaheddtn operation 29-31 January and 2 February on Chawk-e-Dand, Pashtun Bagh and Majani posts, 18 Soviet-Kabul troops were killed and 9 others injured.

* In a mujaheddin attack, 21 January, on Zhara Spinboldak, a tank, four trucks, a heavy gun and three enemy trenches were destroyed and five officers and troops were killed while a government building was also destroyed.

* In the mujaheddin attacks 27 and 30 January and 1 February on Shabul and military headquarters at Teachers School, 19 troops, including Chief of the headquarters, were killed, and a jeep and two heavy guns were destroyed. In the operation two mujaheddin were also martyred.

* Kabul troops entered 12 February Panjwaee but, as a result of mujaheddin resistance, 30 militiamen were killed, four tanks and three trucks destroyed and communists forces had to retreated. In the battle three mujaheddin were martyred and seven others injured.

* In their attacks 14 February on the KHAD office at Kandahar city, Karezak, Shorandam, and "The Company", the mujaheddin killed four Soviet advisers and $18 \mathrm{Kabul} \mathrm{troops,} \mathrm{one} \mathrm{tank} \mathrm{and} \mathrm{nine}$ trucks were destroyed while one mujahed was injured.

* The mujaheddin carried out $10,14,17$ and 19 February operations on government military posts in Tor Ghar and Maiwand sub-division.

* A mujaheddiri group reached the wall around Kandahar prison and by throwing hand grenades killing 13 troops who were busy in military drills in their operation in other areas, 90

Soviet-Kabul troops were killed, an aircraft was shot down and damages were caused to another plane. Three trucks were destroyed and two mujaheddin were injured in the attack.

* As a result of mujaheddin attack 20 February, on a regime post.near the former telecormuni- 
cation office, 15 Kabul troops were killed, and two trucks along with two machine guns were destroyed. In these operations, a mujahed was martyred and another injured.

In the Kandahar battles, 14 mujaheddin were martyred and 22 injured. Kabul lost 259 and the Soviets, 58 of their troops, 104 of their men were injured and 12 were captured. A plane was shot down and another damaged. Thirty four tanks, 41 trucks, three heavy guns and two machine guns were destroyed. Eighty six civilian were martyred.

\section{Helmand}

5. The Helmand mujaheddin attacked 27 December a Soviet base in Gereshk sub division setting ablaze 9 Soviet oil tankers on way to Kandahar from Shindand. Heavey casualties were caused to the Russians although exact details of their losses is not available. Three mujaheddin were injured. The mujaheddin attacked 23 December two trucks heading for an operation. As a result, 17 militiamen were killed and seven others captured.

Soviet troops, arriving 24 January in Helmand from Kandahar and Shindand, attacked Moosa Qala, Zamindawar, Kajaki and Sangin. The troops which had come from Shindand were attacked by the muJaheddin in Landi Nawa of Moosa Qala.

Another two units arrived 24 January from Kabul and Lashkargah to reinforce the troops. Besides battles on the ground, in which 1,000 tanks and vehicles took part, 60 aircraft and helicopters also bombarded the area. Soviet-Kabul troops not only bombarded the mujaheddin positions, they also attacked the villages. The Soviet-Kabul troops intended to construct posts for conquering the Kajaki electric dam that had been under the mujaheddin control for the last eight years. In these attacks all mujaheddin supply and communication routes were blocked. But a number of mujaheddin were able to retreat north. According to reliable reports, 24 January - 1 February, as a result of stiff resistance offered by the mujaheddin, 30 tanks and transport vehicles of the Soviet-Kabul troops were destroyed and an aircraft was shot down in Moosa Qala. The mujaheddin surrounded the area around Kajaki and broke off the siege around the mujaheddin positions. Heavy losses in men and material were inflicted on the Soviet-Kabul troops but there was no authentic report available about it. In these operations 23 mujaheddin were martyred and 70 injured. In the continued fighting, a helicopter was shot down 28 January in Raig and another one in the northern area 7 February.

* The mujaheddin attacked 16 January the Lashkargah airport and some security posts causing damages to the airport building and 29 militiamen were killed and 11 others captured in the posts. Thirty three pieces of light and heavy arms were seized by the mujaheddin and two posts were also captured. Two mujaheddin were martyred and seven others injured.

* The mujaheddin attacked 28 January a Sovlet convoy heading towards Herat 60 kilometers from Geresihk setting ablaze a tank and five trucks,killing 21 Russians and injuring 14 others. Two mujaheddin also sustained injuries. The mujaheddin also eliminated 24 January two Soviet tanks with rocket fire in Kohk-e-Chopen, the Maiwand sub division.

* The mujaheddin attacked during February Qala Bust killing 14 Soviet-Kabul troops and four mujaheddin were also injured.

* Continuous fighting took place $23,21,24$ and 28 February between the Afghan mujaheddin and 
Soviet-Kabul troops in Shorki, Sangin, Baba Faqir and other places as a result of which 90 communists were killed and four others captured. Similarly, seven tanks were destroyed while seven mujaheddin were injured.

In these battles, a total of 25 mujaheddin were martyred and 93 injured. Sixty nine Kabul troops and 21 Russians were killed, 14 Russians were injured and 22 Kabul troops captured. Three aircraft were shot down, 16 tanks and 21 vehicles were destroyed and 33 pieces of light and heavy arms were seized by the mujaheddin.

\section{Nangarhar}

6. The mujaheddin carried out bomb explosions 31 December, 2 January and 7 January in Jalalabad airport and rocketted southern Jalalabad damaging a tank and a truck. There was no authentic report on the details of human losses. Similarly, in mujaheddin attacks 8 January in Rodat six troops were killed and 40 injured. A woman was martyred as a result of Soviet-Kabul bombings of the area.

* The mujaheddin shot down 31 December a helicopter in Surkhroad.

* The mujaheddin carried out operations 21 and 22 January in Enzarian, Nazian, Waley and Taro. Details of Soviet-Kabul troops, losses have not been ascertained but two mujaheddin were martyred and 12 others injured.

* The mujaheddin destroyed 23 January thiree Kabul regime tanks in Garo, Shinwar, and carried out attacks 27 January on Haska Meena posts of Shinwar. Although exact details of the losses were not known, communist picked up their dead and injured by helicopters.

* On the occasion of the anniversary of the invasion of Afghanistan by Russia, the mujaheddin attacked 27 December the Hesarak sub-division killing 9 persons and injuring 9 others. Also a tank and a heavy gun were destroyed. The Surkhroad mujaheddin attacked 28 December enemy forces who were planning to attack mujaheddin positions. In the mujaheddin attack, a tank, a truck and a wireless set were also destroyed.

* The mujaheddin attacked 14 January the Mohmandara and Basol posts killing two officers and a soldier and capturing four pieces of arms.

* The mujaheddin attacked 13 February a military convoy in Shinwar sub-division destroying four tanks and killing 14 troops.

The mujaheddin attacked 16 February Soviet-Kabul posts in the outskirts of Biwa-e-Kando and Shpolis Shinwar, killing 30 communists and destroying seven tanks while two mujaheddin were martyred and four others injured. Similarly, the mujaheddin carried out operations 24-26 January In Shinwar as a result of which five troops were killed and eight others with their arms joined the mujaheddin. The Kabul regime aircraft bombarded 24 February Abdul Khel, Bandar, Acheen, and Nazian martyring two persons.

* The mujaheddin attacked 3, 16 and 17 March Soviet-Kabul posts in Kano Ghunday and Kama Daka. The Kabul regime aircraft bombarded Balabagh, Surkhroad sub division, martyring or injuring a large number of civilians, mostly women, children and old men. In these fightings, the mujaheddin captured 10 pieces of arms.

* The mujaheddin attacked 21, 22, 25 and 27 January Haska Meena,Jalalabad airport, Landi Shinwar, Ghanikhel, Sarobi, Todachina, Gulalai, and Surkhoroad killing 41 Soviet-Kabul troops, in- 
juring seven others, downing two aircraft, and destroying a tank, a heavy gun, two mortars and a depot; two mujaheddin were martyred and three others injured in these operations.

* The mujaheddin attacked 24 December the Mamakhel security posts killing 18 militiamen and destroying 11 posts. The mujaheddin captured 19 pieces of various types of arms. Three mujaheddin were martyred and eight injured.

* In these battles, 12 mujaheddin were martyred and 31 injured. Similarly, 173 Soviet-Kabul troops were killed and 17 injured while 18 tanks, two trucks, four heavy guns, a wireless set and a depot were destroyed and three aircraft shot down. The mujaheddin captured 11 posts and 29 pieces of arms and eight troops with their arms joined the mujaheddin.

\section{Parwan}

7. The mujaheddin eliminatied 26 December a big Kabul regime military base in Onaba of Panjshir, and destroyed a communication base and a security posts, In these operations, another five posts were also wiped out. Fifty troops were killed and 145 persons captured by the mujaheddin. Five tanks were destroyed, 154 pieces of arms and 13 wireless sets were captured. Twenty mujaheddin were martyred and seven others injured.

The mujaheddin attaaked 3-4 February the military bases of the Soviet-Kabul troops in Salang highway, and $\mathrm{Najrab}$ kIlling 46 troops and three KHAD officials and two tanks were also destroyed.

* The mujaheddin carried out operations 17 February on posts in Noman school and Charikar city and in operations 12 and 14 February, in Gulbahar and its outskirts, two posts were destroyed. Four persons were killed and 15 others captured in the operations. The mujaheddin also captured four kilashinkovs, an anti-aircraft gun and a wireless set.

* The mujaheddin attacked 27 December the centers of the Soviet-Kabul troops in Sanjed Dara destroying 37 transport vehicles.

* In these battles seven mujaheddin were martyred and 20 injured. One hundred three SovietKabul troops were killed and 160 captured. The mujaheddin captured 159 pieces of arms and a wireless set and destroyed 39 tanks and transport vehicles.

\section{Logar}

8. The mujaheddin attacked 7 January a convoy of the Soviet-Kabul troops in Kulangar, killing 10 troops and destroying two tanks and two trucks.

* Another round of fighting broke out in the middle of January between the Afghan mujaheddin and Soviet-Kabul troops in Kulangar, killing 40 troops and destroying two tanks.

* Kabul Soviet troops attacked and killed 4 February a group of passangers travelling towards the Iogar sub-division. The mujaheddin, who were busy in a funeral rites, later attempted to reach the area but were blocked by Soviet-Kabul troops in Ziarat-e-Sheikh Wali. In a fierce battle two mujaheddin were martyred and six others injured. Russian casualties could not be ascertained. The exact number of passengers massacred could not be known. The vehicle was also set ablaze. Later Soviet planes carried out intensive bombardment of the area, but exact details of the losses caused in the bombardment could also not be known.

* In Logar combats, two mujaheddin were martyred and six injured. At least 50 Soviet-Kabul troops were killed, two tanks, two trucks were destroyed and financial losses were caused to them. 


\section{Farah}

9. A Soviet-Kabul military truck was blown up 2 January as a result of the explosion of a mine planted by the mujaheddin in Jowain. In the incident, 10 troops, including two KHAD officers, Mohammad Nasim and Mohammad, were killed.

* Soviet-Kabul troops, who had come to Jowain for a house-to-house search, faced stiff mujaheddin resistance and in the fighting between the mujaheddin and the Soviet-Kabul troops, 15 troops were killed and two tanks and a track were destroyed. One mujahed was martyred and two others injured.

* The mujaheddin attacked 27 January a project near Sarnak River, killing 43 troops and destroying a tank and two trucks. In another operation the mujaheddin killed 21 Kabul regime militiamen.

* The mujaheddin attacked 24 December a convoy in Delaram killing 35 troops, destroying three tanks and two trucks and capturing five pieces of arms.

* Soviet-Kabul forces bombarded 13 February a village near Delaram converting the village into debris and martyring its inhabitants. This bombardment by the Soviet-Kabul forces was in retaliation of the mujaheddin operation in which 30 Soviet cormandos were killed and three others injured.

* Forty two militiamen of Qala Sheran post; in Balablook joined the mujaheddin 23 January. The mujaheddin attacked 7 January a communist center in Gilestan killing eight and injuring four others. Seven troops with their arms defected to the mujaheddin. In the battle, a mujahed was injured.

* The imujaheddin attacked 8 February a post in Dezak, Balablook capturing 28 militiamen, 30 rifles and a machine gun.

* The mujaheddin attacked a post in Gulestan sub division during December-January killing eight troops.

* The mujaheddin attacked with rockets 23 February a Soviet base in Fararoad destroying a tank and a truck.

* In these battles, a mujahed was martyred and two others injured. Eighty seven Soviet-Kabul troops were killed and four others injured, 28 captured and 49 surrendered to the mujaheddin. Thirty Soviets were killed and 17 injured. The mujaheddin captured 34 pieces of arms and destroyed eight tanks and 9 trucks were.

\section{Kunar}

10. The mujaheddin attacked $21,24,26$ January and $1,4,7$, and 11 February Assadabad, Pul-e-Nawabad, Chagha Sarai, Nari, the Airport, a power station, both banks of Kunar river, Aghandbagh and some other causing heavy casualties to the Soviet-Kabul troops. In a major attack on a Soviet-Kabul base in Chagha Sarai, $75 \%$ of the base, where 1,500 Soviet and 1,800 Kabul troops were deployed, was destroyed and a large number of tanks and trucks eliminated and the power station and the airport were put out of function. In other combats in that province, 275 troops and officers were killed or injured while three mujaheddin were martyred and two others injured.

* In all these battle, altogether 14 mujaheddin were martyred and 12 injured. Enemy losses were: 
14 persons killed, 10 injured, 106 captured, three tanks destroyed, 72 pieces of arms and a communications set siezed.

\section{Baghlan}

11. Fierce battles were fought 23-27 December and 1 and 13 January between the mujaheddin and Soviet-Kabul troops in the province. Major events were the fall of Borkah Garrison to the mujaheddin, the capture of Governor of Baghlan, Provincial Party Secretary and its KHAD officer. Sultan Mohammad, the governor, the Party Secretary (named not reported) and the KHAD officer Ghulam Farooq were captured 13 January in Pul-e-Khumri and later executed. In the operation in the Borka garrison, 10 troops were killed and 10 others injured, and the mujaheddin captured 100 troops and officers. The mujaheddin also captured two tanks and 72 various types of arms as well as two wireless sets. In these combats, 11 mujaheddin were martyred and 22 others injured.

* In other battles fought between the mujaheddin and the Soviet-Kabul troops, four troops were killed and six others captured by the mujaheddin. Three tanks were destroyed. A wireless set was captured by the mujaheddin. Three mujaheddin were martyred and another injured.

* In all these battles, 14 mujaheddin were martyred and 12 injured. The casualties and losses of the Soviet-Kabul troops were: 14 troops killed, 10 injured and 106 captured, three tanks destroyed, 72 pieces of various types of arms and a wireless set were captured by the mujaheddin.

\section{Bamian}

12. Combats were reported 31 December, 23 and 25 January between the mujaheddin and the SovietKabul troops as a result of which 19 troops were killed and 16 others injured. In Soviet-Kabul bombardments, a truck of the mujaheddin was destroyed and 14 mujaheddin martyred while 40 others injured.

\section{Nimroz}

13. Battles were fought 31 December and 17 January between the mujaheddin and the Soviet-Kabul troops in Charburfak, Khajeer, Zaranj and several other places. A number of posts were captured by the mujaheddin. In these battles, 18 troops and militiamen, including 11 Soviets, were captured with their anns. A desert heavy gun, a tank and a truck were also destroyed by the mujaheddin. Fifteen 15 troops with their arms surrendered to the mujaheddin and the mujaheddin also captured 13 pieces of arms.

\section{Kunduz}

14. Battles were fought 22 and 29 December and 1,5 and 16 January between the mujaheddin and Soviet-Kabul troops in Chardara, Tabakashan, Dasht-e-Arch1, Khanabad and other places as a result of which 133 troops were killed, 58 troops with their arms joined the mujaheddin, six Kabul regime transport vehicles were destroyed while five mujaheddin were martyred. In communist aircraft bombardments, two civilians were martyred and 40 camels killed in Dasht Archi.

\section{Takhar}

15. Battles were fought 22 and 26 December between the mujaheddin and the Soviet-Kabul troops in Taluqan, and Chahaab near the Soviet border killing 52 troops. Two policemen and an officer were captured by the mujaheddin. A helicopter was shot down, seven tanks and trucks were destro- 
yed and the mujaheddin captured 51 pieces of arms. Four mujaheddin were also martyred.

\section{Ghazni}

16. Fighting took place 31 December, 6 January, 25, 27 January and 8 February between the mujaheddin and Soviet-Kabul troops in the airport, Moqor, Bozak Moqor, Gardez, Sarak Ghazni, Ghazni city, Kalago and other places. The most tragic event took place in Kalalgo village which was sieged by Soviet tarks. Seven children were massacred in their homes. The Russians took 12 mujaheddin to the mosque and later blew up the mosque martyring 9 mujaheddin and injuring three others.

Thirty families who were forced to migrate to Pakistan but 11 of them were martyred and eight others injured in bombardment throughout their journey.

In other battles two aircraft were shot down, eight tanks and two trucks destroyed, 30 troops killed and 26 civilians were martyred and 35 injured.

\section{Wardak}

17. Battles were fought $1,2,6$ and 13 February between the Afghan mujaheddin and Soviet-Kabul troops in Check, Maidan, Sisi, Tanki Noor and other places. Twenty two Soviets and 13 Kabul troops were killed and seven Kabul troops injured. Fourteen tanks and four trucks were damaged. Thirteen pieces of arms and a wireless set were captured by the mujaheddin and one mujahed was martyred and four other injured.

\section{Faryab}

18. Fightings took place 22,23 December, 14, and some other dates between the mujaheddin and Kabul-Soviet troops in Maimana, Sheerin Tagab, the airport, Qaisar, Andkhoy, Daulatabad and Taimorak. According to authentic statistics four enemy planes were downed and 68 tanks and other vehicles damaged. The mujaheddin siezed 150 pieces of arms, 14 tanks and one vehicle and 213 soldiers and officers defected to the mujaheddin with their arms and 126 Kabul regime and 4 Soviet troops were captured. One hundred thirty seven Kabul regime and 20 Russian soldiers were killed and six others were injured. The mujaheddin lost 100 of their men. Among the civilians 64 people were martyred and 25 houses demolished.

\section{Badghis}

19. From 18-27 December and 22 and 25 December and 23 January clashes were reported between the Kabul-Soviet troops and the mujaheddin in Morghab, Ghormauch, Kajkal, Kala-e-Nau, Kharshan, Robat and other districts of the Badghis province, in which two enemy tank and eleven vehicles were demolished, 53 Kabul regime soldiers and eight Russians soldiers were killed and five others injured. Three hundred soldiers with their arms defected to the mujaheddin and the mujaheddin also siezed another seven pieces of arms while they themselves suffered nine dead. In these fightings twenty three civilians were martyred and 11 injured.

\section{Balkh}

20. On $23,25,27,31$ December, $5,11,18,22,27$ January and on some other dates battles were fought between the mujaheddin and Soviet-Kabul forces lasting several days in the center of the province, Seh Darak, the security post of the natural gas pipeline, Chamatal, Char Bolak, Aqcha, Sholgara, Taimorak, Laghman and Gerd Tipa. Following is a list of casualties: 
Twenty four mujaheddin were martyred and seven injured. The Kabul-Soviet force lost 373 of their men and 82 of them surrenderred to the mujaheddin. One enemy wireless and 23 vehicle were demolished and the mujaheddin captured 337 pieces of arms, three tanks and 10 vehicles.

\section{Zabul}

21. On 22,23 December 7 January and 26 February the mujaheddin and Soviet troops clashed in Ghorian and Janda and near Qalat; during which eight communist soldiers were killed and four injured. Seven of them defected to the mujahieddin. Two mujaheddin were martyred and 10 others were injured.

\section{Laghman}

22. On 27 December and 15 as well as the last week of January the mujaheddin and Soviet-Kabui forces fought battles in Surkhakan, Qarghaee, Tahana-o-Safaid, nooristan mountains and other areas of the province. One enemy aircraft was downed, five tanks and vehicles destroyed and 21 Kabul and 20 Russian soldiers were killed.

\section{Paktika}

23. On $22,27,30$ December, 1,9 January and 1 February fightings occured between the mujaheddin and Kabul-Soviet forces in Urgun, Wazey Khwa, Pacha Khan Post, Mita Khan, Khairkote and some other areas in which 24 enemy soldiers were killed and 50 injured.The mujaheddin also demolished three tanks and siezed four guns and wireless sets. Six mujaheddin were martyred and two injured during these fightings.

\section{Kapisa}

24. In the firist week of February, as a result of mujaheddin operations on enemy posts in Pahlawan Koh and Sayyad-e-Bala, 29 Kabul Soviet soldiers were killed and four captured, 17 pieces of arms siezed and one jeep was demolished by the mujaheddin. Also 27 December, 3 and 29 January, the mujaheddin in their attacks over several security posts, killed 10 soldiers and captured eight others with their arms and demolished two vehicles and capture 11 pieces of arms. Two mujaheddin were killed during these operations.

\section{Jauzjan}

25. Fightings took place between the mujaheddin and communist forces late January and February in Sang Charak, Pill-e-Ali and Aurang in which at least 200 communist troops were reported killed, five tank's demolished and at least 20 posts destroyed.

\section{Uruzgan}

26. Ori 19 Decémber, the mujaheddin attacked communist positions in Deera sub-division occupying 10 posts ard killing 15 government malitia.

\section{Badkhshan}

27. In the Darwaz sub-division of the province, the mujaheddin were reported to have captured, tried and killed a high ranking KHAD official.

\section{Chor}

28. Battles in this province occured mainly in the Shahrak sub-division 19,20 December and 18 February. In these battles one plan was downed 10 militia killed and four captured. Another battle was reported near Cheghcheran, center of the province, during which two Kabul regime soldiers were killed when the vehicle they were riding hit a mine. 


\section{MAJOR DOCUMENTS:}

() IUAM statement on the mujaheddin interim government,

(1) Biographies of the President and Vice-President of the Interim government,

IUAM statement on the political solution of the Afghanistan problem,

IUAM communique on the occasion of the anniversary of the military invasion of Afghanistan,

O. Join statement by Afghan-Pakistan religious scholars on the occasion of the anniversary of military invasion of Afghanistan,

Text of a report by international jurists on human rights situation in Afghanistan,

( ) Biographies, views and writings of IUAM leaders (Part-I),

Charters of IUAM member parties

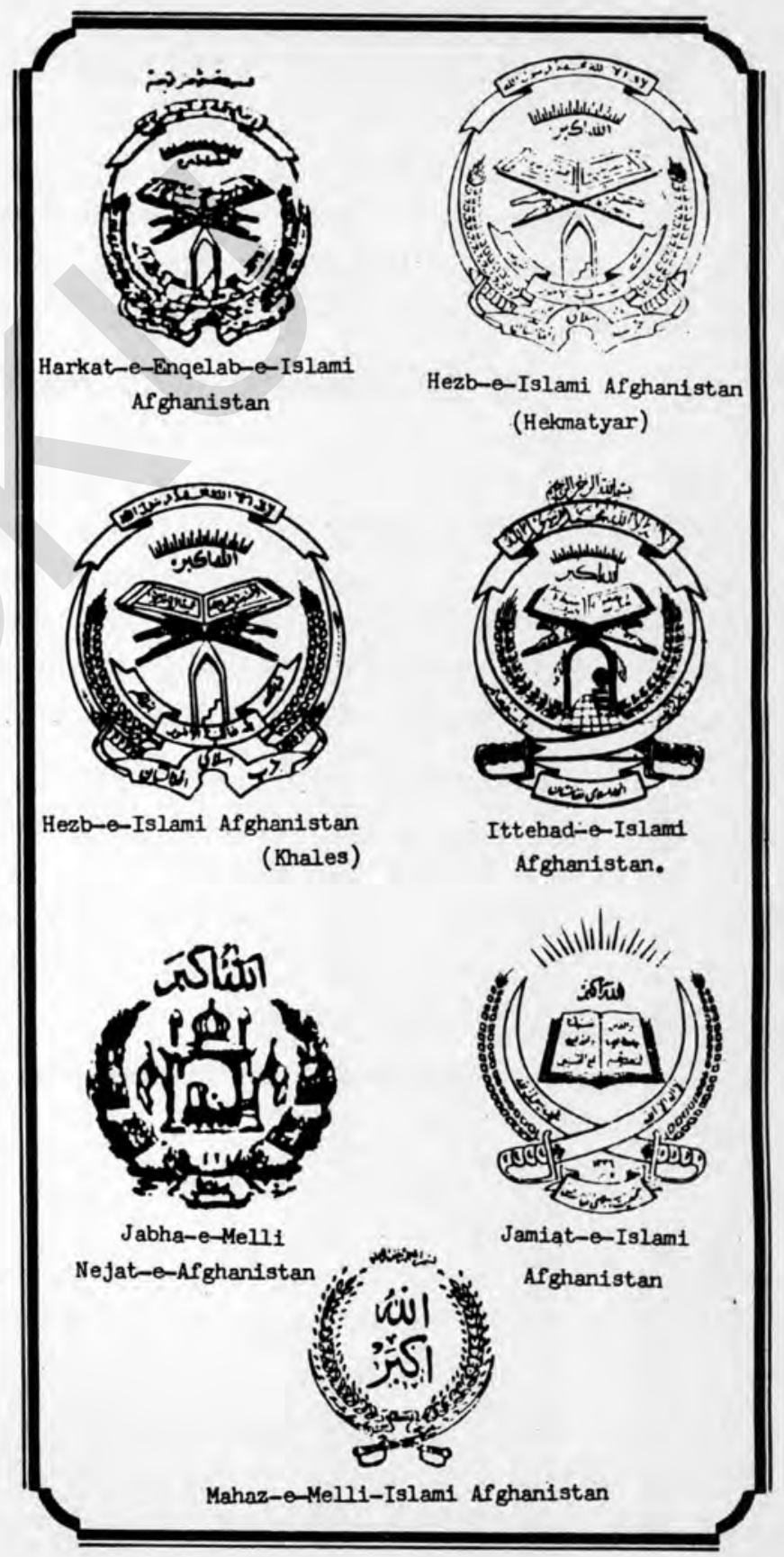




\section{January-March, 1988}

\section{AFFHAN JWHAD}

Vol.1, No.3
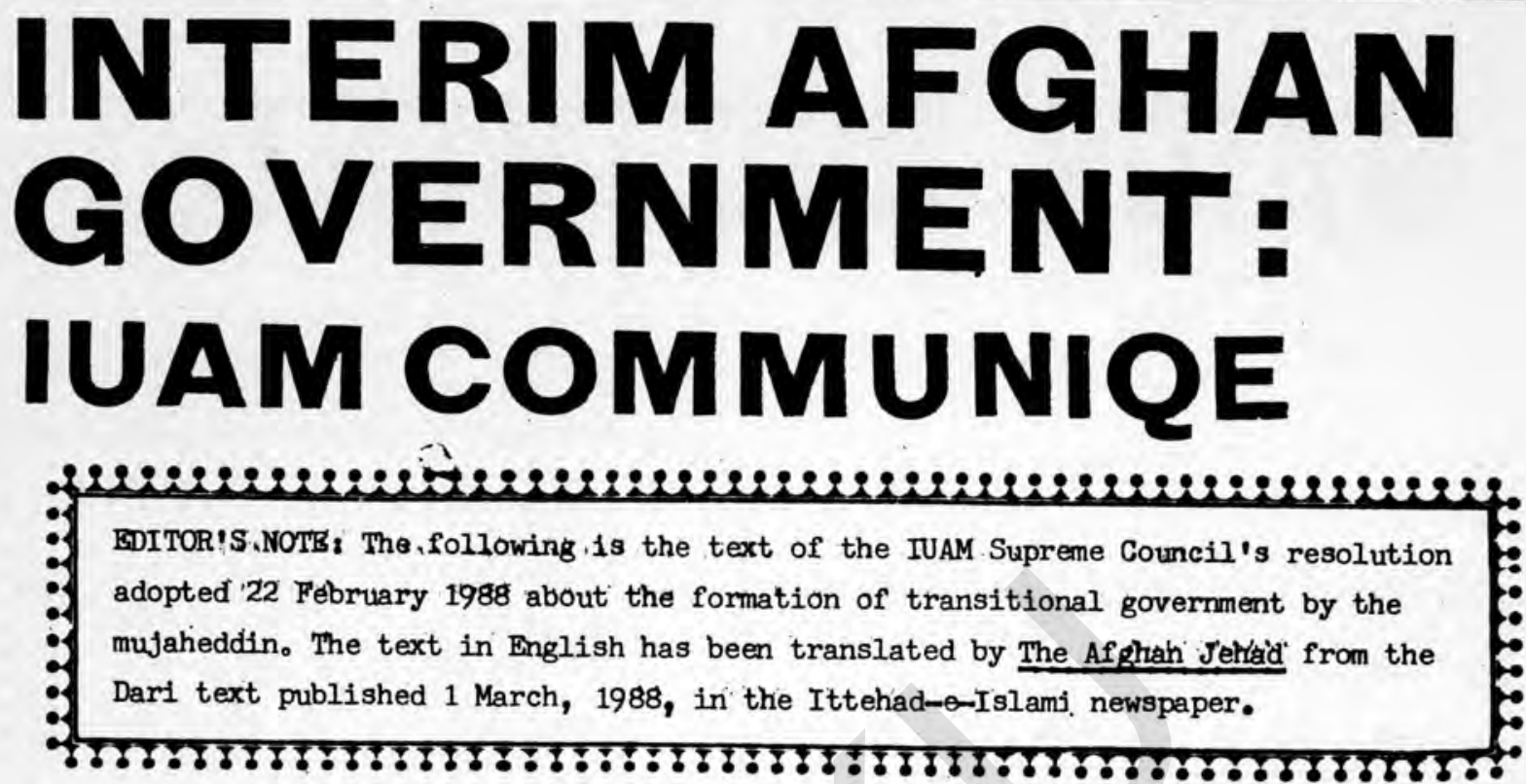

\section{IN THE NAME OF GOD, MOST GRACIOUS, MOST MERCIFUL.}

The Supreme Council of the IUAM adopted 1 March, 1988, the following plan about (the establishment of )interim government in Afghanistan: Before the conclusion of the Geneva agreement under the UN supervision, a broadly based interim government, in which all the segments of the Afghan nation are to participate, should be formed. This government will have a President - who will also serve as head of the state _ - and a 28 members cabinet. Fourteen members of this (cabinet) will be from the mujaheddin, seven of them from the mohajerrin and another seven members from among the Muslims inside Afghanistan.

Furthermore this government will have a 75 member council comprised of two individuals from each province adding up to 56 (EDITOR'S NOTE: Under one administrative count, Afghanistan is considered to have 28 provinces, not 29). One third of the members of this council, comprising of 19 persons, will be from wise (and pious) scholars. This council has the duty to work out an interim (basic) law for carrying forward the affairs of the country until the enforcement of a new (basic) law by the elected council.

Provincial agencies will be established on the basis of mutual consultations to administer the provinces.

Simultaneous with the withdrawal of Soviet forces from Afghanistan, an independent council will be established to propose a plan of election to the council (stet). The future name of Afghanistan will be "The Islamic State of Afghanistan" in which the Quran and Sumnah will be sovereign. This government will have an elected assembly and an elected President.

Also the IUAN is determined to immediately establish a commission of reconstruction and to invite all educated Afghans to apply (for positions) and to begin work afterwards in the office. This government will sign the Geneva agreement and will bear the responsibility for fulfilling its tasks including the safe return of Russian forces, provided the (Geneva) agreement is acceptable (to the IUAM). 
The interim government will pursue a free and neutral (non-aligned) foreign policy and will have friendly relations with all countries, particularly (Afghanistan's) neighbours, provided no interference taks place in (each other's) internal affairs. The supreme council of the IUAM has appointed unanimously esteemed Engineer Ahmad Shah, Deputy leader of the Ittehad-e-Islami Afghanistan, as the President of the government and (President) of the State of Afghanistan and Zabihullah Mojaddidy (Secretary General of the Jabha-Melli-e- Nejat Afghanistan) as his Vice President.

\section{President of Interim Government}

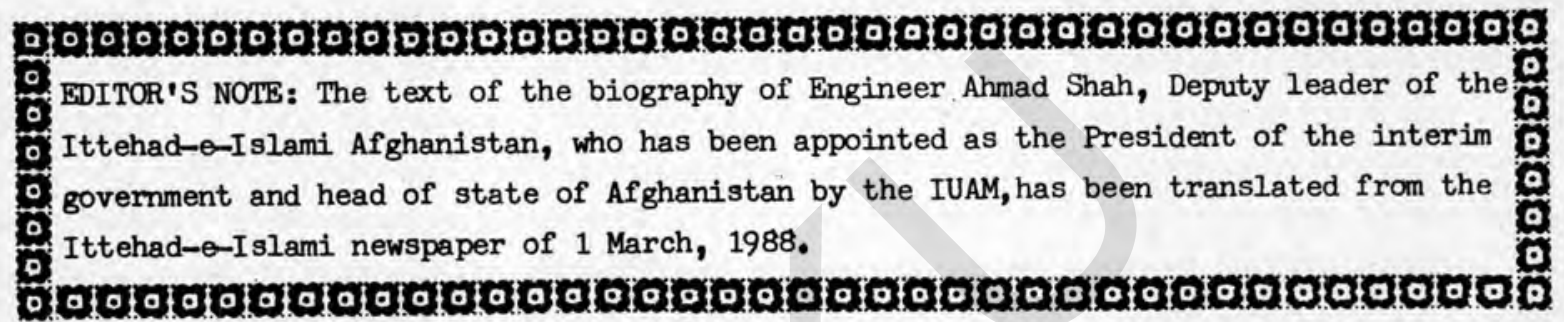

Was born in the Malang. Khurd village of the Bagrami sub-division, the Kabul province, in 1943. Completed his primary education in Khurd Kabul, his middle and high school education in the Ebn-e-Sina high school and secondary technical school in 1962. He then enrolled himself in the Engineering College of Kabul University from where he graduated four years later.

In 1968 he was enrolled in the military reserve course(to serve his term in the army), and in 1969, he was appointed as an Angineer in the Ministry of Agriculture and Irrigation. At the end of 1972, he went for higher studies to the United States under a UN scholarship and received his master's degree in dam and canal engineering. In 1976 he became a teacher at Malek Faisal University in Saudi Arabia. In 1979, he gave up his job as a teacher to participate in the Afghan Jehad, first as the deputy of the Jamiat-e-Islami Afghanistan supervising the affairs. of jehad. In the Islamic Alliance of the Afghanistan Mujaheddin, he served as President of the Committee of Education and afterwards, as President of the Financial Committee and (upto his appointment as President of the Interim Government and Head of the state), he was the deputy leader of Ittehad- $\sigma$ Islami and Chairman of its Financial Committee.

Since 1961, he has been a member of Islamic movement (Tahrik-e-Islami) and, during his studies, he participated in several international Islamic conferences and served as the executive member of the Alliance of Muslim Students。 


\section{Vice President of Interim Government}

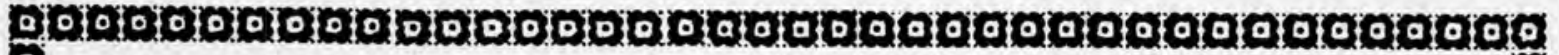 interim government set up by the IUAM, has been provided by Dr. Mojaddidy himself. The spelling of his last name is that of his own.

Was born in 1946, in the Kabul city. He is the son of Professor Sebghatullah Mojaddedr, leader of the Jabha-o-Melli Nejat Afghanistan. He finished his education at the Habibia High School and in 1966 entered the Kabul University from where, after two years, in 1968 he went to the US under a scholarship. After receiving his B.S. in Çivil engineering at the University of Hawaii in 1971, he completed his doctorate degree in engineering in 1971 from Virginia Polytechnic Irstitute and in the same year he went to Saudi Arabia to teach at the Malek Faisal University。 He was not able to return to Afghanistan because in 1973 President Daoud had captured power in a coup as a result of which the Mojaddedi family was threatened。

After the communist coup of 1978 in Afghanistan, he came to Peshawar to participate in the jehad and played a vital role in the establishment of the Jabha-e-Melli Nejat-e-Afghanistan. He served several important posts in the NLF and the three party Islamic alliance of Afghan Mujaheddin. In 1984 he was appointed director general of the Afghan National Liberation Front office in Quetta. The office was responsible for the activities of the party in 12 provinces. In 1986 he was appointed as the Secretary General of the party. Dr. Mojaddidy is a member of the Association of Muslim Scientists and Engineers (AMSE) and member of American Society of Engineers (ASCE). He has been actively involved in the advanced research in his field prior to his involvenent in the jehad and has presented professional papers at conferences on international level.

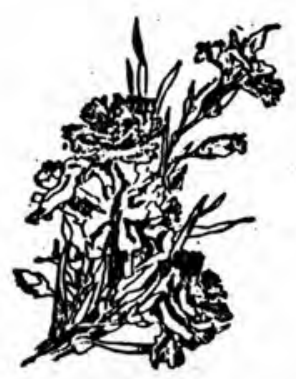




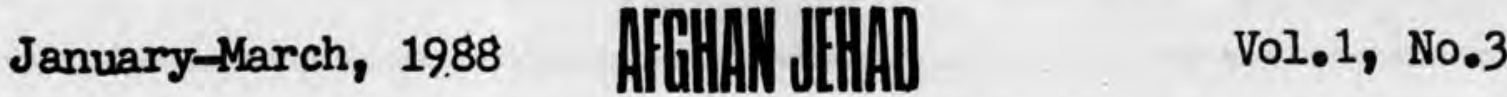

\section{Mujaheddin Statement on Geneva Parleys:}

\section{IUAM AND POLITICAL SOLUTION OF THE AFGHANISTAN ISSUE}

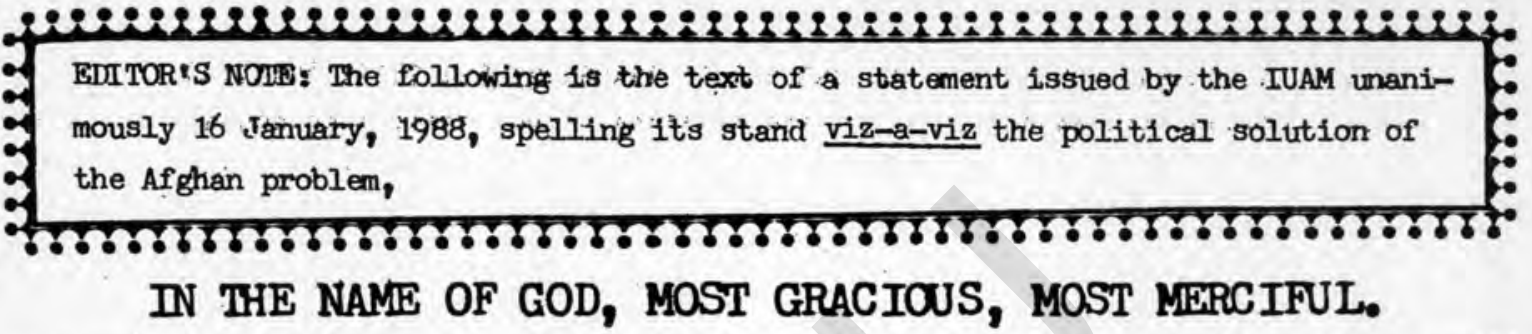

1. All mujaheddin are unanimous that, in the case of the presence of Russian troops, we will not lay down our arms and neither we will accept the government of Najib or his friends nor will agree to the right of participation by them in the government. Because they have been brought in Russian tanks and,like the Russians, have equally the responsibility for the destitution and destruction of Afghanistan. Any agreement and design leading to an acceptance of even one Russian hireling in the government, from our point of view is to serve the Russian interests and in that case we will continue our jehad.

The Afghan issue is related to our own decision and we are not going to permit any government - - Islamic or non-Islami - - to act on our behalf and in case they do so, it will be tantamount to an animosity.

2. In Afghanistan, the war is between atheism and Islam and there is no such element to be considered neither Muslim nor atheist. Rather, the entire Muslim nation of Afghanistan is mujaheddin. Therefore, to refer to so-called neutrals is tantamount to a ridicule of our cause.

3. It is clear that the government cannot be comprised of one person and neither a few people will be able to administer the government and the country. The support of a military power is essential for every government. Therefore, bringing forth a person with no military power and allowing him to rely on the Russian mercenary soldiers in Afghanistan, in itself, is equivalent to serving the Russians. Also by putting an international force under the command of a government will mean that such a government is not a government of the people and this mujahed nation will P1ght that government. If it is intended that a government ought to enjoy the support of the mujaheddin, bringing forth the very idea of (the former type of) government will be meaningless.

4. The IUAM clearly states, anybody who is imposing a specific regime or government on us is considered by us a friend (and ally) of Russia and an enemy of our jehad.

Today, some countries are trying to tie our hands in the name of peace so they may be able to fulfill their own interests and are providing a favorable opportunity for the enemy. The IUAM 
is studying this situation with utmost care because these moves are not in the interest of the mujaheddin and they are meant to support the Russians.

We will not tolerate in our jehad (such) political games and we inform all others that rendering support to an oppressor will lead the oppressor to also bring the supporter under its sway. It is not correct to fear the Russians but we should fear Almighty God.

5. In short, the solution of the Afghanistan issue is dependent on the immediate, complete and unconditional withdrawal of Russian forces and on the transfer of the task of formation of government entirely to the Muslim and mujahed nation (of Afghanistan) which is their right and, for reaching this objective, we will continue our struggle and jehad. 


\section{December 27 Meeting}
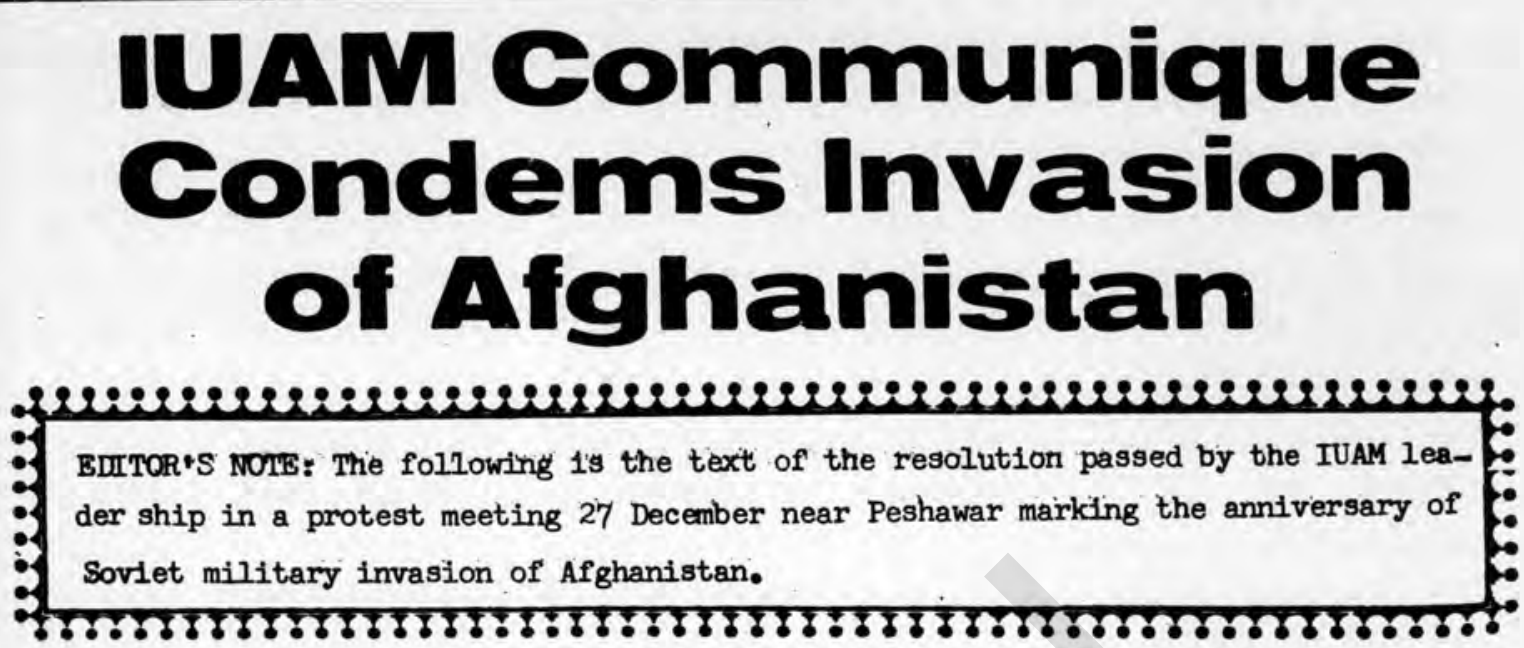

IN THE NAME OF GOD, MOST GRACIOUS, MOST MERRCIFUL.

Fight them and God will punish them by your hands, cover them with shame, and help you (to victory) over them and heal the breasts of believers (The Holy Quran). The Afghanistan issue has come about as a result of the direct intervention and aggression by the Russians. The Russians, by committing this savage and shameful aggression, have not only eliminated the political independence of Afghanistan but, contrary to international norms, have also violated human rights in Afghanistan and thus they have posed a great danger to the security of the region and the world.

The present continuous and prolonged jehad of Afghanistan against Soviet occupiers is the result of the victorious uprising of our valorous and Muslim people. The jehad has started for the sake of defending the sanctities of our faith and country and bas been continuing with perseverance and bravery until the threshold of victory. Although this jehad have meant for our mujahed and faithful nation the martyrdom of 1.5 million and the inury and disableness of millions of widows and orphans and the migration of more than five million from aur beloved country and the internal migration of millions of others of our compatriots, whth the grace of Almighty God, and the perseverance and sacrifice of our mujahed and heroic nation, this savage and world devouring power has been brought down to its knees and, with the help of the awakened conscience of the world, Russia has also been brought to shame at an international level.

Inside Afghanistan, as a result of the crushing blows of the mujaheddin of the righteousness, the Russians have been forced to give-up their offensive posture and to assume a defensive role.

In the past, the Russians would attack the blood stained trenches of the mujaheddin but now the fragile trenches of the Russians are being subjected to the brave attacks of belleving mujaheddin.

The Russians, because of the fear of the mujaheddin, have now confined themsalves at their onn choice and have planted protective mines around their military bases. However the mujaheddin - this army of Almighty God _ - find their way over these bases, despite stiff resistance (by the enemy). 
The Russians in Afghanistan have not refrained from using any kind of savagery and destructive weapons. But, despite this, the situation and conditions are favoring our mujahed nation and prospects for the definite victory of our heroic mujaheddin are becoming clearer.

In the political arena, for the sake of deceiving the people, the Russians have foresaken their puppets (in Kabul), changed their filthy and red communist flag and raised the voice of Islam from the throats of their atheist hirelings.

Also the unilateral ceasefire, the NRP, the convening of the faked loya jirgah and the approval of the so-called Constitution have been among the forgeries that the Russians had recently embarked upon in the field of political activities. However, these snares have brought nothing but shame and disgrace for them.

While the Russians have attacked our country with 150,000 armed troops and have drawn it into blood and tears and still their destruction and aggression continue, under such circumstances, a ceaserire is, indeed, meaningless.

From our point of view, agreeing to a ceasefire would, in fact be equivalent to accepting (the existence of) Russians in Afghanistan.

The NRP plan was coupled with scandal and disgrace from the very start because there is no civil war in Afghanistan for the stopping of which we would need understanding and conciliation among the parties.

In Afghanistan, there is a war between the Russians and Afghans. A handful of Khalqi and Parchami puppets are no more than people lacking their own will and they are nothing but servants who have no authority to make (a) decision (of their own). Supposedly if there is to be compromise and reconciliation, it should be with Russia while it is obvious that the Russians are neither our conpatriots nor any compromise with them is under contemplation.

Similarly, while the Red Army is actively fighting with the oppressed people of Afghanistan, convening of the so-called loya Jirgah and approval of a constitution is actually not acceptable under a Russian pressure. Only the kind of a firgah could be convened which the Russians thenselves desire and only a law could be enacted which will serve Russian interests.

While a fussian occupying army is in Afghanistan, while one third of the population of the country live in exile and while $90 \%$ of the territory of the country has not only been liberated but is directly administered by the mujaheddin and all the affairs of the people, including judicial activities, schools and hospitals are run by the mujaheddin, launching of the loya jirgah and constitution propaganda will only bring about the disgrace and ignominy (of the enemy). Similarly, the Russian proposed plan for the formation of a coalition government is a manifestation of the final stages of their ignominity and shamelessness. How is it possible that our believing nation will form a coalition government with their!murderers who, accompanied by kussian tanks, came into Afghanistan and, during this long war, massacred the oppressed Afghan nation and turned them Into wenderers?

Milighty God and the clean blood shed by our dear martyrs have also disgraced the Russians at the international level and, despite their efforts, aimed at confusing world public opinion, because human conscience has still not become numb, a record number of the members of the UN General Assembly roted against the Russians. 
The Geneva talks, which is not attended by the real parties of the issue, have already been described as futile and a waste of time. These talks, contrary to the UN Charter, is continuing to serve Russian interest. Until a decision is not made on the basis of the desire and aspirations of the believing mujaheddin, and the right to self determination is not delegated only to our nation, such conferences or meetings cannot have positive and desired outcome. Until now, no practical step seems to have been taken to induce a pull-out of Soviet troops. In our view, for such an action the first step will be a Soviet readiness to directly hold talks with the mujaheddin. The IUAM, which is the only representative and advocate of the mujahed nation of Afghanistan, proclaims that it is ready to carefully examine a Russian proposal for direct talks with the mujaheddin. However, we have resolutely decided that our armed resistance will continue until:

1. The Russians pull out of Afghanistan without any conditions and immediately,

2. the political independence, territorial integrity and all the rights of our people are achieved,

3. the genutine Islanic onder has been established,

4. our people have attilned their right of self determination without foreign pressure and threat,

5. as the Afghanistan mujaheddin have alone successfully continued a war against the Russian super power and they have liberated $90 \%$ of the territory of the country and have activated in these areas thousands of schools, hospitals and judicial courts, simultaneous with the withdrawal of the Russian troops, the future government of Afghanistan is also formed by the mujaheddin, and

6. we are not only against the (existence) of Russian forces inside our country and are resisting them but any aljen force - - under any pretext - - that enters our country will be considered as an aggressor. Our believing people have the power to maintain security in the country after the withdrawal of Russian troops. While we offer our gratitude to our neighbouring countries, specially Pakistan and to Islamic countries as well as to the entire peace-loving world which have helped us move aheads towards our goals, we are requesting the entire humanity and defenders and supporters of righteousness to cooperate and help our oppressed nation in all material and moral spheres and to increase their political and economic pressure on the Russians to withdraw their troops without any conditions from Afghanistan at the earliest. From God comes the help and victory is near ,

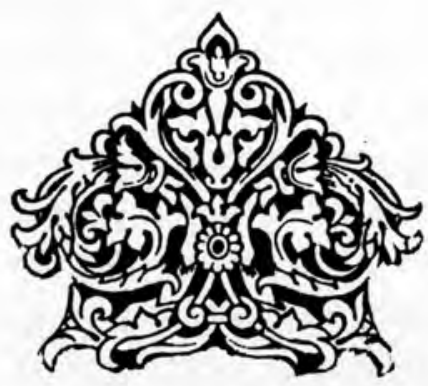




\section{January-March, 1988}

Vol.1, No.3

\section{Afghan-Pakistani Ulama Issue Communique on Soviet Invasion of Afghanistan}

The following is the text of Joint declaration issued by the religious scholars of Pak-
istan and Afghanistan on the eve of the 9 th anniversary of the Soviet invasion of Afghan-
istan, 27 December.

In the name of God, Most Gracious, Most Merciful

Those who believed and adopted exile and fought for the faith with their property and their persons in the cause of God as well as those who gave (them) asylum and aid - - these are (all) friends and protectors of each other (The Holy Quran).

It is the ninth year that the Soviet Union has occupied the Islamic territory of Afghanistan in sheer violation of international rules and (good) neighbourly norms. With their tanks, heavy guns, bombs and other sophisticated weapons, the Russians have destroyed thousands of mosques, schools, villages and houses. Almost 1.5 million people, including religious scholars, spirituals, children and elderlies, have been blood-bathed to martyrdom and the blood of a huge number has been also shed In the dark dens of the prisons. About 90,000 Muslims are yet kept in jails. It is also not a hidden fact that more than five million Afghans have fled their beloved homeland and compelled to migration. With such oppressive measures, the Soviets have been trying to eliminate Islamic values and characteristics in Afghanistan and to replace them with athelst and communist system which would mean only worship to Lenin and communization of "women, wealth and land". Fortunately, by the grace of Almighty God, the courageous and brave Afghan nation has offered a stiff resistance against the Soviet aggression and the Muslim Afghan nation has rendered sacrifices of men and material during these nine years. One who has bowed his head before God Almighty, cannot knee down to any Pharaoic and satanic power. The world people have witnessed that by the virtue of the uprising of this valorous nation, the Russians not only have been faced to defeat in all fields but the entire world has also admitted that the Russian (superpower) "might" could not stand against an unshakeble faith. Now, when the Afghan Muslim nation has reached a sensitive and important phase of its resistance, the Soviets and their puppets once beat the drum of the NRP, at another time harp the tune of a cease-fire and then they switch over to the song of a loya jirgah. But the Afghan Muslim nation fully understands that these are all tantamount to betrayal tactics and, in accordance with the God Almighty's dictates, "fain would they extinguish God's light with their mouths, but God will not allow (this) but that His light should be perfected, even though the umbelievers may detest (it)'(The Holy Quran). The deceits and tricks of the infidels cannot resist the (power of) faith and belief and Almighty God would definitely spread His light. 
So,on this basis, we the religious scholars of Pakistan and Afghanistan unanimously with all unity condemn the Soviet military intervention against Afghanistan and resolve that:

1. While reiterating our previous verdicts, we resolve that the Afghanistan resistance is completely an Islamic crusade against infidelity and atheism and participation in this holy crusade and a support of this resistance are the duty and obligation of all the Muslims,

2. On the basis of Mold fast, all together by the Rope which God (stretches out) for you and be not divided among yourselves" (the Holy Quran), we consider unity among the Muslims and particularly among the mujaheddin as vital. We support and call for strengthening the (present) unity which has been brought about among the mujaheddin by electing a single leader after successive efforts,

3. We assure the mujaheddin that their holy crusade is a success and will emerge triumphant. You enjoy the support of Almighty God and the support of all the Muslim world,

4. We warn the Russian imperialism to immediately withdraw its troops from Afghanistan onconditionally,

5. We warn all the anti-Islamic powers to refrain from every type of interference in Afghanistan and let the Afghan nation form their own government which would be completely Islamic,

6. At this sensitive juncture we appeal to all the Islamic governments, nations and people from all walks of life (religious scholars, preachers, politicians, journalists, etco) to discharge their obligation in respect to the Afghan Muslim nation and further their existing commitment until the establishment of an Islamic government in Afghanistan,

7. We will observe Afghanistan resistance week from 21 December to 27 December, 1987, and during this week, we will stage grand meetings all over Pakistan, including the refugee camps, and the preachers at the grand mosques will deliver speeches on Afghanistan resistance in their Juma sermons.

SIGNED BY: 1. Mawlana Binnori (Mohammad Ayub Binnori), 2. Mawlawi Mohammad Gul, Member, Scientific Research, 3. Qari Faizullah of Samangan, 4. Sayyed Qambar, 50 Mawlawi Gul Mohammad, 6. Mawlawi Mohammad ullah, 7. Faqir Mohammad Ayub, 8. Sahebzada Mohammad Yaqub, Preacher, Grand Mosque, Peshawar, 9. Mawlawi Mohammad Ibrahim, 10, Mawlawi Taj Mohammad, 11. Mawlawi Mohammadullah Member, Islamic Research, 12. Abdullah Ezam, 13。 Mawlana Qari Fayyazurrehman, 14. Qazi Mohanmad Yasin, 15. Mohammad Hassan Jan, Society of Isralululum, Peshawar, Sadder, 16。 Mawlawi Habibullah Sufizada, 17. Mawlana Abdul Rahim Chitrali, 18. Mawlawi Moosa Jan, 19. Mawlawi Mohammad Omar, 20. Mawlawi Ahmadullah Paghmani, 21。 Mawlawi Abdul Rahim, 22. Mawlana Mohammad Nizam, 23. Mawlawi Fazl-e-Hadi Shinwari, 24. Mawlawi Shaista Khan Wardak, 25. Mawlana Abdul Hannan, 26. Mawlawi Mohamad Dost, 27. Mawlawi Hazrat Khan, 28. Mawlawi Abdul Razzaq, 29. Mawlawi Waqaitullah, 30. Mawlawi Kamaluddin, 31. Mawlawi Mohiuddin, 32. Mawlana Abdul Hadi, 33. Mawlawi Sher Akbar Midani, 34. Mawlawi Mohammad Yusuf, 35. Mawlawi Mohammad Azam. 


\section{January-March, 1988}

1. In order to assist governments considering the question of the current state of human rights in afghanistan, the Independent Counsel on International Human Rights present this report on their recent inquiries in this area.

I. Background of The Independent Counsel on International Human Rights

2. The Independent Counsel on International Human Rights is an independent ad hoc multinational panel of experts in international law. In particular, the members of the group are scholars who have special expertise in the law of international human rights, especially humanitarian law.

3. Professor Goran Melander'is Assistant Professor of International Law the University of Lund in Sweden and Director of the Raoul Wallenberg Institute of Human Rights and Humanitarian Law. Professor Melander has written articles and books on the subject of human rights law, with particular emphasis on refugees. He has made many trips to Africa and Asia to assess conditions in refugee camps against international legal standards.

4. Professor W. Michael Reisman, another member of the Independent Counsel on International Human Rights, is Hohfeld Professor of Jurisprudence at Yale Law School in New Haven, Connecticut, U.S.A. Professor Reisman has published many articles and books in the field of human rights and international law. He has also been an expert witness on international legal issues before numerous U.S. and international judicial bodies.

5. Miss Francoise J. Hampson is a Lecturer in Law at the Centre of International Human Rights Iaw at the University of Essex in the United Kingdom. She did her postgraduate work in international law and armed conflicts and has written on various subjects in the field, including works on mercenaries and international crimes. Professor Hampson regularly presents cases to the Buropean Commission of Human Rights.

6. Dr. Mark A. Miggiani is a lawyer in private practice in Malta. In addition to his post-doctoral work on the laws of booby-traps and mines at the Institut de Hautes Etudes Internationales in Geneva, Dr. Miggiani was the rapporteur of the United Nations Conference on the Removal of War Remnants from North Africa.

7. The staff of the independent counsel on International human rights consists of Charles H. Norchi and James $\mathrm{J}$. Busuttil. Mr. Norchi, who directs the project, is currently visiting scholar in residence at Yale Law School in New Haven, Connecticut, USA. He has studied widely in the area of international human rights and has visited Southwest Asia on many occasions. Mr. Busuttil, the rapporteur of the project, is an attorney in private practice with the law firm of Porter and Travers in New York city, specializing in international matters. Two research associate, Rebecca Thompson of Canada and William R. Sims of the United States, and an Afghan interpreter, Moossa Rafey, have also assisted the independent counsel.

\section{Scope and Nature of Inquiry}

\section{A. Legal Terms of Reference}

8. It is apparent that the human rights situation in Afghanistan is a complex one. The state of armed conflict which exists in many parts of the country and the fact that the country is effectively closed to world media makes a 
general analysis of the status of human rights problematic. Nonetheless, questions have been raised by international institutions, including the United Nations and certain non-governmental organizations, such as Amnesty International, about the adequacy of the protection of fundamental human rights in Afghanistan and a number of disquieting reports concerning the situation have been published. The independent counsel is concerned about violations of human rights and humanitarian law by anyone, including governments and opposition groups. Governments have the responsibility for dealing with such abuses, acting in conformity with international standards for the protection of human rights and humanitarian law.

9. The special rapporteur on Afghanistan appointed by the United Nations Cormission on Human Rights has provided much needed information on the situation in Afghanistan. However, his visits to the area, most recently including a stop In Afghanistan have been brief and his access to persons limited. In their inquiry into the state of human rights in Afghanistar, the independent counsel have sought to provide a broader perspective than can be provided by a single individual working within certain constraints and with only limited time and resources.

10. Disagreement is possible concerning what constitutes the full spectrum of internationally protected human rights which should be avallable to the Afghan people. This disagreement arises in part because of the state of armed conflict which exists in Afghanistan. The scope and content of certain internationally protected human rights may be open to some legitimate debate, but it is also beyond doubt that there exists a core of rights from which no derogation is possible without censure. The Independent Counsel wished to limit themselves to those fundamental rights which apply in the current Afghan context without any question. As its point of departure, and as its main reference, the Independent Counsel therefore adopted Cormon Article 3 of the Geneva Conventions of 12 August, 1949, the relevant text of which follows:

In the case of armed conflict not of an international character occurring in the territory of one of the High Contracting Parties, each Party to the conflict shall be bound to apply, as a minimum, the following provisions;

(1) Persons taking no active part in the hostilities, including members of armed forces who have laid down their arms and those placed hors de combat by sickness, wounds; detention, or any other cause, shall in all circunstances be treated humanely, without any adverse distinction founded on race, colour, religion or faith, sex, birth or wealth, or any other similar criteria.

To this end, the following acts are and shall remain prohibited at any time and in any place whatsoever with respect to the above-mentioned persons;

(a) violence to life and person, in particular murder of all kinds, mutilation, cruel treatment and torture;

(b) taking of hostages;

(c) outrages upon personal dignity, in particular, humiliating and degrading treatment;

(d) the passing of sentences and the carrying out of executions without previous judgment pronounced by a regularly constituted court affording all the judicial guarantees which are recognized as indispensable by civilized peoples.

(2) The wounded and sick shall be collected and cared for.

11. Although Conmon Article 3 of the 1949 Geneva Conventions does not need much elaboration, it is appropriate to sketch quickly its terms. The scope of application of Common Article 3 is to armed conflicts which are not of an interna-. tional character. The fundamental safeguards which it provides and from which no derogation is possible have been accepted by the 165 States which have ratified the Geneva Conventions. The basic tenet of Common Article 3 is the affirmative obligation to treat humanely all persons taking no active part in hostillties. Among the outstanding features of Comnon Article 3 applicable to the Afghan situation is 1 ts prohibition of torture and extrajudicial executions.

12. In addition to Common Article33, certain other provisions of international humanitarian law and of international human rights law applicable during times of Independent Counsel. Two of the fundamental customary principles of international humanitarian law which have also been enshrined in the Regulations annexed to the 1899 Hague Convention and the 1907 Hague Convention are that parties to an armed conflict do not have an unlimited choice of methods and means of warfare and that the use of weapons which are calculated to cause unnecessary suffering is prohibited. As these customs developed at a moment in time when hostilities were conducted exclusively between sovereign, independent states, the Independent Counsel have therefore kept in mind that these norns do not necessarily apply automatically in their totality to the Afghan situation; similarly for the provisions of the 1925 Protocol for the Prohibition of the Use in 
War of Asphyxiating, Poisonous or Other Gases (especially as it relates to the use of chemical warfare against civilian populations) and Protocol II to the 1981 United Nations Convention on Prohibitions or Restrictions on the Use of Certain Conventional Weapons Which May Be Deemed to be Bxcessively Injurious or to Have Indiscriminate Bffects (which relates to the use of mines, booby-traps and other devices directed against civilians). These provisions have, nonetheless, provided the Independent Counsel on International Human Rights with guidance as to what is internationally expected and demanded of belligerents in contemporary armed conflicts.

13. In addition to the foregoing rules of international humanitarian law, the non-derogable provisions of the International Covenant on Civil and Political Rights were within the terms of reference of the Independent Counsel. In particular, Articles 6,7 and 18, which to some extent overlap and reinforce humanitarian law principles already discussed, were used by the Independent Counsel. Article 6 protects the right to life, including within its terms protection from extrajudicial executions. Article 7 prohibits torture and cruel, inhuman or degrading treatment or punishment. Article 18 protects the right to freedom of religion. The Convention Against Torture and other Cruel, Inhuman or Degrading Treatment or Punishment provides further guidance in this area.

\section{B. The fact-finding trips}

14. These legal terms of reference were applied by the Independent Counsel during their visits to the region. It was clear to the Independent Counsel that a short visit would not be sufficient to adequately assess the enormous amount of information avallable on the human rights situation in Afghanistan. A series of trips were therefore plarned. $A$ preliminary trip to establish contacts and make an initial assessment was to be followed by a trip by the full group and then another visit would be undertaken to fill in missing or incomplete information and confirm other information, all within a relatively short period of time. This would provide as complete a picture as possible and allow a full and fair analysis of the status of the protection of human rights in Afghanistan within the legal terms of reference which the Independent Counsel have adopted.

15. Because of the complexity of the situation, the staff undertook a three week trip to Pakistan in Jamuary 1987 to establish initial contacts with those persons who would be able to assist the Independent Counsel in their factfinding missions. The project director and the rapporteur spent five days in Islamabad, meeting with diplomatic agents and United Nations officials involved in the relief operations among the Afghan refugees. They then travelled to Peshawar, NWFP, Pakistan, and spent two weeks among the Afghans there. They visited refugee camps in Baryalai and Motta and a camp located in the immediste vicinity of the Afghan-Pakistan border, interviewing in depth over 170 persons wo provided first-hand testimony concerning their experiences in Afghanistan. These refugees came from many provinces including Balkh, Kunduz, Baghlan, Herat, Ghardez and Nangarhar. In Peshawar, more than a dozen persons from Kabul, Paktia and Wardak Provinces who claimed that they were victims of torture were interviewed. Most claimed to have been held in Pul-o-Charkd Prison in Kabul, although other prisons were also mentioned as places where torture took place. The Staff also visited a number of relief organizations, such as the Saudi Red Crescent, Aide Medicale International, Medecins Sans Frontiers, Afghan Aid, International Committee of the Red Cross and German-Afghan Commlttee. Representatives of these organizations and journalists who had spent time in Afghanistan were able to present both analytical information of patterns of activities in Afghanistan based on their organizations' many contacts with Afghans and direct evidence grounded in personal experience.

16. The Independent Counsel on International Human Right's visited Pakistan for appraximately three weeks during March 1987. The penel spent three days in Islamabad meeting with officials of the Goverment of Pakistan and diplomatic

agents. Nine days were spent in Peshawar where the Independent Counsel visited Nonda and other camps. During these interviews with refugees, persons from Nangarhar, Qandahar, Farah, Parwan, Kabul, Logar, Laghman, Kundua, Herat, Kapisa, Kumar, Badghis, Ghazni, Wardak, Takhar and Jauzjan provinces provided testimony. Over 40 torture victims fron Kabul, Takhar, Iogar, Parwan, Kunduz and Baghlan Provinces were interviewed by the Independent Counsel at the Psychistric Center, for Afghans in Peshawar. These persons claimed to have been tortured in Pul-e-Charld, Saddarat, Shashdarak and other prisons. In all, the Independent Counsel interviewed over 150 Afghan refugees in Peshawar. In Peshawar, the Independent Counsel also met with diplomatic personnel, the leaders of Afghan resistance groups, workers in international relief organizations and representatives of the Goverment of Pakistan active in Afghan refugee affairs. The Independent Counsel also spent four days in Quetta, capital of Baluchistan Province. Mhile in Quetta, the Independent Counsel visited a number of refugee camps including Pishin-Sorhab, and interviewed over 100 Afghan refugees from Badghis, Helmand, Qandahar, Zabul, Takhar, Jauz Jan and Kunduz Provinces. They also met with former officials of the Government 
of Afghanistan and representatives of international relief organizations, including the International Committee of the Red Cross.

17. Following this visit, the Independent Counsel on International Human Rights wrote to the Government of Afghanistan on May 18, 1987 requesting permission to visit Afghanistan in order to continue their investigations inside the country. The Independent Counsel recognized the desirability of receiving information on the human rights situation in Afghanistan from citizens of Afghanistan who are still in their country and not yet in exile. The Independent Counsel have not yet received a response to their letter.

18. In order to confirm certain facts and update information, the Project Director and a Research Associate spent three weeks during August and September 1987 in Pakdstan. The Staff spent three days in Islamabad, speaking with officials of the Government of Palcistan and diplomatic agents. They spent four days in Chittral, visiting Orghoch, Dumgshora and Goram Chasma camps. While in Chittral, they interviewed 22 persons from Kumar, Kapisa, Kunduz, Badakhshan, Laghman and Takhar Provinces who described events within Afghanistan occurring during 1987. The balance of the staff's time was spent in Peshawar, where they interviewed over 50 persons from Parwan, Kabul, Nangarhar, Kapisa, Badakhshan, Kundua, Kunar, Logar, Paktika, Paktia, Ghazni, Balkh, Takhar and Laghman Provinces. Relief workers, journalists and diplomatic personnel were also interviewed in Peshawar. Following this trip, the staff also visited the Stiftung Bibliotheca Afghanica Foundation in Liestal, Switzerland, to continue $j$ ts research.

19. In all, during 1987 members of the Independent Counsel on International Human Rights spent 177 man-days in Paldstan and uncounted days outside that country investigating the human rights situation in Afghanistan.

\section{c. Investigative techniques}

20. Aware of the gravity of the matter which they were investigating, the Independent Counsel on International Human Rights sought to use methods which would allow them to make an accurate evaluation of the information which they received. The Independent Counsel interviewed many persons, seeking in numbers to ascertain patterns of testimony that evidenced truth rather than focusing on individual events. Geographic diversity was also sought and persons from nearly every province of Afghanistan have been interviewed by the Independent Counsel. Among the Afghans in exile, there are seven major parties, and persons from all such parties were interviewed. The Independent Counsel visited camps spread along the Afghan-Pakistan border from Chittral to Quetta.

21. Many interviews took place in a random fashion, with the Independent Counsel stopping in a hut or tent and conducting interviews with the persons who inevitably gathered around. So as to further minimize the possibility of coaching of witnesses, guides were not informed of areas of interest to the Independent Counsel and questioning ranged over a number of topics. The persons interviewed included village elders, mujaheddin commanders, ordinary Afghans and children. Some witnesses were university educated, while others were peasants or artisans. All interviews were taped so that the translations could later be checked. Bxcept for certain torture victims, no witnesses were prescreened. Witness demeanor was very Important, with some testimony being rejected because of the witness' behavior and credibility. Arrangements were sometimes made to interview a witness again. An adversarial, probing interview technique was adopted which, because of the Afghan cultural emphasis on speaking the truth among peers, occasionally met with surprise and anger. Anything other than eyevitness testimony was discouraged and discounted. Taken together, the Independent Counsel on International Human Rights believe that these methods, applied during the lengthy period of their investigations, provide them a firm basis for the conclusions which they have reached concerning the situation of the protection of human rights in Afghanistan.

\section{Conclusions of The Independent Counsel}

\section{A. Torture}

22. Torture has been defined by the United Nations General Assembly (G.A. Res. 3452) as wany act by which severe pain or suffering, whether physical or mental, is intentionally inflicted by or at the instigation of a public official on a person for such purposes as obtaining from him or a third person information or confession... Torture constitutes an aggravated and deliberate form of cruel, inhuman or degrading treatment or punishment." Article 7 of the International Covenant on Civil and Political Fights (ICCPR) provides that "No one shall be subjected to torture or to cruel, inhuman or degrading treatment or punishment." Article 4(2) of the ICCPR specifically precludes any derogation from Article 7, even in time of war or other public emergency. Afghanistan acceded to the ICCPR in 1983 and the USSR ratified the treaty in 1973. Afghanistan also signed on 4 February,1985, the United Nations Convention against Torture and other Cruel, Inhi- 
man or Degrading Treatment or Pmishment which has recently entered into force. The prohibition of torture and cruel, inhuman or degrading treatment is absolute.

23. Torture is prohibited under Article 30 of the Fundamental Principles (the provisional constitution), and 1s punishable under Article 275 of the penal code, of Afghanistan and is also contrary to Article 3 of the Afghan law on the Implementation of Sentences in Prisons (1982).

24. The Human Rights Comittee, in its General Comment on Article 7 of the ICCPR noted "that it is not sufficient for the implementation of this article to prohibit such treatment or punishment or to make it a crime. Most States have penal provisions which are applicable to cases of torture or similar practices. Because such cases nevertheless occur, it follows from Article 7, read together with Article 2 of the Covenant, that States must ensure an effective protection through some machinery of control. Complaints about il-treatment must be investigated effectively by competent authoritires. Those found guilty must be held responsible, and the alleged victims must themselves have effective remedies at their disposal, including the right to obtain compensation."

25. In July 1985, during the consideration of Afghanistan's initial report under Article 40 of the ICCPR by the Human Rights Coumittee, reference was made to the allegations of torture cited in the February 1985 report of the United Nations Special Rapporteur on the situation of human rights in Afghanistan. The Afghan representative stated that the information in the report was "totally fallacious" but gave no information to indicate that the allegations had been investigated or that effective action had been taken against those responsible.

26. It has been alleged that Afghans captured by the KHAD (Khedamat-e-Btela' at-e Dawlati, 1.e., State Information Services) are routinely tortured, particularly at KHAD bases in Kabul. Soviet advisers are allegedly often present, either in the same rocm or in an adjacent room. In addition, there have been reports of Soviets torturing Afghan prisoners. The conditions in Pul-a-Charkhi prison are claimed to be both inhuman and degrading.

27. The Independent Counsel received the testimony of over forty alleged torture victims. Most had bee: captured in their homes. In most cases, the KHAD were seeking a specific individual but some were arrested as part of a general roundup of villagers. Only one person interviewed was detained immediately following a military operation. Those arrested outside Kabul were usually taken initially to the KHAD center in the nearest city before being transferred to Kabul. Torture is reported from such centers as Jalalabad and Kandahar. Some prisoners were sent straight to Kabul. The most common pattern is for people to be taken to the KHAD headquarters at Shashdarak for initial interrogation, then being transferred to the central interrogation office at Sadarat, where the interrogation may extend over a few months. Tor ture is reported at both these centers and also at other KHAD offices in Kabul (e.g., "No.5") and at Khad-e-Nezami, the military intelligence wing of the KHAD.

28. The alleged torture was sometimes accompanied by interrogation and in other cases occured between periods of questioning. The information sought included links with the mujaheddin and details of foreign involvement in the conflict.

29. A common pattern emerged from the testimonies. Torture begins with a "softening up" process, consisting of beating (with wire cables and/or sticks) and kicking. Several witnesses stated that they lost teeth and in some cases one or more of their nose, ribs or fingers were broken. One person reported having his hands crushed under a table leg. Torture then escalates. Several people reported having been subjected to electric shock treatment, in some cases to the point of unconsciousness. One witness reported having to sit in a chair in a small room and being forced to put his hands on the arms of the chair, through which he received a shock of such strength as to throw him out of the chair. More commonly, an instrument resembling a telephone with a handle was used. Wires from the machine were attached to the prisoners' fingers and/or toes and the handle was turned to produce the electric shock. In some cases the wires were attached to the prisoner's tongue, testicles or penis. Another technique involved wires from sockets in the walls being attached to the prisoner. The electric shocks were usually administered from two to five times a day for around twenty minutes at a time. This continued from a few days to a few months. Torture by electric shock was most conmonly reported from Shashdarak and Saddarat but was also occasionally reported from other locations.

30. Some witnesses reported that doctors were present whilst they were tortured. Their function appeared to be to say when torture could take place and when it had to stop on account of the condition of the prisoner. The torture was usually administered by Afghans. In one case, the witness reported that Doctor Najibullah, then head of the KHAD and now leader of the Afghan Communist Party, came eight times to watch. In many cases, witnesses reported that Soviet nadvisers" were in an adjacent room whilst the torture and interrogation took place. They knew they were Soviets by their language and appearance. They gave instructions to the interrogators. In some cases the "adviserg" were present in the room during 
interrogation or torture or both. The witness captured after a military engagement was allegedly interrogated and tortured at the 37th Division of Afghan troops in Kabul by Afghans during the day and by Soviets at night. One of the Soviets was a Tadjik and spoke a little Farsi. The other was a Russian. The prisoner was kicked, beaten, subject to electric shock treatment and mock executions.

\section{CONCIUSIONS ON TORTURE}

31. There are inherent difficulties in the proof of allegations of torture. The Human Rights Committee has said that were specific allegations of torture and ill treatment are made and the respondent goverrment merely dismisses them as "totally fallacious" (as did the Afghan goverment) giving no specific response or any indication that it has even investigated them "the Cormittee cannot but draw appropriate conclusions on the basis of the information before 1 t." The evidence given to the Independent Counsel strongly suggests a systematic practice of torture carrled out by members of the KHAD in the presence sometimes of doctors and of Soviets. In addition, evidence was received in one case of tor ture by Soviet officials. Using the Human Rights Committee's standard of proof, the delegation concludes that Afghans who are detained are routinely subjected to torture during interrogation.

\section{B. Targeting of civilians}

32. It has been alleged that civilians have been both the victims of indiscriminate attacks and also purposefully targeted. In some instances, it has been claimed that the latter has been by way of reprisal. Women and children, entit led to special protection under humanitarian law, have allegedly been the object of attack.

\section{Indiscriminate attacks}

33. It has been claimed that attacks have been launched against targets such as villages which make it impossible to distinguish between military and civilian objectives and that weapons have been used which are eighter indiscriminate by nature or have been used in an indiscriminate fashion.

34. One of the fundamental rules of the laws of war is the principle of distinction. Combatants are obliged to distinguish between civilians and combatants. Conmon Article 3 of the Geneva Conventions also requires that "persons taking no active part in the hostilities .. shall in all circumstances be treated humanely". Furthermore, Article 6(1) of the International Covenant on Civil and Political Rights, to which no derogation is permitted under Article $4(2)$, provides that No one shall be arbitrarily deprived of his lifen. Deaths resulting from indiscriminate attacks in breach of the laws of war would appear, from the very nature of the attacks, to represent an arbitrary deprivation of life.

35. As discussed in section D.1 of this report, the use of aerially dispersed mines is widespread in Afghanistan. Carpet bombing frequently occurs and the Independent Counsel received numerous testimonies that prolonged borbardment of villages for from 3 hours to 5 days invariably precedes a ground attack by Soviet troops.

36. The evldence received by the Independent Counsel confirms that in the Report of the Special Rapporteur of the Commission on Human Rights (A/41/778), who reported that whe action taken against the opposition movements and civilian population has been intensified since last year... The bombardment of villages, attacks on convoys of civilians heading for Paldstan in search of refuge and regular house searches make it impossible for the civilian population to lead a normal life." (para. 37) In the annex to that docunent, at para. 28, the Special Rapporteur lists typical examples of indiscriminate attacks resulting in high civilian casualties. The Independent Gounsel received evidence that such attacks had continued even after the announcement of "National Reconciliation" by the Government of Afghanistan in January 1987.

\section{Rurposeful targeting of civilians}

37. It is claimed that civilians have been the target of attacks. Such attacks must be distinguished from those which occur during hostilities between combatants or against military objectives. In this context, it is alleged that troops in a position to distinguish between mujaheddin and civilians, principally soldiers on foot, are not merely falling to identify civilians, but are attacking civilians, including women and children.

38. The evldence presented to the Independent Counsel suggests that there are three distinct situations in which groups of civilians find themselves the object of attack. The first seems directed to the depopulation of areas of strategic value. The second involves the killing of individual civilians as part of a general attack on the civilian population of a village. The third situation is that of attacks on individual civilians, such as village elders or religious leaders, usually as a form of punishment or warning. 
39. Heavy bombardment of frontier regions close to Pakistan, Iran and the Soviet border appears designed to prevent civilians, including the injured, from seeking refugee outside Afghanistan, as well as to protect borders from infiltration. For example, the Independent Counsel received evidence of the flattening of a village in Kunduz Province by bonbardment in order to clear the area and establish a Soviet post. The village was bombed and then surroumded at night hy a mixed force consisting principally of Soviet troops who attacked the next day. Many persons were killed in the bombardment and more were killed in the land-based attack. The crops were burned, livestock killed and most of the houses destroyed. This pattern is repeated in many border areas. Similarly, a 2 kilometer-wide band has apparently been cleared along the Salang Highway to protect the movement of troops and equipment from the Soviet Union to Kabul. The attacks appear designed to clear the areas in question of all persons, including civilians.

40. In addition to these strategic attacks, the Independent Counsel heard much credible testimony that villages with no connection to the resistance were attacked. In fact, a number of witnesses claimed that attacks were launched against villages in which there were no mujaheddeen, the fighters being based in the countryside away from settlements precisely in order to spare civilians fram attack.

41. Frequently, individual civilians are chosen for execution by Soviet troops upon their occupation of a village. In certain circumstances, persons are killed in retaliation for a mujahedeen operation nearby, especially if there have been Soviet casualties, or because they are related to a suspected mujahedeen. Just as frequently, village elders or religious leaders are rounded up and killed. Although in most cases these persons are shot, one popular technique appears to be to burn village leaders alive, with the Independent Counsel receiving a number of reports of persons being thrown wille alive into a room filled with burning wood.

\section{Attacks on women and children}

42. The situation of women in Afghanistan deserves special note. It has been alleged that Afghan women have been raped by Soviet soldiers. There are more than the usual difficulties in investigating such claims in Afghanistan. It is not merely that Afghan women do not want to talk about such attacks, but that there is a conspiracy of silence on the part of Afghan men who feel shamed by their inability to protect their women. Evidence corroborates this abhorrence of rape throughout Afghan society and which helps to explain why allegations are made against Soviet and not DRA troops came from one eyewltness to an attack on a village in Jauz Jan Province by mixed Soviet-DRA forces in January 1987. Soviet soldiers were searching house to house for draft-age men. A twelve year old girl who ran away was caught by a Soviet soldier who started dragging her screaming to a tank. A DRA soldier shot and killed the girl while she was in the hands of the Soviet soldier. The witness was adamant that the Afghan was not trying to shoot, the Soviet soldier, not least because there were many more Soviet than Afghen soldiers.

43. In addition to rape, the Independent Counsel occasionally heard testimony of other types of attacks on women. One perticularly startling report was that given by a former Afghan Air Force pilot. A fellow officer's wlfe had been found praying. Her husband was on duty at the time. The following morning the pilots were called together and given a political lecture and told that their families should not be praying. The breasts of the pilot's wife were then dropped in front of him in a plastic bag.

44. Certain weapons which are of an indiscriminate nature appear to be particularly designed to injure chilidren. In this category fall the various "toy bombs" and attractive booby-traps which are discussed in greater detail in section D. 2 of this report. The hospitals and streets of Peshawar and Quetta are filled with Afghan children who have lost limbs to these deadly "toys".

\section{CONCWSIONS ON TARGETING OF CIVILIANS}

45. In a conflict being fought within one state where the non-goverment forces are suspected of having the support of the civilian population, it may well be difficult to distinguish between military and civilian objectives. Based upon their investigations, however, the Independent Counsel seriously question whether any attempt is being made to distinguish between military and non-military targets by Soviet and DRA forces. On the basie of the evidence received by the Independent Counsel and confirmed in general terms by the reports of the United Nations Special Rapporteur,

the Independent Counsel can state that civilians have been the victims of indiscriminate attacks and attacks by means of indiscriminate weapons in violation of the laws of war and international human rights law.

46. The evidence presented to the Independent Counsel further suggests the regular breach of each of the prohibitions of paragraphs $1(\mathrm{a}),(\mathrm{c})$ and (d) of Common Article 3 during the course of deliberate attacks on civilians. Under 
the Geneva Conventions, States are obliged to seek out and bring to trial alleged perpetrators of grave breaches of the Conventions and can be held responsible for the failure to do so. The State is certainly responsible for the acts of its armed forces when those acts recur in a consistent fashion over the course of time. The evidence that massacres of civilians by Soviet troops are a not infrequent occurrence in Afghanistan suggests at least the tolerance and quite possibly the encouragement of that state of affairs on the part of Soviet officers all the way up the chain of cormand.

\section{Executions in the field of captured combatants and civilians,}

47. Protection against extrajudicial executions, either of civilians or of combatants, is one of the fundamental aspects of the Geneva Conventions. The "passing of sentences and the carrying out of executions (against noncombatants in a non-international amed conflict) without previous judgment pronounced by a regularly constituted court" is a vio lation of Common Article 3 of the Geneva Conventions. Before the death penalty on a prisoner of war can be executed wa period of at least six months" must pass so as to ensure against a judgment "too often affected by emotional considerations." See Pictet's Comnentary on Article 101 of the Third Geneva Convention. Further, non-derogable Article 6 of the International Covenant on Civil and Political Rights protects the right to life of all persons, including within 1ts terms protection from extrajudicial executions.

48. The guarantee against extrajudicial executions contained in the laws of war and the international law of human rights appears to be completely Ignored in Afghanistan by the Soviet and DRA forces. Time after time the Independent Counsel heard of the execution by Soviet and DRA forces of innocent civilians taking no active part in the war. The testimony demonstrates a pattern of aerial and ground bombardment of a village followed by the occupation of the village by mixed DRA and Soviet forces followed by the execution of village elders or leaders, such as the mullah, as a public demonstration of power by the occupying forces.

49. On numerous occasions the Independent Counsel also received credible and confirmed testimony that mujaheddin captured on the battlefield were killed by Soviet and DFA military forces. It appears that mujaheddin cormanders are chosen for special treatment, i.e., they are held for leter torture to extract information about contacts and supply sources, while the rank and file mujaheddin is executed on-the spot usuaily by automatic weapons fire. Without regard to their classification as prisoners of war in an international armed conflict not of an international character, ruch extrajudicial executions are a gross violation of the fundamental dictates of humanity and of international law.

\section{Use of weapons}

50. The Independent Counsel approached the issue of the weapons being utilized by the Soviet and DRA armed forces from two perspectives: that of the unlawful use of lawful weapons and that of the use of unlawful weapons.

\section{Unlawful use of lawful weapons}

51. In this context, Protocol II to the 1981 Convention on Prohibitions or Restrictions on the Use of Certain Gonventional Weepons Which May Be Deemed to be Excessively Injurious or to Have Indiscriminate Effects enlightened the provisions of Common Article 3 for the Independent Counsel. The civilian population is much more likely to be injured by the dispersal of mines or other explosives by means which make it impossible to keep such explosives away from civilian populations. Those persons taking no active part in hostilities can hardly be protected from violence to life and person as required by Common Article 3 if explosives are dropped from high altitudes or dispersed by artillery.

52. The Independent Counsel heard countless reports of small land mines being dropped from helicopters or scattered frow airplanes over fields, mountains and farm land. These bombs can readily be seen in Paldstan where a number of diffused "butterfly bombs" were shovn to the Independent Counsel. While these types of mines might even be illegal weapons under the 1981 Convention when directed at combatants, they are certainly illegal when distributed in such a way as to demonstrate at a minimum a disregard for the safety of the civilian population and more likely, given the widespread nature of their use, the deliberate targeting of civilians and their livestock.

53. Area or "carpet" bombing has been reported for many years in a number of regions of Afghanistan, including most notably the Panjsher Valley. The Independent Counsel received testimony from members of international relief lief organizations who personally witnessed sustained carpet bombing in the Panjsher Valley and from Afghans whose villages where destroyed in this way. This type of high altitude bombing of large areas without regard to the distinction between military installations and civilian populations is inconsistent with the obligations of Common Article 3.

54. The disregard of accurate recordkeeping of mines vis-a-vis the civilian population is most telling when the situetion of anti-persormel mines surrounding DRA and Soviet posts is considered. Afghans involved in the armed conflict 
report that IRA and Soviet outposts are surrounded by anti-personnel-mines. Villagers living near rural outposts report that when one set of Soviet troops relieves another at a post, sone Soviet soldiers are invariably killed when they venture into the minefield to plant new mines. The conclusion reached is that no records of mines are maintained even for transmittal to the next force of Soviet soldiers in a post.

\section{Use of unlawful weapons}

\section{(i.) Booby-traps}

55. Throughout its investigations the Independent Counsel was presented with testimony concerning the use of boobytraps by Soviet forces against the civilian population. The placing of mines, grenades and other explosives in positions where such explosives are calculated to or would reasonably be expected to cause infury to civilians and not to combetants is in violation of Cormon Article 3.

56. Dozens of witnesses told stories of returning to their villages and homes following attacks by Soviet soldiers to find bombs and grenades placed in doorways so as to explode when a door is opened, along paths to fields and by plants and bushes which will be collected for firewood and food. Therefore, in addition then (sic) tc the random plactne of uncharted land mines and the aerial dispersal of anti-personnel mines, the Independent Counsel received evidence of the intentionel placing of explosive material where it was calculcted to cause injurty to civilians when they returned to their homes following an attack.

57. Besides the classic booby-traps described briefly above, it has been alleged that "toy bombs", 1.e., explosive material in the form of children's toys, cassette recorders, pens, radios, watches, cigarette packets, etc. have been left scattered throughout villages and surrounding fields following armed attacks by Soviet troops. The Independent Counsel heard repeated testimony of the use of such weapons. The itens included a small red doll which exploded when pushed with a stick (which was filmed and shown on national television in the USA), pens, tepe-recorders, money, naswar baxes (a form of snuffbox) and cigarette packets. The accounts were consistent but not identical, wich adds to their credibility. So, for example, the descriptions given of the "cassette recorders" varied but the eye-witnesses were certain that what they had seen was supposed to be such a machirle. It was clear from the detailed description of the pens that they were not being confused with "time pencils". The overwhelming evidence suggest.s (1) the fake items are designed to be attractive to civilians; (2) not all objects are fake - some of the objects, such as pens, are real to increase the likelihood that someone will investigate and handle the objects; and ( 3 ) the items are not likely to be attractive to the mujahedeen, who know of the likely dangers.

\section{(ii) Chemical weapons}

58. The use of chemical warfare by Soviet forces was raised by certain of the testimony the Independent Counsel heard. Many persons provided evidence on the use of chemicals to poison food and water supplies. In some instances, chemical weapons were used directly against the civilian population. For example, it is known that villagers in Afghanistan hide in turmels which branch off of water wells. One man, hiding in a house during a Soviet attack on his village, testified that he saw a Soviet tanker truck pull up to a well in the village and a person completely covered in a protective suit pour an unknown chemical into the well from a pipe attached to the tanker. After the truck left, the person in the protective suit threw a small device into the well and ran away. Shortly thereafter, a cloud of gas or smoke energed from the well. After the Soviet troops left his village, the witness and others went to investigate and found everyone in the well, including many members of the witness' family, had died.

59. Use of chemical weapons against civilians is a serious violation of the laws of war, including the Geneva Gonventions and the 1925 Protocol for the Prohibition of the Use in War of Asphyxiating, Poisonous or Other Gases. Although the Independent Counsel cannot determine what particular chemical weapons have been utilized, it seems clear that chemical weapons have been used by Soviet armed forces against civilians on a number of occasions in Afghanistan.

\section{CONCIISIONS ON USE OF WEAPONS}

60. The DRA and Soviet armed forces engaged in the war in Afghanistan do not appear to be inhibited in their choice or use of weapons. These troops continuously use potentially lawful weapons in an unlawful manner. Moreover, and more disturbing, Soviet troops use booby-traps and explosive household objects as part of their ordinary arsenal in blatant violation of the most fundemental laws of war.

\section{E. Unlawful targets}

61. Both the law of the Hague and the law of Geneva regulate, resirict and, in certain instances, prohibit the 
choice of targets by parties to an armed conflict. Certain targets unrelated to the armed conflict are illegal. In the course of their interviews the Independent Counsel noted that, in addition to such legitimate targets as mujaheddin installations, attacks appeared to be regularly launched against a variety of targets which are entitled to protection under international law. The frequency with which such attacks were described leads the Independent Counsel to believe that the reports they received were not of isolated mistakes, but of deliberate target acquisition by Soviet and DRA forces.

62. A previous portion of this report has been devoted to a description of attacks which have taken place on civilians. The targeting of civilians is of course in direct contravention to the affirmative obligation of Common Article 3 which requires that persons taking no active role in hostilities be treated humanely.

63. Intimately related to the lives of the civilian population is their food and water supply. A mmber of international relief organizations indicated that their attention was shifting from the provision of medical care to the provision of food, usually in the form of seed for planting. The shortage of food caused by the destruction of food supplies was independently stressed by a number of Afghan village elders and resistance leaders. As part of their usual practice in the occupation of a village, Soviet troops are reported to destroy crops and kill livestock. The methods described ranged from setting food on fire with tracer bullets or flares to contaminating food by urinating and defecating on stored grains. The water supply is not neglected by the Soviet armed forces. Irrigation canals are reported to be regularly bombed and the Independent Counsel received a number of credible reports of the poisoning of wells and other water sources.

64. Medical facilities and personnel identified as such by the display of the internationally recognized symbols of the red cross or the red crescent are entitled to special protection. They certainly are not legitimate targets of attack. The Independent Counsel leamed from international relief organizations which operate inside Afghanistan that such organizations are reluctant to identify their facilities by use of the red cross. This is because they have learned from experience that identifying such a location appears to draw attacks. For example, reports were received that on two instances buildings in Paktika identified as medical facilities were bombed, in each case by MG's whose sole action was to attack those facilities.

65. A place of worship, such as a mosque, is not a legitimate target of attack, unless it is being used as a military Installation. The Independent Counsel, during the course of their interviews, leamed that following the occupation of a village or other area, Soviet forces usually use the local mosque as a latrine. To further compound the insult, pages of the Holy Koran are used as toilet paper. The fundamental role which religion plays in the life of the Afghans will be discussed in greater depth later in Section G.2 of this report. However, from the manner in which this attack is carried out it is clear that the choice of mosques as targets is not made out of military necessity, but as a means to degrade and humiliate the people, in violation of paragraph 1 (c) of Common Article 3.

66. Refugees fleeing their country or outside their country are protected against attack. Yet, a Pakdstani Government official responsible for Afghan refugee affairs told the Independent Counsel that, while accompanied by the United Nations Special Rapporteur, he and the Special Rapporteur personally witnessed an attack within the Afghan-Pakisten border area on a refugee colum in which a number of people were killed. It is incontestable that the number of aerial attacks on Afghan refugee camps in the border areas of Pakisten has increased dramatically in the last year. During the visit of the Independent Counsel to Pakistan, a mumber of such attacks took place, with many reported deaths. Attacks on refugees within Afghanistan by ambush or helicopter stafing were also reported. While in Quetta, the Independent Counsel heard extremely disquieting testimony that a group of refugees in the Ragistan desert on their way to Pakistan in 1987 were captured by Soviet troops in helicopters and thrown while alive into a bonfire made up of the possessions they had been carrying with the result that all captured were killed.

\section{CONCIUSIONS ON UNIAWFUL TARGETS.}

67. The evidence adduced by the Independent Counsel on International Human Rights indicates that little if any discrimination is made by Soviet and DRA forces between legitimate and illegitimate targets of attack. Rather to the contrary the war is being waged without restraint on the civilian population of Afghanistan and the physical and religious structure that supports it. Bven those persons who have given up their country and are going or have gone into exile are not immune from attack. Unlawful attacks by Soviet and DRA forces on illegitimate targets is widespread and systematic.

F. Obligation to disseminate the laws of war

68. While hardly ranking in importance with some of the other provisions of international humanitarian law which 
have been reviewed in this report, the obligation to disseminate the laws of war should be addressed, if only briefly. The scope and magnitude of the war crimes comitted by the armed forces of the Soviet Union and Afghanistan caused the Independent Counsel on International Human Rights to wonder whether international humanitarian iaw is disseninated among Soviet officers and soldiers as is required by the Geneva Conventions. The Geneva Conventions unequivocally require that the parties thereto disseminate the texts of the Conventions and minclude the study thereof in their programes of military and, if possible, civil instruction, so that the principles thereof may become known to all their armed forces and to the entire population." See, as an example, Article 127 of the Third Convention.

69. The Soviet Union is itself aware of this obligation since I.P. Blishchenko and V.A. Grin, authors of the booklet "International Humanitarian Law and the Red Gross", published in Moscow in 1983 by the Bxecutive Cormittee of the Order of Ienin Alliance of Red Cross and Red Crescent Societies of the USSR, state on page 36 of that booklet, "The Geneva Conventions make 1t incumbent on the states to disseminate their texts as widely as possible and to include them In the programmes of military and civilian education." Later, on page 39, Blishchenko and Grin state that "(the members of the Soviet Armed Forces study the provisions of international humanitarian law regularly and systematically... All members of the Armed Forces are familiarized with the texts of the Geneva Conventions. The officer corps thoroughly study the provisions of international humanitarian law."

70. During its interviews the Independent Counsel were able to speak with a former Afghan Air Force pilot. This officer was trained on a number of occasions in Soviet military academies. He described in detail the manner in which assignments were given him and others to carpet-bomb villages. When he was asked about how he was able to reconcile these blanket attacks which were likely to kill civilians with the dictates of the laws of war which prohibit attacks on noncombatants, he expressed surprise. After some questioning it became apparent that he had never heard of the concept of nthe laws of war" before that interview. While this certainly speaks poorly for Afghan military training, it also indicts the Soviet Union which had played a large role in his training. Moreover, the unremitting pattern of violations of the laws of war by Soviet forces bespeaks a complete lack of awareness of these basic international norms which the Soviet Union has bound itself by treaty to observe.

71. The Independent Counsel were not able to gather much information concerning dissemination of the laws of war by the Afghan resistance. While the Independent Counsel were informed by military officials of the Afghan resistance that they comply with the requirements of international humanitarian law, Helsinki Watch reported testimony in 1985 that Soviet and Afghan prisoners held by the resistance were treated in a manner inconsistent with humanitarian law.

G. Possible intentional destruction of the Afghan people

72. Allegations of genocide practiced by DRA and Soviet forces have been lodged frequently. A brief comment on the international law in this matter is necessary before seeking to apply it to the facts which were presented to the Independent Counsel on International Human Rights.

BUI TOR's NOTB: Paras 73-76 present to resume of international law on the subject).

\section{Depopulation}

78. According to accounts the Independent Counsel received, many of which have been reported elsewhere, substantial programs of depopulation have been conducted in the following provinces: Chazni, Nangarhar, Laghman, Jandahar, Zabul, Badakhshan, Iowgar, Paktia, Paktika, Kunar. In addition, the Wakhan corridor bordering on China has been almost entirely depopulated and effectively annexed by the Soviet Union. The following methods were used to accomplish depopulation: repeated targeting of villages in certain areas; the commission of atrocities in villages with the predictable result of substantial flight of the civllian population; the intentional destruction of food supplies, irrigation canals and wells, makdng it impossible for the civilian population to survive in their villages; looting of property.

79. The Independent Counsel have not been able to examine documents of the government of the IRA or of the USSR, and hence cannot document whether or not these acts were conducted with specific intent. However, the fact that these actions have been persistently comitted for eight years. with the dismaying cumulative result that one-third of the Afghan population has been forced to leave its country and another one-third is in internal exile cannot be ignored. These acts and the resultant exodus continue. Pakistani officials in charge of refugee influx reported to us that about ten thousand Afghans continue to cross the border monthly. International refugee officials allowed that that figure was probably conservative.

80. Where actions with predictable results are taken over an extended period of time and the consequences of those 
actions regularly confirm what their outcome will be, it is, to say the least, reasonable to infer that those responsible for those actions are accomplishing them with specific intent.

81. In the view of the Independent Counsel on International Human Rights, there is substantial evidence to support the allegation that the IRA and the Soviet Union have been pursuing strategies necessarily securing and therefore oresumably aimed at a forced depopulation of substantial areas of Afgharistan. In our view, the flight of a substantial part of the more than five milliọn in internal exile would appear attributable to actions undertaken by the IRA and the USSR. appear attributable to actions undertaken by the IRA and the USSR.

\section{Attacks on religion}

82. Even the briefest contact with Afghans drives home the extraordinary importance to them of their religion. The Independent Counsel on International Human Rights were struck, in the course of their interviews with Afghans, by the extent to which even those who were Westernized and quite worldly shared this basic view. All the Afghans who were engaged in the resistance describe themselves as mujahedden, literally those who are engaged in a religious war. Many spoke with a calm dispassion about the probability of their becoming shahedeen or martyrs. The impression we gained is confir med in the scholarly and ethnographic literature about the Afghans. Religion is one of the basic factors wich establishes their identity and binds them together. Its role in the life of an Afghan cannot be overestimated.

83. The war in Afghanistan is, in a substantial part, a result of governmental actions directed against these . views in an effort to supplant them with the materialistic conceptions of Marxist-Ieninism. Hence, these religious views are frequently targeted. That fact has increased popular resistance and become a basic feature of the war. The Independent Counsel gathered a great deal of evidence confirming that a standard technique of torture is the taunting of the victims about their religion. Many witnesses, after describing a variety of chilling physical tortures to which they were subjected, testified that the cruelest torture involved slurs on their faith and such taunts as where is your God now?" or Why isn't your God helping you now?". We also gathered evidence of the targeting of mosques and relizions schools and, in one case, the intentional desecration of a mosque.

84. Given the values of the Afghan people, there-is good reason to believe that such actions constitute genocide within the meaning of Article $\Pi(\mathrm{b})$ of the Convention, in that they are acts comitted with the intent to humiliate a religious group and hence cause serious mental harm to members of the group.

\section{Forced removal of children}

85. The Independent Counsel collected evidence indicating a coordinated policy of forcibly transferring children from Afghanistan to the Soviet Union. The objective appears to be to deculturate the transferred children from the values of their parents and environing group and to forcibly inculcate in them the values of the Soviet Union. The procedure, as testified by witnesses, is a as follows: Without warning, officials enter a classroom and, giving no expianation, choose a certain number of children who leave with the officials. When the children do not return home that evening, no explanation is given to the parents. But several days later, the parents are told that their children have been sent to the Soviet Union. Some children who are taken are keot for one to two months, with the idea of inculcating in them favorable attitudes toward Russia. Some are kept in the USSR for several years. There is also testimony to the effect that some of the children who are taken are programmed to be saboteurs and assassins and are trained to target a particular mujaheddin commander. Accounts of the forcible transfer of Afghan children from their families to the Soviet Union have also been reported elsewhere.

86. Article II(e) of the Genocide Gonvention defines genocide to include acts cormitted with intent to destroy, in whole or in part, a national, ethnical, racial or religious group by nforcibly transferring children of the group to another group". The text is not explicit as to whether transfers for a period of time in order to change perspectives of identification with the targeted group's values are included in Article II(e). In the view of the INdependent Counsel, however such an interpretation is consistent both with the language of Article II and the obvious policy animating the provision. The anguish and despair caused to the parents of these children would certainly appear to constitute mental harm" within the meaning of Article II(b), but it is not certain, from the testimony we received, whether this obvious and foreseeable consequence was sought with the intent to destroy the older generation of the targeted group.

\section{Strategic attacks on society}

87. Huch evidence suggests that the IRA and the Soviet Union are involved in a complex and premeditated attack on a a traditional society and its values and that the attack is being pressed at. every level of social organization: the 
village and 1ts agricultural infrastructure, the religion, education and the children, and health and life itself. Article II(c) defines genocide to include acts "deliberately inflicting on the group conditions of life calculated to bring about its physical destruction in whole or in part". The cumulative effect of the variety of programs which have been developed and directed against the civilian society of Afghanistan would appear to fall within the ambit of this provision.

\section{CONCIUSIONS ON GENOCIDE}

88. In the view of the Independent Counsel on International Human Rights, there is considerable evidence that genocidal acts have been cormitted against the Afghan people by the combined forces of the DRA and the Soviet Union. The repetation of many of the acts described above and their consistency makes it difficult to avoid the conclusion that the inevitable consequences of those actsare intended. Those consequences are inconsistent with obligations undertaken by the Soviet Union and DRA in ratifying the Genocide Convention.

\section{The situation Since the Announcement of National Reconciliation}

89. A prominent development in this tragic conflict has been the announcement of a policy of wational Reconcilsation" at the beginning of 1987 by the Government of the Denocratic Republic of Afghanistan. The DRA has promoted this policy as a step toward peace. However, an examination of the facts related to the situstion in Afghanistan since the announcement of this policy wich have been gathered by the Independent Counsel indicates that the Government of Afghanistan is acting inconsistently with its announced desire for peace. A short review of some of the substantive points covered in this report as related to events since the announcenent of "National Reconciliation" may be enlightening.

90. The Independent Counsel received reliable testimony alleging incidents of torture occuring as late as July 1987. One witness released from Pul-O-Charki prison during July 1987 had electric shock applied to his toes and testicles. He had been shackled to a wall while an empty, heated soda bottle was repeatedly forced in and out of his rectum. Another witiness had been released from Pul-a-charki prison in June 1987. He had been shuffled from one cell to another during the visit of an international fact-finding teas and had been denied permission to meet with the group. Klectric shock had been applied to his feet, toes and rectum and hot water had been poured into his ears. On one occasion, his urinary trapt was tied off, he was forced to consume a large quantity of liquid and was then beaten on the stamach. These and other incidents reported to the Independent Counsel occurred since the January 1987 announcement of $n$ National Reconciliation" indicate that there has been no change in the use of torture in Afghanistan.

91. Civilians continue to be the target of deliberate attack. One old woman testified that she lost her daughter and four grandchildren when their refugee caravan was bombed en route from Kunduz to Pakistan during June 1987. Several witnesses testified to the destruction of the village of Jarma in Kunduz province. The men of the village were assembled at a mosque on a Friday at prayertime. While they were praying, helicopters and planes arrived and bombed the mosque. The mosque and most of the village was destroyed., Tanks were arriving as the witnesses escaped. Approximately 200 people were killed during this attack.

92. Cross-border aerial attacks on refugees in Pakistan have not merely continued but actually increased in pace since the announcement of "National Reconciliation". Such raids have killed an officially estimated 860 people from the beginning of the conflict through August 1987. In February 1987 at least $58^{\circ}$ people were ldiled and 190 infured when Soviet-Afghan warplanes bombed three Pakistani border villages near Miranshah in the North Waziristen tribal agency. During a 30 minute period of that attack, 16 planes in two formations bombed the village of Moza Qilli Ghulam Khan as Afghan refugees shopped in the bazaar. In March 1987 between 15 and 20 Soviet-Afghan planes violated Pakistanl airspace over the Kurrum tribal agency and bombed the village of Terri-Mangal, killing at least 51 people and infuring more than 100. The number of cross-border violations and bombing of civilian targets indicates the war is spreading into Pakistan despite the policy of "National Reconciliation".

93. Bvery segment of Afghan soclety remains under assault. It is noteworthy that or the millions of Afghans forced to flee their homeland, only very small percentage of refugees have sought to return. Neither the incidents of civilian attacks nor the occurrence and intensity of torture seem to have subsided. The Independent counsel have encountered no evidence to indicate a change in these pattersn. When ecamined in its factual context it is clear that mational Reconciliation" has failed to contribute to a restoretion of the minimal standards.of human rights which the peop le of Afghanistín should enjoy pursuant to international law. 


\section{Separate Statement with Regard to the Application of Common Article 3 to Afghanistan}

94. All members of the Independent Counsel on International Human Rights have agreed to the working assumption of chis report, 1.e., that the law to be applied is not that expressed in the totality of the Geneva Conventions of 1949 And the First Protocol Additional to those Conventions of 1977, but only Common Article 3 of the 1949 Conventions. That orking assumption is premised on the view that the conflict in Afghanistan is not international but is internal in character.

95. Professor Reisman, Miss Hampson, Dr. Miggiani, Mr. Norchi and Mr. Busuttil have agreed to that view in the interests of a unanimous report and a desire not to divert attention from the facts of the conflict to controversy over legal issues. The working assumption of the Independent Counsel has permitted the group to move directly to an examination of the allegations made by Afghan and foreign withnesses. Cormon Article 3 establishes sufficient basic principles to apply to most of the allegations. Nevertheless, those persons named in this paragraph wish it understood that they believe that the war in Afghanistan is an international conflict as between the Soviet Union and the Afghan fighters and civilians and, as such, is subject to the totality of the 1949 Geneva Conventions and, insofar as they are in effect, as conventional or customary law, the provisions of the First Protocol of 1977.

96. Those members of the Independent Counsel believe that position is based on the factual record.On Dec. 28 (sic), 1979, the Soviet Union intervened militarily in Afghanistan. Its forces murdered the President of the country, Hafizullah Amin, and replaced him with Babrak Karmal. The intervention was allegedly effected at the Invitation of Babrak Karmal, but that alleged invitation could have neither international nor domestic legal value. At the time it was ibsued, Karmal had no post in the Afghan Government. He had most recently been the Afghan Ambassador to Czechoslovalia, a post from which he was dismissed. He then went to Moscow, in effect in political exile, and from the USSR issued the invitation to the USSR to intervene in his country. Since the Soviet military intervention, ample evidence indicates that the Soviet Union is conducting the war directly and using the constantly shrinking Afghan army insofar as it still has any utility. The notion that Afghan generals are ordering Sovlet troops is, in the opinion of those members of the Independent Counsel, untenable.

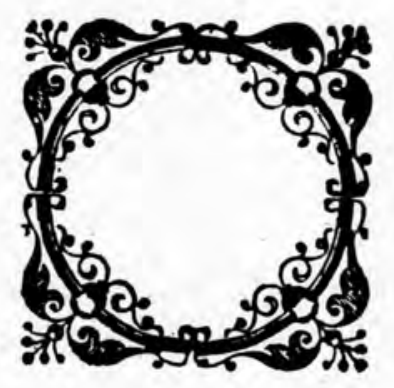



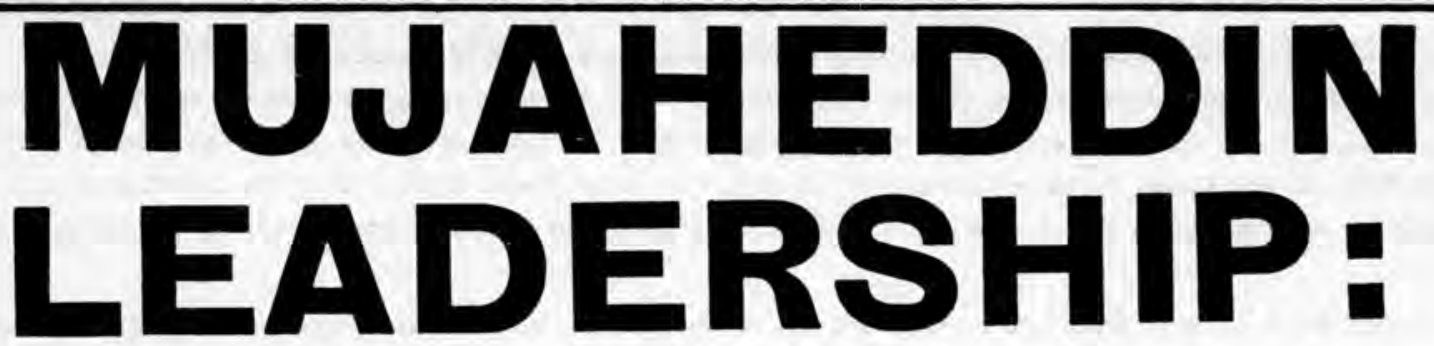

\section{CHARTERS OF MUJAHEDDIN ORGANIZATIONS,}

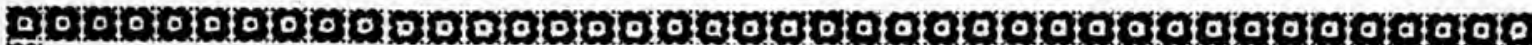
the leaders of the IUAM along with their writings and views and then the charter of their organizations. In this issue we are offering four such features. The other three will be presented in the next issue.

\section{Sayyed Ahmad}

\section{Gailani}

EDITOR'S NOTE: Facts about the life of Pir Gailani has been taken from the official newspaper of the Mahaz-e-Melli Islamic Afghanistan.

\section{Biography}

Pir Sayyed Ahmad Gailani was born 1932 in Kabul. He is the son of Sayyed Hasan Gailani - the Naqib Saheb. He first studied at the Abu Hanifa Madrasa and then at the College of Theology of Kabul University from where he graduated in 1964. He intended to go to Al-Azhar University of Cairo for further studies. However the death of his elder brother, entrusted upon him the role of guidance of the followers of Naqib Saheb and, thus, he had to abandon his plan for going to the Al-Azhar. Four months after the 1978 communist coup in Afghanistan, he migrated to $\mathrm{Pa}-$ kistan where later he founded the Mahaz-e-Melli Islami Afghanistan. He served as the spokesman of the IUAM in 1987.

\section{His Views}

EDITOR'S NOTE: The followtng are quotations depia ting his views on major issues. They being adopted here from the official publication of the Mahaz-eMelli Islamic Afghanistan, The Mehaz:
* If we succeed in forming a (mujaheddin) council, you (the people of Afghanistan) will be able to choose at your own initiative the leader of the IUAM (Mahaz, 6 October 1987).

* We seven (mujaheddin) organizations are advancing from a coalition towards a real unity (Mahaz 6 October, 1987).

* We want to achieve an alliance which is based upon the wishes of the Afghan mujaheddin and mohajerrin and in it their true elected representatives are included. Mahaz, 6 October 1987).

* Our specific and common objective is the withdrawal of Russian forces (from Afghanistan), toppling of the atheist government in Afghanistan and establishment of an Islamic government. "(Mahaz, 21 September, 1987).

* We do not issue a verdict of infedility against any Muslim and also do not give the right to others to make untrue accusations (of infedility) against others (Mahaz, 21 September 1987). * The Afghan mujahed people are not allowed by Islam and Afghan pride to form a coalition (government) with the hirelings and atheists (Mahaz, 9 February, 1986).

By introducing a coalition government in Afghanistan, the Russians want to eliminate all 
the hindrances against their puppets and so their hirelings may be able to continue their rule in Afghanistan (Mahaz, 9 February, 1987). * Until the dusts of the dirty feet of the Red Army and the un-Islamic regime are vanished in Afghanistan, we will never accept any other talks (Mahaz) magazine February, March, 1987).

* We rejected the proposals put forward by the puppet Kabul regime about a coalition govermment, cease-fire and the so called NRP because they were against the wishes of our people".

\section{Gulbuddin Hekmatyar}

BDITOR'S NOTE: Fact about the life of Gulbuddin Hekmatyar, leader of Hezb-e-Islami Afghanistan, has been selected from the English publication of the Hezb - - The Resistance.

\section{Biography}

The 37 year old leader of Hezb-e-Islami Afghanistan was born in the Imam Saheb, Kunduz. His parents were Ghaznavis but, at some stage, chose to move to Kunduz. After attending a 10cal elementary school, he entered the Kabul. military cadet school of Mahtabqala. However he was rusticated from the military school because of his political thought and activities. He later went to Shirkhan high school, Kunduz and, after graduation, entered the Engineering College of the Kabul University.

In 1968, Hekmatyar, along with ten other students, formed the Islamic Movement, then called the Muslim Youth Organization of Afghanistan. He was imprisoned in 1971 on charges of killing a communist student, Saidal. He was released in 1973. During the Daoud Presidency, Hekmatyar went underground and spent about one year in the forests of Paktia. In 1974, he organized a strike force against Daoud government's positions in Panjsher, Laghman and Paktia and several district headquarters were over- run by the mujaheddin. Since the Afghan jehad began against the establishment of a communist regime in Afghanistan in 1978, Hekmatyar has played an active role in the affairs of the jehad. In all Hekmatyar has written 33 books and booklets, the first of which was written in Kabul about the precedence of spirit over matter.

Hekmatyar is married and has fjve children. His other important books are:

\section{His writings}

1. Reasons for the Rise and Fall of Nations;

2. The Islamic Ummah;

3. The Reflection of Faith in Word and in Deed;

4. War in the Eyes of Quran;

5. The Political Solution of the Afghanistan Issue;

6. The Quran and Slave Nations;

7. An Address to the Responsible Commander.

\section{His Views}

EDITOR'S NOTE: The following are his views, as reflected in his speeches on important topics. They are quoted here from the official publications of the Hezb-e-Islami Afghanistan the Shahadat and Shafag.

* Our nation which has rendered 1,1 million martyrs will never tolerate (only) a gradual withdrawal of aggressive Russians (Shahadat, 21 May, 1986).

* The only party which in Afghanistan resorts to people vote and believes in elections is the Hezb-e-Islami Afghanistan (Shahadat, 20 November, 1986).

* A coalition government, not satisfactory to the mujaheddin, will not last even a few days (Shahadat, 27 December, 1986).

* The most harmful people in an organization are the arrogant ones who consider themselves better than the others (Shahadat, 25 March,1987).

* The objective of the entire people of our country is the establishment of an Islamic gov- 
ermment. They are not content with a mixed govermment, not with a coalition government. They say there must be a $100 \%$ Islamic government under a reliable Islamic personality (8 April, 1987).

* The issue of the Shia brethren, who are being treated as a separate group by a number of people with vested interests and thus they are inciting religious prejudices, can only be solved by holding elections and not by accepting a specific Shia party.(Neither) it will besolved by negative and unreasonable approaches of those who excommunicate the Shia people (Shahadat, $15 \mathrm{July}, 1987$ )

* We are going to utilize all our talents for the formation and organization of a disciplined and principled party and we are going to (resist and) resolutely indiscipline, chaos and selfishness (Shahadat, 15 September, 1987).

* Until the entire Soviet forces withdraw from our country without any conditions, we consider a halt and delay in our current jehad, even for a second, a treason and crime (Shahadat, 12 December, 1987).

* No decision can be carried through without our consent (Shahadat, 17 January, 1987).

* The Russians, on the one hand, are trying to make others recognize their puppet government and, on the other, are seeking to weaken and eventually disarm the mujaheddin (Shafaq, No. 7, 1986).

* Afghanistan is now the land of the mujahed and Islam is going to rule in it (Shafaq No.3 and 4,1986 ).

* By forming a coalition government, the Russians want to repeat their experience in Central Asia and East Europe (Shafaq No.7,1986).

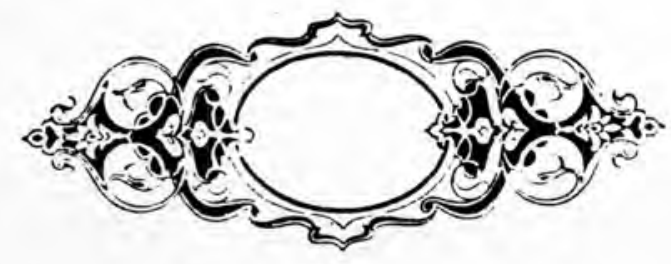

\section{Sebghatullah Mojaddedi}

EDITOR'S NOTE: Facts about the life of Prof. Sebghatullah Mojaddedi, leader of the Jabha-eNejat-e-Melli Afghanistan, have been taken from a book by the Jabha under the title of"The Leader of the Mujaheddin."

Sebghatullah Mojaddedi is 62 years old and was borm in the Shorbazar of Kabul. He finished his high school in Kabul and completed his higher education at Al-Azhar University, Egypt in 1953. In 1956 he participated in the war against the British, France and Israel in the Suez Canal. He later served as teacher in Kabul Teachers' School, Habibia High School and lecturer in the College of Law and Political Science at Kabul' University. In 1953 he was jailed by the Daoud government and spent four years and seven months in jail at Dehmazung, Kabul. After his release, he was advised by the government to leave the country. He lived abroad unti] Daoud had gone from the scence. In 1971, he formed the Jamiat-e-Ulama-e-Mohammadi in Kabul. In 1973 he was invited to an international conference in Libya and served as its President. On his way back to Afghanistan, the 1973 coup, headed by Daoud, took place and he had to change his route. He went first to Beirut and then Saudi Arabia and served in the Rabeta-a-Islami for one year. For four years he supervized the affairs of an Islamic center for the Scandanavian countries. After the 1978 coup in Afghanistan, he formed the Jabha- Melli-e-Nejat- - Afghanistan in Makkah and then came to Pakistan where he was chosen as leader of this front. The following are some of his writings:

\section{His writings}

1. A Proclaimation of the Jabha-e-Melli-e- 
Nejat-o-Afghanistan; 2. Two Principles of Salvation knowledge and unity; 3 . Five speeches; 4. Text of a speech by Professor Sabghatullah Mojaddedi; 5. Digest of the speeches by Hazrate-Professor Mojaddidi; 6. Jehad or Revolution;

7. The Saana Conference.

\section{His Views}

EDITOR'S NOTE: The following are his views on important topics. They are quoted from the official publications of the Jabha-e-Melli-e-Nejat Afghanistan:

* Until the last Russian soldier is in Afghanistan, do not put your weapons on the ground" . (From Digest of the Speeches by Professor Mojaddedi).

* "Those who really support the Afghanistan Jehad should sever their political and economic relations with Russia (From Digest of Speeches by Professor Mojaddedi).

* "Almighty God loves the unity of Muslims more than anything else and orders that the Muslims should, like a wall cemented with led, fight in solidarity and unity the enemies of Islam and Muslims (From Two Principles of Salvation: Knowledge and Unity).

* "We have instructed all our commanders in all fronts of the Jehad to strengthen and support all mujahed brethren of any Islamic organization and be with them in one front" (From Two Principles of Salvation: Knowledge and Unity).

* "Today in our country there are two sects (of Islam). One is the Ahl-e-Sunnah and the other is the Ahl-e-Tashayyu. All of us should gather under one banner, the banner of "There is no God but Allah and Mohammad is His Prophet". and should join in unity and forget tribal, sectarian and linguistic differences (From the text of a speech delivered on the occassion of the condemnation of 27 April, 1978, coup).

* We are for true unity. We consider Islanic unity our religious obligation. We have never refused to join in unity those Mislims who are rendering sacrifices for the cause of truth and will never refuse to do so in the future (From Five Speeches).

* We don't want a coalition government with the communists in Afghanistan. Any Afghan Muslim who may be instrumental in the Russian withcrawal (from Afghanistan) and the majority (of the people) of Afghanistan accept him (and be able to) establish Islamic government in Afghanistan, we will accept him. For this conforms with the Islamic and Afghan traditions. (From The Jabha-@-Jehad, \&-11 May, 1987).

* The freedom loving and Nuslim people of Afghanistan will never put themselves in one line with those whose dirty hands have been stained with the blood of the martyrs of freedom and will never form with them a common government. This is not practical and, as a matter of fact, is im[rssible (From the Jabhe-e-Jehad 1 November, 1988).

\section{Burhanuddin Rabbani}

EDITOR'S NOTE: Facts about the life of Professor Burhanuddin Rabbani, leader of the Jamiat-eIslami Afghanistan are taken here from Meesaq-e Khoon, The official publication of the Jamiat.

\section{Biography}

The 47 year old leader of the Jamiat-eIslami Afghanistan was born in Faizabad the Center of Badakhashan province. He is the son of Mohammad Yusuf. Rabbani went to a middle school Faizabad in 1947 and in 1956 came to Kabul where he was enrolled at the Abu Hanifa Madrasa. In 1960 he entered the College of Theology of Kabul University. After finishing the university with honors in 1963, Rabbani was appointed as a lecturer at Kabul University and was sent in 1956 to Egypt for higher studies at Islamic University of Al-Azhar. He finished his graduate work in philosophy and Islamic theology and enrolled at Al-Azhar to receive his $\mathrm{Ph}$. D. with the title 
of his dissertation being "The Scholarly and Philosophical Aspects of the life of Abdul Rahman Jami"(The Afghan mystic-poet).

After returning to the country he resumed teaching at Kabul University. Rabbani in 1966, when the first nucleaus of Islamic movement clandestinely was being launched in Kabul by a group of teachers and professors, joined the movement. In 1967 he was entrusted by the Supreme Council of the Jamiat-e-I slami Afghanistan to organize the activities of Kabul University students. He was elected as the leader of the Jamiat-e-Islami Afghanistan in 1972.

In 1974, when the Kabul police was after him to arrest him, he was saved from arrest as a result of efforts undertaken by a number of Kabul University students and he went into hiding in mountainous and tribal areas. In 1979 the leader of Jamiat-e-Islami Afghanistan took an active part in the formation of the Islamic Unity for the liberation of Afghanistan.

\section{His writings}

1. "In the Shadows of the Quran" by Sayyed Qutb (translation)

2. Islam and Communism,

3. The Tragedy of 26 of Saratan (17 July) and the Real Face of Daoud Khan (describing the coup by Mohammad Daoud in 1973 which toppled King Mohammad Zahir Shah).

4. Doud Khan in a Shameful Past, Criminal Present and Dangerous Future;

5. What kind of Struggle?

6. The Message of the Martyr;

7. An Explanation of the Beliefs of Motazelis (a sect which have deviated from the main current of Islam and are considered as heretics).

8. Methods of Debate and Research in Islam;

9. Principles of Education in Islam;
10. The Sign Post of the (True) Path (translation).

\section{His Views}

EDITOR'S NOTE: The following are his views as reflected in his speeches on important topics. They are quoted here from the official publications of the Jamiat-e-Islami Afghanistan. The Mujahed and The Messag-e.thoon.

* We should strongly halt the malicious propaganda being waged against our Islamic Revolution and should not allow anymore the time of our brethren wasted in organizing themselves against each other and in backbiting and ill speaking". (Mujahed 29 October, 1987).

* In Afghanistan the Shia and Sunni are all together and the deceitful and crafy Russians will never be able to enslave them by their snares of dividing the two (Mujahed, 29 October, 1987).

* Unless we are confirmed as a principle political party in determining the destiny of the the Islamic Revolution of Afghanistan and unti] the (Afghan) mujaheddin are not recognized as the principle and deciding factor, whoever they are going to instal. (in power) will be faced with a strong resistance of the mujaheddin. (Mujahed, 29 September, 1987).

* The role of our Shia brethren in the coalition is very important. Our Shia brethren, without whom the national unity of Afghanistan cannot be achieved, must have a role in every decision and, by doing so we should frustrate the malicious enemy propaganda which intends to create division and rifts between the Shia and Sunni brethren. (Mujahed, 15 August, 1987).

* Now is the time that the Afghan nation, which has been raising multitudes of champions and rendering martyrs should have the right to determine its own destiny. (Mujahed, 16 July, 1987 speech).

* We are in need of discipline, unity and Isla- 
mic education more than anything else (Mujahed, 27 May, 1987).

* We must admit our mistakes wherever we are. Not having united leadership, and a longterm and all round strategy or program are among the fundamental drawbacks of our revolution . (MuJahed, 28 April, 1987).

* Our people have risen for upholding the cause of God Almighty. Until the glorious banner of Islam is hoisted in their country, their uprising and struggle will continue (Mujahed, 4 March, 1986).

* The Russians and other countries ought to know that peace and security in Afghanistan can be achieved only as a result of the formation of an Islamic country. This is a desire which is nourished in the heart of each one of our people (Meesaq-e-Khoon, 31 December, 1986).

* The imposition of an individual or a group of people over our revolutionary nation through influence and money, is tantamount to an unforgiveable treason against Islamic revolution (Meesaq-e-Khoon, 29 September, 1987 speech). * Slavery in any of its forms is tantamount to one of the most disasterous manifestation of

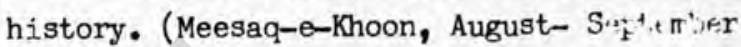
1988)

\section{Charter of Mahaz-e-Melli Islami-e- Afghanistan}

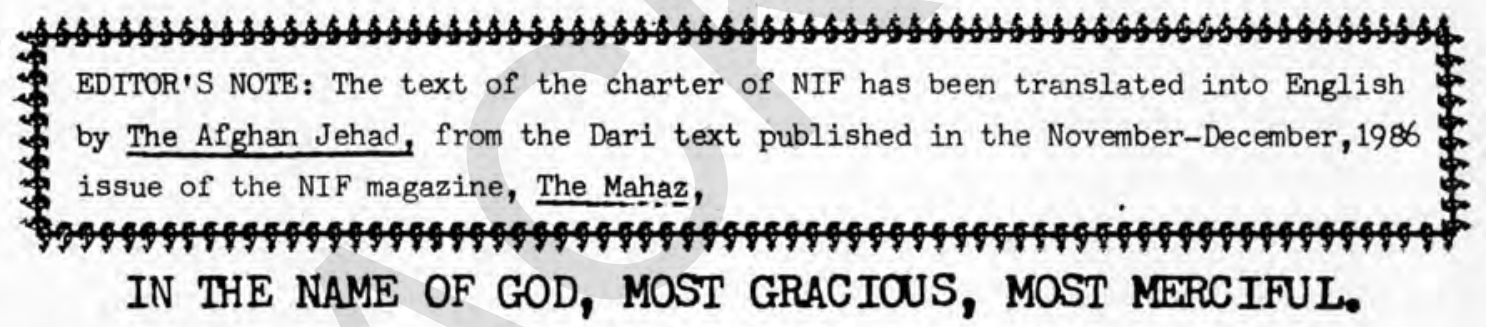

INTRODUCTION:

The necessity for an emergency and immediate establishment of the Mahaz-e-Melli-e-Islami-eAfghanistan(The National Islamic Front of Afghanisten,NIF) was felt when, unfortunately a number of traitors - - who neither in the past nor at present had any roots and support among the Muslim people of Afghanistan - - by making use of shameless military, political and financial support and cooperation of the Soviet Union, formed a gang which, from the very beginning (resorted to) bloodshed and massacre of thousends of Muslims and patriots (of Afghanistan). This oppressive and traitor clique, comprised of the puppets of the Soviet Union, have been imposed in our sacred land contrary to the will and consent of our Muslim nation. The present order in Afghanistan, being un-Islamic ani anti-nationel, is founded on the pillars of atheism, communism and criminal acts and, for its survival, has, so far, put into prison thousands of patriotic people including the religious scholars, spirituals, nationel elements, infant children and innocent women and have eliminated them with utmost ruthlessness without trial.

The mercenary Khalqi-Parchami and their traitor clique (serving) as foreign puppets have levelled to the ground cities and provinces of the country by their cruel and savage bombardments, annihilating thousands of our Muslim and patriotic sons. Workers and activists of this traitor clique have breached the (Afghan) independence and national sovereignty, and have threatened the 
Islamic status and the national identity of the patriotic people of Afghanistan. The traitor KhalqParcham group has clearly violated the fundamentals of the sacred religion of Islam and have trampled human dignity and human rights with utmost shamelessness.

Simultaneous with the founding of the NIF, Sayyed Ahmad Gailani spiritual leader in Afghanistan, in his capacity as the President of NIF, proclaimed, according to a verdict of pious ulama of Afghanistan, the sacred jehad against the cormunist system and against the antiIslam and anti-national Khalqis and Parchams and their supporters.

As a result of this, an Islamic and national uprising was started throughout Afghanistan against the anti-Islamic and anti-national Khalq-Farcham atheists clique.

Members of the NIF are comprised of (the members of) different classes of the Muslim people of Afghanistan, inclucijng religious scholars, tribal chiefs, intellectuals, military officers, statesmen, former honest of ficials in government institutions as well as farmers, workers and students. All have joined hands, by relying on the help of /Imighty God and with an unshakeable will and determination, to proclaim the Word of God and liberate the country from the domination of alien aggressors and regain the national independence and identity (of Afghanistan) and, fortunately, have achieved impressive victories in various fronts of jehad. The NIF urder the leadership of Sayyed Ahmad Gailani, has resolutely conducted - - and will continue $1, \mathrm{c}$ conduct - the sacred Jehad against the atheist, anti-Islamic and anti-national Khalq and Parcham and their supporters until complete victory. From God comes the help and victory is near.

The annihilation of this anti-Islamic, anti-national clique and the establishment of a national Islamic order (in Afglianistan) forms the basic objectives of the jeha' (launched by) NIF. The NIF, in order to achieve these sacred objectives welcomes the sincere cooperation rendered by other mujahed organizations.

The NIF, with the help of Almighty God, efter the toppling of the anti-Islam and antinational Khalq-Parcham group and their traitor and criminal cliques and until all the effects of the intervention of their supporters come to an end, will offer in detail to the Muslim and patriotic nation of Afghanistan, its policy statement. Howerer, at present the general objectives of the NIF in domestic and foreign spheres are explained as follows:

\section{A- IN THE FIELD OF DOMESTIC AFFAIRS}

1. The holy religion of Isilam and patriotism are the basic principles and the only source of inspiration of NIF thoughts anci activities and, on the basis of these, it will fulfillits folitical, social, cultural and economic activities.

2. The NIF considers the defense of the independence, national Islamic sovereignty and territorial integrity (of Afghanistan) as its religious and national obligation.

3. The NIF totally rejects, at present and in the future, the dictatorship of an individual, family or of a party and will struggle against it.

4. The MF, with having faith in the right of self-determination, considers legal only the kind of government which is formed through free and legitimate elections.

5. The NIF supports social, economic and political justice and the participation of all the people, both women and men, in the task of development and progress of the country in accordance 
with the principles of the religion of Islam and acceptable national traditions (of Afghanistan) and opposes all kinds of discrimination, exploitation, despotism and opplession.

6. The NIF, within the framework of the injuctions of the holy religion of Islam, respects freedom of the press and individual and social likerties is accordance with the provisions of the law.

7. The NIF considers free education, with no discrimination whatscever, as the legitimate and clear right of the people of Afghanistan and actively supports oveiall and efféctive measures towards the popularization of literacy. "Acquiring of knowledge is obligatory on all Muslims, men and women". (Hadith of the Holy Prophet Mohammad, peace be upon him)

8. The NIF considers the protection of health and free medicare as a right of all members of the society.

9. The NIF believes in the separation of power of the three branches of the (government) - - the executive, legislative and the judiciary.

10. The NIF cons: ders the protection and respect of private property and fulfilment of individual rights and respect for human dignity in accordance with the in inctions of the Islamic law as its obligation.

11. The NIF supports the establishment of a just economic order - - Islamic economy - - the objective of which is the welfare and prosperjty of the Afghan nation.

12. The NIF, in pursuance of the commands of the holy religion of Islam, is opposed to the propagation of extremist (left or right) political and cultural thoughts and hopes that the Afghan society, as a member of international community and with full respect for the sacred principles of Islam, will play its effective role towards furthering civilization (stet).

13. The NIF supports the creation of all kinds of facilities and assistence to families whose guardians have been martyred for the cauce of Almighty God and liberation of the country or have been inflicted with such (injuries) that they have lost their power to work. Also it considers as its obligation to appreciate and commemorate the martyrs of the sacred jehad.

14. The NIF supports the creation of facilities and the elimination of obstacles towards the return of those compatriots who, as a result of the encroachment and oppression by the traitors to Islam and the country, have been forced to leave the country.

15. The NIF wants unity and solidarity among all jehad forces and, as such, exerts utmost efforts for achieving the formation of a united national Islamic front to symbolize and represent the entire Afghan nation at national and international levels and considers this principle to be among the basic fundamentals of its policy.

16. The INF, after the dissolution of the anti-Islam and anti-national Khalq-Parcham order, considers the formation of an interim national Islamic government, establishment of an assembly comprized of the representatives of the God loving and patriotic ration for the execution of the military and civil affairs as an obvious and necessary move. In addition to the members of NIF, it accepts members of other national Islamic organizations within the framework of these two organizations. This acceptance will be in proportion to their valor and sacrifice for the cause of the liberation of Afghanistan and the degree of the support of the people of Afghanistan for , them. 
17. The interim government will have the duty to prepare the draft of the constitution of national Islamic Afghanistan and present it to the assembly of the representatives of the Muslim nation of Afghanistan and ratify it.

18. The interim government will have the duty to convene the loya jirgah at the fj.rst conducive and appropriate opportunity. Members of the loya jirgah will be elected in the traditional manner by the Muslim people of Afghanistan. The loya jirgah, after a debate, will take necessary decision about the draft of the constitution of the Islamic State of Afghanistan.

19. The NIF will adopt affective measures for the reconstruction, speedy and healthy overall development of the Afghan society, so that, with the support of Almighty God anc participation of the entire Muslim nation of Afghanistan, it may be able to compensate for the destruction caused by the activities of anti-Islam and anti-national Parcham-Khalq traitor clique and their supporters.

B - FOREIGN AFFAIRS:

20. The NIF will establish the foreign policy of Afghanistan on the fundamentals of the nonaligned movement, positive and active neutrality and peace-lovingness and by keeping into consideration the national interest and wij] try to fulfil its active and effective role towards the consolidation of jnternational peace, security and cooperation.

21. The NIF will exert efforts to expand good relations with neighbouring countries on the basis of good neighbourliness, mutual respect and non-intervention in each other's internal affairs.

22. The NIF considers Afghanistan as a member of the community of Islamic countries, It, furthermore, desires expansion and consolidation of brotherly relations with Islamic countries specially the Islamic Republic of Pakistan and Iran and will try to strengthen and further consoljdate these relations, based on the principles of Islamic fraternity, in undertaking economic, cultural and political cooperation.

23. The NIF will make a basis of its foreign policy the establishment and expansion of good relations with other free and really peace-loving countries of the world and for the realization of this object it will adopt effective measures.

24. The NIF supports the principle of the OIC and the UN Charter as well as the Universal Declaration of Human Rights and also desires further strengthening of the UN and its participationin the just solution of interrational problems, as long as it is in accordance with the fundamentals of the holy religion of Islam and the national interest of the mujahed people of Afghanistan.

25. The NIF, on the basis of a belief in the right of self-determination, respects the rights of all nations which are struggling for obtaining their right for freedom and wants the evacuation of all occupied territories which have been subjected to aggression by the occupjers and aggressors.

26. The NIF welcomes unconditional assistance by brotherly and friendly countries for the overall economic and social development of the country and will try to invite the assistance of international organizations (to this end).

27. The NIF is against the imposition of the influence of super powers and the establishment of spheres of influence by them in various parts (of the world) and surports disarmament and 
elimination of nuclear weapons.

28. The NIF condemns expansionism and hegemonism and supports the principles of equality of rights, national sovereignty and equality among the countries of the world.

29. The NIF establishes and relates the degree of its brotherly and good relations with all the countries of the world on the basis of their support of the present jehad of the Muslim Afghan nation.

Triumphant be the sacred jehad of the Muslim people of Afghanistan, down with the enemies of Afghanistan.

\section{Charter of Hezb-e-Islami Afghanistan (Hekmatyar)}

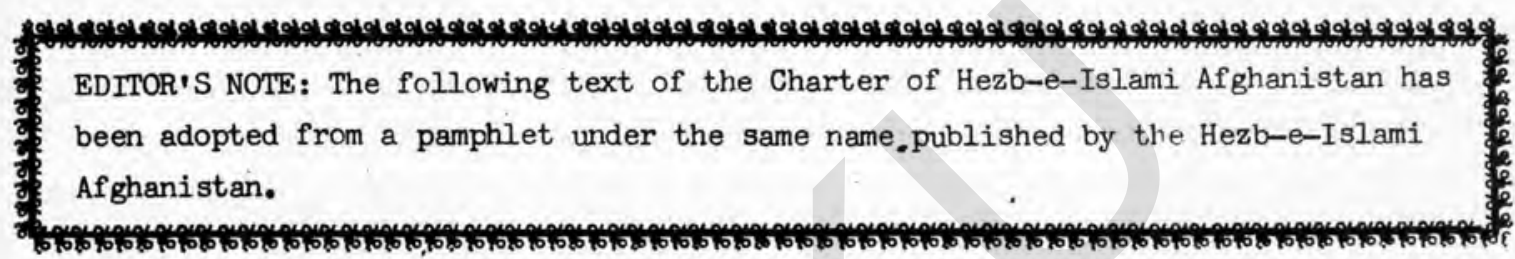
IN THE NAME OF GOD, MOST GRACIOUS, MOST MERCIFUL.

GENERAL

1. It is an obvious and clear fact that Afghanistan is an Islamic country the existence of which has been achieved at the cost of the blood of faithful elements and thousands of God worshipping mujaheddin have fought for the defense of its integrity undertaken at the cost of their lives. Therefore, in this land the kind of political and cultural activities aimed at propagating unIslamic beliefs and ideologies and replacing illegally the Islamic society of Afghanistan into an un-Islamic one, ell such activities, as a matter of fact, are tantamount to attempts aimed at eliminating our country's historic existence. As a staunch guardian of the existence and integrity of the country, Hezb-e-Islami is struggling against such activities.

2. Diligent defense of the territorial integrity, independence and complete unity of the country forms the prominent duty of the Islamic movement of the country and political activities aimed at thedisintegration of our country and (inciting) linguistic, local, regional, racial and sectarian prejudices will be met with stiff resistance of this party.

From our point of view, the independence and survival of the country and security and prosperity of the nation can only be achieved if a sense of unity, fraternity, and brotherhood is revived among the ranks of the members of the nation and a social system based on justice is established in a matiner which will enable all the people of the nation to live in (an atmosphere of) complete confidence without any type of racial, linguistic, regional and secratrian discrimination and enjoy human and legitimate rights and God worshipping and piety is the criteria for super-iority and privilege.

3. We are of the opinion that, unless the following points are truthfully and sincerely accepted 
the possibility of evolving a firm and durable order will not exist in our country.

a) Since the absolute majority of the people of the country demand the establishment of a complete Islamic order, the sovereignty of this order should be accepted in a practical manner and those who do not heed this obvious fact and are exerting efforts for the introduction and dominance of an un-Islami order should be identified as the real enemies of the nation and struggle against them should be recognized as a legal obligation of all members of the nation.

b) This territory is a common land of all the faithfull subjects of this country is not the private property of any specific family. As such, no one has the right to exert impermissible efforts tewards the consolidation of the foundation of the rule of any specific individuals and to consolidate the foundation of an oppressive and dictatorial order and prevent the people of the nation from intervention and participation in national issues and to consider the government his personal and inherited property.

c) Political leadership of the nation should be organized within Islamic principles and with the advice and guidance of the real representatives of the nation, and should takeover the role of supervising the affairs of the country. Those political statesmen who have not received the confidence of the legal representatives of the nation and the responsibility of the supervision of the regime has not been entrusted upon them in accordance with the provisions of Islamic shariat, will never be able to prevent internal tensions and take constructive steps for the progress of the country.

d) Bvery Muslim individual of this soeiety, as a matter of principle, has the right to put forth his personal opinion about national affairs and to communicate it to others by using legal means. Illegal restriction over this will make members of the nation to use other means for obtaining power, which would obviously be more costly to our nation.

e) Complete prevention of the subversive activities of those political groups which do not support the Islamic status of Afghanistan or have set forth as the objective of their efforts the consolidation of an un-Islamic order in this country and are opposing the unity and safety of this country.

4. Hezb-e-Islami Afghanistan has launched (its) struggle for the realization and establishment of such a social order that will embrace the following values, principles and programs in various aspects of life:

\section{CHAPTER-I.}

\section{IN THE FIEID OF CONSTITUTION}

1. The Holy Quran and the valuable Ahadis (sayings) of the Holy Prophet of Islam, peace be upon him, will be established in clear and irrisistible telms as the primary sources of laws. In matters of ijtehad action will be taken in accordance with the Hanafi jurisprudence. 2. An authorized and competent administration will be established to bring at the earliest all laws and official rules of the government in conformity with the spirit of Islam。

3. The shariat courts will be delegated sufficient authority and complete independence of the judiciary will be guaranteed. The office of the judiciary will be assigned only to those ulama whose piety and fidelity are completely proven. 
4. Necessary rules and regulations will be worked out at the earliest for a total implementation of all the Islamic injunctions.

5. All legal suppressive and oppressive matters, through which the ruling circles abrogate the legal and human rights of the people and which put an end to their freedom, prevent the obvious right of expression of opinion and create obstacles for legitimate and legal propagation (of ideas) will be totally abolished.

6. Laws and regulations that will curb at the earliest adultery, drunkenness, gambling, obscenity, and moral corruption will be enacted. Publication and distribution of obscene books, periodicals and(other) published material will be prohibited and the display of unethical and obscene films will be banned.

7. The issue of veil by women, as dictated by the shariat, will be totally observed throughout the country and their shariat and legal rights will be restored.

8. Necessary and essential rules and regulations will be laid down for the improvement of social life and establishment of healthy relationship among the people.

9. (The establishment of) suppressive military governments will be definitely banned.

10. In relation to the declaration of energenctes and continuation of military governments, conditions will be laid down to limit in a reasonable framework the unconditional powers of governments. 11. Secret and military courts will be totally abolished and the trial of the military officers and others attached to the army would be conducted only in the courts (set up by the) judiciary; 12. The parliament of the country will be formed on the basis of free and direct elections and its members would consist of pious members of the country.

13. Amendments will be made in the rules pertaining to courts so that problems of the people are solved speedily and necessary facilities are provided for an early execution of an equitable and fair Justice.

14. About the persons entrusted with the government offices, it will be kept in view that they should perform their duties with honesty and piety and adhere to the Islamic tenets in their private life. Commission of mortal sin will have bearing on the promotion and, if the situation demands, on the termination of the services of the government officials。

\section{CHAPIER-II.}

\section{IN THE FIELD OF RELIGIOUS AND ETHICAL REFORMS}

The programs of the Hezb-e-Islami in the field of religious and ethical reforms is as follow: 15. All necessary measures will be adopted to ensure that no sluggishness takes place in offering the prayers. In this connection, sufficient facilities will be provided to government officials and workers. In assessing the performance of official duties (by government of ficials) attention will be given to the performance of religious obligations (by these officials).

16. In the light of the provisions and directives of the shariat, conditions to ensure profound respect to (and observance of) the holy month of Ramadan will be provided.

17. Sufficient facilities will be provided in connection with the performance of Haf and all 
unnecessary and unreasonable hindrances, presently faced by the people, will be completely eliminated in this respect.

18. The prominent role which mosques should have in the social $1 \mathrm{j}$ fe of the Muslims will be revived and appropriate arrangements will be made to achieve honorable means of livelihood for the imams, khatibs (preachers) and custodians of the mosques.

19. All possible efforts will be exerted to make the situation conducive to higher Islamic studies and to inform the people about religious beliefs and injunctions so that every member of our Muslim society becomes aware of that part of religious instructions, the learning and understanding of which constitutes an obvious daily need of every Muslim.

20. The regular expansion of madrassas religious schools) and darul hufaz (schools for memorizing the entire of the Holy Quran) will be achieved in a manner so that difficulties in training religious scholars and the hufaz, (those who memorize the entire of the Holy Quran) are solved with a better manner within the country and that free pursuance of higher Islamic stucies are available in every province of the country.

21. By making use of all legal ways and means and by utilizing all government resources and possibilities, and with all power efforts will be exerted to abolish corruption and evil and the ways and mear ; through which crimes are propagated.

22. In regard to the ethical training of the people and for the healthy improvement of public and traditional relations, measures will be adopted to revive in the heart of the believing people the fear of God and a sense of obedience and service to God Almighty, so that they may realize their obligations and responsibilities in the light of their faith and a spirit of respect for the limits and dictates of the shariat is hourished in them and, as a result, our Islamic society may reach from the point of view of ethical maturity, a stage where abstention and refrain from evil and attending to social obligations may not be based only on the force of law.

23. Repairing of mosques, training of religious scholars and the hufaz, the delegation of the heavy responsibility of imamat (the duty of leading people to prayers) and remedying the economic difficulties of the imams of the mosques, constitute the important duties of the Department of the Endowments. Imposing on the people to render material support to imams and moazzens (one who calles people to prayers) are tantamount to a contempt and insult of religion and piety. 24. The non-Muslim minorities will enjoy all permissible and legal rights in accordance with the dictates of Islamic shariat, and Islamic hudood (limits) will be fully appljed to them.

25. And finally the government will 'have the duty, to conduct the trial of the apostate elements and punish them in accordance with the provisions of the shariat.

\section{CHAPIER-III}

\section{EDUCATION}

Attention to the issues of education and training, from our point of view, are of vital importance. Programs of the Hezb-e-Islami in this field are sunnarized as follows

26. The existing form of programs for educational and training institutions of the country, which have become totally obsolete and useless, will be reformed. Because (at present) only 
technical persons - - and that too, in a very defective manner - - are being trained in these institutions and religious and spiritual education of students have been completely forgotton. This has entailed a profound mental vacuum in the present educational institutions of the country. This intellectual vacuu paves the way for the nourishment of all types of degraded and dejected thoughts among the ranks of the various components of education.

The various stages of educational system will be shaped in such a manner so that, from the very beginning of education until its final phases, this eminent need constitutes the pivot of our attention that the educational institutions of our country should train such persons and offer them to the society, who, in addition to (acquiring) specialization in their particular fields, would also attain a completely assured level of Islamic knowledge and would be aware of the Islamic injunctions about his profession. Similarity, during the various stages of this program, subjects that will nourish in the hearts of the students a sense of obedience to the Divine cormands and injunctions will be taught.Education and training will not be only confined to enable (the students) to read and to acquire knowledge, but spiritual and ethical training will also be included in each one of the departments so that the scholarly qualifications of those offered to the society by educational institutions, are based on the elements of piety and a fear of being accountant before the God.

27. During the course of studies, every Muslim student will gradually learn Islamic beliefs, injunctions and guidances related to the daily life of believing people and will gradually move forward from the level of (reading and) reciting the Quran upto the level of grasping and understanding its utmost vital concepts。

28. In the field of scientific research, institutions for advanced research will be established and attention will be specially devoted to (conducting) wide-ranging research of Islamic sciences.

29. Necessary measures will be adopted to simplify the difficulty pertaining to the continuation of education and necessary conditions are provided so that no one is deprived of continuing education due to lack of sufficient resources.

30. Educational and training institutions will be opened in every nook and corner of the country.

31. The present system of co-education, where girls and boys acquire education side-by-side, will be abolished altogether.

32. A free academic atmosphere will be created in educational and training institutions of the country and the universities will enfoy complete freedom in the framework of an approved policy.

33. Positive steps will be taken to provide better conditions of living for the teachers and in order to encourage the best of the talents to (enter) this (profession), salaries for the teachers, will be arranged in a way to enable them achieves the highest standard of living in the country. 34. Specific attentions will be devoted to the basic training of teachers and efforts will be exerted to offer desireable teachers to the society - - teachers who, on the one hand, would have a complete hold in their field of specialization and, on the other, serve successfully in the task of Islamic and ethical training of their students.

35. As far as the appointment of teachers are concerned, their academic credentials will not be the sole criteria; importance will also be attached to the fact that they may not be opposed to the fundamental principles of Islamic status of Afghanistan and from the point of view of their 
tactics and ethics they may be capable to train the youth.

36.In the educational program of the academic institutions of the country, necessary military training will be kept in view so that the young generation would have sufficient orientation in the task of the defense of the country.

37. Teaching programs, at their various phases, will be pursued in of ficial languages of the country and efforts will be made that every one is taught in his mother tongue. Necessary measures will be adopted for the promotion of unofficial languages and special attention will be devoted to the teaching of Arabic language.

38. Supervision of the educational institutions will be entrusted to those professional officials who are endowed with religious knowledge and are symbols of piety and rightiousness so that their day-to-day lives, per se, may serve as a practical guide to the students.

39. Regular lessons will be initiated for the military of ficers in Islamic Jehad and a spirit of perseverance, faithfulness and sacrifice and a sense of understanding, awareness and interest to the nation will be nourished in them. Side by side with equipping them militarily, utmost efforts will be exerted to equip them with the precious Islamic guidances so as to make the army of our country an active force for deferiding religious and national principles and virtues and they may not become a tool in the hand of suppression and of non-patriotic leaders.

\section{CHAPTER-IV.}

\section{SYSTEM OF-ADMINISTRATION}

From our point of view, until healthy institutions comprised of religious, responsible and com petent officials, are formal no reform program can prove to be useful and fruitful. The Hezb-eIslami Afghanistan has the following programs for reforms in the administrative system of the country.

40. In order to check embezzlement, fraud and lawlessness in government departments, effec:tive measures will be adopted. All necessary means will be provided to strictly check bribery particularly among government officials and wonkers.

41. At the time of the appointment of high ranking officials to most important and sensitive posts, their financial conditions and that of their close relatives will be ascertained. Later, during the course of their service, they will be kept under strict surveillance so that their wealth may not increase to such an extent that it will show a clear and obvious discripancy with their permissible and legal income.

42. Those government servants whose standard of living appears to be beyond their remunerations or obtain such property or wealth that its permissible and legal source cannot be tract down will be interrogated at the earliest and dealt with under the shariat laws.

43. An independent department will be set up to check the government employees from resorting to injustice, encroachment and unjustified exercise of power. The department will listen to the complaints and objections of the public against government servants. Separate rules will be adopted about the procedure of work by this department.

44. Unnecessary expenditure in government offices will be strictly checked and bringing public property into illegal possession will be stopped. 
45. A specific national uniform will be prescribed for government officials for use during office hours and uniforms, medals and insignias which have been introduced as a result of the influence of western corrupt civilization will be abolished.

46. Resorting to savage and cruel methods now used by the filthy hands of the police during the investigation of crimes and interrogation will be completely banned. .

47. The use of unnecessary espoinage networks and secret police, particularly for creating an atmosphere of fear and terror, will be strictly prohibited. The (intelligence)networks, will(only)be used for keeping a watch on government officials and for a complete eradication of corruption and bribery and preventing the commitment of crimes.

48. Unjustified savage and impermissible dealings, resorted to presently against the poor and defenselessprisonersinside the prisons of the country, will be totally abolished and basic changes will be introduced in this regard in accordance with the requirements of an Islamic approach. Prisons will be converted into centers of reform, amendment and education of the criminal elements to enable them acquire the capability of earning honorable and respectable ways for their living.

49. Salaries of the government servants will be increased to an appropriate and necessary level. The standard of this increase will be to an extent to meet the economic difficulties of government officials and workers in a best manner and to stop a brain drain from the country.

50. The government will be bound to fix equitable remunerations for the military personnel and to recruit, at the first instance, such persons who voluntarily prefer Islamic holy jehad over other engagements. However measures will also be adopted for the military training of others as well.

51. The armed forces of the country will be organized and expanded in a manner so that it may emerge as a strong and assured defense power of the country and all efforts will be exerted so that the armed forces of the country may not come under the influence of imperialist powers.

CHAPTER-V.

\section{IN THE FIELD OF ECONOMIC ORDER}

The existing economic relations of the people, which has formed the basis of the economic order in the country, are based entirely on oppression and injustice. The system is a (in fact) manifestation of all the corruption, cruelties and injustices of non-Islamic orders and particularly the wrong economic policies of the un-Islamic governments have further increased this corruption and adversity. Until profound and fundamental changes are brought about in the economic order, establishment and realization of justice will not be possible. The fundamental changes (in this sphere) should be carried out in the light of Islamic principles and, under these, the legal rights of the people should be maintained.

Islamic guidances in the field of economic order contain clear, directives and Islamic jurisprudence has in this connection rendered complete explanations. The economic order, which we want to achieve, is based on the clear explanations rendered by the Islamic jurisprudence and principles.

The economic policy of the Islamic order consists of the following fundamental points:

a) observance of justice and fairness in different spheres of economic order,

b) complete eradication of different types of oppression, injustice and exploitation, 
c) creation of appropriate, uniform and favourable working conditions and benefits for all the people,

d) consistent struggle against poverty and hunger and untiring efforts for providing such conditions that no one may be deprived of his permissible and natural rights, and

e) skillful and equitable use of national and social (wealth and)capitals,

For the accomplishment of the aforesaid objectives, the program of the Hezb-e-Islami Afghanistan in the economic field is summed up in the following four sections:

\section{AGRICULTURE:}

For a long time, as a result of the prevalence of oppressive and un-Islamic system in the country, inequities and (undue) privileges have prevailed in the sector of agricultural land ownership and benefits from it.

For a complete elimination of these oppressive conditions, the following legal steps will be taken:

52. Ownership of properties which have been put illegally at the disposal of sources of power will be nullified in accordance with the provision of the shariat and will be returned to their legally deserving persons.

53. Cultivable land owned by the state will be distributed free of cost or on easy terms among landless cultivators and to the owners who do not hold an economic unit of land,

In regard to the distribution of land,priority will be given to the deserving people of the area where the land is located and not in an unjust and arbitrary manner among non-deserving people. 54. Serious attention will be devoted to the (implementation) of laws and regulations issued by the Islamic shariat about land ownership,agricultural and farming relations and un-Islamic dealings will be completely stopped.

55. At the time of the distribution of state-owned agricultural land, all possible efforts will be exerted to see that the land (to be owned) by a farmer and cultivator is to the extent that will achieve an honorable standard of living for him.

56. Measures will be taken to directly put at the disposal of cultivators and owmers of the land the fair and reasonable income which they are to receive from their agricultural products and a part of their profit does not fall in the hand of intermediaries, specially in the case of cotton crop.

57. For achieving a healthy (system of) agriculture, the desired agricultural implements, chemical fertilizer and improved seed will be put at the disposal of farmers with a fair price.

58. In order to preserve, develop and properly make use of the forests, necessary measures will be adopted; however, in no way, pastures and properties that are meeting the daily needs of the people will be misappropriated.

60. Except on the occasions that Islamic rules or Islamic economic principles require, fertile agricultural land will not be used for industrial purposes, etc.

61. Basic attention will be devoted to the utmost development of cattle raising in the country. In order to encourage cattle raisers, sufficient facilities will be provided to them and necessary 
measures will be adopted for the preservation of pastures.

62. The problem of shortage of foodstuff will be eliminated with adopting the following fundamental measures:

a) the land that has been fit for agriculture but have remained arid due to unfair reasons, will be put into use at the earliest,

b) in order to develop agricultural land, arid land will be made suitable for cultivation and agriculture,

c) best efforts will be exerted to construct water dams, canals and irrigate deserts and fertile land,

d) in connection with the buying, selling and the transaction of foodstuff, measure will be adopted that, on the one hand, do not stop the flow (of agricultural commodities) and, on the other hand, cultivators and farmers obtain fair and desired price for their agricultural product, and also consumers will be able to make use of them with a fair price.

e) in fixing the volume of foodstuff supplies (to the public) and for commercial purposes, it will be ascertained that no shortages of foodstuff occur (in domestic markets), and

f) in order to increase the income of farmers and to put an end to unemployment and lack of opportunies, cottage industries will be developed in rural areas.

\section{II - TRADE AND INDUSTRY}

In order to utilize the wealth and capital which, as a result of wrong, illegitimate and oppressive policies of un-Islamic government in our country, are being concentrated in the hands of specific people, and to realize the public interests, the following legal measures are to be adopted:

64. Usury, gambling, Impermissible speculation, hoarding and other impermissible and illegal means that have been banned in the Islamic shartat, for obtaining wealth will be legally bamed and only lawful means of obtaining wealth will be recognized. Similarly, action will be taken, on the basis of shariat, about the capital illegally incorporated as private properties.

65. Supervision of the affairs of companies and banks will be handed over to the elected representative of (their) partners and shareholders.

66. Necessary measures, including extending aid in loan will be adopted, to encourage and increase the number of companies, including small and limited companies.

67. In regard to fixing the price of industrial products, measures will be taken not to make these prices disadvantageous either to the owners of the companies or consumers.

68. Factories and companies will be obliged to produce only essential goods such as machinery, industrial goods, etc. and refrain from producing non-essential and luxury items.

69. (Both) in business transaction and in the production of industrial goods in the country, basic attention will be devoted to meeting the domestic needs of the country.

70. The government will control those industries which may play a vital role (for the country) and privately owning them is harmful to social (public) interests. Otherwise we are not in favor of nationalizing industries. 
71. The present banking system, will be reformed, in accordance with Islamic principles, on the basis of mozarebat (limited partnership) and mutual cooperation.

72. In our effort to have complete preparedness for the defense of the country, we are attaching great importance to the weapon production industry.

74. Modern and heavy industries will be created and, for the sake of the development and extension of small industries, necessary measures will be adopted and, in this respect, maximum use will be made of the experiences of other countries.

74. We are supporting the process of the extension and development of industries in appropriate regions and do not agree that industries ought to be built only in specific and special areas.

75. In the course of activities exerted for the industrialization of the country, priority will be given to the principles of "labor" and "need" and not that of "capital".

76. In order to completely protect home industries, the government will be obliged to strictly observe ban on the import of the goods that are being sufficiently produced inside the country.

\section{III-RIGHTS OF WORKERS AND IOW RANKING OFFICIALS:}

77. The present system of wages (paid to government workers and official) which, due to various reasons, is unjust, will be reformed gradually. In fixing the salaries, always the obvious factor, is observed that parallel to changes in conditions and keeping in view the prices of goods (and services), the minimum wage should meet the basic needs of a family. With a rise in prices of essential goods, the total of wages (paid) will be proportionally increased.

78. For government servants and low ranking officials sufficient facilities will be provided in the best manner to meet their needs in housing, medicare as well as proper (and healthy) education of their chtldren.

79. In regard to eapital and labor, laws will be enacted as a result of which cooperative relationship is established between capital and labor and legal wages of the workers are in no way abused and an attempt will be made that, in case of disputes arising between the worker and the owner of the factory, Islamic ways for solving the issue are found and a fair settlenent is reached.

80. The government is to refrain from employing and putting into work children and will adopt necessary measures for the healthy upbringing of children.

81. The system, under which men and women are working together, will be completely abolished and Islamic principles will be strictly observed in this respect.

82. In cases of illness and at times when workers' health is affected, while working, proper arrangements will be adopted for their treatment.

83. The obvious right of every individual to demand his permissible and Iegal wage will be legally guaranteed.

The government will seriously feel itself responsible to attend to people's complaints and defend their rights.

The government's work program in regard to attending to the complaints lodged by the people will be adopted in such a way so as the objections made and complaints lodged by the people are 
heard in the shortest and easiest manner.

\section{GENERAL ECONOMIC REFOPMS.}

84. Necessary measures will be adopted so that the (various kinds of) zakats (compulsory and defined tax paid by the Muslims from their income) alms given under the provisions of the "one tenth" (of the income to be given to the needy), etc. are collected by the state and are spent according to the shariat laws. Taxes which have no basis in the shariat will be completely abolished.

85. The economic policy of the country will be prepared with the participation of the elected representatives of the people and will later be implemented after its ratification by the parliament.

86. The state treasury will be refined in such a manner so that, in no way, it is based on lawful shares.

87. Impermissible investments in illegal fields and unnecessary expenditures are to be completely banned. Specially unnecessary expenditure on constructions serving as show pieces will be stopped.

88. Factors which contribute towards a rise in prices are to be eliminated.

89. Efforts are to be exerted to end unemployment and lack of opportunities.

90. Suitable conditions will be created for medical treatment with little expenses.

91. Effective measures will be adopted for the development and extension of hospitals.

92. Basic needs of the handicap and distitute will be met from the public treasury by (extending to them) salaries to meet their basic needs. Similarly they will be brought under regular Islamic training (and education).

\section{IV - IN THE FIELD OF FOREIGN POLICY.}

In the field of foreign policy, too, changes will be introduced so that, like the policies (pursued) in the domestic affairs it is based on Islamic principles and on the principles (corresponiting with) basic needs of the country.

93. We will consistently keep alive the matter of continued resistance for the complete realization of the truth and justice and will vehemently struggle against oppression, aggression and Infustice. In our relations and dealings, we will be honest and truthfull and persuade others to also do likewise and we will seriously honor our commitments.

94. We are strong supporters of world peace and security and will not refrain from all kinds of sacrifices for achieving this objective. However, from our point of view, only the non-existence of war is not tantamount to peace and security. Our definition of peace and security is (the prevalence) of a condition (as a result of) which right and justice are achieved throughout the world and such a favorable atmosphere prevail in relations among nations as a result of which disputes and tension are completely eliminated and nobody will be able to step over the legitimate rights of others or create obstacles and difficulties on their path towards peace and progress. (Indeed this noble objective can be achieved only when Islamic order is adopted in practice in organizing and leading human affairs in a healthy manner). *

* Brackets those of the original. 
95. We resolutely condemn various manifestations of colonialism, exploitation and oppression and consider the continuation of colonial order as violation of the requirements of justice and equity and recognize the remainings of the colonial oppression as the main element of tension, disputes and insecurity.

96. Equal struggle against East or West imperialism is considered by us as the fundamental obligation of nations and, in order to put an end to this, we will use all the means at our disposal. 97. Those backward nations which in one or another way, are under colonialism will enjoy our support for their freedom, in the light and principles of Islamic guidance, specially the Muslim nations whose independent Islamic existence is under the threat of the force(s) of oppression, aggression and imperialism.

98. We want the establishment of good and reciprocal as well as the consolidation of cooperative relations with all countries of the world. However, in no way we are ready or never we will to lerate to deviate from our principles and beliefs and damage our national interests under the name of establishment of good relations with others, or agree to the kind of relations that will affect the freedom and independence of the country. Furthermore our Islamic sense of reform do not allow us that our relations with a country of the world are established in such a manner to pave the way for the penetration of their deviated beliefs and ideas opening the doors of the country for them to undertake the task of propagating and disseminating their thoughts.

99. We will resolutely refrain from entering military blocks and we do not want our country to become a part of race among big imperialist powers.

100. In international issues, the accords and contracts contrary to Islamic texts will in no way be honored.

101. Our untiring effotts will continue for the consolidation of brotherly and friendly ties with the world of Islam and we confirm our good and sincere efforts for the establishment of relations among Islamic countries around the axis of common objectives.

Under the present circumstances, we are trying to see the revival of the spirit of unity and fraternity among Muslims for achieving the survival and solidarity of the world of Islam.

And finally we are considering as necessary the adoption of a common strategy for the Islamic countries:

(a) Revival of Islamic culture and civilization and prevention of the influence of unIslamic civilizations (In Islamic societies), (b) Joint investments for the development of arms industries of Islamic countries to the extent that these countries, once more, become self-sufficient in arms and military equipment, (c) recognition of Arabic as (an) international language and joint efforts for its wider dissemination, (c) establishment of a competent international court for solving mutual disputes among the Islamic countries, (e) providing easier facilities for travelling within Islamic countries, ( $f$ ) taking necessary measures for expansion and development of trade and financial transactions (among Islamic countries), and ( $\mathrm{g}$ )effective assistance to be rendered to Muslim minorities living in various countries of the world under the burden of oppression and transgression.

FROM GOD WE SEEK SUCCESS 
The Muslim and heroic Afghan nation, on the basis of its belief and strong and unshakeable faith and unrelentless love for the sacred religion of Islam and long standing patriotism, has been struggling inside the country for preserving its Islamic order and national sovereignty for the last nine years against the biggest and blood thirsty military power of the Russia and its satellites and,outside the country, has resorted to a political and propaganda jehad and, despite the fact that it has rendered more than one million martyrs and prisoners and about 5 million of its people have migrated to different countries of the world, nevertheless, it has continued its brave struggle relying on Almighty God and love for freedom, and has achieved big and gloriousvictoriesin uprooting communisim and liberating the country from the claws of the world devouring Russian power despite unbearable difficulties and shortcomings and going through difficult phases and has with the help of Almighty God, day by day, achieved grand and prideful victories. It has tried to overcome its difficulties and lack of order one after the other and to reach a new phase of organization which is the unity and solidarity of all mujahed forces comprizing all Afghan nationalities and strata, and to succeed in achieving its holy aspiration: the proclamation of the Word of God, Sovereignty of an Islamic order, independence of the country, achieving national sovereignty and territorial integrity.

The formation of the Jabha-e-Melli-e-Nejat-e-Afghanistan took place - - after the issue was being pondered upon in relentless activities and ponderings of many important, mature minded and experienced personalities of the country - - during a historic session of these personalities in the land of the inspiration of the Holy Quran (Makkah) in response to a solem responsibility towards Almighty God.

The major objectives of this organization is to organize the jehad and to make it successful against atheism and communism and in toppling the Khalqi-Parchami government, preventing deviating and un-Islamic activities of atheist and misled elements and uprooting of the astray groups, establishing of the Islamic order, achieving Islamic justice, territorial integrity and national sovereignty of the country, preparing the grounds for the popularization of Islamic education, serving the cause of the welfare of the nation and enforcing the national will on the basis of Islamic injunctions, fulfilling an effective role in the field of brotherly relations with the world of Islam and friendly relations with human and peace loving world and meeting all religious obligations. This historic meeting chose from among itself an esteemed and distinguished personality such as Hazrat Prof. Sebghatullah Mojaddedi as the leader of NLF and its organizer. 
The precedence of his struggle against atheism and communism and against ethical and ideological deviations tens of years ago and the acceptance of many hardships by him and also his eloquence, his scholistic position and cultural standard and his tact of life and social relationship, - - all these - - have been important factors contributing to his election by such a body to such a sensitive position.

During the year 1978 in a grand historic meeting attended by the scholars, spirituals and tribal chiefs in Pakistan to consider Issues relating to the jehad, Hazrat Prof. Sebghatullah MoJaddeds was enthusiastically elected with the chants of Allah-u-Akbar as President of NLF and leader of the jehad. The NLF, as it is clear to all, despite many difficulties and accepting losses and deprivations under the auspicious leadership of Hazrat Prof. Sebghatullah Mojeddedi and the endevours exèrted by sincere followers and colleagues (of the NLF) has not only remained firm to its stand, but has gradually and persistently taken solid steps towards its goal and has achieved popularity among the public and has opened its way into the hearts of the mujaheddin and mohajerrin. It is noteworthy that the NIF has the honor of issuing the first command of jehad throughout the country on 13 February, 1978, and despite the fact that throughout the depth and width of the country it has an extremely expanded relationship and organization and, despite the fact, that the public opinion of the mujahed Afghan nation has approved the policies and leadership of the NLF, nevertheless the NLF had refrained so far from organizing itself as a party and, as its name signifies, has kept open its door as a trench of jehad throughout the country for all Islamic organizations and parties and for all Muslims and mujaheddin of the Afghan nation and, for this purpose, the leadership of the NLF also stopped the activities of the already organized Jamiat-ulVlema-e-Mohammadi which had been established long.time ago in Afghanistan and had made impressive headways.

The NLF has not taken a (hostile) stand against any mujaheddin group inside Afghanistan and against any jehad organization outside the country. and - - without paying attention to party membership - - has rendered (all) possible assistance to the mujaheddin and has advised its (own) supporters and mujaheddin to render moral and material cooperation to all other mujaheddin.

This sense of sacrifice, in fact, clearly shows that the NLF has always and sincerely tried to bring about a real unity throughout the country and has discharged its responsibility in this respect. There are many evidences (to prove) that the NLF has rendered sacrifices for achieving this objective and has never refrained from giving sacrifices.

At this juncture, when by the grace of Almighty God, signs of victory and success of the muJaheddin have appeared on the horizon, the Executive Council and leader of the NLF decided that the activities of the NIF, with such a stand and popularity among the people, should not be halted after the independence so a huge moral wealth and investment is not wasted. Also, as the need for positive and truthful activities aimed at the realization of noble Islamic aspirations and objectives are further needed in the future and the future of Afghanistan itself is a matter of great concern, the Executive Council of the NLF decided that the NLF should continue its activities not as a temporary organization but as a fundamental and permanent organization and issued orders for drafting a charter for the organization. Therefore, the charter of the NLF in the form (of a set) directions is being proclaimed. The purpose of this is to continue fundamental and relentless efforts towards the attainment of noble objectives of the NLF and defend the legitimate rights of 
the mujahed and devoted Afghan nation. On God, show us the straight way, the way of those on whom you have bestowed your grace, those whose (portion) is not wrath and go not astray.

CHAPTER I

\section{GENERAL RUIES}

1. The Holy religion of Islam is the official religion and the Hanafi Mazhab (i.e.branch of religion) is the official mazhab of Afghanistan.

2. The Hanafi figh (jurisprudence) is the only source of legjslation in Afghanistan.

3. The NLF considers as its religious and national obligation the defense of the holy religion of Islam, political independence, national sovereignty in the light of the shariat of Islam and territorial integrity (of Afghanistan).

\section{CHAPTER II}

DOMESTIC POLICY

4. The NLF adheres to the principle of shoora (council) and is opposed at present - - and will be so in the future - - to any dictatorship which is contrary to Islamic order and will struggle against it.

5. The NLF (declares) unlawful atheistic, communist and anti-Islamic activities and will stop them.

6. The NLF affirms the principle of Islamic social economic and political justice which guarantees the participation of members of the society in the development and progeess of the country and, in accordance with the principles of the holy religion of Islam and praiseworthy national traditions, rejects all kinds of discrimination, exploitation and oppression.

7. The NLF respects the principle of freedom of thought and expression within the limits of Islamic shariat and will abide by it.

8. The NLF considers as its duty the rendering of health services to all members of the Afghan nation and the deserving people would receive free treatment.

9. The NLF considers free Islamic education for all Afghan people as (a) legitimate right and strongly supports the adoption of effective and overall measures for a campaign against illiteracy. 10. The NLF, in accordance with injunction of the holy religion on Islam, follows (the principle of the) separation of power.

11. The property of (a) person is free from violation in accordance with the injunctions of Islam. The acquiring of private property for public interests, can tale place on the basis (of the payment) of a just price (to the owner). Human dignity and rights is free from violation in accordance with the injunctions of Islam. Judicial prosecution and punishments can only take place by judicial authorities in accordance with the injunctions of Islam.

12. The NLF, for the sake of the welfare and prosperity of the Afghan nation, supports the establishment of a just economic order which is in conformity with the funianentals of Islam.

13. The NLF strongly prevents the propagation of thought and the dissemination of such political and cultural ideas which are contrary to the teachings of Islam and the Afghan culture. 
14. The NLF considers as necessary an allout effort towards preparing constructive plans for sound scientific and technical advances for the sake of raising living standard, achieving of public welfare and strengthening the Islamic assembly of Afghanistan.

15. The NLF supports the creation of all kinds of facilities for helping the families whose guardian and or members have achieved the high position of martyrdom or have lost their capacity to work.

16. The NLF, in case the country is free, will exert utmost effort for the return of those compatriots who have been forced to leave their homes and country due to the encroachment and oppression of traitors to Islam and homeland.

17. The NLF' belleves in the principle of unity and solidarity of all jehad forces and seriously perpetuates its efforts through this (united organization)for the formation of an allout unity wich will symbolize and represent the entire mujahed Afghan nation at national and international levels.

18. The NLF, recognizing the critical realities and conditions of the time, for the sake of achieving two sacred objective - - the (1) establishment of Islamic order(in the country) and (2) independence of the country - - which along with the militery jehad, are our two basic principles confirms a political solution (of the Afghanistan issue) which will affirm the objectives and conditions of the resolutions of the foreign ministers conferences of $0: C$, resolutions of the conferences of the OIC heads of state and ressi] utions of the UN General Assembly.

19. The NLF considers the formation of an interim Islamic national government for fulfilling the tasks of the interim period as an obvious and necessary measure.

20. In the formation of the permanent Islamic government of Afghanistan the will of the majority of the nation is considered a basic principle and this (will) is to be manifested through an elected parliament.

21. The interim government has the obvious duty to prepare, as soon as possible, the draft of the constitution of the Islamic nation of Afghanistan through renowned scholars and people of knowledge and, under suitable conditions, ratify it by the loya jirgah.

22. The NLF adopts effective measures for the reconstruction and speedy, healthy and overall development of the Afghan society.

23. The NLF considers the formation of the interim government as the obvious right of the mujaheddin. In case the interim government cannot be formed by the mujaheddin due to internal or external obstacles, the NLF, for the sake of the establishment of Islamic order and preservation of the supreme interest of the country and prevention of further bloodshed, is ready to support a government formed by a Muslim Afghan who is supported by the majority of the Musiim nation of Afghanistan.

\section{CHAPTER III}

FOREIGN POLICY

24. The foreign policy of the NLF will be based on the findamentals of non-aligned movement, positive and active neutrality and peace lovingness in accordance with the teachings of the holy religion of Islam. The NLF tries that, with keeping in view national interests, it ought to ful- 
fill its effective and active role in the consolidation of world peace and security and international cooperation.

25. The NLF tries to maintain good relations with neighbouring countries on the basis of relations of good neighbourliness and non-interference in the affairs of each other and to expand these relation as much as possible.

26. The NLF, considering itgelf an integral part of the Islamic society, wants the further expansion and consolidation of fraternal relations with Islamic countries specially the Islamic Republic of Pakistan and exerts efforts that these relations, which are based on the principle of Islamic brotherhood, are further strengthened and consolidated in economic, political, cultural and social iields.

27. The NLF will put as the basis of its foreign policy the establishment and expansion of good relations with other neighbouring countries and all the peaceloving countries of the world taking in view their stand vis a vis the Afghanistan Jehad.

28. The NLF supports the principles of the OIC, the UN Charter and the Universal Declaration of the Human Rights. It also wants the maximum and active participation of the UN in the just solution of international solutions, provided this is not contrary to the fundamentals of the holy religion of Islam and supreme interests of the people of Afghanistan.

29. The NLF, taking into consideration its Islamic responsibilities, and its respect to the right of self determination, completely supports the masses of enslaved Muslims who are conducting a jehad for proclaiming the Word of God. It also support other human societies who are truly struggling for their freedom.

30. The NLF accepts unconditional foreign assistance for the overall economic and social development of the country.

31. The NLF is against the influence of super powers and the setting up of their spheres of influence in various parts of the world. It condenns the armament race and the development of nuclear and strategic weapons and supports the elimination of all kinds of weapons which may cause an annihilation of the world in the future.
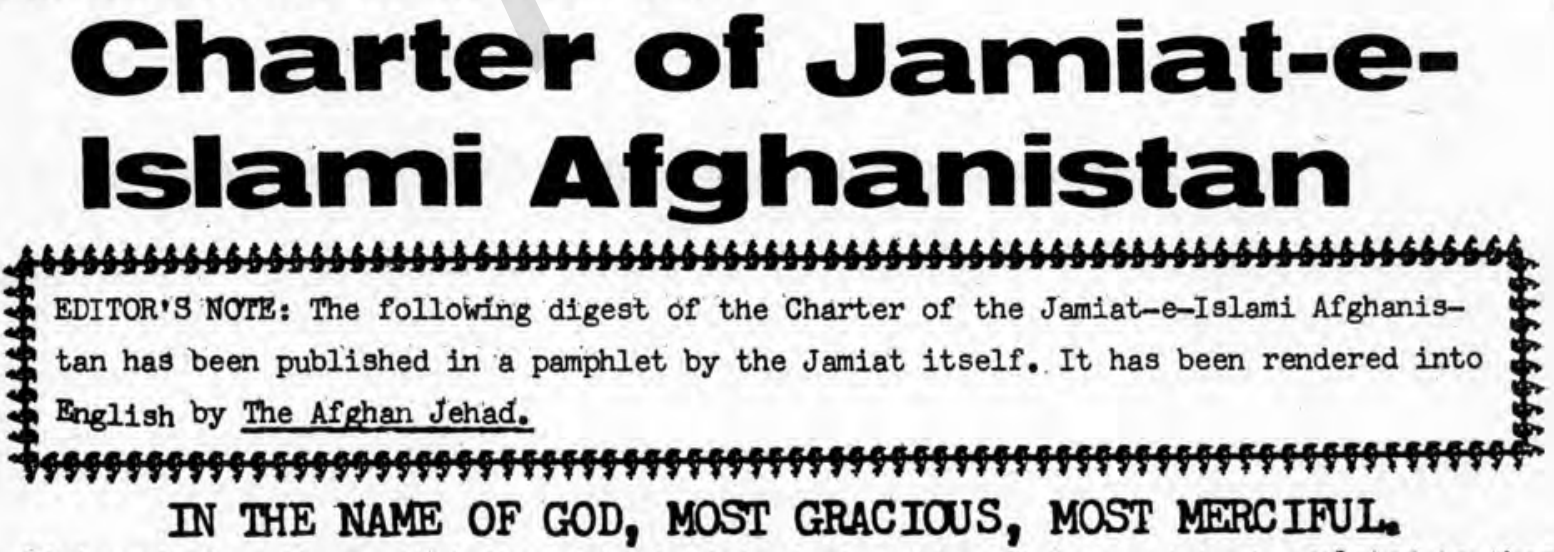

History bears witness that the highest historical prides of our society is related to those auspicious eras when the bright torch of Islam had been shining in the conscience of our nation. A strong unity of different tribes and ethnical groups of our country and the formation of stong central governments, effective participation of our people in world civilization and culture upto 
the level of pioneering and breaking-off the chains of old colonialism for the first time in the East, all these and tens of other great honors, have been achieved under the shadow of lofty teachings and honorable directives of Islam. And until religion in our society had been the order of the day, the foundation of our nation was strong and sound, our country was the center of knowledge and education and cradle of civilization. But at times when shameful governments and corrupt and despotic rulers were exploiting Islam for their evil deeds, criminal ffforts were undertaken to create obstacles in the way of the implementation of lofty teachings of Islam. Treacherous leaders did not allow our (Islamic) religion - - the most perfect program of life - - to manage all aspects of life and lead our society towards its path of progress. It was at this juncture that crushing blows were inflicted to the pioneering role of our Muslim nation.

After 1919, when our brave nation, in the shadow of the revolutionary teachings of Islam hoisted the grand banner of jehad and inflicted crushing blows upon the most powerful imperialist country, and religious leaders, during successive phases, led victorious uprisings to defeat the remnants of imperialism, the advent of such revolution from this small nation put us in the forefront of the heroic nations of the world and, at the same time, (as a result of our uprising) the notches of imperialism were shaken. It was at this time that the filthy networks of imperialism ushered their activities and started their struggle against the new factors which were at work for reviving our grandeur and against the motives of our exciting revolution. Evil plots were hatched to remove the genuine teachings of Islam from the lives of the people. Agents of imperialism in the country brought under their sway the corrupt governments and barred the implementation of Islam and instead of implementing the revolutionary and genuine teachings of Islam they resorted to artificial and demagaugic actions.

From 1955, when the doors of the new imperialism were opened like the mouth of a dreadful dragon, in the face of our aggrieved people, destructive and evil efforts were undertaken to enslave our freedom loving nation. Savage breaches were committed against our values and sanctities under various pretexts and the government disseminated and popularized with a great speed those factors which were to extinguish the passion of faith and kill the feeling and pride (of our people). The umbrella of our defense and the jugular of our economy came under the control of aliens so that our nation would be disamed from all directions and come under the yoke of (a) new imperialism.

The tragedy of 17 July (1973 when Mohammad Daoud overthrew the monarchy) which was the outcome of these evil plots, appeared in our history under the $t \leqslant t$ le of a black and bloody chapter and appeared in scene as a crushing and frightening blow to our national integrity and cultural genuineness. The painful tragedies of that black and deadful period are not hidden from the eyes of our believing and tormented compatriots. Evils of that shameful period ran their roots into the depth of the society, hyborating the factors of shameful and criminal changes in its womb.

The Jamiat-e-Islami Afghanistan, as the sincere custodian of the shining teachings of Islam and the hardline defender of the deprived classes and protector of the national honor and interpretor of the aspirations of the Muslim nation of Afghanistan, has always rendered unhesitating sacrifices for the sake of reviving the grandeur of Islam and for the liberation of (this) deprived nation from the criminal claws of old and new colonialism and for struggling against oppression, and, with such a revolutionary ferver, until it achieves its noble and great ideal, it will 
continue its jehad and struggle.

During the corrupt period of monarchy, the revolutionary herald of this organization had greatly shaken the institutions of corruption and, as an awful storm, it had deprived the criminal element from their sleep (of indifference) and when the criminal Daoud regime was torturing and annoying our helpless nation with cruelty and the political and economic independence of our country was being threatened and our history and culture were leading towards an extinction, at that time, other than the exciting cries of the followers of this organization and their heroic struggle no other voice, not even the hues and cries of pseudo-revolutionaries (who only marched) in the streets, and of the clique which has now come into power after the bloody and tragic catastrophe of 7 th of Saur (27 of April), could be heard.

At that time, these (communists) elements were busy kissing the footdoor of corrupt forces and at looting the properties of the nation and massacring the sons of Afghanistan.

It was only the Jamiat-e-Islami Afghanistan which embarked upon an extensive revolutionary struggle and did not refrain to render any kind of sacrifice. Its valorous pioneers calmly welcomed in the dark cells of prison, savage tortures for the sake of defending their fundamental $s$ and values and, liberation of their deprived and aggrieved nation. Anc. now, after the bloody coup of 7th of Saur, that our beloved country is on the verge of collapse in the mouth of the dragon of new imperialism, during this shameful period when the base and traitor Khalqi stooges have converted our beloved country into a dreadful and horrible prison in which no other voice is being heard other than the voice of the whippings of executioners of the people and the cries of tortured inmates, once again, the fervered and enthusiastic pioneers of the Jamiat-e-Islami have come afore and are wrestling hard (to ward-off) sufferings and tortures (being inflicted upon our nation) and are carrying ahead valorously their vast and overall struggle. The noble ideals of the Jamiat, which are based on the shining teachings of the Quran and the Sunnah of the Prophet (peace be upon him)are summarized in the following points:

- - Our country, Afghanistan, is an Islamic country and will remain Islamic as long as God wills. Therefore, the implementation of Islamic order in our country constitutes our responsibility and our esteemed and sacred ideal and we will put a hard struggle for this cause until achieving victory. We will vehemently quell any effort aimed at changing the Islamic character of the country.

- - Our struggle will strongly continue against (both) old and new colonialism and their shameful remnants and bringing to an end the reign of the stooges of the 7th of Saur will form the axis of our task in our struggle against alien rule and imperialism. We will eliminate all the obstacles on the path of the extension of the education of beloved Islam.

- - this organization wants to save the Afghan deprived pation from the grips of poverty and deprivation, unemployment and need, oppression, imperialism and any other injustice which is the product of the shameful systems of ignorance through the application of the noble system of Islam; it will bring about such conditions under which the basic needs of the people are achieved and all the residents of this country live in a peaceful environment, their honor and prestige are protected, their rights are not usurped, their private and public property are safe from exploitation and looting. We want to provide, under the protection of the noble system of Islam, the primary and essential needs of all the members of our beloved country. 
- - The Jamiat is resolved to put an end to corruption and vices and to uproot' embezzlement, bribery, drukeness, murder and looting, robbery and insecurity and other crimes and unlawful acts.

- - The Jamiat, on the basis of the principles of Islamic economy, consider as accountable the properties collected unlawfully and wants the arid land distributed among the farmers and the people with little land and undertakes fair and effective measures for raising the living standard of the people.

- - The Jamiat wants that the landlord and farmer, owner of the factory and worker, employer and employee, instead of struggle against each other, ought to live in an atmosphere of help and cooperation and share the profit and production in a fair and just manner among each other, and in this way, eliminate from the environment of (social) relationship the injustices and contradictions of ignorant and destructive systems which are brought about by capitalism and communism.

- - The Jamiat vehemently struggles against impermissible privileges, lingusitic, family and regional discriminations and groupings which aim at hostility towards each other and will try that all ethnical groups and tribes of the country, under the name of a single nation, are equal in their rights and obligations and live in a brotherly manner and equally participate in the construction and development of their country.

- - The Jamiat will prepare the kind of educational programs which will enable the young generation to use modern sciences and technology for serving the society while preserving (their) religious principles, cultural and (ethical) standards.

- - The Jamiat, for the sake of the preservation of the cultural genuineness of the religious Afghan nation, wants the religious madrasas (schools) to resume their scholistic and social prestige and status to convey the Islamic invitation (da'awat) to frustrated and numb hearts and minds as the strong religious trench and center of the dissemination of a rooted and swift revolution.

- - The Jamiat wants the mass media to serve the cause of our education and civilization and to become a means for the dissemination of our rich culture and genuine and everlasting values.

- - The Jamiat wants the women to enjoy all the rights and privileges granted to them by the shining teachings of Islam and to assume their proper status in the civilized Islamic society。

- - The Jamiat has no inherent hostility (and opposition) with any person and group and determinesits relations with persons and organizations on the basis of their stand vis a vis the Islamic Da'awat (invitation), defense of the rights of the people which comprizes the religious obligation and historical responsibility of the Jamiat.

- - The Jamiat will defend with might the independence and territorial integrity of the country and, for the sake of the consolidation of the political independence and maintaining the cultural heritage and economic independence (of Afghanistan) will not fall shy of rendering any kind of sacrifice.

- - The Jamiat siders as its o' gation the defense of Islamic minorities and, on the basis of defending the oppressed, supports Liberation movements. 
- - The Jamiat, at an international level, wants friendly relations with all countries and is for the unity and solidarity of the Islamic world and non-aligned countries against aggressive and imperialist forces. It considers as its obligation the revival of the spirit of jehad among the believing and valorous nation of Afghanistan for the sake of guaranteeing progress and consolidating Islamic d'awat throughout the world and breaking the shackles of oppression and suppressing the criminal enemies and the Jamiat mujaheddin will be in the forefront in this respect and in practice they have proven their genuineness and sincerity for uprooting the Khalq puppet clique and will continue to do so in the future.

- - The Jamiat, under the present sensitive conditions, calling for the exercise of full responsibility when the countries (of the world) are on the brink of annihilation and collapse, and servants of new imperliasm, have exposed to danger our political, economic, and cultural independence, under these circumstance, by presenting a fraction of its aspiration and hopes, calls upon the believing and valorous compatriots, the heroic youth who are the sinoere guardians of Islamic resurrection, the sympathetic religious scholars who are the esteemed inheritors of the grand heritage of Islam, the valorous and zealous officers of the army who are the guardians of religious sanctities and national and historical honors of the country, the students of modern sciences who are the thinking brains of our society and the hope of future movements, the honorable and faithful farmers, the believing virtuous worker and the entire noble and valorous Afghan nation to unite under the banner of epic-making Islamic invitation for the sake of saving the country from present tragic condition, the continuation of which vill destroy our history and culture, traditions, sanctities and all other values.

By having complete faith in the help of God,we are continuing our allout struggle. With bayonet andmachine-gun we dig into the heart of enemy and in the field of thought, with the sword of pen we are going to do away with rotten brain and render them ineffective and, in this course of our great struggle, we are not afraid of any difficulty. If today we are weak and wanderers, tomorrow we shall be powerful and magnificent and this is the Law of God: "And We wished to be gracious to those who were being depressed in the land, to make them leaders and make them heirs (The Holy Quran).

With such a hope we march. There shall be no success unless it comes from God. On him we trust and he is the Lord of the Throne.

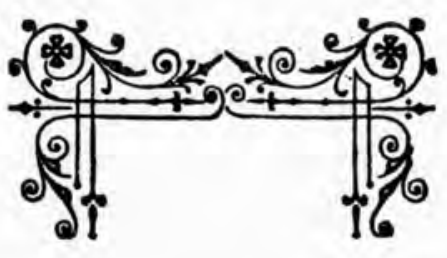




\section{January-March, 1988 \\ Vol.1, No.3}

\section{PARIS CONEFERENCE ON AFGHANISTAN}

\section{DISCUSSES AFTERMATHS OF SOVIET WITHDRAWAL}

\section{Sholars from All Over the World}

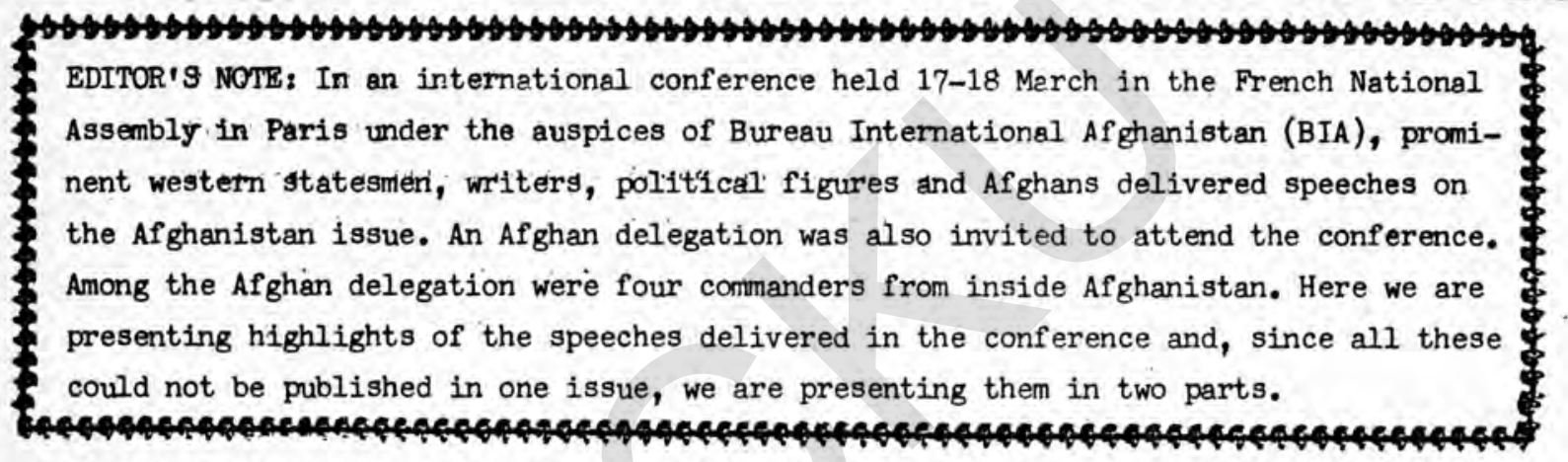

MESSAGE BY JAQUE CHABAN - DEIMAS (President of French National Assembiy).

Two years ago when I had the occasion to welcome you I hoped for your success. During this period a long course has been covered. The opening of the Geneva talks and the decjsion about the withdrawal of occupying forces from Afghanistan, all these are due to the valor of the Afghan people. Still peace has not come and the ominous war continues. Today I hope this brave nation, whose representatives are present in this conference, will be able to reach peace and tranquility in its country, peace not for the martyrs but for the living and the free as well.

I hope the window to peace will remain open so that people in this region will be able to live with their neighbours in freedom.

IAURENT SCHWARTZ (President of the BIA).

* The present Geneva talks are extremely important. However, one must admit that these talks are between other parties and the people of Afghanistan are not present in them. I think the Soviet Government wants to end this war and leave Afghanistan. However, it is so far not ready to take the most important step, i.e., to give up the Kabul Govermment so that a real government of the people of Afghanistan will be established. A government which, according to IUAM, is nonaligned and not a coalition govermment with Najibullah who does not represent anybody. Therefore, nur conference at the time of Geneva talks bears great deal of importance.

* The enemies of the Afghan nation, the enemies of peace, freedom and culture, assassinated Bahauddin Majrooh (Director of Afghan Information Office in Peshawar) savagely in his office. 
(The President then asked for one minute silence and later a recorded voice of Majrooh was played for the audience. The recording was sent by Majrooh's family in response to the invitation which was extended to him by the BIA before hi.s assassination).

YVES TAVEFNIER (President of the conference)

After an introduction and presentation of the members of the conference said:

* I have told the President and Government of Pakistan many times that the Government of France greatly appreciates their efforts for maintaining the interests of the Afghan refugees.

* Expressed his gratitude to the French and international media for devoting attention to the Afghan issue and particularly praised the journalists who accept great risks by going inside Afghanistan to report the events. He particularly mentioned a French journalist sentenced recently to 10 years of jail by the Kabul Government and said the Fiench Parliament demand his immediate and unconditional release. Similarly urged the release of an Italian journalist also in prison by the Kabul authorities,

* The conference is being held at a time when the people of Afghanistan are engaged in a great struggle for the establishment of peace. The Soviets Union clain that if they find politicalcondition acceptable they will quit Afghanistan.

* Leaders of the Afghanistan resistance have announced that they do not oppose talks if the people of Afghanistan alone are able to decide their fate.

* We are following the Geneva talks with interest and hope that it will assisst in achieving peace. The French Parliament will serjously support the UN decisions.

* Last July I met the resistance leaders in Peshawar and in the name of the French Parliamentary delegation I confirmed my support for the people of Afghanistan.

* Once more I affirm the legitimate rights of the Afghan people to decide their own type of government and their economic, political an social system without outside intereference.

* On the basis of the UN resolutions, we demand the withdrawal of Soviet forces from Afghanistan and hope conditions are made conducive for the return of the Afghan refugees to their homeland so that they may resume their lives in certainty inside their country.

* He praised the declaration of 5 December, 1987, of the European Parliament about the valor and spirit of freedom of the Afghan people and said we too are of the opinion that the participation of the resistance is essential for the political solution of the Afghanistan issue.

* France, which is to mark the 200 anniversary of its revolution and the anniversary of the human rights declaration, expresses its support for the people of Afghanistan and hopes they will regain their peace and freedom. It is hoped that this international conference will be successful towards the realization of this objective.

AYATULIAH MOHAMMAD ASEF MOHSENI (On behalf of the Afghan delegation)

* Every struggle needs two factors in order to succeed. One is the military and the other is the political factor. If we do not attain a high level of military success, political propaganda, no matter how extensive it may be, will be futile or at least have little affect.

* Fortunately our people, after nine years of jehad, do not feel tired and are still ready to 
continue their struggle. Today even our women have been participating in the jehad and revclution of their country. In this entire period we have not seen even one person to have felt tired of war and, of course, in this conference four commanders are present from four different areas of Afghanistan and they will he able to give you an intimate account of the mujaheddin feeling including of their will to fight.

* If there were to remain even one million people from the entire Afghan nation, they will still fight and will obviously not submit to aggressive Russians. However, if we devote all our attention to the military dimension and do not pay attention to publicity, obviously our victory might be delayed. We must bring military pressure on the enemy inside the country and political pressure in the outside world in order to force Russian retreat.

* International public opinion and human conscience are in our favor and damaging to the enemy and we should take advantage of this and therefore the importance of holding this conference under such circumstances is clear to us and $I$, on the basis of the honor of representation which my esteened Afghan brothers have bestowed upon me, want to thank the gentlemen who have paved the way for us to convey, the message of our jehad to the people of France and Europe. I pray Almighty God to succeed us in serving humantity. At the conclusion of my speech I condemn the mental and physical torture which thousands of our Muslim Afghans are undergoing in the prison cells of the Marxist regime in Kabul and I hope Almighty God that they, along with non-Afghan prisoners especially the French prisoners, will be released soon.

BERNARD DELPUBCH (Member of the BIA working in Peshawar).

* I have conducted interviews in refugee camps. There are great deal of differences between the refugees say in Chitral and Baluchistan. Everyone makes an attempt to live in an area which has geographical similarity to his own countryside.

* I did not notice any grave conditions in the camps. For instance in Chitral the refugees are free to move. They have built villages. Of course some live in tents waiting to return home sool. I asked the people in a Peshawar camp whether they will return to Afghanistan soon. They said no, not until Soviet troops are in Afghanistan, and then added they will not return until the Najib regime is in power. Here mud and dust have created difficulties for us but, as long as conditions in our country are not fit, our return is not possible.

* The refugees say we do not have anything to do with politics. The mujaheddin organization have to attend to such things. If they cannot unite, the commanders inside Afghanistan have to take the initiative at their hands because they deserve it.

* Relations between the refugees and indigenous population are generally good. Islamic hospitality has shown its affects. Pakistanis say a solution must be found to enable the refugees go back. Competition in finding Jobs and economy exists. If in Kabul there are any remant of communism, the refugees will not return. In the camps I did not observe anything of the ideology. They are realistic people. Of course there is ideology in the circles of party organizations.

* About one third of the Afghan population has migrated and this is the biggest number of refugees in the world. Inside Afghanistan, too, about one million people from the rural areas have gone to the cities. A large number of children and women do not receive any kind of aid. Each of the refugee camp have from 10,000 to 100,000 families which is still the biggest figure throughout 
the world.

* The refugees have about four million heads of catt.le. These have been brought by the refugees five to seven years ago.

* Disputes arise between the refugees and inhabitant about pastures and natural resources. Various tribes have come from all parts of Afghanistan to Pakistan. However $90 \%$ of them are speaking ?ashtu.

* In Pakistani cities mostly people from urban areas of Afghanistan have settled,

PROF. MOHAMMAD FAZEL (Member of the Afghan delegation to the conference)

* The communist regime in Kabul city has adopted programs towards the Sovietization of Afghan education and de-education:

* At the primary education level, they have changed the six years program into a 4 years, the middle level is prolonged to 4 years instead of three and the secondary level is reduced to two years instead of three. The total is 10 years of schooling compared to 12 years before.

* Graduates cannot enrol themselves to the university before completing military service.

* Those who could be enrolled into their desired colleges have to perform their duties wholeheartediy as a cominuist member. Each case should be confirm by a senior Afghan conmunist party member and his Rusian advisor.

* Communists are trying to destroy the Islamic beliefs of our children and youth. They have established children's organizations at the elementary schools and youth organizations at high schools and universities, so that they can effectively destroy their belief in God and cause them to abandon their Islamic values. A new subject has been introduced at schools. It includes Marxist and Communist ideology. Whoever fails in this course has to repeat the whole year.

* Promotion from one class to the next is related to one's political beliefs. Communists are promoted automatically. Instead of the entrance examination for the university, candidate's willing for guarding offices and public places have become tne condition to enter college.

* To the Russians education is the mean to learn how to commit mistakes, and teach the nation to make mistakes. They disregard totally the value of human relationships which is one of the fundamental and integral part of the Islamic educational system. When they come upto be blamed for their blunders, they simply state that it was a "mistake". Lenin and Stalin, after killing millions of people, just said "mistakes have been made". Even now in Afghanistan, after killing 1.5 million people, they say "we comitted mistakes ... miscalculated... the situation was not ripe" etc. * In the Islamic system of education one aim has been to solve conflicts by peaceful discussion and meanro: Or the contrary, in communist regimes they sharpen the conflicts and contradictions through dialectical materialish. Everthing is evaluated by this process.

* The "de-education" of the new Afghan generation is being done by forming children, youth, women, party, labor, class-union, revolutionary soldiers, self-defence and friendship organization, etc.

* During the eight years of war,almost all school buildings have been demolished.If the mujaheddin want to offer education to the children, the site where the teaching is held is being bombed.

* City boys and girls also left schools. They have become refugees throughout the world, specjelly in Pakistan and Iran. In these countries, they have not been able to complete their education. 
* Massacres of the educated cadres, scholars and professors is another big loss to the country.

* At all levels, from the primary school to the university, Russian advisors are implementing plans of ingraining their own system. Four years ago, Russian advisors, including some from Tdjekistan, revised the curriculum of the universities, polytechnics and teachers educational institutes without consulting professors.

* Six years ago the communists established the new institute of social sciencess. This institute is directly controlled by the Central Committee of the Party. Only Party cadres and teachers of political science can attend. Graduates become heads of local party organizations. Some of them replace former professors. At the universities there are not many experienced professors left. They have been replaced either by the inexperienced and unqualified graduates from the Soviet Union or directly by the Russians themselves.

AYATULIAH MOHSENT (Leader of the Harakat-e-Islami Afghanistan)

* I am speaking about a country which during the past nine years, as a result of the use of the most modern weapons against it, has become similar to a ruin and its people have been exposed to annihilation, a pedple who liave rendered hundreds of thousand of martyrs and wounded, people who have millions of wanderers inside and outside the country, a people whose enemy has not refraired from any kind of treason and deception and has used all. kinds of weapons agatnst them and has not left anything for them, a people who has no sin other than a demand for freedom and independence and non-interference by others in their fate, a peollf: viho can be said to have been subjected to an invasion by international communism, a reople who, cespite all these human and material casualtjes, none of their power of resolve and will to achieve their humanitarian objectives and revival of their honor have been reduced and until a long time to come, until they achieve their objective, they will remain so as a mountain.

* The Afghan Muslims mainly follow two Islamic schools of thought - - the Hanafi and Ja'afari. Twenty five to $30 \%$ of the people of Afghanistan are Shia and followers of the Ja'afarj school of thought. They throighout this time, alongwith their Sunni brethren, have continued to fight and have been part of all the difficulties and calamities inflicted upon our people of Afghanistan and we have risen and, will continue to do so, for a united indivisible, independent and free Afghanistan and the establishment of an Islamic order where all members of the nation are living in honor, dignity and enjoy social justice and no form of religious, linguistic, tribal and regional discrimination are observed in it and all of them join hands together for the reconstruction of their ruined country in all dimensions of a new life within the requirements of modern times in economic, agricultural, technical, industrial and other fields.

(EDITOR'S NOTE: The remaining of the speech of Ayatullah Mohseni was delivered in French by the interpretor. He had written his speech in Dari).

* I give the following surmary of the position of the Shia population of Afghanistan vis a vis the Afghan issue:

1. We are opposed to any kind of negotiations with the communists of Afghanistan who are serving the Soviets, because, in our judgement, they are directly responsible for the death of hundreds of thousands of Afghans. They are the source of all this misfortune and have paved the way to annex Afghanistan with the Soviet Union. The presence of even one communist minister in the 
government in our view is the continuation of imperialism and this, in itself, justifies us to continue our armed struggle.

2. In the future government of Afghanistan we are opposed to the participation of those elements who have cooperated with the Khalqis and Parchamis. Also those elements who have had a hand in the administration of old regimes are rejected by us. Finally, we do not consider as desirable the participation of those in the future government of Afghanistan who have remained indifferent throughout the Afghan jehad and have had an opportunistic cautious position.

People who have had responsibilities in the jehad and have proven their ability and comnitment should take part in the future administration of the country.

3. We do not make any criticism of Mr. Diego Cordevez, the UN envoy on Afghanistan and also do not show any pessimism (for the role played by) Pakistan in the course of Geneva talks on Afghanis tan, but want to say that these talks do not enjoy our confidence and we do not consider ourselves binding to decisions that might be adopted as a result of these talks. As a matter of fact, it is clear that in this war the $\Lambda$ fghan mujaheddin have been dealing with Soviet forces, while the Geneva talks are held, on the one hand, between the communists, with no mandate and the government of Pakistan on the other. Therefore, these talks lack any legal basis as they do not translate the true will of the Afghan people. The Muslim people of Afghan are a mature people able to take advantage of all the rights that any member of the community of nations is entitled to. The people of Afghanistan do not need an advocate or executor. With due respect to our neighbours, we do not permit them to interfere in our internal affairs. We believe that the shortest circuit for ending the war is to hold talks between the Afghans and the Soviets. These talks can be held immediately after the withdrawal of Soviet troops from Afghanistan.

Suggestions offered so far by the UN, the non-aligned nations or the OIC have failed to find a solution to important issues.

4. I must say that the only way to put an end to Soviet expansionism is to carry on the armed struggle in which the Afghan Shias have played a considerable role. Although the Shias have not received any military aid from big world powers, we hope the media will devote more attention to this element of the national struggle of the people of Afghanistan.

5. We confirm that non-alignment is a condition that achieves the national interests and interests of Afghanistan.

6. In our view, there are no contradictions between Islam and technical and scientific requirements in today's life. The Muslims can make use of these while maintaining their religious obligations. In Islam nothing prevents woman to take part in the progress of their country.

7. We expect all the responsible elements of Islamic revolution to remain alert at this sensitive juncture of history lest the Soviets might achieve success at the conclusion of political talks and, after their withdrawal, leave their imperialist remnants behind themselves. Our personal likes and dislikes should not distract us from our main objective - - the attainment of the supreme interests of the nation.

8. While we confirm the consolidation of relations between the Shias and Sunnis of Afghanistan, we are surprised for the little attention paid by the the Peshawar leaders to the Shias. 
Our hope is that the Shias will have a role in the administrative organs and in the government of the interim period, taking in view the importance of their size in the country. Any move for separating the Shias and the Sunnis are condenned by us. This participation will result in the consolidation of brotherly Islamic relations and prevent future disputes. The seven resistance organizations should accept the reality and should not allow that on a national level decisions are taken without Shia participation.

9. Interventions by the Indian government are to us part of their opportunistic policies in opposition to Pakistan and we consider them contrary to our national interests and condemn them. 10. The Shias are entirely of the opinion that in previous constitutions of Afghanistan, they were not mentioned and, in the future, amendments should be made to include the Ja'afaris along with the Hanafis.

11. The Afghan Shias, by achieving their complete civil and political rights, hope for the emergence of the kind of Islamic society in which all people enjoy the gains achieved from democratic laws.

COMMANLFR ANWARI (Of the Harakat-e-Islami Afghanistan, member of the Afghan delegation to the conference):

Soviet objectives in invading Afghanistan have been:

1. Swallowing of Afghanistan and controlling its rich mineral resources,

2. Making Afghanistan a part of its own republics such as Tadjekistan, Uzbekistan, etc.

3. Reaohing the warm waters of the Indian Ocean and the Gulf,

4. Overpowering 1ts rival, the US,

5. Dominance over Centrál Asia and the Middle East,

* The Russian estimates about Afghanistan not only went wrong, but Moscow also met defeat in political, economic and milltary dimensions.

* Pointing out to the "Russian crimes" in Afghanistan, he gave the following list:

1. collecting copies of the Holy Quran from the people and burning them and arresting religious scholars, and intellectuals,

2. martyring many innocent people including children and women. The number of our martyrs and diabled people reaches hundred of thousand,

3. destroying agricultural lands by bombs and chemical weapons,

4. converting about six million of our people to wanderers,

5. disseminating the hollow and meaningless communist culture among our people through the communist media,

6. sending our young people and children to the Soviet Union to undergo training in communism,

7. popularizing prostitution and moral corruption in our religious society,

8. demolishing houses and worshipping centers,

9. looting our natural resources, 
10. imposing on us an unequal war and resorting to the use of chemical weapons. In a 22 day war in Sanglakh, the Russians martyred 19 people by using against them chemical weapons.

* He spoke about the sending of Russian agents in the mujaheddin fronts, the establishment of the Ministry of Islamic Affairs in Kabul in order to deceive the people, the establishment of the Ministry of Tribes and Nationalities to fan tribal and ethnical differences, the formation of the National Front to bring greedy and opportunistic people into communist fold and the formation of what they deceitfully call people's militia.

COMMANDER NAQIBULIAH (General Commander of the Jamiat-e-Islamic Afghanistan in Kandahar, menber of the Afghan delegation to the conference):

About the Afghan Ressistance Against The Russians He Said:

* The Russian are trying to convey the idea that the Afghans have become tired of war. But the Afghans say: "This is not a war, it is a jehad. It is a prayer, a worship of God. The Muslims never become tired of worshipping their God. The people of Afghanistan will never retreat.

* Russian oppressions and atrocities are well known to you all. They have clestroyed our orchards and land by using bombs and rockets. Right now a handful of people have been asked to remain and cultivate the land. They are afraid to stay because the Russians would kill them and members of their families in order to prevent them to rebuild what has been ruined.

* Although the mujaheddin face many difficulties and there are no clinics and hospitals to treat them, even small children, the moment they hear that the Russian have come to an area, run and join the mujaheddin and say: "I want to fight the Russians".

* Mosques and houses have been ruined. No place can be seen that is still not ruined. Perhaps some members of the esteemed audience have already gone to Afghanistan. They bear witness that everythings has been ruined. There are no doctors and hospitals. Nevertheless, our resistance has been gaining momentum. The people are happy to fight and do not complain.

* Now that the mujaheddin have consolidated their positions and have learned war tactics, they are on the offensive. Before this, the Russians were on the offensive and the mujaheddin had to defend themselves.

COMMANDER ZAFERANI (Commander of the NIF in Maidan, member of the Afghan delegation to the conference):

* In the world there are such ideologies which destroy all kinds of sentiments, feelings and do not heed the call of conscience and ignore the moral posture of mankind. An example of this is seen in the Russian behaviour in Afghanistan.

* Afghanistan is a small and poor country which did belong to any block. The Russians, under the guise of good neighbourliness, non-interference, etc; at first resorted to deceitful acts which in fact amounted to an interference in our internal affairs. They recruited agents and spies and these were the first instances of KCB encroachments in Afghanistan.

* Later the Russians, by resorting to military coups in Afghanistan, created communist regimes and the entire people rose against them. However, the Russians with utmost shamefulness, and con-

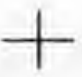


trary to their pledges of good-neighbourliness, etc., and international norms, attacked Afghanistan.

* The Russians and their puppets, under the guise of quelling the opposition, bombed innocent people and used chemical weapons against them, ruined houses and looted cities, stole historical relics, demolished roads, bridges, schools, govecnment buildings and other national properties and massacred in prisons those who wanted freedom. They also sacrificed Taraki and Karmal for their own selfish and evil objectives and brought into the scene their last puppet and slave who is the most faithful and obedient member of the KCOB and taught him to blame his predecessors for the crimes which were actually committed by the Russians and to talk about so called national reconciliation. Fortunately, our nation is aware that the offer is not intended to bring about peace but is a deceit and snare. The same way that the Russians have come to our land, we are going to, likewise, drive them out from it. When they came, they neither asked Diego Cordovez nor any international forum. They came with thej.r aircraft and tanks anc now it will be our weapons that will drive them out of Afghanistan.

* If anybody or any country helped the Russian in achieving their imperialist designs, it has not taken into account the bloodshed by the Afghans. Pakistan and Iran are our Muslim brethren nations. They have given refuge to our five million Muslim people and this is a praiseworthy act. However, If they become soft toward Russia, not only the return of the refugees will be hindered, but these countries, too, like Atghanistan, will be subjected to Russian aggression in the future.

* Our last word is that in Afghanistan we are in no way ready to accept an alien government which has been responsible for the annihilation of a large segment of humanity. We will continue our jehad for the sake of earning the pleasure of God until the establishment of a government supported by the entire Muslim people of Afghanistan.

COMMANDER MAIEK ZARRIN (The NLF commander in Kunar, member of the Afghan delegation to the conference).

When pointed our guns towards the Russians it was not meant to heed the formation of a coalition government. We "did so in order to 'earn the pleasure of Almighty God and for the sake of the holy religion of Islam. The Afghan mujaheddin will not lay down their guns on the ground until an Islamic government is established in Afghanistan.

* We had begun our Jehad first against the communists and, when the communists were not able to resist the mujaheddin, the Russians came from Moscow to defend them. But, the Russians cormitted a mistake. For Afghanistan is no Bukhara or Smarkand. They thought that Afghanistan, too, will succumb. However, we people of Afghanistan have our own standards of belief in God Almighty. God willing, we will restore the freedom, non-alignment and Islamic status of Afghanistan.

* Signing a treaty about Afghanistan in the framework of Geneva agreements will be a blow (to the cause of restoration of peace in Afghanistan). But we will not lay down our arms until the Russians, followed by their puppets, quit Afghanistan.

SABAHUDDIN KUSHKAKI (Member of the Afghan delegation to the conference)

* If the Russians are sincere in having a peaceful Afghanistan after their withdrawal from our country, they know very well that the Afghans are not going to stop fighting until they topple 
the communist regime against which they had risen as early as the regime was established. The Afghans are going to topple the Kabul regime, but meanwhile fighting will continue in the country which will in turn prevent the five million Afghan refugees abroad and about million inside the country to return to their homes. That is why Pakistan insists on the formation of a new government, supported by the people and capable of creating an atmosphere conducive for refugees to return.

* We have to have a government which will be in vogue with the aspirations of our people. Such a government can be created only if we admit certain realities:

1. The communist regime in Kabul, which captured power in 1978 through a military coup assis ted actively by the USSR, has proved its total inability to solve the national problems of Afghanistan.

2. the Afghanistan people decided to topple the communist regime not only because of its failure to tackle successfully the national issues, but because ideologically the regime was diametrically opposed to Afghan Islamic ideals. No matter what this regime says about its respect, etc, about Islam, the very fact that it derives its ideology from Maxism - Leninism, people will not accept it and, until it is in power, they will vehemently and violently oppose it.

3. the existence of a puppet regime in Kabul will not only endanger the law and order situation within Afghanistan, but it will also be a constant source of danger to other countries of the region. Look at the Carribean areas, southeast Asia, Africa. Wherever there is a communist puppet state, it has been motivated by Russian imperialism to cause trouble and tension in other countries aimed at furthering Soviet or so called world communist causes. Look at the extensive chains of agreements, pacts and exchanges that the Russians have concluded with its puppet regime in Kabul. If all these remain intact, despite a Soviet military withdrawal, do you think the Kabul Marxist regime will not serve as a spring board for tension and subversive activities in the region? It is, indeed, perfectly correct to say that when, for instance, the Americans left Vietnam in midseventies they left it physically and mentally. But, as far as the Russians in Afghanistan are concerned, Moscow wants to withdraw only physically. Their overall aim of using Afghanistan as a spring board would not be checked as long as a puppet regime remained in power in Afghanistan. We have to have a genuine Afghan and sovereign government in order to have, what Mikhail Gorbachev, calls a truly independent, peaceful and non-aligned Afghanistan. For the sake of its own interest, this Afghanistan will of course not harbor any hostile policies toward Moscow.

4. one has to look at the real aspirations and derives of those who have participated in this war. Hundreds of thousands of them have been martyred and hundreds of thousands of them are still waging a jehad primarily for the sake of the establishment of an Islamic state.

* When we Afghans talk about Islam nowadays, in the west many misunderstand us. The communist accuse us of taking back the society to the dark ages. Others see Islam in the context of political disputes which they have with some quarters and thus accuse the Muslims of extremism. As far as the establishment of an Islamic order in Afghanistan is concerned, on the basis of my association of many years with the most idealistic young generation of our mujaheddin, I can perhaps correctly lay down a number of principles, which I thjnk translate, on the one hand, the real position of Islam and, on the other hand, the very aspirations of the new generation of Afghanistan. This new 
generation is comprised of a people whom some of you might have seen in the streets of Peshawar or inside Afghanistan, the ones with thin beards and white knitted caps and sandals with no or very little education but with a heart full of belief and hope waiting for the emergence of a society of justice and equality.

* - They want equality. For God Almighty has created all mankind as equal and has deputed man to exercise within his human limitations the powers of Almighty on the earth. This office of vice gerend is a universal right and on the basis of this, and the fact that mankind ought to advance their affairs by holding counsil, the new Afghan generation wants to have a system where people have the right to choose their leaders.

* The new generation of Afghanistan does not believe in coersion. Paramount to them is the central Quranic themes of "there is no coersion in religion" and man is free to choose whatever path he desires, provided he does not transgress. Extremism to them is repugnant, for Islam is advocating the golden medium.

* They believe in a right of access by both men and women to fundamental and social rights provided these rights are not abused or do not become a source for mischief. Thus, for instance, they want their women to engage in social activities second to their fundamental obligation of raising a family. The right of women to consent to a contract or treaty concluded by the state, the right to participate in jehad, not only in fighting but all endeavours aimed at achieving a noble goal, etc. How noble it would be for a society, seeking chastity, to have women doctors to treat only women, women teachers to teach only women, women census works to conduct census inside the household where there are only women and women social workers to help female distitudes, etc. But surely equality in Islam does not include the kind of activities which may breath mischief and immorality or the exercise of which will run contrary to the laws of creation.

* To them all the property belongs ultimately to God. Man is in possession of this property under certain obligations. The economic order in Islam is based on achieving an equilibrium between private and public interests. The Islamic economic order considers both private and public ownership as basic principles but both kinds of ownership are subject to public interests and thus ownership itself becomes a social responsibility.

* I do not intend to outline the entire framework of an Islamic ideology advocated by us and comprising the dreams of our new generation. All I want to impress is that we Afghans are intent to see that the dreams of our new generation come true. These dreams can only be realized when the Afghans, whose, social, economic and political fabrics have been shattered by a cruel and devastating war are able to lay down the founclation of a system, based on national consent.The Kabul puppet regime can in no way be that machinery.

HEDAYAT AMIN-ARSAIA (Member of the Afghan delegation to the Conference).

* As far as the Afghan people are concerned, the two objectives of troop withdrawal and a change in govermment go hand in hand. One without the other is no solution; in fact it is a guarantee of continued bloodshed and instability. Mr. Gorbachev, earlier this year, dropped a diplomatic bomb which caught everyone by surprise when he announced that he was willing to withdraw Soviet troops from Afghanistan. Did he genuinely want to end bloodshed in Afghanistan? Was he willing to give the people the right of self-determination? Or, now that military victory was no longer an option, was 
he simply employing new tactics to gain his objectives by political means?

* I will be the happiest man on earth if I am proven wrong about his motives. But what I have seen so far indicates that Mr. Corbachev's moves are simply tactical, and that they in no way signify fundamental change in Soviet behavior. While he talks of withrirawal, and he most likely will withdraw, Soviet actions inside the country and those of the regime in Afghanistan point to the fact that the Soviet Union has not given up its dreams of keeping Afghanistan a client state. They have not yet accepted the fact that the people of Afghanistan must and will have their right to form their own government in accordance with their own wishes and aspirations.

* If after all our struggles, the Soviets win in Afghanistan, you can rest assured that they will have proven for all time that they can win anywhere. Only the next time they will win much more easily. We must make sure that they lose - - just because aggression must not be rewarded. Aggression must not be allowed to mould and determine the world political order.

What do we want from the international community? I will briefly list a few points.

1) We want international support for the formation of an interim government prior to signing the Geneva accords.

2) If Pakistan is somehow compelled to sign the accord prior to the formation of such a government, the international community should bring pressure on the Soviet Union to cooperate with the Afghans in their efforts to establish a government which will b'. acceptable to the people of Afghanistan, and which derives its legitimacy from the will of the ifghan people and from thejr Islamic traditions. The Soviets should encourage their allies in Kat ul to resjgn in favor of such a legitimate government. .

3) In the event of the formation of such a government, Afghanistan will need massive financial and technical assistance from the international community for the repatriation and rehabilitation of refugees, and for the reconstruction of Afghanistan. Close coordination will be necessary between multilateral agencies and bilateral donors.

4) In case there is no agreement on a government, war will regrettably continue. A quick defeat of the communist regime and formation by the resistance of a government in Kabul may be possible, but it is more likely that the Soviets will continue to prop up the regime through supply of arms and provision of advisors. In this case the life of the regime is expected to be somewhat prolonged, but the regime will be forced to concentrate its forces in a much smaller area of the country which they may consider more defensible. A much larger area of the country will come under the control of the resistance, which will probably form a government in these liberated areas.

The international community should speedily accord full diplomatic recognition to a government formed by the resistance; provide financial and technical assistance to the resistance to administer these areas; provide financial and technical assistance for reconstruction in the liberated areas; and apply massive political and economic pressure on the Soviet Union to desist from supporting and propping up the regime thus to avoid division of the country into two political entitites It is also critical that the international community provide adequate and correct information about the reasons for the continuation of the war, so that world public opinion does not turn against the Afghan resistance. 
5) Finally, help us make sure that the Soviet Union does not gain any advantage in Afghanistan as a result of its aggression. Let us make sure that their aggressive designs - - whether ideological or strategic - - definitely fail.

We seek their failure not because we bear any inkerent ill-will toward the Soviet people, but because one hopes that as a result of a defeat the Soviet Union will become a more sober and constructive member of the world community, that it will become more compassionate toward its own people, and that it finally uses its enormous potentialities to the betterment of all humanity.

BRIGADIFR (RETD) FAHIMULIA KHATEK (Commissioner for Afghan refugees in North-West Frontier province).

* The destruction (in Afghanistan) has been so extensive that it will require another "Marshal Plan" to rehabilitate and reconstruct the infrastructure viable for the economic development of the country. The accomplishment of such a gigantic task will require billions of doller's and expertise of a large number of people. The United Nations, especially the UNHCR have got to gear their operation to this tremendous undertaking, right from now, so that no time is lost in starting the rehabilitation work, once the country attains freedom and political stability. Since the UNHCR have worked very closely with the Afghan refugees in Pakistan, they will be in the best position to coordinate such reconstruction in Afghanistan. Other United Nation agencies like UNDP, FAO, WHO, UNICEF and of course the World Bank will be required to provide the necessary funds and technical expertize. The technical hands in Pakistan who have been working with the UNHCR for various programmes for the benefit of Afghan refugees, can also be co-opted to help in this task. There are over 50 nongovernmental organizations voluntary organizations who have been assisting the Afghan refugees in various programmes like health, education, technical, vocational training, small scale agriculture, animal husbandry, apiculture, etc., who can play useful role in the reconstruction work. These Voluntary Organizations, apart from assisting the Afghan refugees in the provision of various services, income generating programmes have also built reservoir of confidence and cooperation with the Afghan refugees living in camps, and as such, they are in a right position to assess the rehabilitation and reconstruction plans in the future Afghanistan. It will be worthwhile if the United Nations task force is created and placed in Pakistan who should work out the infrastructure for such development, once the agreement is signed and foreign troops leave the country。

* The World community, especially the western bloc and the Islamic countries have generously contributed towards maintenance of Afghan refugees, in Pakistan and elsewhere. The nonGovernmental Organizations have also contributed substantially. Their task, however, will not be complete unless they engage themselves in a much bigger way and with more generosity to assist the Afghans in the reconstruction and rehabilitation work which perhaps will be more important than that which they have done so far. It will also be a great satisfaction to all those people who have been hither-to helping the refugees in the camps to engage themselves in such a purposeful and lasting economic activity. 


\section{UN General Assembly Debates Afghanistan:}

\section{SUMMARY OF SPEECHES BY 12 UN DELEGATES: PART-II}

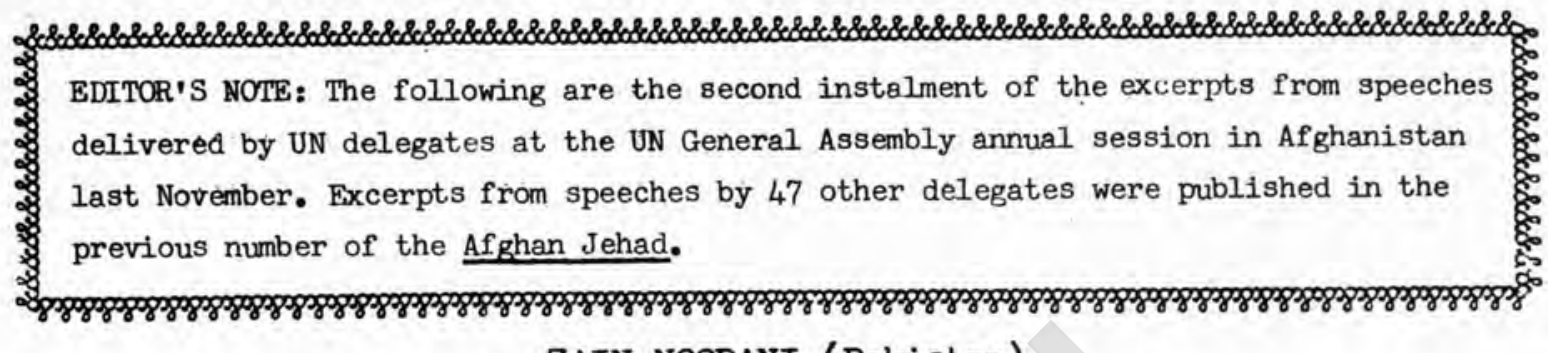

\section{ZAIN NOORANI (Pakistan)}

* No matter how one looks at the situation, the continued presence of the foreign milttary forces meets the eye as the root-cause of the conflict in Afghanistan. The main reason for our disappointment with the recent Geneva rounds is their failure to produce an acceptable timeframe for the withdrawal of these forces from Afghanistan. Despite our best efforts to resolve the time-frame issue in Geneva last March and again in September, the other side did not respond meaningfully nor did it show an interest in sustained negotiations for that purpose.

The Geneva settlement cannot be finalized, nor will it carry credibility, without the availability of a short time-frame. After eight long years of the conflict the people of Afghanistan have a genuine desire for the return of peace and tranquility, which will be expedited by the early exit of foreign forces. The people of Afghanistan naturally want the period of withdrawal to be as short as possible. One reason for that is to shorten the agony of a presence which is a painful reminder of foreign domination; another is the fear that anything other than a short time-frame may tempt the foreign forces to continue to seek a military solution to the problem while the opportunity lasts.

We were heartened by the statement of General Secretary Gorbachev, as reported in Mardeka last July, that the Soviet leader favored a short time-frame for the withdrawal of troops. We greatly look forward to the fruition of this important promise and hope for its reflection in the Geneva accords.

We hope that the next round of Geneva talks will take place without delay. We are committed to making every possible contribution towards ensuring the success of the talks. I wish to avail myself of this opportunity also to express our profound gratitude to the Secretary-General, Mr. Javier Perez de Cuellar, and his Personal Representative, Mr. Diego Cordovez, for the perserverance and dedication with which they have pursued the cause of a political settlement in Afghanistan consistent with universally accepted principles.

We are also sincerely desirous of activating the Pakistan-Soviet dialogue, which has remained dormant since last February. Both sides have recognized the usefulness of this dialogue, and its early resumption will help the cause of a political settlement in Afghanistan. 


\section{MASRI (Syrian Arab Republic)}

* On behalf of the delegation of Democratic Yemen and of my own delegation, I have pleasure in introducing the amendments in document $A / 42 / \mathrm{L}_{\bullet} 19$, of 5 November 1987 . This refers to draft resolution A/42/Lo 16 , of 28 October 1987, on the situation in Afghanistan and its implications for international peace and security.

These amendments cover two main ideas which strengthen the text of the draft resolution. The first calls for strict observance of the principle of non-interference in relation to Afghanistan, a fundamental principle of the Charter and of international law which must be strictly observed in relations between States in order to safeguard the sovereignty of every State in its internal affairs and its free will, compatible with the interests of its people, without any outside intervention. Of course, strict observance of this principle by all countries is necessary to reduce tension in international relations and strengthen world peace and security.

The second amendment welcomes the progress at the Geneva talks, which the international community is following with interest and hope.

\section{WAKIL (Afghanistan)}

* We earnestly hope that the representatives present in this Hall will express their opposition to the unbalanced draft resolution introduced by Pakistan, which experience of the past eight years has shown to be nothing but a propagandistic ploy of certain anti-Afghan and anti-Soviet circles.

For the elimination of regional and world tension, common sense and political insight call for the representatives of member countries to cooperate with the Democratic Republic of Afghanistan and the Soviet Union to remove tension in the region and for the cessation of interference in the Democratic Republic of Afghanistan. Pakistan, the United States and their allies should not be allowed to misuse the decisions of this great Assembly of the world community for furthering their ill-intentioned aims.

. We hope that the new realities which have been created as a result of the policy of national reconciliation in accordance with the common aspirations of Member States will find appropriate reflection. We would like members to join our voice, and the voices of all others. We would like to state that the General Assembly is faced today with a choice which could determine the fate of the ideals for which the United Nations stands. If the United Nations General Assembly is to witness an end to the bitter and painful catastrophe and a war imposed on the people of Afghanistan it is high time for it to exert all its moral influence in favor of the sincere efforts to establish peace in this important region of Asia.

\section{BIERRING (Denmark)}

* I have the honor to speak on behalf of the twelve member States of the European Cormunity.

The Soviet occupation has continued for nearly eight years. The Afghan people are still deprived of their fundamental human and political rights by a regime set up and kept in power by military force. An overwhelming majority in the General Assembly has each and every year condermed the occupation and called for the immediate withdrawal of all foreign troops and a negotiated settlement which would make it possible to restore to Afghanistan its independent and non-aligned status.

For many years the Soviet Union has turned a deaf ear to the clearly expressed demands of the 
international community that it should end the occupation. Recently there have been some indications of a more open and flexible attitude. We welcome indications that the Soviet Union would like to find an early political solution.

The Twelve urge the Soviet Union to withdraw its troops from Afghanistan immediately and thus to create the conditions necessary to allow the refugees to return in peace and safety.

\section{FISCHER (Austria)}

* It is obvious that a lasting solution to the problem of Afghanistan and, indeed, to numerous other problems on our agenda, can never be found by military means, but only by political means. The General Assembly has repeatedly outlined elements which are essential means. The General Assembly has repeatediy outlined elements which are essential for such a political solution: the immediate withdrawal of foreign troops; the right of the Afghan people to determine its own form of government and to choose its own economic, social and political system; international guarantees for the non-use of force and for non-interference; and the voluntary return of all Afghan refugees in safety and honour.

\section{NOWRYTA (Poland)}

* Any draft resolution on the subject under discussion should contain, inter alia, a call for the strict observance of the principle of non-intervention in relation to the situation in Afghanistan and support for the efforts of the Secretary General and h1s personal representative in promoting a comprehensive settlement of the Afghan problem by peaceful means, while welcoming the progress achieved so far at the Geneva talks.

\section{ABDUL HASAN (Kuwait)}

* A comprehensive settlement to the Afghan problem must be based on the following: the immediate unconditional witharawal "of foreign troops from Afghanistan; enjoyment by the Afghan people of its right to self-determination; respect for the sovereignty, independence, territorial integrity and non-aligried status of Afghanistan; maintenance of the distinct Islamic identity of Afghanistan, and the return of the refugees to their homes in full security and dignity.

\section{SHIHABI (Saudi Arabia)}

* We hope that the Soviet Union will respond to the worldwide international wish, as reflected in the General Assembly's resolution adopted by an overwhelming majority, and leave the country to its people, restore the rights to their legitimate owners, anc redress in the future what it has already spoiled. After a very costly experience, it should by now have realized that right is above might and that resolute belief will prevail over the strength of armies. We hope very soon to stand here and hail a free and peaceful Afghanistan, a friend of all. 1ts neighbours and dear to all its friends.

Lastly, I wish to salute the Afghani mujaheddin, who are paying the highest price to realize the highest ideals.

Whatever the reasons given to explain or justify foreign intervention in Afghanistan, cne is tempted to say that such intervention constitutes a flagrant violation of the principles and rules governing inter-state relations with which are associated the ethical values of the community of nations.

* That is why, on the basis of the principles of the Charter, the Organization has from the out- 
set defined the conditions for any solution to the Afghan problem. These necessary conditions remain the withdrawal, without pre-condition, of foreign troops from that country; the restoration to the Afghan people of its inalienable right to determine its own future without outside intervention or constraint; and the creation, by means of sincere negotiations between the parties concerned, of conditions enabling the Afghan refugees to return voluntarily to their homes.

\section{SARRE (Senegal)}

The people and the Government of Senegal will, as in the past, continue to support efforts for peace undertaken at various levels, since we are convinced that the persistence of any side in trying to find a solution by force will merely prolong the conflict and heighten tension in the region.

\section{THIOUNN PRASITH (Democratic Kampuchea)}

* Of a nation of 16 million, more than a million have been killed, 4 million have been displaced and morè thà 5 million have become refugees in Pakistan and Iran, where thousands more arrive each month. Massive air-raids, round-ups followed by the total destruction of villages and the massacre of their populations, repression and crimes by the invaders have depopulated the countryside and spread death, mourning, enormous suffering and ruin.

That has been the situation in Afghanistan since 25 December 1979, when the Soviet Union sent what it called a limited contingent of the Red Army to "liberate" and "pacify" the country and Its inhabitants. Entire regions are today without a sign of life. There, the Red Army has succeeded in establishing peace: the peace of the cemetery.

It is important also to recall that in its push to the south and its quest for warm-water ports, the Soviet Union has already absorbed the Islamic States of Khiva and Bukhara, in 1924; these were subsequently dismembered and incorporated into the "Soviet Socialist Republics" of Turkmenistan, Uzbekistan and Tadzhikistan. It is illuminating to note that et that time the Soviet Union sent to the two Islamic States of Khiva and Bukhara what it called "limited contingents" of its army; they remain there to this very day.

I recall those historical facts to place the invasion and occupation of Afghanistan in 1 ts true context and to stress what is really at stake for the invaders. As Viet Nam is in Kampuchea, the Sovlet military is totally bogged down in Afghanistan; it has had to change the tone of its rhetoric, but has thus far shown no sign of really abandoning its ambition to dominate if not annex the country. Since it cannot conquer the country by military force, it is trying to do so by. political and diplomatic maneuvers and subterfuges such as the "partial withdrawal" of its troops; the change of puppets in Kabul; the proclamation of a "cease-fire"; "national reconciliation"; "halting" foreign interference; and so forth.

Abdur Rahman, Amir of Afghanistan at the end of the last century, described Russian expansionsionism in the following terms:

"The Russian policy of aggression is slow but sure. Its means of advancing resemble that of the elephant, which examines carefully the place where it is going to put its foot down but once it has put its weight on that place it never goes backwards and never takes a second step with undue haste until after it has put all its weight on the first foot and crushed everything underneath it." 
There can be no denying that the underlying cause of the problem of Afghanistan, like that of the problem of Kampuchea, is the invasion and occupation of the country by foreign troops. In Afghanistan, only the immediate total and unconditional withdrawa. of Soviet troops will make it possible to solve the problem, restore the independence, sovereignty, territorial integrity and non-aligned status of Afghanistan and open the way for the return of the Afghan refugees in safety and honor to their homeland. This withdrawal would mark the end of foreign interference in Afghanistan and open the way to national reconciliation, which is the internal affair of the Afghan people.

\section{VALENCIA (Golombia)}

* The serious concern of the international community at the seriousness of the situation prevailing in Afghanistan has found expression in various forums, and in all of them it has been clearly demonstrated that the vast majority of countries are fimly convinced that there is no military solution for the Afghanistan problem and that a political solution is the only possible one.

A political solution to the Afghanistan problem would contribute to restoring political stability to Southwest Asia and to reducing tension between the super-powers. It would also be of benefit in the quest for solutions to other international questions.

\section{AI-ASHTAL (Democratic Yemen)}

* We are now discussing for the ninth time the situation in Afghanistan. Eight resolutions have been adopted by this Assembly. This gives us reason to wonder for what reason the General Assembly is debating this question. What is the purpose of the resolutions adopted by the General Assembly? We believe that the principal aim of the exercise should not be debate for its own sake, or the adoption of resolutions for its own sake, but to find a formula that would make a peaceful solution to the situation in Afghanistan a goal we can achleve. Had it been so, our amendments woulc. indeed have contributed to the achievement of that goal.

\section{RAJAIE-KHORASSANI (Islamic Republic of Iran)}

* The independence and non-aligned character of Afghanistan is not to be negotiated; it is not negotiable under any pretext. We condemn the aggression against and occupation of Afghanistan by foreign forces and we call upon them to withdraw from that land immediately and unconditionally. We believe that the political destiny of the Afghan people must be determined solely by the Muslim people of Afghanistan themselves, about 5 million of whom have been compelled to live in exile.

We believe that the puppet regime in Afghanistan does not represent the Afghan people. A regime which cannot subsist without the support of hundreds of thousands of foreign troops cannot have any claim to legitimacy, and the presence of such puppet elements at the negotiation table explains the evident futility, so far at least, of such negotiations.

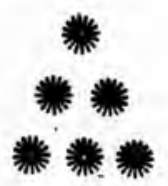




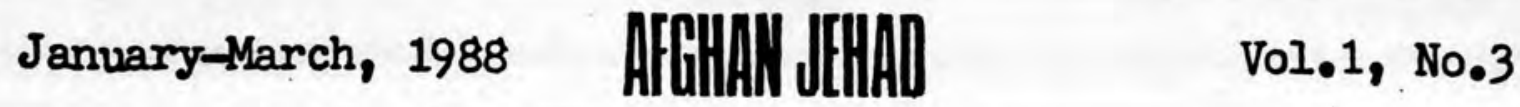

\section{CATALOGUE OF MUJAHEDDIN PRESS}

Part III

(in alphabetical order)

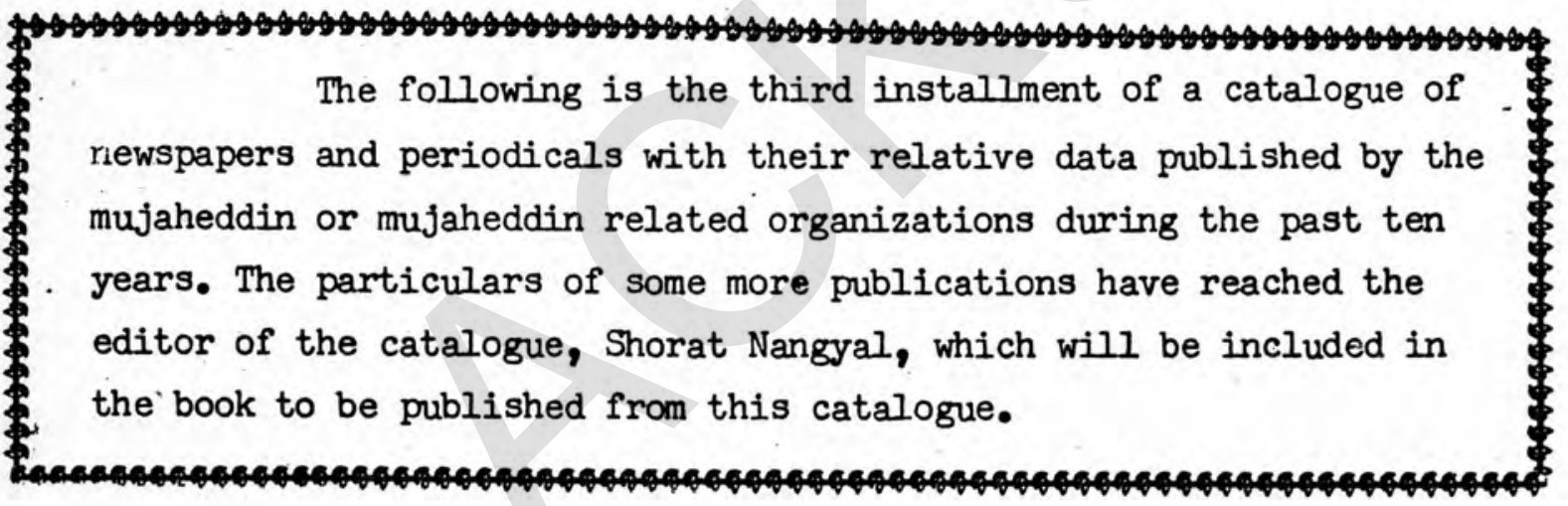




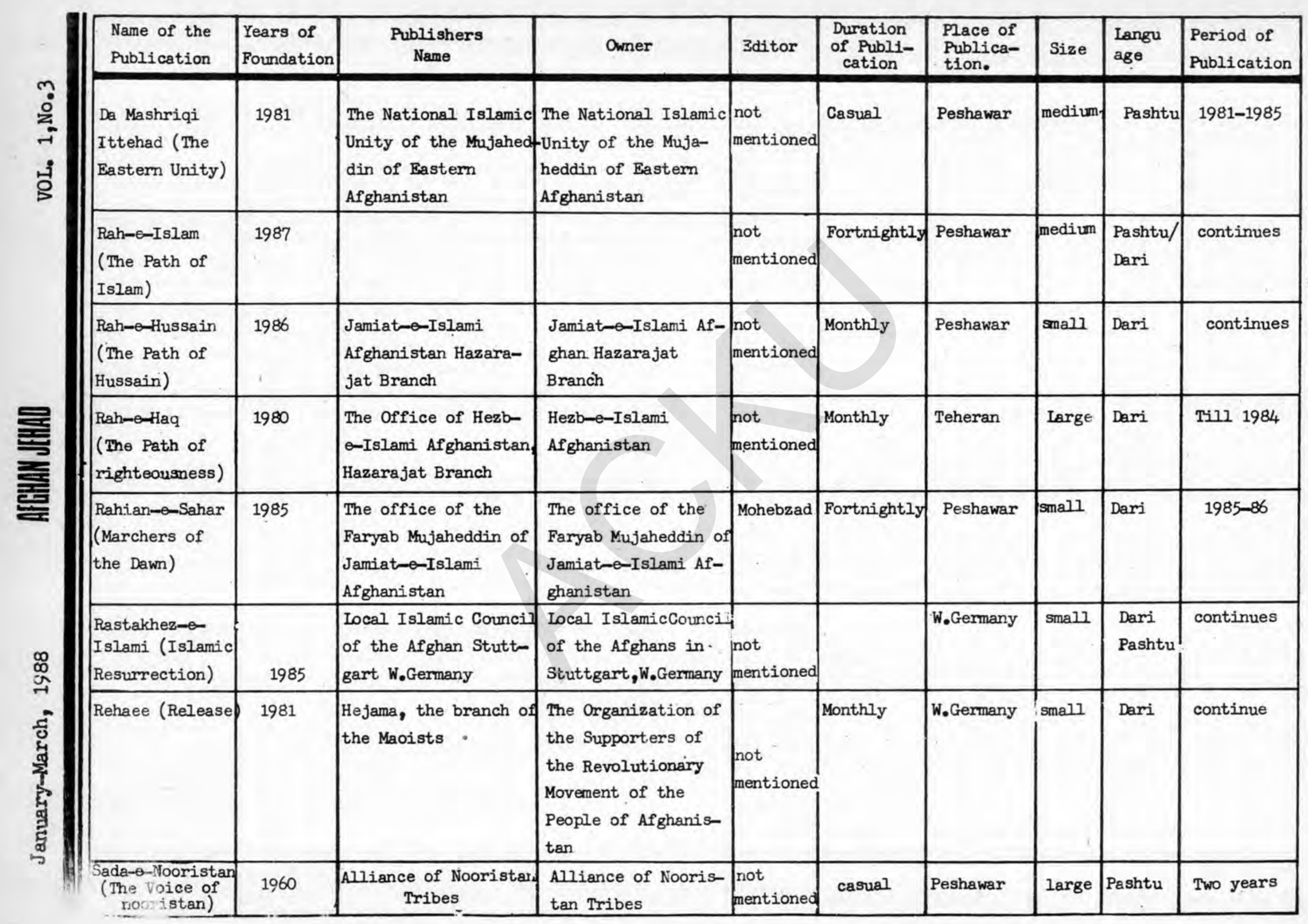




\begin{tabular}{|c|c|c|c|c|c|c|c|c|c|}
\hline $\begin{array}{l}\text { Name of the } \\
\text { Publication }\end{array}$ & $\begin{array}{l}\text { Years of } \\
\text { Foundation }\end{array}$ & $\begin{array}{l}\text { Publishers } \\
\text { Name }\end{array}$ & Owner & Bditor & $\begin{array}{l}\text { Duration } \\
\text { of Publi- } \\
\text { cation }\end{array}$ & $\begin{array}{l}\text { Place of } \\
\text { Publica- } \\
\text { tion. }\end{array}$ & Size & $\begin{array}{l}\text { Langu } \\
\text { age }\end{array}$ & $\begin{array}{l}\text { Period of } \\
\text { Publication }\end{array}$ \\
\hline $\begin{array}{l}\text { Spin Ghar } \\
\text { (White mountain }\end{array}$ & 1987 & & & $\begin{array}{l}\text { Nasrullah } \\
\text { Barakzai }\end{array}$ & monthly & Peshawar & medium & $\begin{array}{l}\text { Pashtu/ } \\
\text { Dari }\end{array}$ & \\
\hline Sangar (Trench) & 1985 & $\begin{array}{l}\text { Office of the Bagh- } \\
\text { lan mujaheddin }\end{array}$ & $\begin{array}{l}\text { Jamiat-e-Islami Af- } \\
\text { ghanistan Office of } \\
\text { the Baghlan Mujahed- } \\
\text { din }\end{array}$ & $\begin{array}{l}\text { M.A. And } \\
\text { eshmand }\end{array}$ & casual & Peshawar & medium & $\begin{array}{l}\text { Dari/ } \\
\text { Pashtu }\end{array}$ & continues \\
\hline $\begin{array}{l}\text { Soem Aqrab } \\
\text { (Third of Aqrab) } \\
25 \text { October) }\end{array}$ & 1979 & $\begin{array}{l}\text { Organ of the Afghan } \\
\text { Students abroad(FAZA) }\end{array}$ & $\begin{array}{l}\text { Organ of the Afghan } \\
\text { Students Abroad } \\
\text { (FAZA) }\end{array}$ & 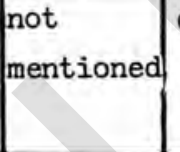 & casual & & small & Dari & $\begin{array}{l}\text { cannot be } \\
\text { ascertained }\end{array}$ \\
\hline $\begin{array}{l}\text { Sheaar-e-Mubari } \\
\text { (The Motto of } \\
\text { the Struggler) }\end{array}$ & 1982 & Al-Muslemoon & $\begin{array}{l}\text { Mawlawi Mohammad } \\
\text { Ghulam }\end{array}$ & $\begin{array}{l}\text { Zmarak } \\
\text { Abid }\end{array}$ & monthly & Peshawar & medium & $\begin{array}{l}\text { Dari/ } \\
\text { Pashtu }\end{array}$ & $\begin{array}{l}\text { three editi- } \\
\text { ons }\end{array}$ \\
\hline $\begin{array}{l}\text { Shams-un-llahr } \\
\text { (The Iight of } \\
\text { Midday) }\end{array}$ & 1980 & The Soldiers Society & $\begin{array}{l}\text { Khan Mohammad } \\
\text { Wazirwal }\end{array}$ & $\begin{array}{l}\text { not } \\
\text { mentioned }\end{array}$ & casual & Peshawar & small & $\begin{array}{l}\text { Dari/ } \\
\text { Pashtu }\end{array}$ & pne edition \\
\hline $\begin{array}{l}\text { Shahadat } \\
\text { (Martyrdom) }\end{array}$ & 1979 & $\begin{array}{l}\text { Publicity and Cul.Com } \\
\text { of Hezb-e-Islami } \\
\text { Afghanistan }\end{array}$ & $\begin{array}{l}\text { Hezb-e-Islami } \\
\text { Afghanistan }\end{array}$ & $\begin{array}{l}\text { Mohammad } \\
\text { Nazir } \\
\text { Basharat }\end{array}$ & monthly & Peshawar & large & $\begin{array}{l}\text { Pashtu/ } \\
\text { Dari }\end{array}$ & continues \\
\hline $\begin{array}{l}\text { Shaheed Paigham } \\
\text { (Message of the } \\
\text { Mrtyre) }\end{array}$ & 1984 & $\begin{array}{l}\text { Islamic Unity of the } \\
\text { Afghans in California }\end{array}$ & $\begin{array}{l}\text { Islamic Unity of the } \\
\text { Afghans in Galifor- } \\
\text { nia }\end{array}$ & not & monthly & USA & Small & $\begin{array}{l}\text { Dari/ } \\
\text { Pashtu }\end{array}$ & $\begin{array}{l}\text { cannot be } \\
\text { ascertained }\end{array}$ \\
\hline Shaheed (Martyre) & 1984 & $\begin{array}{l}\text { Islamic Unity of the } \\
\text { Afghans Students }\end{array}$ & $\begin{array}{l}\text { Islamic Unity of the } \\
\text { Afghan Students }\end{array}$ & not & & & & & $\begin{array}{l}\text { cannot be } \\
\text { ascertained }\end{array}$ \\
\hline $\begin{array}{l}\text { Al-Sabah } \\
\text { (The morning) }\end{array}$ & 1980 & $\begin{array}{l}\text { Hezb-e-Islami Afghan- } \\
\text { istan in Europe }\end{array}$ & $\begin{array}{l}\text { Hezb-e-Islami Afghan } \\
\text { istan in Europe }\end{array}$ & not & monthly & Europe & pmall & $\begin{array}{l}\text { Dari/ } \\
\text { Pashtu }\end{array}$ & \\
\hline Sada-e-Ariana & 1986 & $\begin{array}{c}\text { Voice of Ariana News } \\
\text { Agency }\end{array}$ & $\begin{array}{l}\text { Voice of Ariana } \\
\text { News Agency }\end{array}$ & $\begin{array}{l}\text { A.G. } \\
\text { Gudaz }\end{array}$ & monthly & Islamabad & small & Dari & continues \\
\hline $\begin{array}{l}\text { Sada-e-Afghanis- } \\
\text { tan (Voice of } \\
\text { Afghanistan) }\end{array}$ & 1980 & $\begin{array}{l}\text { Unity of the Afghan } \\
\text { Struggling Students } \\
\text { in Iran }\end{array}$ & $\begin{array}{l}\text { Unity of the Afghan } \\
\text { Struggling students } \\
\text { in Iran }\end{array}$ & $\begin{array}{ll}\text { not } & c \\
\text { mentioned }\end{array}$ & casual & Teheran & medium & Dari & $\begin{array}{l}\text { cannot be } \\
\text { ascertained }\end{array}$ \\
\hline
\end{tabular}




\section{A GLANCE AT MUJAHEDDIN NEWSPAPERS,PERIODICALS} Complete identification of each publication is at the end of this section

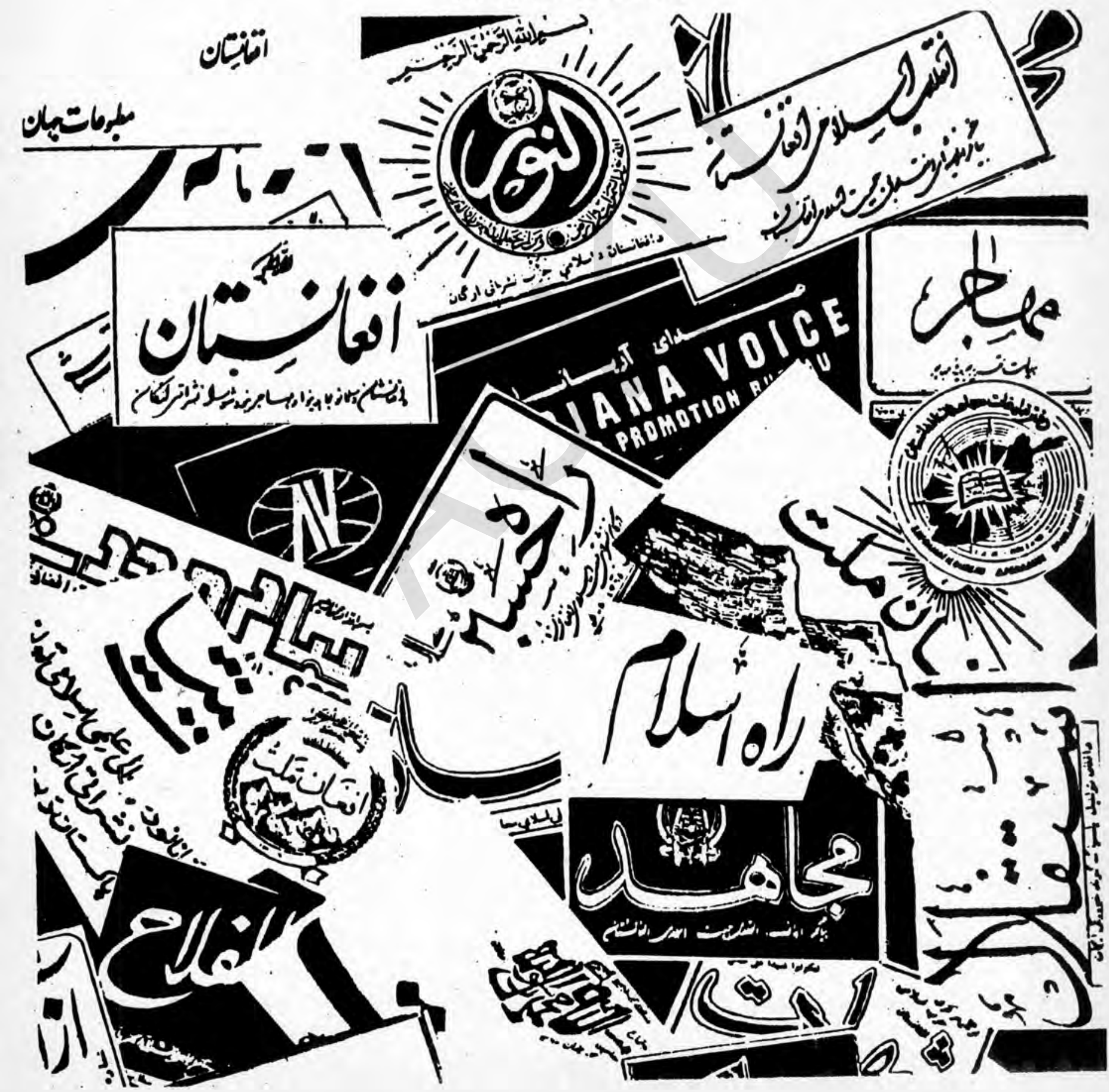




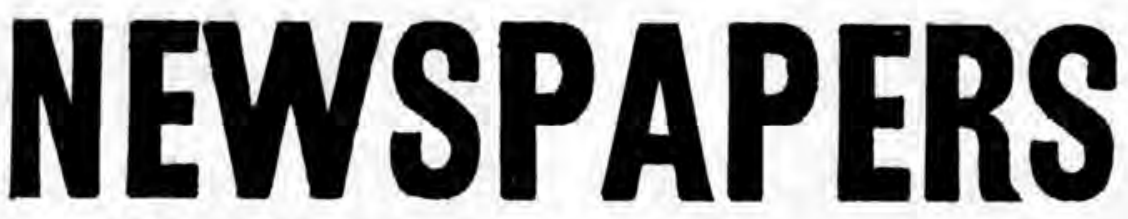

\section{Ukhuwwat 3 Decanber, 1987 .} EDITORIAL: The Afghanistan issue at an international level: At the recent session of the UN General Assembly, the Soviet military invasion of Afghanistan was condemned with majority of 123 votes. Recently the Kabul puppet regime started hue and cry about convening a loya jirgah. Loya Jirgah for what? If it is meant for legalizing the Marxist government in Afghanistan, Amin and Babrak, too, convened such jirgahs and they also made decisions through their mercenaries but what was the outcome?

Now that it is obvious that the people of Afghanistan have not approved the Khalqi and Parchami atheist governments despite nine years of war and Soviet brutalities, it is time for our people to form a government of the mujaheddin to control the affairs of the country and the Russians should accept a ceasefire and withdrawal from Afghanistan. If the formation of a mujaheddin government is not possible, a completely neutral govermment should be formed, ceasefire should be observed by all sides and security should be maintained by the UN forces.

ARTICIBS: Forming a coalition government with the atheist regime of the puppet government by the mujaheddin and the Muslims is tantamount to a suicide for the brave Muslim nation of Afghanistan. Every Islamic or non-Islamic power which views such government practical, is mistaken.

* "Russia the champion of bloodshed and breach of promise". Russia has violated 58 international treaties between 1925 and 1960 , out of which 45 agreements were violated unilaterally. The statistics do not include the agreements signed with various countries and subsequently cancel-

\section{Payam-e-Wahdat}

7 December, 1987.

EDITORIAL: "The new UN resolution". During the current session of the UN General Assembly the Soviet Union was urged more strongly than previous years to end its brutal and cruel invasion of Afghanistan.

It may be recalled Russia had their hirelings to send delegation to sixty countries and to have them harp at the tune of NRP and ceasefire. But, despite such frantic moves, its efforts proved useless and Kabul's bid to assume the membership of the SAARC was also frustrated. NEWS: In a successful mujaheddin operation in Kunar 100 activists of the regime were killed. * Joint mujaheddin operations continue in Arghandab and Kandahar City.

* Afghan refugees in India staged demonstrations in protest against the visit of the Soviet Prime Minister, Nicolai Ryzhkov to India. ARTICIES: "Faith, morality and deeds guarantee eternal happiness". It is a religious article giving many guidelines to the mujaheddin.

INTERVIEWS: In an interview with the correspondent of the Peyam-e-Wahdat about the swinging bridge constructed over the Kunar river for the mujaheddin, the Deputy Chief of the political committee of the Jamiat-ul-Ulema-Mohammadi, Dr. Hashmatullah Mojaddedi has said construction of the bridge took one month and 300 persons were working daily on it. Soviet planes raided that project several times but, by the grace of Almighty God, their attacks were foiled by the mujaheddin. At present the swinging bridge can tran- 
sport eight persons at a time. A bigger swinging bridge is also planned for the area to enable people, vehicles and cattle cross the bridge.

\section{Ara 0107 December, 1987}

EIITORIAI: Jehad and Jamaat-e-Tablighi (Islamic Missionaries). The editorial criticizes preaching in the mosques by the group and writes: If the activities of our Jamaat-e-Tablighi brethren clashes with the interests of arrogent non-Islamic nation, how is it then that neither the communists nor the capitalists hinder their antivities. Othervise, is it not true that the Russians and their puppets have prescribed very severe punishments for religious preachers and any type of preaching is subjected even to execution? Have our preacher brethren ever attempted to find out the motives behind communist fair dealing towards them? Is this toleration due to a vehement and mysterious preaching or because officials of these regimes have found out that the preachers, too, advocate "separation of religion from the politics"?

INTERVIIEW: In an interview with the correspondent of The Islamic Freedom a Muslim officer of the AAF, who has defected to the mujaheddin (the paper says his name is not being disclosed due to certain considerations) has said the Soviets have been facing setback in their aerial operations for the last five months and a boost in the mujaheddin's fighting morale has been a matter of grave concern to them. Increase in the mujaheddin defense capacity can be well understood from an example that the 24 helicopter gunships stationed in Dehdadi airport have been reduced to three only within five months.

STATEMENT: A statement issued from Qum, Iran, is addressed to the Hazara brethren of Afghanistan not to be deceived by the enemy intrigues and the jirgah, which was convened by the mercenary regime in the name of Hazara nationality, was a meeting of only a handfull of the hirelings of the regime who did not enjoy the support of the
Shia Muslims of Afghanistan. The Hazaras like their other Muslims brethren, will not be satisfied until Islamic justice and a government of righteousness are established and those cooperating with the Kabul puppet regime will soon be doomed to a grave fate.

ARTICIES: "With a defeat in diplomacy, the Russians are coming to grips with the realities of war" (name of the writer not mentioned). The open door policies of the present Soviet leader Gorbachev have been discussed. Commenting on his stand towards Afghanistan, it says: a defeat of the Soviets in the polftical arena and their condemnation by the world public opinion have dissipated their hope that further diplomatic moves would not save them from their difficulties. The Russians are now close to admitting that the key to ending the Afghan war and the solution of the Afghanistan problem rests with them.

\section{Saraj-Munir}

8 December, 1987.

EDITORIAL: "Under the shining light". "The shining light" (the name of the paper) has been 1 derived from the text of Holy Quran virtuous rays of which have given spiritual enlightened to humanity. This eternal light gives inspiration to the devotes of Islam.

The "shinning light" teaches us that at the start of this path, full of ups and downs, our strong determination and Islamic decisiveness should be an evidence to our firm faith and we should face the odds with great courage and make a determined effort for making the path smooth for ourselves and others.

"We congratulate the dawn of "The Shining Ij ght" on the horizon of our Islamic Revolution".

ARTICIES: An essay in the paper enumerates five obligations directed towards mankind in the Holy Quran: 
1. belief in the Holy Quran and considering the teaching of the Book as only means for the emancipation of mankind and its good fortune,

2. sincerely understand the Holy Quran,

3. to practice the teaching of the Book and act accordingly,

4. to invite other people to righteousness, 5. to start a Jehad against those who turn down the invitation to Islam and launch a campaign for the dissimination of Islam and the reestablishment of the true institution of the Islamic caliphate so that the true Religion may prevail. Muslims are to become ready for martyrdom for the cause of God.

* "Who is responsible?". An Islamic society can enjoy harmony and good relations among its committed individuals when there is a collective and mass movement towards the common goal. Differences and discrimination gradually alienat the strugglers from the true nature of their aspirations.

The article enumerates the present dispersions of the Islamic Revolution and concludes: "If the day to day activities of the leadership cause dispersion and the very pivot of this Islamic Revolution itself creates difficulties, and fraternity and sincerety give way to hostility and pessimism and people's trust in the ability of the leadership for taking decisions is weakened among members of Islamic activists, a solution of internal problems and avoiding sensivities in relatinns may become difficult".

EDITORIAL: "Hostllity with one self" Criticizes among the Afghans the habit of trying to only find other people's faults and not heed each other and says these trends are specially detrimental for the triumph of the jehad. Our complaint against the resistance leadership was that they were not uniting together. But now that a comparative unity has been achieved, it is the obligation of every Afghan to fully support this unity. Because the resistance leadership demand this from all. If we expect others to respect our leader, first of all we ourselves should gather around them。 NEWS: The former Afghan King is in favor of a dialogue between the Soviet Union and the mujaheddin. He says a political solution of the Afghanistan issue can be attained only through direct talks between the mujaheddin and the Sovilet Union.

* In its issue of March-April the fournal "Azadi" carried a questionnaire for the Afghans residing in the US about "The government in exile". All those questioned have said a government In exile, away from the resistance venue, will not enjoy credibility (The paper says a government in exile would mean the kind of government which was formed some time ago by Afghans in the US.)

ARTICIES: "Iran and the danger of the Red Satan" (By Dr. Rawan Farhadi). The recent closeness of the Iranian government, which claims to be fighting in the name of Islam, with the Soviet Union has two reasons: (1) a defective US policy in the Persian Gulf lacking prudence and (2) a lack of understanding of the true nature of events which have taken place in the last forty years by the Iranian leaders. Iran should understand the Soviet evil designs from the profound relations between the puppet Kabul regime and the Saddam government and it should not sacrifice the capital for the sake of an immediate benefit. Iran should reap a profit with no cost from the costly sacrifices rendered by the Afghan mujaheddin.

\section{Ittehad-e-Islami}

14 December, 1987

EDITORIAL: "The mujaheddin are the ones entitled to decide about the future of Afghanistan".

Muslims should not expect any real good from the Reagan-Gorbachev sumit. Both these materialis- 
tic powers are enemies of, Islam and Muslims. The Afghanistan war is not a US-USSR war. It is a war between the mujaheddin and the Soviet Union. If there is a desire for solving the Afghanistan dispute through negotiation, the Russians shouId enter dialogue with the mujaheddin. The Afghan mujaheddin will not allow any-body to play with their fate.

INTERVIFW: In a special interview with the correspondent of Ittehad-e-Islami about the ReaganGorbachev summit, the leader of Islamic Alliance of Afghanistan, Professor Abd Rab Rasool Sayyaf said we enjoy freedom and (the right to) self determination and it is our right to determine our future. We would never tolerate to disgrace to allow others to have our fate under their sway. The Afghanistan problem will be resolved on the blood-stained trenches of the jehad. It appears that they would agree on the establishment of another secular and atheist govermment after the withdrawal of Soviet troops and would present it to the people of Afghanistan as a neutral and coalition government. But such a govermment would never be acceptable to the mujaheddin.

NEWS: The mujaheddin killed eight Soviets and captured another eight. 25 October in Khair Khana Meena (Kabul city).

* The mujaheddin of Alingar (Laghman) and Nooristan (Kunar) destroyed 29 October the KHAD center of Mango with missiles injuring the KHAD secretary and killing 12 others.

* The mujaheddin killed 24 enemy troops and injured 2 December 41 others in Kahi, Nangarhar.

\section{Hedayat-ul-Islam}

14 December, 1987

BDITORIAL: Discusses the "scandal" of the puppet regime's loya Jirgah and studies the question as to whether the loya Jirgah was attended at all by the elected representatives of the people? Of course not, the editorial concludes. REPORT: Certificates were given to 300 students in special ceremonies in Quetta. Speaking on the occasion, leader of the Harkat-e-Enqelab-e-Islami Afghanistan, Mawlawi Mohammad Nabi Mohammadi said along with their war against Soviet invaders and their puppets, the heroic Afghan nation is learning today religious subjects. Thank God that under these hard conditions of migration, 300 students have secured certificates after attending courses in religious. Our children should, most of all, devote themselves to the acquiring of religious education.

INTERVIFW: A special correspondent of the Harkate-Enqelab-e-Islami Afghanistan who was sent to Khost has interviewed the Deputy Commander of Nari Brigade about the siege of Khost. He has said our mujaheddin unitedly carried out heavy shelling with $122 \mathrm{~mm}$ guns on the Khost airport and the movement of enemy aircraft was blocked. In an attempt to capture from the mujaheddin their guns, the enemy attacked our strongholds which resulted in a fierce fighting. The enemy finally retreated. It was able to construct only one post in a flat area. In order to prevent further enemy attacks, the mujaheddin of five organizations - - Harkat-e-Enqelab-e-Islami, Hekmatyar's Hezb-e-Islami, Hezb-e-Islami (Khales), NLF and IMF - - jointly constructed five trenches.

NEWS: The mujaheddin killed 9 October five Soviet troops in Badghis province near the Soviet borders.

* The mujaheddin killed 24 September eight Soviet troops in Nangarhar.

* The mujaheddin destroyed 30 October a tank with all the persons aboard in Wardak.

\section{Shahdat 14 ocecabor, 198 .}

EDITORIAL: "Our Muslim nation is the guarantor of the purity of our Islamic revolution". In relation with the Hezb-e-Islami historic meeting of 7 December, the plan for a neutral government he- 
aded by people like the former King has been rejected and the slogan "War until an Islamic government" was emphasized.

NEWS: Two Soviet troops were killed 3 December in Chah Aab, Takhar.

* Two mercenarics of Kabul regime were killed and 10 others injured 1 December in Ghor.

* A bus with 20 civilians was set on fire 25 September by the Russians in Altamur, Logar.

* The mujaheddin killed 13 enemy troops and injured a large number of others 18 November in Surkhroad, Nangarhar.

ARTICIRS: "The Soviet mandate and supervision over Afghanistan is a notorious and wretched scheme of the Red Imperialism". (By Mohammad Amin Ferotan): Radio Moscow reported that, under a directive issued by the Politburo of the Central Committee of the Soviet Communist Party, a meeting for making Afghanistan a Soviet protectorate was convened with the participation of the First Secretaries of the Central Committees of the communist parties of the Central Asian Republics and a number of Politburo members of the Central Committee of the Soviet Communist Party. In the meetine. t $^{+}$was officially announced that Afghanistan should be made a Soviet protectorate. This is the very program which was implemented for the annexation of Central Asian areas with Russia in 1924 and $1930 \mathrm{AD}$.

The first session of the group assigned for making Afghanistan a Soviet protectorate is being convened at a time when some people are still hopeful about the results of the talks on Afghanistan between two super powers. The Muslim and mujahed forces should seriously ponder on such ominoys t.rends.

\section{Ekhlas 19 Doceatore, 1987 .}

EDITORIAL: "A United Stand". A gathering was held 7 December in Eidgah Mosque (Peshawar) under the auspices of the Hezb-e-Islami. It was attended by 10,000 persons. In his speech, Hekmatyar, leader of the Hezb-e-Islami, condemned "the joint.ReaganGorbachev conspiracy" for the establishment of an un-Islamic government ín Afghanistan. He described the return of Zahir Shah "or any other hireling, which could hinder the establishment of real Islamic government in Afghanistan", as a big conspiracy.

He said,"other factions of the Islamic movement should also support the initiative of the Hezb-e-Islami and should hold such big meetings and, by doing so, the infidel intriguers would realize that their conspiracies are being condemned not only by the Hezb-e-Islami and Hekmatyar but this is a common stand of all the mujaheddin brethren, resistance organtzations and the struggling staunch Muslim people of Afghanistan".

NEWS: The Herat mujaheddin destroyed 16 December three enemy posts.

* The mujaheddin destroyed 30 November an enemy military workshop in Nangarhar.

ARTICIES: Rise and fa.ll of the Satanic forces in the length of history (By Gul Agha)。

The articles lists "the satanic forces" beginning with the tenure of Gangez Khan. The rest will be covered in the next issue of the paper.

* "What type of government the Afghan Muslim nation wants". The Amir whom the Muslims are obliged to elect should be: a Muslim, duty bound, mascular, of noble birth, not a puppet, possessing the qualities of an Amir, well versed in the Islamic jurisprudence, pious and just.

\section{Ittehad-e-Islami}

EDITORIAL: "Obsolete efforts". The editorial describes the Soviet military might obsolete and ineffective against the mujaheddin will and tactics. It says even in the severe cold of winter, the mujaheddin have been achieving victories. .

NEWS: The Russians have failed in breaking through the siege of Khost cantonment. The Corm ander of Khost cantonment has been compelled to 
surrender.

Four Soviet fighters have been shot down.

* Seven government officials were injured and four killed 14 December in Roadat, Nangarhar. * Seven KHAD officials in the center of Ghazni were killed and two tanks with the persons on board were burnt 25 November.

INTERVIEW: Mohammad Shafiq Ahmadzada, who has arrived in Peshawar after serving six years in prison, has given to the reporter of the newspaper an account of the executions carried in the Pul-e-Charkhi by Kabul authorities. He has said (first) officials of the Investigation Department come to take pictures of those to be executed. Then the prisoners are blind folded, chained and put in a box-type truck. The martyrdom of Dr. Ayub with 40 persons, Qari Abdul Hayee with 66 persons and Abdul Rahim Mohammadi with 80 persons, are the examples of the massacres carried by the puppet regime.

He gave the following information about the number of women and children detenus:

Minors imprisoned exceeded 1,000. Most of them are jailed on account of crimes allegedly conmitted by their parents. There were 2,100 women in prison. Women with child under two years were first brought to Prime Ministry Building. Mothers were kept in the rooms and their children in corridors.

\section{Vaด? 21 December, 1987}

EDITORIAL: "What kind of coalition and with whom" (By "Jaji"). It rules out the plan of a coalition government of mujaheddin with members of the PDPA We will not accept a decision which fails to take into account the national interests and Islamic values of our Muslim and mujahed nation. Our Muslim nation is not ready for any kind of coalition government with the communists.

RBPORT: Speaking 5 December at a press confere nce the IUAM President Mawlawi Mohammad Yunus

Khales said:

- - a brief discription of government is that in it right will prevail, not otherwise. The cri- teria to separate right from wrong is to bring the issue before the law. But it must be the law of God and not the law made by man. To render sacrifices for the supremacy of law of God will surely serve the interests of the humanity.

- Those involved in the conflict are not included in the Geneva talks. Only Pakistan and the Kabul puppets are holding the talks. Neither Pakistan, Russia nor the West can decide our fate.

- - Referring to Reagan-Gorbachev summit, he said if the Soviet Union and the US want peace and security to prevail in the world, they, as big powers, should work for Islam. This is our suggestion to them and I told this directly to Reagan.

DECLARATION: "In a communique the mujaheddin of the cause of truth asked the besieged (government) forces in Khost to overthrow the yoke of the slavery of Red Imperialism and join the ranks of pious 'sons of the country.

"In the light of the principles of the holy religion of Islam and the Afghan way of life, we guarantee your security and safety and, in these trying moments, you can fulfill your obligation for loyalty to the country by complying to the dictates of God Almighty".

NEWS: Four helicopter gunships were set on fire and 20 Russians, including two high ranking officers, were killed 28 November by the mujaheddin in Nangarhar.

* The mujaheddin shot down 19 and 26 November three helicopters in Paktia.

* The mujaheddin destroyed 24 and 27 November a $B M-41$ and a number of warfare machines in Logar province.

ARTICIES: "Najib's jirgah or a shameful spot on the face of traditional loya jirgahs". (by Majrooh - - first name not given). Three centuries back, the system of jirgah emerged as a big political force in Afghanistan and jirgahs played a prominent and fundamental role in the formation of. contemporary Afghanistan.

$\mathrm{He}$ has mentioned the loya jirgahs held 
during the times of Mir Wais, Ahmad Shah, the jirgahs of Afghan (tribal) chiefs in the first, second and third Afghans British wars, and has explained the great and positive impact of these jirgahs. The article has branded "the so-called Jirgah of Najib" held in the presence of 150,000 Soviet troops as a treason.

* "Rubber stamp jirgah and a dictated constitution". (By Mohammad Aref Gharwal).

The objective of loya jirgah under these circumstances had been to put an end to alien aggression but this so-called jirgah was convened by Russian hirelings to further consolidate Soviet domination and approve a constitution actually framed in Moscow, a jirgah not attended by the elected representatives of the people at all.

* "Afghanistan, an issue as well as a responsibility for the Muslim Ummah" (By Sayyed Habib Shah). Afghanistan, as a Muslim nation has been subjected to aggression by infidels and the Afghan nation has been resisting this aggression in accordance with the dictates of God Almighty. The Soviet aggression has taken place on the boundries of Islam. Participation in the Afghanistan resistance means a defense of the boundaries of Islam. It is the duty of every Muslim to discharge his responsibility in connection with the Soviet invasion of Afghanistan. The circumstances demand that all the Muslims should extend political, military and economic assistance to the Afghan nation for the continuation of 1 ts armed resistance and should severe ties with the Soviet Union which is in war with Islam.

\section{Arman-e-Mujahed}

21 December, 1987.

In its first issue, the journal has carried a message from Mawlawi Rafiullah Moazzan which reads :

"In determining a nation's fate, the right of candidature is possible to those who are ca- pable of imparting guidance and have a comprehensive knowledge of this great responsibility. During the years that the struggling Afghan nation has been fighting a super power with nothing but fimited resources, the heroism of the country's Muslims and their repeated and unequalled sacrifices induced the Islamic as well as non-Islamic circles to extend support to this nation.

"True sons of the country, deployed in the sanguinary war trenches with-full confidence, have been expecting the esteemed leaders that fruitful and positive measures be adopted from a unified and strong platform about their political stand befitting their valour. On the contrary, from behind the closed doors, without involving the will of the Afghan Muslims, hasty decisions about the important (issues) of our future are adopted in an urealistic manner but so colored that the people of the world concieve them as emerging from the (true) will of the nation. Even the enlightened sections of society are kept ignorant about the realities of the situation. Considerable amounts of foreign exchange are put at their disposal for rendering cultural services. But the men of vision and the intellectuals of the country, who have not been accommodated in the resistance ranks, do not know about the realities of their country. Occasionally, some intellectuals many visit Peshawar to collect information. But the venue for their information and research would be the Kissa Khawant Bazar only, and the publications issued by the resistance do not contain sufficient information to quench the thirst of our intelligentsia.

"The decisions adopted by a few vested interests, and not embracing the will of the people, create discord and ultimately benefit the Red imperialism. Our country, with a long history, is being dragged to a direction in which our destiny may be decided by others and we are recorded as people who had no authority in determining our own fate... The coming genera- 
tion will consider us gravely responsible (for not achieving our aims) in comparison to sacrifices rendered by our people.

"We have by now crossed the theoratic phase of our heroism (sic) and now we are at a stage to prove our heroism I by rendering services in consolidating unity among those who are bravely holding their chest against the bullet of the Soviet army for the sake of their belief and liberation of the country.

"Those esteemed intellectuals, men of knowledge and the intellegentsia who were not able to join the resistance due to special reasons and sought asylum in the west can play a valuable role and, by making use of their views, the present discord can be converted into a unity".

The paper appeals to all the "intellegentsia to send to the paper their articles and views and the brothers deployed in the trenches, too, should not forget the valuable role they can play because they, as the most important dynamic force, can determine the fate(of our nation) and they should no longer become victims of the personal ambitions.

"With the power of knowledge and scholar ships you can put an end to the monopoly of a few over the fate of the nation and can hand it over to those who are truly entitled to hold this power: The Afghan nation.

ARTICIES: "Silent majority"。 The author's name is not given. It has segregated the people of Afghanistan into six categories:

1. those at the service of Russia,

2. those who carry the armed resistance against the Soviet Union,

3. the five million Afghans who have migrated to Pakistan and Iran,

4. those living in Europe and Western countries to mainly lead a peaceful life,

5. those who have been compelled to migrate from Pakistan to the West,

6. a silent majority residing inside Afghanis $\tan$.

* "Islamic education and training". Author's name not mentions.

The goal of Islamic education is to raise a pious generation. The purpose of man's creation is to worship God and to render justice, favor, help to others under the dictates of God Almighty, and not to learn knowledge (merely) for pilling up of wealth. The principles of an un-Islamic education cluster around the pivot of an overt worldly grandeur.

* "Impracticality of Marxism" The article analysis the failure of Maxist theory in practice. $\Delta 720:$ November-December, 1987. EDITORIAL: "Hostility with one self". Speaks about "enemity with one self" from a social point of view and says it eminates from imorance. Criticizes among the Afghans the habit of trying to find only the faults of the people and not lead each other and says these trends are specially detrimental for the triumph of the jehad. Our complaint against the resistance leadership was that they were not uniting together. But now that a comparitive unity has been achieved, it is the obligation of every Afghan to fully support this unity. Because the resistance leadership demand this from all. If we expect other countries to respect our leader, first of all we should gather around them.

\section{NEWS:}

* The former Afghan King is in favor of a dialogue between the Soviet Union and the mujaheddin. He says a political solution of the Afghanistan issue can be attained only through direct talks between the mujaheddin and the Soviet Union.

In its issue of March-April the fournal "Azadi" carried a questionnaire for the Afghans residing in the US about "The government in 
exile". All those questioned have said a government in exile away from the resistance venue will not enjoy credibility and (The paper says a government in exile would mean the kind of government).

ARTICIES: "Iran and the danger of the Red Satan" (by Dr. Rawan Farhadi) The recent closeness of Iranian government, which says is fighting in the name of Islam, with the Soviet Union has two reasons: (1) a defective US policy in the Persian Gulf lacking prudence and (2) non observance of the events by the Iranian leaders which have taken place in the last forty years: Iran should understand the Soviet evil designs from the profound relations between the puppet Kabul regime and the Saddam government and 1t should not sacrifice the capital for the immediate benefits it may gain and should reap a profit with no cost from the costly sacrifices rendered by the mujaheddin.

\section{Al-Momenat}

December, 1987

* In an interview, the Chairperson of the Sister organization of the Jamiat-e-Islami Afghanistan has said The Society of Muslim Sisters is a crushing blow to foll communist conspiracies claiming that Islam considers women worthless members of the society.

EDITORIAL: "27th of December, an outcome of long Sovlet plots". It explains Soviet efforts to achieve its objectives through training conmunists to capture power in Afghanistan.

ARTICIES: "A short description of women's status in the Holy Quran" (by N.M. Zia Sultani: . Highlights the Qurante principles laid down about the status of woman which, all in all, emphasizes a perfect family system and elimination of women's plight and woes.

\section{Al-Falah Decabor, 1997.}

EDITORIAL: "Unity is essential: who is responsible for disunity? unity for the sake of fear from God and a shame from the nation". Resis- tance needs a single leadership and has no room for more than one leader. To elect a leader for only one seat is the nation's right and nobody can usurp this right. Every individuel, after proving his identity and nationality, has the right to take part in national elections. StronRenst is the government which enjoys the support of the nation.

ARTICIES: "Reagan Khan - Attorney for Afghanistan". The US President "Reagan Khan" defeated by the Veit Cong which was supported by the Soviet Union, has now styled himself as an advocate in the Afghanistan dispute while the Afghan nation is unaware of 1 t and neither it has appointed any attorney nor it would do so (to discharge its affairs).

\section{Neda-e-Haq}

EDITORIAL: "The West Bank and Ghaza strip".

Supports the Palistenians and conderms Israel for its policies.

NEWS: The mujaheddin freed 26 November 1,400 prisoners from the prison in Maimana city. They destroyed 9 security posts of the Kabul regime, shot down three planes, eliminated 21 transport vehicles and tanks, killed 45 Soviet troops, injured 70 others and captured six troops with their arms, while 100 troops joined the mujaheddin.

* Khost and Barikote cantonment are besieged by the mujaheddin.

ARTICIES: In an article, which does not mention the name of its author, the historical background of the loya jirgah; has been enumerated.

"Loya Jirgah, which is a national and important traditional institution of the Afghan Muslim struggling nation, had been instrumental for a long time in solving our national problems It is important in the sense that it is comprised of religious scholars, spirituals and prominent national figures. Whenever the Afghan Muslim nation have been subjected to foreign 
aggression and the central govermment had either been ousted or has collaborated with foreign state, a loya jirgah is convened to rectify the situation.

After the loya Jirgah convened by Mir Wais Khan, the Jirgah's which declared Afghan neutrality in World War-II and the one which approved the 1964 Constitution are considered to be the most prominent conventions of this kind.

The article describes the Najib's jirgah as a meeting of smugglers and traitors' and writes: The position of the Muslim nation of Afghanistan vis a vis such shameful jirgahs is evident and quite clear. Our valorous nation refects and condemns any such Soviet or Kabul hirelings' move and we announce that Najib and his likes who are nothing more than Soviet servicemen can never be considered the real representatives of the Afghan Muslim nation and peace with them will carry no meaning and the only alternative for the Afghans to triumph is the continuation of their jehad.

\section{A $=100$ 22 December, 1987}

"How can an Islamic government be brought about?" Two kinds of people live on earth, Islamic and non-Islamic.

Muslims should be aware to bring about an Islamic government in an Islamic manner. There are demands for general elections and some people also urge voting right for the women.:

These are all unfamiliar to Islam and will not be conducive to the establishment of an Islamic govermment. The Muslims who are forming an Islamic society or an Islamic government through western laws cannot effectively serve Islam. Those who are speaking of "an Islamic democracy" or "Islamic socialism", do not actually understand Islam.

An Islamic, government can be formed by convening the Ahl-e-hal wa agd (men of wisdom) i.e., the spirituals and scholars who are pious and capable of rendering true services to Islam.
They should in turn bring forward a pious and able individual as their leader. The selections of this person should be approved by the people who should declare their loyalty to him. Those who reject the choice made by the ahl-e-hal wa agd are rebels (in the eyes of law) and responsible before Almighty God.

REPORT: Speaking 27 December at gatherings organized by the JUP in Punjab, the IUAM President Mawlawi Mohammad Yunus Khales said we attach utmost priority to the unity among the mujaheddin. Our resistance did not begin to fight against individuals. We will not stop our resistance until the establishment of an Islamic government in Afghanistan.

ARTICIES: Is the President of a state elected by the ahl-e-hal wa agd or the general public? (by A. Ashrati).

There is no difference among the jurisprudents on the election of a khalifa by the ahl-ehal wa agd. They all agree that the khallfa should be elected by the men of wisdom. But the only difference in this connection erupted among the jurisprudents how the election should take place.

\section{Mujahed Ulus \\ 22- December, 1987.}

INTERVIEWS: Mohammad Hassan Ulusmal held 29 November interviewed the former King Mohammad Zahir Shah in Rome on telephone about the loya firgah. The former King said:

Loya Jirgah is one of the most ancient national and traditional Institutions of the Afghan people through which in the course of hism tory our people have been resolving their impor tant problems with a consensus and understanding. Naturally, a loya firgah, being the highest manifestation of the nation's will, should include representatives from all sections of the society including all nationalities and tribes of the country so that its resolutions may enjoy the support of the majority. 
"It was by virtue of the larger support of the people that historic loya jirgahs convened in the past in our country could succeed in adopting important and decisive resolutions having a deep and durable impact on the fate of our people. On the basis of this consideration, the so-called loya jirgah of the present Kabul regime, while more than three fourth of the Afghanistan territory and its people are not under the administration of the regime and the rest of the land, too, is under the domination foreign troops, in no way conforms with the ideas and aspirations of the Afghan people and its decisions also do not carry any legal value and credibility.

"The so-called loya jirgah held by present Kabul regime cannot be compared with the previous loya jirgahs because those jirgahs reflected the aspirations of the larger majority of the Afghan people whereas this so-called loya jirgah represents such a nominal minority whose aspirations and ideals are totally in contrast with the aspirations and moral values of the majority of our people"

* In an interview with the VOA, Mohammad Hassan Ulusmal has said: Five million Afghans were forced to migrate to other countries due to Russian atrocities and a large number of others within the country have shifted to mountains and farflung areas of the country which are considered comparatively safe from enemy bombardments and attacks. Also a number of Afghans have been put In jails and 120,000 Soviet troops are busy in the massacre of the Afghans inside the country. Under these circumstances the convening of a loya jirgah has no legality. This loya jirgah is attended either by the communists or those paid by the Kabul regime or a handful of people from the cities who are no more than prisoners of wars.

ARTICIES: "A petition to the national strugglers and the mujaheddin of the righteous cause" (By Abcul Rahman Pazhwak).
The possibility for the presence of a mujaheddin delegation at the general assembly hall as observers has provided a possible opportunity to the mujaheddin's participation in the future talks. So what should the mujaheddin do in providing such an opportunity?"

1. The Afghanistan problem, manifested as a local issue by the Soviet Union on the basis of its political vested interests and objectives and as a regional issue by the US, should be identified as an international problem and should be pulled out from the narrowness of the Geneva talks context and should be brought within the framework of an international conference under the UN auspices. Representatives of the mujaheddin and the Kabul regime as well as the permanent members of the Security Council should also be included in the conference,

2. in every type of political arrangement the (proportionate?) right of the mujaheddin parties should be recognized in relation to Kabul Communist Party.

3. if the Afghan mujaheddin and national strugglers are invited for participation in the talks, they should not turn it down but should have a vigilent eye about the snares of the other side.

4. demand for Soviet participation in the talks is eminent,

5. If the mujaheddin and national strugglers are invited to the talks, the talks and negotiations should be demanded in two phases. At the first phase, a delegation, consisting of the mujaheddin and national strugglers' advisers, should take part so that they may submit a complete report to their leaders on the entire preludes,

6. in every kind of talks the participation of military advisers of the Afghan mujaheddin is essential,

7. until the Soviet Union agrees on direct talks with the mujaheddin leaders, the Afghan resis- 
tance commanders inside the country should be left free so, like Russians, who have left themself outside the fulfillment of any commitment, they, too, may be free from observing any imposed obligation,

8. on the topic of the pull-out Soviet aggressive troops, the first demand should be its withdrawal from Wakhan which is said to have been annexed to Russia.

9. the idea that part of the Afghanistan dispute is a human rights issue should be vehemently rejected. For the real cause of the issue is the military aggression and invasion against a free country,

10. on the first opportunity, and prior to the beginning of any type of negotiations, the Afghan leaders in Iran should be invited to join the united mujaheddin rank and the Afghan refugees in Turkey should also not be ignored,

11. $a_{4}$ large number of refugees is living in countries belonging to different continents particularly in Western Europe and the US. The positive gains which could be obtained from them; should also be kept in mind,

12. increased and direct contacts by the mujaheddin leaders with the Afghans living in Iran and Turkey and the governments in these two brotherly Muslim countries which have traditional, historical and moral ties with Afghanistan, need further attention,

\section{Scientific Awakening}

NEWS: The mujaheddin attacked recently the Kabul Balahessar.

* The birthday of the Holy Prophet Mohammad (peace be upon him) was celebrated at Naser Bagh (near Peshawar).

* The Khak-e-Jabbar posts (near Kabul city) were set ablaze 23 September by the mujaheddin. ARTICIRS: We should be attentive to the danger posed to us". It warns the Afghans not to fall into the snares of the NRP initiated by Soviets and their hirelings.

* "Scientific awakening says". The article narrates a number of religious, social, and political ideas one after the other. 1U19. 26 December, 1987. EDITORIAL: (By Musafer) The truth about, the government loya jirgah". Jiscussing "the communist suppression" and the casting of votes in muncontested booths", it writes, the conmunist loya jirgah was convened 28-30 November and it unanimously approved a constitution outlined by Moscow and (Najib) the Cow was decorated with a "necklace of fire". Others congratulated him for wearing "the necklace of slavery". Three categories of people were invited to the self-styled jirgah:

1. members of the Khalq and Parcham parties,

2. officials who had sold their religion for worldly considerations,

3. the illiterate and 1gnorant one.

REPORT: Speaking on the eve of the mujaheddin victory in Karan and Manjan, leader of the Jamiat-e-Islami Afghanistan, Professor Burhanuddin Rabbani said this and other victories achleved recently made it clear that the enemy has becone weak and its defeat is imminent.

INTERVIEW: In an interview with The Mujahed, the representative of Jamiat-e-Islami Afghanistan and a member of the delegation attending the 4 nd session of the UN General Assembly, Mawlawi Amir Hamza said the IUAM should send well informed and competent delegations to other countries to apprise them of the Afghanistan dispute and to fully expose the wreched face of red imperialism.

NEWS: Two enemy helicopter gunships were shot down 25 August in Faryab. In the battle on the ground, the mujaheddin kdlled 24 Soviet troops and six militiamen while 12 militiamen were also captured.

ARTICIES: "27th of December: a brutal invasion 
and valorous resistance" (By Nangyal). Enumerating what the writer calls the turns, failures, disgrace and infamies of the Russians and their hirelings in Afghanistan, concludes that the brutal invasion of 27 December (1979) resulted in the glorification of faith and heroic resistance of the Afghans and shameful defeat of the enemy. And, like the British (in the past Afghan history), the enemy has to withdraw today or tomorrow with disgrace from our historic country and Afghanistan will witness the establishment of an Islamic government and the dawn of its freedom.

"Gorbachev's deceitfullness" (By Mohammad Zahir Siddiq). The article sums up the objectives of the visit of Soviet leader Gorbachev' to the US and writes:

1. Wanted to win the public opinion and unfortunately achieved this objective. The powerful westem media turned out to be a source of publicity of his statements and other acactivities during his vịit,

2. change the hardline position pursued by the followers, of Brezhnev,

3. eliminate the entire internal pressure against himself,

4. create a rift among the anti-Russian ranks。

During his visit Gorbachev decieved all the others - - the host, the entire US and world public opinion. For he did not even touch the crux of the (Afghan) issue and shamelessly said he has already made up his mind about the Afghanistan issue.

COMUNIQUE: The joint communique of prominent Pakdstani and Afghan religious, scholars about the Soviet armed invasion of Afghanistan has condenned it as a shameless aggression. It urges all the Muslims to join the resistance against the Russians and sets 21-27 December (1987) as the Afghanistan week.

Mahaz 27 Decanber, 1987 . EDITORIAL: Is about the Soviet invasion of Afghanistan and subsequent Russian atrocities. It then complains against a "major weakness" of the mujaheddin - - disunity. It, however expresses satisfaction that now various mujaheddin groups have got to-gether in an alliance and writes: we pray for the strength of the alliance so that the future leadership of Afghanistan will remain with the mujaheddin in accordance with the wishes of the people. We are confident that if we remain united, the enemy, despite its conspiracies and deceitfulness will be defeated and forced to quit our country.

NEWS: Fifty three Russians and atheists were killed 10 December by the mujaheddin in Laghman. * The mujaheddin killed 23 November 9 Soviets and more than 70 (Afghan) atheists in Samangan. * Nine enemy posts were eliminated 15 December in Shewak Zadran, Paktia.

ARTICIES: "One catastrophe after the other (for the enemy) (By Mohammad Aref Gharwal).

Enumerates the disasters of the Afghans following the bloody April, 1978, coup and the Soviet armed invasion of Afghanistan and predicts full victory for the mujaheddin as a result of the sacrifices rendered by them.

"Difference with the coalition (by Sayyed Masood Majrooh): The Russians and their puppets in the face of staunch resistance of the Afghan people have been facing failures one after the other. For instance they failed in their bid to induce the mujaheddin to agree to a ceasefire or join the so called. NRP. Now they have introduced the ploy of the coalition government. * The struggling Afghan nation will not join the communists in a coalition and the Soviets should leave Afghanistan without any conditions enabling the Afghans to setup an Islamic government of their own choice without foreign inter- 


\section{Shahdat 27 Decanber, 1989.} EDITORTAL: (By Ferotan) Condenns the arrival of 9th year of Soviet invasion of Afghanistan. It writes: It has been 2,880 days that Soviet planes bombing the v1lzages of Afghanistar

and killing hundreds of thousands of our young and old people and our children. The Russians are here producing (another version) of the tales of "One thousand and one night" - - the tales of the biggest crimes of the human history.

This day is a day of mourning but, then, also a day to congratulate the poor and the orphans for their resistance. We are mourning in order to prove that we are not like lambs to be skinned by the Bast and then to be roasted by the West. But we are a responsible nation who knowingly undergoes hardships to establish the sovereignty of God.

INIERVIEW: In an interview with the Shahadat correspondent about the Soviet invasion of Afghanistan, leader of the Hezb-a-Islam Gulbuddin Hekmatyar has said the entire world would rind out that the Afghan nation has waged their resistance to liberate their country in order to Introduce a complete Islamic system in a free and independent Afghanistan.

NENS: Blght Sovlet spies were killed 25 October in Jaghtoee, Wardak.

* Moscow television has shown pictures of Hezbo-Islami leader Gulbuddin Hekmatyar at a war front.

* Bighteen Soviets and 13 local hirelings were kJlled 11 November in successful mujaheddin operations.

* The "tribel army" set on fire recently 12 houses of the mercenarles of Kabul regime killing one and infuring a number of others.

\section{ARTICIBS: "Our overall responsibility for a}

larger unity among the mujaheddin" (By Mohammad Nazir Basharat). Recalls the pledge made by the mujaheddin leaders for holding general elections and their unanimous resolution to stand against the conspiracies of the communist regime's NRP and untlateral ceasefire. It then describes the circumstances leading to the postponement of holding elections and a subsequent decision to elect the IUAM leader for 18 months and promise once more to hold general elections in the future. It says: Past experiences have proved that previous alliances were also faced with difficulties because the leader of each alliance commited to certain issues in order to induce others to consent to his leadership in the election time. The leader forgot his promises and became only interested in his personal grandeour and due to this very reason he engulfed himself and the alliance in problems.

"No service but a big chair" (By Muzammel). Conderns attempts which are hindering the establishment of a mujaheddin govermment. He writes: During the last years of resistance when the Russians perceived disembarking commuism was pre-mature and untimely in Afghanistan, along with making a hue and cry for a political solution, they have also introduced the issue of the reinstatement of Zahir Shah. The drum beaters of this ill fated rumour are the same irresponsible mercenarles who have grown up and are living on

\section{alms. \\ Rah-e-Islam}

27 December, 1987.

NEWS: The Iranian Foreign Minister, Al1 Alkbar Velayati said in Pakistan that the big powers cannot strike a deal on the Afghanistan 1ssue.

* "Cordovez's futile shuttle diplomacy has once again began".

* "Flghting in Afghanistan has been more intensive this year than previous years. The Russians lost 30,000 of their soldiers and presently 30 to 40 Soviet troops are being killed every day.

* Prisoners in Kabul are being despatched to the war fronts but Instead they join the muja- 
heddin as soon as they find an opportunity.

ARTICIES: "The Russians are intent to impose their bankruped ideology on the Afghan people": The people of Afghanistan are fully aware of the failure of socialism in Russia and China. Furthermore, our people have their ow 1deology and actually they are fighting to prove the authenticity of their own beliefs.As such there 1s no room for the introduction of Marxism in Afghanistan.

* "The stand taken by the Muslim about the Afghanistan 1ssue". The paper criticizes the Pakistani newspaper The Muslin for its stand vis a vis Afghan issue. It say: Every new tume by Moscow-Kabul is subsequently replayed by this newspaper. Every new trick played by the cunning enemy against the Afghans is portrayed by this daily as a fresh peace initiative. Whenever the mujaheddin expose the reality of these decelts and do not yield to the yoke of Imperialisin; this newspaper brands $1 \mathrm{t}$ as a US dictate. According to this paper, the Soviets sincerely desire to withdraw from Afghanistan but it is the US which obstructs 1 t.

In a news analysis 9 January the daily questions whether the US would allow Pakistan to solve the Afghanistan 1ssue? On the contrary, it should have asked whether the kind of NRP advocated by Kabul is acceptable from a humanitarian and legal point of view? Yes, Russia wants peace provided the Afghans accept its yoke of imperialim. The "ifs" and conditions attached to these proposals a.ll offer a negative answer. The Russians themselves foretell the essence of their condition which means the Afghans should succumb to their slavery.

The Muslim does not accept the regime in Paldstan because of its support of US pollcies and has emerged as a spokesman for the opposition. But in Kabul it $11 \mathrm{kes}$ the regime which has been presently Imposed on the people undercoercion and whith would be deceitfully imposed on the people of Afghanistan in the future. Is this contradic - tion in policy justified?

The Muslim and the world people should know that the Afghan people have their own ambitions and they want to be masters of their own destiny. They would not submit to imposed regimes and imported atheist ideologies. Bvery proposal, Irrespective of 1ts being Soviet or US or a product of their joint collaboration, which does not achiere that objective, is unacceptable to the Afghans.

* "Resistance continues throughout Afghanistan; a brief analysis of military position in Afghanistan". "Gives an account of the status of the resistance and the position of war during the past year and, enumerating Sorlet casualties and mujaheddin victories, writes: The Mujaheddin attacked March 1987 a number of Soviet military bases in Tadzhisklstan Soviet Republic the news of which were reflected in the Soviet press".

* Soviet economic interests in Afghanistan". As a result of an extensive survey of the underground resources of Afghanistan by the Soviets, It has been established that Afghanistan is enriched with 1,400 kinds of minerals including the most important strategic material. Having come to know about the existance of these minerals, the Soviets have realized that with the occupation of Afghanistan and control over its tremendous underground resources, they can accomplish their manifold objectives.

* "A bird eye view on the last one year's political events in Afghanistan". After describing Soviet policies in Afghanistan, interparty rivalries in the Kabul communist party, removal of Karmal and emergence of Najib and the subsequent fresh differences in the communist party, the article links the Afghanistan issue with Sovlet motives in Pakistan and Iran. Ukhuwwat 27 jecenber, $198 \%$. EDITORIAL: (by Sahtq1) "n27 December; the dar kest day of history". It explains the Sovlet 
light and the devastated homes of the Afghan Muslim nation will once again be enlightened with the bright ray of Theism. NEWS: The Russians are constructing a new airport in Takhar.

* The mujaheddin killed 10 Deceriber 24 enemy troops and set ablaze a tank in Ghazni.

* The mujaheddin killed 9 Decenher 10 SovietKabul troops in Kandahar.

* More than 38,000 occupation troops have been killed since the Soviet invasion of Afghanistan. Political observers say there are about 120,000 Soviet troops in Afghanistan while 3C,000 others are being deployed from the other side of the border.

FEPORTS: At a gathering of more than 300,000 people the IUAM condenned 27 December, 1987 the Soviet invasion of Afghanistan.

MESSAGE: "An open letter addressed to the Resistance leaders" (by Mohammad Yasser)."'Esteemed leaders of the Afghanistan resistance. Greetings to you. Undoubtedly you have rendered renowned services in staging the resistance and have not spared sacrifices. Since the resistance has entered a historic phase now, and secret meetings between super powers have signalled new dangers, the following points are being initimated to you through this joumal so that Almighty God may be a witness and the angels note it down and the struggling nation ( 0 ? Afghanistan) be a witness to the fact that we have discharged our obligation which we had felt as out duty: We have understood the historic importance of the time and fulfilled our duty of rendering counsel. We have not been in your presence to discharge the role of a servant for material considerations. Rather, we have been moving towards the light of this fire because of our resolution to reach the actual light.

We want to ask, whether the time has not come when the hearts of Muslims ought to be afraid from the word of God? Believe me, whenever I recite the Quranic verse of "and hold fast all together by the rope which God (stretches out for you) and be not divided among yourselves", I fear humiliation because I have been with you and I cannot absolve myself of the sin (committed by disobeying this command) May God for-give us and you both. We have spent 12 years hoping for unity and most of our martyres went to the graves with these hopes. Now that there are fears that the blood shed might be sold and our revolution might be stolen from us and we may become slaves of other people in the name of Islamic republic and return to the country under the shadow of the old doom, even now you are not touched.

mow long should we wait for you to unite? Are you not afraid of the day when the patience of the nation reaches its limits? Or may be you cause the nation to destroy itself. If I say something, I fear the enemy may taunt you and, if I keep quiet, I fear you will be taunted by the people of Afghanistan. If I write anything harsh, I feel ashamed, and if I keep silent, I feel guilty before God. Why don't you bring us out of these difficulties. We can neither tolerate enemy criticism of you nor we can answer questions posed by friends. I wish I could write this letter with the tears of the orphans or with the blood of martyrs, or I wish we had written this letter on the coffin of a martyr so as to appease your stone like hearts.

now that our resistance has become a teaching lesson to people of world, has opened a new chapter in the lives of Muslims, the people of the world are astonished and our enemies are trembling, why do you not remove this dark spot of disunity from our foreheads?

"Again, I want to remind you that the day of regret is near and (then) repentance would be of no use. If you are not united today you will be disgraced before God. If you are not united today, you will all meet a doom fate, 
armed aggression against Afghanistan and highlights its continuation; intensity and harrassment.

NEWS: The 15th anniversary of the detention of Allama Faizani was marked at a gathering in $\mathrm{Pe}-$ shawar. The gathering was arranged 18 December and addressed by prominent religious scholars, commanders of the trenches, refugees and people from Pakistan as well as the relatives of Faizani. Articles were read out and verses and impressives melodies were also recited in the meeting.

ARTICIES: "The bell of danger" Describes the. new initiative undertaken by the Setam-a-Melli Party following what the newspaper calls fresh Russian deceits. It is said that the Justice Minister Bashir Baghlani is the Deputy Chief of the Setam-a-Melli Party while Keshtmand's Deputy is the head of the Sitam-a-Melli Party. In fact the two had no portfolios in other governments and they were appointed to these posts after the merger of Setam-e-Milli Party with the PDPA, the party of traitors. It is most astonishing that the two have lately embarked on sofurns in northern provinces delivering speeches saying they do not support the comminist republic of Najib. Rather, they say, they want to establish a national Islamic republic of Northern Afghanistan.

Yes, now the Russians are once again deter mined to disintegrate Afghanistan they disintegrated Bukhara in the name of republics of Tadzhildstan, Uzbekdstan and Turkmanistan.

* Uehad is not a plunder". This continuing article highlights the Islantc dimension of the resistance and mojaheddin duties and notes : the deviations 'mich have taken : place in the jehad. Enqelab-e-Islami Afghanistan 27 December, 1987 ARTICIES: "Russian self styled loya Jirgah in Afghanistann: Convening national jirgahs part1cularly during hostilities, has been a national traditions of the Afghan people. The purpose is to end disputes and settle mutual issues through mediation and public consent and these jirgahs are a historical pride of the Afghan nation.

The Khalq-Parcham party, on the basts of its Marxist Ideology, has been opposed to all national and historic traditions and, at one time all the people, who were now convened to meet in the cormunist sponsored loya Jirgah in Kabul, were branded as feudals in the early days of the wretched coup of $27 \mathrm{Apr}$. 1978. The communists had been considering the loya Jirgah as feudlist tradition and symbol. Following their defeat, the Russians and their hirelings (Khalq and Parcham) have now sought to achieve their satanic designs by banking on a loya jirgah. But this, too, will not help them but further disgrace them.

* Communist Islamic Párty: An International commmist scandal (By Sayyed Mohammad Khair khawa).

Following the failure of communist ideology in Afghanistan and the change of personalities, one after the other, another round of conspiracies and intrigues are being hatched to betray the free Muslim nation of Afghanistan. This time the war of religion has been ignitioned against religion which again, is also not new. However the people already know about the conspiracy and communtst designs have been unmasked before the Afghan Muslim nation.

\section{Ittehad-e-Islami}

27 December, 1987.

EDTTORIAL: "Red sparks", (By Kashaf). A violent stom rose on the eve' of 27 December, 1978, from the north against our poor and helpiess country engulfing our homes in sparks and Plames and the witte heaps of snow were stained with the blood of an aggrieved nation. But, as a result of unparallel sacrifices of our MusIim nation, now the day is not fer when these red flames will be corverted into a bright 
under the earth in the day of reckning you will be brought together, "the day when bome faces will be (lit up) with white and some faces will be (in the gloom of) black." "There is no obligation on us than to tell (you the truth)". (From the Quran).

" May God help you to schieve good things ".

\section{Ummat-e-Azad ${ }^{3100 c a b e r}$, 1987.}

BDITORIAL: "A great responsibility"。 Explaining the struggle of the Afghan nation against colonialism and despotism in the course of history the editorial writes:

Bvery Afghan, having faith and valour, has today once again perceived his great Islamic, national and historic responsibility and despite many odds has kept the hot trenches of jehad for the liberation of his country and empty handed, but blessed with firm faith, has been inflicting heavy losses in men and material to the enemy throughout the course of resistance.

Unity and holding fast the rope of God is a step forward towards betterment and emancipation. Our unity, led by a united center of leadership with the cooperation of all armed resistance forces within the country, as well as abroad, is the key to our victory and prosperity. And 1f, on the contrary, we opt the path of dissertion and discord and fight scatteredly, with a lust for power and status, we are indirectly serving the cause of enemy.

NENS: To condenn the 9th anniversary of the Soviet Invasion of Afghanistan a grand function, attended by more than 140,000 refugees and mujaheddin, was held in Chankani Road, (Peshawar) under the auspices of the resistance organizations. A grand march began by the Islamic Assembly of the Afghan Students and Youth in the front of the Afghan Commissionerate. The marchers walked to the venue of the meeting with the slogans of "Allah-u-Akbar", "Death to Russia" Death to Conmunism" and "Long Iive Islam". ARTICIES: "The 27th of December or the beginn- ing of defeat for world communism" (By Sayyed I smail Fatimi)。 The Soviet invasion confronted with the triumphant resistance of the Afghan people, has faced the Soviet Union to a shameful defeat and now Russian tank skelets, torn out guns, shot down planes, bones and skulls are lying scattered all over the country, serving as a memorial and the territory of Afghanistan from Khum-e-Arab to Torkhala has turned into a museum of Russia's defeat, thus making us confident that 27 December is the beginning of the defeat of world communism.

Muslims say that Islam is the final and most perfect of all the religions and a statement like this in this age of atom and isatelltes is not only made because of a firm faith but also it can be proved scientifically that Islam is the best and most perfect religion for mankind. The article will continue in later issues of the paper.

\section{Shahdat 2 January, 1988.}

EDITORIAL: "Triumph of our revolution - - an assessments by others". The editorial traces the origins of Islamic resistance in Afghanistan and writes, even our close friends had thought that some day Soviet troops would cross the borders treading on the corpses of the mujaheddin. But our continued resistance convinced them that the Russians cannot dominate Afghanistan because:

a) our revolution is a product of decisive determination and valorous resiatence by our Muslim nation.

b) It is not due to a stand and decision by others which have played a role in our revolutionary movement and in the determination of our fate, the bloodshed and resism tance staged by our revolutionary Muslim nation have carved out a prominent position to this revolution.

c) the' Hictoty and success of this Islamic revolution lay in our inherent social 
character and its foundations and not in the outward factors and realities.

d) as the mujaheddin and our nation are exercizing patience, by the grace of God, they have achieved a miracle in carrying forward the Islamic revolution to its present stage, contrary to all assessments, and it will also emerge triumphant in accomplishing the aspirations of the millions of martyrs by setting up an Islamic government frustrating all conspiracies hatched by infidelity and the reaction.

INTERVIEWS: On the eve of the 8th anniversary of the Sovlet invasion of Afghanistan, in reply to a question by The Jang (Pakistan) correspondent as to how long the Afghan resistance will continue, the Heab-e-Islami leader Gulbuddin Hekmatyar has said this question ought to be posed to the Soviets. As far as we are concerned, I can say with certainy that our resistance is strong enough to continue until the last drop of the blood of the last Afghan and it is also quite certain that such time will not come。

In reply to another question he has said the Afghanistan resistance is not a US-Soviet war but it is a resistance by our Muslim nation against an Invader and an aggressive power.

* In an interview about the enemy losses during the past year, Chairman of the Military Affairs Cormittee of the Hezb-a-Islami, Dr. Mohammad Hantf has said from 27 December, 1986 27 Decenber, 1987, 350 enemy aircraft were shot down or destroyed which were mostly helicopters. About 3,000 tanks and armored personnel carriers were eliminated and 4,750 transport vehicles, 52 oil and ammuntion depots and 12 economic installations were wiped out, 312 posts captured and 487 posts destroyed, six sub divisionel centers were captured, eight bridges and a metriological center were destroyed, 28,813 Soviet-Kabul troops were kd1led, 22,510 injured and 4,400 enemy troops were captured including four officers and 55 Russians. One thousand twenty eight troops voluntarily joined the mujaheddin, 13,500 pieces of arms, 27 tanks and amoured personnel carriers, 1,560 trucks and 75 wireless sets were captured, two radar installations, 66 wireless sets and $24 \mathrm{BM}-41,21$ and 13 installations were wiped out. The armed mujaheddin of Hezb-e-Islami total 190,000 persons.

NEWS: Extensive operations were carriec sut 17 December under Hekmatyar's command in Logar province.

* Four enemy aircraft were shot down and 25 high ranking Soviet officers were killed in Parwan 31 December.

* The center of Wardak province was attacked

27 December by the mujaheddin.

* The Publicity and Cultural Commission of the Hezb-c-Islami awarcled 28 December diplomas to a group of graduates who had completed a four months course in journalism.

* All mujaheddin organizations in Chakari, Kabul Province, carried out recently joint operations against the enemy.

\section{Hedayat-ul-Islam \\ 3 January, 1988.}

EDITORIAL: "Our resistance has exposed the reality of the Russian designs".

Nine years ago the brutal Russians intaded our country and imposed an unjust war on the Afghans endangering, at the same time, world peace.Realizing its religious duty, our struggle continues. While we are condenning the 27 Dea ember invasion of Afghanistan by the Red Army, we however notice today that our resistance has unmasked the myth of Soviet super power and its ugly face. This year's victories of our nation convinced the Russians to soon leave our country. Kermal was sacked and Najib was brought on the scene with a new Soviet plan of unllateral cease-fire. Najib announced the so-called NRP 
at the instance of the Russians but it was resolutely turned down by our struggling nation. Even the Russian mass media admitted its ineffectiveness. Their attempts were foiled even at an international level. Soviet aggression was condernned with maximum majority at the UN General Assembly。 The loya jirgah ploy also failed completely.

Our resistance inside Afghanistan and at international political level proved to be a success this year. We defeated the Russians not only on the war fronts but also attained further political credibility at the intermational level. The Parchamis and their supporters have been disgraced and condemned by the people of the world. Our resistance is giving us the good tidings for our victory and freedom. Unity is a guarantee to the continuation of our holy jehad.

ROUND TABIE: At a roundtable Balkh commander Ali Akbar and Satto Kando commander, Adam Gul of Jamiat-e-Islami Afghanistan explained the Russian crimes and atrocities.

The Balkh commander said the Soviets buried alive 250 educationists, elderlies, religious scholars and spirtiuals under bulldozers in Shadian desert, Balkh, in 1980. The Soviets also launched artillery shellings on 100 houses in Deh Taimurak, Char Bolak, martyring 50 children women and old men in 1983. They bombarded 1987 about 50 houses in Faizabad Badakhshan, martyring 20 civilians. They bombarded the Deh Adina Mosque in July 1987 destroying 30 houses and martyring eight ctvilians.

The commander of Satto Kando said Satto Kando is still under Russian aerial and ground attacks and 80 Soviets planes bombarded 1 December, 1987, the Ilavisa villages destroying 700 houses, killing a number of children, women and old men and 1,000 camels and 2,000 other cattle.

REPORT: Mohammad Nabi Mohammadi visited a number of trenches in Paktia, welcomed 15 December the new Zadran refugees in Datta Khel and offered them Rs 60,000 and 700 bags of flour. Addressing the people of Zadran, he said, you are a heroic and brave people and like other Afghans have liberated many parts of the country and have not succumbed to the enemy who is equipped with all modern weapons and has inflicted defeat on the enery in every front during the last nine years of jehad.

\section{Ittehad-e-Islami}

4 Januaty, 1988.

EDITORIAL: "Our honor lies in the continuation' of Jehad" (By Sayyod Ghausuddin Sharaf). When resistance 10 years ago began in Afghanistan, most of the people said the enemy could not be fought with old weapons and now some people say it is not possible to fight the Russians with limited resources and we should accept the NRP. But we are determined to earn the pleasure of God and defend Islam. We believe that in Islam and to us the word death (for those who fight in cause of God) is irrelevant. We will continue our resistance and the enemy propaganda shall have no bearing on our will. We do not allow anyone to to weaken our determination with his propagánda.

NEWS: More than 500 mujaheddin went 2 January

to the war fronts.

* The mujaheddin of Guldara, Parwan, shot down 21 December an enemy plane.

* In their operations 27 December-2 January, the mujaheddin captured several enemy posts, killed 150 troops and damaged a hellcopter at Jalalabad airport.

REPORT: At a gathering 30 December, orphans at the Rashidia Orphange condernned the 27 December, 1979, Soviet invasion of Afghanistan. The meeting was also attended by members of the Supreme Council and Executive Council of the IUAM who delivered speeches. Revolutionary songs were also sung on the occasion. 
Neda-e-Jundullah

5 January, 1988.

The journal, a publicity organ of "Jundullah Front," has the following message: This message $r ?$ The Army of God (Jundullah) which is carried from one trench to another and has not left any stone unturned is a message of solidarity among the mujaheddin so to clear this land of martyrs from the filth of the enemies of Islam.

REPORT: The mujaheddin of Jundullah Front set ablaze 23 July an enemy tank in Begthooth, Paghman, and killed eight enemy troops.

* In an operation 6 August, in Koti Sitara, Paghman, an enemy officer and a soldier were killed.

* Three enemy tanks were destroyed 1 August in an attack with BM-12 on Pajak post, Paghman. All those on board were killed.

* Two trucks were destroyed 4 August as a result of mine blasts in (Begthooth, Paghman, and 28 persons on board were killed and a number of others injured.

* A KHAD major was captured and executed after undergoing trial.

* In an allout operation 9 August on enemy posts in Paghman, 400 enemy troops were killed and six. tanks were destroyed.

* The mujaheddin attacked 10 August the Kar ghah 8 division and other milltary installations killing a number of troops and destroying many butldings.

\section{Afghan Mellat}

\section{January, 1988}

BDITORIAL: (By "Gingineer" Istaqlal). The establishment of the National Progressive Afghan Nation Party enjoyed significant importance in the decade of democracy (1963-73) in our history.

It mentions the "Internal and external enemies" of the party and its difficulties and writes we (at present era) have to cope with the extreme right and left. They are at present on the rise. On the basis of internal, regional and world circumstances, brought about by the heroic struggle of our valiant nation, it is obvious that third force, which is moderate, national and progressive, can emerge triumphant with a decisive role and can lead our resistance towards success.

We should become more cohiesive and, by realizing our principled position at these trying moments, we should render important services to the nation and make history.

ARTICIES: "27th of December, the black day of our history". Considers the presence of Soviet troops in Afghanistan as a danger not only to the region but to the world security as well; proposes that the troops should leave our country immediately.

* "A brief description of our national culture" (By Mohammad Baqir Mohseni). National Culture of the Afghan people, with a 5,000 years history, despite many vicissitudes is original and based on its own indigenous character and supressive and oppressive forces have not been able to change its main and basic features.

* "National will" (By Dr. Abdul Karim Farzan). National will, national originality, national power and national government are four prominent principles in determining the polltical, social, cultural and economic fate of nations particularly of the deprived tolling nations which are dominated by ruling circles acting against national interests of the people. In the light of these values, the writer has analyzed the role of loya jirgahs and describes the loya Jirgah held by Soviet "hirelings" as lacking these qualities.

\section{Ekhlas 5 January, 1998}

EDITORIAL: "The disease of party-making" (By Hkhlas). Complains against the discord and dispersion in the resistance ranks. It says, a party-makdng disease has broken out anong 
the refugees which has posed a danger to the continuation and success of our resistance. Five new organizations have emerged in less than one year in Peshawar: (1) Al-Dawat-ul-. Quran Wal-Sunnat, led by Mawlawi Jamilurrahman (2) Harkat-e-Enqelab-e-Islami Afghanistan, led by Mawlawi Mansoor, (3) Harkat-e-Einqelab-e Islami Afghanistan, led by Mawlawi Moazzen, (4) Tanzeem-e-Refah-o-Muhajerrin, led by Mohammad Gulab Nagarhari and (5) the Jamiat-e-Enqlabi Zanan, an unprecedented one, led by Farida Ahmadi whose real name is not known.

Except three of these parties, the other two might not be so important. The parties founded by the three Mawlawis are important.' they were pioneers of unity and they had distanced themselves from their own parties as they hati accused them of breaking the unity. Now,when all other seven resistance organzzations have untted in the IUAM, how is it that the three have established their own separate camps? The time has come they should inmediately merge in the IUAM. We appeal to all seven party leaders and the goverhment of Pakistan to do away with this party-making disease and work for the strength and unity among our refugees and mujaheddin.

RRPORT: F1ghting in Afghanistan has been intensified ten folds in 1987 in comparison to previous years. In total, 4,436 minor or major battles were fooght during the last 11 months. Their break down is as follow:

January 442; February 212, March 488, Apr-11 498, 498, May 432, June 437, July 498, August 330, September 477, October 350, and November 293. Further more 20,225 persons were killed during 11 months. The following are the' number of casvalties:

Month Russian Afghan Uniden- MujahedCommuni- tified din

\begin{tabular}{lrrrrr} 
& & sts & & & \\
\cline { 2 - 3 } \cline { 5 - 6 } & 266 & 1,003 & 318 & & 243 \\
February & 77 & 156 & 39 & 156
\end{tabular}

$\begin{array}{lrrrr}\text { March } & 167 & 787 & 534 & 234 \\ \text { April } & 356 & 357 & 804 & 331 \\ \text { May } & 280 & 407 & 903 & 196 \\ \text { June } & 395 & 231 & 1,100 & 340 \\ \text { July } & 464 & 256 & 1,296 & 156 \\ \text { August } & 401 & 703 & 56 j & 190 \\ \text { September } & 596 & 855 & 652 & 275 \\ \text { October } & 203 & 574 & 324 & 184 \\ \text { November } & 280 & 326 & 541 & 250\end{array}$

22,510 eneny troops 14,172 mujaheddin were injured, 4,400 enemy troops were captured, 1,028 troops joined the mujaheddin, 502 enemy aircraft were shot down, 3,000 tanks and armored personnel carriers were set ablaze, 4,750 other vehicles were destroyed, 52 oil and ammunition depots were set on fire, 12 economic installations were eliminated and 487 posts were destroyed.

\section{ADONO 6 January, 1988.} EDITORIAL: "The battle of Khost". Giving an account of the condition of the refugees who have newly migrated from Zadran and the areas near Khost it writes: The Russians announced that their losses were 100 dead and those of the mujaheddin 2,000. This means that $40-60$ mujaheddin were martyred in the battle and the remaining are the Afghans who had been recruited forceably or they were prisoners who were brought to the battle front after they were told they were being released. The Russians consider all the Afghans of the same flock and they are pleased to see them die under any name.

Even if the enemy reaches Khost, there is no reason for it to rejoice because the Wuslim nation and mujaheddin are one and the same and the victoriles scored in Khogiani, Kandahar and Panjshir and the casualties inflicted upon the enemy in the battle of Khost are sufficient for Afghans to be proud of their record.

NEWS: Fifty thousand mujaheddin and refugees condermed in a meeting held by the IUAM December, 1979, the invasion of Afghanistan 
by the Soviet Army.

* Mawlawi (Jalaluddin) Haqqani, whose left foot was injured in a recent battle in Khost and Zadran, has said in a message he is feeling well and the mujaheddin should not worry about him.

* Big demonstrations were staged throughout the world to condenn the 27 December, 1979, invasion of Afghanistan.

* The mujaheddin shot down 31 December-2 January seven enemy helicopters at Ghazni and Jalalabad airports.

* The journal published the IUAM resolution condeming the 27 December, 1979, invasion of Afghanistan by the Red Army.(EDITOR's NOTE: See text of the resolution in the "Major Documents" section of Afghan Jehad).

\section{Shahdat 4 danuery, 1988.}

EUITORIAL: "An account of this year's events". Western media resorted to a series of one sided propaganda about the Khost battle and credited some particular people for the victories and resistance while facts are that the mujaheddin as whole were fighting. The role of all commanders representing all organizations who participated in these bloody battles is important. When the Kabul puppet regime is boasting of its "sictories" and some of our own honorable' (friends) 'who ate under' an fllusion that they have the (spiritual) power of having a way over human soul as well as "spirits" also say that the battle in Khost is over. These remarks had created some despair among the refugees and mujaheddin. In reply to all these, and.keeping in vlew conditions at the battle front; it can be sald that the siege of Khost and the escalation of war in Paktia had never been a sudden and unexpected event and neither the resistance was staged under the comnand of any specific individual but it was a culimination of the defeats inflicted upon the eneny as a result of which they finally were forced to resort to a destructive operation to minimize the final pressure and to make a headway to the center of Khost for a number of its forces carrying some conmodities.

Now, while our mujaheddin are bravely offering resistance, the enemy cannot so easily knee us down. Certainly the arrival of a number of trucks in Khost city does not mean the Soviets have occupied Khost. Fighting still continues.

NEWS: After his participation in the resistance operations in Logar and Paktia, Gulbuddin Hekmatyar returned to Party headquarters.

* The mujaheddin foiled 11 December an eneny ambush in Assadabad (Kunar).

* In their operations 24-31 December, the mujaheddin killed three Sovlets and 9 local mercenarles in ghazni.

* The Herat mujaheddin destroyed 18 December eight trucks and killed 15 Russians.

REPORTS: Speaking at a special roundtable organized by the publicity department of the Hezb-a-Islami to conderm the 27 December, 1977, invasion of Afghanistan, Dr. Abdul Hai said our resistance has gained a lofty place in its military dimension but there are some setbacks in the political field and we should all unitedly work to overcome them.

ARTICIES: In a translated version of a news analysis published in The Jange it has been stated that 264 planes were shot down or set ablaze at Afghanistan airports and 238 helicopters were destroyed during the last year. Serat-ul-Mustaqeem 9 January, 1988

EDITORIAL: "A disaster from the very start". A product of discord and rivalries among the seven resistance groups has been that they have resor ted to propaganda against one another which at first resulted in bloodshed between the refugees and the mujaheddin. Then they began bickening. 
against each other in public and in the press. Later they started papers and perlodicals of their own in which the leader of one organization spoke against the other. They then started condemning each other in forelgn media and when leader of one party went to $a_{1}$ foreign country to hold talks with Its leaders, the head of another party also rushed there to discredit the former. By doing so, they were all being discredited.

Such rivalries split the refugees and mujaheddin in several groups in Pakistan and Iran. In addition to many parties, numerous other unions and institutions were set up some of which have worked detrimental to refugees and resistance.

The nation has to ask the leaders: was this what you actually intended for us? And was this the reasons for our migration and placing ourselves under your command.

All this is a prelude with having disastrous consequences. And it should also be remembered that if a real unity is not achieved with a single leader, we will fall under the slavery of those whom we escaped.

NEWS: FIfty thousand Afghan Muslims are waiting for their release in the dark prisons of the hireling regime.

* The great mujahed Mawlawi Haqqani is enjoying a good health (after being injured).

* The Soviet invasion of Afghanistan was conderned all over the world.

* Publications which have come out for the first time: Morchal, Daawat, Al-Saqeb, Sehat, Seerat, Ummat-e-Azaad, Arman-e-Mujahed. An "Institution of Publications and Journals" has also been

established.

ARTICIES: We have started our resistance with the strength of our faith and belief, not the Stinger. (By Bawar Mazeenwal).

At the beginning of the resistance the enemy was heavily armed but those who fought the infidels had to start their resistance empty handed with old local-made rifles and pistols against the arrogant hirelings of imperialism. From April, 1978, coup until November, 1979, the Muslim freedom fighters converted their fight to a nationwide resistance and, within a span of 15 months, 179 sub-divisions were liberated and only 29 sub-divisions remained under the communist control and that, too, only nominal. But districts (alagadari) in general fell to the mujaheddin and out of 29 provinces only 9 were under communist control with enerny forces stationed in them.

We could not match the Russians neither in men or material and we had no air defense but still we could knee down a cruel super power. Our victory was not due the arms we possessed. It was due to our faith and bellef.

\section{Saraj-Munir}

10 January 1988

EDITORIAL: "Under the glows of Shining Light". "Shining Iight" is an attribute of Prophet Mohammad. For he glowed like a burning candle and worried about the fate of humanity. This light did not become still until the very end. Today, as we are struggling to live in the dark alleys of politics, and it is feared we may lose our power to decide our own fate, and we have lagged behind from the rest of the world, we should not fall prey to "Red" or "White" forces or their satanic snares and, by adhering to the tenets of Islam, shun the golden and embriodered traps, so that we may understand the meaning of freedom and emancipate the oppressed ones and once again revive the Islanic grandeur. Having shunned the shackles we can prove to be the devoted defenders of the path of Mohammad (peace be upon him) and march for ward on the path of a long and allout struggle with no fear whatsoever.

ARTICIBS: "Russo-American Collusion against 
Islam". Since their very inception, these two materialist imperialist powers have been struggling against each other over dividing the third world countries but both of them are striving hard to plant their diguised mercenaries in Islamic countries.

Although the Reagan-Gorbachev 1987 sumit 7 December in Washington, which on the surface was to elfminaté medium range nuclear missiles from certain regions of the world, and a trèty in this connection was also signed, secretly and pritately they discussed the dangers which Islamic revolutions in Afghanistan and Iran have posed and wich have awakened the entire Muslin world. They also exchanged view about a coalition government of right and left in Afghanistan whlch would look after their interests.

* "Historic remembrance" When, at a grand gathering'in 1986, leaders of the Jehad rejected Nafib's NRP, they pledged to the mujahed people they would be united. But still the one and only need of this nation - - unity, fraternity and liberation of our territory - - has remained our main goal.

\section{Mujahed 10 Jamary, 1998}

EITTORIAL: "Across the border" (By Nangyal). This year the black day of 27 December was marked in Darul-Hejrat (land of migration) while flerce fighting continued between the mujaheddin and the Soviet invading forces in Khost and Zadran.

World medid had termed these battles as unprecedented. Soviet and Kabul radio stations raised lots of hue and cry. Moscow television showed fllms of these battles. But on the contrary, nothing was done distinctively by resistance organizations to counter enemy propaganda. Ieave this aside, nothing was done for forming a united mujaheddin's military reinforcement in Khost and Zadran.

The IUAM worked several weeks to make arrangements for holding tl e anniversary of condemning the 27 December invasion of Afghanistan, but nothing was hearc in the meeting about the battle of Khost.

NEWS: After his short visits to the UAE and Kuwait, Professor Rabbani returned 31 Decenber to Peshawar.

* General Cómmander of the central fronts of Faryab, Sardar Rashid Islam Yar Mohammad was martyred recently. He had commanded recently the operation for the release of 1,400 prisoners from the Maimana fail.

* More than 2,000 Pakdstani writers and jour nalists delivered a protest note to Soviet Bnbassy in Islamabad demanding Soviet troops withdrawal from Afghanistan.

* The mujaheddin shot down four enemy planes and destroyed a number of tanks in Badakhshan province. ARTICIES: "New KCB propaganda Ploy" (By "N.I,") Creating an atmosphere of misunderstanding among the resistance organizations, publishing fake papers containing hostile propaganda against mujaheddin groups and thus creating discord among the resistance forces are the significant aspect of the $K C B$ heinous designs and poisonous propaganda activities in Peshawar.

One of these papers published recently was a rumour saying Ahmad Shah Masood was martyred by another organization whlle we all know that Masood is well and alive. It asks the people to remain vigilent in the face of such activities:

* "Russian cheats and deceits" (By Dr.Siddiq). Russia hirelings in Kabul are rounding up groups of Kabul citizens to the somcalled NRP under the name of elders of nationalities and seat them in halls, but they are neither the representatives of the nation nor they have any field to speak ori and, after holding such gatherings, Kabul claims that 1ts NRP has been endorsed by the people as a whole.

* Whe Afghanistan Jehad is to honor the entire 
Muslim world". In their joint resolution the prominent religious scholars of Pakistan have said the Afghanistan Jehad is the Jehad of entire Muslim nation and all Muslims should participate in $1 t$.

Neda-e-Mujaheddin 12 January, 1988.

EDITORIAL: "The Drama played by Reagan and Gorbachev". Describing the US-Soviet sunmit as a vain exercize, the editorial writes that Russian words and deeds are never the same. Kremlin is still pursuing the same hypocritic policies, despite the fake face put out by its leader for holding surmits, etc.

HEPORT: Khalilullah! Mateen a correspondent of The Nida-o-Mujaheddin was taken 27 December to a desert in Yawari, Baluchistan, and subjected to physical punishment by the representatives of NLF, Mehaz-e-Milli and Harkat-e-Enqelab-Islami under the directive of the representative of Hazb-e-Islami (Khales), Mawlawi Najmuddin on charges of working for China. But the representatives of Hezb-e-Islami (Hekmatyar), Jamiat-a Islami and Islantc Unity (Sayyaf) saved his life.

In his report the editor has appealed to the resistance leaders, conmanders, religious scholarg and the national elders to appoint a team to probe into the incldent and, if the allegation were untrue, necessary action should be taken (against the transgressors) in accordance with Islamic justice.

NEWS: Valiant mujaheddin attacked 15 December a post in Mahallajat, Kandahar, setting ablaze a tank with all those on board.

* Four KHAD activists were killed 14 December in Kandahar.

* Two enerny tanks with all those aboard were set on Fire 8 December in Farah. Ariana Voice 15 sanury, 1988. EDITORIAL: "27 December". The past Bight years have witnessed bloody events but have also taught a lesson to a super power intent to occupy small countries.

REPORT: Speaking 20 December at a Jehad conferences arranged by the JI in Punjab, the IUAM President Mawlawi Mohammad Yunus Khales said we attach utmost priority to mujaheddin unity。 He added, until an Islamic government is set up in Afghanistan we cannot disarm ourselves and we will continue our Jehad unt1l the establishment of an Islamic government.

ARTICIES: Flucidates the revolt by Esmat Muslim against Najib on the day the Kabul loya jir gah was being held. Rumours say Esmat Muslim intended to kill Najib "The $0 x$ " and his colleagues and declare himself "Amir" and announce a "sultanate".

Azadi: 16 January, 1988

EDITORIAL: Appeal to the IUAM to prevent growing internal feuds. Describes the internal disputes among the mujaheddin emerging out of direct or indirect enemy instigation and resulting in the casualties of renowned commanders. It appeals to the IUAM for necessary preventive measures to check the escalation of these clashes.

REPORT: At a press conference the IUAM President Mawlawi Mohammad Yunus Khales sald we visited the US because the Russians had launched a campaign to weaken the mujaheddin position at an international level. Some people claim that in the US we had said things that we don't say them here. This is not true, he has said.

* In a report on the 27 December meeting, condemning the Soviet invasion of Afghanistan, it has been stated that convening such a mammoth gathering through several political groups is not an easy job. The kind of coordination which was visible in this gathering showed that the organizers had done a real good job. However organizational feelings were also visible in the gathering as supporters of each group coming to the venue of meeting carried pictures of their own leaders. 
ARTICIES: "Need for Iran's support to the IUAM"。 Bnumerates "the evil objectives and wretched designs" of both the East and West about Afghanistan and recounts the links between the Islamic revolutions in Afghanistan and Iran and hopes the Islamic Republic of Iran would extend an allout support to the IUAM.

\section{Mahaz 16 Jamars, 1989 .}

EDITORIAL: "A look at the Zadran battle". Says the situation of battles fought in Afghanistan has changed. Now the mujaheddin are at the 'offensive. The stege of Thost and battle of Zadran were also a mujaheddin tactic. This battle would not be the last one. Russian troops can no more turn the war to their advantage in Afghanistan.

REPORT: At a gathering of mujaheddin, refugees and the local people in Miranshah, North Waziristen, 27 December the NLF leader Sayyed Ahmad Gailani said I expect from the brave Zadran mujaheddin to inflict further heavy blows on the enemy with unity and on the basis of love for their religion and country.

* At a joint gathering of the refugees and Pakistani hosts 27 December the NLF Deputy Chief Dr. Farooq Azam said the present Afghanistan war is not aimed at regaining only our territory or our homes but we are to uphold the cause of Islam and defend our faith. We are all fighting for a common objective and it is essential for our Pakistani brothern to support us in our jehad.

* At a joint gathering of the refugees and Pakistant hosts 27 December, the Pakistan Federal Minister for Culture, Nisar Ahmad Khan told the Afghans: You are a valorous people strong enough to fight a super power for eight long years. I belleve we will not be able to fight even for elght days. Therefore, I say the war waged by the Afghan mujaheddin is a war of the Pakdstani Muslims as well. We have been with you, and will remain with you until Afghanistan is Iiberated and an Islamic government is set up there.

* "Resistance operations during the last year" (Translated from NWT). Iest year 22,000 Russians were killed, 954 captured, 490 aircrafts and helicopters, 960 tanks and military trucks, 1,600 other vehicles were destroyed and 2,000 pieces of arms and 1,500 posts were captured by the mujaheddin. The paper puts the martyred mujaheddin at 1,200 .

NEWS: Eighty eight Soviet-Kabul troops were killed and 37 injured 15 December in Wazi sub division, Paktia.

* Five enemy tanks and three milltary vehicles were set ablaze 23 December in Sarobi, Kabul province.

* More than 2,000 Pakistani intellectuals, men of letters and writers have delivered a protest note to the Soviet Embassy in Pakistan against bomb explosions by the Russian agents in Pakistan.

* Three security posts, belonging to Kabul atheists, were destroyed 27 December in Khogiani, Nangarhar.

\section{Shahdat 17 Janury, 1988.}

EDITORIAL: "A sensitive phase of Islamic revolution" (By "M.N.B."). From recent statements, made by the Soviet Union, the US government, the UN Secretary General's Special envoy, and Kabul leaders it is becoming clear that the USSR and the US have ruthlessly and illegally reached a compromise on the fate of Afghan Muslim nation.

Under this plan, the editorial says the future government of Afghanistan will serve the interests of atheism, imperialism and reaction. But it concludes by saying, despite all difficulties, the Afghan Muslim nation will continue its resistance until it achieves an honorable and dignified status under an Islamic government.

INTERVIEWS: In an interview with the VOA, the 
Hezb-e-Islami leader, Gulbuddin Hekmatyar has strongly condemned the inter-party mujaheddin clashes. He has said we want the entire mujaheddin forces to concentrate against the Russians. Those who have launched an unjustified propaganda campaign against us and accuse us of inciting efghting among the (mujaheddin) groups, actually seek to impose a leadership of their own liking.

* In an interview about the Afghan issue, the spiritual preceptor of the Ikhwan-ul-Muslemin, Prof. Hamid Abu Nasr has said it is responsibility of the Islamic movement's, who are the proved struggling enemy of imperialism, to ask their governments to open their doors for jehad so as (the rest of Muslims) may join the Afghanistan resistance.

* In an interview with The Jassarat (translated by The Shahadat) the NWFP Governor, Fida Moharmad Khen has said those who are waging a propaganda campaign against the mujaheddin and the refugees are the ones have not accepted Pakistan from heart even for a moment. It is not surprizing that the "wise leader" who brands the Pakistan movement as a British conspiracy, would describe the Afghanistan resistance as wS War". * In an interview about resistance operations, the Logar province leader of resistance, Mustafa Badr has said the Iogar mujaheddin carrled out about 265 guerrilla operations and 495 major operations this year.

\section{Ittehad-e-Islami}

18 January, 1988.

EDITORIAL: "Wild Army - - the hunt of mujaheddin". Has narrated the ups and downs of the battle of Khost and recalls the heavy losses in men and material to the enemy saying that Khost should not be considered the only battle fought with eneny: This is a war against falsehood throughout the country and the mujaheddin will continue it until the last Russian and their hirelings are driven out so that an Islamic system is enforced and the banner of Islam is hoisted in Afghanistan.

NEWS: According to a report, the mujaheddin have captured the Governor, Party Secretary and a KHAD commander of the Baghlan province.

* The mujaheddin captured 12 January 14 Soviet diplomats and their hirelings in Paktia.

* Thirty seven enemy tanks and other military vehicles were destroyed 27 December in Parwan. * The Hejrat Kill, Wuntcipality (Pabb1, Pakdstan) has started special youth training programs. In these programs, participants recite poems, sing choruses and deliver speeches to highlight the aims of ' jehad.

* The Mayot of Hejrat Killi, Sayyed Munawwar Shah said, the Kabul atheist regime is training thousands of Afghan youth in Communist ideology, we should also educate our children in Islam and so, instead of roaming in the streets, they may face their communist enemies with knowledge and awareness.

ARTICIES: "A Message from trenches of the resistance". In a message to those who are still trapped in Russian snares and are deceived, it has been said the Soviet Union never honors 1ts undertaking and commitments. Still you have a chance to shun the Russian trap and take shelter with the resistance and lead a free life in the free world of Islam, the message says. UkhuwWat 20 Jamary, 1988 . EDITORIAL: "Anniversary of The Akhuwirat joumal and our proposals". It refers to the difficulties facing the paper, the hindrances caused by others for the proper publication of the newrpaper and "the candidness" of the newspaper and concludes by saying it is ready to publish any criticism, even against the journal itself. REPORT: The 15th anniversary of the imprisonment of Mawlana Falzani, "the preacher of Islam" was marked in Katcha Garhi, Peshawar, by reading articles and reciting revolutionary poem. In his address at the gathering, Mirajan Saheeq 
presented a details life sketch of Mawlana Faizani.

ARTICIBS: Ways to solve Afghanistan problem politically and a social plan worked out by the Afghan Peace Movement. The Movement is of the opinion that under present circumstances there is no time and room for name calling and glving labels to each other. It is a day when all Afghans ought to shun their vested interests. They should give up their selflsh designs and all Afghans, including the Sumnt and 'the 'Shila organizations; as well as those: who have been against the Kabul Communist government and Soviet military invasion, should form a joint front and unite in one rank to enanclpate the country and jointly support the formation of a mujaheddin government.

The movement has forwarded the following proposals for achieving peace in Afghanistan!

1. All sides, including the Russians, Khalqis, Parchamites, Setamis should accept a ceasefire. No arms should be provided to any of them. Those who refuse to accept the ceasefire, should be persuaded by Pakistan and all aid giving countries to do so.

2. A UN peace keeping force should maintain security,

3. Soviet troops should imediately start pulling out,

4. Governmental affairs should be handed over to a neutral government comprised of experiencèd and reasonable people.

5. The return of refugees and Sovlet troops withdrawd 'shoild be supervised by an international tèam.

6. The Interim government should pave the way for a referendum and approving of a constitution wich should naturally and mainly colncide with the Qiranic dictates and national traditions, Insure peace and security and the Islanic identity of an independent, Muslim, norl-aligned Afghanistan being a member of the UN.

If this is not done, war will not end. Bloodshed will continue and Afghanistan will remain as focal point of tension in the region and world.

\section{Qalb-e-Asia Jamury, 1988.}

EDITORIAL: "Distorting the history". Russians pollute every good idea. Commenting on Najib's Jirgah, the editorial writes: They are mentioning the name of Ahmad Shah Baba and conmemorating the loya Jirgah of his Red Iton. They are now looking forward to soon install Najib "The Ox" as the ruler of Afghanistan at the loya jirgah of the Red Bear immitating Ahmad Shah but his Saber Shah (a Minister of Ahmad Shah) would be the Sovilet Ambassador. Their stand cannot be justified by holding such loya j1rgahs and commemorating the elders. Our people are accursing them more and more What they are doing is a contempt of history. People know that Ahmad Shah enjoyed the highest esteem in Asia and Najtb "The Ox" is a Russian dog. People understand well that Ahmad Shah was a patriot1c hero and Najib "The $O x$ " is a coward traitor and hireling of aliens.

ARTICIES: "Refugees without guardian and without a destination" It is now nearly eight years since the direct Soviet invasion of Afghanistan. About six million people have fled their country during this period and have become refugees in foreign soil. This large number of human beings which constitute the biggest group of refugees in the contemporary world, face countless economic, political and cultural problems with their fate at a grave stake.

A question arises as to why this is so? If there were a united leadership and front to back them and if a government and leadership had patronized them and provided them passports and recognition and if there were authorities to Protect them no one would have perpetrated atro- 
cities on them or subjected them to contempt or disgrace. If there were a united leadership the refugees could have been turned into a fighting force or could have been mobilized to do other contructive jobs.

* "Afghans have been invincible throughout the history". The history of Asia is a testimony that the Afghan nation has never ylelded before any foreign power and has always offered stiff resistance with valour against aggression and have ultimately dashed to grounds the oppressors and suppressors during the centuries. It defeated Alexander the Great. It hunillated Genghis Khan. It táught a lesson to Tamerlane and three times inflicted defeat on the British imperialism in whose dornain the sun never seat. This time the Sovlets, who have already occupled vast territories in Asia and Europe, are faced to a shameful and clear defeat.

\section{Jabha-e-Jehad}

29 Decenber, 1987.

EDITORLAL: "Again Geneva". Except "the heinous exposing Russian designs", the Geneva conference on Afghanistan will not accomplish anything in the way of bringing peace in our country.

NEWS: More than one hundred thousand mujaheddin and refugees condemned the Soviet armed invasion of Afghanistan in a mamnoth meeting 27 December.

* A Sovilet reconnassaincé plane wa's shot down in Kabul.

* In Paktia 10 hirelings of the regime were killed and two enemy trenches destroyed.

\section{ARIICIRS: Explatns Sovilet "imperialist" objec-} tives and atrocities in Afghanistan and the awakening of world conscience and the truthfullness of the Afghan struggle.

"Constitution or a snare" (Sayyed Jan Salik). Throws light on the reality of the Constitution promulgated by Kabul communists, saying the promises made in it are actually traps planned by Russians.

\section{Ummat-e-Azad}

21 January, 1988. EDITORIAL: "For further strengthening the Afghan Resistance". The editorial is entirely devoted to a presentation of hopes and aspirations of the nation for achieving unity in resistance ranks. The key to the success of our jehad is unity, it says.

COMMUNIQUE: It is about the alliance formed among three unions of Muslim Youth - - Islamic Union of the Afghan Youth, Afghan Studerits Union and International Islamic Society of the Muslim Youth. It says youngmen with un-Islamic leanings have no room in the Union.

The communique on resistance leaders to realize the current situation and take necessary steps towards unity。

ARTICIES: "Youth on the path to unity". Comments on the objectives of the Union of Islamic Youth and concludes that the Islamic Youth and Students Society has come into being for the pur pose of Islamic awakening, inculcating knowledge and for the social development and progress of 9 the youth enabling them to march towards unity and progress.

* "Unique responsibilities of our Youth" (By Daneshywar). The article describes the various revolutions that have taken place in the course of history and says they were achleved through the sacrifices rendered by the youth and considers participation of the youth in the Afghan resistance necessary and decisive:

* "We will take revenge and demand reparations for the damages inflicted to our country during the war" (By Sayyed Mohamnad Nab1 Khaddam).

With a confidence of victory by the valorous resistance 'of the Afghen Muslin nation, we will revenge the enemy and, we will demand reparations for the war imposed upon us and our successful revolution would be a turning point in the liberation of Russian colonies. 


\section{Al-Noor}

21 January, 1988.

EDTTORIAL: WHthdrawal of Soviets from Afghan1stan". Discusses the news that the Soviets might pull-out from Afghanistan and invites the attention of friends of Afghanistan to be alert. They should study the situation carefully. Committing a mistake at this juncture and after rendering humdreds of thousands of martyrs will sink the boat and the enemy will rejoice:

FEPORT: In an announcement 19 January the IUAM President Mawlawi Mohammad Yunus Khales said we have not accepted the Geneva talks since its very beginning and even now we reject them. During all rounds of Geneva talks, Cordovez has been working for the Soviet interests and to harm the cause of the Afghan resistance and, instead of considering the mujaheddin and Russians - - the real parties to the Afghanistan dispute - - things are rotating aroind a Russian interests.

* In a statement 20 January in connection with the death of Pacha Khan, President of the IUAM Mawlawi Khales said, in view of the fact that an old leader of the Pashuns, Pacha Khan has died and his body is to be transferred to Jalalabad and, disgrace of a dead person is not fustified in Islam, the mujaheddin are utged to stop milltary operations during the burial period. Any vlolation of his directive w111 be severely punished.

NEWS: During the month of December, when the mujahedain had captured the city of MaImana, Sovilet bombarded the city planes plying from Soviet territory and in one of their raids, 50 girls were kdlled.

* In an attack 13 January, on the Naghlú Power plant, the mujaheddin destroyed three pillars of the Naghlu electric transformer and killed 11 atheist guards.

* The Faryab mujaheddin shot down 23 September -
22 December seven helicopters, captured more than 300 enemy troops and destroyed more than 60 tanks and military vehicles.

ARTICIES: "Russians tactics" (By Naseer Ahmad Hares). Russians are still seeking to prove that their intervention in Afghanistan has been correct and proper and, at the some time, want to exclude from the scene the Afghan mujaheddin as a real party to the dispute and to pose the US and others in this role.

\section{Neda-e-Jundullah}

21 January, 1988

EIITORIAL: Message of Jundallah". The enemy has been defeated in the face of righteousness and, for the sake of final victory, cormlete unity in the resistance ranks is vital. REPORT: The Jandullah mujaheddin in Paghman, Kabul provlince, carried 9 September successful operations on the office of Paghman, school which has been converted into a center for teaching communism. They also attacked a number of military posts and bases, causing heavy losses to the enemy. In these operations, six tanks were destroyed and 120 communists killed. ARTICIES: "Urgent need for unity to continue the jehad". - - "Torture and massacre of the Muslims in the Soviet Union". - - "Bring the enerny under your siege". The latter article is a guerrilla guide written by the general commander of the Jandullah front, Mohammad Bilal Niram himself. It is based on his own experiences in the guerrilla ware fare.

\section{Ittehad-e-Islami}

25 January, 1988.

EDITORIAL: Describes the end of Abu-Iaheb, the perverted uncle of the Holy Prophet Mohammad (peace be upon him) and the Yemanese King Abraha, who tried to destroy the Kaaba, and concludes that whosoever has acted against righteousness and supported satanic forces, has always met a disasterous fate. 
NEWS: According to a 18 January report the mujaheddin have shot down 11 aircraft in Takhar province.

* The mujaheddin captured 21 January eight enemy post in Shinwar, Nángarhar.

* In the fierce battle of Khost, 2,000 Russian troops were killed.

* In a mujaheddin attacks 9 January, 10 troops and four officers were killed.

INIFRVIEW: In an interview, the provincial administrator of the Arab Students Society (Jamiat-e-Talaba-e-Arabia-e-Pakistan) Mohammad Ismail, has said, since the very beginning of the resistance in Afghanistan, the organization, on the basis of a decision by its Central Council, resolved to directly participate in the Afghenistan Jehad.

ARTICIES: "Who should determine our fate?" (By Nafibullah Naser). The editorial has condemned " the US-USSR collusion" on the formation of an un-Islanic government in Afghanistan. It consider the right of the Afghan Muslim nation to determine theit om fate and continue thetr Jehad until a complete' Islamic government is set up.

* "I will tell you, but don't tell It to anyone elsen. It is a satirical article in which a well wisher says that Russia and the US have agreed on the establishment of a coalition government in Afghanistan in which the mujaheddin should also participate. The well wisher, however, says our resistance is for \& right cause. It is not for a coalition and is based on ful filling the commands of Almighty God.

\section{Shahdat}

28 January 1988

BDITORIAL (By Ferotan). Invites the attention of Cordoves to his UN responsibility and considers his efforts for the establishment of a costtion goveriment with the commmists in Afghan1stan as a service to the Russians.
INTERVIEW: In an "urgent" interview with 28 January with The Shahadat, Gulbuddin Hekmatyar leader of the Hezb-e-Islami, has said we have never agreed with the Geneva talks from the very beginning and have laid down conditions for these talks. He has said we do not accept these talks due to the following reasons:

(1) The mujaheddin are not attending the talks while they are a party to the dispute,

(2) Najib, although not more than a soldier in service of the Russians, is participating in these talks as the representative of the Afghan nation,

(3) The Russians are involved in the talks directly and Indirectly and every phase of the talks begins when Cordovez visits Moscow for seeking Kremlin's approval,

(4) As upon the conclusion of the tallcs, an agreement would has to be signed with the Najib government, under these circumstances, a (Cordovez) meeting with us, would have been tantamount to receiving our endorsement for the decision adopted by others. We had, therefore, laid two conditions: These talks should be public and whatever we say, should be made known to the world.

The meeting should not be private and un official, but the mujaheddin should be invited to attend them as a party to the dispute. Even now, if Cordovez starts such a move, resulting In talks between the two actual parties of the dispute, there will be no obstacle in meeting Cordovez, but it should also mean official recognition of the mujaheddin.

NIENS: The mujaheddin $\mathrm{kalled}, 24$, October, 50 eneny soldiers and shot down an aircraft in Kob1, Kandahar.

* A Russian armunition depot was destroyed recently and four Russians killed in Badakhshan. * The mujaheddin attacked 13 Decenber ofrices of the provincial party' conmittee, Fat and the 
police in Sharan, center of Paktika.

ARTICIES: "Sensitive position of the resistance and responsibility of the mujaheddin" (By Hekmatyar). Considers recent phase of the Afghan Islamic revolution as sensitive and says the following about solving the Afghan issue: If it settled in the battle-field, it would definitely be settled on the basis of condition laid down by the victor, but if the problem is solved through political conferences it would be solved at the conditions laid down by those who would never be willing to agree for the formation of an Islamic government by the mujaheddin.

* "Pacha Khan's funeral and 21 Guñ fires and two bomb explosions". Offering reasons "for the 21 gun official salute during the burial ceremony of Khan Abdul Ghaffar Khan and two bomb explosions carried by the Russians for creating fear", the writer says: "the entire family of Pacha Khan and member of ANP know more than anyone else that the conspiracy to display a disrespect for the funeral of Pacha Khan was hatched by the Russians and their agents".

\section{Ittehad-e-Islami}

1 February, 1988

BDTTORIAL: "Formation of an Islamic government, the one and only wish of the Afghan nation". (By Sayyed Ghausuddin Sharaf). Describes the Geneva talks as irrevelant because the important party to the dispute, the Afghan mujaheddin, are not participating in them and it considers the estabIishment of an Islantic government in Afghanistan as the one and only with of the Afghan nation. INTKRVIIK: In an interview with The Ittehad-eIslami the Deputy Leader of the "Islamic Unity" (Sayyaf), Fingineer Ahmad Shah has said, taking any dectision about the future government of Afghanistan is the right of the mujahed Afghan nation. The government shovld be formed from the mulahedatn We accept netther a coalition government (with the cormunists) nor a neutral government.
* In an interview about the assistance rendered by the resistance to needy Afghans, Chairman of the Refugees Committee of the Islamic Unity (Sayyaf) Organization, Al-Haj Mohammad Dawran has said relief coupon books for the orphans of 14,000 families have been prepared and, so far, more than 9,000 families have been assisted. The process to assist the rest is still being worked out, coupon books have also been given to 1,700 disabled persons and a monthly assistance of Rs. 500,250 or 150 , is being provided to them respectively on the basis of their needs. NEWS: Three enemy tanks were destroyed 23 January and 17 Soviet troops killed in Tangl Wardak.

* The Badghis mujaheddin destroyed 23 Jamary seven enemy posts killing 31 atheists.

* An enemy tank was destroyed recently and 30 atheists killed in Farah and Nimroz province. IFTTER: In reply to a letter of Gul Mohammad from Kutcha Garhi, Peshawar, asking for the stand of the Islamic Untty Organization about the future government in Afghanistan, the jour nal has given the highlights of a resolution adopted by the supreme Council of the party, saying that the government must be:

(1) formed from amongst the mujaheddin,

(2) on the basis of an agreement by all seven parties.

(3) announced before the Genera political solution of the Afghan problem,

The resolution had also said:

(4) We are not satisifed with an interim govermment and this goverment would directly takeover Afghanistan from the Russians,

(5) this government should make preparations for taking over every administrative unit,

(6) the government should be announced after the merger of the mujaheddin organizations. 


\section{Shahdat}

3 February, 1988

EDITORIAL: "A new phase of talks on the Afghanistan problem is to begin". (By MNB). Anticipates the conclusion of the series of Geneva talks and the beginning of a new series in which the mujaheddin will directly talk with the Russians, and supports such talks. The editorial describes the Pakistan stand not to sign an agreement with a government which is considered the assassin of the Muslims of Pakistan.

RFPORT: At the gathering of Juma prayer 29 January in the grand mosque of Nasrat Meena, $t$ Hezb-e-Islami leader Gulbuddin Hekmatyar sair we will in no way accept a coalition government and a new series of talks should begin on the Afghanistan issue.

NEWS: In a recent successful attack by the mujaheddin, the commander of Ghanikhel 46-3rigade, Nangarhar and 18 troops were killed by tie mujaheddin.

* The mujaheddin shot down 27 December two enemy helieopters which were bombarding the mujaheddin positions.

* Thirteen atheists were killed 31 December and seven others injured in Ghor.

ARTICIES:A revolution within a revolution".Bfforts to create another monarchy should be crushed (By Al-Haj Mohoutmad Amin Ferotan). The antiZahir Shah slogans given by our people in the Jehad and slogans againist all those who have not participated in the Jehad and yet have an ambition'to assune power, are an integral part of their anti-fussian slogans. As such, raising of slogans against Western imperlaists, too, is a a part of 'slogans raised agatnst Russian imperialism.

* "At the Instance of others" (By Mohammad Maaroof Feroghgar). In Afghanistan and most of the Middle East countries there are a number of mase people holding power "with only a handeful of followers that are ready to resort to any base action at the instance of others.

Neda-e-Jundullah

4 February, 1988.

EIITORIAL: Russian objective in invading Afghan border areas, is to block the mujaheddin routes.

REPORT: In their operations 26 and 27 September, the Paghman mujaheddin killed 176 atheists.

ARTICIE: "The nature of so idarity and peace in Islam". Studies the condition for reconciliation and duties of the Muslims under present circumstances from an Islamic point of view.

\section{Armari-e-Mujahed}

4 Febtuary 1988

ARTICIES: "An issue of attention for our readers" (By Moazzen). About the title of the paper it writes: The name does not suggest that I am plaming to form a party. Rather my aim is to bring about a real unity and, if it is accomplished, I would come forward to serve the Muslims as a "sweeper" to serve the cause of unity.

* In reply to an article published in The Ekhlas newspaper about "the disease" of making parties by criticizing the formation of Harkate-Enqelab-e-Islami Afghanistan led by Mawlawi Moazzan, it has been sald our objective is to consolidate unity and not increase the parties.

* "Islamic Relationship". Conderino the soviet invasion of Afghanistan and hails the participation of Pakistani Muslims and strengthening of Islamic links, saying the Afghans are not alone in their resistance.

* "The stand taken by the Islamic countries". Deals with the siege of Khost and "Russian barbarism" and hails the communique issued by the Iranian Consulate in Peshawar expressing support to Afghan Muslims against Russian brutalities.

* The 1979 uprising in the Sandahar military garrison and in the Kabul Balahessar were rea- 
sons for the Soviet loss of confidence in Tarakai and Amin. It considers difference and disputes in the resistance as harmful.

\section{Hedayat-ul-Islam}

4 February, 1988

EDTORIAL: "What kind of Justice". Hás condemned UN attempts to bring about a coalition govermment in Afghanistan and considers it contráry to the objective of our ten years of resistance and Justice.

REPORT: Leader of the Harkat-e-Enqelabme-Islami Afghanistan, Mawlawi Mohammad Nabi Mohammadi has gone to Sudan at the invitation on Al-Jabha-elIslamia-el-Qawmia of Sudan to participate in a meeting of 24 representatives of Islamic Movements. Speaking at a sessions held at the University of Sudan, he said the Afghanistan resistance has unshakeable ties with the Islamic world particularly with Islamic movements.

INTERVISWS: In an interview, the commander of Padkhwab front in Logar, Haj1 Sayyed Roohani has said: I have taken part in many offensives against the enemy, the biggest of which was a battle fought Jume-July 1981. In the battle, in additionfinflicting heavy casualties to the enemy five enemy tanks were also set ablaze. NWWS: In the mujaheddin operation 10 December In Durant Maldan two enemy tanks were destroyed and 15 atheists killed.

* In their operátion 23 November in Fáryab, 30 Rusglans weŕe killed.

* In their opèrdtions 27 December the Iogar mujaheddin killed seven atheists.

ARTICIB: Clains that 1988 is going to be the final year of Russian in Afghanistan is a trap. On the basis of increased Russian espotnage actlvities and world-wide disgrace caused to the Russions, due to their adventure in Afghan- istan, the article considers the "drana" of pull-out as a guile and believes that the Russians want to accomplish through peace-loving slogans what they could not achjeve by war.

\section{Al-Noor}

5 February 1988

EIITORIAL: "The new Soviet policy and changes in the war"。 Discusses the humiliations caused to the Russians and their puppets and their cries for peace, pretending to have become "good boy". However, beyond these, they plan to take positions against the Muslims and fight them from a different venue.

The resistance must counter these maneuvers and introduce a united leadership for the Afghans and the world at large so that the staunch MusIim nation, which has emerged victorious in the battlefield, may not be defeated in the political arena.

INTERVIEW: The Soviet soldier "Darwin Trag Yurovich", Who has sought asylum with the mujaheddin, has said in an interview: "During training in the Soviet Union, our officers had been telling us that if the mujaheddin captured us, they will tear us into pieces, price our eyes out, cut our ears and noses and subject us to all kinds of torture. Now I have sought asylum with the mujahedaln bit I find completely different treatment.

NEWS: In their operation 27 January, the mujaheddin killed 41 atheists and shot down three air craft in Nangarhar.

* The Dak district in Paktia was captured recently by the mujaheddin. During the operation for winning the area, 67 troops and militiamen were also captured alongwith their arms and ammuntion.

* In the mujaheddin operation 31 January on Bagram airport, two aircraft and an ammunition depot were destroyed.

* Eleven guards at Pul-o-Nau Abad, Kunar, were killed 24.4 January in Kunar. 


\section{Ittehad-e-Islami}

8 February, 1988.

EDITORIAL:"AIl out changes In the Afghan sociéty". It discusses educational programs undertaken by previous 3 lines not typed see * on page 1 of the draft have been established in which our youth are being taught about religion and objectives of our revolution.

REPORT: A three day competition seminar was convened 4 February by the Islamic Unity Organization (Sayyaf) of Afghanistan for the youth, The seminar lasted three days. In an address to the youth, leader of the Islamic Unity Organization, Professor Sayyaf said when Afghanistan is liberatéd' by the mujaheddin, its future w1ll be in your hands. The resistance trenches need men of thought: and faith who are nourished in the tradition of jehad with the slogan of Allah-uAkbar being chanted in their ears from their very childhood.

* A solidarity meeting for the Afghan mujaheddin was convened 5 February in Mardan Stadium under the auspices of the Jamiat-o-Talaba-aArabia of Pakistan. Addressing the gathering, the head of the political affairs Committee of the Islamic Unity Organization, Mohammad Yasser said "We are not going to sell out our revolution for the sake of gaining high positions: Rather, we will continue the jehad until the mujaheddin form a government of their own in Afghanistan. NEWS: In a mujaheddin operation recently on the Kabul airporty five aircraft were damaged and a post destroyed.

* Five offlcers were killed and 10 troops captured 31 December in Gulcheen, Badghis.

* A Soviet travisport plane was shot down in Bagram.

ARTICIES: "Betrayal in words"(By Mohammad Yasser) A satirical article considers the BBC programs for Afghanistan as aiming towards a "divide and rule" polfcy. World leaders are hatching a deal on Afghanistan that might render useless the.. bloodshed by our people during the past 10 years: These leader have adopted the following precautionary measures for the implementation of their covert plan.

(1) providing of an atmosphere in which many parties are established in the resistance.

(2) nourishing of the personalities with diversified views and not committed to an ideology.

(3) a campaign to undo everything done towards unity among the resistance organizations,

(4) creation of an atmosphere of distruct among the resistance leadership and fanning a newspaper campaign against each other,

(5) providing money and other facilities for undeserving people and converting of the resistance into a kind of business deal,

(6) alluring the resistance commanders by giving them direct assistance and weakening their links with the central leadership,

(7) elimination of sincere and able commanders by installing inefficient rivals in their place,

(8) creation of a distance between the mujaheddin and refugees and investing power in those who are in a position to distribute coupons among the refúgees:

(9) fanning of national, lingulstic and regional prejudices,

(10) increasing the number of ethnic institutions.

They are expected to achieve the following:

(1) Assumption of power by people with no ideology both at the resistance and leadership ranks,

(2) weakening the determination of people with noble objective and frustrating the ideologically comitted individuals.

(3) weakening the spirit of sacrifice and 
inculcating a luxurious life,

(4) Inducing the leaders to exploit the miseries of the needy for their own cause,

(5) giving to politics an upper hand over the ghariat and, sinally,

(6) making the resistance leadership susceptible to its own wishes and alternatives,

Howover when they worked out this plot, like the Russlans, they also found out the resistance to be a hard nut to crack. They had not expected our leadership would turn down their plan. Neverthless, we should not think that this has been all, for mischief has many tributaries. Our leadership should be attentive and aropt the following messures:

(1) create a cohesive unity trusted by the mujaheddin,

(2) make the commanders and able and pious people the plvots of power,

(3) once again resbrt to the invitation which elevated them to this stage of politics,

(4) for the sake of gaining the pleasure of God they should seek pleasure of the people,

(5) Should set a mujaheddin government at the earliest.

\section{Neda-e-Haq 9 pertrars, 1989}

BDITORIAL: "What does imperialism want"? The sacrifices rendered by the Muslims of AfghanIstan is just about to bear fruits but blood thirty powers have resorted to the flute of reconciliation in an attempt to bar us from our final success. One should not blame imperialism, (for that is its nature). The matter to be regretted is why our leaders fail to grasp the problem? 'They have failed to be worthy of the confidence of the nation and the only reason for indiscipline among the mijaheddin is lack of a united Islamic leadership. We suggest to our leaders to adopt a single and positive Islamic stand and satisfy their Muslim nation that they would not allow anyone to interfere in their right to determine their own fate. INTGRVIEW: In an interview with The Nida-o-Hage leader of Harkat-e-Enqelab-e-Islami Afghanistan Mawlawi Nasrullah Mansoor has said: The Afghanistan problem is a problem of Islam, for our resistance is an Islamic resistance. The issue cannot be solved through the Geneva talks. Because the real 'parties to the dispute are not participating in those talks. One party to the dispute is the Afghan Muslim mujaheddin and the other is Russia

NEWS: The Urgun mujaheddin discovered 8 November a big KHAD network in the area and captured 76 persons working for the ring. Investigation about the activities of this center show they were promised Afs. 12 million for the murder of a prominent commander. They had planted a mine on the route from where a car carrying Mawlawi Arsalan Rahmani was to pass. The bomb exploded but the commander was saved while a number of mujaheddin were martyred. Those who are accused of working for the KHAD spyring are being interrogated.

* In an operation 8 October the mujaheddin killed or injured sight communists in Mirzaka, Paktia.

* Fourteen atheists were killed 18 Jamuary in Jaji Maidan, Paktia.

\section{Shahdat}

9 February, 1988

EDITORIAL: "Once bit twice shy". It is about meeting of the IUAM delegation with Cordovez. The mujaheddin decided to meet him in order tc explain to him their stand. But a coniroversy in the press about this meeting was unnecessary and stems form motives explained in a proverb which says: "Once bit twice shy". The reference is to the meeting of some leaders with Reagan.

* Speaking 5 February at the Jehad Conference In the Mardan Stadium, the Hezb-e-Islami leader Gulbuddin Heknatyar said the day when Russian 
troops pull out from Afghanistan, the communist government will also go. Until we hoist the banner of Islam in Afghanistan and an Islamic govermment of mujaheddin is formed, we will not lay our arms down and will not quit our trenches. NEWS: The-IUAM delegation'met recently Dlego Cordovez, UN entoy on Afghanistän. The delegation, comprised of the representatives from all the mujahedain organizations, apprised Cordoves of the inujaheddin demands and their stand on the Genevia talks.

* Fnemy troóps sieged 29 December mujaheddir position' in' Mahallajat, Kandahar, but, with their strong determination and planning, the mujaheddin broke through the slege killing 1,000 enemy tróps and destroying 20 tanks.

* In their activities 31 December, the mujaheddin killed 120 KHAD agents in Wardak and Maidan.

ARTICIES: "Cordovez's mediation and solution of the Afghanistan issue" (By Heknatyar). The Soviet Union may succeed and with Pakdstan,Iran, China and the US to find an artificial solution of the Afghanistan issue and it may be able to resolve or reduce its difficulties with these countries but, in such case, the eternal hostility between Russia and the Afghan nation will linger and this the problem would not be solved.

* What ought to be done?" (By Diljoe Hussaini). Studies the present "sensitive phase" of the Islamic revolution and writes, if we cannot reach a resl unity in our genuine and long struggle and do not consolidáte out forces, we will be making a mistake and will face great defficulties.

* "The essence of plety in Islam" (By Mohammad Zaman Mosátrinil). Islam condenns all forms of discrimination and narrow mindedness. When one is satisfied about the moral integrity and fine character' of an 'individual' even if the latter does notibelong to'his groupy he is obliged to treat him better than an invirtuous members of his own group; If one considers inlawful things lawful and vice versa because of his own prejudices, he has, in fact, placed Islam second to. his own narrow principles.

IETTER: By "Wohammad Tariq Zabeeh". Criticizes The Afghan Jehad and writes: After going through this magazine one gets the 1dea-that it is a product of a mere research lacking the sentiments of an Islamic bellef towards the Afghan Muslim nation. One finds out that those who work for the magazine are not even Afghans as their country has been subjected to an agsression by a savage super power and in their writings they do not reflect this.

\section{Enqelab-e-Islami Afghanistan 11 perrerery, 1980.}

BDITORIAL: "In the process of the dynamic Islamic revolution of Afghanistan against the world devouring communism, the success of the Islamic revolution in Iran on 11 February, 1979, is also a day to be celebrated by the Afghan Muslims. Becausejwith the victory of the Islamic revolution in Iran, the twilight of hope hit the eyes of the Afghans as well as other Muslim revolutionaries and the deprived people of the world. NEWS: * In a successful operation 26 December, 1987, in Panjshir the Shabah garrison and five communist military posts fell in the hands of the mujaheddin.

* A military post near the Faizabad, Badakhshan, airport was captured 13 December, 1987, as \& result of which air traffic was suspended to and from the airport for a whole week.

* The Ghazni mujaheddin destroyed recently five enemy hellcopters, two military posts and killed 92 Soviet-Kabul soldiers.

ARTICIES: "The fate of our Muslim nation should be decided by the Afghan nation and not by Gorbachev or Reagan. (By Sayyed Mohammad Khairkhwa) 
Our nation began the Afghan Jehad at its own initiative and upon its own will and Gorbachev and Reagán have no right to strike a déal over Afghanistan.

INTERVIFW: The general commander of Sainangan fronts has said in an'interview; since the nature of the athiest comminist regime announced by Tarakai and his Godless companions was known to us, wé began our' gehad against' the puppet Soviet regime and at first, in the course of prlvate and secret meetings, I invited the people to join and later, on the basis of encouragements by our Muslim brethren,we launched our uprising throughout the province.

\section{Serat-ul-Mustaqeem}

13. February 1988

EDITORIAL: "The Afghan Society at a crucial stage" - - After referring to efforts exerted by Cordovez, it points out to what it calls the numbness of the mujaheddin leaders and says we only recognize two groups of people in Afghanistan the mujaheddin and the atheists. It crit1cizes the kind of government which will be comprized from the mujaheddin, refugees and muslims Inside Afghanistan and says that only the mujaheddin will form the future government of Afghanistan.

INTERVIEW: Mawlawi Nasrullah Mansoor leader of the Enqelab-e-Islami Afghanistan has told a reporter of the paper about the future government of Afghanistan with the withdrawal of Soviet forces from Afghanistan, God wlling, this nation will maintain its unity and transfer the power to a government which will manifest the will, aspirations and wishes of the people.

ARTICIES: "If a government with communists is formed, the nation will conderm the council of mujaheddin coalition". The article says if such a thing happened then (1) Muslims throughout the world would say the holy jenad of Afghanistan is an Islamic jehad and therefore, unt1. there are grounds for continuing this jehad, to put a halt on this it is tantamount to an antijehad act. (2) If, before the formation of an Islamic government, national reconciliation takes place the blood-shed by 1.5 million martyrs will be ignored.(3) Hejrat has taken place on the shariat grounds and such a national reconciliation will still allow the Afghan Muslims to ive in migration (4) If an Islamic government is not established what then is the result of our jehad?

* "The Organization of the mohajerrin Welfare: A new trap" ${ }^{\text {) }}$ This is an organization whtch is in operation for long time and established by Zmarai Shaheed. It has many underground friends in the Jabha- - Nejat and on the surface Nangar hari, Khawari, Sardar Khan and Sardar Zahir are working with Shahed. They have left the Jabha for this work and now they are busy creating an organizational structure for the institution. It is possible that in the future, it may emerge as a separate political organization. At any rate, it is to be feared because its identity is not known and also these people have embezzelled the Jabha funds and the leadership of Jabha should investigate the case.

\section{Mahaz}

13 February 1988

EDITORIAL: Will the Russians really pull-out their troops from Afghanistan"? The editorial considers the hue and cry staged by the Russians about their troops withdrawal and the formation of a coalition government as a politicalmaneuver so as to slde track the Afghans and people of the region and the world and to have a breathing space for consolidating its position in Afghanistan. It considers the IUAM as the only representative of the people of Afghanistan and says, without its agreement, no other action can insure peace in Afghanistan.

NEWS: In a book laumcning meeting held by the Afghanistan Jehad Research Center poems, written by Mohammad Irfan Khattak under the title of the Gunpowder and faith was debated. The 
meeting was attended by Pakistani and Afghan literary figures.

* In an operation 31 December, in Ghazni the mujaheddin shot down two enemy helicopters and kdled 22 athelsts.

* The mujaheddin in an operation kllied 1 February 21 enemy soldiers in Kunduz province,

RKFORT: In a meeting 12 February held jointly by the mujaheddin and the Ansars in Peshawar No.1 School, Dr. Farooq Azam Deputy leader of NIF sald "the people of Afghanistan and Pakistan have common herltages and I assure you that the Muslim people of Afghanistan will achieve victory in the near future and the Russians will be condermed to defeat and will quit our country; ARTICIF : "Another show: the loya Jirgah" It says that the loya firgah recently convened by the communists in Kabul did not enfoy any legal support and 1t was held at the behest of the Russians and was only to serve as a propaganda ploy.

\section{Ekhlas}

14 February, 1988. BDITORIAL: "A farce under the name of peacen.

The editorial says the Russian call for peace as well as the peace accords being worked in Geneva on solving the Afghanistan issue one nothing but farce. They will amount to a recognttion of the Naj1b regime and legalizing Fussian interference in the Afghan affairs in the gutse of sssistance to Kabul puppets, while the governments of Pakistan, Iran, other Islamic countries and free world will not be able to support the mujaheddin. Ieaders of the Jehad and other parties involved in the Afghan issue should exercise caution'because, wher' one commlts'a mistake In his prayers, $1 t^{\prime}$ can be rectified bat a pol1t1cal blunder camot be rectified.

MEWS: The Takhar mujaheddin recently destroyed an enemy tark and kdlled 13 Kabul government miIitiamen.

* The Parwan mujahedain kdlled 16 Russian sol- diers and rounded up a great quantity of goods and material from the enemy in their operation in the beginning of February in that province.

* Professor Bahauddín Majrooh Director of the Afghan Information Center was assassinated 12 February at his own offlce by unknown men but It is being taught that the murder was master minded by the KC्B.

ARTICIRS: "Answers by mujahed brother Mawlaw Jalaluddin Haqqani to mercenary Naj1bn. It is a series of letters exchanged between the mujaheddin leader in Paktia provlnce and Najib. Najib has proposed peace to Mawlawl Haqqani saylng: "Iou rest assured about the sacred rellgion of Islam. My revolutionary government, God forbid, 18 not a government of sacrilegton and has no intention to contempt or ignore I 31 am.

In reply Mawlawl Haqqant has said: "For a long time you have been serving as an agent of communism, socialism, atheism and, as the head of KHAD, you have been rendering great servlces. For the sake of your ideology more than one million Afghans have been massacred by the Russians and more than five million of them are going through agonizing times far from their country and more than two milition of them are 11ving as refugees within the country. In my view and that of the world as a whole the Russian wolves are to be hated and if you also take Into account the conditions of your country, you will also view them 11kewise. And if you fatl to do this, your eyes, ears and indeed your brain need treatment. Bven now for you ways to render service to Islam are not closed provided you try. (The series is to be contimed by the newspaper).

\section{Rah-e-Islam 44 Petrenery, 1998} EDITORTL: The Russians are seeking execuses for leaving Afghanistan". The Russians want peace in words but in deeds they want the others to take the first step. They expect the mujaheddin should be disarmed frat, aid should be stop- 
ped to them, the refugees should return home, forelgn countries should sign the giarantee of the accord on non-interference in the internal affairs of Afghanistan and non-aggression, only then the Russis will announce the date for the withdrawal of Its troops from Afghanistan and it will be a right of Moscow and Kabul regimes to $f f x$ a date and evaluate the conditions. Such is "the flexibility" and "readiness" of the Russians in their bid to withdraw erom Afghanistan.

The position of the mujaheddin in this connection has been that of course all foreign interventions should be stopped and others should allow the people of Afghanistan to determine their own fate. 'If today' the' Russians announce that they are going to pull out from Afghanistan and allow the people to'decide about their own political regine, the mujakeddin will also imnediately láy down theit arms and will resume thetr normal lives: However if the Russians desire to interfere in Afghantstan in one way or the other, the mujaheddin will refuse to lay down the1t'arms. The Afghans started their war with very primitive means and will continue to fight with the same kind of weapons. This is the will of the mujahed Afghan nation and nobody can deprive thein of this right - the right to struggle and resist against a satanic force and for the protrulgation of the word of God.

NEWS: "Intervention by the Indian government in our internal affairs continues. Indian Minister of State in the Ministry of External Affairs has met the former Afghan King Zahir Shah.

* By welconing the Kabul reglme Foreign Minister In their cointries, Arab regimes will reduce the Afghan jehad to the status of the situation prevailing in the Palestine movement.

* Thaivalt Ziaul Haq of Pakistan has said the Al' רin thathedin are also defending the borders of Batcitar.

APILELES: 1 Gan a person be both Muslim and na- tionalist at one time?" A person can be one of the two. Because Islam and nationalism are diameterically opposed to each other。

" Big power intrigues against our jehad have been increasing. It refers to what it calls intrigues against the Afghan Jehad and then expresses the view that a campaign for Zahir Shah will cause divisions in mujaheddin ranks and will allow the Russians to tell the international community that there is no other political force to replace the Kabul regime in Afghantotan.

\section{Shahdat}

15 February, 1988

EDITORIAL: "What is Gorbachev sayigy in(By MR).

It considers the latest Gorbachev announcenent 'about the withdrawal of Russian troops from Afghanistan as a political maneuvering and a disinformation gemic. It says that there are two reasons for the Afghan crisis: The Russian army and the Communist government in Kabul. Unt1l these two are not eliminated, aggression will continue and it will not be possible to solve the issue. It says all the Russian tactics have failed and by now they should have understood to give up' in the face of the will and rightful aspirations of the Muslim and revolutionary Afghan nation. The Russians ought to completely leave aside telling Iles and their hypocrisy and sit face to face with the mujaheddin for negotiations because the mujaheddin manifest the will of the 20 million Muslims of the nation. REPORT: Leader of the Hezb-e-Islami, Gulbuddin Hekmatyar has said in a news conference in Islamabad that by side-stepping the issue of an interim government, the Russians are hatching a big conspiracy against our nation.

* Ieader of Hezb-e-Islami Gulbuddin Hekmatyar told the people gathered for Juma prayers 13 February, I assure you that Pakistan is not ready to oppose the mujaheddin because if disputes emerge between the mujaheddin and Paldstan, then the Russians may not need to accept 
Pakistani conditions.

NEWS: Ten Russians were killed by the mujaheddin 23 December 1987.

* Bahauddin Majrooh, Director of the Afghan Information Center has been killed by unknown. gummen. So far nobody has taken the responsibility for his death and neither his assassins have been known. However, the imperialist radio, BBC by exploiting the event wants to create tension among the Jehad organizations.

* In an operation recently in Mugor, Ghaznl, the mujaheddin killed 27 officers and soldiers of the mercenary regime.

ARTICIRs? (By Ferotan) woh mujahed, Oh Muslim. countrymen. Your government is not there. It is right here, for wherever you are, there is your gotetment:

\section{Ittehad-e-Islami}

15 Jahuaty, 1988

BDITORTAL: "Pormation of a mujaheddin goviemment is' the only'sy out". The Russians, who have failed to achieve their aims through armed aggression, are now trying to find a place for the communists in Afghanistan as a party and in a coslition or netural government and, on the baeis of this, want the former King Zahir Shah to also return. However, our revolution has started for the sake of establishing a complete Islamic order and, therefore, the only solution is the formation of a mujaheddin government. FESPORT: The Supreme Council of the TUAM met 2 February under the chairmanship of Mohammad Yunus Khales and approved the principles and means for creating an interim goverrment. The basic reason for bloodshed in Afghanistan is the invasion of the country by Russian troops and the imposition of the present regime. Achleving a lasting peace will be possible through holding talks between the mujahoddin and Russians and intil the Iast 'Russian soluter remains in Afghanisten, the mujaheddin are not going to lay down their arms.

INTVEVIIEW: Abdul Haq, a teacher who spent seven years in the. Pul-oharkhi prison in Kabul and was recently released, has said in an interview that there are more than 2,000 women and more than a 1,000 children in the Pul-e-Charkhi prison most of whom have been jailed due to the crimes supposedly comitted by their husbands or fathers.

NEWS: In a mujaheddin operation in Kandahar 23 January, four enemy personnel were kdlled and 35 others captured.

* The mujaheddin destroyed 22 January 17 neny tanks and killed 30 atheists.

* The mujaheddin kdiled 6 Russians and sevenmembers of the KHAD 15 January in the Tor Ghar of of Nangarhar.

ARTICIBS: What ought to be done (By Mohammad Yasser).Pekistan is in a precarious situation. It should either sign the Geneva agreement with the Russian puppet government in Kabul or try for the formation of the so-called neutral government to sign the agreement with it. What should our jehad leadership do? If it is going to give-up to a coalition government, it would mean that it has sold both themselves and the Jehad and, therefore, at this stage, it should (1) form and promulgaté a mujahedain 'government' (2). should give up maling personal and ptitrate dec1sions and should bring all the people of thought into the cirrent of affairs, (3) all the partiea which are resisting 1ntrigues should merge in an alliance. In the new alliance use should be made of the previous experiences. At the beginriting also use should be made of any force wich is against the enemy but at the time of frultetion only those who have similar bellef and objective should participate in the alliance, (5) they should be ready for one of the two sacrifices. They should either sacrifice themselves or their goals, (6) those who are joining the movement should not do so for material gains,(7)time 
is of vital importance, delay in taking an action would benefit the enemy, ( 8 ) only issuing of statements is not enough, concrete action is needed. Our mujaheddin should make use of utmost shrewdness; should not give up their arms under any circumstances even in the name of a government which says is Islamic. If a mujaheddin government is established, our armed mujaheddin could form the security and defence for ces of the country.'

* mSome frank woras": Upto now we defined division emong the mujaheddin organizations as a race between them to fight the savage Russlans. However, now is the time that if the Russians truely pullout, in the case of divisions and disputes, the Jehad will be converted into mischief and timult. Today oif' Hetor is the Ghazi (one who flghts the infidels) and our killed ones are matyres: However tobortow, as a result of disunity; the Wuslims may find juetification for kflling one another and one group may' 1ssue verdicts supposedly based on the shariat agdinst the other and the blood of one Muslim may be shed without any justification by another Muslim, and the killer and those kdiled will both be punishable in the fire of hell. So, Or, you leaders, for the sake of Armighty God give your hands in unity and establ1sh arid proclatm an Islamic govermment unantmously and with one voice and this is the wsh of the Masitm nation of Afghanistan and that of the Islamic Ummah.

\section{Afghan Mellat}

17 February, 1988

SDTTORIAL: Hayya Alal Falah".(Come forward torards happlness and prosperity). It gives an account of 'wat the editorial calls tactical phases of the Russian imperialist policy viz-avis Afghanistan, and the objectives of the Fast and West as well as the goals of the Afghan nation itself and explains the stand of

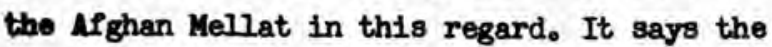

party is for the formation of a broadly based interim coalition government in the form of a broad national unity front headed by a recognized national Muslim figure so that the nation may unite around him and in this government truly mujahed parties and organizations should part1cipate.

REPORTS: Dr. Amin Wakman, leader of Afghan Social Democrat party, in an interview with The Afghan Mellat Journal, has satd in case of a failure of the Geneva talks on Afghanistan, convening of an international conference on the issue will be the only alternative. In this conference Afghanistan's neighbours, the US, representatives of the non-aligned countries, Afghan parties, Jehad organtzations and the Khalq party' should participate, he said. (Vakman has said the Khalqis should particlpate as a party and not as a government). The conference should be convened under the auspices of the IN.

* General Secretary of the Afghan Social Democrat Party, Stana Gul Sherzad, after a trip to West Germany at the invitation of the West German Social Democrat Party, has said in an intervilew with the newspaper, we held discussions with a number of parliamentarians in the Central Parliament as well as members of local parliaments on conditions in Afghanistan.

ARTICIES: "Our war is a national Islamic war".

(By Anwar-ul-Haq Ahadi). After presenting a long range of arguments, the writer says that the Arghanistan war cannot be described as nerely I slamic or merely nationalistic, rather it is a war of both Islem and nationalism, wich has three supreme objectives: 1. Restoration of national sovereignty, (2) Preservation of territorial integrity and (3) defence of Islam.

* A glance at unjustified criticisms by those who did not belong to us and who has criticized the leader of the party Dr. Wakman and one of Its members Taher Kohsini. The article praises the services of both personalities and condenms 
those who are not able to work withtn the party and are criticizing it from "other trenches".

\section{Neda-e-Jundullah}

19 February 1988

RRPCRT: The Paghman mujaheddin in a joint operation 30 December 1987 inflicted heavy blows on the communist garrison which caught fire and remained burning for three hours during which its arms depot was destroyed. In the operations four enemy tanks, a truck and a jeep were also set ablaze. The majaheddin also captured the political chief of the Karezak post along with his body guards.

ARTICIB: "Rre the Russians really flexible by announcing that they are withdrawing their troops from Afghanistan?w. "It describes the "Russian savages" during their occupation of countries and then say when the Russian might and savagery failed, it immediately' resorted to snares which at one t1me was a good weapon for suppressing freedon movements. The Russians committed aggression against Afghanistan but were unable to occupy the country through their military might and, therefore, started various snares by creating false hopes among the people. However they are'still intent to advance their treacherous schemes. Our people should be awaken against these enemy snares and in order to resist them, should further consolidate their ranks.

\section{Al-Momenat}

January/February, 1988

FESPOR: The Borkah, Baghlan, garrison has fallen to the mujaheddin. With the $\mathrm{fall}$ of this garrison 10 administrative unitsen." .comprise a large portion of northern areas bf the country, have been cleared from the enemy forces. On 23 December 1987 Baghlan mujaheddin together with flghters from the Ishkamish sub division of Takhar provtnce in a 13 hour long operation occupied the Borkah garrison. During these heroic operations, 10 persons in the garrison were killed and another 10 injured. The mujaheddin captured 46 persons. They also captured two tanks, machine guns, 60 kilashinkovs, one heavy rocket, two Russian communication sets and a large number of different types of bullets.

NEWS: The chief and a member of KHAD in the Kishm sub division of Badakhshan province were killed 22 November 1987 in a successful mujaheddin operation.

* As a result of mujaheddin operation in Herat 2 February, 10 Russian soldiers were killed. ARTICIE: Mujahed women in the history of Islam: Symbols of Jehad and Chastity". An accoumt of the life of "Bait Aqaba" a mujahed woman during the time of Prophet Mohammad (Peace be upon him") has been given.

\section{AD- Be January-February}

EDITORIAL: "Double standards in the Russia propaganda maneurverg".

- Russians are once again trying to trick the public opinion about the withdrawal of their troops from Afghanistan so that the Afghanistan issue may become a ground for political maneuvering and propaganda rivalries of super powers.

On the other hand the Muslim mujaheddin of Afghanistan have clearly and publialy spelled out their decisive position against any kind of collusion between the super powers over Afghanistan and consider such propaganda nothing more than a political game and, since $90 \%$ of the Afghanistan territory has been liberated from the grips of Russians devils, hopes for the success of the Islamic revolution in Afghanistan have increased.

Bfforts by Cordovez, if the real parties to the dispute (the mujaheddin and the Russians) are hot officially included in the Geneva conference, will yleld no results. The issue of existence of a genuine Islamic force is at stake 
in the Afghan jehad. This force will terminate the armed jehad after the establishment of an Islamic regime in Afghanistan and will then try to achieve a cultural vilctory. No east-west deal whl be acceptable to the Muslim people of Afghanistan and we will eradicate all Soviet propaganda maneuvers with the might of our gums and pens.

REPORTS: Russian aggression in Afghanistan was condemned throughout Europe by holding demonstrations. The Afghan mujaheddin have held talks wh the Foreign Ministry authorities in France, Belgium and Holland and at the news conferences while explaining the recent events inside Afghanistan, shed light on recent savage Russians operating.in Khost. They also made clear the mujaheddin position about the formation of an Islamic government in Afghanistan.

IBTTER: Distinguished western diplomats in a letter to Gorbachev have stated:"The Afghanistan problem will not be solved until your forces are stationed in that country and the present Kabul regime is not acceptable to the overwhelming majorlty of the Afghan nation and has no legal justification for its existence in the eyes of the world public opinion. Worse than any. thing else, inspite of your comforting declarations, bombardment by you air force have doubled, spectally in eastern provinces of Afghantstan.

Mr. Gorbachev, it is now ten years that the resistance of the people of Afghanistan has been continuing. Despite the ruthless massacre of the Afghan people (which has resulted in 1.5 milition martyres) and the destruction of the country which has caused more than five million people to migrate, the Russians were not able to conquer the freedom loving spirit of the Afghanistan people. Are you able to change the Soviet policy Vig a vis Afghanistan? peace, de tante and democracy, which you say you are advocating, must be applied in the case of Afghan1stan as well. You must inevltably have reached the conclusion that your aggression against Af- ghanistan and its occupation was a complete mistake. You should withdraw your forces immediately from now on without any condition and according to the wishes of the mujaheddin forces and, by recognizing the right to self detesmination and the non-aligned status of the Afghan people, you will be taking a very important and historical step towards achieving world peacen.

\section{Al-Noor}

20 February, 1988

EDITORIAL: "Afghan problem cannot be solved in the Geneva talks". The editorlal says that the Afghan problem can only be solved when the Russians and the mujaheddin are recognized as the real parties of the dispute.

NEWS: Sixty atheists were kdlled and 25 armed persons were captured 15 January in the Balkh province.

* Five athelsts were kflled and 11 injured

31 December, 1987, in Bamian province.

* All guards serving in a communist milltary post defected to the mujaheddin 12 February in Chaparhar, Nangarhar.

* Twelve enemy tanks were destroyed by the mujaheddin 6 February in Wardak province.

DECISION: The council of Hezb-a-Islami Afghanistan (Khales) met 15 February in an extraordinary session and discussed the aggressions comitted by the Islamic Republic of Iran against the mujaheddin of this party and decided that all off1ces belonging to this party should be closed in Iran. The office which is functioning there does not belong to this party and is a puppet of Iranian elements.

COMMUNIQUE: The Shinwar, Nangarhar, mujahedatin in a joint communique 16 February said until an independent, Islamic and free government is established among the Afghans, we will contimue our jehad.

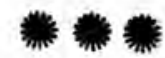




\section{Shahdat}

20 February,

EDITORIAL: (By Ferotan). Raising the issue of Zahir Shah in the present format of Islamic revolution has been rejected. It has condemned attempts by the enemies and pseudo-intellectuals for the return of the former King. It has described as impossible the resurrection of the former bureaucrats who have been spectators of the jehad.

RRPORT: Gulbuddin Heknatyar, leader of the Hezb-e-Islami Afghanistan has told a news conference in Islamabad, a mujaheddin government is planned to be set before the next round of Geneva talks on Afghanistan.

* Until a pure Islamic government is established in Afghanistan, we will continue our sacrifices". This is the resolution adopted by a mohajerrin meeting attended by 30,000 people 16 February from Bajaur camps. They condemed attempts for bringing Zahir Shah back to the scene and considered these as diameterically opposed to the objectives of the revolution.

NEWS: In a mujaheddin operation on Kunduz airport recently, two helicopters were destroyed and 100 Russians killed.

* The Chahaab, Takhar, mujaheddin shot down one helicopter 10 February and killed an assistant KHAD officer of the Chahaab sub division.

ARTICIES: "Don't leave the Afghan freedom movement half-way" (By Mohammad Zaman Mozammil). The article considers the acceptance of a coalition government for the sake of securing positions as a great cruelty to the nation and demands the establishment of an Islamic government.

\section{Kabul}

22 February, 1988

EDITORIAL: "The nessage of Kabul". It describes the ups and downs of life in the history of Kabul. It says, it is a way of the enemy to strike its first blow on the heart and mind. Kabul, as a powerful heart and as the brain for wise and invaded Kabul. However the heroic Muslims of Kabul rose and on 22 February filled the atmosphere of Kabul with the chants of Allah-vAkbar and hoisted three the banner of Islam.

"Please save the beloved mujaheddin of Kabul so that Afghanistan is saved. We are publishing the Kabul journal at a time when our country is speedily moving ahead towards victory over the atheist usurpers and is approaching a special phase of the history and it will be a great honor if men of writing use this newspaper as a form for healthy discussions to bring about further order in the jehad and prevent confusion and disunity."

NEWS: The Russians are further increasing the economic difficulties of our people. They have recently increased the price of per kilo sugar from Afs. 30 to Afs. 80 and one liter petrol from Afs, 20 to Afs. 30.

The mujaheddin destroyed 24 January 33 enemy tanks in Mazar-e-Sharif.

* Four Soviet advisers were killed in Faryab recently.

ARTICIES: "HOOT-3 (22 February) the start of the uprising of a Muslim nation against aggression and atheism" (By Amir Mohammad)

\section{Ittehad-e-Islami}

22 February, 1988

EDITORIAL: "22 February 1979, the sanguinary day in the city of Kabul". In it, a graphic picture of the heroic resistance of the capital city of Afghanistan and the Russian savagery have been given.

FEPORT: The refugees in a big meeting in Bajaur condemned plans for the return of Zahir Shah and demandedithe establishment of a completeIslamic government in Kabul: INTERVIEW: Sayyed Akbar a mujaheddin commander from Bamian has said the latest operation in that province was on the communist post of shar-e-Ghulghula as a result of which 35 Rus- 
sians and KHAD workers were killed and six captured, one of them being a high ranking KHAD official.

NEWS: Two enemy planes have been shot down and 31 atheists killed in Khost, Paktia.

* A large number of scholars and intellectuals expressed their support for the Islamic jehad of Afghanistan in a seminar held in the middle of February in Islamabad under the auspices of World Muslim Congress.

* Thirty enemy soldiers were killed and 100 infured recently in Herat.

ARTICIES: "The message of freedom from Geneva (Mohammad Yasser). The Geneva talks that are centered around four topics of (1) the return of refugees, (2) gradual withdrawal of Soviet troops from Afghanistan, (3) international guarantees (4) non-interference in the intermal affairs of Afghanistan have the following benefits for the Russians:

(1) If an agreement is reached on these points of the treaty, Pakistan and entire world would recognize the Kabul regime and the UN will no longer be able to pass resolutions with 123 votes against the Russians and their servants, (2) the Kabul regime will be protected by the UN troops instead of Pussian troops, (3) the purpose of Russian invasion was to establish a communist regime in Afghanistan and, by mere change of personalities, this purpose will still remains intact, (4) the Kabul regime which is now faced with a complete failure and is considered as an atheist government, will have a new color, (5) after the signing of the accord, the assistance by Islamic countries to the mujaheddin will be terminated, (6) after the agreement any conflict with the puppet regime will be considered as a violation of the treaty, (7) the noninterference will be meaningful when the mujaheddin government is formed; otherwise interference would be tantamount to an aggression against the puppet government, $(8)$ if we are to accept any kind of government on the basis of Geneva accord, it will mean that we have allowd the atheists and aliens to determine our fate, (9) we call the Russians oppressive because they have imposed upon us a puppet government. And if the Americans,Pakistanis or Cordovez do likewise, what will then be their difference from the Russians? (10) the Russians want to weaken the jehad through this agreement and convert it into a scene in which Muslims will kill Muslims... Therefore do not expect any message of freedom from Geneva. Indeed the message of freedon will be borm from the blood stained sword of the mufahed in the trench.

\section{Shahdat} 25 February, 1988

EDITORIAL: "Our Muslim nation at the threshold of crucial test". It points out to the mistake committed by Pakistan in accepting the process of the Geneva talks. This provided for the Russians an opportinity for achieving their hypocritical aims. The editorial has supported the Pakistani position not signing the agreement with the puppet Kabul regime and condemris the fact that Russia and the US have in fact reached a deal on Afghanistan by agreeing to form a coalition government which will serve the interests of both of them. The editorial says these are all the dimensions of the Afghan issue which relate to others. However as far as the Afghans are concerned, the decision of the mujahed forces is to still face the big powers and to make true the dreams of 1.2 millions martyrs and millions of widows, fathers without sons and orphans.

REPORT: Ieader of the Hezb-e-Islami Hekmatyar in a condolence meeting for the martyres said 18 February many phases have passed in our dynamic Jehad and in accordance with the law of Almighty God, of the natural phases of the Jehad, only the last page is left.

* In a big mujaheddin-mohajerrin meeting in Hangu, the participants called for the continua- 
tion of military Jehad and opposed a return of a former King Zahir Shah.

* Two thousand Pakistani poets, literary figures and journalists in a note, which they delivered to the Russian Embassy in Islamabad, urged Moscow to end carrying bomb explosions in Pakistan and pullout its aggressive forces from Afghanistan.

In a press conference they said some so-called leaders of ours go to Kabul to meet the Russian puppets and, after their return, shamelessly support the Russians. National pride calls that we should settle account with the traitors at the airport after they return from Kabul and Moscow. The people ought to raise black flags and shout: "Oh you traitors, go back to the place where you made a bargain over the interests of Pakistan".

\section{Rah-e-Islam 28 perreary, 1988} EIITORIAL: "Prospects of peace in Afghanistan". Evaluates Russian promises and statements issued about peace in Afghanistan and concludes that the the Russians are creating false hopes in order to deceive world public opinion and blame the other side.

NEWS: The THme magazine writes despite their troops withdrawal from Afghanistan, the Russians want the Kabul regime to survive.

* The Kabul regime is still clinging to its old stand for solving the Afghan issue.

* The Iraniar President Sayyed Ali Khamenai has said Iran wants an Islamic and a non-aligned Afghanistan.

ARTICIES: "Joint super power activitles against the Afghanistan jehad" It discusses Russian failures in Afghanistan and the promises it had made to the US, as a result of which, both imperialist powers are trying to prevent the establishment of an Islamic government in Afghanistan.

* "Zahir Shah, the weak monarch, who still remains weak". It says Zahir Shah inherited the throne when he was only a youth and the government was run by his uncles. Now too that he wants to assume power he will not be able to play the role of a "King" and he has to remain only a "private". In that case the game will be in the favor of big powers。He was, indeed, a weak monarch and there is no reason to believe that he will become strong if he returns as a leader. * "Who will be responsible for the continuation of the Soviet military presence?". After dism cussing the long term Soviet objectives, the article says the Russians still do not consider the mujaheddin as the main party and, therefore they should not expect anything from the mujaheddin. The Russians should make peace with the Americans who they say is the real party to the issue. And such peace or agreement will not be binding on the mujahed people of Afghanistan. If the Afghan mujaheddin were able to fight until yesterday with empty hands and with no stinger, tomorrow, too, they can do so so that they may be able to determine their own fate and live in a free and independent country.

\section{Shahdat}

1 March, 1988 EDITORIAL: "Tomorrow's hero shall be known". In case there is a deal over Afghanistan by imperialist powers, the heroic and Muslim Afghans, are able to continue their jehad with their old guns and with the weapons of the1r faith.

REPORT: Gulbuddin Hekmatyar leader of the Hezb-e-Islami in an address to diplomats from Islamic and Western countries said I will go to the interior of the country and join the fronts.

* Gulbuddin Hekmatyar, leader of the Hezb-a Islami told Juma prayer offerers 26 February in Nasrat Meena we should devote our entire attention to the intensification of the resistance and demonstrate to the world that, until the mujaheddin are satisfied, solving the Afghan crisis will not be possible. 
NEWS: The Kandahar mujaheddin during the month of Jaddi (December-January) shot down five enemy planes and killed more than 100 Russian troops.

* In a Mahalla jat district of Kandahar, an enemy program to reconstruct the so-called security belt has been frustrated as a result of mujaheddin vigilence.

One Russian soldier defected to the mujaheddin in Baghlan province. The mujaheddln are also reported to have destroyed six enemy tanks. ARTICIRS: "The Afghan issue and the Geneva talks" (Mohammad Naeem Mustafa). Under the cover of the Geneva talks, the Russians have greatly intensified their savagery against the mujaheddin decelving the people through their hypocrisy and snares.

\section{Mab? $2 \mathrm{March}, 1988$}

EIITORIAL: "Do the mujaheddin really reject peace?". The Afghans have, throughout the history, lived in peace. They have only fought against aggressors but have rendered memorable services towards consolidating peace. The Russians launched both indirect and direct aggression against Afghanistan and the Afghans began their holy jehad against them. Now the Russians are trumpetting for peace. The Afghans, too, want peace, but the kind of peace which will ensure a secure islam, independence of this country, and earnus prestige. Not the kind of peace which Russian hirelings have imposed upon our nation.

NEWS: The mujaheddin killed in Faryab 2 January 14 Russians and downed a fighter plane.

* The mujaheddin in Kulangar, Logar, destroyed 7 January two enemy tanks and two trucks.

ARTICIE: "Gradual withdrawal of Russian troops does not mean Russian withdrawal from Afghanistan entirely and the end of war" (By Sayyed Hablb Shah). "The Demagoguery" pract1sed by the Russians in regard to the withdrawal of their troops from Afghanistan has been analysed:
(1) It is aimed at deluding international public opinion and preventing further political pressure.

(2) The purpose of concentration over a timetable for the withdrawal of Russian troops is to actually prolong the Geneva talks.

(3) The Russians are withdrawing those troops whose term of service is terminating and, instead, they are sending fresh troops to Afghanistan.

(4) Rotation of Russian troops in Afghanistan has become a routine practice, the main purpose of which is to provide practical training to its army. If Russia truly wants to end the war in Afghanistan, as it was able to move in its troops in Afghanistan in 36 hours, it can withdraw within the similar period of time.

\section{Neda-6-Ia) 2 March, 1988}

BDITORIAL: "The decisive stand of the HarakatmeEnqelab-e-Islami Afghanistan. The editorial, rejects in clear terms, the plan for a coalition government with the communists giving the following reasons: (1) the communists are the murderers of more than one million Afghans. They should be tried in the Islamic courts and should not become rulers over the orphans of the martyres, (2) before the pullout of Russian troops from Afghanistan, a debate over such plans is contrary to the decisions of the Islamic and non-aligned countries and the UN, (3) the only purpose of such a coslition government is to handover the mujaheddin, with their hands tied, to the Russians and induce the Islamic nations to officially recognize the communists, (4) whenevar talks are held on Afghanistan, these should be attended by the mujaheddin and the Russians as the two sides of the conflict. The present seven party coalition, dispersed and disunited, cannot represent all the Afghan mujaheddin because, outside this coalition, there are other mujaheddin which do not consider this coalition, as their representative, (5) imperialist powers 
are trying to bring back the former King, (6) if a solution is imposed on the mujaheddin, it will have worse results than present. Therefore, the Harakat-Enqelab-Islami Afghanistan instructs all its mujaheddin and mohajerrin not to pay any attention to the Geneva talks.

PREPORT: The students organization of the Harkate-Enqelab-e-Islami Afghanistan held a grand meeting in the office of the Harkat which, in addition to Mawlawi Mansoor, leader of the organization, was attended Allama Al-Saeed Shaaban, leader of the Harkat-al-Tawheed Al-Bunyan, Ayatullah Jannati, member of the Assembly of the Islamic Republic of Iran, Mohajeri, Editor-in-Chief of The Jamhoori Islam daily newspaper, Najafi, the Counsul General of Iran, Abdul Jalil Hafez Salamat, a renowned Egyptian Scholar, Qazi Mohammad Amin Weqad, Khalili (stet) and thousands of mohajjerin and Ansars.

Mawlawi Mansoor told the meeting there are people who, with a lust for power, have forgotten the Quran and, if a coalition government is formed with the communists and, in it, an important portfolio is offered to them, they will accept it with great joy and readily.

NEWS: In the Bak,Paktia, 30 Russian hirelings were annihilated in a mujaheddin operation.

* In Gorbuz, Paktia, the enemy was inflicted with heavy casualties.

\section{Neda-e-Jundullah}

5 March, 1988 BDITORIAL: "Message of Jundullah"。The mujaheddin of the trenches hope with the formation of an interim government, to pave the way for free and general elections, a united leadership will also emerge.

* A joint letter by the commanders of the "Base of Khatem-ul-Anbia" and "the Base of Ali-Ibn-a Abi Taleb" to Mohammad Bilal, Commander of the Jundullah front says the two commanders will cooperate with him and have urged a reciprocal gesture.

\section{Payam-e-Wahdat}

EDITORIAL: "The epic making $3 \mathrm{rd}$ of Hoot (22 February, 1980, the day of the uprising of the people of Kabul against Soviet invasion of Afghanistan.)"

Enumerates the gains that the Afghans achieved from this uprising. They are: (1) the enemy understood that all the people of Afghanistan hate the aggressive enemy and demand the withdrawal of these savage troops, (2) strengthened the ranks of fighting mujaheddin (3) carried the message to the infidel enemy that the mujahed and heroic Afghan nation will never surrender and it will defend every inch of Afghom nistan.

ARTICIE: "Soviet economic interests in Afghanistan". After pointing out to reasons for the Russian aggression against Afghanistan, it says one importent reasons was to control the naturral wealth of our country. According to a 419 page report produced by the Russians in 1977, about Afghan underground resources, there are 1,400 kinds of minerals, including most important strategic materials, in Afghanistan. By grabing Afghanistan and taking over these resources, the Russians found out that they will achieve yet another objective in Afghanistan.

\section{Saraj-Munir 5 warch, 1988}

EDITORIAL: "Do not trust the enemy". The present Soviet leader is ahead of every body in mischief and guile. Rumours about Soviet troops pullout from Afghanistan are only a plot. We mujaheddin and mohajerrin should not naively accept enemy words that it is going to leave our country alone and completely withdraw. All the mujaheddin and Muslims of the country should unitedly and cohesively join hands to defeat this aggressive army and to resort to a long Jehad and genuine revolution so that the enemy will know that Afghanistan is not Cuba but it is the land of the brave and the eagle. 
REPORT: The Russians have been conducting savage operations for the last six months in Hazrat-eImam Saheb and Dasht-e-Archi, Kunduz, resulting in the martyrdom of hundreds of brave mujaheddin and the defenseless civilians. Thousands of houses have been demolished due to Russian air and ground bombardments. In retaliatory operations, the mujaheddin of the two sub-divisions, along with those of Khawaja Ghar, conducted a wide ranging and successful counter offensive lasting many days. Four Russian military helicopters were downed, 16 tanks destroyed and 100 Russian soldiers and hirelings were killed or injured.

\section{Mujahed} 5 March, 1988

EDITORIAL: "Joint collussions and threats by world super powers" (By Nangyal). The grand Afghan resistance is now faced with a dangerous collusion between world super powers. This is threatening our revolution, which is in the last stages of its victory. In the military field, with the help of Almighty God, our brave resistance has kneed down the enemy. However, in the political dimension, the enemy succeeded to compensate to certain extent its defeat in the battlefield. Present conditions are sensitive and will determine the life or death of our revolution and nation. Our resistance should, with utmost seriousness and unitedly, take steps from a powerful and united political and diplomatic trench, against Russian political maneuvers and, above all, give a new direction to its struggle in the face of a dangerous collusion between the super powers.

RBPORT: The solidarity day with the people of Aighanistan was marked throughout Pakistan 3 March by holding grand meetings. In a march, held on the occasion (in Peshawar), more than 20,000 people from all walks of life participated. Professor Ghafoor Ahmad Deputy Chief of JI, told the gathering the Pakistanis will not allow that the battle, already won by the muja- heddin, be lost around the negotiating table.

The Jamiat-e-Islami Afghanistan held a grand function 11 February to commemorate the martyrdom of Commanders Yar Mohammad, Mawlawi Mohammad Enam and other martyre of the Islamic revolution of Afghanistan. Speeches were delivered and poems recited on the occasion。

* The Jamiat-e-Islami Afghanistan marked Hoot

3 (22 February, the day of uprising in 1980 by the people of Kabul) in the presence of mujaheddin and mohajerrin and Ansars.

NEWS: Leader of the Jamiat-e-Islami Afghanistan, Professor Burhanuddin Rabbani, in a meeting, explained the current events in relation to the Afghanistan issue and explained the stand taken by the Jamiat, in regard to the event.

* Seventy government militiamen were killed and 20 tanks destroyed in a mujaheddin operation 9 January in Herat.

* Two helicopters were shot down by the mujaheddin 27 December, 1987, in Laghman. ARTICIES: "The sanguinary and epic making uprising of Hoot 3, (By MoY. Shahbaz).

* "The fate of Geneva talks: Mirage or whirlpool?" (By Mohammad Nasim Faqiri). The article says the mujaheddin have, from the very beginning, boycotted these talks and the Pakistanis have now realized their mistake and are trying to rectify it. The mujaheddin position is clear, for they see their success only in closing up their ranks.

\section{Arman-e-Mujahed}

5 March, 1988

INTERVIEWS: Mawlawi Rafiullah Moazzin, who within the country has covert and overt commanders' and enjoys the mujaheddin support, recently told a group of commanders and mujaheddin who had come from Afghanistan, the formation of a coalition government was an issue discussed between the Russians and the US from the beginning of our jehad. Fach one of these super satans was trying to get ahead of the other. 
Finally, after a lapse of nine years, they agreed that the formation of a coalition government in Afghanistan serves the interests of both of them. In answer to a question, he said if Pakistan signs the Geneva accord our jehad would still continue. Because the land of God is wide and expanded and the poor man is not lame and, at least, can move from one area to another (Afghan proverb).

* Mohammad Tareq, the valorous Wardak commander, has said in an interview, on the KabulKandahar highway, our mujaheddin in the hide outes launch simultaneous rocket attacks on an enemy convoy to block its way of escape both forward and backward and to inflict them with heavy losses.

ARTICIE: "The interim Afghan government will be formed by the loya jirgah" (the writers name is not given).

* "Unity" A document has been published which had been signed five years ago by the following mujaheddin leaders :

Burhanuddin Rabbani, (Gulbuddin) Hekmatyar, Nasrullah Mansoor, Mohammad Yunus Khales, Abd Rab Rasool Sayyaf, Mawlawi Mohammad Mir and Rafiullah Moazzen. The leaders had promised that they had dissolved their respective organizations and resigned from their leadership positions and a leader will be appointed for the jehad who will be obeyed completely and they all will hand over belongings of their organizations to the newly formed alliance.

The newspaper says, those who have breached this promise have committed an unforgiveable sin.

\section{Al-Noor}

6 March, 1988

EDITORIAL: "Afghanistan is the country of the mujaheddin" (By Zainullah Wafa). It discusses Russian political efforts to make it possible of their communist puppets in Kabul to remain in power but, at the same times, expresses con- fidence that the Islamic resistance of Afghanistan will achieve its final success over the enemy and the enemy will be inflicted, cod willing, with a complete defeat. Outside pressure and dealings will not deter, the Muslim nation of Afghanistan to pursue its path.

REPORT: Mawlawi Mohammad Yunus Khales, President of the IUAM, told a onference of the World Muslim Congress 18 February, while we are not cursing or taunting former government officials, we are, nevertheless, aware that the question of reviving a leadership position for Zahir Shah is being incited by our enemies. Furthermore, incitements about divisions between the Shaia and Sunnis of Afghanistan are also a product of enemy intrigues that are aimed at hindering our true success.

NEWS: Eight atheists were killed and one power pole transmitting electricity from Sarobi to Kabul was destroyed by the mujaheddin 13 February * In Mazar-e-Sharif, 80 soldiers with their arms and six vehicles joined the mujaheddin.

Ninety three atheists militiamen were killed or injured 3 March in Nangarhar province.

\section{Ittehad-e-Islami}

\author{
7 March, 1988
}

EDITORIAL: "Decisions in the framework of Geneva talks is not acceptable to us." Until the mujaheddin are treated as a party to the issue, and Russia does not enter talks with them, any decision in their absence will not be acceptable. The mujaheddin recently approved the framework of an interim government. This government in case of a Russian withdrawal, will supervise the withdrawal, maintain security inside Afghanistan, repatriate the refugees and pave to way for an elected government to take over as a result of parliamentary elections.

REPORT. Professor Sayyaf, leader of Ittehad-eIslami, in a seminar of mujaheddin commanders, while commenting on current affairs, said 3 
March the Russian defeat against our jehad will be the biggest honor which will be recorded in the history of Islam. The basic aim of the Russians in intervening in Afghanistan has been to establish a satanic order and advance Red communism possessions. If resistance forces are not brought under one banner, hope for the success of the jehad will all go vain.

* A conference of enforcement of shariat was called in Lahore at the request of Mawlana Darkhwasti。 In the meeting, Chairman of the Political Committee of the Ittehad-o-Islami Afghanistan, Mohammad Yasser, said the catastrophe which has fallen over Afghanistan has been a result of un-Islamic government and Pakistan, jif it wishes to be saved from such catastrophes, should enforce the Islamic shariat.

NEWS: Two high ranking Russian officials were killed as a result of a bomb explosion in the Kabul Macrorian 27 February.

* Twenty Russian soldiers were killed and one tank was destroyed in Mir Bacha Kot, Kabul province.

ARTICLES: "Our Ansars should know "(By Mohammad Yasser). The main reason for our Hejrat was that we were not able to live under the shadow of a communist and atheist government and now any decision which will not affirm the rights and demands of the mujaheddin will not be accepted by us. If the Ansars leave us alone and sign the agreement worked out in Geneva on Afghanistan, God will not forsake us and he is, indeed, sufficient for us.

\section{Azadi}

10 March, 1988

BDITORIAL: "Elements who lack a Jehad spirit should not be incorporatedin the resistance". At this time when the IUAM is laying down the first foundation of an Islamic government in Afghanistan, it is required that our brethren in the alliance should be very careful so that, following our victory, no undue weakness or vacuum comes about as result of our negli- gence or apathy. Those who do not belong to the Islamic movement should not be allowed to play any role in the gains achieved with the blood shed by the thousands of martyrs. No previlige should be given to those who do not believe in Islamic revolution. There is a widespread temptation today that, if we did not give a part to those who are affected by vestern ways of life and to the nationalists, the possibility of the establishing an independent govermment in Afghanistan will be difficult or impossible. This is a negative approach which should be resisted. These victories have been achieved as a result of our own decisiveness. If once we allow the first Minister or the first President from such people to become a part of the mujaheddin interim government, their roots will gradually grow and linger, which will later be difficult to remove. The Islamic revolution of Iran has gone through these stages and has suffered a lot from them. REPORT: Professor Sayyaf, leader of the Ittehad-e-Islami Afghanistan, in a mujaheddin meeting, attended also by commanders from the trenches, while speaking about the character and personality of the President of the interim govermment, Ahmad Shah, said "I bear witness Almighty God that Engineer Ahmad Shah is ahead of me in his piety and righteousness.

* In an opinion poll, being gathered by The Azadi, Mawlawi Khales, leader of the IUAM, said, in case circumstances become difficult in Pakistan for us, we will take a joint action about the transfer of jehad offices, Qazi Mohamnad Amin Weqad said, a ban of foreign assistance will be in the interest of our Islamic movement. He added the formation of a government at a time when the mujaheddin organizations themselves hold power is not workable. Since I was not in the mujaheditin coalition, therefore, I do not agree with the government which is a product of the coalition. INTERVIDW. The Azadi newspaper, in an interview 
with Mawlawi Mansoor, leader of Harkat-e-EnqelabB-Islami Afghanistan, asked: You have been accusing the leaders of the alliance for breaching their promise. If that is so, they have breached only once their promise while you have breached your's twice, once in the Kaaba and the second time at the Pabbi, Pakistan, refugee camp. I remember that on April 30, 1985 you supported the election of Professor Sayyaf as leader of the alliance and dissolved your own organization but still you continue your activities in the framework of a separate and independent party. In answer, he has said, I have not breached any promise, it was the others who brought about such conditions.

ARTICIES: "An evaluation of the two components of the alliance". After 22 February, when leaders of the alliance agreed on the formation of an interim government headed by Engineer Ahmad Shah, internal conditions of the alliance becarne subject to a number of political arguments as a result of an inclination on the part of Pakistan to sign the Geneva accord on Afghanistan and an opposition, on the part of foreign powers, with the proposed mujaheddin government. These arguments forced the postponement of a proposed seven party program in which, for the sake of the formation of an interim government, a joint rally were to be held 9 or $10 \mathrm{March}$. When we were writing this article, Pir Sayyed Ahmad Gailani had already spent 11 days in Italy to apparently encourage the deposed King to come to Pakdstan and to prepare him for accepting an interim government. Arguments in the Supreme Council of the IUAM intensified when the interim government of Engineer Ahmad Shah was confronted with the Russian and US opposition and Pakistan relinquished its support for the government. The view of moderate groups $\mathrm{viz}-\mathrm{a}-\mathrm{vlz}$ the events has been that if, Instead of Engineer Ahmad Shah, leadershlp of the government would have been given to a personality who does not belong to jehad groups, the new government would have not faced such an opposition. And some moderates have considered the religious beliefs of Engineer Ahmad Shah as another reason for his unacceptability.

Despite all such disputes, the mujaheddin should not entertain the idea of bringing in a personality outside the mujaheddin ranks to serve as a leader of an interim government. Even if such a plan seems to be workable, it will contain two major disadvantages: (1) It will confirm an allegation that the mujaheddin themselves do not have the capability and talent to form a government and (2) the Russians will have a better opportunity to topple and condern a non-mujaheddin government.

\section{Ittehad-e-Islami}

14 March, 1988

EDITORIAL: "The Geneva talks are revolving around Russian interests and not those of the imujaheddin". It is an undeniable fact that the Russians and the mujaheddin are the two sides of the dispute over the Afghanistan issue and that Najib, the present symbol of communism in Kabul, is only a soldier of the Russian army and thus the Kabul government cannot be considered a party in the issue and holding talks with it for solving the issue will have no legal bearing. There is only one way for the success of the Geneva talks and that is the Russians should meet with the mujaheddin. The mujaheddin will put forward their conditions which will be debated. Other than holding such a conference, the Geneva parleys have no value to the mujaheddin and any other decision by the conference will be unacceptable to the mujaheddin.

REPORT: A seminar of the IUAM ulema was held 14 March in which the President of the interim government of Afghanistan, Engineer Ahmad Shah sald, hues and cries are raised by the Americans and Russians and from Geneva about the solution. of the Afghanistan problem. Any decision by them in our absence is not acceptable to us. Because 
our uprising has been to establish, on the basis of our belief, an Islamic government.

INTERVIEW: Mohammad Yasser, Chairman of the political affairs committee of the Ittehad-eIslami Afghanistan, in an interview with The Ittehad-e-Islami newspaper, said we unanimously made the decision about the mujaheddin government and announced 1t. The government of Pak1stan and other friends of our jehad have heard about it and we expect all of them to support and recognize this government.

NEWS: Twenty three enemy tanks were destroyed 14 January and 150 soldiers with their arms defected to the mujaheddin.

* One enemy helicopter was shot down and an ams depot set ablaze 22 February in Paghman, Kabul province.

\section{Ekhlas}

15 March, 1988

EDITORIAL: "Afghanistan does not need a change of name but it needs action". It praises the formation of a govermment by the seven party alliance but counts what it calls defects of this government: (1) The alliance, in its announcement about the interim government, has said that the future name of Afghanistan will be "I.slamic Afghanistan". This is not soch a necessary decision because Afghanistan, by the grace of God, has already been an Islamic country for the last 13 centuries and its inhabitants are Muslims. If we bring about the government of Quran and Sumnah to rule in Afghanistan, this will be more befitting. Only a change in name is of no value. (2) in this interim government, those belonging to the organizations of Mawlawi Sultan Aziz Aziz, Qazi Mohammad Amin Weqad, Mawlawi Jamil-ur-Rehman and Mawlawi Nasrullah Mansoor have not been included, (3) the issue of our Hazara brethren has not been resolved. If in Afghanistan issues like this are not solved it will create other difficulties to the interim government because there are other minorities which also want their rights. And in that case, the concept of an Islamic government will become irrelevant as far as this government announced by the IUAM is concerned, because in Islam, such questions are not decided on the basis of the majority or minority but Islamic criteria is the ability and piety of the people.

FEPORT: It has published the resolution of the leaders of the IUAM about the establishment and framework of an interim government (BDITOR's NOTE: For the text of the resolution, see section on major jehad documents).

NEWS: Sebghatullah Mojaddadi, leader of the Jabha-o-Melli-e-Nejat-e-Afghanistan withdrew his resignation from the seven party alliance.

* The mujaheddin destroyed 9 March six enemy planes at Kandahar airport.

* The Baghlan mujaheddin have killed six communist hirelings.

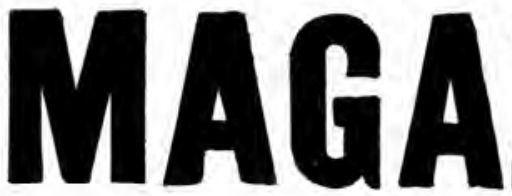

\section{Meesaq-e-Khoon}

Sept ember-October, 1987.

EIITORIAL: "The Hejrat and Mohajer (Migration and the emmigrant")(by F.Fazel). It has explained migration for pursuing the cause of God from

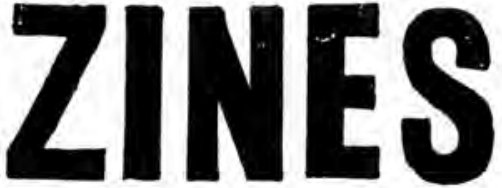

Quranic point of view and also the migration of Prophet Mohammad (peace be upon him) from Makkah to Medina. It has called on the Afghan mohajerrin to uphold the cause of their hejrat and refrain from acts which, in one or another way, damage this cause. 
FRSORT: Professor Burhanuddin Rabbant, leader of the Jamiat-a-Islami Afghanistan, at the second anniversary of the martyrdom of Commander Safiullah Afzali marked in a function in Peshawar 23 September, said with the martyrdom of the pioneers of jehad not only the torch of the Islamic revolution is not extinguished but it is being brightened as time passes.

* Brother Ahmad Shah Masood, the Cormander-InChief of the Jamiatmo-Islami Afghanistan in northerr Afghanistan in an interview in Warsaf, Takhar, said 21 July, to stop fighting in jehad will be in itself a crime and our jehad should reach to its zenith and logical point: the defeat of the enemy and victory of Islam.

* The Commander-in-Chief of Jehad for the Jam1at-o-Islami in Samangan has said in an interview: If we were in concord with the return of Zahir Shah we would not have resorted to anmed jehad to begin with. It was this very Zahir Shah that, as result of corruption in his administration and his pro-Russian policies, Afghanistan of to day is in tears and blood. If he were to be given an opportunity again, he would surely obliterate Afghanistan from the map of the world, he said:

ARTICIES: "The Independence of our revolution"

(By Professor Burhanuddin Rabbant)。 It is a detalled article which insists for the independence and non-allgnment of the Afghanistan revolution. The writer says no one can make the Islamic revolution of Afghanistan dependent on itself through money and other types of help. But of course, we can become aligned to others on the basis of the noble ideals and values of Islam. Dependence on others, in whatever form it may be, has been one of the worst manifestations of history. The writer explains, imposing a person or a group of persons on the revolutionary Afghan nation through influence and expenditure of money will be tantamount to an unforgiveable crime to the process of our Islamic movenent.

* Commenism is the opium of nations" (By
Paikargar Sulehjoa). It discusses what the writer calls the deceitful nature of the ideology of "Karl Marx, the Jew" and says, indeed, communism is the opium of nations.

Naha2 September-November (Bimonthly) EDITORIAL: "World wide disgrace and condermation of the Russians" (by Jaji)。The writer discusses the Russian "disgrace" in the light of 123 votes cast at the UN General Assembly conderming Soviet aggression of Afghanistan.

RRPORT: Pir Sayyed Ahmad Gailant, leader of the NLF, in a speech to the mujaheddin, mohajerrin and Ansars of Waziristan said we are trying to evolve an alliance which is desired by all the mujaheddin and mohajerrin and their elected representatives participate in ruming the affairs of the country.

* Dr. Farooq Azam, deputy leader of NIF, in a grand assembly on the occasion of the birth anniversary of Prophet Mohammad (peace be upon him), said in a speech today, when our compatriots are scattered in the deserts of foreign countries, today, when we are faced with many hardships and, today, when our youth are using their chest as a shield to the destructive weapons of the enemy in the mountain slopes of our beloved country, all these are only and only for the protection of the religion of God and for following the path of Holy Prophet Mohammad (peace be upon him). And we are proud that, as true followers of the leader of humanity in both worlds, we have chosen the path in which the secret of obtaining the plessure of God and achieving success in both worlds is hidden.

* Sayyed Fazluddin Agha, commander of the NLF In Panjwaee, Kandahar, said in an interview I and my herolic mujaheddin have taken part in the battles fought in Kandahar so far between the right and the wrong and I cannot definitely tell the number of these battles because if there are no daily battles, at least a battle is being fought in the course of one week. 
ARTICIES: "The Stingers scandal is a KCB plot" (By General Abdul Rahim Wardak). It was the work of KCB to pave the way for the firing from a boast Stinger rockets which were earlier seized under duress by the Iranians from the mujaheddin. These very rocket then fell in the hands of American forces.

* "The Islamic Party of Najib in the role of the Mosque of mischief" (By Al-Haj Ahmad Hotaki). Najib in Kabul through his satanic networks has announced a new party called "Hezb-e-Islami" which the writer says is equivalent to the "Mosque of the mischief" built at the time of the Holy Prophet Mohammad (peace be upon him) by the hypocrits of Medina, aimed at creating divisions among Muslims.

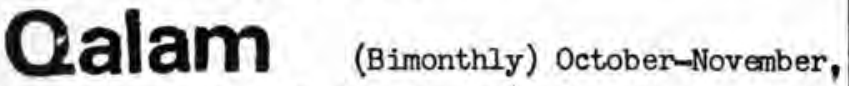
EIITORIAL: It explains the objectives and gains of the prophethood of Mohammad (peace be upon him) on the occasion his auspicious birth anniversary.

ARTICIES: "Events related to the first years of the Hejrat by the holy prophet Mohammad (peace be upon him" (by Al Haj Kamal Shinwari).

* "123 votes, means world wide condemnation of the Russians (by Habibullah Rafie).It has evaluated the history of UN voting on the Afghan issue and analyzed the nature of the policy pursued by those UN member states which cast a negative vote against the resolution on Afghanistan. by showing to which degree these countries are subservient to Sovilet interest.

* "Commenorating the great Iqbal" (Dr. Sayyed Khalilullah Hashemian). The writer has given an account of the Islamic Ideas advocated by the great philosopher and poet of Pakistan, Allame Iqbal as well as his interest and love for the Afghan and Afghanistan saying he was really right by predicting that a ntumult in Afghanistan" will result in a tumult in the entire continent of Asia.

* Marshal Asghar Khan, with looking from a wrong angle at the issue of the Afghan independence, actually lost the independence of his own party" (By Rokiyari). The writer gives an account of the confusion and division which have taken place in the TIP of Marshal Asghar Khan since his visit to Kabul.

* "Power versus faith" (By Al-Haj Nangial). It is a review written on a book with the same title containing collection of the poens written by the Pakistani poet Urfan Khattak related to the Afghan Jehad and valoury.

\section{Shafaq}

(Monthly) September-October. EDITORIAL: It is about the birth anniversary of Prophet Moharmad (peace be upon him). ARTICIE: "The Afghanistan issue at the UN" (By Mohammad Nazir Basharat). It has comments on the latest UN voting on the Afghanistan issue. * "The Bulgarian Muslims and Communist crimes" (By Al-Haj Moharmad Amin Ferotan). It has given an account of Communist attempts for eliminating mosques and the Islamic character of Bulgarian Muslims.

* "The main reason for tension" (By Wahdat). It has given an account of "imperialist intrusions" in the warm waters of the Indian ocean and Persian Gulf and in this comection has said Russian aggression against Afghanistan and its designs towards Pakistan and Iran are also part of Moscow's policies for achleving 1ts imperialist objectives.

INIFEVIEW: President of the Organizing and Planning Committee of the Hezb-e-Islami, Mojahed Brother Mohammad Zaman Mozarmel, who had recently gone to the jehad trenches, in an interview has spoken about his memories: Ky good memory is about the cooperation and understanding which prevail among the Logar mujaheddin where one could not know that the persen who was talking with me in a very sweet language actually belonged to another mujaheddin organization. My bad memory, however, is from Jalrez, Ghazni, and some areas of Kabul where mujahed- 
din differences have converted the villages into countries and the streets into border lines.

\section{Khpulwaki}

September-October ARTICIES: "The Najib constitution" (By Professor Rasool Amin). It has analysed articles 1-4 of the communist constitution and also the aims of this document as well as those of the NRP.

* Circles intent for deceit in the Afghanistan Jehad" (By Faqir Musafer). The writer closely examines the oblectives and nature of those circles which he says are related to Russia in Pakistan as well as offices which have come about in this country under the Islamic name but are actualy enemies of Islam.

* "Ioya Jirgah" (By Senator Ghulam Nabi Chaknawri). Gives his eye witness accounts of the 1941, 1955 and 1964 loya jirgahs convened in Afghanistan.

* "The mujaheddin and air defense weapons"。 (By Nasrullah Safi). It contains professional and military guldelines about the maintenance and installation of anti-aircraft weapons for the mujaheddin.

* "Long term war in Afghanistan" (translated by Hakdm Tanmiwal). Bxplains the reasons for the fall of monarchy and the national character of the Afghan nation inducing them to fight communism.

* The Kabul regime propaganda methods and aims" (By Ghulam Dastagir Shekaib). It contains examples of the Kabul communist propaganda and says they are actually an imitation of Russian propaganda methods.

* "PDPA relapses" (Mohammad Asef Ilkram)。 It has analysed the steps taken backwards by the PDPA. The writer says however, a total mujaheddin victory in Afghanistan, depends on unity and proper organization.

\section{Qest}

October-November

ARTICIES: "Ioya Jirgah, a traditional trap used by previous governments, now in the hands of Najib, the Servant". It describes the loya jirgah from an Islamic and historial point of view in Afghanistan and then, while commenting on the loya Jirgah held by Najib, says the communists, on the one hand, were flatly opposed to what they called antiquated traditions and, on the other, they now resorted to holding that very loya Jirgah and this will of course further in crease their difficulties and subsequent. disgrace.

* "Russia, from military defeat to political stalemate". In the light of the latest UN voting on the Afghanistan issue, it gives an account of Russian difficulties and political dilema. * "About an TUAM delegation's visit to NY and their meeting with the US President Ronald Reagan". The article compares the visit to US by the IUAM delegation headed by Mawlawi Khales with the one paid by Professor Rabbani last year and the reaction of Gulbuddin Hekmatyar's Hezbe-Islami and Sayyaf's Ittehad- - -Islami to these visits. It concludes by saying that: The visits will be interpreted as a weak spot in the history of our nation.

* "Unsuccessful overtures by the Kabul Cormunist Party"。 In relation to the second national conference of the Kabul communist party, it enumerates the internal dissentions and purges taking place the PDPA.

* "Five years of negotiations or intrigues?". Has considered the five years of successive negotiations held in the framework of Geneva talks since June 1982 as a chain of intrigues and nothing more。

* The magazine has added to itself a section about women and says 1ts objective is to "convey the suppressed voice of the women to all freedom loving and enslaved people of the world in this era of freedom and independence movement launched by our valorous Muslim women and men against Russian imperialism". 


\section{Meesaq-e-Khoon}

October-December. (Monthly)

EDITORIAL: It has given an account of the jehad victories in November-December and while reffering to the loya Jirgah convened and the constitution promulgated by the enemy and to the election of a President for that regime, it has sald that all these are to be considered comical political dramas of the century.

RRPORT: Professor Burhanuddin Rabbant leader of the Jamiat-e-Islami Afghanistan, in a function on the occasion of the birth anniversary of Prophet Mohammad (peace be upon him) said, with his advent, not only world map underwent transformations but great and profound changes also occured in human society。

* In a function held, celebrating "the unprecedented" mujaheddin victories in northern provinces of Afghanistan, Professor Burhanuddin Rabbani, leader of the Jamiat-e-Islami said in a speech the military achieve of our jehad have been so immense that they, indeed, compensate for the drawbacks in the political arena of our Jehad.

INTERVIEW: Professor Ghulam Mohammad Aryanpoor, leader of the Jehad in Badakhshan, has said in an interview in Warsay, Takhar, at present a standing committee in seven or eight northern provinces is working to bring about unity of action and thought in the task of Afghanistan revolution and the elimination of divisions and the battles fought at random without any planned strategy.

ARTICIES: "The artificial loya firgah and the artificial President of the Kabul regime " (by Mohammad Nasim Faqiri), After discussing the role played by Jirgahs in the Afghan society, refers to the superficiality and lack of importancie of the jirgah held recently by the Kabul regime.

"Atheism" (By Abu Tareq). Discusses what it calls the superficial atheistic communist ideology.

* "Hejrat and the task of preserving our. cultural heritages" (By Isa Mohammad Zabuli). Refers to the importance of the preservation of Afghan cultural heritages under the harsh conditions of migration and writes, alive nations and peoples have indeed the power and determination to preserve these heritages and will in no way shirk their responsibility.

"Thievish political maneuvers from hideout following their defeat in the battlefield" (By Nangyal). It discusses the changing conmuntst tactics in Afghanistan. It was unable to win the war. Now it tries to achieve Its aims through political tactics.

\section{Lawa-e-Haq}

Novenber-December.

BDITORIAL: Discusses the blessings and gains that Mohanmad (peace be upon him) has offered to mankind during his prophethood.

ARTICIES: It has presented the sumary of a seminar held by the fronts belonging to the Hezb-o-Islami Afghanistan to discuss the views and thoughts of the martyred Herat1 commender Safiullah Afzali. The seminar reached the conclusion that Safiullah Afzali had reached a stage in which he was not satisfied only with advocating unity at a theoratical level but he was not able to tolerate activities which marred unity and he actually suffered from the prevalence of divisions in mujaheddin ranks. NEWS: In this section news items related to the battle Pronts of Hafizullah Afrall from 3 September-2 November, 1987, in the Zindajan, Ghorian and Kughk as well as the Koht base's have been given. Altogether 30 battles have been fought during this perlod.

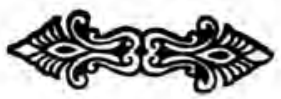




\section{Payam-e-Zan}

(Monthly November-December, 1987. "From propaganda to reality" Discusses the Russian propaganda about the withdrawal of its troops from Afghanistan and says, the intensification of war in Afghanistan, makes one to conclude the Russians want to withdraw only verba$11 \mathrm{y}$ 。

FISPORT: Is about the activities of the Malalai hospital in Quetta, Baluchistan, serving the refugees and mujaheddin. The hospital has 16 beds, an operation theater, first aid and mater nity departments, an x-ray laboratory, pharmacy and other essential services. The hospital has P1ve doctors and six nurses. The report says in the course of its 10 months activities, the hospital has treated 'thousands 'of Afghans, specially women and childreh.

* "Diplomatic efforts and a disgraceful defeat". It has discussed the Russian disgrace at the UN and their diplomatic tactics to save themselves. * Marshal Asghar Khan's gift from Kabul". It has referred to "meaningless" propaganda launched by the TIP leader after his return from Kabul about the Najib government.

\section{Jehad Palwasha}

November-January

BIITORIAL: The "trumpet" of political solution of the Afghanistan problem has been described as a plot aqdding if the Afghan jehad came to a halt we all have to live under a regime setup by Moscow in Afghanistan.

ARTICIIS: "Prof. Khalili and the issue of the Pashtu language" (by Professor Sanandar Ghoriani) The writer, giving his own eye witness accounts, reports that the late Khalili (renowned Dari poet) did not hold any grudges against the Pashtu language.

* "A short biographical sketch of the mujahed leader Professor Burhanuddin Rabbani leader of the Jamiat-e-Islami Afghanistan。

* "Tank or tractor: A difficult choice for Gorbachev". It has given an account of economic difficulties facing Russia saying due to these difficilties, Gorbachev has been forced to increase investment in non-military fields.

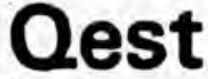

(Monthly November-January. EDITORIAL: Discusses various aspects of the Jehad including its difficulties and problems and says a series of bargaining and hectic activities for creating alliances and coalfitions for the last 9 years have created a distance between the people and the jehad leadership and it will take several decades until our naggrieved people" will be able to gather around a united ideological and political axis.

ARTICIES: "Russia after the invasion of Afghanistan".' Evaluates the economic, military and political losses 'which the Russians have suffered in Afghanistan and compares the power of weapons in the face of the power of faith and belief saying now a new phase is being ushered in our struggle.

" The UN mission viz-a-viz the Afghanistan problem: from displomacy to encroachments".

Describes the secret meeting held by Dlego Cordovez, the UN mediator on Afghanistan; with Zahir Shah and "others" as an encroachment against the legitimate rights of this Muslim nation.

* "The new Gorbachev policy and Afghanistan". It says the difficulties which the Russians have been facing in Afghanistan, the process of reawakening of the peoples of Central Asia and freedom trends among the people of Eastern Europe have been reasons forcing the Russians to a decision to pull out their troops from Afghanis$\tan$.

* "An introduction to the literature of the rovolution". It has criticized the pro-revolution literature as being contrary to realism and 
has urged literary figures of the age of Afghan revolution to remedy this defect and to come into grips with the reality of Afghan life.

* In its section on women, a women, who has recently been released from the Pul-e-Charkhi Prison, has been interviewed. According to her, about 200 women were detained in the Sadarat (Prime Ministry) building undergoing interrogation. However in the Pul-e-Charkhi "Bastile" about 75 Muslim sisters were behind prison bars serving $2-20$ years terms of imprisonment.

\section{Qalam}

November-January.

"The PDPA propaganda" (By Mohammad Asef

Ikram). The trumpetting of the NRP by the communist regime in Kabul and the fact that the regime has allowed representatives of the Inter national Red Cross and Human Rights Commission to conduct a series of limited studied about the Afghan situation is part of communist regime propaganda efforts for receiving recognition and international support.

* Would the Russian Red anmy quit Afghanistan with a clearn conscience?". Comments on remarks by Russian authorities that they will withdraw from Afghanistan with a "clean conscience". To begin with, the writer says, the communists lack any moral values and they actually do not have any conscience to speak about. And then, he says, the very move for the withdrawal of an aggressive force from a country is contrary to the ideology of aggressor.

"The loya Jirgahs are aimed at achieving much greater and nobler ideas"(Habibullah Rafie).

It has given a historical account of the loya Jirgah in Afghanistan and says the objective of these jirgahs have been to liberate the country, elect national leader, and echo national views on world issues and take decisions based on people's' interests. And all these are contrary to the Jirgahs held by communists aimed at legalizing their own regime. Furthermore, the very concept of holding such jirgahs had been in contradiction to communist ideological thinking.

* "Rxamples of crimes committed by Russian troops in Afghanistan" (By Rookiyani).

Another part of a serial published in the magazine on the massacres conducted by the Red Army in the Waghaz, Chazni.

\section{Shafaq} November-January.

EII TORIAL: In relation to the 27 Decentber, 1979 , invasion of Afghanistah by "arrogant" Soviet" forces, it discusses, what it calls, the acceptance of this invasion at first as a reality by the people of the world, the uprising of the people of Afghanistan with empty hands brit with an Islamic faith and finally the definite defeat of the savage enemy.

ARTICIES: "The process of unity in ranks and" its social repercussions" (By Mohammad Maaroof Feroghgart). It has referred to bitter experiences from efforts exerted by the mujaheddin for achieving unity and has then lists present difficulties saying the present mujaheddin coalition was able to elect a President for 18 months with the condition that he must during this period create an elected council for the formation of an interim government. hille praising this move, the writer still wants to walt and see.

* "About the loya' "Jirgah" (By Waheed Muthda). The oppressive' regimes in Afghanistan, whenever they have found it expedient to wear the mask of a government supported by the people, have been always resorting to an antiquated practice of the tribal order - - the loya Jirgah. These regimes, in order to legitimize the holding of rubber stamp loya jirgahs said at times their action was besed on Islamic foundations and other times claimed the firgahs were a popular national tradition. And even the cormunists, who had committed themselves more than any other group to the destruction of the 
foundations of the antiquated tribal order, have now clinged to this tribal structure due to their utmost helplessness.

\section{Lawa-e-Haq}

December-January.

(Monthly)

BDTORIAL: "27 December: confrontation between

right and wrong". The article gives actual examples of martyrdom of those who had launched

their struggle against evil and has given the good news of the victory of the forces of righteousness against those of the evil.

ARTICIES: "The loya Jirgah, Why did the Russians staged this puppet show in Kabul?" (Mohammad Mazhar Waheedi). It was a futile exercise launched by the Russians and their puppets to convince others that they enjoy the support of the nation.

* "Atheletics, a means for strengthening the jehad". Islam has enjoined its followers to physical exercise with a view of preparing themsel es for the jehad.

REIORT: In a grand meeting held to commemorate the martyrdom anniversary of Safiullah Afzali 23 September, 1987, Sebghaturlah Mojaddedi lea-. der of the Jabha-e-Melli said he had met the late Safiullah in Islamabad. He was an enlightened man advocating unity among Muslim ranks, abhoring killings and conflicts among Muslims and considering this a great sin.

NEWS: News items related to the jehad activities of the Hafizullah Afzali Fronts in NovemberDecember have been given. In this period, the mujaheddin of these fronts have fought more than ten battles with the enemy.

\section{Afghanistan World Press \\ December-January}

ARTICIES:"Afghanistan in the Polish dissident press"(translated from Central Asian Survey 1987)

* "Retreat, a maneuver"(from Al-Mujtamay,Kuwa1t)
While the Russians and their puppet regime are talking about the reconciliation and the conditions for the withdrawal of Russian forces from Afghanistan, in practice they had been taking consistent steps for consolidating their existence by resorting to different tactics and franchising for thenselves all the Afghan projects.

\section{Morchal}

December-January

ARTICIES: "Islamic socialish, a trap" (Translation). The purporse of this "plot" is to Isolate Islam from political and 'economic spheres of life.

* "The role played by our magnificent revolution in the world" (by Samiullah Sabawoon). While listing the effects of the Afghan victor ious revolution on the world community, the writer says, cur revolution for the first time was able to expose the blood thirsty nature of dangerous Russian imperialism and to bring it into par with the American, British and other imperialist powers。

* Another article, by Sayyed Gulab Sabawoon, speaks about the "opportunistic line taken by Ajmal Khattak (a Pakistarti'Pashtun now Iivirig in Kabul supporting the puppet regine) and says Khattak has been brother to all- - Zahir Shah, Daoud, Tarakai, Anin, Karmal and Najib and now has been arrogantly assuring the comminists that the noble tribesmen are heartfeltIy supporting the loya jirgah held by the Kabul regime.

* "In Afghanistan the clock of history has been turned backwards" (By Feda Mohammad Faiz). The Communists have been always holding that history cannot be turned back and a communist revolution is irreversible. However, we noted that the KabuI communists, by quickly relapsing to the past, (holding of roya jirgah) demonstrated the hollowness of Marxism.

* "Relief committees or spying nests" (By Thandar Kodakhel). Particularly signles out the 
French hospital serving the refugees, Condemns the activities of its President (a lady) and proposes that relief organizations should be strictly controlled, otherwise, under the conditions now prevailing, other than Christian and Wahabi (a sect in Islam) missionery activities, another "flower" may also blossom" among the refugees.

\section{Meesaq-e-Khoon}

December-January

ARTICIES: "The independence of revolution vs. political dependence (by Burhanuddin Rabbani). Political dependence, after the achievement of freedom and independence by nation, is the most daigerous factor in the deprivation and backwardness among nations entailing numerous miseries and problems.The biggest tragedy which has been threatening, specially the Islamic countries, after the age of colonialism has been political dependence. Old hand colonialist, using intrigues and snares, have penetrated in the political organizations of a number of Islamic countrles; threatening them to dissolution from within and isolating them from Muslim nations. Such governments have no other support for their survival and continuity other than truist on colonialists.

* "Gffective factors for speeding up the victory to be achieved by the Islamic revolution of Afghianistan." (Mohammad Nasim Faqiri). This article, which has won the first prize offered by the Iranian House of Culture in Peshawar, Kas given the following factors as effective for expediting the success of revolution:

(1) Faith and belief: taking of action in accordance with belief in jehed, (2) unity of all faithful forces, (3) preservation of the independence and the genuineness of the revolution, (4) having high and noble spirit during the course of revolution, (5) pursuing of Islamic ethical standards in words and action, (6) trust on the solidarity of the people (7) boldness and initiative in action and preservation of the offensive positions of the mujaheddin, (8) intensification of political and cultural struggle.

* "Gorbachev and his love for peace"(By Shahbaz) Hues and cries by communists, specially "the big imposter" Gorbochev, is sheer hypocrisy in the shadow of which they want to continue their war. Therefore, human community, and in special the Islamic world, should be aware of the form of their struggle against coniminism.

\section{Zan-e-Muslaman \\ December-February.}

ARTICIES: "Half of the body' of a society is made up of women and in proportion to this women play a role in the society." Without women and men it is not possible to find a society and without a society, a social order and Islamic state cannot be established. Let the women become aware of Islam, the liberator of mankind, and let women understand themselves and discharge their religious obligations with a healthy knowledge and Islamic prudence and are liberated from superstitions and let them pursue the line taken by women during the advent of Islam。

* "A mother has explained how her sons Omar and Sayyed Mohammad Usman began their jehad and were martyred. She has concluded by saylng as a mother, "I ask blessings to 'our dear martyrs from Almighty God and want perseverance and faith by our mujahed nation for continuing the jehad fin order to make the Afghanistan revolution a success."

REPORT:"Sister Fatima, responsible for the Islamic Organization of Women, who was invited to Saudi Arabia by the AKAZ publication Institution to take part in events related to the Afghanis tan Week, participated in the meetings held specially for women. The conference was held in Jedda and Sister Fatima in her fiery speech said, My sisters in religion, the cries of the infant tarld Hungry orphins 'wittiout shelter are still echoing in my ears, I'still hear 'tha't thiey are cryltrig witnle ctaght at a cross fire of Ris- 
sian weaponery. I hear thein cry' in the burning deserts of the 'refugees. 'These are sufferings which we have accepted for the sake" of Islam. These sufferings consist the sufferings of the entire world of Islam."

\section{Mahaz}

November-January

ARTICIES: "Prospects of jehad in Afghanistan" (by Abdul Bari Ghairat) (1) All Afghans are participating in the jehad, (2) the resistance of our nation is their Jehad, (3) they want a system based on Islam (4) one party or group cannot represent all the mujaheddin and, therefore, no one should meddle in the internal affairs of our jehad and, unless the mujaheddin are consulted, no peace plan and agreement can be implemented.

* "The Afghian mujaheddin are the only power ful obstacle on the path of Russian strategy and Muslim mujaheddin are fighting at the frontline of the defense of the region specially that of Pakistan (By Sayyed Habib Shah) FEPORT: Dr. Hassan Kakar, who spent six years in the Pul-Charkhi Prison, came early this year to Peshawar and in a news conference 12 January said the main reason for the Afghan problem is the existence of Russian forces in Afghanistain. While Sovlet forces are present, all peace plans, national reconcillation and other efforts will be futile. I think the only thing that can help solve the Afghanistan issue is tó stop foreign intervention. The Afghans do not lack experience and know well how to take care of their own affairs.

\section{Afghanistan World Press \\ December-January.}

* "The so-called Gorbachev" Glasnost" and Afghanistan". The so-called Gorbachev "Glasnost", about which so much is being said nowadays, is no more than side tracking the people from their ever increasing difficulties inside the Sovilet Union. A favorable effect of the Afghan Jehad on the Soviet Muslims has been that they are now no longer inclined to call the Soviets their "Big Brother". However it is appropriate that such a title is allocated for the Afghanistan mujaheddin。

* It is a report published by a Polish Journalist. RADSK SIKFRSKI who had spent. three months with the mujaheddin inside Afghanistan in August, 1987. He was witness to a bombing operation by four Soviet fighter planes in Kushk, Herat, in which 70 people were kdlled.

* The affects of war on the education of Afghan children" (By Floris ven Straaten).

Afghanistan was a backward country from an educational point of view even before the Soviet aggression; however during the past seven years the situation has worsened. Children under the control of Kabul regime are being educated on the line of Soviet idea. However, fortunately children in the liberated areas and refugee camps are being trained against the Russians and are being prepared to continue the jehad. By 1978 there were 1,154 primary schools in Afghanistan and this number has shrunk to 210 now. At that time there were 163 high schools but in 1984 it was rechuced to 44 . Serious attention is needed in the field of education of Afghan children.

\section{Qest}

Jamuary-February.

BDITORIAL: The Afghanistan Islamic revolution

is in a sensitive and historical juncture. Some of the biggest plots of world arrogant powers and imperialist have been put into operation against the valorous Afghan mujaheddin. Consecutive statements by Russian arrogance that it is seriously desirous of its troops withdrawal from Afghanistan has been somehow supported by statesmen and western media. This campaign, the worst of its kind, against the reaistance of our nation cannot be ignored. According to Gorbachev, a mere withdrawal of Soviet army 
from Afghanistan will be enough. The communiques issued by the seven parties of the TUAM and the Islamic Organization in Teheran, in answer to Russian nonsense, show that the jehad organizations of Afghanistan are aware of enemy intrigues and snares and there is no chance the Russians or some other force would trick our valorous mujaheddin, for they want nothing less than the establishment of an Islamic order in Afghanistan.

Now that the question of the formation of an interim government in Afghanistan has become a basic and important issue, we mujaheddin have to be alert. Our council of leaders should not ignore other Islamic organizations fighting inside the country。 Unfortunately at this stage, too, there are no understanding and consultations between the Peshawar based IUAM and some main Islamic parties in Teheran.

Although an increased understanding betweẹn these parties will be of great benefit, we also have at our disposal the example of the interim government which at one time was set up by the Islamic Republic of Iran.

Some monarchist members of the council of the TUAM also do not favor the formation of an Islamic interim government in which the Islamic "fundamentalist" parties, may play a dominant role. is natural that, under such circumstances, they will try to prevent the creation of an understanding between the Peshawar based IUAM and revolutionary"groups in Teheran and, possibly, as an answer to the "fundamentalists", they would like to pick up a so-called moderate perschality from the Teheran organizations (to serve in the IUAM council). However, they should realize that it is the revolutionaries who determine the course of a revolution.

ARTICIES: "The plot hatched by world arrogant and our stand". Negotiations held between the heads of state of two super powers and visits and exchange of views at an international level to find a solution for the Afghanistan problem within the framework of the "shameful" talks in Geneva, have been condemned and the Afghan mujaheddin position that Russian troops should withdraw without condition, the communist hireling regime should be toppled and an Islamic government should be established has been reiterated. The mujaheddin will never relinquish their stand.

* "Imperialist Media against the Islamic revolution". The so-called world media, which is in the service of East-West imperialism, is the enemy of the third world but specially that of the Islamic world and furthermore of the Islamic revolution of Afghanistan. It proposes that the world of Islam and Islamic liberation movements should have their own media to counter the imperialist media.

\section{Meesaq-e-Khoon}

EDITORTAL: On the occasion of the 9 th anniversary of the victory of the Islamic revolution of Iran, it has given an account of events during the last hours of the monarchy regime in that country and, at the conclusion, has congratulated the Iranians on behalf of the Afghan mujaheddin on the occasion.

\section{ARTICIES: "The issue of a return by Zahir} Shah: its possibilities" (By Mohammad Nasim Faqiri). Is a return by Zahir Shah appropriate? The record of his government, lasting 40 years, is the answer. The writer evaluates the weaknesses of Zahir Shah, the negative aspects of his domestic ploicies, the penetration of the Russians in Afghanistan during his monarchy and the effects of his foreign policy. He speaks about the unfaimess of the propaganda advocating his return as well as the obstacles that exist for his return. The writer says it is essential to say once more that the people of Af hanistan and specially the prominent commanders of the jehad as well as those who are working in mujaheddin organizations have become 
tired of present indifferences prevailing and are urgently demanding a united and clear stand by the mujaheddin coalition. The coalition should finally accept one of the two options: "Either move ahead or let me have my way (Pashtu proverb).

"The Islamic revolution of Afghanistan and the task of mourishing intellectuals" (Dr. Abdul Hai). In order to provide the grounds for such nourishment, the writer lists the following:

(1) establishment of a department of intellectual training in the center, (2) holding of conferences for intellectual training, (3) showing films on jehad and Islam, (4) estabment of a political ideology courses, (5) eslishment of an academy of Islamic sciences,

(6) Establishment of intellectual training centers in refugee camps,

* "A picture of Russia in the mirror of history" (By Dr. Haq Shenas). The Russian dirtyness, bloodthirstyness and savagery have been similar to that of the age of primitive man when civilization had not yet dawned. The writer has converted an elegy sung by renowned Dari poet Nizami Ganjaee to fit the Russian character. The verses in their ultered form say: No body should expect human feelings from the Fussians. All of them are thieves or wolves and lions who are shy of kindness and care but are brave at shedding blood.

They are grabbing otherg' towns and countries and are by nature lowly creatures.

When they find a way to some wealth, they will not move their foot from it once they hold it underneath.

They are not satisfied with one territory for as soon as they conquer a territory, their greed for other areas increase.

\section{Afghanistan World Press \\ February-March}

"The new answer to a bleeding wound (By Anthony Hyman). With the advent of the 9th year of war in Afghanistan, the difficulties of solving the Afghanistan issue, which Kremlin thought to be easy, have become clearer. Moscow consistently holds that it is ready to quit Afghanistan but at its own terms, and, until this is so, it appears the war will continue.

"The strategic importance of Wakhan" (By Fahmeedah Ashraf). The invasion of Afghanistan by the Soviet Union in 1979 and reports about the annexation of the Wakhan Corridor to the Soviet Union in 1980 have altered the strategic conditions of the region. After giving an account of the geographical position of the corridors, the article says it is about $300 \mathrm{kilo}$ meters long,its width at the narrowest point is 10 kilometers and at its widest 60 kilometers.

* "Soviet peoples opposition to the Afghan war" (By Aarontriheb)

The Pravda recently published a series of letters by its readers about Afghanistan. Most of these letters expressed opposition to Sovlet involvement in the Afghanistan war showing that opposition to the war is growing. The letters complained that the sons of members of the Communist Party have been exempted from serving their military terms in Afghanistan.

"Afghan or communist" (Swiss Press Review). The mujaheddin are of the opinion that the Soviet Union will not quit Afghanistan and all its promises are nothing but lies. The mujaheddin believe in freedom of logic and reject the idea of a coalition government in Kabul. 


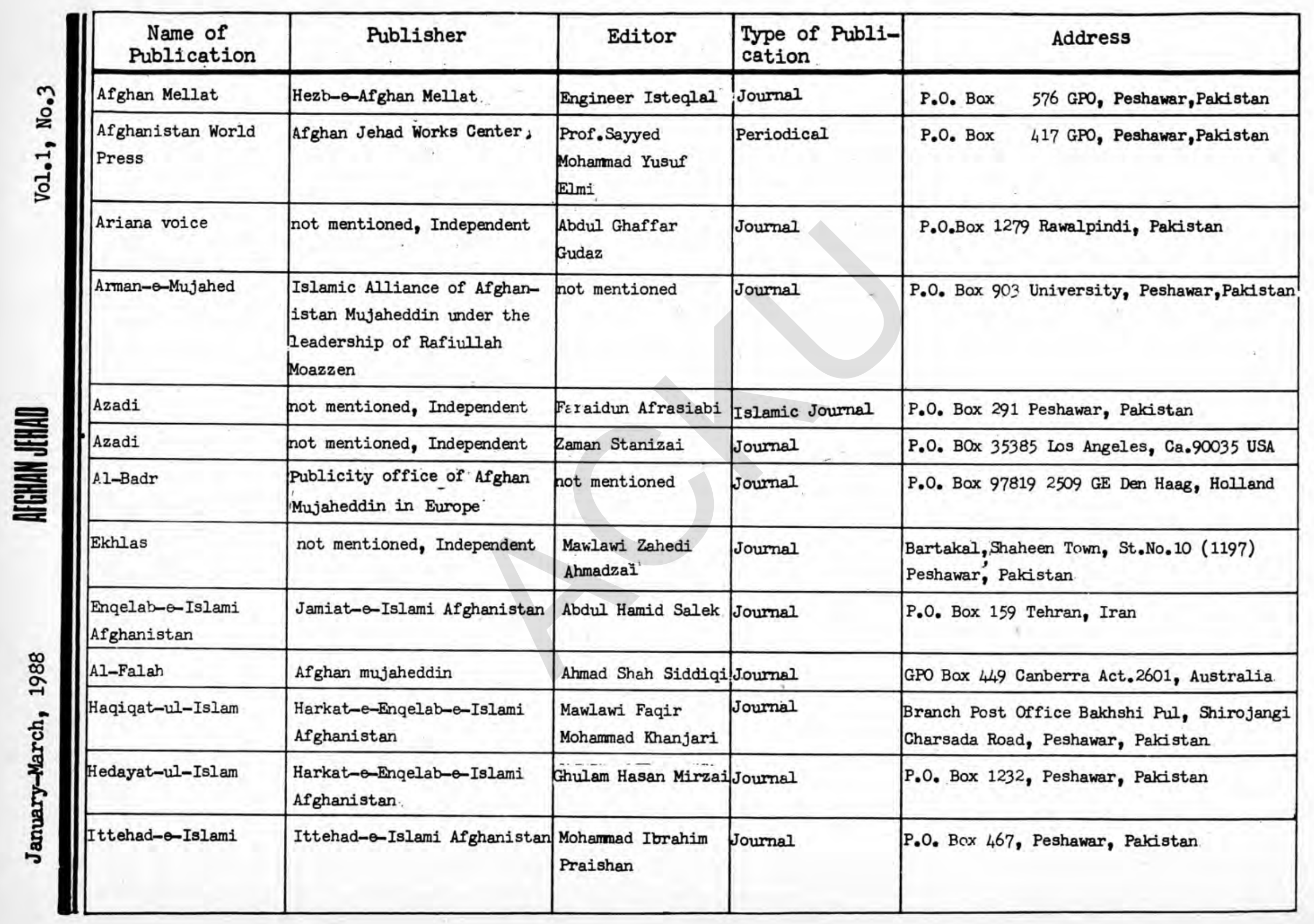




\begin{tabular}{|c|c|c|c|c|}
\hline $\begin{array}{l}\text { Name of } \\
\text { Publication }\end{array}$ & Publisher & Editor & $\begin{array}{l}\text { Type of Publi- } \\
\text { cation }\end{array}$ & Address \\
\hline Jabha-e-Jehad & NLF & not mentioned & Journal & P.0. Box 377 Sader, Peshawar, Pakistan \\
\hline Jehad Palwashay & Jamiat-e-Islami Afghanistan & Esmat Qaney & Periodical & P.O .Box 345 Peshawar, Pakistan \\
\hline Kabul & Jamiat-e-Islami Afghanistan & not mentioned & Journal & P.O. Box 519 Peshawar, Pakistan \\
\hline Khipulwaki & WAFA & Niazi Umaidwar & Periodical & P.0. Box 867 University Peshawar, Pakistan \\
\hline Lawa-e-Haq & $\begin{array}{l}\text { Martyr Hafizullah Afzali } \\
\text { Front }\end{array}$ & not mentioned & Periodical & $\begin{array}{l}\text { P.O. Box } 521 \text { Peshawar, Pakistan (or) } \\
\text { P.O. Box } 91375 / 5371 \text { Mashhad, Iran (or) } \\
\text { P.O. Box } 95715 / 55 \text { Turbat-e-Jam, Iran }\end{array}$ \\
\hline Mahaz , & NLF & not mentioned & Journal & $\begin{array}{l}\text { P.0. Box } 542 \text { Warsak Road, Kababian, } \\
\text { Peshawar, Pakistan }\end{array}$ \\
\hline Mahaz & & not mentioned & Periodical & $\begin{array}{l}\text { P.O. Box } 542 \text { Warsak Road, Kababian, } \\
\text { Peshawar, Pakistan }\end{array}$ \\
\hline Meesaq-e-Khoon & Jamiat-e-Islami Afghanistan & F.Fazel & Periodical & P.O. Box 1106 Peshawar, Pakistan \\
\hline Al-Momenat & Jamiat-e-Islami Afghanistan & not mentioned & Joumal: & P.0. Box 345 Peshawar, Pakistan \\
\hline Morchal & $\begin{array}{l}\text { Islamic Movement of Tribal } \\
\text { Thoughts }\end{array}$ & Saboon Mohmand & Periodical & P.0. Box 1207 GPO Peshewar, Pakistan \\
\hline Mujahed & Jamiat-e-Islami Afghanistan & A. Nangyal & Journal & P.O. Box 1107 Peshawar, Pakistan \\
\hline Mujahed UIus & $\begin{array}{l}\text { Information Center of Afghan } \\
\text { Mujahed }\end{array}$ & $\begin{array}{l}\text { Mohammad Hassan } \\
\text { Ulusmal }\end{array}$ & Journal & $\begin{array}{l}\text { Leili } 44 \text { Schous Plass } 3 A \\
0552 \text { osio Norway }\end{array}$ \\
\hline Neda-e-Mujaheddin & not mentioned, Independent & $\begin{array}{l}\text { Khalil-ul-lah } \\
\text { Mateen }\end{array}$ & Journal & P.O. Box 296 Quetta, Pakistan \\
\hline Neda-e-Jundullah & Jundullah Cultural Center & not mentioned & Journal & P.O. Box 560 Sadder Peshawar, Pakdstan \\
\hline Neda-e-Haq & $\begin{array}{l}\text { Harkat-e-Enqelab-e-Islami } \\
\text { Afghanistan }\end{array}$ & Shujauddin Khaddam & Journal & P.0. Box 164 Sadder Peshawar, Pakistan \\
\hline
\end{tabular}




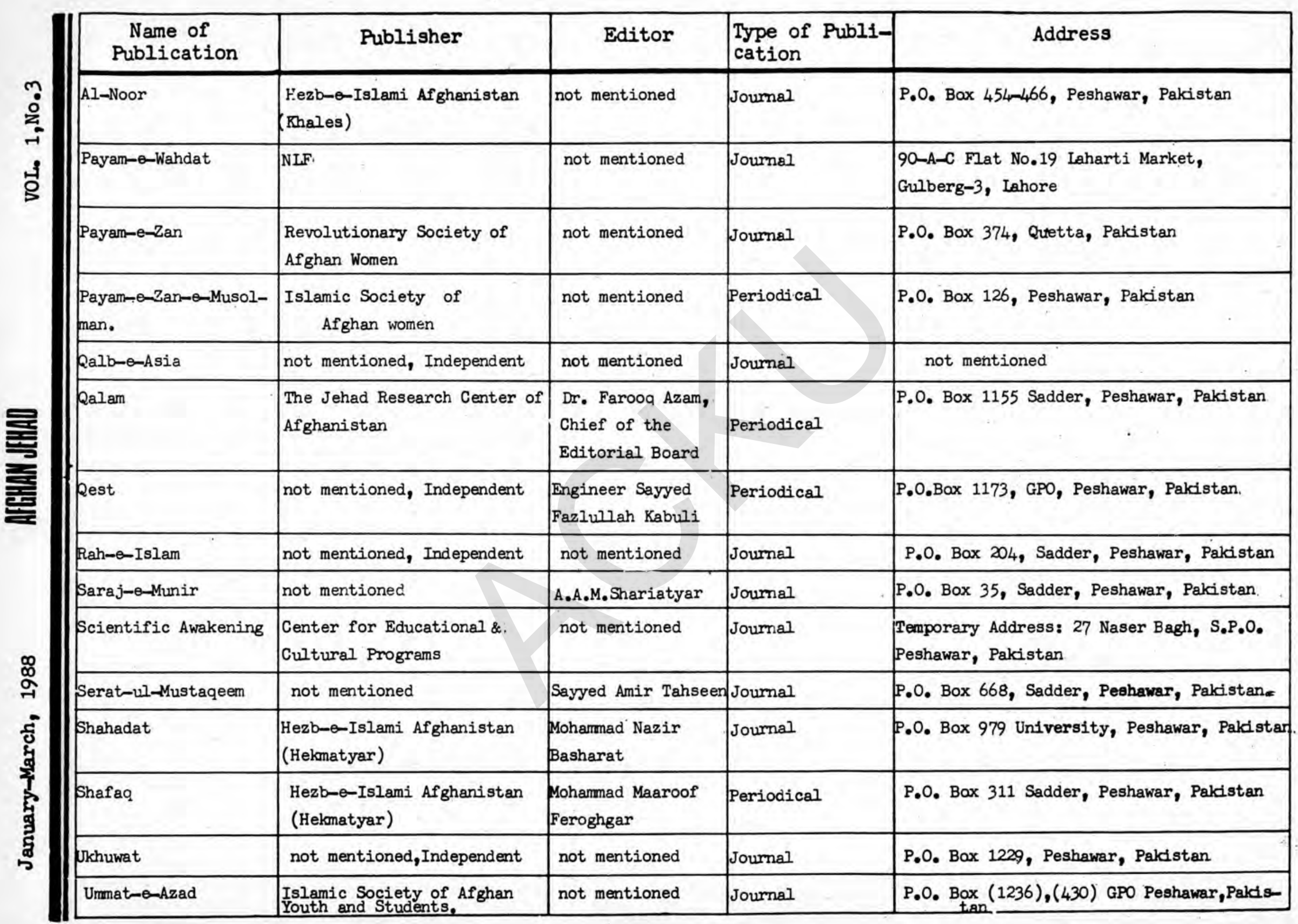




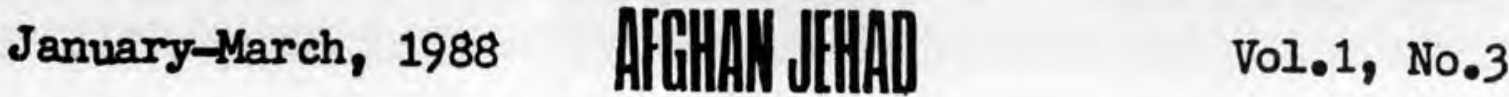

\section{BOOKS FOR THE MUJAHEDDIN BY THE MUJAHEDDIN}

\section{(ALL PUBLISHED IN 1987)}

\section{THE QURAN AND THE FAITHFUL (PASHTU)}

By Zamrak Aabed; Pubilished by flezb-io-ISlami Afiflinistan; 169 pages. Dates related to the first inspiration of the Holy Quran; the purpose of the inspiration of the Holy Quran; Quran, a guide to those who believe in it, the promises made in the Quran and the consequences of a refusal to follow the Quranic teachings are discussed.

$$
\text { THE B.M• - } 20 \text { (DARI) }
$$

By Lt. Col. Asadullah Khan, Senior Gaptain Abdul Fattah Zahed, Captain Qurban Shah; Published by NIF; 40 pages. A manual on the construction and launching methods of the B.M. 012 rocket launchers.

\section{A NUMBER OF SUGGESTIONS BY BROTHER HEKMATYAR TO THE REFUGEES(PASHTU)}

Speech by Hekmatyar (leader of the Hezb-e-Islami Afghanistan); Published by Hezb-e-Islamic Afghanistan; 54 pages. The text of a speech by Hekmatyar in Kalakatak, Chitral Afghan refugee camp in August, 1986.

\section{THE NEW CLASS (DARI)}

An Analysis of Communist system By Milovan Djilas; Trarislated by T.H. "Tbralinimi PubIished by WAFA, 243 pages. A prominent member of the Yugoslav Communist Party's critique of communist system which advocates a classless society, but, in fact, is nourishing the emergence of a new class - - the communist party.

\section{THE RAVISHIMENT OF JEHAD (PASHTU)}

A collection of poems by Ghamgin; Published by the Jamiat-e-Islamic Afghanistan; 22/4 pages; Contains the poems written by Ghangin (first name not given) about jehad. One part is in alphabetical order and the rest in random.

\section{THE GHARTER OF JABHA-E-MEILI NEJAT-E-AFGHANISTAN(DARI)}

Published by the NLF: 19 pages. Contains rules regarding the organizational features of the NLF and its aims and objectives.

\section{THE RAIN OF FIRE (PASHTU)}

By Amanulla Nasrat; Published by the author himself; 86 pages. The second collection of Jehad poems by Ghamgin. 


\section{IS THE AFGHAN WAR A WAR BETWEEN RUSSIA AND THE US? (PASHTU)}

By Mawlana Jalaluddin Haqqani; EDITOR; Abdul Hadi Mullakhel. Published by the Harakat-eMujaheddin; 34 pages.

The text of a speech delivered by Mawlawi Haqqani, leader of Paktia mujaheddin of the Hezbe-Islami Atghanistan (Khales) about Russian savagery and Afghan valor and resistance saying that the war is fought by the Afghans themselves against atheism and agression and not any one else.

\section{THE BRAVE TORAN AFGHAN (PASHTU)}

By Mohammad Aref Gharwal; Published by NIF, 56 pages.

A commemoration of the life of an Afghan jehad commander, Toran Afghan martyred in Paktia province.

\section{THE HERALD OF INDEPEENDENCE (PASHTU)}

By Ghulam Simsar Kamawi; collected by Sufi Ghulam Hazrat Simsar; Published by Ghulam Qader Simsar; 133 pages.

A collection of Jehad poems explaining jehad values and love for the country in a simple language.

\section{A DIAIOGUE BETWEEN TWO MUJAHEDDIN (DARI)}

Name of the author is not mentioned; Published by Ettehad-e-Islami Afghanistan; 41 pages.

A discussion between two mujaheddin about the future leadership of the Afghan society. The bottomline is that, according to them, Zahir Shah is not a Muslim and not fit for a leadership position in an Islamic Afghanistan.

\section{ISLAMIC MODESTY AND VELL (PASHTU)}

By Maulawi Zahedi Ahmadzai; Published by the Ekhlas Journal; 74 pages.

Discusses the importance and benefits of veil for woman and various kinds of veil.

\section{DISTURBED MEMORIES (DARI)}

By Dr. Abdul Hakim Tabibi; Publisher not mention; second print; 82 pages.

The first part of the book contains poems of the author during his life as a refugee; its second part is a critique of mystical Pashtu and Dari poets.

\section{PRESS CONFERENCE (DARI)}

Collected by Mehdi Hamai; Publisher not mentioned; 8 pages.

A summary of a press conference by Feruzuddin Afzali, a mujahed. It has been mentioned in the pahmphlet that 500 reporters were present in the press conference. In his conference he has discussed life in prison and the mujaheddin fronts in Herat.

\section{ASKING PERMISSION How to enter other's Homes?(PASHTU)}

By Mawlawi Zahedi Ahmadzai; Published by the Fklas Journal; 59 pages.

Discusses the ethical aspects of asking permission to enter other people's homes from an Islamic point of view. 


\section{THE GENEVA TAIKS (DARI)}

By Abdul Rahman Pazhwak; Collected by Mohmmad Hasan Ulusmal; Published by the Afghan Mujahed Information Center, 354 pages.

Discusses the Geneva talks held on Afghanistan under the UN auspices from the beginning and, taking in view the national interests of Afghanistan, points out the weaknesses of the talks.

\section{IEADER OF THE MUJAHEDDIN (DARI)}

By the NLF: Published by the Lahore Agency of the NLF, 128 pages.

A detailed biography of Sebghatullah Mojaddedi leader of the NLF and the family members of Mojaddedi.

\section{A GIANCE OF THE ADVANCES IN THE JEHAD (DARI)}

Written and published by the General Commander of Wardak Islamic Mujaheddin Commando Unit, 108 pages.

Discusses the invasion of Afghanistan by Soviet forces, Russian policy towards Afghanistan countered by the mujaheddin strategics

\section{IHE BIOSSOMS (DARI)}

By Ustad Shafaq; Published by Nasr Organization of Afghanistan; 73 pages. Thirty love and jehad poems of Shafaq.

\section{PIETY AND THE TRENCH OF JEHAD (DARI)}

By Ustad Shahriani; Published by the Jehad and Da'avat University., 95 pages.

The need for piety in jehad trenches.

\section{AI-MASSORAT (DARI)}

By Martyred Hasan-el-Banna; Translated by Abdul Ahad Ashrati; Published by the Society of Islamic Da'awat, 118 pages.

CONTENTS: The role of prayers according to the Quran, prayers that could be recited during the day and night and prayers suggested by the Akhwanul Muslimin.

\section{ISIAMIC COUNSEL AND IFADERSHIP (PASHTU)}

By Kamal Shinwari; Published by the Society of Islamic Peace Makers; 71 pages.

CONTENTS: The importance and value of Amir in Islam, the importance of Counsel in Islam and a number of questions and answers in this regard.

\section{FROM HAZARAJAT TO IONDON (DARI)}

By Mohammad Isa Gharjestani; The Islamic Cultural Council of Afghanistan, Quetta; 91 pages.

It says the Hazaras, Uzbeks and Tajeks should consolidate their unity against the Pashtuns and achieve their rights. Proper measures ought to be adopted for redeeming the Hazaras.

\section{PRESENT TAIKS AND THE FUTURE OF AFGHANISTAN (DARI)}

By Moharmad Zamen Mozammel; Published by the Hezb-e-Islamic Afghanistan; 219 pages。

CONTrarTs: War and negotiations, the Afghan nation is not taken into confidence about the 
talks on Afghanistan, Afghanistan of the future, coalition government, a neutral government, the other side of the plot, elections and the intermm government.

\section{TWO SPEECHES (DARI)}

By Mohammad Aryanpoor; Published by the Jamiat-e-Islami Afghanistan, 73 pages.

Contains two speeches by Arianpoor General Commander of the Keshem, Badkhshan, fronts. One is about the birth of Prophet Mohammad (peace be upon him and the other is on 27 December, 1979, the date of Russian invasion of Afghanistan.

\section{NEW IUES FOR OID (DARI)}

By Anatoliy Golitsyn, former KCBB officer; Translated by Sayyed Faqir Alawi; published by WAFA; 62 pages (vol.II).

SUBJECT: Discusses the role of historians, economists and writers in changing the Russian nation into a democratic society.

\section{HISTORICAL DOCUMENTS OF AFGHANISTAN (DARI)}

By Al-Ha'g Nangyal; Putolished by The Jehlat Culture; 74 pages.

From the time of Amir Sher Ali Khan until the Presidency of Mohammad Daoud, texts of documents dealing with cultural, social and political subjects have been produced, many in the original.

\section{JEHAD VERDICTS (DARI)}

Collected and Translated by Al-Haj Nangyal; Published by the Jehad Culture; $84_{4}$ pages.

Text of verdicts issued in support of the Afghan jehad by Pakistani, Arab, Egyptian and other Islamic countries' ulema since 1978.

\section{THE WAVE OF MARTYRS (PASHTU)}

Collected and edited by Abdul Moqim Poltiwal; Published by Harkat-e-Enqelabi Islami Afghanistan, 1987. Volumn I, 68 pages, Volumn III, 41 pages (Volume II could not be located).

Biographies and pictures of a number of mujaheddin who have been martyred during the war.

\section{KEHAD FFOM THE VIEW POINT OF THE QURAN AND HADIS (DART)}

By Mawlawi Nezamuddin Nafey; Published by the CCAR; 271 pages.

A collection of all the verses of the Holy Quran as well as of the sayings of Prophet Mohammad (peace be upon him) about the jehad. The author has offered detailed conmentries about the verses and the Ahadis.

\section{KNOW THE ENEMY (PASHTU)}

By Prof. Bahauddin Majrooh; Published by the Society of Afghan Mujahed, Writers; 52 pages.

CONTENTS: The Soviet Union, a despotic regime, the four pillars of the palace of depotism; totalitarianism, a few words about the nature of Soviet system; a classless state; a corrupt imitation; mysterious nature; government of ideology; terrorist regime, etc.

\section{GORBACHEV'S NEW STRATEGY IN AFGHAN ISSUE (DARI)}

By Marin Stremcki,translated by Dr. Elmi; Published by the Afghan Jehad Works Translation 
Center, 56 pages.

CONTENTS: Verbal pressure, creating division among the tribes and nationalities, terrorism, air strikes, the policy of General Ziaul Haq, prespect of the resistance forces, the political objective of Moscow, new Soviet strategy, Soviet casualties and their disgrace in all dimensions,

\section{A CRITIQUE OF THE DIAIECTICAL MATERIALISM (DARI)}

By Abulwafa Afghani; Published by WAFA; $\&$ pages.

Contents: A definition of matter, new definition of of matter, a criticism of classical definition of matter, the reality, the theory of reflection, events and laws, principles, materialism in quality, the negation of the negative.

\section{BRINGING UP ISIAMIC CHIIDREN IN NON-ISIAMIC SOCIETIES(DARI)}

By Sabahuddin Kushkaki; Published by CCAR; 191 pages.

It is a guide to Muslim parients in western societies telling them not to be overwhelmed by concepts and to uphold the moral and Islamic principles in bringing up their children. 


\section{January-March, 1988}

\section{January-March}

\section{January, 1}

* In his New Year Day message, General Mohammad Ziaul Haq has wished 1988 as a year of freedam for the Afghans (RPDS).

* Pakistan Minister of State for Foreign Affairs, Zain Noorani has said the Soviet Deputy Foreign Minister would soon visit Islamabad to hold talks on the next round of Geneva parleys (RPDS).

* The Interior Minister of Pakistan Nasim Ahmad Aheer has said that bomb explosions cannot force Pakistan to forego its principled stand on Afghanistan issue (RPDS).

* Work on the extension of the Indra Gandhi Child Health Institute which began early this year will be completed in the second quarter of next year. Afs.283 million is being spent on the project provided as a grant. by India (RA).

* In an interview with the Jange the provincial Secretary of ANP said the entire Afghan people want peace but the leaders of extremist groups, by receiving military and economic aid from imperialist circles, continue the war and bloodshed in Afghanistan (RA).

* Talking 31 December to the Muslim, the Jamiat-e-Islami Afghanistan.leader Professor Burhanuddin Rabbani said that Dr. Najibullah's brother Siddiqullah who had defected to the mujaheddin was somewhere in the northern area between Badakhshan and Panjshir in the custody of commander Ahmad Shah Masood (MIM).

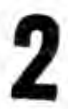

+ The mujaheddin say shops in Kandahar city remained closed 27 December on the eve of the anniver3ary of the Soviet invasion of Afghanistan but PDPA activists opened and looted a number of shops

(VADS).

* Before his departure 1 January for Karachi enroute to Morocco, the Minister of State for Foredgn Affairs Zain Noorani said in Islamabad during his visit to Islamabad, the US Deputy Secretary of State, Mr. Armacost would brief the Pakistani leaders on Reagan-Gorbachev summit (MIM).

* Sayyed Ahmad Gailani leader of the Mahaz-e-Melli Islami-e-Afghanistan has refuted the Kabul govermment claims that the siege around Khost has been broken off. He added that pitch battle is going on between the mujaheddin and the Soviet-Kabul troops in Sayyedkhail and Khost is still besieged by the mujaheddin (NWT).

* The Reagan administration officials and other analysts say a Soviet backed military drive to 
lift the guerrilla siege of Khost is intended to strengthen the Kabul government position in peace talks (IN).

\section{3}

* To follow-up the transportation of essential commodities for the people of Khost, 210 transport vehicles carrying 1,331 tons of goods arrived 3 January in that sub-division (RA).

* Thirty two prisoners were released 3 January in Paktia on the basis of the Presidential amnesty decree (RA).

* The Charge d' Affaires of the Pakistan Embassy in Kabul was summoned 3 January to the Foreign Ministry and a protest note was handed over to him against the violation of Afghan air space by a Pakistani helicopter in the Nangarhar province (RA).

* Having been informed by the inhabitants and the NRP conmission of the Bagram sub-division, Parwan security forces discovered recently 10 ground-to-ground missiles and stopped the extremists from their criminal activities in the outskirts of Bagram (RA).

* In its 40th session, the General Council of the International Federation of the Iabor Trade Unions addressed a message to the Central Council of the Afghanistan Labor Trade Unions expressing support to the NRP aimed at ending bloodshed and war in Afghanistan (RA).

* Quoting 3 January the US administration sources, The Washington Post writes the US President Ronald Reagan has sent a message to the "ring leaders" of the Afghan anti-revolutionaries assuring them of continued and increased US military and political aid (RA).

* In its 3rd January issue, The Pravda writes as prospects for a political solution of the situation around Afghanistan become clearer, opponent of the Republic of Afghanistan are increasing their activities (to sabotage these prospects) (RA).

* Twelve Soviet republics, so far have concluded agreement with 29 Afghan provinces for direct cooperation (PMDS).

* About the solution of the situation around Afghanistan, a Radio Moscow commentator says past years experience proves that the Afghan issue can be solved only through political means (FMDS). * In an interview with the correspondent of a Soviet newspaper, the French journalist who was arrested last September in Afghanistn has said he is not a spy (BBCFS).

* The US Assistant Secretary of State Michael Armacost intends to meet the IUAM President Mawlaw1 Mohammad Yunus Khales and other mujaheddin leaders during his visit to Pakistan (BBCFS)。

* Voice of Germany has reported that President Najib's brother Siddiqullah Rahi, who defected to mujaheddin last October, is seeking political assylum in some western country (MIM).

* At a session of the JI provincial council in Peshawar it was urged that efforts should be exerted to make the situation conducive for direct talks between the mujaheddin and the Soviet government for the solution of Afghanistan issue. It was warned that any solution not enjoying mujaheddin consensus would be dangerous for the security of Pakistan (JG).

* Men from the Torikhail Ali Khail tribes in north Waziristan have dismantled the houses of a number of suboteurs and they have been warned not to have contacts with the Kabul puppet goverrment. They have also captured their arms which were supplied to them by the Kabul government (NWT). 


\section{4}

* The Soviet Foreign Minister, Eduard Shevardnadze arrived 4 January in Kabul to hold talks with President Najibullah (RA).

* The trial of a French citizen Alian Guillo, who, in violation of the laws of Afghanistan, had entered the country nine times for making films and radio cassettes and conducting espoinage activities in link with the armed bands, was conducted 4 January in a special revolutionary tribumal. He was sentenced to 10 years imprisonment (RA).

* Quoting the US administration sources, The Washington Post writes the US military aid to the anti-revolutionaries of Afghanistan for 1987 fiscal year was $\$ 600$ million. The daily writes funds, allocated for current year, are a little less than that. But, quoting an informed source, the daily writes that the amount can be increased later (RA).

* The US Assistant Secretary of State, Michael Armacost held talks 4 January with the Pakistan Foreign Secretary Abdul Sattar in Islamabad on recent developments concerning the political solution of the Afghanistan dispute (RPDS).

* The Newsweek has reported that at last Moscow has agreed to specify a date for the pull-out of its troops from Afghanistan (RPDS).

* The Izvestia has claimed that Iranian government is sending the Afghan mujaheddin to Iran-Iraq war after training them in Iran (BBCFS).

* Pakistani Security sources say a prominent KHAD member Lal Mohammad Kokikhail who worked as the ring leader of the KHAD agents in Pakistan has been arrested (VOAPS).

* According to The Washington Post 3 January, President Reagan has reassured Afghan mujaheddin leaders that the US will continue and even increase its military and political support to the mujaheddin as long as the Soviet Union continues to press its battle in Afghanistan (MIM).

* Afghans in Brussels staged demonstrations 3 January against the Soviet invasion of Afghanistan. The demonstrators demanded the immediate withdrawal of the Soviet troops from Afghanistan (NMT).

* The Washington Post says Saudi Arabia has indicated it will discontinue aid to mujaheddin after the Soviet troops withdrawal from Afghanistan. The Saudi government has told the Soviet Union it will start oil trade with Moscow if it withdrew its troops from Afghanistan (JG).

* Siddiqullah Rahi brother of Dr. Najibullah has disclosed that he was kidnapped by the Kabul agents from West Germeny and taken to East Germany and ultimately shifted to Kabul where he was rendered jobless and kept under detention for several months. Siddiqullah recently defected to the mujaheddin(JG).

* Six Afghan planes bombed border areas inside Afghanistan across North Waziristan Agency 3 January and mujaheddin claimed that they shot down one of them with ground-to-air missile (MIM).

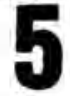

* A British Parliamentary delegation, led by the President of Anglo-Afghan Friendship Association now visiting Kabul at the invitation of Afghan Peace. Solidarity of Friendship Organization, held talks with the Deputy Prime Minister, Abdul Hamid Mohthat and the President of the National Front, Abdul Rahim Hathef on the promotion and expansion of friendly relations between the two countries, and implementation of the NRP process (RA).

* The seventh supply convoy of 117 transport vehicles, carrying 635 tons of goods, arrived 5 Jan- 
uary, in Khost (RA).

* Special rapporteur of the UN Human Rights Commission, Professor Felix Ermacora arrived 5 January in Kabul for preparation of a report on the human rights situation in Afghanistan (RA).

* The Soviet Union is to supply 88 items as a grant needed by the Kabul province until the end of 1988 (RA).

* With a timely action, the security officials discovered and defused a US made five kilogram plastic explosive meant for causing a tragedy by the extremist elements in Mir Wais Maidan, Kabul

* The US Under Secretary of State, Michael Armacost held talks 4 January with President Ziaul Haq in Rawalpindi on the Afghanistan issue (RPDS).

* France has protested against the detention of a French journalist in Afghanistan. The French Foreign Ministry has asked Moscow for the immediate release of the correspondent (RPDS).

* The Soviet Foreign Minister Eduard Shevardnadze held talks 4 January with President Nijabullah in Kabul on the settlement of situation around Afghanistan and implementation of NRP in the country (RMDS).

* Bakhtar has said that the doors of Afghanistan are open to all "real" journalists and 250 journalists visited Afghanistan only during the 1987 (PMDS).

* The US Under Secretary of State, Michael Armacost, now visiting Pakistan intends to meet the IUAM President Yunus Khales and deliver him a message from President Reagar (RMDS).

* The Times (London) writes Soviet Foreign Minister's aim for visiting Afghanistan is to find out whether the Najib regime will be able to sustain itself after the Soviet troops-pull out from Afghanistan (BBCFS).

* In its issue of 5 January The Washington Times writes that setting up a date for the beginning and completion of Soviet troops withdraval will all of a sudden put the Afghan resistance to agree with the cease-fire conditions and a halt in US military assistance. Similarly the Kabul conmunists will be deprived of a Soviet security cover (VOADS).

* The Washington Times writes Moscow wants to repress the massacre of its stooges in Afghanistan after its troops pull-out from that country. It is quite evident that prominent figures in Kabul government and its espoinage network, including Najibullah, will have to leave Afghanistan. According to some diplomats, perhaps one purpose of Shevardnadze's visit to Kabul is to make arrangements for Najibullah's exit from Afghanistan (VOADS).

* Western diplomats in Moscow say the Soviet Union might be ready to accept a government in Kabul without Najibullah's participation. The diplomats say Soviet officials have concluded that, after a Soviet troops withdrawal, Soviet role in the formation of a govermment in Kabul might be nominal

(VOADS).

* The US Under Secretary of State for Political Affairs Michael Armacost held talks 4 January with the Pakistan Foreign Secretary Abdul Sattar in Islamabad. During the talks views were exchanged on the latest developments about a political settlement in Afghanistan (PT).

* Another 5,000 Afghan refugees have entered Pakistan from Eastern Afghanistan, while thousands others are also expected in the near future. The refugees are reported to belong to Khost city which has been captured by the Soviet-Kabul troops (JG). 


\section{6}

* The Pekistan Civil Aviation officials say the PAF aircraft are now escorting Pakistani commercial and transport planes flying near the Afghan borders (VOADS).

* On the conclusion of his visit to Kabul 6 January the Soviet Foreign Minister Eduard Shevardnadze returned to his country (RA).

* In an interview with the correspondent of the Soviet TV in Kabul, the Soviet Foreign Minister Shevardnadze said the withdrawal of Soviet troops from Afghanistan has been fixed to be completed in 12 months and the forthcoming round of Geneva talks in February would be the last phase in this connection (RA).

* The eighth government convoy, comprised of 279 transport vehicles carrying 2,237 tons of essential goods, arrived 6 January in Khost (RA).

* Twenty lorries of the extremist groups, carrying arms and ammunition, were captured by the tribal youth on the Karakurram Highway (RA).

* At a conference 6 January in Islamabad, the US Under Secretary of State Armacost expressed surprise as to why it should take the Soviet Union as long as 12 months to withdraw its troops from Afghanistan (RPDS).

* The Kabul regime Charge d' Affaires in Islamabad was summoned in the Pakistan Foreign Ministry 5 January to be told that Iolamabad rejected Afghan claims about violation of its territory(RPDS). * At a press conference in New Delhi, the visiting Soviet Deputy Foreign Minister has said the program for the Soviet troops wi.thdrawal from Afghanistan will be finalized in the next round of Geneva proximity talks (RPDS).

* A protest memorandum on the Afghan war, signed by 50,000 Swedish citizens, was delivered to the Soviet Embassy in Stockholm (RPDS).

* The Norwegean Labor Party newspaper writes that their medical teams in Afghanistan have been attacked by Heknatyar's Hezb-e-Islami and Islamic Unity of Sayyaf during which their doctors have been imprisoned (BBCPS).

* In an interview 6 January with The Washington Post the UN envoy on Afghanistan Diego Gordovez said the Soviet Union intends to put forwarc a proposal at the forthcoming indirect talks between Pakistan and Afghanistan in Geneve next month about the withdrawal of its troops from Afghanistan even in less than 12 months (VOAPS).

* The US Under Secretary of State Michael Armacost held another round of formal talks 5 January with Pakistan Foreign Secretary Abdul. Sattar in Islamabad on matters of mutual interest (MIM).

* Pakistan Prime Minister Mohammad Khan Junejo received 5 January US Under Secretery of State for political Affairs, Michael Armacost in Rawalpindi. During the meeting, Armacost briefed Junejo about the Reagan-Gorbachev summit talks on Afghanistan (PT).

* Talking to newsmen 5 January, the Interior Minister Mohammad Nasjm Aheer said law enforcing authorities have arrested $90 \mathrm{Afghan}$ and 138 Pakistani saboteurs who were planning to carry out explosions in congested areas of the country. He disclosed that 50 of the terrorists were handed over to Pakistan authorities by the Afghan mujaheddin (NWT). 


\section{7}

* A spokesman of Pakistan Foreign Ministry says the UN special envoy on Afghanistan Diego Cordovez will arrive 20 January in Islamabad for talks on preparations of the next round of Geneva talks. He will also visit Kabul (RPDS).

* In an interview with The Washington Post, the UN special envoy on Afghanistan, Diego Cordovez said Moscow and Washington have agreed that, after reaching an agreement on a time-table for the Soviet troops withdrawal, the people of Afghan would be encouraged to concentrate on a multi-party system of government (RPDS).

* Radio Kabul reports that fierce fighting between the mujaheddin and the Soviet-Kabul troops continues in the outskirts of Khost cj.ty (RPDS).

* The Washington Post writes that the first decision to be taken by the future US government should be to change a good intention but wrong decision of the Reagan administration in treating the Afghanistan problem with that of Angola, Kampuchea and Nicaragua under one topic in its talks with the Soviet Union (VOADS).

* The Pakistan government has welcomed a Soviet Foreign Minister Eduard Shevardnadze statement about Moscow's readiness to withdraw Soviet troops from Afghanistan this year (BBCFS).

* A spokesman of the Pakistan Foreign Ministry told 7 January newsmen that Pak-US officials talks early this week have paved the way for seeking an early solution of the Afghan problem (BBCFS).

* In an interview with the BBC, the Jamiat-e-Islami Afghanistan leader Burhanuddin Rabbani said, under present circumstances, the Soviets want to impose a regime on the Afghan people through their tanks and aircraft. This right should be a right of the Afghan people, to choose their type of government, he said (BBCFS).

* In its meeting 7 January under the chairmanship of vice-President Haji Mohammad Tsamkani, the Executive Committee of the Central Council of Supreme Tribal Jirgah adopted decisions about the implementation of NRP in border provinces, acceleration of development work in border tribes and a number of administrative issues (RA).

* The first convoy of the relief goods of direct cooperation between the Azerbaijan of the Soviet Union and Khost arrived 6 January in Khost (RA).

* Another convoy of 274 vehicles, carrying 1,260 tons of food stuff and other commodities were transported 7 January to Khost (RA).

* On the basis of Presidential amnesty decree 260 prisoners $*$ re released in Kunduz and Nimroz provinces (RA).

* The New York Times said 7 January Soviet officials have indirectly told diplomats and newsmen that the Soviet Union has lost patience with Najibullah's insistance that he did not want to lose Soviet military support (VOAPS).

* The New York Times writes while the US has not said openly that it will stop its military aid to the Afghan mujaheddin, American of ficials have confirmed that Washington has pledged to stop aid to mujaheddin upon the withdrawal of Soviet troops from Afghanistan (VOAPS).

* US Under Secretary of State Michael Armacost concluded 6 January his three day official visit to Pakistan and left Islamabad for Washington. His visit has, according to diplomatic observers, 
failed to make any headway towards the soluticn of the crucial question of a future government in Afghanistan (MIM).

* According to a Hezb-e-Islami Afghanistan press release, the Hezb-e-Islami leader Gulbuddin Hekmatyar has denied thet he met the US Under Secretary of State Michael Armacost with other mujaheddin leaders in Islamabad 6 January (MIM).

\section{8}

* Special rapporteur of Human Rights Commission Professor Felix Ermacora visited 7 January Kandahar and held talks with the governor of the province on the Kandahar organizational and economic sıtuation. He and his entourage also visj.ted Herat (RA).

* To follow-up the transportation of food stuff and essentiall commodities to Khost, another 10 convoys, comprising 193 transport vehicles with 1,046 tons of goods, arrived 8 January in Khost (RA). * The Pakistan Minister for Information and Broadcasting has praised the people of the NWFP for their hospitality to the Afghan refugees. A tribal leader of Bannu donated a plot of land for the residential quarters for 2,000 Afghan refugees (VOADS).

* The Financial Times (London) writes from Moscow, after eight years of futile efforts for gaining control of Afghanistan, it appears that the Soviet Union has lost hope for imposing a puppet Government in Afghanistan and it is.now prepared to withdraw its troops from that country (BBCFS).

* In an editorial 8 January The Daily Telegraph (London) writes the world might be at the threshold of a historic moment. Because after its retreat from Austria in 1955, the Red Army would leave a foreign country for the first time (BBCFS):

* The Pravda writes during his recent visit to Pakistan the US Under Secretary of State Michael Armacost did nothing to help the prospects for a restoration of peace in Afghanistan (RMDS).

* A Radio Moscow commentator says the date for the beginning of the Soviet troops withdrawal from Afghanistan should coincide with the date for a halt of military and financial assistance to the rebels (RMDS).

* The US Secretary of State George Shultz says when the Soviet Union began its troops with-drawal from Afghanistan, the US will also stop assistance to the mujaheddin (VOAPS).

* Delivering a lecture 7 January at the International Relations Department of Karachl University, former Pakistani Foreign Minister, Agha Shahi said the return of Afghan refugees could only be possible if the situation in Afghanistan got normalized with the return of Soviet troops (MIM).

* At a weekly briefing 7 January in Islamabad, a Pakistan Foreign Office spokesman told newsmen, to meet the Soviet position that its troops will not engage in military operations once the withdrawal starts from Afghanistan, except in self defense, Pakistan has suggested that the UN monitoring force for the Geneva accord should be enlarged to a peace keeping force (PT).

\section{0}

* Special Afghan envoy to the UN Shah Mohammad Dost said all necessary conditions exist to make the forthcoming phase of Geneva talks for the settlement of situation around Afghanistan as a final phase of these talks (RMDS).

* At a press conference 8 January, the US Secretary of State George Shultz said in Washington that the US military assistance to the mujaheddin can be stopped even prior to the pull-out of 
the last Soviet soldier from Afghanistan provided the US is assured that the independence and freedom of Afghanistan is guaranteed (BBCFS).

* A high ranking Soviet Foreign Ministry official says the US and the USSR have agreed upon most of the points of a solution of the Afghanistan problem (VOADS).

* The VOA correspondent reports from Islamabad, Kabul citizens say they have been witnessing a totally different behavior from the Communists nowadays. He says a number of them are already trying to alienate themselves from the Soviet Union and say that they have been nationalists, not Marxists (VOADS).

* According to a representative of the "Afghan Islamic Wing" in Holland, the Afghan "national freedom fighters" are not prepared to participate and cooperate with communists in a coalition government after the Soviet troops withdrawal from Afghanistan (VOGDS).

* The Christian Democrat and Christian Socialist parties of the FRG have asked the Soviet Union to take-up proper and realistic steps for the withdrawal of its troops from Afghanistan (VOGDS).

* The Pakistan government has called its Ambassadors in the USSR and US to Islamabad for consultations on the Afghanistan issue prior to the visit of UN special envoy to the region (RPDS).

* The special UN repporteur on human rights Felix Ermacora, now visiting Afghanistan, is also expected to visit the refugee camps in Pakistan (RPDS).

* The special rapporteur of the Human Rights Commission, Felix Ermacora met 9 January with the Chairman of National Front Abdul Rahim Hathef. He was apprised of the activities and measures adopted for facilitating the implementation of the NRP process in the country (RA).

* After an interview with the former Afghan Monarch Mohammad Zahir Shah a correspondent of Columbia Broadcasting System (U-S) reports both sides of the Afghan war are now thinking that Zahir Shah may be a key to a political solution of the Afghanistan problem (VOAPS).

* Alexander Khatchikian of Novosti Press Agency of Moscow writes, at the end of his visit to Afghanistan, the Soviet Foreign Minister Eduard Shevardnadze told the Bakhtar that, having discussed the question of the Soviet troops pull-out with President Najibullah, it was decided that the necessary conditions for it can be created in the near future (MIM).

* Addressing 8 January the Pakistanis in Paris, the Pakistan Minister of State for Foreign Affairs Zain Noorani said, as soon as a political settlement is reached in Afghanistan and the Soviet troops pull-out by the end of the current year, the Afghan refugees would go back to their homes

(MIM),

* According to Western press reports, although the withdrawal of Soviet troops from Afghanistan does not appear so imminent, Soviet leader Gorbachev's promise to complete Soviet troops withdrawal in 12 months has sent shock waves through the communists in Afghanistan. For they worry about thej $r$ own fate after the withdrawal of Moscow Soviet troops (MIM).

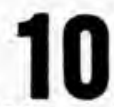

* Foodstuff and other commodities were delivered in a convoy of trucks for the first time to areas under the jurisdiction of Khost after the siege around the Khost sub-division was lifted recently

(RA). * A convoy, carrying goods offered by the Soviet Union as a grant, has arrived in Assadabad, Kunar. 
The aid was part of a program aimed at promoting direct link between Kunar and the Minsk province of Byelorussian of the USSR (RMDS).

* Prime Minister Sultan Ali Keshtmand attended 10 January in Kabul a ceremony for the signing of an agreement on the exchange of goods between the Soviet Union and Afghanistan for 1988 (RA).

* A protocol on the promotion and expansion of agricultural cooperation between the Ministry of Agriculture and Land reforms of Afghanistan and the Agricultural and Industrial State Committee of the Soviet Union was signed 9 January in Moscow (RA).

* The special rapporteur of the UN Human Rights Commission, Professor Ermacora and his entourage visited 9 January Jalalabad and Khost (RA).

* To follow up the transportation of foodstuff and essential commodities to Khost, the 12th convoy comprisong 180 transport vehicles carrying 1,244 tons of goods, arrived 10 January in that city (RA).

* Thirty two prisoners were released 10 January in Samangan province on the basis of Presidential amnesty decree (RA).

* A woman and two children were martyred 9 January as a result of ground to ground fire by the extremist elements in Gulbahar sub-division of Kohistan (RA).

* Ninety five per cent of construction work on the extension of Mazar-e-Sharif Silo which began in 1983 has been completed. The project is expected to be completed this year (RA).

* In a report, the weekly Observer (London) writes that Zahir Shah is the only Afghan personality who is capable of unifying the warring groups and forming an interim government acceptable to all (BBCFS).

* According to a Bakhtar report, six extremists, who were being trained in shelling methods under the supervision of foreign advisers, were killed and another five injured when a heavy gun exploded in a training center at Balazhara of Pakistan (RPDS).

* According to Radio Moscow a Soviet of ficial spokesman in Moscow said all the proposals made by Kabul on holding a dialogue with the former King Mohammad Zahir Shah have been rejected by the rpyal family (MIM).

* Addressing 9 January a camp of the Islami Jamiat Talaba in Mardan, the IUAM President Mawlawi Moharmad Yunus Khales alleged that the stunt of former King Mohammad Zahir Shah was raised by the enemies of Islam to weaken the resistance against the communists in Afghanistan. He reiterated that the ex-King was unacceptable to the Muslims as it would be a betrayal of the 1.5 million martyrs in Afghanistan who sacrified their lives to establish an Islamic society rather than return to the old system (MIM).

* Pakistan's UN Ambassador S. Shahnawaz left 8 January NY for Islamabad for consultations with the government amidst quickening pace of diplomatic activity for settling the Afghanistan issue

* At a conference 9 January in New Delhi the Italian Foreign Minister Guilio Andreotti said his country wants the former Afghan King Zahir Shah to return to his homeland in a bid to reach a settlement to the Afghanistan problem (PT).

* Talking to newsmen 9 January in Rawalpindi the ANP President Khan Abdul Wali Khan said Pakistan's security was seriously threatened because of Afghanistan problem and it should be resolved 
as early as possible (NWT).

* In an interview 9 January in Peshawar, leader of the Hezb-e-Islami Gulbuddin Hekmatyar said the mujaheddin neither sought any assistance from the US nor they would ask for it in the future. He said the mujaheddin waged resistance with their limited resources and they will continue it until the withdrawal of Soviet troops from Afghanistan and the end of Soviet backed government in Kabul (NWT)。

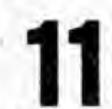

* In an interview to Radio Netherlands, President Ziaul Haq of Pakistan urged 11 January the Soviet Union to hold direct talks with Pakistan on the solution of the Afghanistan problem (RPDS).

* Radio Peking said hundreds of political prisoners in Afghanistan have been forced to join the armed forces of the Kabul regime and fight against the mujaheddin. The radio added 12 of these prisoners have been killed by the Kabul regime in Nangarhar province (RPDS).

* President Najibullah held talks 11 January with the special rapporteur of the UN Human Rights Commission, Felix Ermacora. The UN official expressed his gratitude for the facilities extended to him during the visit (RA).

* The special rapporteur of the UN Human Rights Commission, Felix Ermacora concluded his second visit to Afghanistan and left 11 January for New Delhi (RA).

* On behalf of the PDPA's Central Committee, a condolence message was sent to the Central Committee of the Pashtunkhwa National Awami Party on the death of Abdul Razzaq Doftani the Secretary General of that Party (RA).

* The Thirteenth supply convoy, comprising 220 transport vehicles carrying 1547 tons of foodstuff and essential commodities, arrived 11 January in Khost (RA).

* A delegation of the Executive Committee of the representatives of the council of Moscow city arrived 11 January in Kabul. During its stay in Kabul, the delegation will hold talks on educational, health, transport and construction matters in the framework of direct cooperations between the Kabul and Moscow cities (RA).

* Under the Presidential amnesty decree, 21 prisoners have been released in Farah province (RA).

* Documented evidences and a confession by a French citizen Alian Guollo, accused of espoinage and anti-government activities, in Afghanistan were shown 11 January to journalists at a press conference in Aryana Hotel, Kabul (RA).

* In its 11 January's issue, the Pravda writes hopes are being strengthened among world circles that the next round of Geneva proximity talks between Pakistan and Afghanistan in February will turn out to be the final round of such talks (RMDS).

* The Pravda writes that there is no obstacle for fixing a date for the withdrawal of Soviet troops from Afghanistan but the difficulty lies in the date for stopping US aid to the Afghan robels (RMDS).

* The Pravda has, for the first time, given a hint that the May, 1980, can become a date for starting the Soviet troops withdrawal from Afghanistan (BBCFS).

* A US State Department spokesman said in Washington the US is still looking for action rather than words and Moscow should immediately fix a date for the pull-out of its troops from Afghan- 
istan (VOADS).

* In its editorial 10 January The New York Times writes that having "come to its senses" the Soviet Union now needs courage to end its costly war with the mujaheddin. Iogic and interest argue powerfully for a Soviet withdrawal in 1988 of its troops in Afghanistan (MIM).

* A well placed source, connected with the Afghan refugee cell in the Interior Ministry, disclosed 10 January that a plan, containing detailed arrangements to move Afghan refugees from urban areas back to the camps mostly in the NWFP, is in the making. The source expected all the refugees to be back to camps near Afghan border by the middle of this year (MIM).

* In an interview with Radio Netherlands, President Ziaul Haq has said that both politically and geo-politically the stability of the region was disturbed by Soviet movements in Afghanistan and its presence in the region was a direct threat to smaller states (PT).

* In an interview with The Observer (Iondon), the former King Zahir. Shah has said that he is awaiting a message to proceed to the country. According to the paper, Zahir Shah has laid three conditions for his return to the country, i.e. the Afghan nation should be given an opportunity to form a free government at their own will, the government should enjoy the authority to expel Najib and his colleagues and the Soviet troops should withdraw (JG).

* The Afghan Publicity Center says the mujaheddin captured 3 January in Nangarhar near Pakistani borders 30 mules loaded with Soviet wine and vodka intended for Pakistan. The smuggler said the beverages were supplied by the KHAD officials in Jalalabad to be sold in Pakistan (VOAPS).

\section{2}

* At a press conference, while expressing gratitude to the socialist countries for their assistance to the Afghan revolution, the Afghan Ambassador in Bulgaria Mehrabuddin Paktiawal said new efforts and ideas should be tackled for the establishment of peace in Afghanistan (RMDS).

* A BBC commentator Gordon Adam says the significance of Soviet statements about Afghanistan during the past 15 days is that the hint of a Soviet troops pull-out from Afghanistan without reaching an agreement on the pattern of the future government of Afghanistan (BBCFS).

* The Financial Times writes 12 January, the Soviet Union agrees on the formation of an interim government headed by Zahir Shah to prevent disturbance in the country (BBCFS).

* The BBC correspondent in Islamabad writes in The Guardian that the hardline mujaheddin leaders believe they are at the threshold of a military victory. They say, the least reconciliation and compromise with the enemy will be tantamount to a treason to the aspirations of the mujaheddin who not only want a withdrawal of the Soviet troops but also the establishment of an Islamic government in Afghanistan (BBCFS).

* In its issue of 11 January The Wall Street Journal writes that Soviet leader Gorbachev has intensified his efforts for a Soviet pull-out from Afghanistan because the eight year long war has caused great financial losses and international prestige to Moscow (VOADS).

* In an interview, the Pakistan Minister of State for Foreign Affairs, Zain Noorani said Pakistan is ready to cooperate with the Soviet Union for an immediate solution of the Afghanistan problem * President Najibullah met 12 January with the Alingar, Laghman, elders and issued necessary directives for the elimination of their problems (RA). 
* The delegation of the Executive Committee of the Council of Representatives of Moscow City held talks 12 January with the Kabul Mayor on municipals problems of the Kabul people and problems arising from an influx of population in the city and promised Soviet cooperation in solving these difficulties (RA).

* At the invitation of the Ministry of Religious Affairs and Endowments, a delegation of the Religious Department of the Central Asia and Kazakhistan USSR, headed by Mufti Shamsuddin Baba Khan, arrived 11 Jamuary in Kabul on a friendly visit to Afghanistan (RA).

* Two persons, affiliated with the French relief organizations, who witnessed recent Soviet bombings in Paktia, said on their return 11 January to Peshawar, the people of Khost need foodstuff and clothings. Twelve thousand families have been rendered homeless and have moved to Pakistan as a result of these bombings (VOADS).

* An Afghan Foreign office source told Bakhtar that the Bmbassy of the Republic of Afghanistan in Democratic Peoples Republic of Korea was inaugurated 11 January in Pyongyong (RA).

* Fourteenth supply convoy of 134 transport vehicles, carrying 790 tons of foodstuff and essential goods, arrived 12 January in Khost (RA).

* According to reports reaching Bakhtar, two persons were killed in a scuffle between two Afghan extremist groups on the distribution of US arms in Miranshah (RA).

* Dr. Mohammad Hassan Kakar, who was arrested in 1982 and released last March, migrated 15 days ago to Pakistan. He says the Soviet and Kabul communists did not refrain from torturing prisoners and the tortures comitted by them cannot be translated into words (VOAPS). * US officials have cautiously reacted to the latest Soviet proposal suggesting the 1st of May, 1988, as a date for the beginning of its troops withdrawal from Afghanistan. The US Defense Secretary Frank Carlucci says the US cannot trust such pronouncement. He said the Soviets have been making such statements in the past as well. He added, as it was easy for the Soviets to enter Afghanistan, it should also be easy for them to withdraw from Afghanistan provided they want to withdraw (VOAPS),

* Talking 11 January to newsmen in Islamabad, the ANP President Khan Abdul Wali Khan said the Afghan issue can be resolved only through a political settlement. He said the issue had been unnecessarily played up by the Zia-Junejo regime to divert the people's attention from the internal problems occuring from the ten years of martial law (MIM).

* As diplomatic activities to resolve the eight years old Afghan crisis reach a crucial juncture, tension between the various resistance groups seems to be increasing (MIM).

* In an interview with a French daily, L'Figaro, the Pakistan Minister of State for Foreign Affairs has expressed cautious optimism on the solution of Afghanistan issue. He said Pakistan would go half way in peace efforts if the Soviets were sincere in withdrawing their troops from Afghanistan this year (MIM).

\section{3}

* President General Mohammad Ziaul Haq and Prime Minister Mohammad Khan Junejo of Pakistan have said members of the present goverrment in Afghanistan should be included in an interim government after a peace accord in that country (BBCFS).

* In an interview, the UN mediator Diego Cordovez has said he would soon visit Pakistan and Afghanistan to pave the way for the next round of indirect talks on Afghanistan next month in Geneva 
* The NIF leader Sayyed Ahmad Gailani says we are not interested in only a Soviet withdrawal from Afghanistan. We also demand a solution of the Afghan problem on an international level and reaching a comprehensive agreement on the future of the country (BBCFS).

* The TUAM President Mawlawi Mohammad Yunus Khales says the Soviet Union does not intend to withdraw its troops from Afghanistan unless it is satisfied that a non-Islamic government will come into power in Afghanistan (BBCFS).

* The Jamiat-e-Islami leader Burhanuddin Rabbani believes it will not be possible for officials of the ruling PDPA and the mujaheddin leaders to work together in a coalition government (BBCFS).

* A former history professor at the Kabul University Dr. Mohammad Hasan Kakar, who has arrived in Peshawar after being released from jail, said the Kabul government is hated by the people and, after the Soviet troops withdrawal from Afghanistan, the people of Kabul will topple this government even before the arrival of the mujaheddin (BBCFS).

* President Najibullah met 13 January with the UNDP Director in Afghanistan during which he stressed the need for UN assistance to Afghanistan (RA).

* President Najibullah received 13 January The Washington Post correspondent for an interview(RA).

* In a meeting 13 January with the preachers and imams of the mosques in Kabul, the Director of the Religious Affairs of the Central Asia and Kazakhistan of the Soviet Union Mufti Shamsuddin Khan said that clause 52 of Soviet Constitution guarantees freedom of religious rites of the Muslims and followers of other religions. He said mosques in the Soviet Union are full with worshippers at prayer times (RA).

* The New York Times writes the Pakistani officials and some of the Afghan leaders have proposed that an alternative for the solution of the Afghanistan issue will be to convene a loya jirgah with the participation of Afghans from inside and outside Afghanistan. This jirgah should decide about a transitory government (VOADS).

* The mujaheddin of Hekmatyar's Hezb-e-Islami claim to have actacked with heavy arms 30 December

a Soviet military base in Darzak, Kushk (Herat) killing 15 troops and injuring a number of others

(VOADS).

* Addressing 12 January a press conference in Peshawar the leader of Tehrik-e- Nifaz-Fiqah Jafferia (TNEJ) Sayyed Arif Hussain Al-Hussaini called upon the Afghan mujaheddin to beware of US mechinations as it aimed at avenging its debacle in Vietnam by exploiting the sacrifices of the Afghan Muslims. He advised the mujaheddin leadership not to be misled by stunts like Geneva talks and other western ploys and continue their resistance (MIM).

* Speaking at the parliament, the Pakistan Minister of States and Frontier Regions, Sayyed Qasim Shah denied the report that 70 Christian missions were active in the Afghan refugee camps (JG).

* In order to awaken the public opinion and to apprise the Pakistani politicians, journalists, religious scholars and lawyers of the importance of the Afghanistan resistance, a converition of the religious scholars was held 12 January in Islamabad which was attended by representatives from the four provinces belonging to various sections of society (NWT).

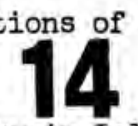

* A Foreign office spokesman said 14 January in Islamabad that Pakistan will extend all out cooperation to the UN Secretary General's special envoy on Afghanistan arriving 20 January in Islamabad and necessary preparations have already been made for his visit (RPDS). 
* An Indian Foreign Ministry spokesman said 13 January his country has been in contact for the last one year with a number of persons including Zahir Shah, various Afghan resistance groups, the US, Soviet Union and Pakistan leaders for finding a solution to the Afghanistan issue (RPDS).

* The Kabul based Radio Moscow correspondent reports that, following the opening of Gardez-Khost highway, shipment of goods from Azerbaijan of the Soviet Union to Khost has begun. The exports are made under an agreement about the establishment of direct links between the provinces of the two countries (RMDS).

* The political chief of the Kabul army General Ziarmal has admitted that fighting between the mujaheddin and Kabul troops, led by Soviet forces, continues near Khost (VOADS).

* A source of Jamiat-e-Islami Afghanistan said the niujaheddin attacked with rockets a Soviet military base in Herat causing a big fire in the base. Details of the losses are not yet available (VOADS). * In reply to a question whether the Soviet Union will withdraw its troops from Afghanistan even if Najib does not remain as head of the Kabul regime, the Soviet Foreign office spokesman told the US television network CBS 12 January, the question is part of the Afghan NRP. We think that it is upto the Afghans themselves to form a coalition government and select its components (VOAPS). * Intelligence agencies have succeeded in obtaining photographs of about 50 beautiful Afghan girls who have entered Pakistan for espoinage and subversive activities. These photographs have now been sent to different agencies to trap the spy girls (MIM).

* In an interview 13 January with VOA in Islamabad, the leader of Hezb-e-Islami Hekmatyar said the Afghan war would continue until the presence of a single Soviet troop in Afghanistan (MIM). * The UN special envoy on Afghanistan Diego Cordovez, who is to visit next week Kabul and Islamabad, is also expected to hold talks with the mujaheddin leaders in Peshawar on an interim government in Kabul (NWT).

\section{5}

* A Soviet government spokesman has said his country does not have any information about the US military adviser said to have been killed last month on Khost front in Paktia (RPDS).

* A Radio Moscow correspondent reports that 705 armed groups, comprising 41,000 people, joined the NRP during the last 12 months and 10,000 prisoners have been released from the jails and 110,000 Afghan refugees have returned to their country (RMDS).

* Chief of the Religious Department of Central Asia and Kazakhistan of the USSR Mufti Shamsuddin Khan and his entourage held talks 14 January with the Dean and Professors of the College of Theology of the Kabul University and heads of the religious schools in Kabul city on religious education. The delegation also presented to the Ministry of Islamic Affairs and Endowments 1,000 copies of the Holy Quran published in the Soviet Union (RA).

* A source of the Supreme Council of Religious Scholars and spirituals reports that the government expenditure on religious affairs of the people during the years of the revolution have exceeded Afs. two billion. This is three times more than the money spent on such affairs in the paist 50 years before the revolution. Similarly, 251 mosques, religious centers for the shias and other religious centers were constructed after the revolution. One thousand and 500 mosques, religious centers for the shias and other religious centers were constructed after the revolution. One thousand and 500 mosques, religious centers for the shias and other religious centers have been repai- 
red or renovated at the government expenditure (BA).*

* On the basis of Presidential amnesty decree, 64 prisoners were released 15 January in Badakhshan province (RA).

* A group of Western journalists, who came to Paktia province to find the facts about the situation in Paktia specially in Khost after the lifting of economic siege of the town, also visited 14 and 15 January other parts of Paktia as well as the outskirts of Khost (RA).

* The elders of North Waziristan held recently a grand national jirgah under the chairmanship of Malik Mohammad Alam and urged the Afghan extremists in Miranshah to leave and the area should not use the tribal areas to continue the war and fratricide (RA).

* The New York Times 15 January wrote the US officials have been surprised over the statement of Pakistani officials that communists may remain in the interim government as a condition for the withdrawal of the Soviet troops from Afghanistan (VOAPS).

* In an interview, broadcast by the BBC, UN special envoy on Afghanistan Diego Cordovez said he was convinced that the Soviet Union had a "firm intention" to pull-out its troops from Afghanistan. He said this political decision was taken by the Soviet leader Gorbachev immediately after assuming power (MIM).

* As many as 75 Afghan nationals suspected to be involved in sabotage activities have so far been handed over by the Pakistan authorities to the mujaheddin parties for further investigations (MIM). * A Pakistan Foreign Office spokesman has said all the concerned parties of the Afghanistan issue, wanting a political solution of the issue, have openly expressed their views that the future goverrment would be formed by the people themselves. He expressed these views when asked for conments on Indian reports suggesting that the Indian government has expressed support for the return of Zahir Shah as head of government in Afghanistan. The spokesman said the Afghan issue should be settled by the people of Afghanistan. As such, it is quite unreasonable for any outsider to give opinion about the future government in Afghanistan (JG).

* It has been reliably learnt that the Soviet Deputy Foreign Minister will visit Pakistan late this month to discuss the Afghanistan issue (NWT).

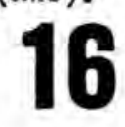

* In an interview with the APP at the UN, the UN mediator on Afghanistan, Diego Cordovez described his forthcoming visit to Pakistan and Afghanistan as an important diplomatic exercise (RPDS).

* Following his meeting with the Soviet leader Gorbachev, the Soviet opposition leader Andrie Sukharov told newsmen that a speedy withdrawal of Soviet troops from Afghanistan is necessary and it should be with no conditions (RPDS).

* US government officials have expressed concern over the impact of a halt of US aid to Pakistan on. mujaheddin's war against the Soviet troops and say that Pakistani cooperation in providing military aid to the mujaheddin is necessary (VOADS).

* President Najibullah received 16 January a jirgah of the Kunar province as well as a number of other compatriots and issued directives for the removal of their grievances (RA).
Mohmand tribes and the people of listened to their petitions and 
* The Bakhtar Bicycle Manufacturing Factory a joint government-private enterprize was inaugurated 16 January in Pul-e-Charkhi Industrial Estate (RA).

* The Afghan-Soviet Friendship Award was conferred 16 January on the head of the Religious Department of Central Asia and Kazakhistan Mufti Shamsuddin by the Deputy Prime Minister Guldad (RA). * On the basis of Presidential amnesty decree, 373 prisoners were released 16 January from jail in Balkh province (RA).

* On the eve of NRP's anniversary 16 January, President Najibullah said we can witness the NRP's internationalist aspect in the fact that its roots belong to Lenin's ideas about peace and it is a basic objective of all social revolutions (RA).

* A former Fimish Ambassador to the UN has said if the Soviet Union withdraws its troops from Afghanistan and leaves that country alone it would be indeed an unprecendented political act. (BBCPS).

* President Najibullah of Afghanistan has announced to hold national and regional elections. He has invited the opposition parties to take part in the elections. He did not mention a date for these elections but said that election campaign would soon begin (VOAPS).

* Addressing-a press conference 15 January in Peshawar, a noted Afghan historian Professor Dr. Mohammad Hassan Kakar, after his escape from Afghanistan, said he doubted the sincerity of the Soviet Union to withdraw its troops from Afghanistan (MIM).

* In an interview with the AAP the leader of Jamiat-e-Islami Afghanistan, Burhanuddin Rabbani said Afghan mujaheddin leaders are ready to meet the Soviet leader Gorbachev (JG).

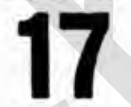

* President Najibullah of Afghanistan said 16 January in Kabul that general elections to a National Assembly and local bodies elections will be held in the country and a law for elections will soon be approved (RMDS).

* TASS reported that President Najibullah has once again invited the mujaheddin organizations of Afghanistan for talks and participation in the elections. The IUAM in Peshawar has already turned down the offer (VOGDS).

* The chief of Soviet Army Staff said 16 January not only Soviet troops would be withdrawan from Afghanistan but military units and arms would also be pulled-out and the present Soviet arms in Afghanistan would not be handed over to the Afghan army (VOGDS).

* President Najibullah received 17 January a British television team for an interview and answered questions about the political and military importance of Khost military operation and about the Soviet troops pull-out from Afghanistan (RA).

* About the forthcoming visit of the UN Special envoy to Pakistan and Afghanistan, a (Kabul) foreign Ministry spokesman said 17 January that ground has been paved for a final agreement on the talks. Three out of four instruments, under discussion, have almost been finalized and it is hoped that the fourth instrument, pertaining to the withdrawal of the limited contingents of Soviet troops from Afghanistan would also be finalized on the basis of positive stand of the Afghan side provided the other side also exhibits goodwill and political realism (RA).

* At the invitation of the Czechoslovak Council of Ministers, an Afghan government delegation, led by * US senator Steven D. Symns visited today an Afghan refugee camp in Peshawar (RPDS). 
the Deputy Prime Minister Sayyed Amanuddin Amin, left 17 January for Czechoslovakia. During its stay the delegation will hold talks with the Czechoslovak officials on promotion of economic relations and establishment of joint projects with the participation of government and private sector (RA).

* In honor of the first anniversary of the NRP, a religious seminar was held 17 January under the auspices of the Ministry of Islamic Affairs and Endowments, the Supreme Council of the Religious Scholars and Spirituals in cooperation with the Central Committee of the Afghan Youth Organization (RA).

* A protocol on economic assistance in the framework of direct cooperation between the Flectricity Department of Moscow City and Kabul Electricity Department was signed 17 January in Kabul. Under the protocol, the Moscow City Electricity Department will provide implements and workshop equipment for the repair of transformers and oil storages worth rubles one million as a grant to the Kabul Electricity Department (RA).

* A protocol for the promotion of direct relations between Kabul and Moscow cities, under the framework of a cooperation agreement for 1988-1990, was signed 17 January in Kabul Municipal Corporation (RA).

* A grand jirgah of Uzbek and Turkaman nationalities, was held 17 January in the Ministry of Nationalities to mark the first anniversary of the NRP (RA).

* Hundreds of Paktia toilers met 17 January in Gardez city to celebrate the reopening of GardezKhost highway and the lifting of the economic siege of the city (RA).

* The agreement on the appointment of Assadullah Keshtmand as Ambassador of Afghanistan in Hungary has been received (RA).

* At a press conference 17 January in Moscow, the Soviet Deputy Foreign Minister V. Petrovsky said there is favorable background for achieving a final agreement on Afghanistan on the next round of proximity talks in Geneva (RA).

* Speaking 16 January in the "meet the Press" program of Karachi Press Club, the JI Chief Qazi Hussain Ahmad said the Afghan issue could best be solved through direct talks between the Soviet Union and the Afghan mujaheddin. This suggestion, he said, has been conveyed to the Soviet Ambassador in Pakdstan by him in a recent meeting (MIM).

* The Paldstan Minister of State for Foreign Affairs Zain Noorani gave 16 January a thorough briefing on the Afghan issue to the Senate standing committee on Foreign Affairs (MIM).

* A Kabul Foreign Ministry spokesman said the indirect Geneva talks with Pakdstan have been fruitful and have paved the way for a realistic solution of the Afghan problem (BBCFS).

* Jean Francois Deniau, a prominent politician and adviser to the French Prime Minister, held talks 18 January with the Pakistan Minister of State for Foreign Affairs Zain Noorani in Islamabad on the recent developments about Afghanistan issue (RPDS).

* In an interview with The Washington Post, the Foreign Minister of Kabul regime Abdul Wakil said, on the basis of an understanding between Kabul and Moscow, the withdrawal of Soviet troops from Afghanistan will start two nont $s$ after signing the documents of indirect Geneva talks (RPDS). 
* A military parade was held 18 January in the Revolution Ground of Kabul City to celebrate the victories of the armed forces in lifting the nine year long economic siege of Khost and reopening of the Gardez-Khost highway (RA).

* Prime Minister Sultan Ali Keshtmand met 18 January the President of Soviet Academy of Sciences who is visiting Kabul at the head of a delegation and exchanged views with him on cooperation between the science academies of the two countries (RA).

* A protocol on cooperation between the Religious Department of the Muslims of the Central Asia and Kazakhistan of the Soviet Union and the Ministry of Religious Affairs and Endowments of the Republic of Afghanistan was signed 18 January in Kabul (RA).

* A group of journalists from socialist and capitalist countries arrived 18 January in Kabul on a fact finding trip about the NRP and lifting of the Khost economic siege (RA).

* Twenty six prisoners were released 18 January on the basis of Presidential armesty decree in Ghazni and Takhar provinces (RA).

* A British adviser of the extremist anti-revolutionaries was killed recently during military operation in Afghanistan (location not mentioned) (RA).

* In a statement published in The Washington Post 11 January the IUAM President Mawlawi Mohammad Yunus Khales has ruled out cooperation with the communists and said how the Afghans, who have lost their kiths and kins during the eight year war with the communist, can cooperate with them (VOADS). * In an interview with The Washington Post the Hezb-e-Islami Chief Hekmatyar has said we do not expect from Pakistan to ask us to participate in a government with the Soviet puppets (VOADS).

* In an interview with The Washington Post the JI Chief Qazi Hussain Ahmad said the Soviets should hold direct talks with the mujaheddin for the solution of Afghanistan problem (VOADS).

\section{9}

* The UN mediator on Afghanistan Diego Cordovez has hoped that the final round of talks on Afghanistan will begin late February (BBCFS).

* President Najibullah met 19 January in Kabul with a delegation of Soviet Academy of Sciences and discussed scientific cooperations between the two countries (RA).

* A protocol of cooperation between the Academy of Sciences of Afghanistan and the Soviet Academy of Sciences was signed 19 January in Kabul (RA).

* The Deputy Prime Minister, Sayyed Amanuddin Amin, now visiting Czechoslovakia at the head of a delegation, held talks 18 January with Czechoslovak authorities on the promotion of economic and trade relations between the two countries (RA).

* A protocol for the development of the Ghazni electric supply project was signed 19 January in Kabul between the Republic of Afghanistan and the Moldavian Republic of the USSR (RA).

* An agreement for the supply and procurement of equipment required for the exploration of gas in Jarq-Duq, Jauzjan, and equipment for oil and gas wells was signed 19 January in Kabul between the Economic Attache of the Soviet Embassy and Ministry of Mines and Industries (RA).

* Seventeenth convoys of 150 transport vehicles carrying 1,207 tons of essential goods arrived 
19 January in Khost (RA).

* The Soviet Union has supplied 530 items of goods including foodstuff and clothings worth 150 million rubles to Afghanistan as a grant for the implementation of NRP (RA).

* The IUAM President Mawlawi Mohammad Yunus Khales says the Geneva proximity talks should be abandoned and only the mujaheddin and the Soviet Union should be identified as the real parties in the talks (VOADS).

* Mawlawi Mohammad Yunus Khales has laid down four conditions for the solution of Afghanistan dispute.

- - Soviet Union and the mujaheddin should be identified as the real parties at talks,

- Geneva talks should be set aside,

- - Soviet Union should explicity express desire for a political solution of the Afghan problem,

- - the mujaheddin should be the only party to reply the Soviet announcements (VOADS).

* In an interview with The Washington Post, the Kabul regime's Foreign Minister Abdul Wakil has said although a number of problems are yet to be resolved, the next round of Geneva talks would prove to be final and decisive. He said all the documents which are to be signed, have been somewhat finalized. The American side, he said, has agreed to be one of the guarantors and we welcome this gesture (MIM).

* According to a VOA report, the IUAM President Mawlawi Mohammad Yunus Khales in a statement has again ruled out the possibility of mujaheddin accepting a coalition with the Kabul regime leaders

* In an interview with The Washington Post the Foreign Minister of Kabul regime has said, under an agreement between Moscow and Kabul, the withdrawal of Soviet troops from Afghanistan will begin two months after signing all the four instruments of an agreement on the solution of Afghanistan problem by Pakistan and Afghanistan at the Geneva talks (NWT).

* Western diplomats in Islamabad say Soviet-Kabul troops are increasing their pressure on the Afghan guerrillas strongholds near areas bordering Pakistan (BBCFS).

\section{0}

* President Najibullah of Afghanistan told a group of foreign journalists in Kabul that the current year might be the last year of Soviet troops' presence in Afghanistan (RMDS).

* Special UN envoy on Afghanistan Diego Cordovez arrived 20 January in Islamabad to make preparations for the next round of indirect Geneva talks on the Afghanistan problem (RPDS).

* On the conclusion of his visit to FRG, the Soviet Foreign Minister, Eduard Shevardnadze said Soviet troops will be pulled out from Afghanistan within 12 months and the process of withdrawal can be accelerated (RPDS).

* President Najibullah of Afghanistan has said if a complete agreement is reached between Pakistan and Afghanistan at the Geneva talks next month, 1988 can become the last year of the Soviet troops presence in Afghanistan (BBCFS).

* Leaders of the seven mujaheddin groups have so far not reached an agreement whether to meet UN 
special envoy on Afghanistan during his visit to Pakistan (BBCFS).

* The Kabul government Health Minister Sher Bahadur will visit next week England to participate in a conference on "AID". He is the highest Afghan government official to visit Britian after the Soviet invasion of Afghanistan (BBCFS).

* The great Pashtun leader and a struggler for peace, freedom and justice Khan Abdul Ghaffar Khan died 20 January in Peshawar after a six months prolonged illness. Khan Abdul Ghaffar Khan, according to his own wish, will be buried in his house in Jalalabad (RA).

* The Kabul University has for the first started its program for offering PhD diplomas to its students (RA).

* On the basis of an instruction issued by President Najibullah, the Council of Ministers has changed the name of Bakhtar Afghain Airline to Ariana Airline Corporation (RA).

* The ordinary session of the Afro-Asian writers Association was opened 20 January in Kabul (RA).

* Badges and medals were conferred 19 January on the Khost army officers who had exhibited enthusiasm in the performance of their duties (RA):

* Under the Presidential decree, 72 prisoners were released in Balkh province (RA).

* US President Ronald Reagan assured 19 January all freedom fighters that Soviet troops will definitely pull out from Afghanistan and the US would never enter any agreement which might harm the Afghan people's right to self-determination (VOAPS).

* Mawlana Mohammad Afzal of Nooristan has told a Pakistani news agency that the Soviet Union is not sincere in the withdrawal of its troops from Afghanistan (VOAPS).

* In a statement, the TUAM President Mawlawi Mohammad Yunus Khales has instructed the mujaheddin that, as Islam does not allow disgrace to the dead, all military activities between Jalalabad and Torkham should be suspended until all the people attending the funeral of Khan Abdul Ghaffar Khan return to Peshawar from Jalalabad (VOAPS).

* In a policy statement issued 19 January by the Afghan Islamic Press, the IUAM President Mawlawi Mohanmad Yunus Khales has announced in Peshawar the leaders of seven party alliance were at present unwilling to meet the UN mediator on Afghanistan Diego Cordovez (MIM).

* The UN mediator on Afghanistan said 19 January in NY steps to create a new government in Kabul could be taken quickly once the Soviets set a time-table for the withdrawal of its troops. He said "I think, when we get an agreement on the time-frame, things will change dramatically (MLM).

* According to Teheran Radio, the Deputy Chief of the Soviet Novosti news agency has said that the former Sovilet leader Brezhnev committed a mistake to send troops to Afghanistan (PT).

\section{1}

* Afghan mujaheddin leaders turned down 19 January present UN peace efforts and said the mujaheddin and the Soviet Union should be identified as real parties of the Afghan dispute (VOADS). * The UN special envoy on Afghanistan Diego Cordovez has began his talks in Pakistan (BBCFS). * The Soviet military organ The Krasnayas Zvezda writes the US continues to create hinderances in the solution of Afghanistan problem. It says Washington is persuading Islamabad to pursue its policy of supporting the anti-revolutionaries of Afghanistan (RMDS). 
* President Najibullah met 20 January the Indian vice-President now visiting Kabul at the head of a high level delegation for participation in the funeral rites of Khan Abdul Ghaffar Khan. In the meeting Najibullah stressed the importance of historic relations between India and Afghanistan and appreciated Indian support to the Afghan people (RA).

* While overflying 20 January the Afghan territory, the Indian Prime Minister Rajiv Gandhi in a message to President Najibullah, hoped that peace and tranquility would be restored in Afghanis$\tan (\mathrm{RA})$.

* At the invitation of the Central Committee of the Afghanistan Youth Organization, a seminar of Asian students on "Education, training, progress and society" will be held in Kabul (RA).

* Under the amnesty decree, 130 prisoners were released 21 January from Pul-a-Charkhi Prison (RA).

* An armed extremist group, indulging in subversive activities Zurmat out-skirts, Paktia, was wiped out 20 January with the cooperation of the people (RA).

* In a recent fierce clash between an Afghan extremist group and the Iranian revolutionary guards on Pakistan-Iran borders, two extremists were killed (RA).

* The Afghan resistance sources reported they attacked a Soviet-Kabul military convoy (place and time was not mentioned) inflicting heavy losses in men and material to communist troops (RPDS). * The opposition sources in Poland say Polish police has arrested six persons who staged a demonstration in front of the Soviet Consulate in Cracow demanding Soviet troops withdrawal from Afghanistan (VOAPS).

* On his arrival 20 January at the Islamabad airport, UN mediator Diego Cordovez indicated that he would not only discuss a time-frame for the withdrawal of Soviet troops but would also discuss matters related to the Afghanistan problem in order to finalize a settlement. (MIM)

* In an interview with The Muslim 20 January, Sayyed Ahmad Gajlani has sharply criticized the statement of the IUAM President Mawlawi Yunus Khales announcing mujaheddin's boycott of talks with UN envoy Diego Cordovez (MIM).

* The Afghan government has announced a four day state mourning in the country and has cancelled all festivals to condole the death of freedom fighter Khan Abdul Ghaffar Khan, Radio Kabul reported 20 January (MIM).

* Faqir Mohammad, an agent of KHAD, was caught by Afghan mujaheddin in Jaji Maidan while trying to cross into Pakistan territory with large quantity of explosives and currency for distribution amongst KHAD agents in Pakistan. He was handed over to mujaheddin shariah court in a liberated areas of Afghanistan. He was awarded a death punishment and executed (PT).

\section{2}

* Australia recognized 22 January the states of Afghanistan, Kampuchea and Fiji but not their regimes. Australian Prime Minister Bob Hawke said in Canberra that Australia does not acknowledge the ruling regines in those countries and recognition of a state does not necessarily imply the recognition of the regime in power (RPDS).

* The fumeral rites of the great Pashtun leader Abdul Ghaffar Khan were held 22 January at his residence in Sheesham Bagh, Jalalabad (RA).

* In a recent statement, the President of "the so-called IUAM", Yunus Khales has said that his 
ap has turned down the NRP of the Republic of Afghanistan and does not recognize the government of the Republic of Afghanistan as a possible party at talks on the restoration of peace and selfdetermination for the people of Afghanistan (RMDS).

* The Afghanistan resistance sources report that five Soviet aircraft have been shot down recently by the mujaheddin at different locations in Afghanistan (RPDS).

* The UN envoy on Afghanistan Diego Cordovez met 21 January Prime Minister Mohammad Khan Junejo in Islamabad. During the important meeting, lasting more than an hour, all out-standing aspects of the Afghanistan problem were discussed (MIM).

* Another leader of the seven party IUAM, Professor Sebghatullah Mojaddedi told 21 January The Muslim he strongly disagree with the statement of Mawlawi Mohammad Yunus Khales in which he announced a boycott of talks with the UN envoy Diego Cordovez (MIM).

* Speaking at a dinner 20 January in Madrid, Spain, Sovlet Foreign Minister Bduard Shevardnadze promised a fast withdrawal of Soviet troops from Afghanistan if UN mediated negotiations in Geneva produced a peace accord next month (MIM).

\section{3}

* The UN Special envoy on Afghanistan, Diego Cordovez left 23 January Islamabad for Kabul. He confirmed in Islamabad that the withdrawal of the Soviet troops from Afghanistan is not a precondition to the formation of a coalition government in Kabul (BBCFS).

* The BBC correspondent in Islamabad reports in a statement 22 January the seven Afghan guerrilla parties described Khan Abdul Ghaffar Khan as a prominent Pashtun leader and said his death was an irreparable loss. The seven parties denied their involvement in the bomb explosion and held the Kabul regime responsible for the blast (BBCFS).

* The Daily Telegraph (Iondon) wrote 23 January it is not clearly understood who carried the bomb explosion at the funeral rites of Khan Abdul Ghaffar Khan in Jalalabad but a source close to the ANP believes that dissidents inside the PDPA were responsible for the explosion (BBCFS).

* A condolence meeting was held for Khan Abdul Ghaffar Khan 23 January in the Sherpur Mosque Kabul city, under the auspices of the government and National Front of Afghanistan (RA).

* On the sad demise of Khan Abdul Ghaffar Khan a message of condolence was sent to the ANP Central Committee by the Toilers Organization of Afghanistan (RA).

* In an explosion 23 January by the criminal extremists at a Jalalabad bus stand during the funeral rites of Khan Abdul Ghaffar Khan, eight persons were martyred and 47 others injured (RA).

* An International Symposium of writers on "Writers and the NRP" was opened 23 January in Kabul with the participation of writers frorn Africa and Asia and prominent cultural and literary figures of Afghanistan (RA).

* The vice President of the Islamic Unity Council of Afghanistan Sayyed Hussain Aalami, has described the present situation in Afghanistan as promising (MIM).

* Two alleged terrorists, who were arrested 20 January from Rawalpindi with a huge quantity of explosives, were termed 22 January by the police as KHAD agents (MIM).

* In his address 22 January on the fumeral of Khan Abdul Ghaffar Khan in Jalalabad, President Najibullah of the Kabul regime told the mourners that Afghan refugees should come back to their 
homes. He said, "I announce that Russian troops will withdraw soon from Afghanistan" (PT).

* Addressing 21 January a meeting in Karachi, former Foreign Minister of Pakistan Sahebzada Yaqub Khan said 1988 would prove to be decisive for the solution of Afghanistan dispute (JG).

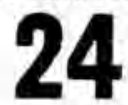

* About the explosions in Jalalabad on the eve of the funeral rites of Khan Abdul Ghaffar Khan, the IUAM President Mawlawi Mohammad Yunus Khales said the Kabul regime has always been looking for an opportunity to create rift among the Afghans and it has committed these explosions through its activists, Common sense cannot believe that it would have been done by the mujaheddin (VOADS).

* On his arrival in Kabul, the UN special envoy on Afghanistan Diego Cordovez said the Paldstani leaders are ready to extend an all out help in seeking a solution to the Afghanistan problem (RPDS;

* The UN special envoy on Afghanistan, Diego Cordovez held talks 23 January in Kabul, with the Afghan Foreign Minister Abdul Wakil on the situation around Afghanistan. He hoped this phase of negotiations will be the final round of UN talks on Afghanistan (RMDS).

* UN envoy on Afghanistan Diego Cordovez has said it appears that all the concerned parties to the Afghan conflict desire.an early settlenent of the 1ssue (BBCFS).

* In an article 24 January, The Observer (Iondon) writes the Afghanistan government was more than happy to fulfill Khan Abdul Ghaffar Khan's will that he should be buried in Jalalabad, for it has provided abundant opportunity to the government for propaganda (BBCFS).

* President Najibullah exchanged views 24 January with the UN special envoy Diego Cordovez on matters related to the process of the settlement of the situation around Afghanistan (RA).

* President Nafibullah received 24 January the delegations of Afro-Asian writers participating in the international symposium of writers and the reconciliation (RA).

* The President of Pakistan says he is not ready to sign any agreement with Najibullah or the puppet regime headed by him. The Washington Post describes this statement of Ziaul Haq last week in Islamabad as a change in Pakistan's stand (VOADS).

* In an interview with The Washington Post President of Paristan General Ziaul. Haq has said Soviet casualties in Afghan war were 35,000. He said the USSR has lost 1,600 tanks and 1,000 aircraft in the Afghan war (VOADS).

* Kandahar mujaherdin say, 35 prominent mujaheddin commanders have reported acute shortage of foodstuff, medicines, clothings and even arms and have asked the leaders of Afghanistan resistance in Peshawar for solving their difficulties lest the resistance would face failure (VOADS).

* In a statement, a leader of Great United Front of Afghanistan (Afghanistan Melli Islami Muttehedda Jabba) Haji Almas said the Afghan people believe that only the former King Zahir Shah - - a man of rare insight and calibre - - can play a historic role in defusing the Afghan crisis and bringing peace and stability to the war ravaged Afghanistan (PT).

* In a statement to The Nawa-i-Wagt a spouse of a foreign diplomat based in Kabul said that the people of Kabul city and the diplomats were very much harrassed of the activities of the antirevolutionaries (The paper did not mention the name of the diplomat's wife) (NWT). 


\section{5}

* Afghan President Dr. Najibullah says his country will participate in the forthcoming indirect talks with Pakistan with goodwill and flexibility (BBCFS).

* In a commentary the VOA says the US government is ready to guarantee an international settlement if such a solution ensures a complete and immediate withdrawal of the Soviet troops and after the Soviet troops pull-out, the present regime does not hold any privilege over the resistance forces (VOADS).

* Pakistani officials said in a bomb explosion 25 January at a bus stand in Mingoras, Peshawar, at least 9 persons were killed and 27 others injured (VOADS).

* A high level Afghan delegation, led by the First Deputy Premier Sayyed Amanuddin Amin, which had gone to Czechoslovakia on an official visit, returned home 25 January. The delegation held talks on promotion of economic relations between the two countries and the establishment of joint Afghan-Czechosolvak factories in Afghanistan (RA).

* A high level delegation of Kazakhistan and Azerbaijan of the USSR arrived 25 January in Kabul at the invitation of the Department of Direct Cooperation of the Council of Ministers of Afghanistan (RA).

* A delegation of the Soviet Construction Committee arrived 25 January in Kabul on an official and friendly visit at the invitation of the Afghan Ministry of Constructing Affairs (RA).

* In a message addressed to the Peace, Solidarity and Friendship Organization of Afghanistan, the Soviet Afro-Asian Solidarity Comittee has expressed profound sadness at the death of Khan Abdul Ghaffar Khan (RA).

* On the basis of Presidential amnesty decree, 195 prisoners were released 25 January from Pul-eCharkhi jail (RA).

* The Director General of Planning, in the Ministry of Agriculture and Land Reforms says the UNDP will provide in 1988 more than $\$ 1,419,700$ to the Ministry of Agriculture and Land Reforns for the development of forestry, hybrid seeds, planning and bee farming (RA).

* Badakhshan Kohi province of Tadzhikistan Soviet Republic has given 1,200 tons of wheat, 400 tons of edible oil, 800 tons of rice, and 200 tons of salt to the Badakhshan province of Afghanistan as aid (RA).

* The UN mediator on Afghanistan Diego Cordovez met 24 January the Afghan President Najibrillah Kabul (MIM).

* Diego Cordovez UN special envoy on Afghanistan said 24 January his visit to Pakistan and Kabul is taking place at a time when prospect for an agreement on the final settlement of the Afghanistan problem looks brighter (MIM).

* The Jamiat-o-Islami Afghanistan leader Professor Burhanuddin Rabbani, NLF leader Professor Sibghatullah Mojaddadi and senior mujaheddin leaders of Nangarhar have rejected Kabul regime's allegations that the mujaheddin had carried the two bomb explosions in Jalalabad (MIM).

\section{6}

* A branch office of the UNHCR in Pakistan was inaugurated 26 January in Lahore. The Punjab gov- 
ernor assured that the provincial government would render all kin's of assistance to the office

(RPDS).

* In his 7th State of the Union Message, the US President Ronald Reagan said the Afghan mujaheddin are the key to peace and security in Afghanistan. We support them and no settlement is possible there except the total withdrawal of Soviet troops and granting the right of self-determination to the people of Afghanistan (VOADS).

* The Washington Post wrote 25 January while Moscow is exhibiting enthusiasm in its troops pullout from Afghanistan, it is increasing its interference in the daily life of the Afghan people

(VOADS).

* The Washington Post wrote 25 January although the Afghan indignation against the Soviets is in its climax, Moscow's influence will remain there even if the Soviets leave Afghanistan under the conditions fixed by the Afghans (VOADS).

* Under article 8, clause 75 of the constitution, the Afghanistan President has pardoned the following opposition commanders who had been sentenced to capital punishment in absentia:

1. Ahmad Shah Masood son of Dost Mohammad, of Panjshir,

2. Jalaluddin Haqqani son of Fateh Mohammad of Urgun,

3. Abdul Saboor son of Abdul Shakoor of Kapisa,

4. Mohammad Fana son of Mohammad Amin of Panjshir,

5. Mohammad Ismail son of Mohammad Aslam of Herat,

6. Saleh Mohammad son of Abdul Qayyum of Kandahar.

* Afghan Foreign Minister Abdul Wakil and the UN special envoy on Afghanistan Diego Cordovez exchanged views 26 January in Kabul on the settlement of situaition around Afghanistan and preparations for the next round of Geneva talks (RA).

* A high level delegation of the Soviet State Construction Committee met 26 January the Afghan Building Minister, Nazar Mohammad In Kabul. The delegation assured the minister of assistance and promotion and expansion of Soviet scientific and technical cooperation (RA).

* A delegation of the Kazakhistan of the USSR held talks 26 January in Kabil with the governors of Kandahar, Zabul, and Uruzgan on direct cooperations between those provinces and the Kazakhistan of the USSR (RA).

* An agreement was signed recently in Kabul between the United Beneficiary Institution of the Soviet Foreign Trade and the Afghanistan Mines and Industries Ministry on the export of gas from Afghanistan to the Soviet Union (RMDS).

* On the conclusion of his three day visit to Kabul, the UN envoy on the Afghanistan returned 26 January to Islamabad. His talks in the Afghan capital made no headway in the advancement of his mission (BBCFS).

* In an interview with a local newspaper of Arlington, Virginia, USA on the Afghanistan issue, the former Afghan King Mohammad Zahir Shah has said he has no ambition for reviving his monarchy in Afghanistan and he simply wants peace and progress in Afghanistan after the current war (VOAPS) * The Pakistan President Ziaul Haq says all the groups in Afghanistan should unite and share the coalition government. He said these two objectives are also shared by Washington and Moscow(BBCPS) 
* The Kabul regime leader Najibullah told 25. January UN mediator on Afghanistan Diego Cordovez the Afghan delegation would take part in the next round of Geneva talks with good will and political determination so that a settlement was concluded, reported Radio Kabul (MIM).

* Talking 25 January to newsmen at a Bulgarian Rmbassy reception in Islamabad, the Soviet Ambassador in Pakistan Abdul Rehman Vezirov said the Soviet Union was very keen to have the Afghan issue resolved as soon as possible (MIM).

\section{7}

* The Pakistani government has proposed to the UN special envoy Diego Cordovez to extend his stay in the region for the solution of important issues of the Afghanistan problem before the finalization of the Geneva agreement (RPDS).

* Leaders of the IUAM in Pakistan have expressed their willingness to meet the UN envoy Diego Cordovez presently visiting Islamabad (BBCFS).

* The Guardian (London) wrote 27 January that Pakistan is not ready to sign any agreement until a coalition government comes into power in Kabul. Because it apprehends that when the Soviet troops withdraw from Afghanistan prior to the formation of a coalition government in Kabul, Afghan istan would be engulfed by disturbance and bloodshed (BBCFS).

* Quoting diplomatic sources The Washington Times wrote 27 January confused and nervous Afghan communists are planning to procure foreign exchange and passports to flee Afghanistan prior to the Soviet troops withdrawal from the country. It says some locals as well as the members of the Soviet families have already left the country (VOADS).

* The Afghan government has pardoned the "ring leaders of the rebel bandits" who were sentenced sometime ago to capital punishment for their crimes against the Afghan people (RMDS).

* The Izvestia (Moscow) writes the Afghan government has announced its military units will be withdrawn very soon from Zadran, Paktia, residential areas (RMDS).

* President Najibullah received 24 January an Afro-Asian delegation of writers who are participating in the international symposium on "Writers and the NRP" and apprised them of the need for the proclamation of NRP (RA).

* A high level delegation of Kazakhistan of the USSR held talks 27 January with Deputy Prime Minister and Chairman of State Planning Committee Mehboobullah Koshani in Kabul on the promotion and expansion of direct cooperation between Kazakhistan with Kandahar, Zabul and Uruzgan provinces this year (RA).

* The Kunduz Spinzar Corporation has supplied during 10 months this (Afghan) year goods worth more than Afs. 302 millions to the Afghan industrial establishments and local market (RA).

* On his return from Kabul 26 January the UN mediator on Afghanistan Diego Cordovez said in Islamabad that his mission to promote a settlement of the Afghanistan question was facing a lot of difficulties (MIM).

* The UN mediator on Afghanistan Diego Cordovez met 26 January US and Soviet ambassadors in Islamabad (PT).

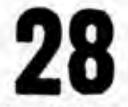

* A Soviet soldier who defected to the mujaheddin five years ago from military service 
in Afghanistan, met President Reagan in the White House and requested him to also help the 18 other Soviet troops presently in Afghanistan (VOADS).

* The VOA correspondent in Islamabad reports, in a statement, leaders of seven mujaheddin organizations have said they will meet the UN Special envoy Diego Cordovez if he announces that the mujaheddin were a party to the Afghanistan dispute and that no solution of the Afghan issue would be achieved without mujaheddin's participation (VOADS).

* The US senator Steven D. Symms who recently visited Afghan refugees camps in Fakistan has said the course of war has clearly turned in favor of the Afghan resistance and now the Soviets are trying to gain their political and terrorist objectives through what they could not achieve in the battlefield (VOADS).

* In an interview 27 January with the Reuters, the Commerce Minister of Kabul regime Mohammad Khan Jalallar said even after the Soviet troops withdrawal, Afghanistan would depend on the Soviet economic aid but he stressed that Afghanistan would not be converted into a Soviet colony. He also painted a grim picture of the economic situation in Afghanistan (VOADS).

* The PDPA's Central Committee Plenum was held 28 January and approved the following measures:

- - a resolution about the results of the implementation of NRP and Party obligations towards the implementation of the constitution,

- promotion of Zahoor Razmjo to the post of the Secretary of the Central Committee of the PDPA,

- - promotion of a number of party members as Central Committee members and the appointment of a number of other members.

* An American Geologist in an interview said no-body knows about the quantity of Afghan gas : exported to the Soviet Unionsince the gas meter has been installed in the Soviet territory

(VOAPS).

* Addressing 27 January a reception in Peshawar, the PNP President Mir Ghaous Bakhsh Bizenjo said the Soviet Union and Afghanistan were ready to remove all hurdles towards the settlement of Afghanistan dispute and it was now upto Pakistan, the US and the Afghan refugees to positively respond to the gesture (MIM)。

* The Central Council of Pakistan Muslim League, meeting 27 January under the chairmanship of Prime Minister Junejo, supported the efforts of the Pakistan government for a shorter time-frame for the Soviet troops pull-out from Afghanistan to enable the Afghan refugees to return home with honor and dignity (PT).

\section{9}

* About the recent statement of Pakistan President General Ziaul Haq, The Izivestia (Moscow) has written that such statements are tantamount to an interference in the internal affairs of Afghanistan. Only the Afghan people should settle such issues, the paper says (RMDS).

* Radio Moscow correspondent has been a witness to the arrival of 16 th convoy of the Soviet supplies to Khost. He has expressed regret that these goods did not bear any Soviet sign (RMDS).

* The UN special envoy Diego Cordovez held 28 January talks with Pakistan President General Zia- 
ul Haq in Rawalpindi on the solution of Afghanistan problem (RPDS).

* In its recent issue The Izvestia (Moscow) has written that the issue of composition of a government relates to the Afghan people and it would be decided in the country itself. Sharing of power in such a government is anticipated by all the forces who are in favor of internal peace and ending bloodshed or willing to struggle for such objectives (RMDS).

* The French Prime Minister's special envoy told newsmen in New Delhi, an essential ingredient for the solution of the Afghanistan problem is that the forthcoming Afghan government should be neutral, independent and friendly to its neighbours (RPDS).

* Mass media in a number of countries have reported about the publication and secret distribution of a card among the prominent PDPA members for their emergency exit from the country. The Afghan government has refuted these unfounded rumours spread by imperialist institutions (RA).

* The Washington Post wrote 28 January that the Soviet Foreign Minister Eduard Shevardnadze has said in Moscow, "We want to withdraw our troops from Afghanistan as soon as possible and all issue are linked with the Geneva talks" (VOADS).

* According to The Washington Post, the Soviet Foreign Minister Eduard Shevardnadze said 27 January in Moscow that his country will not interfere in the leadership affairs in Afghanistan after the Soviet troops pull-out from Afghanistan. He has been also quoted to have said that any leader of the present Afghan government who wished to go to Soviet Union would be welcomed (VOADS). * In an exclusive interview with the PPI, leader of Hezb-e-Islami Gulbuddin Hekmatyar has termed the offer of a coalition government in Afghanistan with the participation of Soviet lackeys a trap to end the Afghan mujaheddin resistance and thus to spoil the fruits of their eight long years struggle for complete freedom from the foreign influence (MIM).

* The UN mediator Diego Cordovez, now on a shuttle diplomacy between Islamabad and Kabul to promote a comprehensive settlement of the Afghanistan issue through the Geneva process, had 28 January another round of talks with senior Pakistani officials in Islamabad (MIM).

* It has been reliably learnt that the IUAM President Mawlawi Mohamnad Yunus Khales held a detailed meeting with the UN mediator Diego Cordovez on the solution of Afghanistan problem (NWT). * The IUAM has decided to form an interim government in order to pave the way for the withdrawal of Soviet troops from Afghanistan and holding of general elections in that country. According to ANS the decision was adopted after a heated debate (NWT).

\section{0}

* Saudi Foreign Minister, Prince Saud-el-Faisal, now visiting Moscow, expressed happiness on the Soviet government's decision to pullout its troops from Afghanistan (RMDS).

* In his meeting with the UN mediator on Afghanistan Diego Cordovez, Prime Minister Mohammad Khan Junejo reiterated Pakistan's commitment to an early success of the Geneva talks which, he said, should guarantee the Soviet troops withdrawal and the right of self determination to the Afghanistan people free from outside interference (RPDS).

* A BBC correspondent reports from Islamabad the moderate leaders in IUAM are persuading Pakistan to help in the convening of an Afghan loya jirgah to urite the mujaheddin and provide them an opportunity to adopt a stronger position at talks on solving the Afghanistan issue (BBCFS). 
* At a national jirgah, the Kurram Agency tribes have resolved that the Afghan should withdraw from that Agency at the earliest and abandon their armed activities against the Republic of Afghanistan (RA).

* Talking 29 January to a PIV correspondent in Islamabad, the UN intermediary on Afghanistan, Diego Cordovez described his talks with President Mohammad Ziaul Haq as very constructive, positive, useful, forward looking and very pleasant. In an apparent reference to a VOA report about his alleged discussion with the IUAM President Mawlawi Mohammad Yunus Khales during President's dinner Mr. Cordovez said it is totally inaccurate, misleading and a wild piece of fiction (MIM).

* A spokesman for Mawlawi Mohammad Yunus Khales the TUAM President denied a press report that he had a clandestine meeting 29 January with UN mediator on Afghanistan Cordovez in Islamabad (PT), * In a joint statement 29 January in Karachi the convener of MRD and PNP President Mir Chous Bakhsh Bizenjo, Chairman of QMA Meraj Mohammad Khan and President MKP Fatehyab Ali Khan said that failure to reach an accord on the Afghan issue would mean continued bloodshed of the Pash'suns (DN). * The Sovlet Forelgn Minister Eduard Shevardnadze told 29 January US journalists in Moscow that Geneva talks have come close to a peace accord. He however said Soviet troops' withdrawal time table might be prolonged upto 1989 (NWT).

\section{1}

* After four days of talks in Pakistan, the UN special envoy on Afghanistan, Diego Cordovez could not proceed to Afghanistan due to bad weather. Pakistan TV said he would leave 31 January for Kabul (BBCFS).

* Teheran Radio reported, the speaker of Iranian Assembly Hashmi Rafsanjani has told the Soviet Ambassador in Teheran, Vlacijir Gudev Iran would help the Soviet Union so that the US would not dominate Afghanistan after the Soviet withdrawal from that country (BBCFS).

* Quoting an interview of The New York Times' correspondent with the Pakistan President Ziaul Haq, The NWT and The Millat wrote that the Soviet Union has lost the war in Afghanistan and the future government in Kabul should be independent and non-aligned and should be shared and supported by the mujaheddin (VOADS).

* A Radio Moscow commentator writes, it has become clear from the statements of Pakistan and Afghanistan foreign ministries that at present all possibilities exist for holding a successful round of talks in Geneva (RMDS).

* Menber of the House of Commons, Ronald Brown said in London the anti-aircraft Blowpipe, rockets supplied to the Afghan anti-revolutionaries, are being sold to Iranian officials (PMDS).

* The Times (Iondon) reports, according to an expertig assessinent, $50 \%$ of the arms supplied to the rebels are sold in the Pakistani markets by the "ring leaders" of the rebels (RMDS).

* The Afghanistan Minister for Nationalities and Tribes, Suleinan Layeq said the Zadran tribes can independently safeguard Gardez-Khost highway and also can decisively counter the anti-revolutionary bandits (RMDS).

* The Observer (London) conmented 31 January, even if the Geneva talks can reach a success, most Afghans believe some of the guerrilla groups would continue fighting (BBCFS).

* In its 31 January issue The Ooserver (Iondon) writes the murder of an English cameraman, said to 
have been carried by the supporters of Gulbuddin Hekmatyar, has enraged guerrilla commander Ahmad Shah Masood and his supporter are reported to be seeking revenge from the Hezb-e-Isiami (BBCFS).

* The Afghanistan Foreign Minister Abdul Wakil and the UN envoy on Afghanistan held 31 January talks in Kabul on the solution of situation around Afghanistan and preparation for convening the next round of Geneva talks between Pakistan and Afghanistan (RA).

* Protocols on direct cooperations between Paktika and Paktia provinces, including Khost, and Azerbaijan of the USSR were signed 31 January, Kabul (RA).

* A protocol on direct cooperations between Kazakhistan of the USSR and Kandahar, Zabul and Uruzgan provinces was signed 31 January in Kabul (RA).

* A protocol on direct scientific and technical cooperation between the Soviet Union and the Afghanistan Construction Ministry for promoting engineering and practical skills of the Afghans in the Soviet Union was signed 31 January in Kabul (RA).

* On the basis of Presidential amnesty decree, 21 prisoners were released in Kunduz province (RA).

* The IUAM released 31 January in Pakistan a communique saying that after the Soviet troops withdrawal from Afghanistan the mujaheddin would form a government shared by the mujaheddin and Muslim people of Afghanistan. The cormmique once again rejected a coalition government with the communsts (WOAPS).

* In an interview with The Washington Post, a Soviet military officer, who has participated in the Afghanistan war and has now returned to his country, said the Soviet media reports on Afghanistan events were misleading. The Soviet press conceals what is really happening in Afghanistan thus no-body knows about the realities of war in Afghanistan, he said (VOAPS).

* In an interview with the APP, the UN special representative on Afghanistan, Diego Cordovez said, "negotiations (on the Afghan issue) is not $s^{+}$alled, it is slow but this is what it is like in this part of the world" (MIM).

* The VOA reported that a senior official of the Washington based Institute of Strategic and International studies, Stephen Testamo Wiek has said the Soviet Union wanted to pull out its troops from Afghanistan because it has now realized that the situation in Afghanistan can never be better for it or for the government installed by it (MIM).

* In an interview 30 January with a panel of The Mashrig editors in Lahore, the US Ambassador in Pakistan Arnold Raphel said the US dnes not want the Soviets bogged down in Afghanistan (PT). * In a statement, a prominent leader of Tehrik-e-Nifaz-e-Fiqah Jafferia, Allama Arif Hussain paid rich tribute to the Afghan nation and said any decision at the Geneva talks without the consent of the mujaheddin would have no bearing (JG).

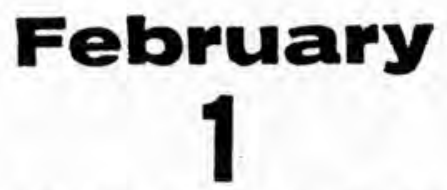

* Five person, including three Afghan refugees, were killed and 20 others injured 1 February in

a bomb explosion at a market in Peshawar (BBCFS).

* The BBC correspondent says thousands of Afghan refugees in Pakistan participated 1 February in 
a gathering near Quetta, Baluchistan, expressing support to international endeavours for restoration of peace in the region and demanded the return of former King Mohammad Zahir Shah to Afghanistan (BBCFS).

* Bakhtar has released a statement in Kabul saying that rebels have been spreading a rumour suggesting the distribution of cards, in Dari and Russian, among the PDPA members to enable them to leave the country in case of an emergency after the Soviet troops withdrawal. Bakhtar categorically denies such allegations (RMDS).

* In a meeting 1 February In Rawalpindi with the Canadian envoy at the UN, Stephen Lewis, Prime Minister Mohamad Khan Junejo expressed the hope that the current mission of UN special envoy on the Afghanistan, would prove fruitful (RPDS).

* A Director of Freedom House in NY, Rosanne Klass, who once lived in Afghanistan, has said she does not think the Soviets are serious in losing control over Afghanistan. She says she is concerned at what the Russian say and what they do (VOADS).

* With the participation of President Najibullah, a meeting of the activists of the party organizations of the Afghan armed forces was held 1 February to debate the outcome of the PIPA's central committee January plenum and the duties of the party organization of armed forces towards the implementation of the constitution ( $R A)$.

* President Najibullah held talks 1 February with the UN special envoy on Afghanistan, Diego Cordovez on solution of situation around Afghanistan (RA).

* In an attack recently the youth of North Waziristan captured in Suratavi an arms convoy of the Afghan extremists which they planned to send over to Afghanistan (RA).

* In an interview with the Islamic Afghan Agency, a Farah commander Mullah Wazir said all the people migrating from Farah have gone to Iran but the Iranian officials do not treat them fairly. He added the mujaheddin were being harassed by the Iranian offictals (VOAPS).

* At a sumit 31 January in Peshawar, the IUAM finally agreed on the composition of the future government of Afghanistan which it demanded should comprise mujaheddin, refugees and Afghan Muslims living inside the country (MIM).

* Addressing 31 January a big gathering in Manki Sharif (Nowshera) Prime Minister Mohammad Khan Junejo said that conditions were becoming conducive for an honorable return of the Afghan refugees to their homeland (MIM)。

* According to Radio Moscow, in his meeting with the Soviet Foreign Minister Eduard Shevardnadze, the Saudi Foreign Minister, Saud-el-Faisal has welcomed the Soviet decision to pull-out its troops from Afghanistan (JG).

\section{2}

* The UN Secretary Generals' special representative on Afghanistan issue Diego Cordovez, who returned 2 February to Islamabad from Kabul, held another round of talks with the Pakistani Minister of State for Forelgn Affairs Zain Noorani about his recent negotiations with the Kabul regime officials (RPDS).

* In an interview, the speaker of Iran's Assembly Hashemi Rafsanjani said his country would exert efforts to prevent any foreign influence in Afghanistan after the Soviet troops withdrawal from 
that country (RPDS).

* Before his departure from Kabul, the UN special envoy on Afghanistan Diego Cordovez said he has been assured that Afghanistan is willing to resume, by the end of current month, indirect peace talks with Pakistan in Geneva (BBCFS).

* The British press carried 2 February details of the murder of British cameraman Andy Skrzypkowiak. According to the press, the investigations carried by Pakistani officials indicate the cameraman was killed by the mujaheddin of Hekmatyar's Hezb-e-Islami. The papers say he was a veteran cameraman who had been providing photographs of the Afghan war to the west more than any-body else and had visited Afghanistan several times (BBCFS).

* In an interview, the IUAM President Mawlawi Mohammad Yunus Khales has said that if the Soviets do not interfere in the affairs of Afghanistan and adopt a path of peace, based on social justice, the Muslim nation would not cause them any harm during their withdrawal from Afghanistan (VOADS)。

* President Najibullah held talks 2 February in Kabul with the Soviet Oil and Gas Minister on Soviet cooperation in exploration of oil and gas (RA).

* A protocol on economic and technical cooperation between the Soviet Ministry of Industries and Gas and the Afghanistan Ministry of Mines and Industries was signed 2 February in Kabul (RA).

* Foreign Minister Abdul Wakil left 2 February at the head of a delegation for friendly visits

to Islamic countries of Kuwait, Libya, Syria and Jordan (RA)。

* The UN special envoy on Afghanistan Diego Cordovez, who recently visited twice Kabul for a series of talks and consultations with the Afghan officials on the settlement of situation aroumd Afghanistan and making preparations for convening next round of Geneva talks, left Kabul 2 February for Islamabad (RA).

* Some 50,000 followers of Manki Sharif Pir expressed their solidarity with the Afghan refugees and supported the Pakistan government policy on Afghanistan issue (VOAPS).

* Speaking 1 February in Rawalpindi Press Club, the JI Chief Qazi Hussain Ahmad said the mujaheddin have won the war in Afghanistan and the Soviets are, therefore, inclined to withdraw from that country. He said only the Afghan mujaheddin are entitle to assume power in Afghanistan (NWT)。 * The US permanent envoy to the UN, Vernon Walters said 31 January the Soviet Union must act to end regional conflicts such as Afghanistan if it wants better relations wi.th the US (PT).

\section{3}

* The UN special envoy on Afghanistan Diego Cordovez, who returned 2 February to Islamabad from Kabul, said his negotiations in Kabul has so far not been finalized. He complained that the talks are being unnecessarily slow (BBCFS)。

* A spokesman for the IUAM condemned the 2 February's meeting of the refugees and the guerrilla 4ormanders near Quetta asking for the return of Mohammad Zahir Shah and described it as a Soviet conspiracy (BBCFS).

* The Hezb-e-Islami Afghanistan leader Hekmatyar accused the BBC of broadcasting news about the weeting of the refugees and guerrilla commanders in connection with the return of Mohammad Zahir Shah and said the BBC is fanning disturbances among the Islamic world movements (BBCFS). 
* The UN special envoy on the Afghanistan issue Diego Cordovez held 3 February in Islamabad a second round of talks with the Pakistan Minister of State for Foreign Affairs. He earlier met the Soviet and US ambassadors in Islamabad (RPDS).

* In a press interview 3 February, a spokesman for the Chinese Foreign Ministry once again demanded Soviet troops withdrawal from Afghanistan and said the pull-out would enable the Afghan people to determine their own future (RPDS).

* A report from Afghanistan says value of the Afghan currency against the US dollar and the French frank has fallen down by $11 \%$ and $13 \%$ respectively and the price of petrol has risen by $50 \%$ (RPDS).

* AIR says the Indian Minister of State for Foreign Affairs, Natwar Singh is scheduled to meet 5 February in Rome with the former Afghan King Mohammad Zahir Shah on the solution of Afghan issue (RPDS).

* The UN special envoy on the Afghanistan issue Diego Cordovez, who has arrived in Islamabad, told. journalists the Afghan side has expressed readiness for goodwill and flexibility for the resumption of Geneva talks between Pakistan and Afghanistan (RMDS).

* On the basis of direct cooperations between Moscow and Kabul province, 200 furniture sets are ready for transportation to Kabul for schools in that city (RMDS).

* A former Afghan diplomat, Dr. Abdul Hakim Tabibi, said after the Soviet troops withdrawal from Afghanistan, our relations with Moscow would be based on complete independence of Afghanistan and respect for the right of self-determination of the people of Afghanistan and no body, including the Soviet Union, would be allowed to enjoy any military, economic or political priviliges (VOG). * A journalist and cameraman who is working for the mujaheddin news agencies in Peshawar has said after returning from Afghanistan recently, he has witnessed the massacre of nine Afghan guerrillas and seven children by the Afghan militiamen and the Soviet troops in a village near the city of Ghazni (BBCFS).

* The pro-Kabul Masood tribesmen have brought from Afghanistan about 500 klashinkoves to their villages in South Waziristan Agency. A huge quantity of ammumition has also been handed over to them as gift by the Afghan government (MIM).

* Pakistan Minister of State for Foreign Affairs, Zain Noorani will leave 7 February Islamabad for Beifing for consultations with Chinese authorities on the Afghan issue in the context of recent developments taking place in the region (MIM).

* The Canadian envoy at the UN Stephen Lewis, now on a visit to Pakistan, met 2 February in Islamabad the Pakistan Federal Minister for Kashmir Affairs and Northern areas and States and Frontier regions Sayyed Qasim Shah and discussed with him the Afghanistan issue (PT).

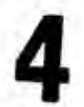

* In an editorial recently The Economist (Iondon) writes the significance of a Soviet withdrawal from Afghanistan would be that communist troops are to be pull-out from a foreign country for the first time curing the last thirty years and a communist government would fall for the first time in history (VOADS).

* A BBC commentator says, on the first leg of his visit to the Arab countries, the Afghanistan 
Foreign Minister Abdul Wakil arrived in Kuwait. The Arab countries of the Persian Gulf, particularly Saudi Arabia, has been extending generous assistance to the Afghan mujaheddin and a visit by Wakil to the area is perhaps aimed at persuading those countries to severe assistance to the mujaheddin (BBCFS).

* A member of the British Labor Party Ron Brown in Iondon said in an interview it appears that still both Iondon and Washington are not interested in the restoration of peace in Afghanistan and the settlement of the Afghan issue to a large extent still depends on the stand of Washington and some other Western countries (RMDS).

* Speaking 4 February at an international women's conference in Lahore, President Ziaul Haq of Pakistan poi.lted out that 1.2 million people have so far been killed in Afghanistan and the explosions that are taking place in Pakistani cities are aimed at achieving the objectives which 150 thousand foreign troops have failed to obtained in Afghanistan (RPDS).

* The UN mediator on Afghanistan Diego Cordovez continued 4 February talks with the senior Pakistani Foreign Office officials on the settlement of the Afghanistan problem (RPDS).

* One hundred and thirty flats were distributed 4 February in the apartment houses' district of Kabul city to the survivors of the martyrs as well as the injured and the disabled and deserving persons (RA).

* The noted pro-Afghan Malik Haleen Jan Khwaezai Mohmand surrendered 4 February to the political administration of Mohmand Agency alongwith hundreds of his followers and declared his allegiance to the Pakistan government (PT).

* According to the latest figures, collected through various sources, over the last eight years the Soviets have completely changed the Afghan educational system to that of a Soviet system and has killed or wounded nearly $14 \%$ of the population (PT).

* The VOA correspondent reports from Islamabad, the UN special envoy Diego Cordovez has two main problems before him. Firstly, how to establish direct contact with the mujaheddin leaders and secondly to prevent bloodshed in Afghanistan after the Soviet troops withidrawal from that country

(VOAPS).

* Major Gul Mohammad, a pilot who has just migrated from Afghanistan, says the morale of the AAF is at its lowest ebb because of the presence of the Stinger rockets, resulting in the suspension of flights. Important flights are made directly from Uzbekistan of the Soviet Union, he said

* Talking to The Muslim in Lahore, a noted revolutionary leader Jam Saqi has urged the goverrment to hold direct talks with the Kabul government on Afghanistan issue (MIM).

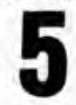

* The UN envoy on Afghanistan issue, Diego Cordovez continued 5 February in Islamabad his talks with the Pakistani officials on the Afghanistan problem (RPDS).

* The Krasnayas Zvezda writes, by adopting a reasonable view of the prevailing situation, a real opportunity has become available for the solution of Afghanistan and Kampuchea problems (RMDS).

* The British Foreign and Commonwealth Office Minister Timothy Bggar, who is to leave 6 February for visits to Pakistan and Thailand, has accused the Soviet backed goverment in Afghanistan of not preventing poppy cultivation in the areas under its control (BBCFS). 
* The British Foreign and Commonwealth office Minister Timothy Eggar said there is no evidence to show the Afghan mujaheddin are involved in drug trafficking and in principle most of the mujaheddin keep themselves away from drug trafficking due to their religious belief (BBCFS).

* The Afghan Ambassador designate in Hungary Assad Keshtmand presented 5 February his credentials to the Hungarian Chairman of the Council of Ministers (RA).

* The UN envoy on Afghanistan Diego Cordovez continued his talks with Pakistani official on the Afghanistan issue. But a report by the VOA correspondent from Islamabad says the atmosphere of optimism which prevailed earlier has now been converted into one of pessimism (VOAPS).

* According to a Radio Moscow report, the Soviet Foreign Minister, Eduard Shevardnadze has reaffirmed his country'sinterest in solving the Afghanistan problem immediately (MIM).

* Addressing a press conference 4 February in Peshawar, an Afghan pilot Major Gul Moharmad disclosed about 25,000 prisoners kept by Kabul regime in Pul-e-Charkhi jail included mostly Afghan mujaheddin (MIM).

* According to a VOG report, the Afghanistan crisis has once again become the center of world attention (PT).

* A spokesman of the ICRC said in Peshawar that more than 3,000 Afghans wounded in the war were treated in the ICRC hospitals in Pakistan in 1987. This was $\%$ more than the previous year (PT).

* In a meeting in Moscow with the Iraqi Foreign Minister Tariq Aziz, the Soviet Foreign Minister Eduard Shevardnadze has said, the Soviet Union has made a policy decision entailing the withdrawal of its troops from Afghanistan (JG).

* Leader of the Islamic Revolutionary government of the free Afghanistan State of Nooristan, Mawlawi Mohamad Afzal has said that the Afghans holy crusade would continue until a complete Soviet troops pull-out from Afghanistan (NWT).

\section{6}

* The UN mediator on Afghanistan, Diego Cordovez met 6 February the Peshawar (Pakistan) based IUAM leaders for the first time during the six years of his mission aimed at finding a political solution of the Afghan problem (BBCFS).

* In a statement, the Pakistan government has laid special emphasis on the meeting between the IUAM President Mawlawi Mohammad Yunus Khales and the UN mediator Diego Cordovez and has said that the IUAM is a manifestation of the struggle by the people of Afghanistan and is entitled to play a role in the settlement of the Afghanistan problem (BBCFS).

* A Pakistan Foreign Ministry spokesman expressed 6 February in Islamabad support to the right of the people of Afghanistan for self-determination and once again said any agreement prejudicing this right would not be acceptable (RPDS).

* Quoting the IUAM spokesman, Reuter reports that the Pakistan President Ziaul Haq had asked the IUAM President Mawlawi Mohammad Yunus Khales to meet the UN envoy (VOADS).

* A Radio Moscow commentator says the visit of the Afghan Foreign Minister Abdul Wakil to the Arab countries of the Gulf once again refutes Western propaganda about a lack of credibility for the Afghan government at the international arena (RMDS)。 
* A protocol of technical cooperation between Kabul Municipal Corporation and the Soviet Union was signed 6 February in Kabul (RA).

* A local television station was inaugurated for Paktia province 6 February (RA)。

* The Young World of GDR wrote 5 February that with the assistance of the COMBCON member states about 170 projects, related to geological research, mineral exploration minerals, agriculture, have been built and another 120 projects are either being constructed or their projects are being completed (RA).

* The Hezb-e-Islami leader Gulbuddin Hekmatyar has denied allegations that his party was responsible for the murder of a British cameraman last October and said the mujaheddin of his organization never resort to the killing of foreigners (BBCPS).

* The Indian External Affairs Minister Natwar Singh has arrived in Rome for talks with the former Afghan King Mohammad Zahir Shah. It is said in India that the trip to Rome to meet Zahir is part of Indian efforts to end the Afghan dispute (BBCFS).

* Addressing 5 February in Mardan a Jehad conference, the Hezb-e-Islami leader Gulbuddin Hekmatyar said the Afghanistan war has entered its last phase and the Soviet Union is seeking to flee. The time is not very far away that Afghanistan will be an independent Islamic country (NWT).

* Speaking 5 February in Mardan at a Jehad conference, the JI leader Qazi Hussain Ahmad said there would be no room for the communists in Afghanistan after the Soviet troops pull out from that
country (NWT).

* Talking 5 February to newsmen, the NWFP Governor Fida Mohammad said Afghan refugees love their homeland and they will return to their country as soon as the Soviet forces are withdrawan from Afghanistan (PT).

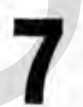

* The UN special envoy on Afghanistan, Diego Cordovez left Islamabad 7 February to Kabul for the third time during his current visit to the region to make preparations for the next round of the indirect Geneva talks between Pakistan and Afghanistan on the Afghanistan issue (RPDS).

* During his visit to Kuwait, the Afghan Foreign Minister said his country is inclined that the next round of indirect Geneva talks between Pakistan and Afghanistan should turn out to be the final round of talks (PMDS).

* Special UN envoy on Afghanistan arrived 7 February in Kabul for the third time and held talks with the Afghan leader Dr. Nafibullah. It is assumed that the two might have discussed Cordovez's talks 6 February in Peshawar with the IUAM President Mawlawi Mohammad Yunus Khales (BBCFS).

* The Washington Post 7 February referred to the signing of a number of agreements concluded by the Soviet Union with the towns, local governments and provinces of Afghanistan on promoting the Afghan local economy. A US State Department official says the Soviets have adopted a double standard which signifies that they do not intend to withdraw from Afghanistan and they are only diverting the public opinion aimed at cutting aid to the Afghanistan resistance (VOALS).

* The Washington Post wrote 7 February, some think the Soviets Union is trying to widen its influence in Afghanistan in a different form. Soviet attention is focused on the aftermath of a Soviet 
troops withdrawal which would mean Moscow will no longer excersize a direct influence in the Afghanistan affairs, and, therefore, it is trying to establish closer economic ties to offset the results of their withdrawal (VOADS).

* The Washington Post 7 February writes that in a letter 49 u's Congressmen, inclucing nine Democrats, have asked President Reagan to continue military assistance to the mujaheddin until the withdrawal of the Soviet troops from Afghanistan and the establishment of a real independent government in that country (VOADS).

* President Najibullah held talks 7 February in Kabul. with the UN envoy Diego Cordovez on issues pertaining to the political settlement of the situation around Afghanistan (RA).

* Forelgn Minister Abdul Wakil met 7 February the Kuwaiti Deputy Premier and Foreign Minister Sheikh Sabaul Mohammad Al-Sabah and apprised him of the developments on the process of the settlement of situation around Afghanistan, the NRP and its achievements (RA).

* In an interview 6 February with The Arab Times, Kuwait, Foreign Minister Abdul Wakal said the former Afghan King Zahir Shah can certainly play an important role in the restoration of peace in Afghanistan. But in this connection, too, leaders of the opposition groups are creating obstacles and are opposed to any role for Zahir Shah in the future while he is acceptable to us (RA).

* Sovlet and Indonesian Forelgn Ministers have stressed the "vital need" for the political solvtion of situation around Afghanistan in the interest of peace and stability in Asia (RA).

* In a press release 6 February at Peshawar, it has been said that during his meeting with Diego Cordovez, the IUAM President Mawlawi Mohammad Yunus described the Geneva talks futile and said the talks were contrary to the UN General Assembly resolutions (NWT).

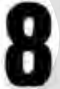

* The UN mediator on the Afghanistan 1ssue, Diego Cordovez met 8 February in Islamabad with the Pakdstan Minister of state for Foreign Affairs, Zain Noorani. He said discussions are underway on the formation of an interim government. The issue should be settled before the beginning of Geneva Indirect talks (RPDS).

* The British Foreign and Commonwealth office Minister Timothy Eggar met 10 February in Peshawar the NWFP Governor FIda Mohammad Khan. They exchanged views on the elimination of drug menace and the question of Afghan refugees in Pakistan (RPDS).

* The Independent (London) wrote 8 February the UN mediator in Afghanistan issue Diego Cordovez says the Soviet Union, contrary to the Afghan regime, does not want the ruling PDPA should be the real force in a coalition government. It says the establishment of an independent government not hostile to Moscow would be a matter of satisfaction for the Soviet Union (BBCFS).

* The Guardian (Iondon) wrote 8 February analysts in Washington are skeptical about Soviet designs on the withdrawal of its troops from Afghanistan. The Defense Department and the CIA say the Soviets continue to strengthen their military and defense positions in Afghantstan. This, they say, is an indication that they are not only not ready for a pull-out but are also seeking to strengthen their position in the country (BBCFS).

* In a statement 8 February broadcast from Radio Moscow the Soviet leader Gorbachev announced that Soviet troops would start to withdrawn from Afghanistan 15 May provided an agreement is signed 
on the Afghan accord prior to that date (BBCFS).

* The VOA correspondent reports from Peshawar a meeting was held 7 February in Bajaur, NWFP by tribal leaders and commanders of the Afghanistan resistance in support of the former King Zahir Shah. The meeting endorsed the resolutions adopted in another meeting of Afghan refugees and muJaheddin in Baluchistan 1 February (VOADS).

* In an interview 8 February, the IUAM President Mawlawi Mohammad Yunus Khales said at the request of the Pakistan President General Mohammad Ziaul Haq he agreed to meet the UN envoy on Afghanistan. The statement said Khales, however, is inclined the Russians should enter a direct dialogue with the mujaheddin for the solution of Afghanistan problem (VOADS).

* In a statement 8 February President Najibullah said the finalization of Geneva talks and Soviet troops pull-out should not be linked with efforts for the formation of a coalition government in Afghanistan. The NRP and the formation of a coalition government is exclusively an internal issue of Afghanistan (RA).

* President Najibullah received 8 February the Indian Ambassador in Kabul Indarpaul Khoslaw and apprised him of the Afghan stand on Geneva talks between Pakistan and Afghanistan (RA).

* President Najibullah received 8 February the Bangladesh NAP Chief Professor Muzaffar Ahmad. The two held talks in a friendly atmosphere on topics of mutual interest and the implementation of the NRP in Afghanistan (RA).

* Foreign Minister Abdul Wakil curreritly on friendly visit to a number of Arab countries at the head of a delegation, arrived 7 February in Tripoli. (RA)

* A delegation of the Ministry of Health of the Armenian USSR met 8 February the Afghan Public

Health Minister, Sher Bahadur. They held talks on the direct Armenian assistance to Logar and Ghor provinces (RA).

* A large quantity of arms which were placed by the extremist elements in Paghman for disturbing the peaceful life of the people of that area, was discovered by the security forces of the country (RA).

* According to reliable sources, the Soviet Deputy Foreign Minister Yuli Vorontsov is expected to visit soon Islamabad for peace talks on Afghanistan (MIM).

* Addressing 7 February a seminar in Rawalpindi on foreign policy organized by National Unity Front (NUF) the leader of NPP, Ghulam Mustafa Jatoi, a former Federal Minister, Rao Farman Ali, prominent jurist S.M. Zafar, Editor in Chief of The Muslim Agha Murtaza Pooya and several other leaders called for an early solution of the Afghanistan problem (MIM).

* Latest reports from Kabul say, almost 10 years after the communist coup and eight years of the Soviet invasion, the Kabul regime still cannot feed its people or provide a functioning economy, even with large amounts of Sovlet aid (PT).

* In an interview with the AAP, a NLF commander in Kabul Mohammad Zareef Aatesh said the Geneva talks cannot be successful without mujaheddin's participation (NWT).

\section{$(1)$}

* The UN Secretary General's Special envoy for Afghanistan, Diego Cordovez said 9 February in 
Islamabad the main agreement on the issue of a time-frame for the Soviet troops withdrawal from Afghanistan has been achieved and the two sides have agreed that the major part of the troops be withdrawn in the first months of the withdrawal period (RPDS).

* The UN mediator Diego Cordovez met 9 February in Islamabad with President Ziaul Haq and apprised him about his talks in Kabul and the understanding reached about a comprehensive solution of the Afghanistan issue (RPDS).

* The US envoy at the Human Rights Commission in Geneva has strongly protested against the trampling of the right to self-determination of the people of Baltic republics of the Soviet Russia, the people of Afghanistan and the Eastern European countries (RPDS).

* Pakistan has strongly protested to the Kabul regime against violation of Pakistan's airspace 26 January and dropping three bombs in Ghazi, Bajaur Agency (RPDS).

* The UN envoy on Afghanistan, Diego Cordovez said 9 February in Islamabad that the Kabul regime and Pakistan have virtually agreed on the time-table of Soviet troops withdrawal from Afghanistan. Time frame has been the last hurdle in reaching an agreement on the solution of the Afghanistan problem (VOAS).

* The US State Department spokesman says the time-table for the Soviet troops withdrawal should also be acceptable to the millions of Afghan refugees in Pakistan and other countries and any such time table under, which the Soviet Union can retain the best of its units in Afghanistan to attack the Afghanistan resistance forces, will not be acceptable (VOADS).

* A spokesman for the US State Department said 9 February his country would guarantee the understanding achieved through Geneva talks, including an end to military aid and the establishment of a neutral government in Afghanistan not aligned with any power (VOADS).

* About a TASS communique in connection with a date for the beginning of Soviet troops withdrawal from Afghanistan, The Washington Post writes western experts believe that, by fixing a date for the withdrawal of its troops from Afghanistan, Moscow intends to put pressure on the parties involved to minimize their difference (VOADS).

* Quoting a US official, The Christian Science Monitor (USA) writes that linking an agreement on Soviet troops withdrawal with a transitory government would not be a wise move. As it has been stated by Gorbachev, as well as the US officials, the formation of a goverment in Afghantstan should be left to the Afghans (VOADS).

* The Soviet Deputy Foreign Minister, Anatoli Vorontsov described the Soviet proposal for the withdrawal of its troops from Afghanistan as the only opportunity for ending the Afghan war (BBCFS). * The Afghanistan Foreign Minister, Abdul Wakil met 8 February the Iibyan Foreign Minister. In the meeting a stress was laid on cooperation between the two countries in political, economic, cultural and religious fields (RA).

* A protocol of cooperation between the Central Committee of the Democratic Youth Organization of Afghanistan and the Moscow city national KOMSOMOL was signed recently in Kabul (RA).

* A protocol on establishing direct railway link for transportation of goods from the Soviet Central Asian Republics to Hairatan port was signed recently in Hairathan between the Afghanistan 
Ministry of Commerce and the Soviet Central Asian Railway Department (RA).

* The Agricultural Development Bank has extended aid during the current year amounting to Afs.164 million for the purchase of 219 tractors on loan or cash to farmers, and agricultural cooperatives

* About the recent announcement by the Soviet leader Gorbachev for the Soviet troops withdrawal

from Afghanistan, the Hezb-e-Islami Chief Gulbuddin Hekmatyar said it appears that Gorbachev wants to find reasons for remaining in Afghanistan and for continuing the war (VOAPS).

* In an article 9 February, The Dawn concludes that if an offer of neutrality - - with a coalition government that safely contains PDPA - - is not accepted, the alternative can only be continued civil war with the super powers inevitably remaining engaged on opposite sides (DN).

* AIR reported that the Soviet First Deputy Foreign Minister, Yuli Vorontsov conferred 8 February in New Delhi with the Indian Prime Minister, Rajiv Gandhi and apprised him of the progress made so far by the UN envoy on Afghanistan during his current visits to Pakistan and Afghanistan (MIM).

* In an editorial 9 February, The Pakistan Times highlighted the vital importance of the participation by the mujaheddin in negotiations for the settlement of Afghanistan crisis. It stressed the need for a cautiousness at this sensitive juncture (PT).

\section{0}

* The VOA correspondent reports from Islamabad. some Soviet experts are being repatriated from Afghanistan without being substituted and Soviet families have put their household on sale preparing for the withdrawal of Soviet troops from Afghanistan shortly (VOADS).

* The IUAM President Mawlawi Mohammad Yunus Khales told newsmen 8 February in Peshawar that if Najibullah and his colleagues adopt Islam wholeheartedly, we are ready to accept them. But it does not mean they would be entrusted with sensitive posts from the very start (VOADS).

* While the US government officials have welcomed a Soviet offer for fixing a date for the Soviet troops withdrawal from Afghanistan, they warn against optimism saying all problems have so far not been removed (BBCFS).

* The Soviet Deputy Foreign Minister, Yuli Vorontsov met 10 February the Paldistan Minister of State for Foreign Affairs, Zain Noorani in Islamabad and discussed with him various aspects of the Afghanistan dispute (RPDS).

* At a press conference in Moscow the Soviet Deputy Foreign Minister, Anatoly Kovayov said Gorbachev's offer for the Soviet troops withdrawal from Afghanistan within 10 months is an unprecedented opportunity to end the Afghanistan war. He said the objective of the offer is to change the path of one of the widest regional conflicts and the opportunity should not be missed (RPDS). * According to the US press, Moscow has intimated Washington that in case of signing the Geneva agreement on Afghanistan, $50 \%$ of the Soviet troops will be withdrawn from Afghanistan within 17 days (RPDS).

* A former US Ambassador in Kabul Theodor Eliot visited today an Afghan refugee camp at Nasir Bagh near Peshawar city (RPDS).

* The US Secretary of State George Shultz said 10 February in Washington the proposed time-frane 
for Soviet troops withdrawal from Afghanistan should be further reduced (BBCFS).

* A senior correspondent of The Washington Post in an interview said he does not think US assistance to the Afghan mujaheddin would be stopped even when Soviet troops withdrawal from Afghanis$\tan$ begins. But he believes a reduction in the US military assistance to the mujaheddin should be in proportion to the withdrawal of Soviet troops (BBCFS).

* The Christian Science Monitor (USA), says Gorbachev's offer for the Soviet troops withdrawal from Afghanistan within 10 months is a new indication of the fact that Moscow is tired of fighting in Afghanistan (VOADS).

* The New York Times wrote 10 February the UN mediator on Afghanistan Diego Cordovez has started secret negotiations with the former King of Afghanistan. The envoy believes Zahir Shah can help bring together rival political factions in Afghanistan (VOADS).

* Asian countries have welcomed the Soviet resolute decision to solve the Afghanistan issue (PMDS).

* The China Daily (Peking) has emphasized that the Soviet decision to withdraw its troops fram Afghanistan from 15 May gives a real hope for the success of Geneva talks on Afghanistan (PMDS).

* The Pakistan Minister of State for Foreign Affairs, Zain Noorani has pointed out that the Pakistani officials are prepared to accelerate their efforts towards the overall solution of the Afghanistan problem (RMDS).

* The Afghanistan Foreign Minister, Abdul Wakil, now visiting libya, has told TASS Gorbachev's announcement is a reply to Western propaganda making hue and cry about fixing a date for the return of Soviet limited contingents from Afghanistan (RMDS)。

* A Chinese Foreign Ministry spokesman has said in Peking the Soviet Union must take such real steps which will enable Afghanistan regain its independence and neutrality (VOAPS).

* The UN envoy on Afghanistan Diego Cordovez told newsmen in Geneva during his visits to Kabul and Islamabad two important topics were solved: an acceptable time-frame for the Soviet troops withdrawal and practical aspects for such a pull-out (VOAPS).

* The Chinese government in a communique about the Soviet plans has stressed the importance of an early political reconciliation in Afghanistan (VOAPS).

* The Pakistan Minister of State for Foreign Affairs, Zain Noorani said 9 February Pakistan will sign the Geneva accord only with a legitimate Afghan government. He said it was wrong to assume that by the time Geneva accord is signed, Kabul will not have a legitimate government (MIM). * The US has welcomed Kremlin leader Gorbachev's offer to start pulling Soviet forces out of Afghanistan in May, but it says it wants concrete deeds and not just words from Moscow (IN).

* Quoting the East European diplomatic sources, The Washington Post reported that a secondary school for the children of Soviet militarymen and advisers in Kabul has already been closed in anticipation for a Soviet troops withdrawal (JG).

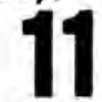

* The Afghanistan Resistance leaders met 10 February in Islamabad to discuss the establishment of an interim government, which according to them, will be composed of resistance forces, the ro- 
fugees and those whom the IUAM calls "real Muslims" inside Afghanistan (VOADS).

* In its annual report to the US Congress, the US state Department says that human rights violations in Afghanistan worsened in 1987 and it will only be improved when Soviet troop will be withdrawn from that country (VOADS).

* Before his departure 11 February from Islamabad, the Soviet Deputy Foreign Minister, Yuli Vorontsove said the only way to form a broadbased government in Afghanistan is to accept the peace accord reached at Geneva (VOADS).

* The Soviet Furst Deputy Foreign Minister, Yuli Vorontsove has returned to the Soviet Union after his one and a half day talks with Pakistani leaders. He said, as far as the Soviet Union is concerned, no reason for any delay existed any more for signing a peace accord on Afghanistan (BBCFS).

* A mujaheddin commander of Hezb-e-Islami (Khales) in Faryab, Faqir Ahmad has said a number of Stinger rockets, sent for the mujaheddin last year, had fallen in the hands of the Iranian forces and at present Iran possesses 20 Stinger rockets (BBCFS).

* The Soviet Deputy Foreign Minister, Yuli Vorontsov met 11 February in Rawalpindi with Pakdstan Prime Minister Mohammad Khan Junejo and discussed with him in detail issues related to a peaceful and comprehensive solution of the Afghanistan problem (RPDS).

* The Chairman of International Students Union arrived 11 February in Kabul to participate in a seminar of Asian students on the role of education and training in the development of society (RA). * A meeting, attended by Foreign press attaches and journalists, was held 11 February in the Foreign Ministry to explain the recent statements of President Najibullah and the Soviet leader Gorbachev about the Afghan issue.

* At their meeting in Paldstan, the resistance leaders have said they would continue fighting until all Soviet troops are pulled out from Afghanistan. In their communique the leaders have once again rejected talks with the Najib regime about a future Afghan government (BBCPS).

* The Director of AMRC in Peshawar, Dr. Bahauddin Majrooh said 11 February all member of the PDPA are responsible for crimes committed in Afghanistan and forming a coalition government with them would be very difficult (BBCPS).

* Sabahuddin Kushkaki of the CCAR says the Afghans had not waged resistance only for a Sovlet withdrawal from Afghanistan but they also sought the establishment of an Islamic government in the country (BBCPS).

* The Soviet Deputy Foreign Minister, Yuli Vorontsov admitted 11 February in Islamabad that at present the most important issue at the Geneva indirect talks was the establishment of an NRP government in Afghanistan (VOAPS).

* The Soviet Deputy Foreign Minister Yuli Vorontsov called 10 February on President Ziaul Haq in Rawalpindi and conveyed to him an important message from Mikhail Gorbachev (DN).

* The UN mediator Dlego Cordovez sald 9 February in Geneva that he saw progress towards the formation of a new government in Kabul, an issue believed to be crucial for peace once the Sovlet troops pull-out from Afghanistan (IN).

* Diplomatic sources in Islamabad reveal that serious difficulties continue to obstruct an Afghan 
peace settlement. They pointed out that Gorbachev's statement did not at all address the question of the return of the Afghan refugees which is an objective imperative for Pakistan. Agreements that do not secure peace inside Afghanistan and do not lead to the return of the Afghan refugees would not be worth the paper they are written upon, the diplomats say (PT).

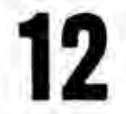

* The Iranian Foreign Minister Ali Akbar Velayati says his country welcomes the plan for the Soviet toops pull-out from Afghanistan but he pointed out that Iran could be satisfied only when an independent and Islamic government is formed in Afghanistan (BBCFS).

* The Director of Afghan Information Offlce Professor Bahauddin Majrooh was buried 12 February in Gharibabad, Peshawar, in the presence of thousands of Afghan refugees and Pakistanis (VOADS). * A member of the Institute of Strategic and International Studies at Georgetown University, Washington, and a former US Ambassador in Kabul, Dr. Robert Neuman, says the Soviet announcement about a date for the withdrawal of its troops from Afghanistan carries with it an impression of an end of Najib's period of leadership (VOADS).

* A US State Department spokesman told newSmen in Washington the US has so far not taken any decision to stop aid to the mujaheddin (RPDS).

* The Pravda (Moscow) writes the Soviet Union and Afghanistan are in favor of an early signing of the Geneva instruments and an insistence by Pakistani leaders to tie the Geneva accord with the formation of a new government in Afghanistan is not justified (RMDS).

* protocol on cooperation between the Democratic Youth Organization of Afghanistan and the Nepalese Students Organization was signed 12 February in Kabul (RA).

* The joint space flights by the Afghan-Soviet astronauts is scheduled in August this year (RA)。

* The Director of Afghan Information Office in Peshawar, Professor Sayyed Bahauddin Majrooh was killed 11 February by a gang of armed thieves associated with the extremist elements (RA).

* The Director of the Afghan Information Office in Peshawar Sayyed Bahauddin Majrooh was shot dead 11 February. He was among those who supported the possible participation of the former Afghan King Zahir Shah in the future coalition government of Afghanistan (VOAPS).

* Chairman of the Kabul National Front, Abdul Rahim Hathef has said in Geneva that President Najibullah is ready to exhibit flexibility in talks on an interim government (BBCPS).

* In a letter addressed to the UN mediator on Afghanistan Diego Cordovez and issued 11 February to the press in Peshawar, the IUMA President Mawlawi Mohammad Yunus Khales emphatically said that Geneva process could not culminate in a lasting peace in Afghanistan (DN).

* Talking to newsmen 11 February in Islamabad before his departure, the Soviet Deputy Foreign Minister, Yuli Vorontsov said any attempt to delay the Soviet troops withdrawal from Afghanistan would hamper a solution of the Afghan problem (DN).

* The US Congressman, Charles Wilson met 11 February President Ziaul Haq and discussed with him matters of mutual interest and the withdrawal of Soviet troops from Afghanistan and creation of a condition and a political environment in Afghanistan conducive to the return of 
refugees (PT).

* In an article under the heading of "Soviet exit from Afghanistan and its aftermaths" By Moqbul Sharif The Pakistan Times, has said a solution appears to be at hand for solving the Afghanistan problem (PT).

* Speaking 11 February to newsmen in Peshawar, the NWFP governor said although the solution of Afghanistan problem appears to be near, there is an apprehension that after Soviet troops withdrawal mutiny and chaos might ensure in that country (JG).

* Talking to newsmen 11 February at Islamabad airport, the JI Chief Qazi Hussain Ahmad said the Afghan refugees would not cause any difficulty for the Pakistani people and they would return home after the solution of Afghan problem (JG).

\section{3}

* The Pakistan Ambassador to the US, Jamshed Marker has said an important reason for Pakistan for the establishment of an interim government in Kabul before concluding Geneva peace accord is to make the situation conducive for the return of Afghan refugees from Pakistan (VOADS).

* At a meeting 12 February with the Pakistan Minister of State for Foreign Affairs, Zain Noorani, the US Congressman Charles Wilson discussed the latest developments on Afghanistan (RPDS).

* The Soviet Deputy Foreign Minister, Viladimir Petrovsky arrived 11 February in Teheran and held talks 13 February with the Iranian Deputy Foreign Minister, Jawwad Larajani on the Soviet military presence in Afghanistan and Iran-Iraq war (BBCFS).

* At a press conference in Moscow, the Afghan Ambassador to the Soviet Union Mohammadullah Safi said latest announcements by the Soviet and Afghan leaders prove the two countries' interest in speedy solution of the situation around Afghanistan and now there is no reasons for the leaders of the opposition groups to continue the war (RMDS).

* President Najibullah received 13 February representatives of the World Youth and Students Organization now participating in the seminar on "Education and Training" and "Progress and Society" organized by the Asian Students Information Center in Kabul. Dr. Najibullah discussed with them the role of the youth in the establishment of peace and implementation of the NRP in Afghanistan

* A protocol on promotioning trade and economic cooperation between Czechoslovakia and Afghanistan was signed 13 February in Kabul (RA).

* After thoroughly examining the Afghan candidates for the joint Soviet-Af'ghan space mission, the commission of medical experts approved Iieutenant Colonel Mohammad Dawran and Captain Abdul Ahad for a flight in a Soviet space ship later this year (RA).

* In an editorial, the Norwegian independent conservative daily The Aften Posten writes the Krentlin leadership has now understood it cannot win the Afghanistan war. It says the Russian have learnt the lesson that they were unwanted in Afghanistan and will be unwanted in the future as well (VOAPS).

* The Morgen Bladet (Norway) says Soviet assertion that intervention by other countries in Afghan istan should cease, means that Moscow will withdraw when all other countries abandon their support 
for the Afghan cause and by that time the Russians would have left nothing for the Afghans (VOAPS)

* A Norwegian daily The Vaartland writes Soviet leader Gorbachev should in no way be allowed to have an easy win at a dialogue table of what he could not accomplish in the battlefield. It says the mujaheddin should be given the right to self-determination (VOAPS).

* The Washington Times wrote 12 February the Kabul communist regime warned 11 February if Pakistan insisted on the formation of a new government in Kabul, the Soviet troops might not leave Afghanistan (VOAPS).

* At a press conference in Geneva, the NRP Chairman Abdul Rahim Hathef said President Najibullah cannot quit power merely to please the mujaheddin and Pakistan (VOAPS).

* Indian Minister of State for External Affairs, Eduardo Faleiro will be seeking Iran's support for the reinstatement of Afghanistan's former King Mohammad Zahir Shah, during a trip to Teheran next week, a leading Gulf newspaper reported 12 February (DN).

* A big rally of Afghan mujaheddin and refugees was held 12 February at Shah Bak refugee camp, Sadda Kurram Agency, in favor of former Afghan Monarch Zahir Shah (IN).

* China all but dismissed 12 February a Soviet offer to withdraw its troops from Afghanistan, calling the plan a manoeurre to bestow legitimacy on Kabul's communist regime by political means after the failure of military efforts (PT).

* In an article, Maleeha Lodhi asserts Sovlet leader Gorbachev is setting the stage for the Geneva talks on Afghanistan in a psychological atmosphere of compulsion and pressure. In publicly making an offer that looks hard to refuse, Mr. Gorbachev has hit the ball at hurtiling speed into the court of Pakistan and the mujaheddin, she, writes. (MIM).

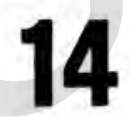

* The British Foreign Minister, Sir Jeoffrey Howe has expressed his country's concern over the form of government in Afghanistan after the Soviet troops withdrawal from that country (BBCFS),

* The British Foreign Minister, Sir Jeoffrey Howe arrived 14 February in Moscow. He is expected to particularly hold talks with the Soviet officials on the Soviet troops withdrawal from Afghan1stan and disarmament (BBCFS).

* About the recent statements of the Soviet leader Mikhail Gorbachev on the Soviet troops pullout from Afghanistan, the Turkish Foreign Ministry spokesman has said a government should be formed in Afghanistan at the earliest to represent the people of that country (RPDS).

* Bakhtar reports an extremist group, belonging to Hezb-e-Islami, had chalked out a terrorist plan to hit with Stinger rockets the plane carrying Diego Cordovez from Islamabad to Kabul. But, as a result of vigilence and timely action by the security forces of Afghanistan, the plan was foiled (RMDS).

* Foreign Minister, Abdul Wakdl arrived 1j February in Damascus from Tripoli and met the Syrian President Hafez Assad. He apprised the President of all aspects of the NRP and its achievements and the process of Geneva talks particularly in the context of President Najibullah's recent announcement (RA). 
* A protocol on direct cooperations for overall promotion and development of public health in Logar and Ghor provinces was signed 14 February between Afghanistan and Armenian Republic of the USSR (RA).

* The Soviet Union has donated 14 February essential goods worth 400 thousand rubles to the Watan child care center (RA).

* The New York Times wrote 13 January some US officials are concerned that the internal political problems of Afghanistan and external considerations related to tying-up Soviet troops withdrawal from Afghanistan with the halt in US aid to the mujaheddin might jeoperdize the Soviet troops pull-out program (VOADS).

* In a statement February 13 to the press in Peshawar, the ANP President Khan Abdul Wali Khan has opined that Soviet leader Gorbachev's announcement regarding a time-frame and definite withdrawal date of Soviet troops from Afghanistan had put the Pakistan government, Americans and the Afghan refugees to a test and their response would expose their real intentions for peace or otherwise

(MIM).

* In an interview with the BBC, Pakistan Minister of State for Foreign Affairs, Zain Noorani has said Pakistan had told the Soviet Union that a key clause of the proposed Geneva agreement was that such condition ought to be created under which the Afghan refugees could return home in an honorable and orderly manner and this required a change in the Kabul regime (MIM).

* Talking 13 February to newsmen at Karachi airport before his departure for Jedda enrouie to Baghdad, the OIC Secretary General Sharifuddin Pirzada said he had detailed discussions with Pakistani authorities about the Afghanistan issue during his stay in Pakistan (IN).

* A military expert, ex-colonel Ghaffar Mehdi has said that India wants to bring back Zahir Shah into power in Afghanistan in order to achieve its own "wretched designs" (NWT).

* In a joint statement 13 February in Lahore, Professor Mohammad Munawwar, Mufti Mohammad Hussain Naeemi, Mohammad Ajmal Khan, Senator Professor Khurshid Ahmad, Mawlana Mohammad Malik Kandhlawi, Dr. Mohammad Shafique Chawdri, MNA, Sayyed Assad Gailani MNA, Assadullah Ghaleb, Irshad Ahmad Arif, Mawlana Abdul Rehman Madani, Pir Ejaz Hashmi, Liaqat Baloch MNA, Justice (Retd) Malik Ghulam Ali, Mawlana Abdul Malik, Naeem Siddiqui and Ch. Ghulam Jeelani reiterated their support to Pakistan government's stand on the Afghanistan issue and said assistance to the Afghan Muslims is the duty of the Pakistani Muslims (JG).

\section{5}

* Teheran Radio has said talks were held 14 February between Iranian Foreign Minister Velayati and Soviet Deputy Foreign Minister Petrovsky in Teheran. The Iranian Foreign Minister stressed that his country supports the establishment of an independent and a non-aligned government in Afghanistan and the Afghan mujaheddin would have a main and effective role in the future of Afghanistan

(BBCFS).

* The British Foreign Minister, Sir Jeoffrey Howe arrive in Moscow for talks with the Soviet leaders on the pi blems of Afghanistan and Bast-West relations (BBCFS).

* The Pakistan Minister of State for Foreign Affairs, Zain Noorani left 15 February for Washington for consultations with US officials on the Afghanistan issue (RPDS). 
* The British Foreign Minister, Sir Jeoffrey Howe asked 15 February the Soviet Union to make efforts for the establishment of a government in Afghanistan which would truly represent the people. The establishment of a representative regime would be an important criterion in the voluntary return of the Afghan refugees to their country (BBCFS).

* Speaking 15 February at a press conference in Iondon, the Afghan Charge d' Affaires in London said the Kabul government is ready to include the opposition in government. But President Najibullah would not quit his office and the state will in no case hand over the power to the opposition groups (BBCFS)。

* The Heab-e-Islami (Khales) in a statement issued in Peshawar has said it has closed its offices in Teheran. The Hezb has accused Iranian officials attempting to takeover the control of the organization and impose their views on it (BBCFS).

* The Times (Iondon) wrote 15 February Professor Bahauddin Majrooh a prominent Afghan in Peshawar, had a great deal intellect, assassinated 11 February of influence on the international public opinion in connection with struggle against the Soviet invasion of Afghanistan (BBCFS).

* The BBC correspondent reports, a statement released 15 February by 28 relief organizations in Peshawar says the ruthless assassination of Professor Bahauddin Majrooh, Director Afghan Information Center is a new step in the intensification of terrorism which has blood bathed during the last months a large number of Pakistanis and Afghans in the NWFP, Pakistan (BBCFS).

* The New York Times writes interruption in daily work at Kremlin during the recent months speaks of the possibility of an internal difference over the Soviet policy in Afghanistan. Western analysts has been speculating for some time that putting on an end to the Soviet military role in Afghanistan may lead to rifts in the Communist party leadership in Moscow (VOADS).

* Foreign Minister Abdul Wakil concluded 15 February his visit to Syria and has now arrived in Amman, Jordan, on a friendly visit (RA).

* The Afghan Communication Minister, Mohammad Aslam Watanjar, who had gone at the head of a delegation to the Soviet Union for signing the final documents on Joint Soviet-Afghan space mission, returned home 15 February (RA).

* A high ranking delegation of Georgia Republic of the USSR arrived 15 February in Kabul on an official and friendly visit in the framework of direct cooperations between Kapisa province and ; Georgia SSR (RA).

* Afghanistan has protested to Pakistan against the military intervention by the Pakistani troops in Chaman and has also rejected a Pakistani claim about Afghan aircraft attacks in Ghashi Bajaur Agency (RA).

* The People's Republic of Bulgaria has supplied foodstuff, medicines, medical sundries, clothes, shoes and blankets worth three million liras equal to Afs. 200 million as a grant to Afghanistan

* The Republican leader in the US Senate, Senator Robert Dole has said the US would help the Soviet Union so long as 1 t withdraws its troops from Afghanistan. He, however, very cautiously warned, Moscow should not be allowed to leave behind its puppet regime after its exit (VOAPS). * The US Vice President George Bush has said he is happy the Soviets have spoken of their pullout from Afghanistan. However, he said, some issues have so far not been resolved which include 
the return of Afghan refugees from Pakistan and the composition of the future government in Afghanistan (VOAPS)。

* Addressing 14 February a seminar on Pakistan's foreign policy at Al-Hamra Art Center, Lahore, a former Foreign Minister of Pakistan, Agha Shahi said Pekistan should sign the agreement offered by the Soviet Union without insisting on the formation of an interim government as a pre-condition. However he said, Pakistan should clearly state that it would not recognize the Kabul regime because, being in possession of just $20 \%$ of the country's territory, it did not come upto the international standards required for recognition ( DN)。

* Briefing newsmen 14 February in Lahore, the JI Chief Qazi Hussain Ahmad said 110 permanent solution of the Afghan issue is possible without taking the Afghan mujaheddin into confidence in any future agreement (IN).

* In an editorial 15 February, The Dawn urged Islamabad to adopt a firm position in support of the Geneva accord and persuade the IUAM to work for a compromise with the other political groups to ensure a possible peace accord (DN).

\section{6}

* Pakdstan Minister of state for Foreign Affairs Zain Noorani arrived in Washington to consult US officials about the latest peace initiatives for the solution of Afghanistan problem (VOADS).

* The New York Times says a reason for the change in Pakistan's stand vis a vis the Afghanistan issue is that Pakistani leaders are not prepared to solve a problem which has been annually bringing hundreds of millions of dollars income for the country (VOADS).

* According to The New York Times, Pakistani and Indian officials believe, despite its announcement not linking Soviet troops withdrawal with the formation of an interim government, Moscow wants the formation of such a government. They described Gorbachev's statements as a calculated pressure on the concerned parties to discuss the establishment of a government in Afghanistan in order to prevent violence and disturbance after the Soviet troops withdrawal from Afghanistan (VOADS).

* A Pakistan foreign office spokesman told newsmen 16 February the Afghanistan crisis cannot end without the formation of a new government in Kabul and the Afghan refugees would not return until the formation of such government (RPDS).

* The US Undersecretary of State, Michael Armacost is to arrive 24 February in Islamabad. He will hold consultations with the Pakistani officials in the light of the Shultz-Shevardnadze discussion in Moscow (RPDS).

* Prime Minister Sultan Ali Keshtmand held 16 February talks with the Chairman of the Council of Ministers of Georgia Republic of the USSR on direct cooperations of that Republic with Kapisa, Afghanistan (RA).

* Talkg were held between Foreign Minister Abdul Wakdl and the Jordanian Foreign Minister Tahir In Amman. During the meeting the Jordanian side was apprised of the NRP process and settlenent of the situation around Afghanistan in relation to Nafibullah's recent announcement (RA).

* On the second day of his meeting with Soviet leader Gorbachev in Moscow, the British Foreign Minister, Sir Jeoffrey Howe said he is convinced Georbachev seriously wants the Soviet troops to 
withdraw from Afghanistan but the difficulties pertaining to the formation and composition of a transitory government have not yet been resolved (BBCFS).

* The People's Daily (China) writes the transitory government should represent all the people in Afghanistan and the achievement of any complete settlement of the Afghanistan issue is impossible without an acceptance of the mujaheddin forces (BBCFS).

* In an article 16 February, The Financial Times (London), observes that if Soviet troops are withdrawn from Afghanistan before the establishment of an interim government in that country, the occurance of an internal war in Afghanistan is almost definite (BBCFS)。

* In his report from Peshawar, The Guardian (Iondon) says although the refugees are not actually sure of a Soviet withdrawal from Afghanistan, they stress on two points: (1)support from an Islamic country and, (2) no communist should have any prominent role in that country (BBCFS).

* A spokesman of Hezb-e-Islami has told The Guardian, after a Soviet troops' withdrawal, there would remain no room for talks with the communists and even if we allowed them alive, it would be a great kindness to them (BBCFS).

* The Izvestia says war in Afghanistan has intensified tensions and has had a negative bearing on the political arena in other parts of the world. The war has been a lesson for us as well as for the Afghans (RMDS).

* Speaking 15 February at a reception in Moscow, the British Foreign Minister, Sir Jeoffrey Howe urged the Soviet leadership to help establish a representative government in Kabul (IN).

* According to a report, the US Ambassador to Pakistan, Arnold Raphel has suddenly been called to Washington for consulations on the current situation in Afghanistan and Soviet leader Gorbachev's announcement to withdraw Soviet troops from Afghanistan (PT)。

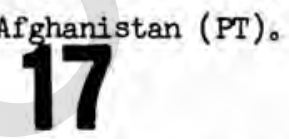

* The Paldstan Minister of State for Foreign Affairs, Zain Noorani held talks 17 February with the US Secretary of State, George Shultz in Washington on the Afghanistan issue (RPDS).

* In his meeting with the Soviet Deputy Foreign Minister, Viladimir Petrovsky in Teheran, the Iranian President Ali Khamenai has stressed the right of self determination for the people of Afghanistan (RPDS).

* The Hezb-o-Islami leader Engineer Gulbuddin Hekmatyar told newsmen in Islamabad that, without the formation of an interim government, every type of peace plan would fail in Afghanisten (VOADS)

* The Afghan mujaheddin leaders say they intend to form an interim government in Afghanistan before the beginning of forthcoming Geneva talks. Gulbuddin Hekmatyar, leader of the Hezb-eIslamic, has said the mujaheddin, refugees and the Muslims living inside Afghanistan would form the government. He said the non-communist members of the present government might also be asked to share power in that government (VOADS)。

* The Iranian President Sayyed Ali Khamenai says the influence of the US and other Western countries on every sort of plan for the future of Afghanistan after the Soviet troops withdrawal will be checked (VOADS).

* The Coordination Council of the Democratic teftist Parties of Afghanistan met 17 February 
under the chairmanship of President Najibullah and discussed matters of interest (RA).

* Prime Minister Sultan Ali Keshtmand left 17 February for the Soviet Union on a short visit for

a medical check up (RA).

* Deputy Prime Minister Mohammad Aziz met 17 February the Secretary Transport, of the Russian Soviet Federated Socialist Republic in Kabul and held talks with him on improving condition of motor transport in Afghanistan (RA).

* On the conclusion of his friendly talks on bilateral relations and matters of mutual interest, regional and international issues with the Jordanian Foreign Minister, the Afghan Foreign Minister Abdul Wakil left 17 February that country. He also delivered to the Jordanian Minister a message from President Najib to King Hussain (RA).

* The Chairman of National front and the NRP President, Abdul Rahim Hathef, who led a delegation to the UN Human rights commission sessions in Geneva, returned 16 February to the country. He said the delegation actively participated in the work of the commission and met the UNHCR conmission in Geneva and discussed with him the work done by the Afghan NRP commissions and other recent developments in the country (RA).

* Afghanistan lodged 17 February a strong protest with the Pakistan government against the firing of ground-to-ground rockets in Spin Boldak, Kandahar, by the Pakistan armed forces and the violation of Afghan airspace by Pakistani planes (RA).

* The Afghan Ambassador designate in Libya Naeem Ajmal presentec 17 February his credentials to the Libyan Secretary of the People's Committee (RA).

* Engineers of the Farghana Gas supply department recently completed a project of gas supply for 100 peasant families in Jauzjan province in the framework of friendly assistance between the Soviet Union and Afghanistan (RMDS).

* The BBC correspondent in Islamabad says thousands of Afghan refugees and the mujaheddin staged 17 February demonstrations in Bajaur Agency, Pakistan, to express their opposition to the return of the former Afghan Monarch, Mohammad Zahir Shah to head the transitory government in Afghanistan (BBCFS).

* Anthony Hyman a BBC commentator, who recently returned from Peshawar, Pakistan, says Afghan guerrilla leaders, who have been installed in leadership position by the virtue of a staunch and continued Afghan struggle, have not been able to eliminate their differences for the sake of national unity. Thus the important issues pertaining to the future of Afghanistan and peace in that country have remained unsolved. He says resistance parties have not gained sufficient political experience in the nine years of struggle (BBCFS).

* The Independent, (Iondon) wrote 17 February officials of the UNHCR have said if the government in Afghanistan is not changed after a Soviet withdrawal, the Afghan refugees would not return to their country (BBCFS).

* The Guardian (London) refuted 17 February the assumption that, by deciding to withdraw 1 ts troops from Afghanistan, the Soviet Union has not yielded to the world public opinion and the change in the Soviet policy is due to the valour and perseverance of the Afghan people (BBCFS). 
* The Afghanistan resistance sources say the Kunar mujaheddin and the refugees held 18 February a gathering in Janda, Dir District, NWFP, and asked the former Afghan King Mohammad Zahir Shah to share the coalition government as a national symbol (VOAPS)。

* The Afghan Ambassador in New Delhi Abdul Samad Azhar has rejected a Pakistan demand for the formation of a transitory government in Afghanistan before the Soviet troops withdrawall from that country. He says this is an internal issue of Afghanistan (VOAPS).

* Before his departure for Moscow, the US Secretary of State George Shultz told newsmen he would press the Soviet Foreign Minister to tell him the details of a phased time-frame for the Soviet troops withdrawal from Afghanistan (VOAPS).

* Pakistani officials say the Soviet Union had agreed last year that an interim government ought to be formed in Afghanistan to check the internal feuds after the Soviet troops withdrawal in that country (VOAPS).

* Talking 18 February to editors of national dailies, news agencies and periodicals at Alwan-eSadr Islamabad, President Ziaul Haq said Pakistan has not changed its principled policy on Afghanistan since it has always pressed for the withdrawal of Soviet forces and creation of conditions under which Afghan refugees could return to their homeland in peace and honor (DN).

* According to a report from a prominent commander of Ittehad-e-Islami (Sayyaf) in Parwan, Soviet troops, manning 16 security posts in strategic regions of the province, have started pulling-out and gathering at Bagram airbase last week (DN).

* Women activists came out 18 February on Karachi roads to collect signatures in favor of making the forthcoming Geneva talks a success. In a memorandum they called upon the Pakistan government to sincerely accept the pull-out offer by the Soviet Union and help the return of the Afghan refugees to their country (MIM).

* In a statement 18 February in Peshawar, a former member of Afghanistan Parliamert, Fatehul Mulk Nang Yousufzai pointedout that the Soviet Union has no right and justification to demand a neutral Afghanistan in the wake of the withdrawal of its troops from Afghanistan (MIM).

* Addressing receritly a public meeting in Karak, NWFP Air Marshal (Retd) Asghar Khan, the TIP leader has said some elements who are profiting from the Afghan conflict are not sincere in its early solution (MIM).

* The US State Department spokesman Charles Redman said 18 February the formation of an interim govermment in Afghanistan would be desirable but he stressed the main priority still remained the withdrawal of Soviet troops from Afghanistan (DN).

* The Afghan Ambassador in New Delhi Abdul Samad Azhar said 19 February at Pakistan's conditions for the signing of a peace agreement on Afghanistan are unacceptable to the Kabul government (DN). * Tunisian President Zine Al-Abidin bin Ali received 19 February an important message from Soviet leader Mikhail Gorbachev concerning the conflict in Afghanistan, the Tunisian news agency reported

* The BBC reported, Pakistan's proposal, that an agreement on an interim government in Afghanistan before the withdrawal of Soviet troops from Afghanistan was essential to avert subsequent bloodshed, has been strongly criticized by several US Congressmen (MIM). 
* The Washington Times wrote 17 February the agreement on the political solution of the Afghanistan problem prepared by the UN is on the one hand not complete and, on the other, it can be broken at every moment, and only firm cooperation between the US and the USSR would be able to save it

(VOAPS).

* Speaking 16 February to newsmen in Islamabad, leader of the Jamiat-e-Islami Afghanistan,Professor Burhanuddin Rabbani said after the Soviet troops pull-out from Afghanistan a government, consisting of mujaheddin, will be formed in the country and it will not include any communist. He added the Afghan mujaheddin will never accept the former King Zahir Shah (NWT).

* A former Indian Foreign Secretary, M.K. Rasgotra has said that Pakistan will try to establish an Islamic government in Afghanistan after the Soviet troops withdrawal from that country (JG).

* The Iranian Foreign Secretary, Ali Mohammad Basharati said 15 February Iran will do all it can to help Moscow withdraw its troops from Afghanistan so as to ensure that the country is not taken over by a pro-American regime (MIM).

* Pakistan Foreign Secretary Abdul Sattar will leave 19 February for Teheran. His visit is a part of Islamabad's latest efforts to brief friendly and neighbourly countries on the recent developments on Afghanistan (MIM).

\section{8}

* Gordan Adam of the BBC says Gorbachev is interested in resorting to reconciliation with the formation of a coalition government in Afghanistan and, coinciding with the Pakistani view point, wants to persuade Dr. Najibullah to accept a less important role in the transitory government representing all the parties (BBCFS).

* The Pakistan Minister of State for Foreign Affairs, Zain Noorani met 17 February the US Secretary of State George Shultz in Washington. He later told newsmen there are many similarities in the stands of Pakistan and the US on the Afghanistan issue (RPDS).

* A seven member delegation of the World Islamic Unity visited 18 February an Afghan refugee camp in Katcha Garhi near Peshawar city (RPDS).

* A spokesman of the Bangladesh Foreign Office has asked for an immediate solution of the Afghanistan issue and the withdrawal of foreign troops from that country (RPDS).

* In an interview with The Pravda, the Soviet Deputy Foreign Minister, Yuli Vorontsov said the establishment of a coalition government in Kabul is very important task but this should be the assignment of the Afghans themselves and it has no link with the Geneva accords because these agreements pertain to the settlement of the foreign factors of the Afghanistan situation (RMDS). * The BBC correspondent says the mujaheddin in Pakdstan have put pressure on the Pakistan govern-

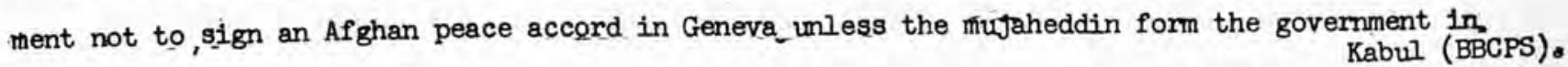
* At. a press conference the Hezb-e-Islami leader Gulbuddin Hekmatyar said Pakistan should continue its stand in regard to the Afghan issue. He expressed his opposition to the proposal suggesting the return of the former Afghan King Mohammad Zahir Shah to head the transitory government in Afghanistan (BBCPS).

* Speaking 17 February informally to editors of national dailies in Rawalpindi, Prime Minister 
Mohammad Khan Junejo said the triumph of the Afghan people's struggle is in sight and Pakistan will continue to uphold their interests (IN).

* The BBC has quoted a Kabul government diplomat in London Ahmad Sarwar to have ruled out the removal of Kabul regime's President Dr. Najibullah from his office (DN).

* Apprehending a change in Pakistan's Afghan policy, Pakistani opinion leaders have urged the government to avoid complicating the situation and to make serious efforts towards reaching a final settlement at the forthcoming Geneva talks (MIM).

* At a press conference 17 February in Islamabad, the Hezb-e-Islami Chief Gulbuddin Hekmatyar said the resistance movement would announce its interim government by the end of February and reiterated that the solution of Afghan issue lay in dialogue and mutual trust and not in war (MIM).

\section{9}

* Soviet officials have criticized Pakistan for its insistance on the formation of an interim government in Afghanistan before signing a peace accord at the UN sponsored Geneva talks (VOADS).

* In an article in a literary magazine, a Soviet expert on Afghanistan Alexander Proupanov writes Soviet planners had a wrong impression that Afghanistan was treading on the path of communism and they had ignored the long standing historic heritages of the Afghan people (VOADS).

* The US State Department officials say the US and Pakistani officials have agreed that an interim government in Afghanistan is a requirement to facilitate the Soviet troops withdrawal from the country (VOADS).

* In an interview with the US television network, the US Secretary of State George Shultz has said the US would persist that with a halt in US military aid to the Afghan mujaheddin the Soviet Union should also stop its assistance to the Afghan government (RMDS).

* In a statement in Peshawar President General Mohammad Ziaul Haq has said the Afghanistan issue can be solved in total by forming an interim government in that country (RPDS).

* The Pakistan Foreign Secretary, Abdul Sattar left 19 February Karachi for Teheran to consult the Iranian leaders on the latest developments in the solution of the Afghanistan problem (RPDS).

* The Pakistan Minister of State for Foreign Affairs, Zain Noorani met 19 February the British Foreign Minister Sir Jeoffrey Howe in London. At a press interview he said if a transitory government is not formed in Afghanistan prior to the Soviet troops withdrawal from that country, it is feared that the country might be engulfed in another round of bloodshed (BBCFS).

* In an interview 19 February, the adviser to the US State Department and member of the Planning Commission of the US Foreign policies, Dr. Zalmey Khalilzad said he does not think that the US would accept an agreement under which the US should stop aid to the mujaheddin and the Soviet Union could continue aid to the Kabul regime. The point which can be acceptable to the US is that aid ghould be stopped from both sides (BBCFS).

* In an article on political developments in Afghanistan, The Times (Iondon) writes an opportunity has now come that the real objective of Pakistan and Western countries - - the Soviet troops withdrawal from Afghanistan - - can be accomplished and this opportunity should not be missed due to difference of views on other issues (BBCFS). 
* The Independent (Iondon) reports the US State Department agrees with Pakistan that it would be better if the difficulty of setting up a transitory government in Afghanistan is solved before signing the Geneva accord. But apparently it is worried that" an_exaggerated insistence in this connection might defer the Soviet troops pull-out (BBCFS).

\section{0}

* On his return 20 February from the US and the Britian, the Pakistan Minister of State for Foreign Affairs Zain Noorani reiterated the necessity for setting up an interim government in Afghanistan simultaneously with Soviet troops pull-out from that country (RPDS).

* The US Secretary of State George Shultz, who arrived in Helsinki for a short stopover enroute to the Soviet Union, told a television network that the replacement of the Soviet backed regime in Kabul with a transitory government would help establish stability in Afghanistan on the threshold of the Soviet troops withdrawal (RPDS).

* A five menber Canadian delegation, led by the Canadian Foreign Secretary for Asia and Pacific, visited 20 February an Afghan refugee camp in Kolcha Garhi near Peshawar. A three member Sudanese delegation, including former President Field Marshal Abdul Rehman and former Prime Minister Dr. Hassan Tarobi, also visited Afghan refugee camps in Peshawar (RPDS).

* The US Secretary of State George Shultz, told newsmen 20 February in Finland that his country would stop military assistance to the Afghan rebels provided the Soviet Union also refraines from such aid to the Afghanistan government (BBCFS).

* At a press conference 19 February in Teheran, the Iranian Foreign Minister, Ali Akbar Velayati opposed talks on Afghanistan without the participation of Afghan Muslims and the mujaheddin. He described the mujaheddin as the real party of the Afghan war (BBCFS).

* The Iranian Foreign Secretary, Ali Mohammad Besharati said 19 February Pakistan and Iran should be ensured that the US would not interfere in the issues pertaining to the future of Afghanistan

(BBCFS).

* In an interview, carried by The Risalat (Teheran), the Soviet Ambassador in Teheran, has said Soviet troops would leave Afghanistan on the fixed date even if an agreement is not reached at the Geneva talks before the date announced by Gorbachev for the Soviet troops pull-out from Afghanistan (BBCFS).

* The US Secretary of State George Shultz says during his talks in Moscow he would urge the Soviet Union to support the formation of an interim government in Afghanistan (VOADS).

* President Najibullah received 20 February the Deputy Chairman of the Council of Ministers of Georgian Republic of the USSR and his entourage and held talks with them on direct cooperations of that Republic with Kapisa province (RA).

* Foreign Minister Abdul Wakil, returned 20 February to the country after paying friendly visits to Kuwait, Libya, Syria at the head of a delegation(RA).

* Under the Presidential amesty, 24 prisoners were released 20 February from jail in Balkh (RA).

* A group of Afghanistan resistance has accused Iran of hindering the use of Stinger rockets - against the Soviet-Kabul troops (VOAPS). 
* A member of the advisory council of Jabahai Nejat-e-Melli, Ishaq Gailani told newsmen a mujaheddin delegation has gone to Rome to meet Mohammad Zahir Shah within a couple of days and to ask him to return to the country and head an interim government in Kabul (VOAPS).

* Pakistan says it has received a message from the Soviet leadership expressing their stand on the formation of a coalition government (BBCPS).

\section{1}

* The US Secretary of State, George Shultz said in Helsinki that he is optimistic about the success of current efforts to end the Afghanistan problem and the talks on the Afghan issue have now entered a final stage (BBCFS).

* In his meeting with the Pakistan Foreign Secretary, Abdul Sattar in Teheran, the Iranian Foreign Mintster sald Iranian believes the Afghan mujaheddin should be allowed a prominent role in the decisions about the future of their country (BBCFS).

* The Palistan Minister of State for Foreign Affairs, Zain Noorani has rejected Soviet government's claim that Islamabad was hindering a peaceful solution of the Afghanistan issue by insisting on the establishment of an interim government in Kabul (VOADS).

* A high ranking Soviet official met the Kuwaiti leaders to win their support to the Moscow plan about Soviet troops withdrawal from Afghanistan (VOADS).DS).

* Prime Minister Moharmad Khan Junejo said the creation of favorable atmosphere for the honorable return of the Afghan refugees to their country is a main issue of the Afghan problem (RPDS).

* The Pakistan Minister of State for Foreign Affairs Zain Noorani met the Chinese Deputy Foreign Minister in Beijing for talks on the solution of Afghanistan issue (RPDS).

* The Pakistan Ambassador in Moscow Shahid Amin delivered messages from the Pakistani leaders to the Soviet leaders about the recent statement of the Soviet leader Gorbachev in connection with the Soviet troops withdrawal from Afghanistan (RPDS).

* A seven member Saudi delegation led by the Saudi Haj Minister Abdul Wahab Waseh met 21 February the NWFP governor Fida Mohammad Khan in Peshawar and also visited the Afghan refugee camp in Katcha Garhi (RPDS).

* In an interview with the VOA, the US Secretary of State George Shultz reiterated that setting up a transitory government in Afghanistan can be beneficial to both sides but most of the US experts and political figures reject such unrealistic demands (RMDS).

* President Najibullah conferred 21 February medals and badges to those Soviet subjects who have shown particular ability in the performance of their internationalist duties in Afghanistan (RA).

* A protocol on direct cooperation between the Georgia Republic of the USSR and Kapisa province was signed 21 February in Kabul (RA).

* Pakistan Minister of State for Foreign Affairs, Zain Noorani said 20 February in Islamabad that a very bloody civil war could begin in Afghanistan if the issue of forming a transitional government in that country was not solved (DN).

* A JI leader Khurshid Ahmad Kanjo said 20 February in Shujabad the JI Chief Qazi Hussain Ahmad has met the Soviet Ambassador in Pakistan twice and made it clear that the Afghan issue cannot be 
resolved unless Afghan mujaheddin are taken into confidence (DN)。

* In a statement 20 February in Peshawar, the ANP Deputy Secretary General Iateef Afridi apprehended dangers of a civil war in Afghanistan in the wake of the discord among the various groups of Afghan refugees over the question of future government, with particular reference to Zahir Shah (DN).

* Speaking 20 February in Peshawar the $J$ Chief Qazi Hussain Ahmad stressed unity among the mujaheddin leaders adding with differences, their final victory could be delayed (MIM).

* It has been reliably learnt that the Soviet Embassy in Islamabad has extended invitation to some of the mujaheddin leaders for attending a function 21 February on the occasion of Soviet Army day. But the Afghan mujaheddin leaders have turned down the invitation (NWT).

\section{2}

* The Washington Times has quoted a Pakistani military analyst saying that Soviet troops will withdraw from Afghanistan but they will put that country in an internal war so as to keep a way open for its re-entry into Afghanistan (VOADS).

* The Chinese defense analysts agree on further US and Chinese aid to the Afghan mujaheddin as a most effective means to persuade the Soviets on a pull-out from Afghanistan. (VOADS).

* The Indian Prime Minister Rajiv Gandhi has called for a complete end to interferences in Afghanistan after the Soviet troops withdrawal from that country. Speaking at a session of the Congress party in New Delhi, he said India wants an independent and genuinely non-aligned Afghanistan (BBCFS).

* Teheran Radio reported the Iranian President Ali Khamenai says the mujaheddin are the real spokesman of the Afghans and entitled than anyone else to adopt decisions about the futue of their country (BBCFS).

* The Pakistan Minister of State for foreign affairs, Zain Noorani met 22 February the Chinese Foreign Minister in Beijing and discussed with him various aspects of the Afghan problem (VOADS).

* The Chinese news agency says the Chinese government supports Pakistani proposals about a secure return of Afghan refugees to their country and the formation of a transitional government in Kabul (BBCFS).

* The Iranian Foreign Secretary Besharati has said the Soviet backed government in Afghanistan is responsible for the massacre of more than one million people in that country and it cannot have any share in organizing the future government of Afghanistan (BBCFS).

* The BBC correspondent says, as diplomatic efforts are underway to seek a solution to the Afghanistan issue, the Afghan Shia refugees and the mujaheddin supported by the Iranian government have urged a role for themselves in the future government of Afghanistan (BBCFS).

* The Soviet Deputy Foreign Minister, Yuli Vorontsov met the Chinese Ambassador in Moscow and discussed Soviet leader's recent announcement on the Soviet troops pull-out from Afghanistan (RMDS)

* In an interview 22 February with a US correspondent, Soviet leader Mikhail Gorbachev said a consensus was reached on Afghanistan at the US-Soviet summit in Washington and now steps ought to be taken towards implementing it (RMDS). 
* A delegation of the Kirghizistan Republic of the USSR arrived 22 February in Kabul in connection with the direct cooperation of that Republic with Bamian and Wardak provinces (RA).

* Foreign Minister Abdul Wakil met 21 February the Deputy Chairman of the Council of Ministers of the Georgia Republic of the USSR on matters of mutual interest in Kabul (RA)。

* A delegation of the Soviet Civil Aviation Ministry arrived 22 February in Kabul for talks on cooperation for the promotion of civil aviation in Afghanistan (RA).

* According to Afghan mujaheddin, they attacked recently $12 \mathrm{KHAD}$ and KCB officials near the border and killed them on the spot (RPDi).

* Talking 21 February to newsmen in Sibi, Prime Minister Mohammad Khan Junejo expressed optimism on the mujaheddin struggle and reiterated that Pakistan will continue to uphold their interest

(MIM).

* Another anti-Zahir Shah rally was staged 21 February in the Kotki refugee camp in Hangu Tehsil of Kohat district where speakers reiterated their opposition to the return of the ex-King and resolved that only the Afghan mujaheddin have the right to form the future government in Afghanistan (MIM).

* Talking 21 February to reporters in Lahore, the PDP President Nawabzacla Nasrullah Khan proposed the appointment of a UN administrator to help in the holding of free and fair elections and establishment of a representative government in Afghanistan (IN).

* It has been reliably learnt that the Soviet Ambassador in Islamabad Abdul Rehman Vezirov has been summoned to Moscow for holding important consultations (NWT).

\section{3}

* Concluding his two days talks in Moscow, the US Secretary of State George Shultz says now there is a great possibility for the establishment of peace in Afghanistan (BBCFS).

* On his return from China, the Pakistan Minister of State for Foreign Affairs Zain Noorani, said the Soviet Union has revoked its decision by refusing to link Soviet troops withdrawal from Afghanistan with the replacement of Dr. Najibullah by a coalition government (BBCFS).

* The UN Human Rights Commission has once again called for the immediate withdrawal of Soviet. troops from Afghanistan. In a resolution it has been stated that Afghanistan should be a part of the non-aligned countries and the principle of non-interference and non-aggression in the affairs of Afghanistan should be rigidly observed (BBCFS).

* The IUAM in Peshawar, Pakistan, has proposed a plan for the formation of a transitional government in Kabul which would supervise the Soviet troops withdrawal from Afghanistan and the holding of general elections in that country (BBCFS).

* In an interview in London, a commander of the Hezb-e-Islami(Khales) Abdul Haq has pointed out the people of Afghanistan are fighting for two objectives, - - to put an end to the Soviet invasion of Afghanistan and installation of an Islamic state in Kabul. He said, the continuation of communist regime in Kabul would cause mutiny (BBCFS).

* In his meeting 22 February with the US Secretary of State, George Shultz in Moscow, the Soviet leader Gorbachev reiterated that Afghanistan would be an independent country after the Soviet 
troops withdrawal from Afghanistan (BBCFS).

* Reports from Italy say the Afghan Charge d' Affaires in Italy, Noorzai Fidaee has sought asylum in the west. Apparently he and his wife disappeared four days ago from Rome (BBCFS).

* At a press conference in Brussels, the US Secretary of State George Shultz expressed satisfaction that the Soviet Union is ready to leave Afghanistan. He said, from their public statements and their private discussions, I feel they consider their presence in Afghanistan harmful and they want to leave that country (VOADS).

* The Washington Post wrote 23 February, in their letters addressed to President Reagan many US Senators and Congressmen have expressed concern over a possible halt in the US aid to the Afghan mujaheddin under a 1985 understanding reached in the framework of Geneva accord (VOADS).

* The government of Poland has agreed to the appointment of Noor Ahmad Noor as Afghan Ambassador to that country (RA).

* At the invitation of Foreign Ministry, UNHCR delegation arrived 23 February in Kabul to hold talks about the return of refugees and providing facilities and other essential services to them after their return (RA).

* More than 10,000 Pakistanis have signed a memorandum calling for the solution of Afghanistan problem. The move has been initiated in Lahore by the Federation of Democratic Women of Pakistan

(RMDS).

* Islamic Alliance (Sayyaf) mujaheddin report from Quetta the mujaheddin approached 16 February behind the military drilling ground of Kandahar prison and threw a number of hand grenades on the troops killing 13 of them (VOADS).

* The mujaheddin sources report the mujaheddin attacked 20 February a communist troops platoon busy constructing a new post in the old communication center of the Sixth District of Kandahar. In the four hours long battle two heavy guns and two trucks were destroyed and at least 15 communist activists were killed. The communists had to abandon the construction (VOADS).

* The Director of Afghanistan Information Center in Freedom House, New York, Rossane Klass is of the view that Gorbachev's offer has put a great deal of pressure on the West to accept an agreement under which Afghanistan would practically remain under the Russian control (VOAPS).

* An expert on Soviet affairs at the US strategic and international center says the mujaheddin, Pakistan and the US should adopt pre-cautionary measures at the Geneva talks prior to signing any agreement (VOAPS).

* The Afghan Islamic Agency in Peshawar says a high ranking official of the Kabul regime's Health Ministry, Mohammad Nasir Ranzoorpal defected 7 February to the mujaheddin in Peshawar (VOAPS).

* Speaking 22 February to newsmen on his return from China, the Minister of State for Foreign Affairs, Zain Noorani said Soviet leader Mikhail Gorbachev's recent statement on the Afghanistan issue amounted to an ultimatum as it contained a number of conditions. He said it falls short of ensuring a peaceful settlement of the Afghanistan crisis (MIM).

* Radio Moscow reported that Soviet leader Gorbachev said 22 February his country was prepared to do every thing possible to facilitate an agreement on Afghanistan (MIM). 
* At a press conference 22 February in Peshawar, Afridi tribal elder Wali Khan Kukikhel decried efforts by the Pakistan government to insist on having a regime of its choice in Afghanistan at a time when its own representative character was questionable (MIM).

* In a press statement 22 February in Rawalpindi the MRD Additional Secretary General and a prominent leader of QMA, Tanvir Iqbal Pasha, said at a time when a settlement of the Afghan problem is in sight, Pakistan's new condition of "an interim government first" is bound to vitiate the atmosphere and delay an accord in the forthcoming Geneva round (MIM).

\section{4}

* The US Under Secretary of State Michael Armacost met 24 February Prime Minister Mohammad Khan Junejo in Rawalpindi and apprised him of the recent discussions of the US Secretary of State, George Shultz with the Soviet leaders on Afghanistan issue in Moscow (RMDS).

* The Pakistan Minister of State for Foreign Affairs, Zain Noorani, who had gone to Saudi Arabia for consultations with the Saudi leaders on Afghanistan, on his return 24 February to Islamabad said the Saudi leaders believe the solution of Afghanistan problems lies in the immediate withdrawal of the Soviet troops from Afghanistan and creation of conditions in that country for a voluntary return of the Afghan refugees (RPDS).

* A spokesman of the Pakistan Foreign Office said 24 February there is complete similarity of views between Pakistan and Iran on Pakistan's stand for a comprehensive solution of the Afghanis$\tan$ issue (RPDS).

* The Iranian government says the Soviet Union has shown an interest in Iran's proposal for direct talks on Afghanistan issue among the other warring parties including Pakistan, Iran and the Afghan mujaheddin (RPDS).

* Quoting a US State Department official, The Financial Times (Iondon) wrote 24 February that the US does not support Pakistan's request for the formation of a transitional government in Kabul before the Soviet troops withdrawal (BBCFS).

* The THmes (London) reported 24 February that the US information sources say Soviet troops right now look for pull-out from Afghanistan and families of Soviet military personnel are steadily being returned to Soviet Union and its military bases are gradually are taking defensive positions

(BBCFS).

* In a meeting with the elders of Kandahar province, President Najibullah said the formation of a coalition government relates to the people of Afghanistan themselves and no other country should interfere in the internal affair of Afghanistan (RMDS).

* The Deputy Prime Minister, Nazar Mohammad met a Soviet civil aviation delegation 24 February and exchanged views with it on matters of mutual interest including the creation of an organized system of civil aviation network, organizing the civilian aircraft flights and training of personnel (RA).

* At the invitation of Soviet officials, Deputy Prime Minister, Sayyed Amanuddin Amin, leading a government delegation and representatives of private enterprises, arrived in Moscow for discussions on determining the volume of Soviet cooperations in joint Afghan-Soviet projects as well as the private sector and signing a protocol of economic cooperation (RA). 
* The Deputy Prime Minister and Chairman of the Department of Refugees Affairs, Mohammad Hasan Sharq met the UNHCR delegation which has come to Kabul to discuss with the Afghan authorities matters related to providing essential relief items to the refugees (RA).

* The Indian Prime Minister's special envoy, carrying a message for the Afghan leaders, arrived 23 February in Kabul. The Indian news agency says the Indian envoy is carrying India's assessment report about the recent developments on the solution of the Afghanistan problem (BBCFS).

* The Soviet Union has turned down the IUAM proposal for the formation of a transitional government to supervise Soviet troops withdrawal from Afghanistan (BBCFS).

* The UN mediator in the proximity talks on Afghanistan, Diego Cordovez says the UN is now busy preparing observer groups to supervise every kind of cease-fire agreed upon in the Geneva talks

(BBCFS).

* The form of coalition government in Afghanistan, as explained 18 February by the Soviet Deputy Foreign Minister in an interview with The Pravda, means the mujaheddin should accept communist domination in a coalition government in Kabul (VOAPS).

* Western diplomats in Islamabad say the mujaheddin have carried out a series of operations in the outskirts of Kabul city and 18 bomb explosions took place during the last week in Kabul city. A bomb went off inside the Soviet embassy and another one exploded near the Radio-Television building (VOAPS).

* On his return 23 February from his successful visit to Iran, the Pakistan Foreign Secretary said Iran has reiterated support to Pakistan's stand that the Afghan problem would not be solved unless a government supported by the people of Afghanistan is established in Kabul (NWT).

* Afghan guerrillas based in Iran have said they would not share any government with the communists in Kabul (JG).

* TASS has quoted Soviet leader Mikhail Gorbachev as saying the Soviet Union never had and does not have any secret plans about Afghanistan such as making that country a bridgehead, etc (PT).

* In a press release 23 February, the IUAM finally came up with its own set of proposals for a transitional government in Afghanistan which will oversee a cease-fire, ensure the Soviet troops withdrawal, facilitate the return of Afghan refugees and hold general elections within six months

\section{5}

(MIM).

* A BBC correspondent says the TUAM based in Peshawar, has nominated Engineer Ahmad Shah deputy leader of Ittehad-e-Islami of Sayyaf as the head of an interim government to succeed the present government in Afghanistan (BBCFS).

* The US Under Secretary of State Michael Armacost met 25 February President Ziaul Haq in Iahore and discussed with him matters about Afghanistan with particular attention to the recent US-USSR talks in Moscow and on the Geneva proximity talks as well as the issue of an interim government in Afghanistan (RPDS).

* A US State Department spokesman said 24 February in Washington that no change has occured in the US policy about Afghanistan and the US government stands by its pledge to support the Afghan- 
istan resistance (RPDS).

* A source of Pakistan government said about 25,000 Afghans sought refuge during the last three months in Pakistan. Most of them were rendered homeless in recent fierce fightings in Khost and Paktia (RPDS).

* At a press conference 24 February, head of the Information Department in the Soviet Foreign Ministry,Genady Gerisomov said the present Kabul government for the time being is functioning in Afghanistan and the transitional government proposed by the IUAM cannot be described as a legal representative of the people of Afghanistan (RMDS).

* Leaders of 16 opposition parties in Pakistan have urged the government to sign the Geneva accord on the settlement of Afghanistan problem. They have pointed out that the issue pertaining to the establishment of either an interim or permanent government in Afghanistan should be solved by the people of Afghanistan themselves (RMDS).

* After his talks on the Afghanistan issue, the US under Secretary of State Michael Armacost proceeded to New Delhi. In Pakistan he apprised Pakistani leaders of the US stand and said Soviet troops withdrawal from Afghanistan should not be made conditional with the formation of a coalition government in Kabul (BBCFS).

* Afghan mujaheddin leader, Gulbuddin Hekmatyar said 24 February if Pakistan signed an agreement with the government of $\mathrm{Dr}$. Najibullah, he would shift the headquarters of his organization from Pakistan to Iran (BBCFS).

* A BBC commentator writes, the Afghan mujaheddin believe that, while time for the Soviet troops withdrawal is drawing near, the US government has left the mujaheddin at their own (BBCFS).

* A protocol of cooperation between the Civil Aviation Ministries of Afghanistan and Soviet Union was signed 25 February in Kabul. Under the protocol, the Soviet Civil Aviation Ministry will help in personnel training, technical services and providing of equipment to airports (RA).

* The mujaheddin leaders have accused the US of having colluded with the USSR for seeking an immediate solution to the Afghanistan dispute (VOAPS).

* A commander of Hezb-e-Islami (Khales) Abdul Haq said in Iondon if the mujaheddin join a coalition government with the Kabul regime, they will be opposed and antagonized by the Soviet Union. He was of the view that the US has relaxed its stand against the Russians because, according to him, it wants to earn a special name for President Reagan in the history (BBCPS).

* The IUAM leader Mawlawi Mohammad Yunus Khales has said we clearly told the US Under Secretary of State Michael Armacost that the US government policy is wrong and it will result in continued bloodshed in Afghanistan. If the US accepted the Geneva accord it would harm the mujaheddin by creating the impression to the people of world that the mujaheddin were opposed to peace (VOAPS)。

* Quoting reliable Kabul sources, Western sources say more than 50,000 prisoners are presently kept in Pul-e-Charkhi jail and 23 or 24 imprisoned mujaheddin were killed 13 February there (VOAPS). * The Indian news agency UNI reported that Indian Prime Minister, Rajiv Gandhi has invited the Pakistan President Ziaul Haq to visit New Delhi for talks on the Afghanistan issue (VOAPS).

* A high ranking US official has said in Washington that the US has been making endeavors always io persuade the Soviet Union to pull-out its troops from Afghanistan. The US official says it 
is not fair to tell the Soviets to remain in Afghanistan until a political solution is accompli-

* At a press conference 24 February, the Hezb-e-Islami leader Gulbuddin Hekmatyar said the US and USSR have colluded against the mujaheddin and an influential circle in the US which is alergic to the name of Islam and Islamic government, prefers the continuation of a communist government than the establishment of an Islamic state (VOAPS).

* The Jamiat-e-Islami Afghanistan leader, Professor Burhanuddin Rabbani in telegrams to the Amnesty International, the ICRC in Geneva and the UN human rights Rapporteur on Afghanistan Felix Ermacora has alleged that the Kabul regime has started executing political prisoners in government jails (MIM).

* In an interview 24 February in Islamabad, South Korean Ambassador to Pakistan, Woong Choi said South Korea fully supports Pakistan's stand for the safe and honorable return of Afghan refugees and formation of an interim government in that country before the Soviet troops withdrawal (PT). * Talking to Iranian news agency IRNA at the end of his four day visit to Iran before his departure for Islamabad, Pakistan Foreign Secretary Abdul Sattar reiterated Pakistan's stand that a coalition government which must include the mujaheddin should be formed in Kabul before the Soviet troops withdrawal from that country (PT).

\section{6}

* US officials say, Washington will stop aid to the mujaheddin only when the Afghanistan peace accord fulfills all the US objectives and the US would not leave the anti-communist mujaheddin of Afghanistan alone in their attempt to get the Soviet troops withdraw from their country (VOADS).

* President Ziaul Haq has summoned the joint session of Parliament for a debate on the Afghanis$\tan$ issue 28 February in Islamabad (RPDS).

* At a session 25 February in Rawalpindi the Federal Cabinet discussed the Afghanistan issue in the light of recent developments (RPDS).

* In a statement in Brussels, the EFC has said a transitional government is a key to restrengthening Afghanistan as an independent and non-aligned country (RPDS).

* South Korea has expressed full support to Iakistan's principled stand on the Afghanistan issue (RPDS).

* The Pravda wrote 26 February that the US government has so far not answered the question as to when it would stop assistance to the Afghan "anti-revolutionaries", an issue which carries great importance in the solution of the Afghanistan dispute (RMDS).

* The BBC correspondent in New Delhi says India has not received well the proposal suggesting a prominent role for the Islamic "fundamentalists" in the composition of future government of Afghanistan, although New Delhi is interested to play some role in the latest developments in Afghanistan (BBCFS).

* Afghan Foreign Minister Abdul Wakil left 26 February Kabul for Geneva at the head of a delegation for participation in the next round of Geneva talks (RA).

Pakistan President Ziaul Haq has said there is no difference between Pakistan and the Ameri- 
cans on the agreement for restoration of peace in Afghanistan (BBCPS).

* The Kabul regime has turned down the mujaheddin's plan for setting up an interim government and has described it as a wishful thinking. The Anis daily of Kabul has said that the plan does not carry any legal weight (BBCPS).

* The UN envoy on Afghanistan, Diego Cordovez has described mujaheddin's proposals for setting up an interim government as promising (BBCPS).

* A high ranking US State Department official has assured the mujaheddin so long as the Soviet troops are in Afghanistan, the US would not stop its assistance to the mujaheddin. He added the US has not colluded with the USSR against the interests of the mujaheddin (VOAPS).

* The Indian Prime Minister, Rajiv Gandhi has invited Pakistan President Ziaul Haq to Delhi for talks on a wide range of issues including the future of Afghanistan which Gandhi described as a matter of great interest to both the countries (DN).

* Six of the seven leaders of the IUAM who met 24 February the US Under Secretary of State Michael Armacost in Islamabad are said to have had a pretty tough exchange of words with him on the question of concluding an accord on Afghanistan (without a change in the government of Kabul)

(DN).

* A two member delegation of eight Shia groups alliance of Afghanistan in Iran told a press conference 25 February in Peshawar the majority of Afghans were in favor of setting up an Islamic government by the Afghan mujaheddin and Islamic parties (PT).

\section{7}

* The Iranian President Hujjatul Islam Ali Khamenai has strongly urged the Afghan mujaheddin to preserve their unity and continue fighting until the accomplishment of a final victory. Teheran Radio reported that, speaking at the Juma prayers, he said the Afghan mujaheddin are the symbol and identity of the Afghan nation (BBCFS).

* A US State Department official has vehemently refuted recent renorts suggesting a secret deal between the US and USSR for stopping US aid to the Afghan mujaheddin (BBCFS).

* In an interview, a former Pakistan Foreign Minister, Agha Shahi has said he thinks at present the Indian interference in talks on the solution of the Afghan dispute is in no way appropriate and it can disturb the role of the UN envoy Diego Cordovez on the issue (BBCFS).

* A US State Department official said the Soviets now appear to be less interested in encouraging an interim or coalition government for Afghanistan. He says the Soviets want to go ahead on the path of a solution and withdrawal of their troops without any agreement on the future government of Afghanistan (VOADS).

* The US Senate and House of Representative unanimously resolved 26 February to mark 21 March colnciding with the new year in Afghanistan - - as Afghanistan Day and urged the US President to issue a statement on the occasion and to ask the US people to observe the day in a proper manner

(VOADS).

* Leader of the Jamiat-e-Islami Afghanistan, Professor Burhanuddin Rabbani arrived 26 February in Teheran. He is expected to meet Iranian officials. The office of the Jamiat-e-Islami Afghani- 
stan in Teheran has refrain to comment on the trip (BBCFS).

* Reports from Teheran say Iranian officials have had secret contacts with the Afghan mujaheddin leaders assuring them that Iran supported the Afghan mujaheddin opposed to the Geneva accord. The statement of the Hezb-e-Islami leader Gulbuddin Hekmatyar,saying that if an accord is signed in Geneva he would go to Iran, has been warmly welconed in Iran ( $33 \mathrm{CF}$ J).

* According to diplomatic sources, the Soviet government is persuading the Indian Prime Minister, Rajiv Gandhi to play an active role in finding a solution to the Afghan issue (BBCFS).

* Prime Minister Mohammad Khan Junejo has invited leaders of major political parties for a meeting on 5 March in Rawalpindi to discuss with them the Afghanistan issue (RPDS).

* In his meetings with the Asian and African Ambassadors in China, the Pakistan Ambassador in Beifing has explained the latest developments on Afghanistan issue (RPDS).

* Two prominent Indian newspapers The Statesman and The Times of India have criticised New Delhi for assuming an active role in diplomatic endeavors for the solution of the Afghanistan problem (RPDS).

* President Ziaul Haq of Pakistan has thanked the Indian Prime Minister Rajiv Gandhi for his invitation for a visit to India but has regretted that, due to internal engagements, he cannot presently visit New Delhi (RPDS).

* The VOA resident correspondent reports that, in order to strengthen personal security in the country after a possible Soviet troops pull-out, the Kabul regime has sent more than 20,000 students to the Soviet Union for training and have also built a number of security posts in Nangarhar and Laghman (VOAPS).

* A conference of the opposition politicians, ${ }_{\hat{\prime}}$ caller by Prime Minister Junejo to evolve a national consensus on Afghan issue, is expected to be held 4 March or the following day if a majority of the invitees agree to attend it, it is reliably learnt (MIM).

* Pakistan Minister of State for Foreign Affairs, Zain Noorani told 26 February The Muslim that he is "cautiously optimistic" about the success of the UN sponsored talks between Pakistan and Afghanistan due to begin in Geneva 2 March (MIM).

* A US Senate majority leader Robert Byrd said 25 February the US President Reagan intends to keep up with military aid to the Afghan mujaheddin until the Soviet troops withdraw from Afghanis$\tan (\mathrm{MIM})$.

* A Soviet official said 25 February there is a real danger of bloodbath in Afghanistan after the withdrawal of Soviet troops from that country (PT).

* At a press conference 26 February in the Indian Embassy in Islamabad, the Indian Ambassador, S.K. Singh said Indians interest in the Afghanistan issue is not an intervention, rather, it is since it his political and economic relations with that country (NWT).

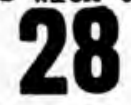

* The Indian Prime Minister, Rajiv Gandhi is to send a high ranking official of the External Affairs Ministry to Pakistan for discussion on the Afghanistan issue (BBCFS).

* The two houses of the Pakistan Parliament began 28 February a joint session in Islamabad to 
discuss the Afghanistan problem (RPDS).

* The Assistant Commissioner of UNHCR, Arthur David will arrive 29 February in Pakistan on a 9 day visit of the Afghan refugee camps (RPDS).

* In a television statement, the Soviet Deputy Foreign Minister, Yuli Vorontsov has said Pakistani demand for setting up a new government of Pakistan's liking in Kabul is not justified. He said the formation of a government in Kabul was an issue for the Afghans themselves and Pakistan, Moscow and Washington should have nothing to do with it (RMUS).

* The Soviet press says the ratio of Soviet ald to Afghanistan is more than $70 \%$ of the total foreign assistance to that country and it is expected that another 140 economic ventures will be inaugurated in Afghan during the next five years with Soviet assistance (RMDS).

* President Najibullah said 28 February opponents of his regime say Soviet troops withdrawal should take place after the establishment of an interim government proposed by the extremist groups. He said this means that the Soviet forces should instal these groups in power and then leave the country (RA).

* Pakistani security officials say five persons were killed and 11 injured 28 February in a bomb blast in Tall, (BBCPS).

* The Indian External Affairs Secretary, K.P.S. Memon will leave 1 March for Islamabad to discuss issues relating to Afghanistan (IN).

* The Federal Cabinet of Pakistan, finalized 27 February a detailed brief on Afghanistan issue for presentation to the members of Parliament summoned to close-door consultations in Islamabad

29 February (MIM).

* In an interview with NWT 27 February, the IUAM President Mawlawi Mohammad Yunus Khales said India has no right to interfere in the Afghanistan issue as it has been adopting hostile attitude towards the Afghanistan issue and it is a Russian ally (NWT).

* Speaking 27 February at a cabinet meeting, President Ziau'. Haq said any solution of the Afghanistan issue which does not enjoy consent of the fighting mujaheddin cannot be conducive to peace: and the return of Afghan refugees (NWT).

* It has been reliably learnt that the Saudi King Fahd has sent a personal message to the IUAM President Mawlawi Mohammad Yunus Khales. The massage was delivered 27 February to Khales by Prince Tark-el-Faisal (NWT).

\section{9}

* A joint session of the two houses of the Parliament was convened 28 February in Islamabad at the invitation of Prime Minister Mohammad Khan Junejo. He said the forthcoming round of Geneva talks on Afghanistan can be a final and most important round of negotiations the subject (RPDS).

* Before his departure 29 February for Geneva, the Pakistani Minister of State Zain Noorani said Pakistan would participate in the Geneva talks on Afghanistan with a completely constructive stand and would make efforts for the solution of all the remaining issues (RPDS).

* The Afghan leader, Dr. Najibullah has once again turned down the proposal for setting up an interim government before the Soviet troops withdrawal from Afghanistan (BBCFS). 
* Pakistani officials have protested to the Afghan government against the incident of 27 February in which Afghan planes bombed Pakistani territory killing one civilian (BBCFS).

* Benazir Bhutto head of the People's Party has hoped that an interim administration acceptable to all the elements in the Afghanistan war would be set up in Kabul to ensure peace and stability in view of Moscow's decision to pull its troops out of Afghanistan (MIM).

* The UNHCR Deputy Chief has arrived in Pakistan on a 9 day visit. He will look into the condition of Afghan refugees in Pakistan and the manner of their return to the country in case the Afghanistan problem is solved (BBCFS).

* President Najibullah held talks 29 February in Kabul with the delegation of Soviet Republic of Kirghizistan on cooperation schemes between that Republic and the Wardak and Bamian provinces of Afghanistan (RA).

* A delegation of the Soviet Republic of Byelorussia arrived 29 February in Kabul on a friendly and official visit for discussions with the Afghan officials on direct economic cooperation between the Soviet Republic of Byelorussia and Kunar and Laghman provinces of Afghanistan (RA).

* The majority of the Pakistani parliament in a special meeting 28 February asked the goverment to forego its demand for the formation of a coalition government in Kabul prior to a Soviet troops withdrawal from Afghanistan (VOAPS).

* In an interview to the BBC, a former Pakistani. Foreign Minister, Agha Shahi has said that, after eight years of indifference to Soviet occupation of Afghanistan, Indian Prime Minister, Rajiv Gandhi does not have a credible credentials to play a role in the issue (PT).

* Addressing 28 February a press conference in Lahore, the Senior Vice President of Pakistan Muslim League, Asif Fasihuddin Wardag has said Pakistan should not quit its principled stand on the Afghanistan issue and continue its efforts until the withdrawal of Soviet troops from Afghan1stan and setting up of an acceptable government to the Afghan refugees in Kabul (PT).

* Several friendly countries, consulted by Pakistan on Afghanistan issue, are reported to have advised Pakistan to secure the withdrawal of Soviet forces from Afghanistan by signing the proposed Geneva agreement (IN).

* Addressing 28 February a close-door session of the parliament, the $\pi$ Chief Senator Qazi Hussain Ahmad said Pakistan shoul.d not sign the Geneva accord on the Afghan issue without the formation of an interum government.

* The US government has sent an important message to the Pakistani leaders on the latest situation of the Afghanistan problem and the Geneva talks beginning 2 March (INT).

* Reports from Afghanistan indicate of large scale defections in the Afghan troops. The reports say $50 \%$ of troops have already defected with their arms from Kargha Military Garrisson near Kabul

(NWT).

* The former King of Afghanistan Mohammad Zahir Shah has accelerated his efforts to come to Pakdstan and meet the Afghan leaders. According to informed clrcles in Islamabad, Zahir Shah has told about this in a message to his friends in India (NWT).

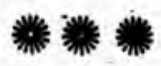




\section{March}

* The Pakistan Foreign Ministry spokesman said 1 March the visit by an official of the Indian External Affairs Ministry to Islamabad has been cancelled and it appears that the Indian efforts to play a role in the solution of Afghanistan issue have failed (BBCFS).

* The UN envoy on Afghanistan, Diego Cordovez left 29 February NY for Geneva to participate in talks which are expected to be the final round of negotiation for the solution of the Afghanistan issue (BBCFS).

* A number of commanders of the South Western provinces of Afghanistan held 28 February a meeting in Quetta, Pakistan, and decided that the mujaheddin should not share any coalition with conmunists even if it is suggested in the framework of a Geneva accord (VOADS).

* The UN sponsored Geneva talks on Afghanistan issue will be resumed 2 March. The Pakistan Minister of State for Foreign Affairs Zain Noorani is expected to return to his country during the weekend to apprise Prime Minister Junejo of the state of talks (RPDS).

* According to Pakistani reports, one person was killed and three injured 1 March in a bomb blast at a government building in Peshawar (BBCFS).

* In an article The Times (London) has expressed pessimism about the Soviet troops withdrawal from Afghanistan. It writes the US Secretary of State George Shultz has put pressure on Pakistan not to help setting up an independent government in Kabul prior to a halt in US assistance. It can be concluded that Shultz wants the Soviet troops withdrawal at any cost from Afghanistan. Although this policy is apparently very attractive yet it is to large extent a foolish stand (BBCFS).

* About the Geneva talks on the solution of the Afghanistan issue, a BBC conmentator writes difference of opinion on two clauses of an accord still remain between the two sides but it is anti- . cipated they might agree on a 9 months time-table for the Soviet troops pull-out from Afghanistan

(BBCFS).

* According to an AP report, the US Senate has approved a resolution about Afghanistan which reflects the US intention on continued intervention in the affairs of that sovereign country (RMDS).

* The Pravda, wrote 1 March if Pakistani leaders are truly interested in the solution of the Afghanistan problem, they can prove this by signing the Geneva accord (RMDS).

* The US Senate unanimously adopted 29 February a resolution urging the government not to halt aid to the mujaheddin until the completion of Soviet troops withdrawal from Afghanistan. The resolution was adopted unanimously (VOADS).

* A source of Jamiat-e-Islami Afghanistan has reported from Quetta that in their heavy shelling 21 February on a Soviet military post in Chehl Zeena, Kandahar, the mujaheddin killed four Soviet troops and, in an attack on the Kandahar jail, 10 communist troops were killed and a jeep set ablaze (VOADS).

* U.S. Congressman Charles Wilson says the entire world is amazed at the valour and courage of the Afghan people. The blood and flesh of the Afghans defeated the Soviet arms and strength. The 
Soviets are withdrawing from Afghanjstan because of their defeat anc they can no more resist there

(VOAPS).

* Rossane Klass, who has conducted a great deal of research on Afghanj.stan, writes in The Washing-

ton Times that on the basis of the proposed agreement on Afghanistan the Soviets would control Afghanistan without utilizing a military force and there is no indication showing the Soviets are going to end their Afghan involvement (VOAPS).

* The Afghanistan Foreign Minister, Abdul Wakil during a short stopover in Moscow enroute to Geneva, held talks 29 February with the Soviet Foreign Minister Eduard Shevardnadze. In the meeting they discussed in detail all aspects of the solution of the Afghanistan issue (RA).

* The Afghanistan Bar Association conducted recently a survey among its members about the political settlement of the situation around Afghanistan. The survey says $79.95 \%$ of those questioned say formation of a coalition government pertains mainly to the Afghans themselves while $83.44 \%$ have rejected the Pakistan government proposal for setting up a coalition government (RA).

* Western diplomats say rumours are circulating in Kabul that the Soviet government intends to establish a separate government in northern Afghanistan in case communists power in Kabul after Soviet troops withdrawal (VOF.PS).

* India says it has dropped the idea of sending a high level Indian envoy to Islamabad at the request of Pakistan (VOAPS).

* Talking 29 February to newSmen in Islamabad, the Pakistan Minister of State for Foreign Affairs, Zain Noorani said Pakistan neither wanted to delay the withdrawal of Soviet troops from Afghanistan nor did it desire a partial settlement which would not enable the Afghan refugees to go home

(MIM).

* The Hezb-e-Islami Afghanistan leader Gulbuddin Hekmatyar, in a letter to prominent politicians and parliamentarians of Pakistan, has explained the mujaheddin perspective on the latest Soviet moves to resolve the Afghanistan problem. He has alleged that the super powers had reached an understanding on the Afghan issue and the US, which portrayed itself sympathetic to the mujaheddin, wanted Pakistan to disentangle itself from the dispute. He warned that the mujaheddin would shift their headquarters to Iran should Pakistan conclude an agreement vith the Kabul regime at Geneva (Hekmatyar's letter to the MIM).

* Another big rally against ex-King Zahir Shah was staged 29 February in the Shashoo refugee camp near Sadda in Kurram Agency. The rally resolvec that no government other than the one controlled by Afghan mujaheddin was acceptable to them (MIM).

* Addressing 29 February a conference organized by the Afro-Asian People's solidarity organization in Lahore, top ranking opposition leaders including Nawabzada Nasrullah Khan, Abdul Wali Khan and Mir Ghous Bakhsh Bizenjo, underscored the need for adopting a sane and rational policy on the Afghanistan issue (PT).

* A leader of the IUAM Professor Burhanuddin Rabbani has left for Teheran at the invitation of Iranian government to discuss with the Iranian leaders the Afghanistan issue (JG). 


\section{2}

* The Pakistani and Kabul governments resumed 2 March their talks under the supervision of the UN in Geneva seeking a political solution to the Afghanistan conflict. The UN mediator; Diego Cordovez said the two sices are determined to reach an early agreement (VOADS).

* Before the commencement of Geneva proximity talks between Pakistan and Afghanistan the UN envoy Diego Cordovez at a press conference said 2 March still there are many difficulties before reaching a final settlement of the Afghan issue and the mistrust ensuing the last five and a half years of talks has not yet been completely removed (BBCFS).

* In its editorial 2 March The Financial Times (London) writes a failure of the Geneva talks would mean to accept the point that the people of Afghanistan would prefer their country remain under the Soviet occupation until they themselves take any decision about their fate (BBCFS). * In an article, captioned "Brezhnev's Catastrophic Heritage", The Independent (Iondon) writes the Soviet empire has seen shock and the Afghan mujaheddin have kneed down the Red Army. There is a possibility that this state of affairs will encourage all nationalities insice the Soviet Union to seek more freedom (BBCFS).

* At a press conference in Geneva, the Pakistan Minister of State for Foreign Affairs, Zain Noorani said Pakistan wants the USSR to withdraw $50 \%$ of its troops from Afghanistan during the first three months in the first phase of its troops pull-out program and the withdrawal should take place with setting up of a transitional government in Afghanistan (PPDS).

* The Nobel Prize wimners and members of the European Parliament in Paris have asked the Soviet leader Mikhail Gorbachev to hold talks with the Afghan mujaheddin. The demand, carrying 1,500 signatures, was published 1 March by the Frensh newspaper Le-Monde, (RPDS).

* At a press conference in Multan, the Imam of Kaaba Mukarrama, Sheikh Mohanmad bin Abdullah has said his country wants the Soviet troops to withdraw from Afghanistan (RPDS).

* At a press conference $1 \mathrm{March}$, Foreign Minister Abdul Wakdl said the idea of a transitional government presented by the lcaders of seven opposition groups in Peshawar is unrealistic. He said undoubtedly the plan has not taken into consideration the views of all the opponent forces particularly those inside Afghanistan (RA).

* The Charge d' Affaires of Pakistan Embassy in Kabul was summoned 2 March in the Foreign Ministry and a protest note was delivered to him against the violation of Afghan air space by the Pakistani planes (RA)。

* In a report 2 March The Washington Post said Pakistan is ready to adopt a lenient stand in the Geneva talks. But Pakistani officials say the Pakistan government has so far not decided whether to sign the peace accord or not (VOAPS).

* The UN Deputy High Commissioner for refugees discussed 1 March with Pakistani President Ziaul Haq matters related to the requirements of the Afghan refugees in the current situation as well as in the future (PT).

* Commenting on the latest round of talks on Afghanistan beginning 2 March in Geneve, the vOG has said political observers are expressing apprehension that Afghanistan will face another serious 
crisis if Soviet forces go back, because, after the withdrawal, a bloody war among the Afghan mujaheddin and the ruling PDPA can break out for the assumption of power (PT).

\section{3}

* The Pakistan Minister of State for Foreign Affairs, Zain Noorani said 3 March in Geneva that Pakistan wants a comprehensive solution of Afghanistan issue including the formation of an interim government (RPDS).

* The UN mediator on Afghanistan, Diego Cordovez separately met 2 March the US and Soviet envoys who are presently in Geneva to observe the proceedings of Geneva talks (BBCFS).

* In an interview $2 \mathrm{March}$, the Iranian envoy to Geneva said Iran certainly consicler the Soviet troops withdrawal from Afghanistan a positive measure. Our problem is not the Sunni or Shia. Cur view point is that the entire people of Afghanistan should be able to have a share in the future government of their country (BBCFS).

* A report of the UN Hunan Rjghts Commission says human rights condition in Afghanistan is improving. But according to reliable reports, torture and massacre of political prisoners still. continue in the country (VOADS).

* Deputy Prime Minister Sayyed Amanuddin Amin, heading a delegation, arrived recently in Budapest at the invitation of the Hungarian Deputy Chairman of the Council of Ministers for talks on further promotion of economic and trade relations and the signing of a protocol on scientific and technical cooperation between the two countries (RA).

* In an interview, a spokesman for the former Afghan King, Zahir Shah has said as a member of his nation, the former King considers his religious and national duty to stand-by the side of the aggrieved people of the country in the bitter Afghanistan issue and selflessly do what he can for the prosperity of the nation and the establishment of peace (BBCPS).

* The UN envoy Diego Cordovez, has ruled out the possibility of talks on Pakistan's demand for the formation of an interim government (VOAPS).

* Quoting a high level UN official, The New York Times writes that the UN has prepared a plan for sending a military monitoring force to Afghanistan if a peace accord is achieved about Afghanistan

(VOAPS).

* The Washington Post writes the UN mediator on Afghanistan Diego Cordovez has said he is happy that the leader of Pakistani delegation, Zain Noorani has not immediately repeated a demand made earlier by President Zia about the formation of an interim government in Afghanistan (VOAPS).

* In a UN, report on human rights condition in Afghanistan it has been stated that the system now being evolved in Afghanistan has failed to provide the right of redress from injustice. It says in the new constitution, free, secret and universal right to vote has not been guaranteed

(VOAPS).

* In an interview, the commander of Amir Hamza Unit in Logar province, Hameedullah Niazi has said $90 \%$ of the area in Logar is under the mujaheddin control. He said we are awaiting a decision in Geneva, but we will not lay down our arms until an Islamic government is set up in Afghanistan (VOAPS). 
* In a lengthy statement 2 March the IUAM President Mawlani. Mohamma' Yunus Khales reiterated that the Geneva proximity talks on Afghanistan were unacceptable as the twc main parties to the conflict - - the Afghan mujaheddin and the Sovitt Union - - had gone unrepresinted (N.IM).

* Addressing 2 March a press conference in Geneva, the LN mediator on Afghanjstan Di ego Cordovez said his talks with Pakistani and Afghan leaders as well as American and Soviet diplomats show that there was a real determination on all sides to have an early settlement of the Afghan issue

(MIN)。

* In a recent interview with ANS in Panjshir valley, the younger brother of Dr. Najibulz.sh has said that the former King Zahir Shah will face great difficultites if he was installed as head of an interim government in Kabul (MIM).

* Talking 2 March to The Muslim in Islamabad, Air Chief Marshal (Retd) Zulfiqar Ali Khan said no agreement signed at Geneva would be of any gain and in the national interest unless it provided safe return of the Afghan refugees to their homeland (MIM).

* Addressing 2 March a rally organized in Rawalpindi to express solidarity and cooperation with the mujaheddin, the JI Chief rejected any solution of the Afghanistan problem not acceptable to the Afghan mujaheddin and warned the government not to sign the Geneva accord without their willingness (MTM).

* A sizeable JI rally staged 2 March in Karachi raised pro-mujaheddin slogans and demanded that Pakistan should not sign the Geneva accord until an Islamic government of the resistance fighters was formed in Afghanistan (DN).

* The Pakistan Minister of State for Foreign Affairs Zain Noorant said 2 March in Geneva "we are cautiously optimistic" about the talks on Afghanistan (PT).

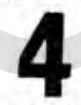

* The Foreign Minister of Kabul government, Abdul Wakil says his government has agreed on a 9 months time-frame for the Soviet troops withdrawal from Afghanistan and $50 \%$ of the Soviet troops would be pulled out within the first three months of the time-table (VOADS).

* The alliance of the prominent opposition parties in Pakistan have agreed to meet 5 March Prime Minister Mohammad Khan Junejo for a discussion on the Afghanistan issue (VOADS).

* The UN mediator on Afghanistan Diego Cordovez says he has no doubt about the importance of the agreement achieved this week in Geneva on a time-frame for troops withdrawal in connection with the Sovilet troops withdrawal from Afghanistan. But he has said that the Geneva affairs have so far not been finalized (BBCFS).

* The Pakistan Minister of State for Foreign Affairs, Zain Noorani has refuted the Kabul government communique suggesting a 9 months time-frame for Soviet troops withdrawal from Afghanistan would compel the Pakistan government to sign the Geneva accord (BBCFS).

* In an interview, the Chairman of the Special Committee of the US Senate on Afghanistan issue, Gordan Humphrey has said Najib and his communist colleagues are in power merely because of Soviet presence. He said: "I believe after the Soviet, troops withdrawal, the present government would not continue even for a week" (BBCFS). 
* The Danish Parliament has urged the government to help in the formation of a broadbased transitional government in Kabul and to support UN endeavours for a political solution of Afghanistan problem (RPDS)。

* The Special Rapporteur of the UN Human Rights Commission on Afghanistan, Feljx Ermacora has called for the establishment of a broad-based government in Kabul so that the Afghan refugees are enabled to return to their country with full confidence (RPDS).

* The Japanese Foreign Secretary visited 4 Marck an Afghan refugee camp near Peshawar and assured the Afghans of his country's continued moral and material assistance to the Afghans (RPDS).

* In a message, addressed to the UN Secretary General, Perez De Cuellar, President Najibullah has said we have enthusiastically made preparation for participation in the next round of Geneva talks and would not spare any effort and goodwill for reaching a final agreement but, at the same-time, the accomplishment of the objective depends on the goodwill and political intention from the other side $(\mathrm{RA})$.

* At a press conference 3 March, Foreign Minister Abdul Wakil said the issue of the Soviet troops withdrawal from Afghanistan has completely been solved and now the two sides should agree on the remaining problems and sign the ciocuments pertaining to the political settlement (RA).

* Kabul Foreign Minister, Abdul Wakil has said in Geneva that there seems to be no hinderances between Pakistan and Afghanistan in signing an agreement on the Soviet troops pull-out (BBCPS).

* Following a two day meeting in Iahore, the MRD has collectively decided to accept the Prime Minister's invitation for a discussion on Afghanistan issue (BBCPS).

* In an interview, a commander of Harkat-e-Enqelab-e-Islami Afghanistan in Khost, Paktia, Mulla Khel has said there are no problems among mujaheddin group in that area and we are assisting each other. He said the mujaheddin will stop resistance when Soviets withdraw from Afghanistan without any pre-conditions and the Afghans themselves determine their fate (VOAPS).

* Talking 3 March to The Muslim on telephone from Washington, a prominent US scholar S. Harrison said Pakistan is justified in raising the issue of an interim government in Kabul but he believed that it would be a "tragic blunder" if it allows this issue to frustrate the negotiations at Geneva (MIM).

* There has been a significant break-through in the Afghan talks in Geneva with Pakistan taking the position that arrangements should be made for an interim government before an agreement is signed, but it is not essential that such a government be formed before the actual signing (DN).

* In a statement 3 March in Rawalpindi, leader of the QMA, Meraj Mohammad Khan called on Pakistan to sign the Geneva accord (NWT).

\section{5}

* The US officials have welcomed the shortened time-frame offered for the Soviet troops withdrawal from Afghanistan. The offer was made by the Kabul regime in Geneva (BBCFS).

* A representative of INF in Europe, Waheed Tarazi says, after the Soviet troops withdrawal from Afghanistan, the Afghan resistance movement will never accept communist participation in the government (VOADS). 
* A spokesman for the US State Department has welcomed the progress achieved in the current Geneva talks on Afghanistan. But he said if the Soviets continued to support the government forces in Kabul, the Afghan guerrillas would also receive US military assistance (BBCFS).

* The Pravda, official organ of Soviet Communist Party, has said the Afghan mujaheddin are busy piling up military hardware and if, as a result of an agrement in Geneva, the US assistance. to the mujaheddin is stopped, they would still be able to continue their resistance (BBCFS). * The correspondent of The Independent (London) reports from Geneva that Pakistan is under pressure from all sides, including the US, to sign the Geneva accord at the earliest despite its inability in pursuading the Soviet Union on a pledge for the formation of a transitional government in Afghanistan (BBCFS).

* A conference of 19 Pakistant political parties called by Prime Minister Mohammad Khan Junejo for discussion on the Afghanistan issue held 5 March its session in Rawalpindi (RPDS).

* According to a Pravda report the flow of arms to the Afghan opponent groups from abroad has been speeded up recently into the Afghanistan territory (RMDS).

* Speaking to Journalists in Geneva, the Pakistan Minister of State for Foreign Affairs, Zain Noorani has once again linked the issue of signing an agreement on the settlement of the situation around Afghanistan with the formation of a transitional government while this is considered to be purely an internal affair of Afghanistan (RMDS)。

* According to The New York Times a high ranking US state Department official has said some people accuse the US as if it is prepared to sell the mujaheddin.He said: We clearly say that we will never allow the Soviets to continue aid to the Kabul regime if we were to stop our assistance to the Afghan mujaheddin (VOADS).

* In a statement to the correspondent of The New Times (Moscow) Prime Minister Sultan Ali Keshtmand said the Afghan leadership has expressed its readiness in the framework of NRP for seeking a reasonable and acceptable solution to the problems around Afghanistan (RA).

* An international seminar to celebrate the 103rd birth anniversary of the Afghan historian Faiz Mohammad Hazara Kathib was opened 5 March in Kabul (RA)。

* A great supporter of the Afghan mujaheddin in the US Congress, Senator Gordon Humphrey has said the US arms supply to the mujaheddin has suddenly been reduced and he demanded a probe into the present process of arms supply to the Afghans (VOAPS).

* A spokesman for the US State Department said, until a satisfactory agreement is reached in Geneva on the Afghanistan issue, the US would continue to support the Afghan mujaheddin (VOAPS).

* Addressing 4 March a press conference in Islamabad, the NPP Chairman Ghulam Mustafa Jatoi said the return of Afghan refugees to their homes was the top most priority for Pakistan (MIM).

* The UN Human rights investigator Felix Ermacora in an impassioned speech to the UN Human Rights Commission said Afghanistan's Human Rights record could only improve when Soviet troops withdraw from that country (MIM).

* In a written statement, a leader of a mujaheddin faction Qazi Amin Waqad rejected the talks being held on Afghanistan in the framework of Geneva talks and added only a government formed by 
the mujaheddin will be acceptable to the Afghan people (MIM).

* At a press conference 4 March in Geneva the UN mediator Diego Cordovez said he is in constant touch with all parties to the Afghan conflict including the two proposed guarantors of the peace accord - - the US and the USSR - - about the formation of a broad based government in Afghanistan

(DN).

* On his arrival in Lahore after his meeting with the Afghan mujaheddin, Mawlana Fazlurrehman JII Secretary General said the mujaheddin are not satisfied with the Geneva talks and it is not possible for them to return to Afghanistan apologetically after rendering one million martyrs (JG).

\section{6}

* In the UN sponsored indirect Geneva talks, Pakistan is proposing for the suspension of signing of UN agreement on the Soviet troops withdrawal from Afghanistan until grounds are laid down for the emergence of a transitional government in the wake of Soviet troops withdrawal from Afghanis$\tan$.

* In Pakistan a long meeting between Prime Minister Mohammad Khan Junejo and leaders of prominent opposition parties has concluded. Most of the participants have asked the government to exert efforts for making the Geneva peace talks conclusive and to abandon insistence on the formation of an interim government in Kabul prior to the Soviet troops withdrawal from Afghanistan (BBCFS).

* The Observer, (Iondon) reported 6 March Pakistan is not happy on the manner the Geneva talks on Afghanistan are being conducted as it had hoped that the Soviet Union could be persuaded to agree on setting up a coalition government in Afghanistan (BBCFS).

* The Sunday Times (Iondon) writes the Soviet Union is determined to withdraw its troops from Afghanistan but at the same time Soviet leader Mikhail Gorbachev wants to preserve Soviet interests in Afghanistan (BBCFS).

* The PPP Chairperson Benazir Bhutto has asked the Pakistan government to outrightly sign the agreement of a political settlement of the Afghanistan issue (RMDS).

* The Pakistan Minister of State for Foreign Affairs, Zain Noorani left 6 March Islamabad for Geneva to participate in resumed talks on Afghanistan. On his way to Geneva he had a short stopover in Moscow (RMDS).

* An extraordinary plenum of the National Front was opened 6 March with the participation-of President Najibullah to discuss and take decisions on some issues of historic importance (RA)。

* Speaking 6 March at the plenum of National Front President Najibullah said we are at the threshold of holding elections for a national assembly. He said the elections will be held throughout country. (RA).

* The ANS reported that reports are circulating In Helmand, Parwan and Kapisa provinces that, following Soviet leader Mikhail Gorbachev's March 8 announcement, Soviet troops are being deployed in provincial centers from other areas. The move is said to be tactical in order to know the mujaheddin reaction (VOAPS).

* The Hezb-o-Islami (Khales) sources say its mujaheddin have attacked six security posts in Dehbaba Nangarhar, tne posts were constructed recently to maintain road safety (VOAPS). 
* According to resistance sources, the mujaheddin attacked a security post in Dalgari of Roadat, Nangarhar, killing a KHAD officer and five troops (VOAPS).

* A source of Hezb-e-Islami (Hekmatyar) said the mujaheddin attacked 3 March the Kano Ghunda security post near Kamkai Dakka, Nangarhar. After a five hour battle, communist troops were forced to abandon the post. The mujaheddin caritured 10 pieces of arms in the operation (VOAFS).

* The Afghan mujaheddin sources report Soviet jet bombers attacked 4-5 February the Balabagh village in Surkhroad, Nangarhar, causing civilian casualties. Many people of the area had to seek refuge in Pakistan (VOAPS).

* The Palistan Minister of State for Foreign Affairs, Zain Noorani said 5 March in Islamabad that Pakistan had urged the UN mediator, Diego Cordovez to continue his efforts for the formation of a broad based government in Afghanistan as the Soviet Union is still hesitating to settle this issue (MIM).

* In an interview with the BBC, a spokesman of the former Afghan King Zahir Shah has urged the people of Afghanistan to maintain unity in their ranks (MIM)。

* The Peshawar Mujahed Press Agency (MPA) reported rift between the ruling puppet regime in Kabul and the supporters of Babrak Karmal is on the increase (PT).

* Speaking in Peshawar about the Afghanistan issue, Prime Minister Junejo said Pakistan wants the setting up of a government in Afghanistan acceptable to the people of that country so that the way may be paved towards peace and guarantee the return of Afghan refugees to their country in honor and dignity (RPDS).

* The Pakistan Minister of State for Foreign Affairs, Zain Noorani told newsmen in Geneva formation of an interim government in Kabul is as important as the signing of a peace treaty. He added the setting up of a government supported by the people of Afghanistan is a matter rej.ated to the freedom of a nation which has rendered more than one million sacrifices (RPDS).

* The West German press has hailed Pakistan's stand on the proposal for setting up an interim government in Kabul simultaneously with the Soviet troops withdrawal from Afghanistan (RPDS).

* The leader of NLF, Professor Sibghatullah Mojaddadi has resigned from the IUAM and his party. In an interview with the BBC, he said his supporters were not ready to accept Ahmad Shah as President of the proposed government for Afghanistan and Pakistan has been favoring the fundamentalist groups in comparison to the moderates and thus he could not provide his mujaheddin with sufficient quantity of arms (BBCFS)。

* Expressing optimism in an interview with The Khalee, News, Dobai, about the conclusion of a peace accord with Afghanistan, the Pakistan President Ziaul Haq has said there is no reason to fear that an agreement will not be signed by the two sides in Geneva on Afghanistan. He added Pakistan's stand at the Geneva talks has not been changed (BBCFS).

* The Geneva talks between Pakistan and Afghanistan were resumed 7 March but an agreement on the demand of Pakistan for the establishment of a transitional government in Afghanisten is not visible (BBCFS).

* An agreement was signed 7 March between Afghanistan and the Soviet Union for the construction 
of a barrage in the Haitathan port (RA).

* According to TASS 6 March, the Afghan President Najibullah has said that a number of seats in the Kabul parliament would be reserved for exiled Afghan leaders during proposed elections in Afghanistan (PT).

* In a letter 6 March to the UN Secretary General Perez De Cuellar, President Najibullah has accused Pakistan of trying to undermine the process of an agreement on Afghanistan by demanding the setting up of an interim government in Kabul (DN).

* In an interview with the British Commercial TV,Pakistan Foreign Secretary Abdul Sattar has indicated Pakistan might sign the agreement on Afghanistan without any commitment on a new government in Kabul (DN).

* Talking 6 March to newsmen in Rawalpindi, the JI Chief Qazi Hussain Ahmad opposed the signing of an accord on Afghanistan without pre-conditions and warned that the situation would further deteriorate if the agreement was signed under present circumstances (MIM)。

* Addressing 6 March a press conference in Rawalpindi, the ANP Secretary General Rasool Bakhsh Palejo said Pakistan should immediately sign the Geneva accord (JG).

* Talking 6 March in Rawalpindi, the JUJ (Darkhwasti) Secretary General Mawlana Samiul Haq said without the establishment of an interim government acceptable to the mujaheddin the accord on the Afghan issue should not be signed (JG).

* The JUI Secretary General Mawlana Fazlurrehman told 6 March newsmen in Rawalpindi that no agreement would be durable without taking the mujaheddin in confidence (JG).

\section{(a)}

* The IUAM President Mawlawi Mohammad Yunus Khales says if the present Kabul communist regime remains in power following the Soviet troops withdrawal, the three million Afghan refugees presently living in Pakistan cannot return to their country with safety (VOADS).

* The Deputy Chief of INNHCR, Arthur Dewey met 8 March the Pakistan Minister of States, Frontier Regions and Kashmir Affairs, Sayyed Qasim Ali Shah in Islamabad. He expressed satisfaction over the facilities extended to the Afghan refugees by Pakistan (RPDS).

* The UN officials in Geneva said the UN sponsored proximity talks on the Soviet troops pull-out from Afghanistan are slowly going ahead (BBCFS).

* At a press conference in Geneva the representative of Hezb-e-Islami, member of IUAM, Abdul Qader (stet) said any agreenent in Geneva which is not approved by the mujaheddin would not stop war in Afghanistan. He demanded direct talks between the mujaheddin and the USSR (BBCFS).

* The JN official says Pakistan is firm about its demand on the establishment of an interim government in Kabul (VOADS).

* The Pakistan Minister of State for Foreign Affairs, Zain Noorani has refuted the report suggesting the Geneva talks for the establishment of peace in Afghanistan have reached a deadlock. Meanwhile the UN mediator Diego Cordovez has said reaching a rapid agreement between Pakistan and Afghanistan was not in prospect (BBCFS).

* A BBC commentator says that the resignation of a moderate leader of IUAM and the NLF Chief Professor Mojaddadi reflects frustration by the moderates about the situation at a time when $\mathrm{Pa}-$ 
kistan believes that all mujaheddin factions ought to unite prior to a Soviet troops withdrawal from Afghanistan (BBCFS).

* A message addressed to the UN by the participants of a grand gathering of Kabul citizens was circulated 7 March in NY as an official document of the UN and the Security Council. The meeting was held recently in connection with the resumption of Geneva talks between Pakistan and Afghanistan (RA).

* About peace in Afghanistan, The Financial Times (Iondon) writes there is an apprehension, if an agreement on setting up a transitional government in Kabul is not reached, war in Afghanistan would continue and the three million Afghan refugees would stay in Pakistan (BBCPS).

* The Times (London) reports Pakistani political party leaders have advised Prime Minister Junejo to support the mujaheddin as far as possible in the formation of a transitional government but such a support should not jeoperdise an agreement on the Soviet troops withdrawal from Afghanis$\tan$ (BBCPS)。

* In a press statement 7 March in Peshawar, the IUAM President Mawlawi Mohammad Yunus Khales said the formula for a transitional government in Afghanistan mooted by the IUAM was not negotiable (MIM).

* Addressing 7 March a select gathering in Peshawar, Prime Minister Junejo said while finalizing Pakistan's position at the on-going Geneva proximity talks on Afghanistan, his government will not remain oblivious of the country's national interests and the need for the honorable return of Afghan refugees (MLM).

* The APP's special correspondent reported 7 March that some slight signs were visible in the UN circles 7 March about the possibility of a compromise to accommodate Pakistan's point of view vis a vis the establishment of a transitional government in Afghanistan (PT).

* Addressing 7 March a press conference in Islamabad, the PNP Chief Mir Ghous Bakhsh Bizenjo said in his opinion the government has so far taken no decision whether to sign the Geneva accord. He added he felt the government was in a difficult position in this regard (DN).

* Talking 7 March to newsmen in Multan, the JUI Secretary General Mawlana Fazlurrehman said now the ball is in the court of the government and it has to decide about the solution of Afghanis$\tan$ issue (DN).

* Addressing 7 March a press conference in Islamabad, the TIP Chief Air Marshal (Retd) Asghar Khan said public opinion in Pakistan is in favor of a settlement of the Afghanistan issue. He hoped the government would sign the Geneva accord (DN).

* It has been reliably learnt that Pakistan has made it clear to the UN mediator in Geneva talks that it would be very difficult for Pakistan to sign the accord without a workable formula on the formation of an interim government in Afghanistan and surety for the Soviet withdrawal from Wakhan (NWT).

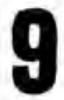

* In a press interview, the Kabul government envoy to New Delhi Abdul Samad Azhar said his goverrment has the right to procure every type of assistance from any country and it will continue obtaining all kinds of ald it needs from the Soviet Union. He further stressed if his government. 
feel the need, it will not hesitate seeking military aid from the Soviet Union (VOADS).

* The IUAM President Mawlại Mohammad Yunus Khales once again ruled out any agreement which will leave the Kabul regime intact. He said the mujaheddin will never accept a Soviet puppet regime

(VOADS).

* At a gathering 8 March in Karachi, Prime Minister Junejo said Pakistan will sign the Geneva peace accord about Afghanistan after consultations with the people's representatives of the country. He hoped that following the Soviet troops withdrawal from Afghanistan, the Afghan refugees will honorably return to their country (RPDS).

* High ranking US officials have said Washington wants to thoroughly study the Geneva instruments before it commits itself as a guarantor of its provisions (RPDS).

* In an interview with the correspondent of The Times (London) Sébghatullah Mojaddadi, leader of Jabha-e-Melli Nejat-e-Afghanistan who resigned from the IUAM and his own party, said chaos prevails at the meeting of the IUAM leaders and every topic put forth for discussion is being opposed one way or another. He added he does not see any difference between the government advocated by the people whom he termed extremists and the present Soviet backed regime in Afghanistan (BBCFS).

* The Independent (Iondon) writes that, as long as the issue of stopping Soviet aid to the Kabul government and halting of US assistance to the mujaheddin is not solved, the US will face a strange situation as it would be forced to guarantee an agreement which would result in the perpetuation of the rule of Kabul leaders whom the mujaheddin wanted to remove with the US aid (BBCFS).

* A large number of people gathered 8 March in Peshawar in front of the house of the Jabha-e-Melli leader Sibghatullah Mojaddadi to express their opposition to his resignation (VOR.PS).

* Western diplomats say the Soviet Union has recently accelerated arms supplies to the Kabul government. The VOA correspondent writes from Islamabad, it is said that strengthening of the defense arrangements in the outskirts of Kabul and Kandahar show that, following Soviet troops withdrawal from Afghanistan, the communists anticipate mujaheddin attacks on big cities (VOAPS).

* The UN representative in the Geneva talks on Afghanistan D: $\in$ go Cordovez says an agreement for the solution of the Afghan problem would not be signed this week (VOAPS).

* The Christian Science Monitor writes besides reaching an agreement on a time table for Soviet troops withdrawal from Afghanistan, another accord should also be considered to strengthen peace in Afghanistan (VOAFS).

* The Geneva talks are now expected to go on almost indefinitely as Pakistan will make no decision on signing a peace accord with Afghanistan until there is a visible movement on the Soviet side for an interim coalition government in Kabul. On the other hand, the Soviets have refused to divulge their plans to the US on the disengagement of their troops in Afghanistan until Pakistan shows a readiness to sign the proposed accord (DN).

* In an exclusive interview 6 March in Rawalpindi with The Gulf News, President Ziaul Haq said in his view India ought to stay out of the Afghan situation (MIM).

* According to a mujaheddin report, a military ware-house was rocked 20 February in the northern port of Hairatan by a huge explosion as a result of surface to surface missile attack by the mujaheddin (MTM). 
* The Supreme Council of the NLF, which met 8 March in Feshawar, has not yet accepted the resignation of Professor Sebghatullah Mojaddadi as the party chief (MIM).

* Addressing party workers in Charsadda, the PPP provincial chief Aftab Ahmad Sherpao has demanded that the Geneva accord on the Afghan issue be Immediately signed (MIM).

* A high official of the UNHCR, Arthur Dewey, who returned to Islamabad after extensively touring the tentage villages, has said he was not sure when the repatriation of Afghan refugees will begin. "It will be a happy day when the refugees go back," he remarked (NIM).

* Addressing 8 March a press conference in Rewalpindi, the Senior Vice President of Fiqah Jafferia movement in Pakistan, Sayyed Sajid Ali Naqvi urged that there should a direct dialogue ketween the Afghan mujaheddin and the Soviet Union on the Afghanistan issue (JG).

\section{0}

* The Afghanistan Foreign Minister Abdul Wakil has said talks on the Soviet troops withdrawal from Afghanistan are approaching a deadlock. The Sovlet government is said to very much annoyed over delay in the Geneva talks (BCFS).

* The BBC correspondent in Pakistan says a leader of TUAM Sibghatullah Mojaddadi, who had said he will quit the IUAM and his party's leadership, has now withdrawn his resignation (BBCFS).

* At a gathering in Lahore, Prime Minister Junejo said a final decision on signing the Geneva accord will be made after the conclusion of present round of consultations. Any decision in this connection will secure maximum interests of Pakistan and the Afghan people (RPDS).

* The PML has expressed complete satisfaction on the efforts being exerted by Prime Minister Junejo for the solution of Afghantstan problem (RPDS).

* The UN mediator on the Afghanistan issue, Diego Cordovez said 10 March efforts are under-way to prepare the final documents of the Geneva accord, but still a great deal of work has to be accomplished (PPDS).

* In his annual report for 1987, special UN rapporteur on Human rights, Felix Ermacora has proposed an interim government should be established in Afghanistan with the participation of all concerned parties (RPDS).

* Quoting diplomatic sources, Reuter has reported that the US wants more assurances from the Sovlet Union about 1ts troops withdrawal. Delegation from the two countries will meet this week in Geneva for direct talks on the UN peace proposal about Afghanistan (RPDS).

* At a press conference in Geneva, the Afghan Foreign Minister, Abdul Wakdl said the joint Soviet Afghan initiative on the reduction of period for the Soviet troops withdrawal has not enjoyed positive and desired reaction from Pakistan (RMDS).

* In an interview with The Frontier Post (Peshawar) leader of the Jaba-e-Melli Sibghatullah Mojaddadi confirmed that Pakistan government had pursuaded the IUAM leaders to convene a meeting and announce a transitional government. Reports say, following his resignation, Mojaddadi's residence in Islamabad has been surrounded by the Police (RA).

* Blders of Lowargi, Khyber Agency, held a large Jirgah in the White Mosque, Peshawar, to support the Sovlet-Afghan leaders announcement in connection with the settlement of situation around 
Afghanistan (RA).

* At a press conference in Geneva, Foreign Minister Abdul Wakdl said Pakistan is seeking to impose new issue about Afghanistan which had never been raised during the last six years of talks and, by doing so, is endangering the success of negotiations (RA).

* The PDPA Central Committee Politburo met 10 March and discussed the following items:

- - Establishment of a society at a university level for studies and research in Islamic sciences in the framework of the Ministry of Higher and Vocational Education,

- - training of the youth in the framework of the NRP,

- - strengthening the leadership cadre of the youth and boosting up the role of party committees and youth organizations,

- - preparations for holding national elections (RA)。

* The UN Cormissioner for refugees held a meeting in Peshawar to make arrangements for the millions of Afghan refugees who might return to their country (VOAPS).

* The Deputy Chief of the NIF political committee, Hamid Karazi said the immediate reason for Sibghatullah Mojaddadi's difference with the IUAM was that he was not happy over the IUAM's failure to seek the opinion of the people on the formation of an interim government (VOAPS). * About the political solution of the Afghanistan issue, The Wall Street Journal (US) wrote 8 March some Reagan government officials say it is not sufficient to urge Moscow to abandon aid to the Kabul government. They say that Moscow should also be asked to withdraw its advisers from Afghanistan and such military agreements between Moscow and the Kabul which might tie Afghanistan: with Moscow for ever ought to be revilewed and such demands, however, will hinder the Geneva talks

(6)

(VOAPS).

* The Muslim (Pakistan) writes, the Pakdstan JI Chief Qazi Hussain Ahmad has refuted the Paldstan government statement suggesting that China and Iran have asked Pakdstan to sign the Geneva accord on Afghanistan. He charged the Soviet Union, the US and India have hatched a conspiracy against Pakistan, the Islamic world and Afghanistan (VOAPS).

* The Paldstan Times writes that Prime Minister Junejo disclosed 9 March in Karachi that, while signing the Geneva accord, Pakistan will give priority to its national interests. He added that no decision has so far been taken whether to sign the Geneva accord or not (VOAPS).

* It has rellably been learnt that the head of interim government, proposed by the mujaheddin Engineer Ahmad Shah, has held detailed meetings with Pakdstani leaders, the foreign office officials, heads of political parties and ambassadors of many countries in Islamabad (NWT)。

* The German press in general has lauded Pakistan's stand with regard to the proposed formation of an interim government in Kabul (PT).

* Speaking 9 March in Karachi, Prime Minister Junejo said it was too late for Pakistan to lave a new element added to the four instruments now being finalized at the UN-sponsored proximity talks at Geneva (DN). 


\section{1}

* Accorcling to British Press reports, a Soviet roving Ambassacior said 10 March in Geneva the US . is unnecessarily relating a halt of US aid to the mujaheddin to the Soviet assistance to the Afghan government (BBCFS).

* The UN intermediary on Afghanistan, Niego Cordovez has urged Pakistan and Afghan Celegations to go 12 - 13 March to their countries and return to the talks with a more clear mandates for conducting the talks (BBCFS).

* Radio Pakistan says the Foreign Ministry in Islamabad has lodged a protest with the Afghanistan Embassy in Islamabad against the artillery shelling on its border areas last week killing eight persons (BBCFS).

* A former Foreign Minister of Pakistan, Agha Shahi says Pakistan should get rid of Afghanistan issue and, after Sovift troops withdrawal from Afghanistan, should have no litigation with the Soviet Union. He anticipated that, after reaching an agreement on Afghanistan, re] ations between Pakistan and the US would decline (BBCFS).

* In an article, The Pravda wrote 11 March prior to the commencement of fresh rounc of Geneva talks, the US secretly increased the supply of military hardware to the anti-government Afghan groups (FMDS).

* After talks In Geneva, 10 March, the Pakistan Minister of State for Foreign Affairs, Zain Noorani said the current round of talks was tackling the most difficult problems. He refuted the Kabul allegations as if he was hindering the progress of talks (RPDS).

* In a resolution adopted with 29 votes, the UN Human Rights Commission has asked the Kabul regime to adopt all necessary measures to guarantee human rights and basic freedoms in Afghanistan

* In a statement 10 March in Geneva, the Soviet roving ambassador Nicolai Kozyrev said the main issue - - a timeframe and phases of the Soviet troops withdrawal from Afghanistan - - has been settled but Pakistan, instead of finalizing the instruments for signature, is passing the time and putting forth new proposals (RA).

* The VOA correspondent in Paldstan says the Afghan mujaheddin parties are holding consultations whether to send a delegation to Ḡeneva to be on hand when talks are held between Pakistan and Kabul regime on the formation on an Interim Government in Afghanistan (VOAPS).

* Addressing 10 March a gathering in Lahore, Prime Minister Junejo said no decision has so far been adopted on the Afghanistan issue. He said any decision in this connection will keep in view the best interest of the people of Pakistan (NWT).

* In its editorial The Nawai-e-Wagt (Pakistan) 11 March laid emphasis on the need for adopting necessary preparation for the repatriation of Afghan refugees in case of an accord in Geneva(NWT).

* The head of Kabul administration, Dr. Najibullah is thinking of reshuffing his goverment. $\mathrm{He}$ is expected to ask the refugee leaders for participation in the forthcoming elections (JG). * Addressing 10 March a press conference in Karachi, the representative of Hezb-e-Islami AfghanIstan, S.G. Abid disclosed that the mujaheddin will issue a joint statement of far-reaching consequences on the Geneva talks before 15 March. He announced that any agreement reached at Geneve 
would not be acceptable to mujaheddin and they would continue their resistance irrespective of outside aid (PT).

* In an interview 10 March in Peshawar, the IUAM President Mawlawi Mohammad Yunus Khales said the resistance parties would prefer to shift their headquarters to Pakistan's tribal belt inhabited by their Pashtun brethren instead of seeking refuge in Saudi Arabia or Iran in case Islamabad signed the Geneva accord against the aspirations of the mujaheddin (MIM).

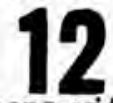

* The US state Department says the Soviet troops withdrawal from Afghanistan would not be sufficient for stopping US aici to the mujaheddin and the Soviet Union should also abandon its military assistance to the Kabul government (VOADS).

* The VOA correspondent says US miljtary officials have now admitted that the Soviets would withdraw from Afghanistan and they are of the view that Moscow is ready to pull its troo-ps out of Afghanistan without the condition of keeping the pro-Soviet government in Kabul (VOADS).

* On his return 12 March from Egypt, the Pakistan Minister for Religious Affairs Haji Saifullah Khan said the Egyptian President Hosni Mobarak has expressed strong support to the Pakistan stand on the Afghanistan issue (RPDS).

* In an interview the FRG Foreign Minister Genscher has said he is convinced that the Soviet leader wants an end to the Afghanistan dispute because the Afghan war is causing tension in the Bast-West relations (RPDS).

* The UN mediator on Afghanistan, Diego Cordovez has said apparently very serious difficulties still prevail in reaching a final settlement of the Afghan issue and we are trying to solve them. He added the two sides have been asked to return to the talks 14 March with more clear mandates from their governments (RPDS).

* A number of units of the Afghanistan army have been conferred the title of the MGuard Units of Afghanistan" following their enthusiastic participation in the defense of the country and establishment of peace (RA).

* The Charge d' Affaires of the Pakistan Embassy in Kabul was summoned 12 March to the Foreign Ministry and Pakistani claims suggesting heavy shelling by Afghan artillery on the Kurram border areas were described as baseless and far from truth (RA).

* A US state department spokesman once again asked the Soviet Union to withdraw its troops from Afghanistan and stop military assistance to the Kabul regime (VOAPS).

* A former UN high ranking official Waheed Tarazi says the transitional government in Afghanistan should be set up by the people through a loya jirgah and the jirgah should be participated by the refugees living in Pakistan, Iran and other countries, the mujaheddin and the people inside the country excluding the communists (VOAPS).

* After emerging 11 March from a one hour private meeting with the UN mediator on Afghanistan, Dlego Cordovez in Geneva, the Pakistan Minister of State for Foreign Affairs told newsmen progress In Geneva talks has been slow, so far, but hoped that things will pickup on Monday (PT).

* Talking 11 March to PPI in Lahore, Air Marshal (Retd) Asghar Khan, the Chief of TIP has said that government should not allow the Afghan mujaheddin to create hurdle in the solution of Afghan- 
istan issue. He said Pakistan should not miss the opportunity as both the big powers seem to have reached an agreement to solve the Afghan issue (PT).

* In his article in Dawn, captioned "Afghanistan problem: the end in sight?" Air Chief Marshal (Retd) Anwar Shamim has highlighted the salient features of the Afghanistan conflict and asserted that Soviet Union was mistaken in invading Afghanistan.

* Radio Kabul reported 11 March President Najibullah, while talking 11 March to a Soviet delegation, appealed to all peace-loving countries and governments to prevail upon Pakistan to sign the Geneva accord as soon as possible instead of raising new issues (MIM).

* In an interview 11 March in Peshawar, the Hezb-e-Islami Chief Gulbuddin Hekmatyar has said he was convinced the Soviet troops would be withdrawan from Afghanistan in 1988 because Sovlet Union has come to the conclusion that it was difficult for him to defeat the Afghans (MIM).

\section{3}

* The Observer (Iondon) wrote 13 March neither the US nor the Soviet Union can ouggest a solution to the Afghanistan problem. It said the people of Afghanistan should be left at their own to ascertain their future difficulties (BBCFS).

* In a statement 13 March in Quetta, Paldstan Prime Minister Junejo said final stand of his country on the Afghanistan 1ssue at the Geneva talks will be adopted keeping in view the national interests and peoples' aspirations. He again called for the formation of a coalition government for the establishment of peace inside Afghanistan (RPDS).

* According to a Bakhtar report, announcements by Soviet and Afghan leaders about a solution of the Afghan problem has perturbed the Pakdstan government and the Afghan.opposition forces. They cannot stand against the constructive stand of the Kabul government in Geneva (RMDS).

* Soviet experts are completing work on the establishment of a new institution for the exploration of gas which is expected to increase considerably the volume of gas exploited in Afghanistan

(PMDS).

* The IUAM President Mawlawi Moharmad Yunus Khales resigned from his office on health grounds. His resignation came amidst reports about differences between fundamentalists and moderates in the IUAM (VOADS).

* On the proposel of the Council of Ministers and approval of the President, the following appotntments have been made in the Council of Ministers. Najibullah Maseer as representative of the Council of Ministers with the portfolio of deputy prime minister. Fida Mohammad Dehneshin as head of administration in the social publicity department attached with the Council of Ministers; Sayyed Murtaza, as first director of State Planning Committee, and as Sultan fussain as Director of State Planning Comittee (RA).

* The New York Times correspondent writes during the 9 years of war in Afghanistan no one in the Afghan refugee camps in Pakistan has become tired of war. Every one whom he inquired, said the war would continue until an Islamic government is set up in Afghanistan free from communist participation (VOAPS).

* The Afghan Information Center reports the mujaheddin exchanged 26 February a Soviet prisoner with a commander of Jamiat-e-Islam1, Akhtar Mohammad. In the report, the place, where the exchange 
occured, was not mentioned (VOAPS).

* Four persons were killed 10 March in Tarimangal, Kurram Agency, due to an artillery shelling by the Afghan forces (DN).

* The US rejected 11 March Soviet insistence that it had the right to continue arming the Kabul government even if US aid to mujaheddin ceased (MIM).

* In an interview, the Jamiat-e-Islami Afghanistan leader, Professor Burhanuddin Rabbani said he is willing to meet the Soviet leader Mikhail Gorbachev for ending bloodshed in Afghanistan (NWT).

* According to an AAP report, the head of Hezb-e-Islami's political cormittee Abdul Qadeer Karyab at a press conference in Geneva explained the mujaheddin stand on the Geneva talks. He said the Afghans consider the Kabul administration as a part of the occupant Soviet troops and thus they want direct dialogue with the Russians (JG).

\section{4}

* The Afghań Information Center in Peshawar reports the Kabul regime has recently been posing itself an advocate of Islam since the establishment of Parcham and Khalq! groups saying they will continue to remain Islamic in the future as well.

* The Washington Post, quoting 13 March Pakistani officials, said terrorism in Pakıstan is being planned by the KCB and implemented by KHAD or the Afghanistan Ministry of Nationalities and Tribes (VOAS).

* The Pakistan Minister of State for Foreign Affairs, Zain Noorani has said some points for the four instruments in the solution of Afghanistan issue still remain unresolved (RPDS).

* Britian has announced an aid worth two million rupees for the Afghan refugees in Pakistan. The aid has been delivered to the ICRC (RPDS).

* The Pakistan Minister of State for Foreign Affairs, Zain Noorani has said he hopes a final decision about signing the Afghanistan peace accord will be taken 14 March. But his press interview, which was to be held 14 March was cancelled without any reason being given (BBCFS).

* A Radio Moscow commentator say obstructions are creeping in the Geneva talks on Afghanistan Pakistan has been demanding that the issue pertaining to the removal of present regime in Kabul should be solved and a decision be adopted on the formation of a so-called transitional goverthment and the US side has violated its previous pledges with the Soviet Union (RMDS).

* The leader of Islanic Unity, Professor Sayyaf, has said nodbody, other than the mujaheddin, has the right to take a decision on the Afghanistan issue. He added we are seriously opposed to sending a delegation to Geneva and we will never ente: direct or indirect dialogue with the Kabul regime (VOAPS).

* The Washington Times writes the Pakistan Prime Minister Junejo has said he has concluded his consultations with people from all walks of life in Pakistan on the Afghanistan issue and now it is to be decided whether Pakdstan should sign the UN sponsored peace accord or not (VOAPS).

* The Washington Times report Gulbuddin Hekmatyar leader of Hezb-3-Islami has been appointed as the IUAM new President (VOAPS).

* According to The Washington Times mujaheddin conmanders, fighting in the outskirts of Kabul, 
met in Peshawar vowing to continue their resistance until the formation of an Islamic government

(VOAPS).

* Leader of the Hazarajat Unity Revolutionary Council Organization of Afghanistan, Sheikh Sadruddin Mehdavi says every government formed without consulting the Hazaras, would be rejected by the Unity Council and we have not delegated authority to Pakistan for talks on the fate of Afghanistan nor Pakistan has the right to hold talks about the fate of others (VOAPS).

* The New York Times wrote 13 March UN envoy Diego Cordovez hopes the two sides at the Geneva talks on Atghanistan should reach a compromise based on the commitment by Kabul regime for the formation of a coalition government (VOAPS).

* The Chief or Hezb-e-Islami Atghanistan Mawlawi Mohammad Yunus Khales said 14 March Min times like these one should compromise, but I could not do so. I am a religious figure. Moreover I am also not at home in politics. Because of this I decided to resign" (VOAPS),

* Addressing 13 March a gathering in Quetta, Prime Minister Junejo said Palistan was striving f'or a solution of the Afghan problem which is commensurate with its supreme national interest and insures peace inside Atghanistan so that the three million refugees return to their country with safety and honor (MIM).

* Eight aircraft violated 12 March the Pakistan airspace in North Waziristan Agency (PT)。

* The VUA reported there are signs that the Soviet Union is preparing to quit Afghanistan without securing the assurance of survival of the pro-Moscow regime in Kabul (PT).

* Talking 13 March to newsmen in Quetta, Pakistani Prime Minister Junejo said he would take a definite decision 14 March with regard to the Pakistan's position on the current Geneva talks on Afghanistan (DN).

\section{5}

* The Soviet Foreign Ministry says it has not fixed any deadline for the solution of Afghanistan issue. It said 15 March has been fixed as a target, not a deadline (VOADS).

* The new IUAM leader Gulbuddin Hekmatyar has told the AP his group wants to hold talks wth Soviet officials but Moscow has rejected the proposal to talk with the mujaheddin in Geneva (VOADS).

* Leader of the Pakistani delegation at the Geneva talks on Afghanistan, Zain Noorani said 15 March Pakistan warits to see an interim coalition government is set up in Kabul and talks are commenced between the Afghans so that, with the formation of an interim government, the process of withdrawal is implemented (RPDS).

* In an interview with the Bakhtar, President Najibullah has said the formation of a government in the country is an internal subject for the people of Afghanistan. He reiterated his readiness on talks with forces opposing his government about the formation of a coalition government (RMDS).

* The VOA correspondent reports from Islamabad the Pakistan cabinet continued its discussions on the Afghanistan 1ssue until midnight 14 March but no statement has been issued as to when Paldstan will be ready to sign the Geneva accord (VOADS).

* The Hezb-e-Islami (Hekmatyar) announced 14 March if the Geneva accord was signed contrary to the consent of the mujaheddin, they will shift their offices Inslde Afghanistan and will form their 
government and intensify their resistance (VOADS).

* The Soviet Union says still there is a slight chance in the UN sponsored Geneva talks to reach an agreement on Afghanistan (BBCFS).

* The UN special envoy on Afghanistan, Diego Cordovez has said if the Geneva talks on Afghanistan did not conclude $15 \mathrm{March}$, they would continue until an agreement is reached (BBCFS).

* The Afghanistan resistance sources reported Sardar Agha a mujaheddin commander in Logar who was captured this year by the Soviet troops, was exchanged with a Soviet officer in an area between Dakka and Torkham, Nangarhar. He is a member of the Jamiat-e-Islami (VOAPS).

* The Christian Science Monitor in a report 14 March said high ranking officials of the Reagan government stress, as long as the Soviet Union does not stop its military assistance to the Kabul regime, the Afghanistan problem would not be solved (VOAPS).

* Replying 14 March to newsmen in Geneva, the Pakistan Minister of State for Foreign Affairs, Zain Noorani remarked some points still remained unresolved in the four instruments of the accord on Afghanistan (MIM).

* According AMRC seven Afghan mujaheddin were reportedly exchanged for two Soviet soldiers in Kandahar city and the border town of Torkham in Afghanistan (MIM).

\section{6}

* Pakistani Minister State for Foreign Affairs, Zain Noorani said 16 March in Geneva positive headway has been made in the Geneva talks and the Pakistani delegation is seeking solution to two remaining points - - the formation of a transitional government in Afghanistan and simultaneous halt of military aid to the Kabul regime and the mujaheddin (RPDS).

* A Soviet Foreign Ministry spokesman has told newsmen ultimately an agreement on Afghanistan will be signed in Geneva by the end of this month. The spokesman added a withdrawal of Soviet troops might be deferred but the intention and determination of his country for a poll-out from Afghanistan would not change (RPDS).

* At a press conference in Velma, the UN special rapporteur on human rights in Afghanistan Professor Ermacora said human rights in Afghanistan continue to be violated and he has received two reports on the human rights violation during his recent mission in Afghanistan indichtshg about 30,000 people, including childiren, hàve beeni killed (RPDS).

* The Soviet Presidium has appointed Negorychev Nicolai Gregorichev as Soviet Ambassador in Afghanistan (RMDS).

* The Soviet Union has announced, since the Afghanistan peace talks in Geneva have not been concluded until 15 March as fixed by that country, the deadline for the Soviet troops withdrawal from Afghanistan would be deferred (BBCFS).

* Afghan Foreign Minister Abdul Waldl told newsmen 16 Match in Geneva if an agreement is not reached on Afghanistan problèm in Geneva, Afghanistan would spread the war inside Pakistan (BBCFS).

* A spokesman in the Soviet Foreign Minister says he thinks an agreement for ending the Afghan1stan war would be reached by the end of this month (VOAPS).

* A mujaheddin delegation is planning to go to Geneva for talks with the UN envoy on Afghanis- 
tan Diego Cordovez on the formation of a transitional government in Kabul. Professor Abd Raab AlRasool Sayyaf and Mawlawi Mohammad Yunus Khales have refused to send their representatives to Geneva (VOAPS).

* The UN mediator on Afghanistan, Diego Cordovez said 15 March in Geneva negotiation towards a cease-fire and Soviet troops withdrawal from Afghanistan will continue in Geneva despite the passage of a Moscow deadline (MIM).

* Pakistani Prime Minister Junejo, who had an hour-long meeting 15 March with the Soviet Ambassador Vezirov in Islambad, has instructed the Minister of State for Foreign Affairs, Zain Noorani to press for the finalization of the details of the four Geneva instruments for reaching a final comprehensive accord (MIM).

* Official sources indicated $15 \mathrm{March}$ in Islamabad signing of the Geneva accord may take another week or more so that there is enough time for agreement on vital issues (MIM).

* A US state Department spokesman brushed aside 15 March reports that the US was pressuring Pakistan to sign a UN mediated settlement on Afghanistan. It was for Islamabad to make such decision, he said (MIM).

* According to AMPC, a 27-year-0ld Uzbek officer Meer Ahmadov killed his contingent cormander in the Republic of Uzbekistan and took shelter with a mujaheddin group led by Engineer Basheer of Hezb-e-Islami (MIM)。

* Speaking 15 March to The Muslim in Lahore, the PNP President Ghous Bakhsh Bezinjo said former King Zahir Shah is the only Afghan who can preside over the adjustment of the three main forces, i.e. the royalists, the PDPA and the fundamentalists (MIM).

* The Muslim published 16 March a picture with a questions mark of a group of Soviet soldiers sitting on a tank in Jalalabad asking whether the soldiers were getting ready to leave Afghanistan. The paper published another photograph with the caption, "Afghan refugees flock a currency dealer in Peshawar 15 March to get afghanis expecting agreement in Geneva talks on Afghanistan. which will entail their return to their homes.

* The Afghan peace talks are nów expected to continue indefinitely with reheived semiousnebs, the participents having agreed to discontinue criticizing each other through press conferences(m).

\section{7}

Pakistan and Afghanistan have blammed each other for obstructing the success of Geneva talks. A US reporter says from Geneva, despite this, the two sides have agreed to continue the UN sponsored talks (VOAPS).

* Pakistani representative in the Geneva talks on Afghanistan, Zain Noorani denied he has been insisting on the formation of an interim government in Kabul before signing the Geneva accord. He said the Pakdstani government only wants that it should be admitted as a principle that a transitional government be formed in Kabul before the Soviet troops withdrawal from Afghanistan (BBCPS).

* TASS says an Italian joumalists, has been sentenced to seven years imprisonment by the Kabul regime on charges of espoinage in Afghanistan (BBCPS).

* Quoting travellers recently reaching Peshawar from Kabul, the VOA correspondent says the Soviets 
withdrew 13 March all their troops from the posts in the outskirts of Kabul on Kabul-Kandahar highway and Kabul regime troops and militiamen were deployed in their place (VOAPS).

* The Soylet Union says even if a peace accord is not reached in the UN sponsored Geneva talks on Afghanistan, it intends to withdraw its troops from Afghanistan (VOADS).

* The US Secretary of State, George Shultz said if the Soviet Union does not stop its aid to the Kabul regime, Washington, too, would not refrain aiding the mujaheddin. He added, under the Geneva agreement, guarantors of the settlement - - the US and the Soviet Union - - should not interfere in Afghan internal affairs and supplying arms to them is tantamount to intervention (VOADS).

* Leader of Hezb-o-Islami Afghanistan, Mawlawi Mohanmad Yunus Khales says he does not want any position for himself in the future government of Afghanistan. He urged the IUAM leaders to elect a permanent President from amongst themselves because a rotation system for presidency will neither strengthen the unity nor the alliance of the TUAM (VOADS).

* The head of the Soviet Institute of World Social Systems, who is close to the Soviet leader Gorbachev, has said in a memorandum in 1980 he had put forth 10 reasons for the Soviet leadership that a despatch of Soviet troops to Afghanistan will cause setbacks to the Soviet interests. The Washington Post writes, by publishing this letter for the first time, Soviet of icials are openly saying differences existed in the USSR leadership whether to despatch Soviet troops to Afghanistan (VOADS).

* President Najib issued 17 March "Decree 244" in comection with making arrangements for holding National Assembly elections under section 19 of the Law for the National Assembly Elections (RA).

* Afghan Foreign Minister Abdul Wakil said Pakistan is jeoperdizing the process of Geneva talks on the settlement of situation around Afghanistan as it has forwarded a number of problems which had never been discussed in the talks before (RMDS).

* In an exclusive interview with the American Broadcasting Corporation, Prime Minister Junejo has said he has instructed Pakistani negotiators in Geneva to sign the accord on the Afghanistan problem (MIM).

* Pakdstani Minister of State for Foreign Affairs Zain Noorani said 16 March in Geneva the Pakistan government has made a clear policy decision in favor of signing the proposed agreements as soon as the outstanding issues are satisfactorily resolved and Pakistan's legitimate concerns are satisfied ( DN).

* Talking 16 March to newsmen near Peshawar, the Chief of Harkat-e-Enqelab-a-Islami Afghanistan Mohammad Nabi Mohammadi said the IUAM has decided to send a delegation to Geneva very soon (DN). 18

The new IUAM President Gulbuddin Hekmatyar has ruled out the possibility for any type of coalition or a dialogue with the present goverment in Afghanistan. In an interview he said only an interim government under the mujaheddin can guarantee peace in Afghanistan (BBCFS).

* About the Soviet announcement of 17 March saying it will withdraw its troops from Afghanistan regardless of whether Geneva peace agreement is reached, The Times (London) writes the Soviet announcement in fact means the Geneva talks carry no longer any importance (BBCFS).

* The UN mediator on Afghanistan, Diego Cordovez told newsmen 18 March in Geneva the proximity 
talks between Pakistan and Afghanistan are making headway on many dimensions (RPDS).

* The UN mediator on Afghanistan Diego Cordovez has held detailed talks with the representatives of the US and USSR in Geneva (RPDS).

* The Soviet Union says it will withdraw its troops from Afghanistan regardless of an agreement in Geneva peace talks. The Sovlet Foreign Ministry spokesman said 17 March Kremlin would, however, prefer to link its troops withdrawal with the peace accord (VOAPS).

* The IUAM spokesman Gulbuddin Hekmatyar addressed 17 March a press conference in Peshawar. Leaders of five other mujaheddin orgatizations also attended the press conference. It was officially announced in the conference that Ahmad Shah was appointed as the President and Dr. Zabihullah Mojaddedi as the Vice President of the mujaheddin government (VOAPS).

* The VOA correspondent reports from Geneva, based on recent press conference, private conversations and interviews with those dealing with the Geneva talks, it appears a broad formula may emerge for solving the Afghan issue which could pave the way for an agreement. But it is certain that only a part of such an agreement would be achieved in the framework of the Geneva proximity talks (VOAPS).

* The US criticized 16 March the Soviet Union for postponing its planned May 15 troops withdrawal from Afghanistan and accused Moscow of not dealing seriously with the unresolved issues at the Geneva talks (MIM).

* There are chances that any agreenent on Afghanistan at Geneva may be signed on or after 23 March as the US Secretary of State George Shultz and Soviet Foreign Minister Eduard Shevardnadze are meeting 22 March to discuss the UN sponsored parleys on the Afghanistan problem (MIM).

* Addressing 17 March a press conference in Peshawar, the new IUAM President Gulbuddin Hekmatyar said the IUAM has finally decided not to send a delegation to Geneva (DN).

* The Singapore Prime Minister, Lee Kuan Yew, speaking at a dinner hosted in his honor by Pakistani Prime Minister Junejo, in Rawalpindi conmended the major role played by Pakistan in a quest for a political settlement of the Afghanistan problem (PT).

* Addressing 17 March a press conference in Peshawar, the new IUAM President Gulbuddin Hekmatyar listed five conditions for return of Afghan refugees to Afghanistan. These are: (1) the complete withdrawal of Aussian forces, (2) removal of Najib's regime, (3) establishment of a government approved by the Afghan people, (4) removal of causes and possibilities of war and (5) defusing of all mines planted by the Russians in villages, roads, forests, and around the cities (PT).

\section{9}

In an interview, the Pakistan Ambassador in Washington said a coalition government representing the mujaheddin ought to be formed in Afghanistan so that the refugees would have the confidence to return to their country (VOADS).

* In a statement $19 \mathrm{March}$, on the eve of Afghan New Year Day President Najibullah said "I hope the year 1367 may become a year for the withdrawal of Soviet troops - - our tested friends who have been training their Afghan friends" (RA).

* Jordan, in a statement, has said the first and foremost duty of the Afghan people is to exert 
efforts for strengthening national unity through NRP (RMDS).

* A Radio Moscow commentator has said Pakistan is arresting all people who intend to return to Afghanistan. Such people are subjected to contempt and are put into the jails where most probably they are killed (RMDS).

* During his visit 19 March to an Afghan refugee camp near Peshawar, Pakistan, the Prime Minister of Singapore Lee Kuan Yew said following recent developnents on the international arena a comprehensive solution of the Afghan problem, guaranteeing the return of Afghan refugees, will be achieved (RPDS).

* The new IUAM President Gulbuddin Heknatyar has told the AP the Soviet government has established secret contacts with the Afghan mujaheddin (VOGDS).

* The IUAM President, Gulbuddin Hekmatyar says his mujaheddin are preparing for attack on military installations near Kabul. He warned the people of these areas to leave their homes (BBCFS).

* An Afghan mujaheddin delegation has gone to Amman, Jordan. The delegation is seriously intent to occupy the Afghan seat in the OIC (BBCFS)。

* A BBC commentator says it is apprehended in Geneva that if an agreement is reached between the US and USSR on halting Soviet assistance to the Kabul government, the Kabul delegation will quit the talks.He says only an agreement between the two super powers on their aid to Afghans may save the talks from deadlock (BBCFS).

* The VOA correspondent in Geneva says while US and Soviet officials are making preparations to hold talks next week on the Afghanistan issue in Washington. In Geneva the UN sponsored Afghanistan talks have been suspended for the weekend (VOAPS).

* At a briefing 18 March to newsmen the UN mediator Diego Cordovez said the Geneva peace talks on Afghanistan are moving ahead, and making progress in numerous fields (PT).

* At a press conference 18 March in Quetta, the PNP Chief Mir Ghaous Bakhsh'Bizenjo said there was no justification for Afghanistan to ralse the issue of Durand Line, as also there was no justification for Pakistan to raise the issue of forming an interim government in Afghanistan as part of a parcel agreement in the framework of the Geneva peace accord (DN).

* Afghan refugees held 18 March a rally in Bajaur Agency rejecting the Geneva talks and opposing the return of former King Zahir Shah (MIM).

* Talking 18 March in Islamabad to the MIM correspondent, Prime Minister Junejo declared final agreement on Afghanistan problem was now subject to an agreement between the two super powers - the Soviet Union and the US (MIM).

* Talking 18 March to newsmen in Islamabad airport, Pakdstan Federal Minister for Commerce, Planning and Development Dr. Mehboob-ul-Haq urged the international community to support Pakistan's efforts for the broad-based government in Afghanistan so that the Afghan refugees could return home with honor and safety (MIM).

* The District Magistrates all over the country have been directed to collect latest particulars about the Afghan refugees and various agencies have been asked to trace out such Afghan refugees who have reached different parts of the country in search of a living. On the other hand, the countrles giving aid to the Afghan refugees have already suspended the supply of sugar, ghee, 
pulses, flour, etc, and Pakistanis shouldering the entirt burden (JG).

\section{0}

* The Soviet Foreign Minister Eduard Shevardnadze has arrived in Washington. It is expected that he would discuss problems pertaining to the Middle East, Afghanistan issue and Central America (PMDS).

* A Mongolian newspaper says only the people of Afghanistan have the right to choose their government and, as such, to prolong the Geneva talks has been a cause of concern among the people of the world the responsibility of which lies on Pakistan (RMDS).

* The Pravda writes it is hoped prudence will prevail in the Geneva talks on Afghanistan. However the talks suddenly has been deadlocked delayed the responsibility for which lies with Pakistan and the US (FMDS).

* A BBC commentator, Anthony Hyman reports, most of observers have anticipated a dark future for Afghanistan and they are of the view that it would be engulfed in turbulance and disturbances and inability of the mujaheddin parties to evolve a stable and united front against the Soviet backed regime has disappointed many supporters of the Afghanistan resistance (BBCFS).

* The US Senate Committee on Foreign Relations has demanded the current US humanitarian aid to the mujaheddin, amounting to $\$ 45$ million, should be doubled (VOADS).

* Quoting a relief official in Peshawar, The Times (Iondon) has said following the end of war between Soviet forces and the mujaheddin, a second war will be fought between the Kabul regime and the mujaheddin and a third one among the mujaheddin themselves (BBCFS).

* The IUAM President Gulbuddin Hekmatyar has said the people of the would come to know the reality of Najib's election as leader of Afghanistan when the Soviets troops pull out from Afghanistan. Then neither Najib would be there nor his followers would have any influence (VOADS).

* Kabul Radio says the Kabul regime will hold elections to the two houses of parliament next month. The Kabul regime leader Najibullah has fixed April 6-12 for elections (VOAPS)。

* In a report, the US Senate has said it is not much optimistic about the future peace accord between Pakdstan and Soviet puppet regime and stated there is a great possibility of a civil war in Afghanistan after Soviet troops withdrawal from that country (VOAPS).

* Addressing 19 March the Afghan refugees in Katcha Garhi, Singapore Prime Minister Lee Kuan Yew lauded the chivalry of the Afghan people against the might of a super power and said they would be remembered as a valient nation in the history (MIM).

* A 14 member TUAM left 19 March for Amman to attend the OIC meeting (MIM).

* In press statement 19 March in Peshawar the IUAM President Gulbuddin Hekmatyar warned the mujaheddin would soon launch extensive attacks on military installations in Kabul in retalliation to Russian and Najib's threats against their opponents (MIM).

* In a special interview 19 March with ANS, the President nominate of proposed Interim government of TUAM, Engineer Ahmad Shah said the mujaheddin would never forget the anti-Afghan Indian policies during the past eight years (PT).

* Addressing 19 March a crowded press conference in Peshawar a prominent tribal leader Wali Khan 
Kukikhel said Pakistan should immediately sign the Geneva accord (NWT).

\section{1}

* In an interview with The International Herald Tribune, the US President Ronald Reagan has said the US will not take any step which might endanger the Afghan mujaheddin and, so long as threat against them continues, the US will not cease assisting them (RPDS).

* The Afghanistan Foreign Ministry in a statement in connection with the 17th session of the OIC Foreign Ministers has said: "We strongly feel there is no logic in keeping our Islamic country out from the OIC and its meeting. The decision to suspend the membership of the Republic of Afghanistan has been unjust and without any reason" (RA).

* An agricultural delegation from the Armenian Soviet Republic headed by the Deputy Chairman of the Agricultural Committee and the Minister of State of that Republic arrived 21 March in Kabul. The delegation met the Minister of State for the Direct Cooperation, Sayyed Ikram Paigir on the Armenian assistance to Iogar and Ghor provinces (RA).

* A delegation of the GDR Ministry of higher and technical education arrived 21 March in Kabul at the invitation of the Afghanistan Ministry of Higher and Vocational Education for talks on scientific and cultural cooperaticns between the two countries (RA).

* The Pashtun Socialist Party, led by Kabir Satorey in Germany, in letters to the foreign ministers of the USSR, the US and the UN Secretary General has expressed support to President Najibullah's announcement on the solution of situation around Afghanistan (RA).

* About the solution of Afghanistan issue, The Times (Iondon)wrote 21 March apparently the Geneva talks are deadlocked and if talks held by the Soviet Foreign Minister in Washington do not pave the way for a headway, increased disturbance and clashes are possible in Afghanistan after the Soviet troops withdrawal (BBCFS).

* On the eve of Afghanistan Day, the US President Ronald Reagan said the Kabul regime does not represent the people of Afghanistan but it is there due to foreign intervention. The real voice of the Afghan people is the voice of the mujaheddin and the refugees. I feel proud that my government, the US Congress and the US people have been supporting the Afghan people during the last seven years for the withdrawal of Soviet troops from Afghanistan (VOAPS).

* In a message to the Afghan nation on the eve of Afghan New Year, the former Afghin King Mohammad Zahir Shah said whatever achievenents made by the Afghan people by virtue of their faith, and their trust in God and their sacrifices, should be strengthened with unity and sincerity. He said unity and understanding among all our people is vital for making Afghanistan an independent and Islamic country (VOAPS).

* The New York Times writes, on the basis of an official report of the US Congressional Committee on Foreign Affairs, the Reagan Government's demand for a linkage between a halt in Soviet assistance to the Kabul regime with the US ald to the mujaheddin might create a big hurdle in the Soviet troops withdrawal (VOAPS).

* The NWFP Chief Minister Arbab Mohammad Jehangir Khan said 20 March in Peshawar he was convinced Afghan refugees would return home, the moment conditions were created in Afghanistan to facilitate their homecoming (MIM). 
* The IUAM President Gulbuddin Hekmatyar in a statement said 20 March, "we are constrained to start teaching Najib a lesson very soon and we are preparing to launch extensive attacks on all major military installations in Kabul"(PT).

* There are 3\% KGB trained terrorists in refugees camps in Pakistan duly equipped with most sophisticated weapons and these terrorists can cause a havoc in Pakistani cities. This was disclosed by a member of the Kabul team participating in the Geneva talks while talking to newsmen having leanings towards Kabul (NWT).

* The Jordan Times and Radio Amman disclosed 20 March the OIC Secretary General Sharifuddin Pirzada, who is visiting Amman, met a high ranking Soviet diplomat and discussed Soviet troops withdrawal from Afghanistan (NWT).

* Addressing a reception 20 March in Bahawalpur, Pakistan, the JUP Chief Mawlana Shah Ahmad Noorani said under present circumstances, Pakistan should sign the Geneva accord and not signing it will be dangerous (NWT).

* In a special interview 20 March with The Jang (Pakistan) the Pakistan Minister for Cormunications and Railways, Mohammad Aslam Khan Khattak said Pakistan will not accept any scheme to divide Afghanistan and international conspiracies in this connection will be foiled at all costs. He said the Padistani people believe in the solidarity and security of Afghanistan (JG).

\section{2}

In a statement $22 \mathrm{March}$, the President of Gambia, Dawda Jawara presently on a visit to Pakistan, said his country is hopeful of successful conclusion of Geneva talks on the Afghanistan issue and Soviet troops withdrawal in a way that should not create difficulties to Afghans (RPDS). * Pakistan Minister of State for Foreign Affairs Zain Noorani told newsmen in Geneva his country wants an end to bloodshed in Afghanistan and the present difficulties can only be solved by Moscow

* On the eve of the Afghan New Year Day US President Ronald Reagan has said there should be a symmetrical halt of the US ald to the mujaheddin and Soviet military assistance to the Kabul regime (RPDS).

* In a message to the OIC foreign Minister meeting, which opened 21 March in Amman, the Afghanistan Foreign Ministry said it is seeking to establish friendly relations with all Islamic countries including Pakistan and Iran. He has said NRP coincided with the Islamic principles and it is the only alternative to war (FMDS).

* King Hussein of Jordan has arrived in Islamabad on a state visit to Pakistan. One of the 1 ssures of his talks will be to help end the deadlock in the Geneva talks on Afghanistan (BBCFS).

* Western diplomats in Islamabad say Soviet milltary commanders are busy preparing the ground for the pull-out of their troops from Afghanistan (BBCFS).

* The Fynancial Times (Iondon) wrote 22 March if the Foreign Ministers of the Soviet Union and the US could not reach a compromise in stopping a failure of Geneva talks, the UN mediator Diego Cordovez has no altermative than to end the current round of talks (BBCFS).

In an interview with The Independent (Iondon) the former Afghan King Mohammad Zahir Shah has 
rejected any power sharing with the Kabul regime and has asked for international support to convene a loya jirgah enabling the Afghans to take part in the formation of a government (BBCFS).

* Radio Pakistan reported that Pakistani President General Ziaul Haq has expressed gratitude to Jordan for support to Pakistan's efforts in finding a solution to the Afghanistan dispute, withdrawal of Soviet troops from Afghanistan and return of refugee to their country (VOADS).

* President Najibullah held talks 22 March with a delegation of the Russian Soviet Federated Socialist Republic on the expansion of direct cooperation between that Republic and Nangarhar province (RA).

* Afghan Foreign Minister Abdul Wakil has sent a message to the Chairman of the 17th Session of the OIC Foreign Ministers in Amman saying, "it is regrettable that, contrary to the will of the Muslim people of Afghanistan and the OIC Charter, membership of the Republic of Afghanistan to the OIC has once again remained suspended. This decision is infested with political motives and has been imposed on the OIC by some member countries"(RA).

* A protocol on technical cooperation in electric power was signed 22 March in Kabul between the Afghanistan Electric Energy Ministry and the Department of Electric Energy Supply of the Turkiministan Republic of the USSR in Kabul (RA).

* Bxtremists placed 10 kilograms of explosives in a bag to cause losses in men and material in a populous point of Jalalabad city. The plan was discovered and foiled by the security forces in cooperation with the people (RA).

* In a statement, the Vietnamese Foreign Ministry expressed support to the 16 March statements. of the governments of the Soviet Union and Afghanistan about solving the Afghan issue (RA).

* At a recent Jirgah, the Mohmand tribe of Bajaur Agency described tension in tribal situation a product of the presence of Afghan extremists in their area and urged the Afghan extremists to leave the free tribal zone soon (RA).

* The IUAM says investigation is underway to probe into reports that a British TV cameraman was killed inside Afghanistan by a resistance organization (VOADS).

* The former Afghan King Mohamnad Zahir Shah has refuted reports that he had met recently the Kabul regime leader Najibullah in Moscow on the future of Afghanistan (VOAPS).

* At a press conference in Peshawar, an officlal of the Kabul regime Foreign Ministry Chulam Ghaus, who has migrated to Pakistan with his family, has said the Kabul regime is no longer harping on the Marxism and communism songs. Rather they have now concentrated on Islamic topics and want to show to the people as if the Kabul government is really an Islamic. He said all these are done under Soviet directives (VOAPS).

* A VOA correspondent reports from the White House that President Reagan wants to raise the Afghanistan 1ssue next week with the Soviet Foretgn Minister Shevardnadze when the latter 1s to visit Washington (VOAPS).

* The Pakistan Minister of State for Foreign Affairs, Zain Noorant said 21 March in Geneva Pakistan has no hestitation in signing the Geneva peace package as soon as the four instruments are ready and Pakistan's concerns are attended to satisfactorily (MIM).

* Addressing 21 March a banquet hosted by him in honor of the visiting Gambian President Alhay 
Sir Dawda Kaira Jawara in Islamabad, Paklstani President Ziaul Haq hoped the Geneva negotiations will lead to a comprehensive solution of the Afghanistan question (MIM).

* The Soviet Union shipped 800 air to ground rockets to Afghanistan only days before the latest round of Afghan-Pakistan peace talks opened in Geneva, usually reliable Afghan refugee sources said 21 March in New Delhi (MIM).

\section{3}

In an interview carried 23 March by The Pravda, Foreign Minister Abdul Wakil has said Pakis$\tan$ would shoulder a big responsibility for not signing the Geneva accord because all the hidem ances in signing the agreement which were referred to by Pakistan in the past have already been removed (RA).

* In an interview in Geneva, the Pakistan Minister of State for Foreign Affairs, Zain Noorani has said the Soviet Union is sincere in pulling its troops from Afghanistan but 1t seems that Kabul regime is creating hinderances in solving the issue (RPDS).

* At a banquet 22 March in honor of the Jordanian King Hussein in Islamabad, President Ziaul Haq said his country never sought to establish any government of its own choice in Afghanistan and its main aim is to restore peace and tranquillity in that country (RPDS).

* The Frankfurt Zeitung writes Indian experts admit India's link with the Kabul regime during the last eight years has been so close that neither Pakistan nor the Afghan mujaheddin accept a mediatory role for that country (VOGDS).

* The leader of Harkat-e-Enqelab-e-Islami Sheikh Mohammad Asef Mohsani has told a West German newsmen a coalition government with the Kabul communists will not be formed and Afghanistan will not be liberated simply with the withdrawal of Soviet troops until a non-aligned government is set up in that country (VOGDS).

* Quoting reliable Soviet officials, Western diplomats in Islamabad say inventories are being taken of the goods, arms and equipment at 204 Soviet military bases throughout Afghanistan to hand them over to the Kabul regime officials after Soviet troops withdrawal (VOAPS).

* The TUAM met 22 March in Peshawar to discuss a venue for setting up the mujaheddin's interim government and a 14 member team was appointed to look into the time and manner of elections among the mujaheddin and the refugees (VOAPS).

* In a conference in Washington on the eve of Afghanistan Day, US Senator Gordon Humphrey said we should not submit to any type of solution other than the one based on justice for the Afghan people and we should not yield to any inadequate solution and there should be no collusion or insincere accord on the Afghanistan issue. (VOAPS).

* US Senator David Dreir of California said the US is proud to support the mujaheddin and there are no division in the US on the Afghanistan issue. He said the Democrats, Republicans and the liberals unanimously support the Afghan mujaheddin (VOAPS).

* Speaking 22 March at a banquet in his honour by President Zlaul Haq in Rawalpindi, the visiting Jordanian King Hussein hoped that Pakistan's efforts for the solution of the Afghanistan problem would help safeguard Afghan independence and bring peace and stability to the Muslim 
country (PT).

* US Secretary of State George Shultz and the Soviet Foreign Minister, Eduard Shevardnadze began 22 March their second round of talks expected to focus on preparations for another super power sumit and withdrawal of Soviet troops from Afghanistan (PT).

* Pakistani Minister of State for Foreign Affairs, Zain Noorani said 22 March in Geneva he is waiting for a signal from Moscow to meet Pakistani concerns over the formation of a transitional government in Afghanistan and a simultaneous cutwoff, of military supplies to all sides in Afghanistan (PT).

* The US Defense Secretary Frank Carlucci will discuss the Afghanistan situation and review the on going US security assistance program for Pakistan with Pakistan leaders when he visits next month Islamabad, according to Defense Department officials (DN).

* In an exclusive interview with The Jang (Pakistan) the US Ambassador to Pakistan, Arnold Raphel unequivocally said if the US cuts off aid to its friends then the Soviet Union will also have to stop assistance to its friends - - the Kabul regime (JG).

\section{4}

About the solution of Afghanistan 1ssue, Pakistani Minister of State for Foreign Affairs, Zain Noorani said 24 March we have not raised any new issue in the talks and we continue our principled stand in connection with the contents of the Geneva proximity talks (RPDS).

* The UN mediator on the Afghanistan issue, Diego Cordovez has said experts are working on the final text of an agreement on Afghanistan. He told 23 March newsmen in Geneva texts of the agreement will be handed over to the parties concerned seeking their views (RPDS).

* Speaking at the OIC Foreign Ministers conference in Amman, leader of the Pakistani delegation, Dr. Mehboobul Haq pointed out that the Soviet insistence to continue assistance to the Kabul regime even after the cut-off of the US aid to the mujaheddin means a unilateral disarmament following eight years of war (RPDS).

* The US has suggested that Moscow and Washington should implement the military assistance cutoff to both the Kabul regime and the mujaheddin in order to pave the way for a solution of the Afghanistan issue (RPDS).

* Chairman of the US Economic Council visited 24 March the Afghan refugee camp in Katcha Garhi, Peshawar (RPDS).

* In a meeting 24 March the Pashtun and Baluch free tribesmen living in Kabul condemned the 1ssue of so-called Durand Iine raised by Pakistan and asked the Pakistan government to adopt a constructive attitude at the Geneva talks on Afghanistan (RA).

* Permanent Executive Committee of the Council of Ministers met 24 March and approved 37 proposed projects related to private sector in small industries, chemical plants, foodstuffs, building material and carpet manufacturing in the capital and the provinces of the country. Fleven of these projects are to be constructed with Soviet cooperation (RA).

* The US Secretary of State George Shultz has said the Soviet Foreign Minister has not accepted a US proposal for arms cut-off to the Kabul regime in response to a halt of US aid to the mujaheddin (BBCFS). 
* Following his talks in Washington, the Soviet Foreign Mintster said the Soviet Union would not accept the US conditions for the solution of Afghanistan issue because the Soviet Union has cer tain cormitments about Afghanistan (VOAPS).

* The Afghan Information Center in Peshawar says rumour of Soviet troops withdrawal from Afghanistan has caused despair in the Khalq party. Many members of the PDPA have refrained from paying their membership fee and do not attend most party meetings (VOAPS).

* The Soviet Forelgn Minister, Eduard Shevardnadze told newsmen in Washington some progress has been made to remove differences between Washington and Moscow about Soviet troops withdrawal from Afghanistan (BBCPS).

\section{5}

* The BBC correspondent reports frot Geneva, there is a possibility the UN mediator in Geneva proximity talks between Pakistan and Afghanistan Diego Cordovez may postpone the talks because they are deadlocked due to a number of important problems (BBCFS).

* Speaking at the OIC Foreign Ministers conference in Amman, the Palistan Federal Commerce Minister Dr. Mehboobul Haq reiterated that, with the Soviet troops pull-out from Afghanistan, the Soviet installed regime in Kabul should also be dissolved and replaced by a government chosen by the people of Afghanistan (RPDS).

* TASS says certain southern parts of Balkh and Jauzjan provinces of Afghanistan, south of Soviet borders, are being amalgamated in a new province. This has been decided by the Kabul regime without giving any reason (RPDS).

* In an interview recently with two Tunisian newsmen, the Hezb-e-Islami leader Ingineer Gulbuddin Hekmatyar has hoped the mujaheddin's interim government will be recognized at the OIC Foreign Ministers conference in Amman (VOAPS).

* Sources close to the Geneva proximity talks say the accord on Afghanistan has been finalized and now the Pakistant and Kabul regime delegations are working on the technical and legal aspects of the document (VOAPS).

* In an interview in Peshawar, the head of interim government for Afghanistan, Bngineer Ahmad Shah has said the IUAM has decided never to allow Afghanistan to become a neutral country. We want a free, Independent and Islamic Afghanistan and not a neutral Afghanistan. The country will always preserve its non-alignment but we cannot convert it into a country like Finland having no military force (VOAPS).

* Addressing 24.4 March a press conference in Washington, at the end of his talks with the Soviet Foreign Minister, Eduard Shevardnadze, the US Secretary of State George Shultz said the US has proposed Moscow and Washington should observe a three-month moratorium on military aid to the Kabul regime and the Afghan mujaheddin respectively after the complete Soviet troops withdraw (PT).

* Addressing 24 March a press conference in Karachi, the IUAM President Gulbuddin Hekmatyar said a lasting and practicable solution to the Afghanistan problem can only be achieved through direct talks between the mujaheddin and the Soviet Union (DN). 
* Addressing 24 March a workers meeting in Karachi, the JUP Chief, Mawlana Shah Ahmad Noorani urged the Pakistan government to sign the Geneva peace accord immediately and stop delaying tac-tics (DN).

* In an interview $24 \mathrm{March}$, in Amman the Pakistan Commerce Minister Dr. Mehboobul Haq said Pakistan would never bargain away the rights of the mujaheddin fighting the Soviet backed government in Afghanistan (MIM).

* In its editorial 25 March The NWT has hailed the policy statement of the US President Ronald Reagan who has said: "I am proud of the fact that my administration, the US Congress and the US people have been supporting the Afghan cause for seven years. Our objectives are yet the same, - an early Soviet troops withdrawal from Afghanistan, restoration of the independent and non-aligned entity of Afghanistan, the right of self-determination of the Afghan people enabling the Afghan refugees return in honor and dignity" (NWT).

* In a brief interview telecast by the Independent Television, Pakistan President Ziaul Haq hoped Soviet troops will withdraw from Afghanistan. He said it was the Stinger missiles which forced Soviet troops to withdraw from Afghanistan. He said although the Russians would not like the fall of present Kabul administration but if the Kabul regime is toppled, the Russians would not mind it (JG).

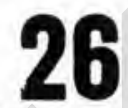

* Informed sources say, UN envoy on the Afghanistan issue Diego Cordovez has asked both the US and USSR to send their high level representatives to help break the Geneva peace talks deadlock

(VOADS).

* Quoting Western and Asian diplomats, The New York Times writes the only major hurdle in reaching an agreement on Soviet troops withdrawal from Afghanistan is a difference between the US and the Soviet Union over an agreement about simultaneous aid cut-off to the mujaheddin and the Kabul communist regime (VOADS).

* A BBC correspondent reports, it was demanded at the OIC session in Amman that the Soviet troops should be immediately withdrawn from Afghanistan but this simple demand could not satisfy the Afghan mujaheddin (BBCFS).

* The Financial Times (Iondon) wrote 26 March, the Pakistan government has, to some extent, given up its efforts at the Geneva talks for the formation of a coalition government in Kabul

(BBCFS).

* The Guardian (England) says the Paklstan govermment has said 'it would sign the Geneva accord provided the UN Secretary General's envoy Cordovez continues in his personal capacity - - not as a UN envoy - - endeavors for the establishment of an acceptable transitional government in Afghanistan (BBCFS).

* On his arrival in Karachi, Pakistan Federal Minister for Commerce and development, Dr. Mehboobul Haq said the OIC Foreign M-nisterial meeting in Amman has endorsed the Palcistan stand on the Afghanistan issue (RPDS).

* A high ranking BEC official told 25 March newsmen in New Delhi the EFC is willing to assist the rehabilitation of the Afghan refugees after their return following Soviet troops with- 
drawal from Afghanistan (RPDS).

* The OIC in its concluding meeting in Amman welcomed Soviet announcement for the withdrawal of its troops from Afghanistan (RMDS).

* The UN envoy on Afghanistan, Niego Cordovez openly announced in Geneva that he will not allow the UN sponsored talks on the Afghan issue to fail (VOAPS).

* The Washington Post writes diplomatic and UN sources have said the Reagan gnvernment would stop the supply of Stinger rockets to the mujaheddin for achieving a national reconciliation in Afghanistan (VOAPS).

* The UN mediator on the Afghanistan issue, DHego Cordovez announced 25 March indirect Geneva talks between Pakistan and Afghanistan on the Soviet troops withdrawal from Afghanistan are to continue next week (MIM).

* Four Afghan refugees were killed and another four serlously injured when a bomb exploded 25 March in a shop in Teri Mangal, Kurram Agency (MIM).

* In its editorial 26 March captioned "Afghan Peace: The Search Continues" The MuM wrote, a spirit of accomodation needs to be exhibited by all sides to ensure that the pessimists are not proved right (MIM).

* A woman and her son, were killed and two minor boys injured 24 March as a result of Afghan artillery shelling in a border village in Tarkhu Gohati, Bajaur Agency (DN).

* Chinese Acting Premier li. Peng firmly hoped 25 March the Soviet Union, as it has already announced, will withdraw all its troops from Afghanistan (PT).

* Senior diplomats said 25 March in Geneva, India has no role to play in the current Afghanistan peace talks (PT).

* It has been leamt through diplomatic sources that the Soviet leader Mikhail Gorbachev will issue an important statement in the light of Shevardnadze's report on his meeting with the US Secretary of State, George Shultz (NWT).

* Pakistan M1nister of State for Foreign Affairs, Zain Noorani has said he has informed the UN mediator on Afghanistan that Pakistan does not propose any amendment in the text of the four instruments of a accord on Afghanistan (RPDS).

* At a gathering in Khost, the Wazir and Achakzai tribes of North and South Waziristan strongly condemned the raising of Durand In ne issue at the Geneva talks. They have said the free tribal people have never recognized the Durand line and they will never do so (RA).

* Tens of thousand of people gathered at Meezan Chowk, Quetta city and expressed support to the announcements of the Soviet and Afghan leaders about achieving peace in Afghanistan (RA).

* A protest note was delivered 27 March to the Charge d' Affaires of the Pakistan Embassy in Kabul against heavy shelling by the Pakistant military on the outskirts of Torkham, Nangarhar (RA). * In an interview, the Kabul Chief of Army Staff General Shah Nawaz Tani has said extremists have violated about 15,000 times the ceasefire in Afghanistan and rebel arm convoys entering Afghanistan from Iran and Pakistan have been wiped out (BBCFS).

* A protocol on direct cooperation between Armenian Soviet Republic and Logar and Ghor provinces 
of Afghanistan was signed 27 March in Kabul (RA).

* A radio relay station, built with Soviet assistance, was handed over 27 March in Kabul to the Afghanistan government (RA).

* A protocol on cooperation between the Ministry of Technical, Vocational and Higher Education and the Soviet Embassy in Kabul was signed 27 March in Kabul (RA).

* A protocol on trade cooperations between Afghanistan and Bulgaria was signed 27 March in Kabul

* Mujaheddin sources report Kabul communist troops rocketted 24 March Mohmand pass and Bajaur pass inside Pakistan territory from Cheghsarai, Kunar, killing a women and a child (VOADS). * Pakistan Minister of State for Foreign Affairs Zain Noorani said 26 March in Geneva Soviet willingness to assume equal and reciprocal obligations as a guarantor will help in the signing of Geneva agreement (MIM).

* At a press conference 26 March in Islamabad, President of PML (Malik Qasim group), Malik Mohammad Qasim said under no circumstances, Pakistan should delay the settlement of the Afghan is issue (MIM).

* Addressing a big gathering in Quetta, leader of the Hezb-e-Islami (Khales) appealed to the world community particularly the non-aligned countries to recognize the mujaheddin's interim government (JG).

* The US Ambassador in Islamabad said 26 March the US is optimistic about the signing of Geneva accord (NWT).

* In a message 26 March to the US Secretary of State George Shultz, the UN mediator on Afghanistan, the UN Secretary General and the OIC, the IUAM President Gulbuddin Hekmatyar has said the Afghan people will not accept any decision which is adopted without the consent of the Afghans. He stressed the need for direct dialogue between the mujaheddin and Soviet Union for settling the Afghanistan ispute (NWT).

* In its editorial 27 March The Nawai-Waqt has urged the two super powers to seek a comprehensive and practicable agreement and it is in the interest of the super powers that the eight year bloodshed is ended in Afghanistan so the region may become peaceful in the future (NWT).

* In an article 27 March captioned "Afghanistan: How a sellout was foiled", The Muslim has carried a report from William Saffire in The New York Times alleging the State Department had made a secret agreement with Moscow which would heve resulted in a sellout of Afghan freedom fighters but the US Congress stopped the deal (MIM).

\section{8}

Newsmen report from Genera that the Geneva talks on Afghanistan have been deadlocked because of the difference on the question of cut-off US-USSR military assistance to the Afghan mujaheddin and the preserit Afghanistan regime (BBCFS).

* In an interview, the British Prime Minister, Margaret Thatcher said the time has reached the Soviet Union carry its pledge and withdraw from Afghanistan and no body should create hinderances for a Sovlet pull-out from Afghanistan (BBCFS). 
* A delegation from Moldavian Soviet Republic arrived 28 March in Kabul, to meet Afghan officials on direct cooperation and expansion of relations between that republic and Ghazni province (RA). * Representatives of national and peace committees from foreign countries arrived 28 March in Kabul to participate in the international conferehce of the Sollarity Origanization of the Asians and African' Peoples - - "AAPSO" - - being convehed in Kabul to alscuss the role of social circles in the solution of regional issues" (RA).

* In a message recently to the UN Secretary General Perez De Cuellar, the Council of National Front of the Republic of Afghanistan has urged him to check the artificial and unwanted pretexts created by Pakistan in the Geneva talks on Afghanistan. He has said obstructions should not occur in the progress so far made by raising the issue of so-called Durand Iine (RA).

* At a press conference 27 March in Peshawar, a leader of the SBPF, Abdul Hafeez Pirzada said if Pakistan did not sign the Geneva accord, it would entail drastic consequences (NWT).

* Speaking 27 March at a book launching ceremony in Islamabad, President General Mohanmad Ziaul Haq said, the mujaheddin are fighting our war and if they were defeated today, tomortow it would be our turn. He said we should pray for their victory (JG).

* Addressing the students in the Punjab University New campus, Lahore, the IUAM President Gulbuddin Hekmatyar sald if Pakistan was pressured to sign the Geneva accord, even then, the mujaheddin will not stop their Jehad. They will further intensify it. He said we would soon celebrate our victory in Kabul (JG).

* The Sind PNP President Shah Mohammad Shah said 27 March in Karachi a six members delegation of PNP will participate in the three-day international conference being held 29 to 31 March by the Afro-Asian solidarity in Kabul (PT).

* In an interview with Radio Moscow broadcast 27 March, the Afghan Ambassador in Moscow Mohammadullah Safi said he was optimistic that an agreement would be reached in Geneva talks ( IN).

* The IUAM spokesman Gulbuddin Hekmatyar in a message to the UN special envoy on Afghanistan and the OIC Secretary General has stated Afghanistan would never agree to become a neutral state. The government in Afghanistan would take part in all the international affairs as an independent country and would take decisions on the basis' of true justice (VOAPS).

\section{9}

Mrs. Karin Ahrland member of Swedish Parliament conducted talks about Afghan refugees with the Vice President of the Afghan Refugees Commissioner in Peshawar 29 March (RPDS).

* Japan has extended a $\$ 2$ million grant to the Afghan refugees in the framework of the UNHCR program for Afghan refugees (RPDS).

* A protest note was delivered 29 March to the Afghan Charge d' Affaires in Pakistan about the bombardment of an area in northern Baluchistan by two Kabul regime planes 24 March and about a artillery firing by Kabul armed forces in the Bafaur agency (RPDS):

* Western diplomats in Pakistan say that in a bomb exploding in a car in Kabul, four Russian consulars were kdlled 28 March (BBCFS).

* Mohammad Asef Mohseni, an Afghan Shiae leader in an interview in West Germany has said that Shia parties of Afghanistan should also participate in the future government in Afghanistan (BBGFS) 
* President Najibullah of Afghanistan in a message on the occaston of the inauguration of elections for the national assembly has told the leaders of opposition we are ready to take further steps for the sake of peace. We can jointly reallze and implement your proposals about the establishment of a coalition government and you should not miss this historic opportunity (RA).

* In a separate message, President Najtbullah of Afghanistan on the occasion of the inauguration of the Parliamentary elections in Afghanistan has utged opposition connanders to elect and send their representatives from the 54 constituencles under theit control (RA).

* Upon the invitation of the Organization of Peace, Solidarity and Friendship of Afghanistan and at the initiative of the solidarity organisation of the peoples of Asia and Africa "AAPSO" the AAPSO international conference on the role of social bodies in solving regional conflicts was opened 29 March in Kabul (RA).

* Ayatullah Mohseni, leader of the Harakati-O-Islaiti Afghanistan has said in West Germany that until the formation of an Islamic government in Afghanistan, the Jehad will continued Talks should be held directly between the mujaheddin and the Soviet Union. He condemned the Geneva talks on Afghanistan (VOGDS).

* Minister of State for Forelgn Affairs, Zain Noorani has criticised the Sovlet Union for creating obstacles in reaching agreement on the withdrawal of Soviet troops fi Jm Afghanistan (BBCFS). * The British Prime Minister, Margret Thatcher has said in a BBC interview that Russia is extending arms to the Kabul government and, therefore, 1t has no right to demand that the West should not give arms to the Afghan resistance. I make it perfectly clear that the arms cutwoff should be either symmetrical or there should be no cut off to elther side (BBCPS).

* American officials have confirmed that weapons, including mortar and mine sweaping equipment, will be delivered to the Afghan mujaheddin. They say the pragram is being implemented on a routine basis and there has been no speeding up of arms delivery (BBCPS).

* American officials have confirmed that the reasons for the American decision to stop sending Stingers to the Afghan mujaheddin has been that, in the face of reduced Soviet air operation in Afghanistan, the mujaheddin have sufficient number of these weapons at their disposal (BBCPS).

* An NLF commander in Ghazni Mirza Mohammad Naseri has said that the mujaheddin, by causing electrical faults in an operation inside the Soviet Union in the month of Hoot (February-March) have kdlled 650 people. The mujaheddin lost 22 of them (BBCPS).

* Pakistan Minister of State for Foreign Affairs, Zain Noorani said 28 March in Geneva lack of Soviet willingness to agree to symmetry cut-off of 1 ts military aid to the present ruling faction in Kabul, and the American assistance to the mujaheddin is the only thing holding up the signing of Geneva peace package (PT).

* An Afghan company of light infantry led by its cormander has crossed over to Pakistan via Chaman from Kandahar (PT).

* Lev Zaikov, the third most powerful man In the Soviet Union, says Moscow wants to withdraw its troops from Afghanistan in order to build normal relations with the Afghan people (PT).

* Paldstan has rejected Kabul's charges about putting new "pre-conditions" for signing an Afghan1stan peace settlement in Geneva saying that Islanabad is seeking an implementable agreement (PT). 
* Addressing 28 March the Lahore High Court Bar Association, the IUAM President Gulbuddin Hekmatyar said, we have defeated the Russians on the ground, whether any one accepts it or not. He said unless there was a just, lasting and practical solution, the mujaheddin will keep on fighting until the last Russian soldier leaves Afghanistan (MLM).

* The US Assistant Secretary of State, Robert Peck sald 28 March in Geneva the US is awaiting a Russian response to US proposals for removing deadlock in the Geneva proximity talks on Afghanistan (JG).

\section{0}

* The UN envoy on the Afghanistan issue met US and Soviet officials, 30 March, on the cut-off of their assistance to the mujaheddin and Kabul regime. Robert Peck, an assistant American Secretary of State said still there are differences with the Soviet representative on the issue

* President Ziaul Haq of Pakistan has said in a speech in Karachi that the people of Afghanistan, by rendering unequal and majestic sacrifices, have brought about a new age in the history of Islam and we, as Muslims, have followed the true traditions of the Madina Ansars in sharing our means with them (RPDS).

* A Soviet Foreign Ministry spokesman has admitted that during one week two bomb explosions took place in Kabul but he denied the news that four Russian military advisers have been killed in these explosions (RPDS).

* The New York Times says that with the Soviet readiness to pull-out its troops from Afghanistan further details about differences of opinion among Soviet leaders over the issue of Soviet involvement in Afghanistan since 1979 are being known (VOADS).

* The Washington Times reports of renewed clashes between the Parcham and Khalq wings of the PDPA in Kabul, saying that the explosion of a bomb in the Shahr-e-Nau of Kabul city recently in which four Soviet military advisers were killed were due to rivalries between the two wings (VOADS) * The Nashington Post reports Saleh Mohammad Zairey, Secretary of the Central Coimittee of. the Communist Party and a member of the Khalq wing was injured when his car while crossing a bridge in Kabul was hit as a result of a bomb explosion. Several of his body guards were however kdlled

(VOADS).

* According to western diplomats in Islamabad; the first batch of light anti-tank rockets manufactured in France and West Germany have been put at the disposal of the Afghan counter revolutionary elements (RMDS).

* Mawlawi Abdul Haleem Raqem founder of the Hizbullah in Afghanistan has said in an interview with Bakhtar that his party has disassociated itself from the rest of Islamic organizations which had rejected an offer by the Afghan leadership for bringing about peace in the country after the snnouncement of the NRP (RMDS). * A Soviet Foreign Ministry spokesman has said that an Afghan peace accord can be achieved without a guarantee on the part of the US not to interfere in the internal affairs of Afghanistan

(VOAPS).

* The Soviet Forelgn Ministry' says that 'In' order to end the 'Afghan conflict, there is need for 
goodwill and realism and he once again reiterated Sovlet allegations that Pakistan and the US have been imposing unjustified conditions towards the efforts for solving the Afghanistan issue

(BBCPS).

* The Soviet backed Kabul regime has offered the portfolios of the Prime Minister and the Vice President to the Afghan mujaheddin. This was arnounced 29 March in Moscow by the Soviet Foreign Ministry spokesman, Genady Gerasimov in Moscow (JG).

* The Afghan leaders met 29 March Pakistani high officials in Islamabad while senior diplomats and military attaches from a number of Islamic countries were also present (NWT).

* In an interview 29 March with the AMRC, a mujaheddin commander of Hezb-e-Islami Mahmood said the mujaheddin would be able to protect their posttions in the event of shifting their headquarters inside Afghanistan because of its mountainous position (PT).

* According to a report from Kandahar, defunct NAP leader Ajmal Khattak, leading a self-exiled life in Afghanistan for a decade, has decided to shift to Delhi after the settlement of Afghanistan issue. His decision followed fear of harm to him and his family after the settlement of Afghanistan problem (DN).

* The Pakistan government rejected a protest by the Kabul authorities $21 \mathrm{March}$, in which it was alleged that on March 17, three MI-17 helicopters of the Afghan armed forces, while flying from Barikote to Faizabad, were fired at near Dregmatal by a PAF F-16 aircraft with rocket (DN).

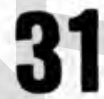

* President Najtbuliah of Afghanistan, In 'hts bid for nattonal reconciliation anong all hostile parties in Afghanistan, has urged their participation' in national assembly elections. The TUAM headed by Gulbuddin Hekmatyar has already turned down the plea (BBCFS).

* A spokesman of the Soviet Embassy in Iondon has said that the patience of Soviet leader Gorbachev has reached its claim in the face of American and Pakistani insistence for continued aid to the Afghan mujaheddin (BBCFS).

* The Pakistan Minister of State for Foreign Affairs, Zain Noorani said in Geneva 31 March the moment other parties involved in the Afghanistan peace accord were ready to sign the agreement, his government too will sign it (BBCFS).

* The Agro-Asian Peoples Solidarity Conference (AFSO) which had begun in Kabul two days ago ended $31 \mathrm{March}$. In a message to the Afghan people, the participants have said that peace loving forces of the world are watching hopefully the talks now being held between Afghanistan and Pakistan in Geneva (RA).

* Construction work for the new sites at the Torghundi port which had been completed by joint Afghan-Soviet Company, were handed over 31 March to Afghan authorities (RA).

* In an interview with a Bulgrian journalist, Soviet Foreign Minister Bduard Shevardnadze has said even if the US refused to serve as a guarantor for the solution of the situation arosnd Afghanistan, the Geneva talks on the Afghan issue can be carried through because this region geographically is no way related to the US.

* The Soviet representative in Geneva, Nicolai Kozyrev has confirmed that talks about Sovlet aid to Afghanistan cannot be held within the frame work of Geneva accord on Afghanistan (RMDS). 
* Robert Peck an assistant US Secretary of State, who is holding talks with the Soviet envoy in Geneva, has said Afghanistan's non-aligned position can only be maintained if an agreement about Soviet troops pull-out from Afghanistan takes into account the right of the people of Afghanistan to self determination and return of the refugees to their country (RPDS).

* According to VOA, in an interview, the IUAM President Gulbuddin Hekmatyar has said a parallel government will soon be formed in a safe place inside Afghanistan (NWT).

* It has reliably been learnt that the Pakistan Federal cabinet has given approval for signing Geneva accord on the Afghan issue (NWT).

* The JI Vice President and Senator, Professor Khurshid Ahmad has said Pakistan should not sign Geneva accord until Soviet and Kabul regimes agree on the formation of an interim government and Yoscow agrees on halting ald to the present Kabul regime (NWT).

* Addressing 30 March the 9th session of the World Muslim Congress in Karachi, Pakdstan President General Mohammad Ziaul Haq hoped the Afghán mujaheddin will soon emerge victorious (JG).

\section{CHRONOLOGYOF AFGHAN EVENTS, MILITARY
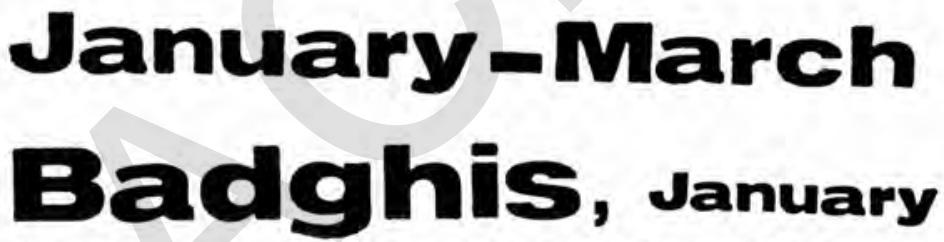

The Afghanistan resistance sources say the mujaheddin attacked 18 November a military convoy coming into Afghanistan from the Soviet Union in Kachal, Badghis. In the fighting which lasted 24 hours, a tank and 11 military trucks and their occupant were eliminated (VOAPS).

* The Badghis mujaheddin report they destroyed a Kabul regime post in Ghormach, Badghis, killing a number of Kabul troops and injuring several others (VOAPS).

31 A source of Badghis mujaheddin reports that the Ghormach mujaheddin captured 3 January a government post in Doabi village killing two militiamen, injuring five others and capturing seven pieces of arms (VOADS).

* The Badghis mujaheddin report they captured recently three posts in Mogor near Qala-e-Nau killing 21 regime soldiers. Six mujaheddin were also injured in the fighting (VOADS).

\section{February}

The Afghanistan resistance sources say 300 militiamen, belonging to 10 posts in Qala-o-Nau, Badghis, joined 15 January the mujaheddin (VOAPS).

5 The Afghan mujaheddin sources report that the mujaheddin captured a post in the outskirts of 
Badghis and also captured 10 militiamen with their arms 11 February (VOADS).

\section{March}

24. The office of Harkat-e- Inqelab-e-Islami Afghanistan reported the mujaheddin attacked 18 March a Soviet convoy in Najia, Badghis, heading towards provincial capital. The mujaheddin were able to halt the convoy until 21 March. In the fighting three Soviet tanks and two trucks were set ablaze while another truck with medicines, arms and ammunition was captured by the mujaheddin

(VOAPS).

* A source of the Badghis mujaheddin says they attacked early February a number of posts in Murghab killing 12 militiamen and two officers (VOAPS).

* The mujaheddin sources say in Jowain, Badghis, they attacked 15 March a communist post kdlling 20 militiamen and capturing six others (VOAPS).

* The mujaheddin sources say the Soviets bombarded Panjbore area of Jowain sub division, Badghis, killing six mujaheddin including commander Adam than of Islamic Unity (Sayyaf) and infuring five others. Losses were also caused to the civil population. About 50 houses were damaged and 25 civilians killed (VOAPS).

\section{-}

3 According to AMRC, the mujaheddin destroyed 19 December a Kabul regime security post in Pul- $\theta$ Khumri, Baghlan. Five lorries were also set ablaze (VOAPS)。

12 A spokesman of Hekmatyar's Hezb-e-Islami said the mujaheddin have captured a high ranking PDPA and high ranking KHAD official in Baghlan. According to the statement, the two were captured in a mujaheddin ambush on Salang highway. They will be tried soon, the statement added. (BBCFS).

23 According to mujaheddin report they killed four communist troops and destroyed a tank 3 January in Baghlan (RPDS).

26 The Afghan Media Center says the mujaheddin attacked 1 January the Kabul regime posts in Haji Malang, Baghlan, destroying three tanks and killing four militiamen and capturing sever. others with their arms (VOAPS).

29 The AMRC reports that Mohammad Javed a cameraman of Jamiat-e-Islami was killed 24 January when the mujaheddin attacked a garrison in Baghlan. In the attack 16 Soviet-Kabul troops were killed and 10 others injured (VOADS).

\section{February}

3 Afghanistan resistance sources say the mujaheddin have captured the Baghlan governor Sultan Ahmad and a number of KHAD officials. The Kabul regime is reported to be seeking the release of these officials. The mujaheddin have sentenced these persons to capital punishment (VOAPS)。 6 The Hezb-e-Islami mujaheddin attacked 28 January communist posts on Salang highway in Baghlan province killing four Kabul troops and injuring many others and capturing a huge quantity of arms

11 A source of Hekmetyar (NWT). lan, in an effort to free the governor, provincial secretary of the PDPA and a KHAD officer. The mujaheddin say the provincial secretary has already been executed after being tried in an Islamic 
court and the Baghlan governor Haji Sultan Mohammad and the KHAD office, Mohammad Nasir are still with the mujaheddin (VOADS).

1 At a press conference, Hekmatyar's Hezb-o-Islami general commander in Baghlan province, Rasool Javed said Soviet troops will not pull out from Afghanistan because of the Geneva talks. He said, if they withdraw, it will be due to the resistance conducted by the Afghans. He added, the mujaheddin control 98\% of Baghlan province. This year,1,800 militiamen with their arms, joined the mujaheddin, he added (VOAPS).

14 The Hezb-e-I slami (Hekmatyar) sources in Peshawar said the mujaheddin have executed the Baghlan governor, Sultan Mohammad after a trial (VOADS).

\section{March}

2 A source of the Hezb-e-Islami (Hekmatyar) says two Soviet troops defected 26 February to the mujaheddin after killing their three officers in Baghlan. A fierce battle was fought between the mujaheddin and the Soviet troops after the defection (VOAPS).

* Mujaheddin sources say the mujaheddin destroyed 19 February five Kabul regime military posts in Mulkian village, Baghlan, during which they also killed 9 militiamen and captured 16 others(VOAPS). 11 A source of Hezb-e-Islami (Hekmatyar) reports the mujaheddin attacked 1 March a Soviet-Kabul military convoy in Doshi, Baghlan, wiping out four tanks with all the personnel on board. Another tank was damaged in mine explosion. After eight hours of battle, communist troops were forced to

retreat. In the fighting two mujaheddin were killed and four others injured (VOADS),
13 source of Hezb-e-Islami has said the mujaheddin attacked 8 March a Kabul regime post in Baghlan. They captured the post and Kabul troops fled the post and the mujaheddin set the post ablaze

(VOAPS).

* The Afghanistan resistance sources say the mujaheddin attacked 10 March the Yakhchal post and mountainous battalion in Baghlan destroying two Soviet tanks, killing 16 troops and 6 officers and capturing nine others (VOAPS).

19 Afghan resistance sources report the mujaheddin destroyed $10 \mathrm{March}$ a post in Baghlan killing 16 troops and six officers and capturing 300 pieces of arms (VOADS).

* The Afghan mujaheddin claim the mujaheddin killed 1 March the KHAD Secretary of Baghlan and captured his body guard (VOADS).

25 The Hezb-e-Islami office says the mujaheddin destroyed 18 and 19 March 12 Kabul regime posts in Baghlan province capturing 50 troops, killing 30 others and capturing a huge quantity of arms and ammintion. In the operations four Soviet tanks were also wiped out (VOAPS).

\section{Balkh, January}

The Soviet Counsul in Washington says whatever agreement is reached on Afghanistan it should be guaranteed in that no one would interfere in the future government of Afghanistan (VOAPS).

* The mujaheddin sources in Peshawar say the Balkh mujaheddin attacked 27 December a security post on the gas pipeline killing two troops and capturing two others and the post was totally destroyed (VOAPS).

* The mujaheddin claim that they attacked 27 December a military convoy near Seh Darak village in Balkh province. The mujaheddin destroyed three tanks of the convoy heading towards Shiberghan from Balkh province. In the attack three troops were killed and two others joined the mujaheddin 
with their arms (VOAPS).

18 A spokesman for Nasr organization of Afghanistan says, in the fighting 10 days ago in Chmatal, Balkh, 100 Soviet-Kabul troops were killed or injured and the guerrillas captured a huge quantity of arms and ammunition. The mujaheddin lost 17 of their men (BBCFS).

26 The Harkat-e-Enqelab-e-Islami Afghanistan office reports that the mujaheddin attacked 17 January Kabul troops in Balkh killing a large number of them, capturing 12 others and seizing 60 pieces of arms (VOAPS).

29 The Jamiat-e-Islami Afghanistan reports from Balkh fierce fighting between the mujaheddin and the communist forces since 28 January in Sholgara. The mujaheddin have so far captured three posts in the area. Their casualties are not known (VOADS).

\section{February}

The AMRC reports the mujaheddin attacked 23 January a communist convoy on Balkh-Jauzjan highway killing 19 Soviet-Kabul troops and destroying a tank (VOAPS).

14 The mujaheddin sources report in a battle in the middle of January in Chamtal, Balkh, the mut jaheddin captured 25 Kabul troops while four mujaheddin and at least 12 civilians were killed in government bombardments (VOADS).

* A Hezb-e-Islami Afghanistan source in Peshawar says in their attack mid January in Charbolak, Balkh, the mujaheddin destroyed four tanks and two trucks and killed five Kabul troops (VOADS).

$16 \mathrm{~m}$

The mujaheddin sources report they captured recently 10 Soviet-Kabul officers in Balkh province

\section{March}

(RPDS)。

4. The ANS says the mujaheddin of Martyr Zabihullah Front ambushed 28 February Soviet troops in Mazar-e-Sharif city capturing a Sovite officer. Later the Kabul. regime freed 15 mujaheddin from Mazar-e-Sharif prison in exchange of that Soviet officer (VOAPS).

* The mujaheddin sources report that the mujaheddin captured 29 February a Kabul regime post near Mazar-e-Sharif (VOAPS).

5 The Afghanistan resistance sources say the mujaheddin of Martyr Zabihullah Front attacked 22 February a Kabul regime post in Chehlgazi, Balkh, killing eight personnel of the post and capturing four others (VOAPS).

\section{Bamian, February}

14 The Bamian mujaheddin say they destroyed in January a helicopter during an attack on the Bamian airport killing two Kabul communist troops and injuring five others. In a retaliatory air raid by Soviet aircraft 13 mujaheddin were killed and one of their trucks, belonging to a convoy, was des-
troyed.

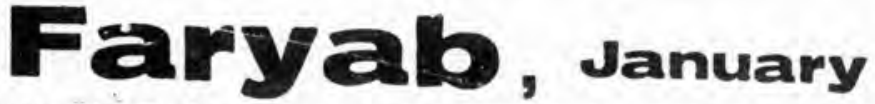

4. The mujaheddin sources in Peshawar say the Faryab mujahedain have executed the six Soviet troops who were captured last week in a fighting near Maimana city。 The Soviets had carried out an intensive operation in Faryab for the release of these soldiers (VOAPS).

8 The Faryab mujaheddin claim to have recently shot down a Soviet helicopter gunship (RPDS). 

three persons were injured and the grand mosque in the agricultural school of the city was badly damaged (RA).

\section{February}

2 According to a mujaheddin report, two Kabul government posts in Faryab have fallen recently to the mujaheddin. The mujaheddin say in the operations for capturing the posts 14 government troops were killed.

5 According to an Afghan mujaheddin report, 30 civilians were killed recently in the outskirts of Daulatabad, Faryab, as a result of a Soviet bombardment (RPDS).

7 According to Teheran Radio, the mujaheddin killed 60 Soviet-Kabul troops and captured 180 others in Maimana, Faryab (RFDS).

\section{March}

The Jamiat-e-Islami Afghanistan reports that the mujaheddin set ablaze 29 February 25 Kabul regime trucks on their way to Mazar-e-Sharif from Faryab (VOAPS).

\section{Farah, January}

The Farah mujaheddin report they forced a Soviet-Kabul troops unit to abandon a searching operation of houses in Balablook. The communists retreated from the area after they found their three tanks destroyed and a number of their troops killed (VOAPS).

13 The mujaheddin sources say the Sharafat Koh, Farah, mujaheddin attacked 29 December communist roops in Dirkoh, Balabalook, destroying a tanks, killing four government troops and capturing three others with their arms (VOADS).

10 A source of Jamiat-e-Islami Afghanistan reports from Zabul, Iran, the mujaheddin clashed 13 January with the communist troops in Jewain, Farah. The communist troops were engaged in a house to house searching operation. In the fighting two tanks and a lorry were destroyed and 15 Soviet-Kabul troops were killed or injured (VOAPS).

* A source of Jamiat-e-Islami Afghanistan reports from Zabul, Iran, that 10 persons were killed recently when a Kabul government truck hit a mine near Jewain Farah.Three persons were injured. KHAD superintendent of the battalion was among those killed (VOADS).

20 A report from Farah says the mujaheddin attacked a communist convoy heading towards Jowain, Farah, destroying three tanks and a truck (VOADS).

27 Afghan mujaheddin sources say in their attack 26 January on Soviet Commando units near Dilaram, Farah, they killed 30 Soviet commandos and injured 17 others. In retaliation to the mujaheddin attacks, the Soviet-Kabul air force bombarded a village near Dilaram, Farah, killing its entire and destroying their houses (VOADS).

31 The Afghanistan resistance sources report that in an attack on a military camp near Herat city the mujaheddin killed 15 communist troops. Meanwhile 17 troops deployed at a post in Farah province with their arms joined the mujaheddin (RPDS).

\section{February}

According to the Islamic Unity (Sayyaf) sources, the mu,jaheddin attacked and captured 8 Februa- 
ry the militia post in Dehzak, Balabalok, Farah. They also captured 28 militiamen and seized 30 pieces of arms and a machine gun (VOAPS).

21

The Soviet military leaders have massed a large number of troops, arms and ammunition in the headquarter of Farah provinie close to Iranian borders after suffering great setbacks and reverses in the area (PT).

22 According to an Afghanistan resistance report, the mujaheddin attacked in February a SovietKabul military convoy in Farah. Details of the fighting were not avaikable (RPDS).

\section{March}

4 A source of the IUAM reports that the mujaheddin attacked 25 February a Soviet military base in Fararoad, destroying an armored personnel carrier and a truck and causing damages to the base. Soviet casualties are not known (VDADS).

24 Afghan resistance sources say in their attack 5 March on a Kabul regime convoy heading towards Jowain near Farah, the mujaheddin destroyed three tanks and a truck killing 21 troops and militiamen and injuring 14 others. Also on the same day the mujaheddin hit three posts near Desht-eroad killing 18 troops and militiamen (VOAPS).

28 The Afghan mujaheddin have reported from Farah, they attacked 18 March a communist convoy north of the province heading towards Shindand, destroying a tank and two trucks, killing 14 Soviet troops including two officers and injuring seven others (VOADS).

* The office of Hezb- - -Islami (Hekmatyar) reports the mujaheddin attacked 14 March communist troops who were preparing to put Qala-e-Surkh, Farah, under seige. In the attack, a truck was destroyed, 15 Kabul troops killed and 12 others injured (VOADS).

\section{Ghazni, January}

The Afghanistan resistance sources report, in an attack 29 December on the Ghazni airport they destroyed three helicopters, 27 tanks and lorries. About 100 Soviet-Kabul troops were also killed or injured and three security posts of the airport were destroyed (VOADS).

3 Mujaheddin sources in Quetta say they sieged 22 December a number of militiamen aboard two lor ries in Nawa, Ghazni, and set on fire the two lorries. In the fighting 17 militiamen were killed and seven others captured by the mujaheddin (VOAPS)。

4 The resistance sources say that according to a Ghazni mujaheddin conmander, Arsala Khan, follow ing a series of mujaheddin attacks, the Soviets bombed two villages (no name given). Twenty six civilians were killed and about 35 others injured (VOAPS).

7 The AMRC says, in a 12 day battle until 31 December in Ghazni, the mujaheddin killed 52 Kabul troops and injured 53. Three tanks and 17 transport vehicles were also destroyed (VOAPS).

15 A source of Hekmatyar's Hezb-e-Islami reports the mujaheddin of Mogor, Ghazni, attacked 20 December with heavy arms the Ghazni No. 7 Military Division destroying a number of barracks, a military hospital, two heavy guns and killing 25 Kabul regime troops (VOADS).

16 The Islamic Unity (Sayyaf) sources say a Soviet plane was shot down 6 January in Ghazni province (VOAPS).

21

A mujaheddin source reports they have attacked a Soviet-Kabul post in Karabagh, Ghazni, killing or injuring 15 cormunist troops (RPDS). 
25

The Afghan mujaheddin sources say they attacked recently a military base in Moqor, Ghazni, killing three Soviet troops and damaging two tanks (RPDS).

27 The AAF helicopters bombed 6 January in Ghazni a convoy of the Afghan refugees heading towards Pakistan killing 11 civilians and injuring eight others (NWT).

\section{February}

The Islamic Alliance (Sayyaf) off Ace in Quetta says a Soviet tank was blown up 27 January near Ghazni city killing all the personnel on board (VOAPS).

7 The Islamic Alliance (Sayyaf) says the mujaheddin captured 22 January six officers in Gulchin, Ghazni, and $10 \mathrm{Kabul}$ troops with eight pieces of arms joined the mujaheddin. Four mujaheddin were martyred (VOAPS).

14 A mujaheddin source reports from Ghazni that the Kabul-Kandahar highways has been under the mujaheddin control for several weeks and three communists tanks and trucks were destroyed 11 February in Karabagh, Ghazni (VOADS).

\section{G OH, January}

21 The mujaheddin sources report from Quetta they attacked 19 December communist security posts in Shahrak, Ghor, destroying one post, killing six militiamen and capturing two others (VOAPS).

\section{February}

5 According to an AAP report, two Kabul troops were killed when their vehicle hit a mine planted by the mujaheddin near Chighcheran, Ghor (RPDS)。

6 The mujaheddin sources say the mujaheddin of Kuchï (nomad) fronts in Ghor province attacked 8 January a communists base in Farah killing eight Kabul troops and injuring four others while seven troops, with their arms, joined the mujaheddin (VOAPS).

\section{March}

5 The Afghanistan resistance sources report from Shahrak, Ghor, that commuist troops attacked 20 February mujaheddin positions in the area. Four communist troops were killed and two others were captured by the mujaheddin (VOADS).

\section{Helmand, January}

The Helmand mujaheddin claim to have attacked 27 December a Soviet base in Gerishk, Helmand, destroying 9 oil tankers and a number of other vehicles (VOAPS)。

19 c Commander Bahlol of NIF has reported that two Soviet tanks, with all the personnel aboard, was blown up 5 January in Iashkargah, Helmand (VOADS).

23 The Afghan mujaheddin say their two trucks, carrying goods, were attacked and destroyed by the Kabul helicopters in Moosa Qala, Helmand. Two mujaheddin were martyred in the attack (VOADS).

\section{February}

3 The mujaheddin sources in Quetta have reported, as a result of mujaheddin attack 16 January on the IAshkargah airport, heavy losses were caused to the buildings and 27 militiamen of Lashkargah posts were killed and six others captured. The posts were occupied and two mujaheddin were killed and six others captured during the operation (VOAPS)。 
The mujaheddin sources in Quetta say the mujaheddin attacked $24_{4}$ January a Soviet military base in Sarban Qala, Helmand, setting ablaze a logestic and arms depot. Three tanks and five trucks were also burnt and a large number of Soviet troops were killed or injured while the mujaheddin lost two of their men (VOAPS).

6 The Afghanistan resistance sources say fighting continues between comnunists and mujaheddin in Helmand where the communists are reported to have constructed a series of posts. Details of losses are not available (VOAPS).

7 The mujaheddin sources say the Comnunists lost 24 January-1 February 30 tanks and trucks and a helicopter in battles in Helmand (VOADS).

15 The Afghanistan resistance sources say Soviet-Kabul troops attacked their areas 24 January in Zamindawar and Moosaqala, Helmand, killing 100 civilians and injuring a large number of others

(VOAPS).

* The office of the Islamic Revolution Organization of Afghanistan in Quetta has said in a battle 25 January-1 February between the mujaheddin and the Soviet-Kabul troops in Helmand, 40 Soviet tanks with their personnel were destroyed, two jet aircraft and a helicopter were shot down and hundreds of communist troops were killed. Twenty 23 mujaheddin were also killed in fighting (VOAPS).

* Afghan mujaheddin say they shot down 4 February a Soviet helicopter in Kuki Karez, Helmand

* The Afghanistan resistance sources report that the mujaheddin have attacked a Soviet post in Yakhchal, Helmand, setting ablaze an arms depot and a truck with eight of its personnel (VOAPS). 17 A mujaheddin source in Quetta says Soviet-Kabul troops started 1 February a major operation in Kajaki, Helmand against the mujaheddin. Both sides are reported to have been inflicted with heavy losses. Soviet planes are said to have bombarded and destroyed 450 houses and martyred 220 persons. Four hundred and fifty others are reported to have been injured (BBCPS).

19 The Afghanistan resistance say the mujaheddin repulsed last month the Soviet led offensive on their positions in Helmand province (VOAS).

\section{March}

\section{1} Afghanistan Resistance sources say communist troops entered 24 February Kajaki, Helmand ensuing a fierce fighting as a result of which 15 tanks were destroyed and 10 communist troops killed or injured. Five mujaheddin were killed and 10 others injured (VOADS).

* The Helmand mujaheddin report that they have shot down a helicopter and a jet bomber north of Helmand while 14 government troops with their arms and ammunition joined the nujaheddin (VOADS). 4. The Afghanistan resistance sources report that, in a battle 29 February between the mujaheddin and Kabul communist troops in Baba Faqir of Sangeen, Helmand, 50 communist troops were killed or injured and the rest of them retreated to Sangeen (VOADS).

* The office of Hezb-a-Islami (Hekmatyar) in Quetta reports that four communist tanks were destroyed and all the personnel on board were killed 22 February by the mujaheddin in Shorki, Helmand. Three communist militiamen were killed and four others captured 24 February by the mujaheddin in the outskirts of Sangeen, Helmand (VOADS).

* The office of Hezb-e-Islami (Hekmatyar) says an oil tanker and a communist truck were blown up 
14 February in Nehr-e-Seraj, Helmand, killing 14 persons. At least another 15 Communist 'troops were killed or injured by the mujaheddin (VOADS).

10 The Helmand mujaheddin report communist forces retreated 1 March from Moosaqale, Kajaki and Sangeen, Helmand, The communists are reported to have built a number of posts in Kajaki, Sangeen and Deh Adam Khan and mujaheddin attacks continue on these posts (VOAPS).

* A mujaheddin source reportec that a bomb, planted by the mujaheddin, went off 1 March in the Lashkargah cotton factory causing damages to a portion of the plant and setting ablaze other parts of the factory (VOAPS).

22 A source of the Harkat-e-Enqelab-e-Islami says the mujaheddin attacked 7 March communist: posts in Kajaki and Zamindawar, Helmand. Fighting lasted until 9 March and the mujaheddin captured seven posts. Communist losses have not been assessed while eight mujaheddin were killed and 60 others injured (VOAPS).

* The Afghanistan resistance sources report the mujaheddin shot down 6 March a communist aircraft. in Bughra, Helmand (VOAPS)。

* The mujaheddin sources report the mujaheddin attacked 6 March a Soviet-Kabul convoy in Helmand destroying four tanks. In the operation, $25 \mathrm{Kabul}$ and nine Soviet troops were killed while three mujaheddin were killed and seven others injured (VOAPS).

26 Afghan mujaheddin sources say they destroyed 10 March a number of Kabul regime security posts in Kajaki, Helmand, killing 25 communist troops and injuring six others (VOADS).

* The Afghanistan resistance sources reported the mujaheddin attacked 17 March a cormunist vehicle base in Sangin, Helmand, and while fleeing from their center, the vehicles hit mines planted by the mujaheddin destroying 18 tanks and trucks (VOADS),

27 The mujaheddin sources report from Quetta, as a result of a recent attack by 2,000, belonging to different mujaheddin organizations on Sangeen, Helmand, the mujaheddin captured cormmist positions killing 207 Kabul militiamen and capturing 11 others. No communist troops is now left in the area (VOADS)。

\section{Herat, January}

3 Afghan resistance sources report fierce fighting between the Afghan mujaheddin and the SovietKabul troops continued 21 to 26 December in Shindand, Herat, in which 15 Soviet tanks and 13 lorries were set on fire by the mujaheddin and large number of Soviet-Kabul troops killed (TOAPS). 4. Quoting two French nationals, who recently visited Afghanistan, the AFP has reported that a military center of the Kabul government, west of Herat, has been sieged by the mujaheddin and no supplies could reach there even by air (RPDS).

9 Afghan mujaheddin report from Herat they have attacked Soviet-Kabul troops engaged in searching the people in Herat. Four communist troops were killed and four captured during the operation(RPDS) 11 The Herat mujaheddin report a military transport vehicle of the Soviet-Kabul troops was destroyed in a mine explosion near Herat city killing 10 persons on board (RPDS).

* A source of Hekmatyar's Hezb-e-Islami reports that the mujaheddin of Doab, Herat, attacked 27 December Kabul government border posts setting two tanks and an ammunition lorry ablaze and killing a number of Kabul militiamen (VOADS).

11 A report trom Herat says the Afzali Front mujaheddin attacked 27 December the KHAD office in 
Ghezan height, Herat military division, 4th armored unit and Dilkhushk base killing 30 Soviets in Ghezan height and destroying 10 tanks in the Herat military division. In other attacks on communist forces, five tanks were destroyed and 45 troops killed (VOAPS).

* The Afghan Publicity Center says the Jamiat-e-Islami mujaheddin shot down 27 December a jet aircraft and a helicopter in Zekoh of Shindand (Herat) (VOAPS).

13 source of Hekmatyar's Hezb- - Islami reports from Quetta that, in a mujaheddin attack 30 December on a communist base in Kohsan, Herat, 13 tanks and armored personnel carriers, nine military lorries and three motor cars with arms and ammunition depot were set ablaze and 200 communist troops and militiamen were killed or injured (VOADS).

14 Asource of Hekmatyar's Hezb-e-Islami has claimed that a fierce battle broke out in Injeerak, Karokh (Herat) following a Soviet attack 23 December. In the fighting, lasting two days, two Soviet tanks and two lorries were destroyed and 16 Soviet troops killed. Thirty five mujaheddin were also martyred and 50 pieces of arms captured by the mujaheddin (VOADS).

* Hekmatyar's Hezb-e-Islami reported that the Herat mujaheddin fired ground-to-ground rockets

29 December on a Soviet military base in Gulbacha causing a big fire which in turn destroyed five tanks and armored personnel carriers. Following the incident, the Soviets are said to have vacated the base (VOADS).

20 According to a Bakhtar report, rebels have attacked the Noor Hospital in Herat with mortar gun killing two patients in bed (RMDS).

21 The Afghan mujaheddin say they destroyed 7-17 January 14 Soviet-Kabul military posts in Herat capturing 1,400 pieces of light and heavy arms (VOAPS).

23 The Afghan mujaheddin claim to have killed 20 communist troops and destroyed a number of tanks and military vehicles in an attack 3 January in Herat city (RPDS).

25The Herat mujaheddin report in an attack on a military post in Herat city they killed seven Soviet-Kabul troops and damaged the communication system (RPDS).

27 The Herat mujaheddin say they attacked 8 January in Ghorian a Kabul regime convoy heading towards Islam Qala setting ablaze seven trucks with their contents and capturing 18 pieces of arms and Afs. 20 millions (VOAPS).

* Mujaheddin sources in Quetta say the Herat mujaheddin attacked a Kabul government militia base in Ghorian killing six militiamen including their commander and capturing 12 others (VOAPS).

28

The mujaheddin sources report that the mujaheddin of Afzali fronts attacked 21 January a Shindand bound Soviet military convoy in Siahsang of Adarskan, Herat, destroying two tanks, killing six Soviet troops, injuring three others and capturing a machine gun, 50,000 afghanis, 5,000 rubles and 10 tape recorders (VOADS).

* The mujaheddin sources report from Quetta that in an attack 21 January, on an Islam Qala bound Kabul government convoy in Rozanak, Herat, they destroyed a tank and three trucks and killed 11 persons aboard the vehicles. Two mujaheddin were also killed in the operation (VOADS).

* According to mujaheddin report from Quetta, a militia commander in Islam Qala, Herat, Nooruddin was killed when his vehicle hit a mine in Surkh Darra. Two others were also injured in the incident (VOADS).

30 The Afghanistan resistance sources report that in an attack on a military camp near Herat city the mujaheddin killed 15 communist troops. Meanwhile 17 troops deployed at a post in Farah pro- 
vince with their arms joined the mujaheddin (RPDS).

\section{February}

3 A source of Jamiat-e-Islami in Quetta says the mujaheddin captured in mid-January, a post in Nawa, Herat. During the operation for capturing the post, they killed two militiamen and capturec ive others (VOAPS).

5 AAP has reported that the mujaheddin blew up recently an arms depot of the Kabul regime in Doaab near Herat ci'vy destroying two tanks and a trailer and killing 12 communist troops (RPDS).

14 Border security forces destroyed a number of vehicles carrying arms and ammunition and captured a number of vehicles belonging to extremist groups. The vehicles had entered recently Shindand, Herat (RA).

20 According to a report by the Afghan resistance sources, the mujaheddin captured during the : last four days 9 communist military posts inside Herat city and its outskirts. They also captured another post near the Iranian border (RPDS).

* The Afghan mujaheddin reported that 30 persons were killed and 100 injured recently in a bomb explosion inside a cinema in Herat. The blast is said to have occured at a time when a Soviet film was being shown to Soviet troops (RFIS).

2 The mujaheddin sources report that the mujaheddin captured 16 February an important post south of Islam Qala, Herat,killing the commander of the post and capturing 13 troops with their arms and equipment (VOAPS).

* The Herat mujaheddin claim that 30 militiamen were killed 16 February when their truck hit a mine planted by the mujaheddin (VOAPS).

* The mujaheddin sources report that the mujaheddin attacked 15 February a convoy of the SovietKabul troops near Islam Qala destroying a tank and a truck and killing all the seven persons on board (VOAPS).

* The mujaheddin say they attacked 13 February a Kabul regime post in Pul-e-Pashtun, west of Herat city, killing six troops and capturing their six klashinkovs. One Mujahed was injured in the fighting (VOAPS).

26 Teheran Radio has reported the mujaheddin destroyed recently a Soviet gas pipeline in Shindand airport, Herat. The Herat KHAD office was also destroyed (RPDS).

\section{March}

2 The Jamiat-e-Islami commander in Herat, Ismael Khan yeports that the mujaheddin attacked 25 February a post in the city eljminating an armored personnel carrier with its crew. The mujaheddin also attacked 22 February eight security posts and damaged two tanks. While 27 troops were killed and 15 others captured (VOAPS).

* Mujaheddin sources report that in clashes 14 February between two Connunist regime militiamen groups in Ranjina Put, Chakan and Nawin, Herat, sixty persons were killed and a number of thers injured (VOAPS).

1 The office of Jamiat-e-Islami in Quetta says the mujaheddin attacked 27 February the Herat security belt destroying a post and two tanks and capturing another tank (VOAPS).

* The mujaheddin sources report that the mujaheddin fired 21 February on the Soviet military 
base in Adraskan, Herat, destroying eight tanks, killing a number of Soviet troops and injuring 18 others (VOAPS).

11 The mujaheddin sources in Islamabad have said the mujaheddin attacked 24 February a military convoy in Herat at 150 kilometers killing at least 70 Soviet-Kabul troops (VOAPS).

28 A source of the Jamiat-o-Islami Afghanistan reports the mujaheddin attacked 14 March communist centers in Herat, Zindajan and Ghorian destroying eight transport vehicles. In the fighting, lasting until $18 \mathrm{March}, 60$ communist troops were killed and a number of others injured (VOADS).

* Afghanistan resistance sources say, in their attack 1 March on communist positions in Shindand, Herat, the mujaheddin captured a military base, destroying four tanks, and killing 20 Kabul troops. Three of them joined the mujaheddin. In the battle the mujaheddin also seized a tank, a truck and a wireless vehicle. Four mujaheddin were killed (VOADS).

$3 \int$ Afghan Mujaheddin report that their units attacked 29 March a small Soviet-military convoy moving.from Kandahar towards the Shindand military base. In the operation two Soviet tanks and trucks as well as 14 Soviet soldiers, including two officers, were killed and eight injured (VOADS).

\section{Jauzjan, February}

* According to reports reaching Peshawar, during the month of January-February in clashes between the mujaheddin and Kabul-Soviet forces in Sangcharak, Pul-e- $\Lambda 1 i$ and Aurang 200 communist soldiers have been killed, five tanks and 20 military posts destroyed.

\section{IN 200 , January}

Afghan mujaheddin claimed to have destroyed 26 December a post in Iata Band, Kabul province, and killed three militiamen and destroyed four electric poles carrying power from Naghloo to Kabul. (VOADS)

* The mujaheddin of the Mahaz-o-Melli report that they attacked and destroyed 26 December the Kharoti Bagrami post in Kabul province. In the attack, two tanks, eight trucks, and four long range guns were set on fire (VOADS).

4. Quoting mujaheddin commander Abdul Haq, resistance sources say the mujaheddin, in a rocket attack 27 December, on a Soviet base in Darul-Mman, Kabul, killed 11 Soviets, destroyed two tanks and three lorries and caused heavy losses to the buildings in the base (VOAPS).

5 Two anti-air rockets with rocket launchers were captured 5 January by the security officials in Paghman, Kabul province (RA).

6 A NLF source says the mujaheddin in an attack in the apartment houses district of Kabul city have killed a communist military officer and four members of his family. They have also attacked the Shiwakd military post and have launched attacks from Chakari and Benihessar on Kabul military bases (VOAPS).

* The NIF office reports that the mujaheddin fired 2 January on a post in Guldara, Kabul province, killing 12 communist troops (VOAPS).

8 According to mujaheddin source, the mujaheddin attacked a military training center and an oil depot east of Kabul, setting the military installations ablaze. In the operation a Soviet aircraft was atso shot down (RPDS).

13 The Afghan Publicity Center says the mujaheddin attacked with rockets 5 January the Soviet mi- 
Litary base in Khairkhana, Kabul City, killing eight Soviet troops and destroying eight tanks

14. The Afghan mujaheddin report that they have shot down two Kabul regime fighter planes in Khost and destroyed 14 Soviet-Kabul military posts in Sarobi (RPDS).

16 The Afghan Publicity Center says the mujaheddin eliminated 28 December a Soviet military base in Guldara, Kabul province, destroying two tanks and two lorries (VOAPS).

18 The Afghan resistance sources reported that the mujaheddin shot down two Soviet helicopters in Paghman, Kabul province (RPDS).

21 Teheran Radio reported the mujaheddin captured a Soviet-Kabul military post between Kabul and Paghman killing all the troops in it (RPDS).

23 The mujaheddin sources report, in an attack 8 January on a communists post in Sarobi east of Kabul province, they killed or Injured a number of Soviet-Kabul troops and destroyed three milltary trucks and a jeep (RPDS).

29 The Hezb-e-Islami (Khales) has reported that, in an attack 6 January in Sarobi, Kabul province, the mujaheddin killed four Soviet troops and in'jured four others. A tank, a jeep and a transport vehicle were also destroyed (VOADS).

\section{February}

The security forces of the country discovered and siezed 12 ground-to-ground rockets and three detonators in Oriakhel, Paghman, with the cooperation of the people of that sub division (RA).

* Afghan Press International reported that two heavy bombs exploded 29 January in a Soviet garrison near Kabul city killing at least 44 Soviet troops and injuring a number of others (PT). 7 A source of the Islamic Alliance (Sayyaf) reports that the mujaheddin attacked 29 January the Kabul airport setting seven planes ablaze. Further losses are not yet known (VOAPS).

Afghan resistance sources say the mujaheddin blasted 4 February a bridge with mine near Naghloo, Kabul Province (VOAPS).

17 The Afghan (Publicity Center reports that in an ambush 5 January the mujaheddin killed a Soviet soldier and captured a rifle in front of the Coca Cola Company in Daraulaman, Kabul (VOAPS).

\section{March}

10 A mujaheddin commander, operating in southern Afghanistan, Mulla Malang has accused the Kabul regime of executing last December more than 400 political prisoners outside the Pul-e-Charkhi jail

(VOAPS).

1 The IUAM office in Quetta has reported the mujaheddin attacked 22 February a big Sovlet-Kabul military post in Mir Bacha Kot, Kabul Province, killing a Soviet military officer and 11 troops

(VOAPS).

* A huge bomb reportedly exploded 15 March in Forel'g Office building in Kabul killing and injuring many people (PT).

17 The Afghan Information Center says a bomb went off 4 March in the Education Ministry in Kabul kililing a number of officials. Bxact details of casualties are not known (VOADS). 27 A bomb, planted by extremist near Aisha Durrani girls school in Kabul, was discovered and defused by the security officials before it exploded (RA). 


\section{Kandahar, January}

The Mahaz-o-Melli reports from Quetta that the mujaheddin attacked Soviet-Kabul troops who were busy in constructing a base in Mahallajat, Kandahar, destroying four tanks and forcing the enemy to retreat (VOADS).

* The Kandahar mujaheddin say, as a result of an attack on the border areas in the north east of Spin Boldak, one enemy truck, a heavy gun and five defense trenches were destroyed and at least 9 troops were killed and 12 injured (VOADS).

2 The mujaheddin sources in Quetta say the Mahallajat, Kandahar, mujaheddin have been constantly attacking the Kabul communist troops for the last one week and now the government forces have returned to the Kandahar airport (VOADS).

* Nooruddin a mujaheddin commander reports from Kandahar that a number of mujaheddin groupsjointly. destroyed the Nassaji post of the city killing 11 militiamen (VOADS).

* Cormander Lalak of Islamic Unity Organization of Afghanistan (Sayyaf) reports that the general who was cormmanding the Kandahar garrison was accused of cooperation with the mujaheddin and the Kabul Defense Minister during his recent visit to Kandahar replaced him and appointed General Mohammad Asef to the post (VOADS).

9 The Kandahar mujaheddin claim to have killed five Soviet-Kabul troops and destroyed two armored personnel carriers recently in the Dand sub-division (RPDS).

11 The office of Harkat-e-Enqelab-e-Islami reports from Quetta that the mujaheddin attacked 1 January a Soviet military unit heading towards Karezak, Kandahar, destroying two lorries with its passengers and their contents. It is said 14 Soviet troops were killed and eight others injured 11 According to Afghan resistance sources, the mujaheddin captured a security post in Qalasar, Kunar, killing three Soviet troops (RPDS).

12 The resistance sources report from Kandahar that, as a result of clashes between the cormunists and mujaheddin in Mahallajat Kandahar, 11 communist tanks and two lorries were destroyed and all those aboard were killed or infured. In the fighting itself 35 Soviet troops were killed while 11 mujaheddin were killed and 9 injured and the roads leading to Mahallajat were blocked (VOAPS). * A source of the NIF reports that the Mahallajat, Kandahar, mujaheddin attacked a new Soviet post in Mir Bazar destroying two tanks and a lorry, killing 11 Soviet troops and injuring 13 others (VOAPS).

1 Resistance sources report the Kandahar mujaheddin attacked 6 January in Pashtun Bagh a Soviet convoy of oil tankers heading towards Kandahar airport setting two tankers on fire and burning two Soviet troops (VOADS).

14 The Kandahar mujaheddin report they attacked 9 Jamuary the Kandahar main prison and after destroying the northern portion of the jail freed 18 prisoners (VOADS).

1 Themujaheddin sources report from Quetta that a big Soviet force succeeded 1 January to tighten the communist siege around the mahallajat, Kandahar. The siege was completed 9 January (VOADS).

* According to the mujaheddin of Harkat-e-Enqelab-e-Islami Afghanistan they attacked 1 January a government post in Maiwand, Kandahar, killing 11 militiamen and capturing the post (VOADS). 
According to Afghan resistance sources in Quetta, 1,500 mujaheddin have been besieged in Mahallajat and their siege is being narrowed every day. The source said the mujaheddin are offering stiff resistance despite shortage of food and military hardware (VOAPS). Jamiat-e-Islami commander Mohammad Wali has reported that a group of Jauzjani militia, patrolling in Deh Khawaja, Kandahar, was sieged 15 January by the mujaheddin. In the fighting, two militia jeeps were set ablaze, 20 militiamen killed and seven others injured. Three mujaheddin were injured (VOADS).

* According to mujaheddin, they attacked recently a military convoy on Kandahar-Herat highway killing or injuring 70 Soviet troops (RPDS).

21 The Kandahar mujaheddin report they blocked 6 January Soviet troops movement in Siahsang pass. In the fighting 17 commandos were killed or injured (VOAPS).

24 Mujaheddin sources say they carried out 10 January heavy shelling on the Soviet military oase in Chehl Zeena, Kandahar, damaging the base and killing two Soviet troops and injuring two others

(VOADS).

* Kandahar mujaheddin report that they besieged 17 January a group of government militia in Mir Bazar village, Kandahar. Three communist militiamen were killed, three injured and another three captured by the mujaheddin during the fighting (VOADS).

* The Kandahar mujaheddin say they destroyed 10-18 January 13 communists tanks and other vehicles in Mahallajat and continue their attacks on the recently constructed government posts in the area

27 Afghan mujaheddin in Quetta say they attacked 26 January the communists "security belt" in Mahallajat capturing six posts. In the attack 25 troops were killed and all the equipment at the posts were captured by the mujaheddin (VOADS).

28 The Kandahar mujaheddin say they sieged 17 January Shorabak, Kandahar and fighting lasted untiI 26 January. Five government troops with their arms joined the mujaheddin on the first day of the battle (VOADS).

31 According to Kandahar mujaheddin, despite heavy communist bombing, they are still holding six posts at the security belt in Mahallajat. They had occupied these posts 25 January (VOADS).

* The Afghanistan resistence sources report that, in a mujaheddin attack 23 January on a mechanic school and office of public auditor in Kandahar, 13 communist troops were killed and the military post at the public auditor's building was completely destroyed. Heavy losses were also caused to the post at the School of Mechanics (VOADS).

31 The Afghanistan resistance leaders say their forces killed or injured in Kandahar 27 January 43 Sovilet troops while they also killed 27 Pakistani Baluch tribesmen and injured 27 others (VOADS)

* The ANS says 11 mujaheddin were martyred and a large number injured recently in Mahallajat, Kandahar. In the fighting 20 January near Mahallajat, 14 Kabul militiamen were killed (vOAPS).

\section{February}

According to an ANS report, the mujaheddin destroyed 31 January a pro Ismatullah Muslim militia base in Spin Boldak, near Pakistani border. In the attack, 22 militianen were kdlled or injured and three mujaheddin sustained injuries (VOAPS)。

2 The Afghanistan resistance sources say a leader of the Kabul regime militia, Esmatullah Muslim 
is at present under the surveillence of Khalqi troops in Kandahar (VOAPS).

* According to mujaheddin sources, a post of Band-e-Qater, Kandahar was eliminated 26 January by the mujaheddin and an arms and ammunition depot of the post was set ablaze while 14 communist troops were also killed. Seven mujaheddin were injured in the operations (VOAPS).

* The Afghanistan resistance says, in an attack 29 January on a post in Madkala of Mahallajat, Kandlahar, the mujaheddin destroyed two transport vehicles and killed 16 persons (VOAPS)。 3 A NIF source said the mujaheddin destroyed 24 January a post in Mir Bazar, Kandahar, killing nine Kabul troops and injuring 12 others while one mujahed was killed and anotner injured (VOAPS). * The Jamiat-e-Islami office in Quetta says the mujaheddin attacked 28 and 29 January posts in Haji Baqi, Qalacha, Karpur Bazar and Mahallajat, Kandahar, killing 11 militiamen and damaging the posts. Two mujaheddin were killed and seven injured in the fighting (VOAPS).

* The mujaheddin sources say they succeeded 29 January entering Kandahar city and blowing up with time-bombs the seven bulldozers brought for the construction of buildings (VOAPS). 4. The mujaheddin sources in Quetta say the pro - EsmatullahMuslim militiamen killed 29 January 13 persons in Spin Boldak Kandahar. They said Ismatullah Muslim had invited these people fnr food in Spin Boldak during which they were all killed (VOAPS)。

* The mujaheddin sources claim, the Kabul regime Defense Minister General Mohammad Rafi went 27 January to Kandahar with 230 officers and troops and organized a number of operations against the mujaheddin. Six of the officers were killed in fighting and the rest fled the battlefield (VOAPS). * The Islamic Alliance (Sayyaf) has reported that the mujaheddin attacked 29-30 January the Kagiran and Mehrain posts in Mahallajat, Kandahar, killing two troops and injuring 12 others and
setting a truck on fire (VOAPS).

* A mujaheddin commander, Lala told ANS that a senior adviser to the Kandahar governor was killed recently by the mujaheddin (PT).

5 A mujaheddin source says the mujaheddin blocked 29 and 30 January all the supply routes in Panjwai, Kandahar, resulting in a Soviet bombardment of the areas in which 20 civilians were kdlled and a large number of others injured (VOAPS).

* The Islamic Alliance (Sayyaf) office reports that several mujaheddin groups jointly attacked 28 January the Kandahar prison and the Dand sub-division killing 24 Kabul troops and militiamen. Nine prisoners fled the prison. The mujaheddin also attacked 31 January a post in Bund killing eight troops and injuring six others (VOAPS).

* A source of Kandahar mujaheddin reports that a prominent commander of the Islamic Alliance (Sayyaf) Captain Abdul Hai was killed 3 February in Taimurian, Mahallajat (VOAPS).

7 A source of Hekmatyar's Hezb-e-Islami reports that in an attack 29 January on a security post at Chawk-e-Dand, Kandahar, the mujaheddin killed four government militiamen and injured three others (VOADS).

* The Kandahar mujaheddin say they attacked 31 January a Soviet patrol party in Pashtun Bagh setting a truck ablaze, killing eight Soviet troops and injuring two others (VOADS).

* The Kandahar mujaheddin report a city post, known as Ajani, was damaged 2 February in a mujaheddin attack. Two communist trenches were destroyed killing four militiamen and injuring four 
others (VOADS)。

* The ANS says the mujaheddin attacked 22 January a Kabul regime post in Durrani near Kandahar city, destroying four Soviet tanks, and killing 20 Soviet-Kabul troops. One mujahed was killed and another injured (VOAPS).

* The ANS reports that a special banquet 26 January in Kandahar city, the mujaheddin killed four high ranking officers of the Kabul regime including the Deputy Chief of Kandahar military KHAD, Deputy Chief of political affairs of Brigade No.8 and the Chief of the Brigade. Two mujaheddin were also killed (VOAPS).

8 The Afghan mujaheddin claim to have repulsed recently Soviet-Kabul troops offensive in Mahallajat, Kandahar, destroying four communist tanks (RPDS).

15 As a result of ground-to-ground rocket fires recently in Spinboldak, Kanadahr, by the extremist groups, one of our compatriots was killed, 10 others injured and a mosque and a school were damaged. A number of houses were damaged in the attack (RA).

17 The mujaheddin sources report in a battle 13-14 February between the mujaheddin and SovietKabul troops in Sarpooza, Kandahar, the mujaheddin destroyed five Soviet tanks with its crew and 25 other Soviet troops were also killed (VOAPS).

* According to a report of the Hezb-e-Islami (Khales), in a battle 5-11 February between the mujaheddin and the Soviet-Kabul troops in Panjwaee, Kandahar, communist positions and ammunition depots were destroyed and the Kabul troops entered 12 February inside Panjwaee but they came attaunder the mujaheddin at back at a crossroad. Thirty militiamen were killed, three tanks and a truck were destroyed and communist troops retreated (VOAPS).

2 The mujaheddin sources in Quetta said three communist helicopters were hit 11 February with. antiaircraft rockets by the mujaheddin in Garmabad of Maiwand Kandahar. One helicopter crashed on the spot and burned with its crew, while the other two were damaged. The source added the mujaheddin had shot down 7 February another helicopter in Daraig of Maiwand (VOAPS).

* An NIF source reports, the mujaheddin attacked 7 February the Kandahar military division kill1ng 25 troops. The Harkat-e-Enqelab-e-Islami sources also say its mujaheddin attacked 12 February the Kandahar military division killing a number of Soviet-Kabul troops (VOAPS).

* The mujaheddin sources claim the mujaheddin jointly attacked 12 February Soviet positions in Kandahar killing 13 troops. In another attack 11 February the mujaheddin destroyed communist. tank and its crew. Seven militiamen of the communist regime were also killed (VOAPS).

23 The Afghan mujaheddin report that a Soviet helicopter was shot down 19 February by the mujaheddin in Daman, Kandahar. Another helicopter was seriously damaged with the anti-aircraft rockets

(VOADS).

* The mujaheddin sources claim, as a result of their heavy shelling 14 February on a Soviet military base in Maiwand sub-division, Kandahar a depot of military hardware, a tank, and a truck were set on fire. Details of the Soviet casualties are not known (VOADS).

* The Afghanistan resistance sources say they attacked 14 February a Kabul regime security post in Maiwand, Kandahar,killing seven militiamen. Two mujaheddin were also injured in the operation (VOADS). 


\section{March}

Mujaheddin sources in Quetta has said 13 Kandahar mujaheddin groups attacked 26 February the KHAD special office in front of Ice Factory capturing the office and killing its commander, Major Amanullah and his assistant Captain Mohammad Bashir with 20 other officials. Two trucks and the building where the office was located were destroyed. Two mujaheddin were killed and eight others injured in the operation (VOADS).

* Mujaheddin sources report that the Gerishk, Helmand, mujaheddin attacked 14 February a Soviet military base in Sangeen, Kandahar, setting ablaze two helicopters, eight tanks, six oil tankers and six trucks. No details were available about Soviet human casualties (VOADS).

* A source of the Hezb-e-Islami (Hekmatyar) says a tank, carrying high level communists officers, hit 24 February a mine in Salehan, Kandahar, killing commander of the Unit-15, commissioner of Panjwaee and five others. Similarly, 80 militiamen were killed and seven tanks with four trucks were destroyed from 21-28 February in the area (VOADS).

2 Afghan resistance sources say a government helicopter was shot down 14 February in Daman, Kandahar, killing all those on board (VOf:PSi).

3 The Afghanistan resistance sources say $22 \mathrm{KHAD}$ personnel were killed 27 February in an attack on their office in Kandahar. Similarly, 14 Kabul troops were killed last week in the mujaheddin attacks on Kandahar city outskirts (VOADS).

8 The Afghan mujaheddin sources say more than 110 Kabul troops and officers have recently joined the mujaheddin in Mahallajat, Kandahar. The troops are trying to join the mujaheddin because of the insecurity they feel, following the probable withdrawal of Soviet troops (RPIS).

$10 \mathrm{~m}$ The Hezb-e-Islami office in Quetta said its mujaheddin attacked 28 and 29 February, the offices of Arghandab, Kandahar, Administration destroying a tank, killing 13 militiamen and injuring 14 others. The mujaheddin also killed 3 March 14 Soviet-Kabu2 troops anc destroyed a Soviet tank in Punjab (VOAPS).

1 Afghan resistance movement in Pakistan says in an attack $8 \mathrm{March}$ on the Kandahar airport the mujaheddin destroyed four jet fighter aircraft, two Soviet helicopters and three tanks. Nine Soviet and 16 Kabul troops were also killed in the operation (VOADS).

* The Afghan resistance says the mujaheddin have been fighting 29 January - 3 March against the Soviet-Kabul troops in Panjwaee destroying 17 tanks and transport vehicles, killing 20 Kabul regime troops and a large number of Soviet troops while 150 Kabul regime troops have joined the mujaheddin (VOAPS).

17 Informed mujaheddin sources say the mujaheddin have been fighting since 14 March against the Kabul troops in Nazian and Acheen, Nagarhar, as well as Sarobi, Kabul. Thirtyfive Kabul troops, with their arms, have joined the mujaheddin as a result of fighting in these area. A truck was blazed 13 March on the road between Torkham and Daka killing a number of persons on board and injuring a number of others (VOAPS).

20 The Afghanistan resistance say following a month long fighting in Panjwaee, Kandahar, the mujaheddin have captured a strategic center and eight Soviet tanks (VOADS).

23 Reliable mujaheddin sources have said in Quetta Soviet troops handed over recently two militar? 
bases near Kandahar to the Kabul communist regime and the Soviets have shifted to their main base in Kandahar (VOAPS).

* Mujaheddin sources say the Kandahar mujaheddin attacked 13-16 March six Kabul regime posts in Kandahar city and in its outskirts killing at least 25 Kabul troops and injuring 22 others (VOAPS). * The Afghanistan resistance sources report the mujaheddin ambushed 15 March a Soviet convoy north of Kandahar destroylng seven trucks and five tanks along with their drivers who were all Soviets. The convoy was on way to Kandahar for reaching a big Soviet base (VOAPS)。 20 The mujaheddin have 'reported from Kandahar'before the Afghàn New Year Day, the Kandahar local Radio one day asked for cease-fire but; the mujaheddin responded by attacking nine sites in the city outskirts. They killed 12 troops and officers in a day time attack on the city (VOAPS).

* The mujaheddin report that 13 mujaheddin units attacked 24 March ot, midnight, the Daman subdivision; Kandahar, capturing the sub-division. In the attack 25 Kabul troops were killed and 10 others injured. The remaining troops fled at night. Daman sub division has been a commmist stronghold for several years (VOAPS).

* The Afghanistan resistance sources say the mujaheddin 18 March liberated Panjwaee, Kandahar, from communist control for the first time in eight years. Soviet troops did not come to help Kabul troops eventhough fighting between the mujaheddin and Kabul troops continued for about one month

(VOAPS).

31 Afghanistan resistance sources say that on 22 March they intercepted a big Soviet military convoy moving towards Kandahar in the Karwangah region of the Herat-Kandahar highway, destroying 22 tanks and eight trucks (VOADS).

\section{Kapisa, January}

As result of firing of ground-to-ground rockets by extremist elements in Gulbahar, Parwan, 9 January one woman and two children were killed.(RA).

\section{Kunar, January}

12. The mujaheddin say they attacked 8 January a military convoy led by Soviet troops attermpting to reach Barikote Cantonment, Kunar. The convoy was forced to retreat. Twelve Kabul and six Soviet troops were killed during the operation (VOADS).

16 The Afghanistan resistance sources report that the mujaheddin attacked the Kabul regime posts on the eastern and western banks of Kunar river eliminating a post (VOAPS).

19 Extremist groups attacked with rockets residential buildings in Jan Kali village, Kunar, injuring five persons including women and children and destroying 15 houses (RA).

21 According to Bakhtar,anti-government armed groups launched rocket attacks on three Kunar villages causing serious infuries to five persons and destroying 20 houses (RMDS).

24. The Afghan mujaheddin report that in their recent attack on Assadabad,Kunar, they inflicted heavy losses in men and material to Soviet-Kabul troops and eliminated government arms and ammunition depots and oil reservoirs (RPDS).

2 Quoting Western diplomats, The Washington Post writes that in their attack with heavy mortars 10 days ago on a Soviet military camp in Kunar, the mujaheddin eliminated 200 Soviet troops with their tents and other belonging (VOADS). 
30

Mujaheddin sources have said they shot down recently a Kabul regime helicopter in Nooristan Kunar (RPDS).

\section{February}

1 The Kunar mujaheddin claim to have destroyed 9 February a post in Kunar. No details were available (VOADS).

14 Criminals, associated with the extremist groups, launched recently a ground-to-ground rocket attack in Narang, Kunar, seriously injuring two persons and destroying a number of houses (RA). 2: The ANP reports that the mujaheddin attacked 17 February Soviet-Kabul bases in Pashad, Kunar, killing six Kabul troops (VOAPS).

* Mujaheddin sources say they attacked early this month a Soviet commando base in Chagha Sarai, Kunar, where 200 Soviet commandos were deployed. Details of the losses are not known (VOAPS).

* Quoting the mujaheddin, the Afghan Information Center reports that the mujaheddin attacked 14 February a government security post in Narang, Kunar, killing three troops and destroying a number of tanks (VOAPS).

20 The Afghanistan resistance sources say the mujaheddin attacked the Pashed village, Kunar, kilMarch ling more than government 10 troops and militiamen (VOAPS).

\section{Kunduz, January}

1 The mujaheddin sources report they attacked 29 December the Kabul troops in Dasht- $\bullet-\Lambda$ rchi, Kunduz, killing 35 troops and militiamen, injuring 30 others and capturing five pieces of arms

\section{February}

(VOAPS).

The office of Harkat-e-Enqelab-e-Islami Afghanistan has reported that the mujaheddin attacked a Kabul regime convoy in Dasht-e-Archi, Kunduz, destroying six transport vehicles and killing 46 troops. Four mujaheddin were kilied and another injured in the operation. In retaliation, the Soviets bombed the area killing two civilians and 40 camels (VOAPS)。

17

Abdul Latif Tbrahimi a commander of Hezb-e-Islami (Hekmatyar) in Hazrat-e-Imam,Kunduz, has said in Peshawar the mujaheddin under his command killed 21 November 40 troops and set on fire an arms depot inside the Soviet territory (VOAPS).

21 The Afghanistan resistance sources say the mujaheddin attacked 6 February a Kabul regime post

- in Jannat Bagh, Khanabad city, Kunduz, destroying the post and killing an officer and seven militiamen. Two mujaheddin were killed and another injured. The mujaheddin captured two troops in the operation (VOAPS).

* The Afghan mujaheddin say they attacked a Soviet post in Khanabad, Kunduz, killing four militiamen. A KHAD deputy and an offirer were captured by the mujaheddin. In the fighting seven mujaheddin were also killed (VORPS). 


\section{March}

12

The Afghanistan resistance sources say the mujaheddin killed 25 February 12 Kabul regime militiamen in Kunduz near the Soviet border and captured three others (VOAPS).

* The Hezb-e-Islami (Khales) reported the mujaheddin killed 14 February nine Kabul regime troops and injured four others in Iskalaib, of Imam Saheb, Kunduz. The Kabul forces later bombed the area causing losses in men and material (VOAPS).

* The mujaheddin reported, in a battle 8 February against the Soviet-Kabul troops in Imam Saheb, Kunduz, they killed six Kabul troops and injured two others (VOAPS).

17 The Afghan Information Center in Peshawar reports the mujaheddin attacked 27 February Imam Saheb sub-division, Kunduz, killing 17 militiamen while two others surrendered to the mujaheddin

(VOADS).

\section{Laghman, January}

Afghan mujaheddin sources report that they shot down recently two Soviet helicopters north east of Iaghman killing their pilots and 9 Soviet troops (RPDS).

\section{February}

7 The AMPC reports that the mujaheddin attacked 20 January, Qarghayee, Laghman, killing 18 Soviet troops and setting a building ablaze (VOAPS).

\section{Logar, January}

6 The mujaheddin sources say they have blocked Kabul-Gardez Highway on various points from Mohammad Agha to Pul-e-Alam in Logar and Gardez paralyzing Soviet-Kabul troops' movement. The attacks are taking place to reduce Soviet-Kabul troops pressure from Khost front (RPDS).

9 The Hezb-e-Islami Chief Gulbuddin Hekmatyar says fighting still continues in Khost and the mujaheddin have been attacking communist convoys in Iogar. Attacks also continue on the Khost airport. He said, "I have personally witnessed the mujaheddin attacks on the convoys in Logar" (VOAPS).

\section{February}

17 The AMRC says Sovilet troops killed 4 February all passengers riding a bus between Kabul and Charkh, Logar. The number of those killed has not been mentioned in the report. But it is said that they included chiliron and elderlies (VOAPS).

\section{Nangarhar, January}

The mujaheddin sources report they attacked 31 December the Jalalabad airport and a Soviet base In Samarkhail, Nangarhar, destroying three helicopters, and two tanks and killing 9 Kabul troops at the airport. In Samarkhail, 13 Kabul troops were killed or injured (VOADS). 3 Mujaheddin sources reported they have captured two security posts in Nazian Nangarhar, and Jaji, Paktia, and two Soviet helicopters have been shot down in Nangarhar province (RPDS).

* As a result of a bomb explosion near Jalalabad airport 1 January, five Soviet troops were reported killed. The airport also remained closed for three hours (RPDS).

6 A source of Hekmatyar's Hezb-e-Islami says the mujaheddin, commanded by Abdul Hadi, shot down a 
helicopter in Sorkhroad, Nangarhar (VOAPS).

21 Mujaheddin sources say two Soviet helicopters were destroyed 18 January in Jalalabad airport killing eight Soviet and four Kabul troops (VOADS).

22 In a powerful car bomb blast 22 January a few meters from the venue where the legendary Afghan leader Khan Abdul Ghaffar Khan was being laid to rest in Jalalabad at least six persons were killed and several injured (BBCFS).

23 Afghan anti-revolutionaries carried out 22 January two bomb explosions in Jalalabad during the funeral rites of the prominent Indo-Pakistan personality Khan Abdul Ghaffar Khan. Twelve persons were killed in the blasts. Reuter reported the explosives were placed in the vehicles accompanying mourners from Pakistan (RMDS).

24. The Afghanistan resistance sources report that in their recent operations the mujaheddin captured 12 posts in Nazian and Sarobi of Shinwar (RPDS).

26 The ANS reports that the mujaheddin destroyed 21 and 22 January 12 Kabul militia posts in the outskirts of Nazian, Nangarhar, killing 30 militiamen (VOAPS).

31 The Afghanistan resistance sources say Soviet commandos killed 26 January four mujaheddin and arrested two others in Rodat, Nangarhar (VOAPS).

\section{February}

The AMPC reports, having killed their three communist officers 23 January, the 52 Kabul troops with their arms joined the muiaheddin in Shinwar, Nangarhar (VOAPS).

4 A source of the Nangarhar mujaheddin has said, under the command of Engineer Mahmood, the mujaheddin attacked 29 January communist posts in. Chaparhar and 11 troops were killed only in on post (VOAPS).

6 An arms convoy of the extrenists, on way to Khogiani, Nangarhar, meant for disturbing the peaceful life of the people of that sub division was captured recently by the security forces (RA). 7 ANS reports that six civilians were killed 25 and 26 January in Rodat, Nangarhar, as a result of the explosion of mines planted by the Kabul regime (VOAPS).

11 A mujaheddin source has reported the mujaheddin attacked a Kabul regime convoy moving from Jalalabad to Cheghasarai destroying a truck carrying foodstuff and killing four Kabul troops (VOADS). 13 The mujaheddin sources claim the mujaheddin attacked 6 February communist posts in Tore Ghaar, Nangarhar, killing or injuring more than 30 communist troops. Three soldiers with their arms joined the mujaheddin while four mujaheddin were killed and 20 others injured in the operations

$1 \operatorname{lat}_{1}$ A source of the Af tary convoy of the Communist troops in Shinwar, Nangarhar, destroying four tanks and killing 14 Kabul troops (VOADS).

* The mujaheddin sources report from Nangarhar that the mujaheddin attacked 14 January the Qalae-Surkh posts in Khogiani killing three Kabul troops and injuring seven others (VOADS).

* Afghan mujaheddin report that they fired recently 25 rockets on Jalalabad city, Nangarhar, and also hit tine Kabul regime posts in Durooneta killing $15 \mathrm{Kabul} \mathrm{troops} \mathrm{and} \mathrm{injuring} \mathrm{three} \mathrm{others}$

* The Afghanistan resistance sources in Peghawar (VOADS). porary porary base of the Kabul communist regime in Chaparhar, Nangarhar (VOADS). 
* The mujaheddin sources report more than 100 communist tanks and trucks left 11 February Jalalabad for military operation in Deh Bala, Nangarhar, where they faced mujaheddin attacks in Deewar. Thirty mujaheddin have been injured in the fighting, but details of Kabul regime losses are not available (VOADS).

* Mujaheddin sources claimed, in their attacks 4 February in Chaparhar, Nangarhar, the mujaheddin killed at least 12 troops or militia and injured 15 others (VOADS).

15 The Far Eastern Economic Review in a Moscow report says the Russians are sure that Dr. Najibullah would not be able to continue his rule as he is not supported by the masses (JG).

* Quoting the mujaheddin sources, the AMRC reports a time bomb blew off 12 February in Hazar Nau, Shinwar of Nangarhar killing a KHAD officer (PT)。

20

The mujaheddin sources say in a mujaheddin rocket fire recently on a security post in Achin, Nangarhar, four communist troops were killed (RPDS).

27 Mujaheddin sources say they attacked 23 - 25 February communists centers in Shinwar, Nangarhar, killing five Kabul troops and injuring a number of others. Another eight of them joined the mujaheddin with their arms and ammunition (VOAPS).

* Afghan mujaheddin sources report a Kabul aircraft bombarded 25 February mujaheddin positions in Acheen and Nazian, Nangarhar, killing two and injuring a number of others. Meanwhile the Kabul regime bombers inadvertently bombarded 25 February government posts in Nazian killing a number of militiamen (VOAPS).

\section{March}

$11^{\text {nat }}$

The Afghan Information Genter reports, in a mujaheddin attack 1 March on a number of Kabul regime posts in Shinwar, Nangarhar, 14 militiamen were killed and 10 injured. Six of them with their arms joined the mujaheddin (VOADS).

13 The IUAM sources report the mujaheddin attacked a Kabul regime post in Roadat, Nangarhar, killing $1_{4}$ and injuring four others (VOAPS).

* The ANS reports the mujaheddin rocketted 7 March a Kabul regime military base in Ghanikhel of Shinwar, Nangarhar, kllling 11 government troops and injuring six others. The mujaheddin also killed 10 militiamen and four officers while nine others were seriously injured (VOAPS)。 17 The mujaheddin sources say they attacked $10 \mathrm{March}$ the office of Nangarhar Canal in Jalalabad killing two militiamen and injuring two others (VOADS).

17 The Afghanistan resistance sources say the mujaheddin attacked 5 March the Kabul. regime posts in Dehbala, Nangarhar, killing five Kabul militiamen and an officer (VOADS).

25 Quoting an eye witness, the Afghan Information Center says a battle was fought 25 March between cormunist troops and the mujaheddin near Torkham, Nangarhar, killing five bus passengers and injuring four others (VOAPS).

* The Hezb-e-Islami office reports the mujaheddin attacked 19 March a Kabul regime post near Dakka, Nangarhar, k-1lling 10 troops and destroying the post (VOAPS). 26 Mujaheddin sources report they blocked $24-25$ March the Jalalabad-Torkham highway. The same day they killed 13 Kabul troops in Girdi Ghaous, Nangarhar, and captured a post in Basol of that province (VOAPS).

* Resistance sources report the mujaheddin fired 25 March four rockets on the Jalalabad airport 
but details of losses are not known. Two Kabul regime troops. were shot dead while they were attempting to defect (VOAPS).

27 The Afghanistan resistance say the mujaheddin captured $25 \mathrm{March}$ a communist military post in Gerd-o-Ghaus, Nangarhar, and seized five items of arms. The mujaheddin also killed 13 communist troops and injured three others in that area (VOADS).

30 According to Teheran Radio, Afghan mujaheddin closed the Kabul-Jalalabad highway during a two day operation along this route (RPDS).

\section{NFingoz, February}

17 The Jamiat-e-Islami commanders report from Nimroz the mujaheddin attacked a post in Charburjak capturing three trucks and seven government militiamen and seized 13 item of arms (VOAPS).

\section{March}

24. A source of the Jamiat-e-Islami reports communists raided in February mujaheddin positions in Reg-e-Mor., of Kang sub-division in Nimroz. In the attack, the communists captured 22 mujaheddin and killed several others. Due to stiff resistance by the mujaheddin, a communist tank and a truck were destroyed and about 19 troops and militiamen were killed (VOAPS).

28 The Nimroz mujaheddin report that they attacked 3 March a post in Kang, destroying an armored personnel carrier and a truck and three troops joined the mujaheddin (VOADS).

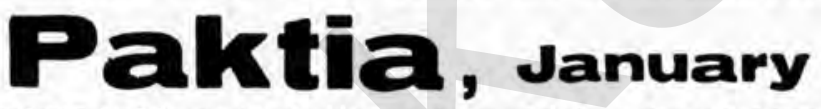

Some mujaheddin commanders believe that the convoy which entered 31 December in Khost was a unit which had come out of Khost recently with the hope to join the reinforcements from Gardez (VOAPS).

* The IUAM President Mawlawi Mohammad Yunus Khales has said in Peshawar Soviet claim that communist forces have reached Khost is totally baseless. But it might be possible for their troops to reach that city. However, he said, the battle for Khost cannot be considered as a yard-stick for the war in the entire country. We will fight the enemy in every corner of Afghanistan, he said (VOAPS)

* The office of Jalaluddin Haqqani reports from Peshawar that the siege around Khost has so far not been broken and fighting still continues in the Mirajan Shops area (VOAPS)。

* Claims about the opening of Gardez-Khost highway by Soviet-Kabul troops were denied by mujaheddin commanders in the battle fronts of Khost. They informed Peshawar througn ANS that the enemy's units have been contained (MIM).

* Quoting an Afghan General Emaduddin, TASS has reported that during the opening of a mountain route in Paktia province, 100 Afghan troops were killed while the guerrilkhas 'suffered 2,000 asuaIties (BBCFS)。

* The BBC correspondent reports from Islamabad the arrival of military convoy in Gardez indicates that battle for Khost has not ended (BBCFS).

* The mujaheddin of the Mahaz-e-Melli-e-Afghanistan claim they captured the Jodi height, Paktia, post from government forces after a four hour battle 29 December. In the combat, 17 government militiamen were killed and three captured (VOADS).

* Following the opening of Gardez-Khost highway, a third convoy carrying 398 tons of food-atuff and other items in 229 vehicles, arrived 1 January Khost (RA).

* The mujaheddin sources in Peshawar say a Soviet-Kabul unit entered 31 December the besieged 
city of Khost and was warmly welcomed by people in the cantonment (VOAPS).

2 A delegation of Kherson province of Ukrain of the USSR, which visited Nimroz province of Afghanistan, for the establishment of friendly relations and direct cooperation, between the two provinces has returned to the Soviet Union (RMDS).

* To follow up the supply of relief goods, including foodstuff and consumer goods for Khost, the fourth convoy of 228 transport vehicles carrying 1,282 tons of essential goods arrived 2 January in Khost (RA).

* In a series of operations for dismantling bases of extremist groups in Zadran, another arm depot was discovered and evacuated 2 January, (RA).

* Bakhtar says interrogation of the West German citizen "Usman" by the concerned quarters continues and he has confessed that he was teaching the use of Stinger rockets to the anti-revolutionaries first in Pakistan and then in Afghanistan and he had personally shot down two Afghan planes (RA).

* The Afghan mujaheddin say they have repulsed a fresh Soviet-Kabul troops offensive in Khost killing 40 troops, destroying three enemy tanks and a helicopter (RPDS).

* Quoting an Afghan mujaheddin spokesman, Teheran Radio has said that 40 helicopters and jet aircraft of the Soviet-Kabul forces have been shot down and 700 Soviet-Kabul troops killed in the battles for Khost during the last several davs (RPDS).

* Mujaheddin leaders and western diplomats say fighting still continues in the outskirts of Khost (VOADS).

* A Western journalist, who has just returned from south-east of Afghanistan, has confirmed Soviet and Afghan government's report that the guerilla blockade of the garrison town of Khost has been broken. The journalist, who visited the battle front, said although the convoys got through, they were considerably small as compared to the claims of the Kabul government (DN).

According to the Afghan guerrillas and fresh reports from Khost, the mujaheddin commander in Khost.Mawlawi Jalaluddin Haqqani has been injured (BBCFS).

* A western correspondent has said another 5,000 mujaheddin, belonging to the Sayyed Ahmad Gailani group, have been sent to Khost to stop Soviet-Kabul troops construct security posts on Gardez-Khost highway (BBCFS).

* Mujaheddin sources have said fierce fighting is going on in Khost area and the city is still under the mujaheddin siege (RPDS).

* According to a Teheran Radio repart, the Afghan mujaheddin have repulsed a fresh Soviet-Kabul attack in Khost destroying three tanks and a helicopter and killing 40 troops (MIM).

4 The sixth convoy of 194 transport vehicles, carrying 1,355 tons of foodstuff and other essential commodities, arrived 4 January in Khost (RA).

* Afghan resistance sources say the mujaheddin shot down 3 January a communist helicopter in Bari, Paktia. All the persons aboard were killed (VOAPS).

* The Afghan resistance sources report that, in a combat 29 December between the mujaheddin and Soviet-Kabul troops, Jaji,Paktia, the mujaheddin captured three communist posts and a base killing 21 Kabul troops and injuring a number of others (VOAPS).

* Tehran Radio reported that fierce fighting between the mujaheddin and Soviet-Kabul troops continues in the Khost outskirts (PT).

* The BBC reported 3 January the mujaheddin and Soviet-Kabul troops are giving contradictory re- 
ports about the siege of Khost but one Western journalist, who claims to be a witness to the recent battle, has said the siege has been partly broken but fierce fighting still continues (MLM). 5 Mujaheddin sources say they repulsed all Soviet-Kabul attacks and foiled their attempts for breaking through the Khost siege and the Soviet-Kabul troops have been forced to retreate from Mirajan Pass on the Gardez-Khost highway. In the fresh combats, LO Soviet-Kabul troops have been killed and three tanks destroyed (RPDS).

* The Afghanistan resistance leaders in Pakistan said the fierce fighting between the mujaheddin and the Soviet-Kabul troops for the last two months in Khost has ended and the mujaheddin have retreated from Khost (VOADS).

* Leader of the Afghan mujaheddin Mohammad Yunus Khales has said he does not describe retreat from Khost as a defeat. He sair Soviet troops have not been able to defeat the Afghans for the last eight years (VOADS).

* Reports reaching ANS from Afghanistan say the mujaheddin have shot down three Soviet aircraft during the last three days in Sharnai, Baray and Jaji, Paktia (VOAPS).

* The Afghan Publicity Center in Peshawar says after 49 days of fighting between the mujaheddin and the Soviet-Kabul troops in Satto Kando between Gardez and Khost, a Soviet-Kabul convoy of some lorries entered 3 January in Khost. The source adds that, in the battle, hundreds of Soviet-Kabul troops were killed and a large number injured, 12 jet aircraft and helicopters were also shot down and 200 armed troops were captured while 60 mujaheddin were martyred' (VOAPS).

* Nineteen Afghan troops, fighting in Khost, have defected to Pakistan and surrendered to the Government officials in Chaman. The commander of these troops says dozens of helicopters are transporting dead bodies to Kabul and the authorities have rumout of coffins (JG).

* Quoting its cameraman Inayat Hussain Shah who has retumed after two weeks stey in Iogar province, Agency Afghan Press reported that the mujaheddin have begun operation against the SovietKabul troops between Kabul and Gardez in order to divert the pressure of Soviet-Kabul troops from Khost (JG).

6 The mujaheddin sources say they have blocked Kabul-Gardez Highway on various points from Mohammad Agha to Pul-e-Alam in Logar and Gardez paralyzing Soviet-Kabul troops' movement. The attacks are taking place to reduce Soviet-Kabul troops pressure from Khost front (RPDS).

9 The Afghan resistance sources have said they are continuing their activities against the Soviet-Kabul troops in Khost and fighting has also broken out in Dayo Mando. Radio Australia has also confirned that battle in the outskirts of that city still continues (RPDS).

* Quoting reports confirmed by the independent sources, the VOA correspondent reports that the mujaheddin captured 7 January a big Soviet trench on the Gardez-Khost highway. In the fighting 10 Soviet troops were killed and a large number of others injured (VOAPS).

* The Hezb-e-Islami Chief Gulbuddin Hekmatyar says fighting still contimues in Khost and the muJaheddin have been attacking communist convoys in Logar. Attacks also continue on the Khost airport. He said, "I have personally witnessed the mujaheddin attacks on the convoys in Logar" (VOAPS). Afghan mujaheddin sources said 5 January that a big mujaheddin force occupied 1 January 16 Soviet-Kabul posts near Gardez, Paktia, after a fierce fighting (VOADS).

* The mujaheddin sources report that the mujaheddin carried out heavy shelling 30 December on Gundigan base in Khost pass where the Soviet troops are deployed. The mujaheddin destroyed two 
armored personnel carriers killing or injuring 12 Soviet troops. But in the attack of 31 December on the post of Baba Ghazi height a godown of arms and ammunition was set on fire and eight soviet troops were killed or injured (VOADS).

* The mujaheddin sources report that the mujaheddin shot down a Soviet reconnaissance plane, north of Khost (VOAPS).

* The Afghan mujaheddin sources say that in a mujaheddin attack on a post in Khalbosat, north of Khost, 30 communist troops and six militiamen were captured (VOAPS) .

11 The Afghan mujaheddin claim to have captured an important government post in Pak, northern Khost, Paktia (RPDS).

* The Afghan Publicity Center says the mujaheddin have captured 11 January 9 tanks and other transport vehicles from the Soviet-Kabul troops in Paktia (VOAPS).

* A commander of Mawlawi Jalaluddin Haqqani reports that the mujaheddin destroyed 11 January two tanks of the Kabul regime in Tani, Paktia (VOAPS).

12 According to an Afghan mujaheddin report, a number of security posts of the Kabul regime between Khost and Jaji Maidan fell to the mujaheddin early this week. The mujaheddin claim to have killed 15 troops and militiamen and captured 40 others (BBCFS).

* The mujaheddin claim to have shot down 11 January a plane while taking off from the Khost airport (BBCFS).

* A spokesman of Hekmatyar's Hezb-e-Islami has said a number of newly established government posts near Satto Kando were captured 8 January by the mujaheddin in a joint operation with Gailani and Jalaluddin Haqqani mujaheddin (BBCFS).

* The Afghanistan resistance say the mujaheddin have captured 10 January a big Kabul military base with the security posts surrounding it near the border with Pakistan (VOADS).

13 According to a Teheran Radio report, the Paktia mujaheddin have shot down two fighter planes of the Kabul regime in Charozi and Zadran while they were bombing the mujaheddin positions (PT). 14 Teheran Radio has reported that in a fierce combat between the mujaheddin and the Soviet-Kabul troops in the outskirts of Khost, the mujaheddin succeeded in blocking the Soviet-Kabul supply route to that city (RPDS).

* According to VOA, fierce fighting is going on between the mujaheddin and Soviet-Kabul troops on the road leading to Barikote. The radio said similar fighting is continuing in Khost (JG).

* A Hezb-o-Islaml source says eleven Kabul regime and three Soviet pilots were captured after their planes were shot down near the Khost cantorment (VOAPS).

16 According to a VOIRA report, the mujaheddin shot down two Kabul aircraft in Khost where fierce fighting continues (MIM).

* The Afghan mujaheddin say about 1,000 Soviet-Kabul troops were killed in a week long battle between the mujaheddin and the Soviet-Kabul troops around the Khost cantonment (RPDS).

17 A big convoy of the 150 transport vehicles carrying 1,210 tons of foodstuff and essential goods arrived 17 January in Khost (RA).

18 Sovlet military spokesman has said in Kabul that in recent battles in Khost, the Soviet fought a unit of 200 aggressors who were not usual rebels but a group of hirelings or Pakistani militiamen whose main objective was to cut Gardez-Khost highway but their attempts were foiled (RMDS). 
* According to Teheran Radio, the mujaheddin hit the Soviet-Kabul troops positions in Kabul killing or injuring a number of them. The radio added a general of the Kabul regime was also killed in Paktia (RPDS).

2 Seventeenth convoy of goods have arrived in Khost but the situation in the area is still serious and losses in men and material continue (RMDS).

* Teheran Radio has reported that, in a mujaheddin ambush on Gardez-Khost highway, 50 Soviet-Kabul troops were killed or injured and a fighter plane was shot down (RPDS).

21 The mujaheddin commander in Paktia, Mawlawi Jalaluddin Haqqani reported his mujaheddin attacked 20 January a Kabul government convoy between Gardez and Khost destroying eight transport vehicles and halting traffic (VOADS).

24 The Afghanistan resistance forces say they have again gained control over the strategic positions in the outskirts of Khost cantonment and have reoccupied some parts of the Gardez-Khost highway (VOADS).

26 Afghan guerrilla sources say they have once again gained control of the Gardez-Khost strategic highway in Paktia. Following 'a fierce battle last week the Soviet-Kabul troops have retreated from Zadran pass, north west of Khost (BBCFS).

* The ANS reports that the mujaheddin captured 24 January two Kabul regime posts in Ali Sher, Khost. The source adds that the mujaheddin attacked four days ago the Kabul regime posts in Nadir Shah Kot killing 35 Soviet-Kabul troops (VOAPS).

27 The Kabul press has reported, due to complaints launched by the people that their areas have been converted into battlefields, government troops have been withdrawn from two localities on the Gardez-Khost highway. The announcement coincides with a mujaheddin claim that they have reoccupied this week a portion of the highway (VOADS).

31 According to ANS, prior to the retreat of the Soviet troops from Gardez-Khost highway, all the houses in Zadran pass were looted and the Soviet aircraft bombed the area destroying a large number of houses (VOAPS).

2 Western diplomats in Pakistan reported that the Afghan mujaheddin have again gained control over a major portion of Gardez-Khost highway (VOADS).

* WOA reported that the mujaheddin have inflicted heavy losses of life on Soviet troops in their recent operations in Southern Afghanistan (PT).

3 The mujaheddin in Miranshah, Pakistan, say they blew up 29 January five tanks with mines in Zinikhel, Paktia, and the Khost mujaheddin captured recently the 15 camels on which the Kabul regime was transporting arms to the Wazirs. The entire shipment were captured by the mujaheddin'(VOAPS). 4 Teheran Radio reported the mujaheddin shot down recently a Soviet aircraft in Zadran, Paktia, and destroyed seven trucks alongwith their men on board (RPDS).

* A spokesman for the Hezb-e-Islami (Khales), Mawlawi Mohammad Yaqub Sharafat said in the two months long fierce battle of Khost, Paktia, 750 troops were killed, the majority of them being Soviet soldiers, 1,500 Kabul troops were injured and 111 others captured, while 15 military planes, including four transport planes, were shot down, 30 tanks, 10 armored personnel carriers and 70 trucks and oil tankers were blown up. During these battles the chief of the Kabul government operational staff General Imamuddin and Brigadier General Arif Kandahari were also killed (NWT). * The Islamic Alliance (Sayyaf) in Peshawar said the mujaheddin shot down 2 February a jet air- 
craft near the Khost airport. Similarly, ANS says the mujaheddin shot down a Kabul regime transport plane carrying 15 military officers (VOAPS)。

* The NLF office reports the mujaheddin destroyed 18 January five Kabul regime posts in Kharot, Paktia. Details of the losses could not be known. Four mujaheddin sustained injuries in the operation (VOAPS).

13 The AMRC reported the mujaheddin' have shot down a Soviet plane in Jaji Maidan, Paktia, and destroyed a transport plane in the Khost airport (VOAPS),

* The AMRC reports that the mujaheddin attacked 24.4 January a communist posts in Torabi, Paktia, eliminating a post and killing more than 20 Soviet-Kabul troops and officers. Ten mujaheddin were killed and five others injured in the battle (VOAPS).

24 Quoting the Afghan mujaheddin, The Times (London) reports Soviet troops shot dead two guer-: rillas in Dehkada, Paktia and confined a number of others in a mosque and subsequently blasted the mosque killing all the guerrillas except two. Seven children in a house, adjacent to the mosque, were also killed (BBCFS).

17 A source of commander Jalaluddin Haqqani in Paktia said the mujaheddin have shot down a Soviet transport plane east of Khost, Paktia (VOAPS).

20 The AIA reports the mujaheddin have recently captured a Kabul regime military base 10 kilometers from Khost, Paktia. Scores of communist troops were killed and 50 others were captured by the mujaheddin in the operation (VOADS).

23. The extremist groups carried out recently mortar gun fires on residential buildings in Herat city seriously injuring 13 compatriots and destroying 18 houses (RA).

* Anti-vehicle mines planted by the extremist elements on the Gardez road, Paktia, have been dofused by the security forces (RA).

25 A source of Harkat-e-Enqelab-e-Islami Afghanistan says the Gardez mujaheddin in Paktia rocketted 16 March Khost and its airport killing 60 communist troops (VOAPS)。

* The Afghanistan resistance sources report the mujaheddin attacked 19 March the Darwazagi and Baghi Khan posts in Paktia, killing 50 Kabul troops and destroying three posts (VOAPS).

* The Hezb-e-Islami office reports the mujaheddin attacked 18 March two militia posts in Jaji Maidan, Paktia. Twenty militiamen with their arms joined the mujaheddin (VOAPS).

* A source of Hezb-e-Islami reports the mujaheddin attacked 20 March a Kabul regime Radar post near Urgun, Paktika, killing 10 Kabul troops (VOAPS).

27 The mujaheddin in Peshawar, say they rocketted Darwazagai, Paktia, 30 Kilometers from Pakistan border, destroying six mortarland heavy guns and killing all the troops deployed in the area 31 Radio Teheran says that, after capturing the Kabul Soviet military post in Khost, Paktia, the mujaheddin are now in control of the vast portions of the Paktia province (RPDS).

\section{Paktika, January}

The Afghanistan resistance sources say, in an attack, the mujaheddin destroyed 13 Kabul regime posts in Sharan, Paktia, and 300 troops joined the mujaheddin (VOAPS). 21 The Afghan mujaheddin claim to have closed down the Urgun,Paktika, airport for several weeks 
and shot down a jet fighter in the area (VOADS).

\section{February}

3 According to a mujaheddin report, they attacked Ahmad Shah Khan in Urgun, Paktia, killing an officer. Four soldier joined with their arms the mujaheddin (VOAPS).

16

The AIA reports the mujaheddin commanders have said they discovered a few days ago a Kabul regime plan suggesting the installation of big militia force in Paktika. After the discovery of the plan the mujaheddin have captured 72 militiamen in a campaign to frustrate the plan (VOAPS).

\section{Parwan, January}

A spokesman of the Jamiat-e-Islami Afghanistan says the mujaheddin attacked 17 December a number of communist centers, including two Soviet posts west of Panjshir. The mujaheddin attacked the base situated in Shaba area. The base and seven other posts were captured only within 25 minutes. In the fighting, 24 Kabul troops were killed and 113 captured (VOAPS).

* A spokesman of the Jamiat-e-Islami said the mujaheddin captured 17 December five security posts near Panjshir and in the fighting 16 Kabul troops were killed and 26 others captured (VOAPS)。 6 News sources say the US Under Secretary of State Michael Armacost has held formal talks with the Afghan leaders in Pakistan and has once again assured them about the continued US assistance. He told them the US would not make any deal in the absence of the mujaheddin leaders (VOAPS).

* A source of the Hezb-e-Islami (Khales) says the commanders who had surrendered with their 80 persons three months ago to the Kabul regime in Jabal-us-Seraj, Parwan, were killed 27 December by the mujaheddin (VOAPS).

8 Teheran Radio says two Soviet planes were shot down recently in Charikar, while they were bombing the mujaheddin positions (RPDS).

* According to Afghan mujaheddin, they shot down a transport plane while it was landing in Bagram airport killing 25 persons aboard (RPDS).

9 The mujaheddin sources in Peshawar say the mujaheddin attacked 6 January the Soviet-Kabul posts in Panjshir and destroyed a big military base in Onaba killing 41 troops and capturing 145 others

(VOAPS).

14 The Afghan mujaheddin say the mujaheddin shot down four planes last week near Bagram airport... They say 10 Soviet troops aboard aircraft were also killed (VOAPS).

18 According! to a mujaheddin claim a military base of Kabul regime was destroyed recently in Chari. kar, Parwan, killing four Soviet-Kabul troops (RPDS).

29 Jamiat-e-Islami Afghanistan reported that the Sovlets constructed 4 Jamuary two new posts near Panjshir. Iater these posts were destroyed by the mujaheddin. In the operation, the freedom fighters also captured eight Kabul regime troops (VOADS).

* A source of the Jamiat-a-Islami has reported that a Soviet soldier was killed 25 December when he was busy supplying a military post in Panjshir. A Soviet tank with all persons aboard was also destroyed (VOADS).

\section{February}

2 The Afghan mujaheddin have reported they shot down recently a Soviet transport plane while $1 t$ was landing at the Bagram airport (RPDS).

* The Hezb-O-Islami (Khales) has said the mujaheddin launched 29 January a major offensive on 
Bagram airport destroying two aircraft and eliminating seven troops and an arms depot (VOAPS).

7 Reports from Afghanistan say the mujaheddin captured recently Soviet-Kabul two posts in Charikar, Parwan (RPDS).

\section{March}

12 The Hezb-e-Islami (Hekmatyar) says the mujaheddin destroyed 21 February 10 tanks and trucks and killed four Soviet troops and injured three others in Parwan. The report says the mujaheddin attacked the Soviet base in Pusht-e-Toot, Parwan (VOAPS).

* The Hezb-e-Islami (Hekmatyar)says the mujaheddin damaged 25 February 12 Kabul government posts in Soofian and Noman villages, Parwan. The report says the mujaheddin also set ablaze the house of the Parwan party leader. Similarly the mujaheddin killed two militiamen on the Kabul-Parwan highway and captured their arms (VOAPS).

19 The office of Hezb-e-Islami (Heknatyar) says the mujaheddin have sieged Siahgard sub-division in Ghorband pass, Parwan, and four aircraft have so far been shot down in the area. Three tanks, four heavy guns and a number of government building have also been destroyed and 20 Kabul troops have joined the mujaheddin (VOADS).

21 The Afghan mujaheddin reported Soviet troops in Bagram airport attacked recently mujaheddin positions in Bagram killing two mujaheddin commanders - - Ahmadzai and Abdul Hadi and injuring 30 others (VOADS).

* The mujaheddin sources reported the mujaheddin attacked 11 March Soviet troops in Jabal-usSeraj destroying a military post, a tank and three trucks. Soviet casualties are yet not known

(VOADS).

\section{Tล}

16 The Afghan Publicity Center reports that the mujaheddin killed 30 communist troops and militiamen and destroyed seven lorries and tanks 26 December north of Takhar three kilometers from the Soviet border (VOAPS).

22 Mujaheddin sources say they attacked the center of Takhar province near the Soviet border kdling three Soviets and 9 Kabul regime troops and injuring a number of others (RPDS).

\section{February}

2 The Takhar mujaheddin report, in three days fierce fighting during January in Majnoon near Taluqan city, 11 Kabul troops were killed and 17 others injured while three mujaheddin were also killed (VOAPS).

* The Takhar mujaheddin say they attacked 6 February Kabul troops on the road to Koldar killing three militiamen and injuring four others and an officer was captured by the mujaheddin (VQAPS).

\section{March}

25 A source of Hezb-e-Islami reports the mujaheddin attacked 3 March the Kabul regime posts in Yungi Qala; Takhar, klliing 70 troops and downing a hellcopter (VOAPS)。

\section{Uruzgan, January}

13 The Harkat-e-Enqelab-e-Islami Quetta office has reported that the Sangin, Helmand, mujaheddin attacked 19 November communist bases in Dehraud,Uruzgan, inflicting heavy losses to 10 security posts and killing at least 10 Kabul militiamen and injuring a number of others (VOADS). 


\section{Zabul, February}

2 The office of Harkat-e-Enqelab-e-Islami in Quetta says a lorry, belonging to its mujaheddin hit 17 January a mine planted by the Soviets in Meezani, Zabul. The lorry was blown up and all the persons aboard, including commander Shahzada, were killed (VOAPS).

6 The office of Harkat-e-Enqelab-e-Islami in Quetta reports that the Meezan, Zabul, mujaheddin attacked 10 January the Omaki post near Qalat causing heavy losses to the post and killing four militiamen and injuring six others (VOAFS).

\section{March}

4 The mujaheddin sources say a truck, carrying mujaheddin, was attacked 28 February by the Soviet commandos in Bolan, Zabul, killing 10 mujaheddin and injuring 9 others. It is said that the Soviet failed to capture any arms from the mujaheddin (VOADS).

$26^{T h e}$ office of Harkat-e-Enqelab-e-Islami Afghanistan has reported the mujaheddin attacked 17 March with rockets the Baba Gul post inside Zabul city killing six Soviet troops and infuring a number of others (VOADS).

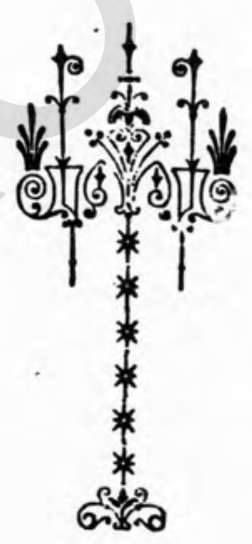




\begin{tabular}{|c|c|c|c|c|c|c|c|c|c|c|c|c|c|c|c|c|c|c|c|c|c|c|c|c|c|c|c|c|c|c|c|}
\hline & DETAIIS & & L & as & & & & & & & & & & & & 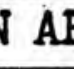 & & & & & & & & & & & & & & & \\
\hline $\begin{array}{l}0 \\
\sum_{0}^{1}\end{array}$ & & 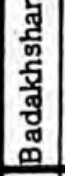 & 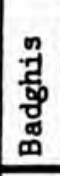 & 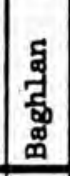 & 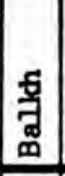 & 㽦 & 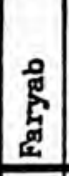 & $\begin{array}{l}\text { 鬼 } \\
\text { : } \\
\end{array}$ & స్ & $\begin{array}{l}5 \\
\text { 돓 } \\
\end{array}$ & 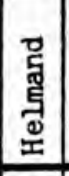 & $\begin{array}{l}\text { 苾 } \\
\text { 至 } \\
\end{array}$ & 超 & 㿣 & 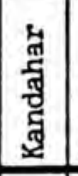 & 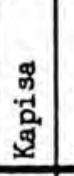 & 蛋 & 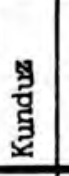 & 馬 & 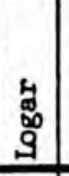 & 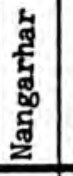 & 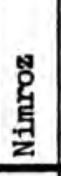 & 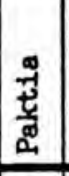 & \begin{tabular}{|l|} 
\\
苞 \\
है \\
\end{tabular} & 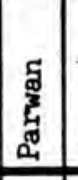 & 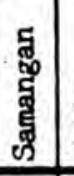 & 热 & $\begin{array}{l}\text { క } \\
\text { है } \\
\text { है } \\
5\end{array}$ & 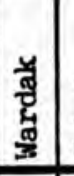 & 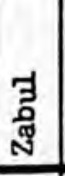 & 疍 \\
\hline 1 & Aircraft shot down & - & - & - & - & 1 & 2 & - & 4 & - & 9 & 10 & - & 11 & 11 & - & 1 & - & 4 & - & 8 & - & 27 & 6 & 6 & - & 1 & - & - & - & 101 \\
\hline 2 & $\begin{array}{l}\text { Tanks and Vehicles } \\
\text { destroyed }\end{array}$ & - & 53 & 15 & 9 & - & - & 25 & 12 & 1 & 142 & 127 & 7 & 28 & 136 & - & 2 & 6 & - & 1 & 32 & 14 & 82 & 45 & 16 & - & 8 & - & - & 12 & 773 \\
\hline 3 & $\begin{array}{l}\text { Securl ty posts captu- } \\
\text { red by the aujaheddin }\end{array}$ & - & 3 & 8 & 4 & - & 3 & 9 & 3 & 4 & 14 & 24 & - & 26 & 59 & - & $L$ & - & - & - & 22 & 1 & 42 & 13 & 22 & - & - & 1 & - & - & 268 \\
\hline 4 & Soviet troops killed & - & - & 3 & - & - & - & 16 & 115 & - & 10 & 205 & - & 22 & 171 & -2 & 203 & - & 18 & 5 & 69 & - & 150 & 83 & 11 & - & 3 & - & - & 6 & 1090 \\
\hline 5 & Soviet troops infured & - & - & - & - & - & - & 8 & - & - & 14 & 35 & - & 4 & 210 & - & - & - & - & - & 3 & - & - & - & - & - & - & - & - & - & 274 \\
\hline 6 & $\begin{array}{l}\text { Kabul troops and } \\
\text { aillitiaman bdlled }\end{array}$ & - & 55 & 212 & 30 & 2 & 60 & 83 & 59 & 12 & 174 & 346 & 11 & 31 & 877 & 200 & $547 \mid \varepsilon$ & 812 & - & 74 & 292 & 79 & 470 & 18 & 50 & -1 & 120 & 15 & - & 30 & 4659 \\
\hline 7 & $\begin{array}{l}\text { Kabul troops and nilli- } \\
\text { t1amen injured }\end{array}$ & - & 19 & - & 195 & 5 & - & 21 & 78 & - & 14 & 126 & - & -1 & 111 & - & - & 4 & - & - & 58 & - & 4 & - & - & - & 21 & - & - & 16 & 672 \\
\hline 3 & $\begin{array}{l}\text { Number of Kabul troops } \\
\text { jointing the mujaheddin } \\
\end{array}$ & - & 309 & - & 3 & - & - & 7 & 10 & -1 & 314 & 28 & - & - & 220 & - & - & 2 & - & - & 233 & - & 20 & 304 & 80 & - & 1 & - & - & 1 & 1532 \\
\hline 9 & $\begin{array}{l}\text { Well knom commists } \\
\text { killed }\end{array}$ & - & - & 2 & - & - & - & - & - & - & - & - & - & - & 14 & - & - & - & - & - & - & - & - & - & - & - & 1 & - & - & -1 & 17 \\
\hline 10 & $\begin{array}{l}\text { Anms captured by the } \\
\text { mujaheddin }\end{array}$ & - & - & - & 115 & - & - & 7 & - & 24 & 33 & 1462 & - & 27 & 281 & - & -2 & 21 & - & - & 23 & 13 & 97 & 32 & 122 & - & - & - & - & -1 & $225 ?$ \\
\hline 11 & Musaheddin artyred & - & 11 & 9 & 24 & 25 & - & 4 & 13 & 4 & 55 & 14 & - & 2 & 66 & - & 3 & 41 & - & 2 & 34 & - & 95 & 25 & 2 & - & 5 & - & - & 4 & 438 \\
\hline 12 & Musaheddin infured & - & 44 & 1 & 17 & 13 & - & 8 & 38 & - & 76 & 15 & - & 3 & 73 & 13 & 2 & 3 & - & 6 & 79 & - & 82 & 25 & 12 & - & - & - & - & - & 510 \\
\hline 13 & Civilians martyred & - & 48 & 33 & 12 & - & 30 & - & 34 & - & 337 & 8 & - & 17 & 27 & 3 & 5 & 22 & - & - & 19 & - & 20 & - & - & - & - & - & - & - & 615 \\
\hline 14 & Civilians infured & - & 73 & - & - & - & 3 & - & - & - & - & 1 & - & - & 9 & 3 & 2 & - & - & - & 7 & - & 45 & - & - & - & - & - & - & - & 143 \\
\hline 15 & Villages destroyed & - & 50 & - & - & - & - & 4 & 2 & - & 450 & - & - & - & 3 & - & 17 & - & - & - & - & - & - & - & - & - & - & - & - & 1 & 527 \\
\hline 16 & $\begin{array}{l}\text { Bases aidminated by } \\
\text { the cominnists }\end{array}$ & - & - & - & - & - & - & - & - & - & - & - & - & - & - & - & - & - & - & - & - & - & 108 & $=$ & - & - & - & - & - & - & 108 \\
\hline 17 & Arms captured & - & - & - & - & - & - & - & - & - & - & 50 & - & 22 & 7 & - & - & - & - & - & - & - & 390 & - & - & - & - & - & - & - & 469 \\
\hline 18 & Kabul regine captures & - & - & 228 & 43 & - & 287 & 34 & 6 & 14 & 11 & 54 & - & -1 & 159 & - & 3 & 4 & 9 & -1 & 55 & 3 & 370 & - & 153 & - & 1 & $\begin{array}{lll}- & - & -1\end{array}$ & -1 & 12 & 11446 \\
\hline
\end{tabular}




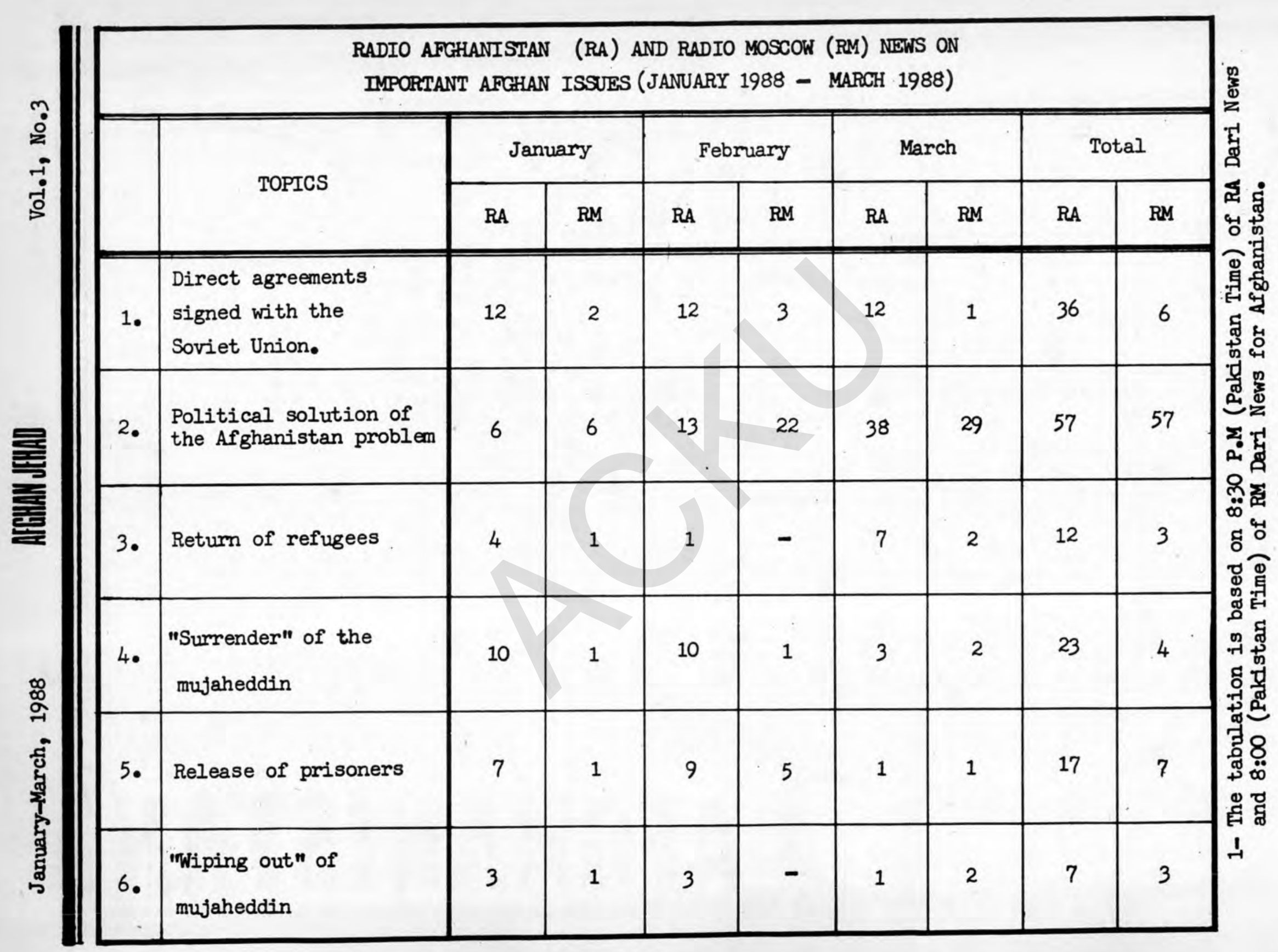

$\stackrel{m}{m}$ 


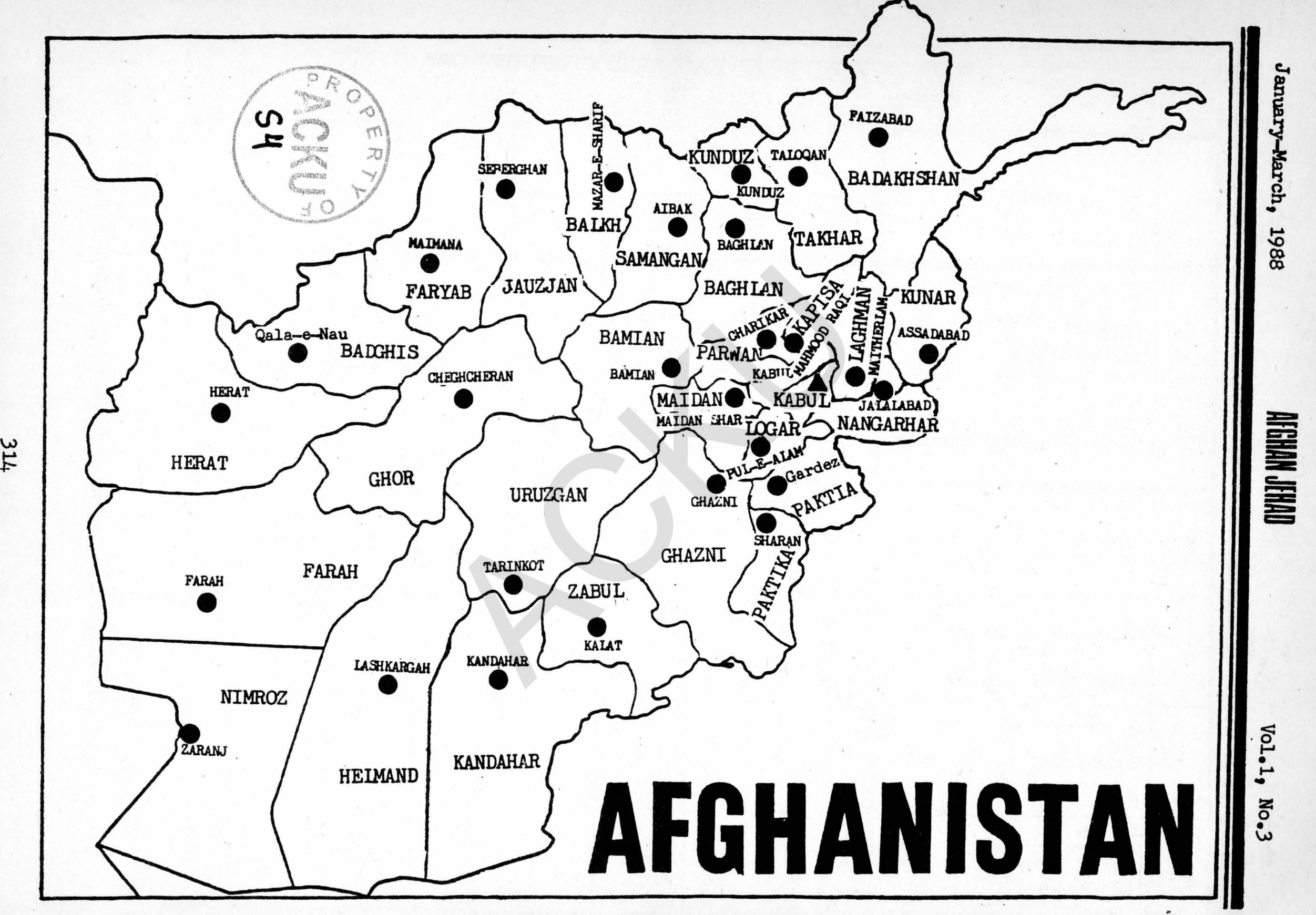




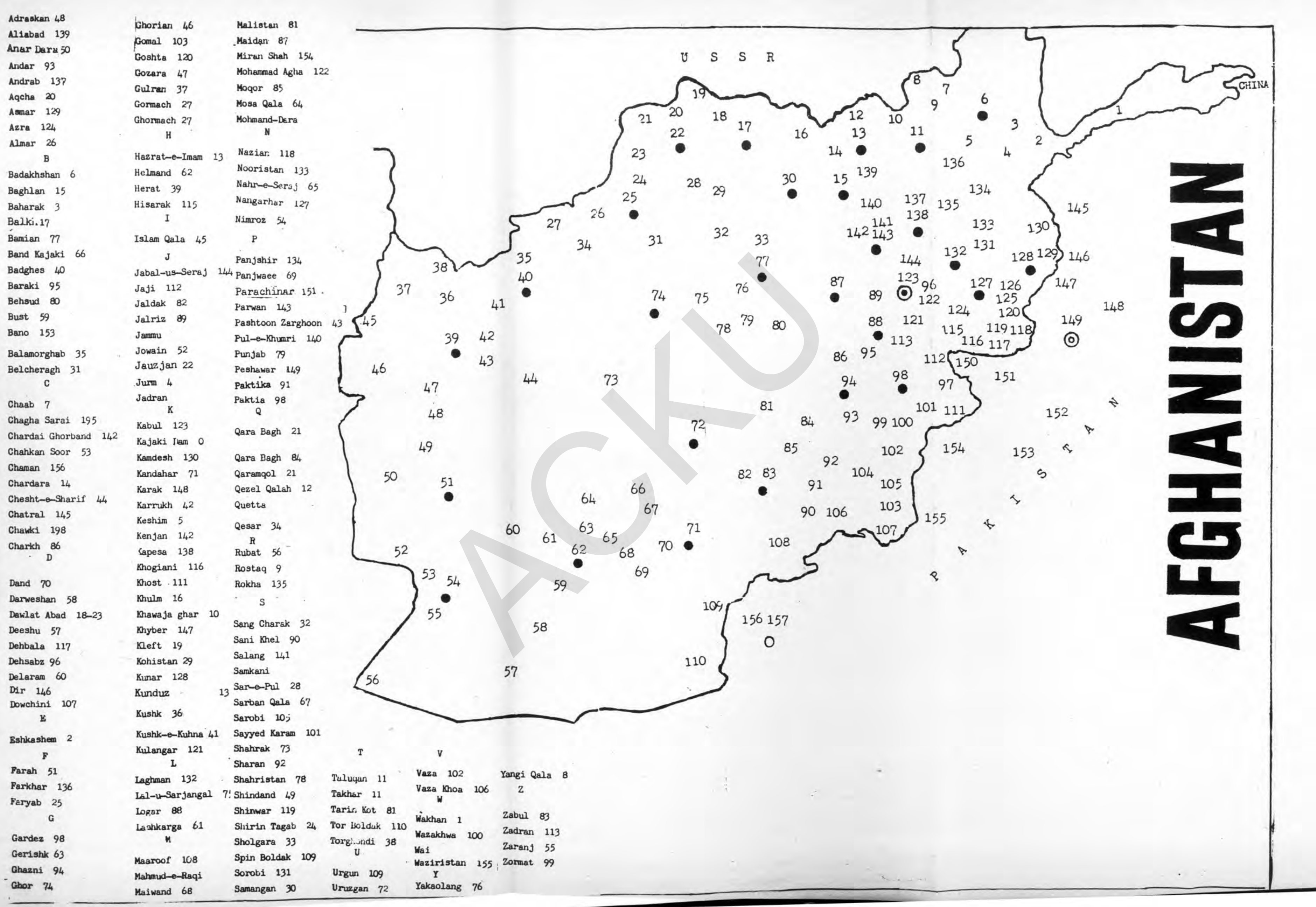




\section{ABBREVIATIONS}

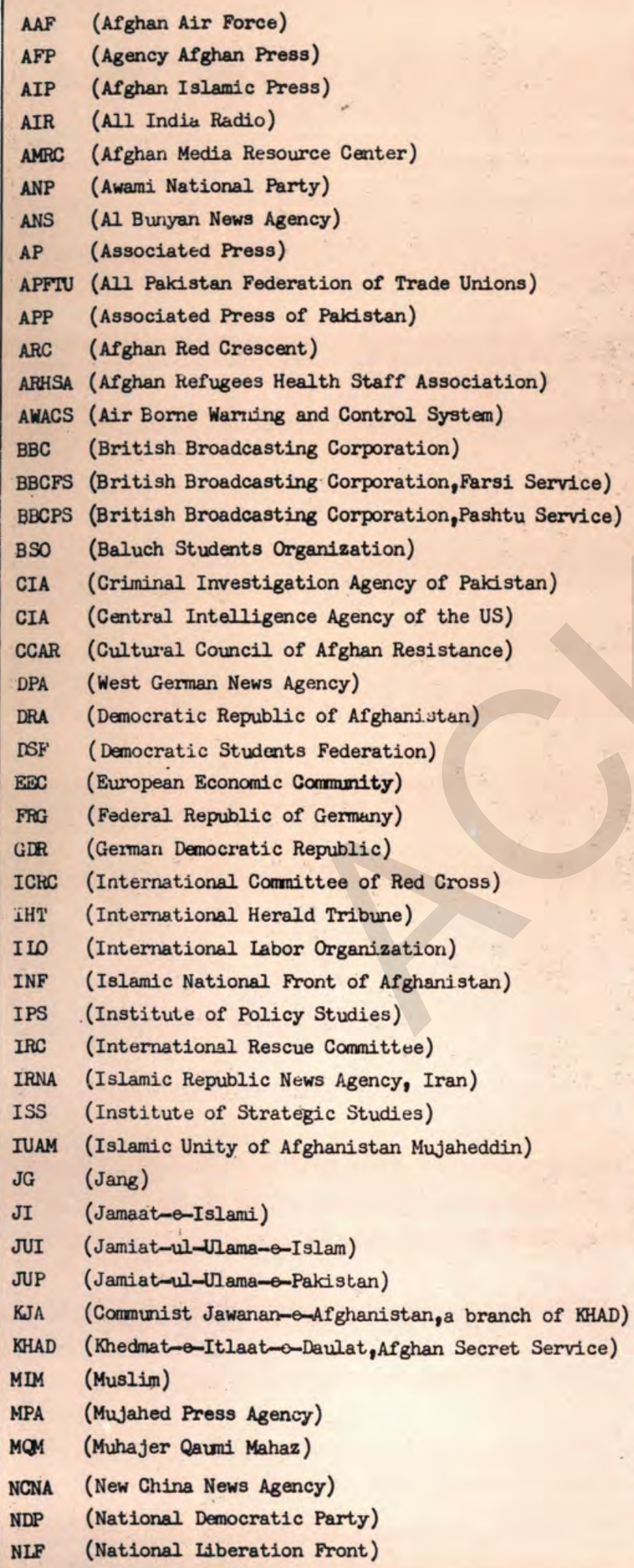

\begin{tabular}{|c|c|}
\hline NIF & (National Islamic Front) \\
\hline NPP & (National People's Party) \\
\hline NRP & (National Reconciliation Policy) \\
\hline NWFP & (North West Frontier Province) \\
\hline NY & (New York) \\
\hline NWT & (Nawa-i-Waqt) \\
\hline OIC & (Organization of Islamic Conference) \\
\hline PDP & (Pakistan Democratic Party) \\
\hline PDPA & (People's Democratic Party of Afghanistan) \\
\hline RMKP & (Pakistan Mazdoor Kissan Party) \\
\hline PML & (Pakistan Muslim League) \\
\hline PNA & (Pakdstan National Assembly). \\
\hline PL & (Palestine Iiberation Organization) \\
\hline PNP & (Pakistan National Party) \\
\hline PPI & (Pakdstan Press International) \\
\hline PPP & (Pakistan People's Party) \\
\hline PSP & (Pakistan Socialist Party) \\
\hline QMA & (Qaumi Mahaz-o-Azadi) \\
\hline RA & (Radio Afghanistan) \\
\hline RAWA & $\begin{array}{l}\text { (Revolutionary Association of Women of } \\
\text { Afghanistan) }\end{array}$ \\
\hline RMDS & (Radio Moscow, Dari Service) \\
\hline RPDS & (Radio Pakistan, Dari Service) \\
\hline SANMA & $\begin{array}{l}\text { (Sazman-e-Nejat-e-Mardum-e-Afghanistan, a branch } \\
\text { of KHAD) }\end{array}$ \\
\hline SAARC & $\begin{array}{l}\text { (South Asian Association of Regional } \\
\text { Cooperation) }\end{array}$ \\
\hline SOKHA & $\begin{array}{l}\text { (Sazman-e-Wahdat-e-Khalq-o-Afghanistan, a branch } \\
\text { of KHAD) }\end{array}$ \\
\hline TIP & (Tehrik-e-Estaqlal-e-Pakistan) \\
\hline TR & (Tehran Radio) \\
\hline UNESCO & $\begin{array}{l}\text { (United Nations Educational, Scientific and } \\
\text { Cultural Organization) }\end{array}$ \\
\hline UNCA & (United Nations Correspondents Association) \\
\hline UNHCR & (United Nations High Cormissioner for Refugees) \\
\hline UPI & (United Press International) \\
\hline USIA & (United Nations Information Agency) \\
\hline USSR & (Union of Soviet Socialist Republics) \\
\hline VOA : & (Voice of America) \\
\hline VOADS & (Voice of America, Dari Service) \\
\hline VOAPS & (Voice of America, Pashtu Service) \\
\hline VOGDS & (Voice of Germany, Dari Service) \\
\hline VOIRA & (Voice of Islamic Revolution of Afghanistan) \\
\hline WAFA & (Writers Association of Free Afghanistan) \\
\hline WFP & (World Food Program) \\
\hline
\end{tabular}


FROM NIF PUBLICATIONS
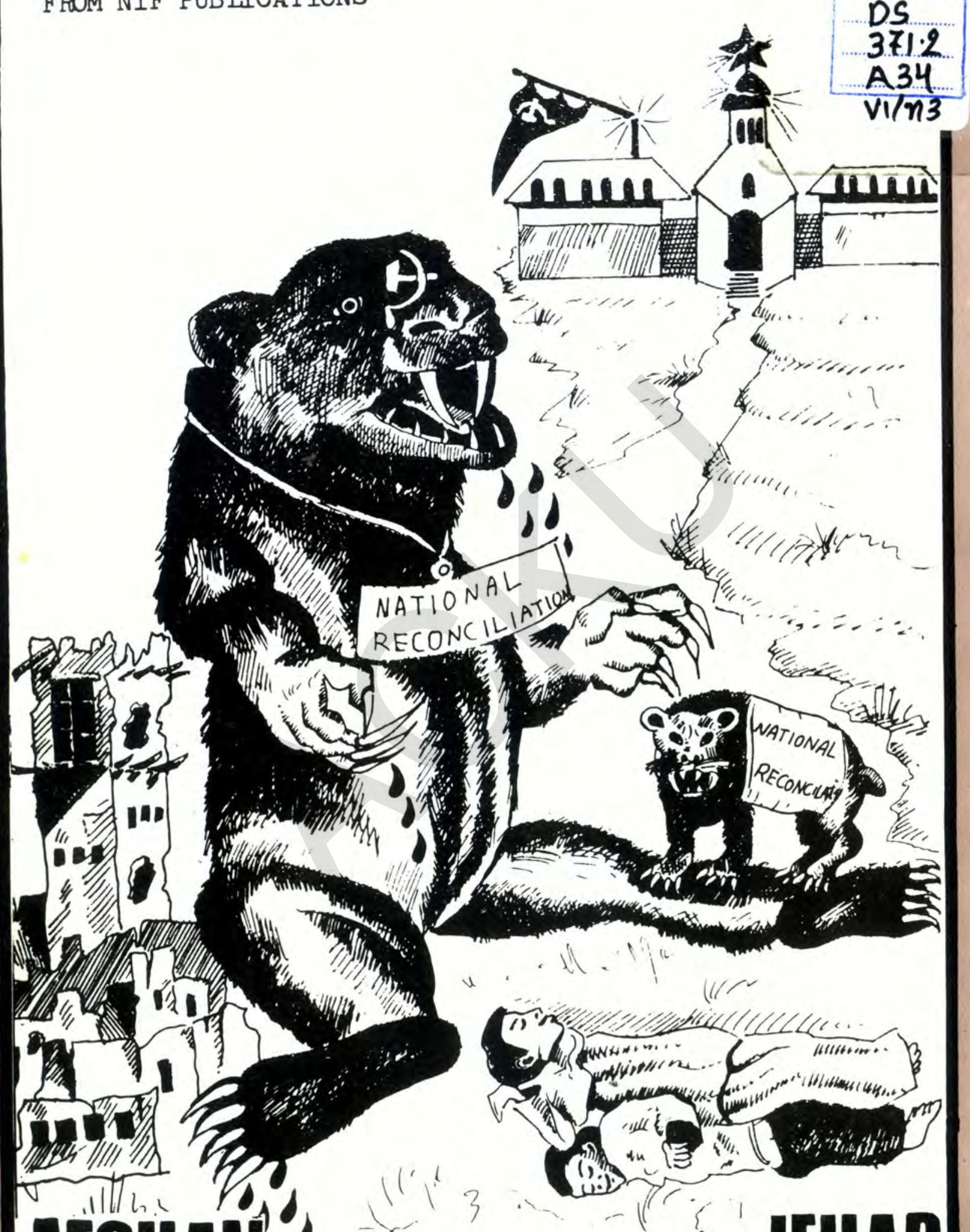

r.

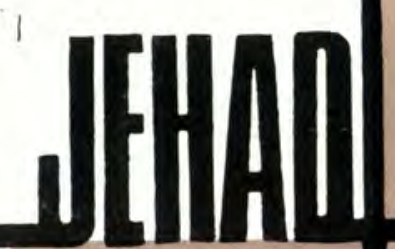

